\title{
Savannah River Site Environmental Report for 1996
}

by

M. Arnett

Westinghouse Savannah River Company

Savannah River Site

Aiken, South Carolina 29808

A. Mamatey

This paper was prepared in connection with work done under the above contract number with the U. $S$.

Department of Energy. By acceptance of this paper, the publisher and/or recipient acknowledges the U.S. Government's right to retain a nonexclusive, royalty-free license in and to any copyright covering this paper, along with the right to reproduce and to authorize others to reproduce all or part of the copyrighted paper. 


\section{DISCLAIMER}

This report was prepared as an account of work sponsored by an agency of the United States Government. Neither the United States Government nor any agency thereof, nor any of their employees, makes any warranty, express or implied, or assumes any legal liability or responsibility for the accuracy, completeness, or usefulness of any information, apparatus, product, or process disclosed, or represents that its use would not infringe privately owned rights. Reference herein to any specific commercial product, process, or service by trade name, trademark, manufacturer, or otherwise does not necessarily constitute or imply its endorsement, recommendation, or favoring by the United States Government or any agency thereof. The views and opinions of authors expressed herein do not necessarily state or reflect those of the United States Government or any agency thereof.

This report has been reproduced directly from the best available copy.

Available to DOE and DOE contractors from the Office of Scientific and Technical Information, P. O. Box 62, Oak Ridge, TN 37831; prices available from (423) 576-8401.

Available to the public from the National Technical Information Service. U. S. Department of Commerce, 5285 Port Royal Rd., Springfield, VA 22161 


\section{DISCLAIMER}

Portions of this document may be illegible electronic image products. Images are produced from the best available original document. 
Westinghouse

Savannah River Company

Aiken, SC 29808
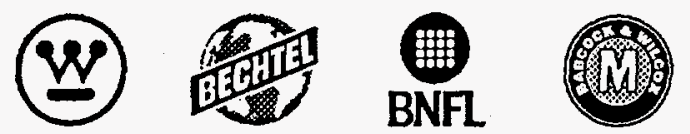

\section{SAVANNAH RIVER SITE ENVIRONMENTAL REPORT FOR 1996 (U)}

On behalf of the U.S. Department of Energy, I am pleased to provide you with a copy of the Savannah River Site Environmental Report for 1996. The report, prepared by Westinghouse Savannah River Company under U.S. Department of Energy guidance and requirements, contains information about the site's environmental activities. Specific issues addressed include environmental monitoring program results, dose estimates to the general public, environmental restoration and waste management activities, and environmental research projects.

The environmental report production staff is interested in any comments you have on the 1996 report. To this end, you will find a postage-paid reader survey card in the front of the report. Please take a few minutes to share your opinions with the staff by filling out and returning the card.

If you wish to speak directly with someone about the report, please contact

Bob Lorenz, Manager

Environmental Sampling and Reporting

Westinghouse Savannah River Company

Building 735-16A

Aiken, SC 29808

Telephone: 803-725-3556

E-mail address: robert.lorenz @srs.gov

Sincerely,

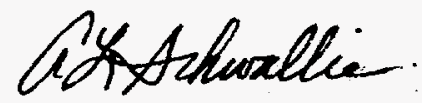

RECEIVED

OCT 06997

OSTI

Ambrose L. Schwallie, President

Westinghouse Savannah River Company 


\section{Can We Make This Report More Useful to You?}

We want to make the Savannah River Site Environmental Report more useful to its readers. Please take a few minutes to let us know if the report meets your needs. Then fold and tape this page so the postage-paid notation and the mailing address are visible, and place it in the mail.

1. How do you use the Savannah River Site Environmental Report?

$\square$ to learn general information about the Savannah River Site

$\square$ to learn about doses received for the current year

$\square$ to learn about site compliance information

$\checkmark$ to gather effluent data

$\square$ to gather environmental surveillance data

$\square$ other

2. What part(s) of this report do you use?
$\square$ main report
data book
summary pamphlet

3. Does the Savannah River Site Environment Report contain

$\square$ enough detail?

$\square$ too much detail? For example,

$\square$ too little detail? For example,

4. Is this report

$\square$ too technical?

about right?

not technical enough?

5. If you could change this report to make it more readable and useful to you, what would you change?

6. What is your affiliation?
$\square$ DOE Headquarters
$\square$ other DOE facility
$\square$ regulator
$\square$ other government office/agency
$\square$ environmental group
elected official

$\square$ university/academy
$\square$ library/public reading room
$\square$ media
$\square$ industry
$\square$ other group
$\square$ other individual

7. To help us identify our audience, please indicate your educational background.

$\square$ graduate degree in scientific field

$\square$ graduate degree in nonscientific field

$\square$ undergraduate degree in scientific field

$\square$ undergraduate degree in nonscientific field

$\square$ experience with science outside college setting

$\square$ little or no scientific background

If you are interested in attending a workshop to critique the 1996 report, please provide your name, address, and telephone number.

For more information, please call Bob Lorenz - Manager, Environmental Sampling and Reporting, at 803-725-3556 or E-Mail at robert.lorenz@srs.gov 


\section{BUSINESS REPLY MAIL}

FIRST CLASS MAIL

PERMIT NO. 76

AIKEN, SC

POSTAGE WILL BE PAID BY ADDRESSEE

Attn: Bob Lorenz

Westinghouse Savannah River Company

Building 735-16A, Savannah River Site

Aiken, SC 29803-9899

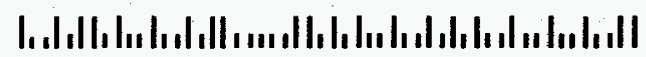




\section{Savannah River Site}

\section{Environmental Report for 1996}

\section{Editors}

Margaret W. Arnett

Albert R. Mamatey 


\section{Acknowledgments}

- The editors acknowledge with deep appreciation the efforts of the following individuals, who, in addition to the authors, reviewed-and/or contributed valuable resources, information, or technical data to-the Savannah River Site Environmental Report for 1996:

$\begin{array}{lll}\text { Chike Amobi } & \text { Doris Hoel } & \text { C.E. Murphy, Jr. } \\ \text { Jim Bollinger } & \text { Tracey Humphrey } & \text { Lindy Nowak } \\ \text { Sandra Boynton } & \text { Chuck Hunter } & \text { Vern Osteen } \\ \text { Bruce Cadotte } & \text { Greg Jansen } & \text { Matt Parker } \\ \text { Carl Cook } & \text { Larry Koffman } & \text { Priscilla Patterson } \\ \text { Lori Coward } & \text { Jeff Lintern } & \text { Dan Rogers } \\ \text { Keith Dyer } & \text { Nancy Lowry } & \text { Jane Sanders } \\ \text { Larry Eldridge } & \text { Bart Marcy } & \text { Bob Steitler } \\ \text { Ross Fanning } & \text { Lynn Martin } & \text { Ann VanBrackle } \\ \text { Natalie Ferguson } & \text { Jack Mayer } & \text { Curt Walker } \\ \text { Steve Glover } & \text { Jim McConathy } & \text { Gary Wein } \\ \text { Elizabeth Goodson } & \text { Don Morris } & \text { Michele Wilson } \\ \text { John Harley } & \text { Hal Morris } & \text { George Wingard } \\ \text { Chuck Harvel } & \text { Edgar Berkey } & \text { Rer }\end{array}$

Environmental Advisory Committee: Dr. Edgar Berkey, Dr. Keros Cartwright, Dr. Bernd Kahn, Dr. Milton Russell, and Dr. Gordon Wolman

- Listed below are those who provided expert publications support.
Bruce Boulineau
Stephanie Doetsch (printing)
Cherry Glisson (forms)
(photography)
Ann Scott (offsite printing)
Bernadette Hobbs (forms)
Dennis Hendrix (illustrating)
Debbie Beckett (forms)
Norene Powell (forms)

- A special thanks to Mary Langford for coordinating the DOE-SR review and approval process. The review and approval process requires dedication and support from both WSRC and DOE-SR.
Trish Baughman, WSRC
Juli Hearn, WSRC
Vernon Gardner, DOE-SR
Randy Collins, WSRC
Sharon Lybrand, WSRC
Tom Coughenour, WSRC
Donna Nichols, WSRC
Ben Gould, DOE-SR
Pat Dominey, WSRC
Jeanne Sellers, WSRC
Mina Perrin, DOE-SR

- Thanks to Karl Bergmann and John Ellinger for providing timely and effective computer support.

- Gratitude is expressed to the following for management, administrative, and other support:

$\begin{array}{lll}\text { Chris Arenz } & \text { Jay Hutchison } & \text { Neil Suttles } \\ \text { Manley Grove } & \text { Bob Lorenz } & \\ \text { June Hall } & \text { Meghan McGrath } & \text { Brenda Walker } \\ \text { Jim Heffner } & \text { Becky Sturdivant } & \text { Robin Young }\end{array}$


The Savannah River Site (SRS) conducts effluent monitoring and environmental surveillance to ensure the safety of the public and the well-being of the environment. U.S. Department of Energy (DOE) Order 5400.1, "General Environmental Protection Program," requires that SRS submit an environmental report documenting the impact of facility operations on public health and on the environment. The report's purpose is to present summary environmental data that characterize site environmental management performance, confirm compliance with environmental standards and requirements, and highlight significant programs and efforts.

SRS has had an extensive environmental surveillance program in place since 1951 (before site startup). At that time, data generated by the onsite surveillance program were reported in site documents. Beginning in 1959, data from offsite environmental monitoring activities were presented in reports issued for public dissemination. SRS reported onsite and offsite environmental monitoring activities separately until 1985, when data from both surveillance programs were merged into one public document.

\section{The Savannah River Site Environmental Report for 1996 is an overview of effluent monitoring and environmental surveillance activities conducted on and in the vicinity of SRS from January 1 through December 31, 1996. It is prepared by the Environmental Monitoring Section (EMS) of Westinghouse Savannah River Company (WSRC). The "SRS Environmental Monitoring Plan" (WSRC-3Q1-2-1000) and the "SRS Environmental Monitoring Program" (WSRC-3Q1-2-1100) provide complete program descriptions and document the rationale and design criteria for the monitoring program, the frequency of monitoring and analysis, the specific analytical and sampling procedures, and the quality assurance requirements.}

Variations in the environmental report's data content from year to year reflect changes in the routine program or difficulties encountered in obtaining or analyzing some samples. Examples of such problems include adverse environmental conditions (such as flooding or drought), sampling or analytical equipment malfunctions, and compromise of the samples in the preparation laboratories or counting room.
Unless otherwise indicated, the figures and tables in this report are generated using results from the regular monitoring program. No attempt has been made to include all data from environmental research programs. A more complete listing of data can be found in Savannah River Site Environmental Data for 1996 (WSRC-TR-97-0077).

The following information should aid the reader in interpreting data in this report:

- Analytical results and their corresponding uncertainty terms generally are reported with up to three significant figures. The last significant figure of a result is determined by the quantification of the uncertainty term. EMS attempts to report the appropriate confidence in the result with the correct number of significant figures.

- The reported uncertainty of a single measurement reflects only the counting error-not other components of random and systematic error in the measurement process-so some results may imply a greater confidence than the determination would suggest.

- An uncertainty quoted with means represents the standard deviation of measurements about the mean value. This number is calculated from the results themselves and is not weighted by the uncertainties of the individual results.

- All values represent the weighted average of all acceptable analyses of a sample for a particular analyte. Samples may have undergone multiple analyses for quality assurance purposes or to determine if radionuclides are present. Concentrations may be below the minimum detectable activity of an analysis, in which case they are presented to satisfy DOE reporting requirements.

- The generic term "dose," as used in the report, refers to the committed effective dose equivalent (50-year committed dose) from internal deposition of radionuclides and to the effective dose equivalent attributable to penetrating radiation from sources external to the body.

Inquiries regarding this report should be made to

Bob Lorenz, Manager

Environmental Sampling and Reporting

Westinghouse Savannah River Company

Building 735-16A

Aiken, SC 29808

Telephone: 803-725-3556

E-mail address: robert.lorenz@srs.gov 



\section{Contents}

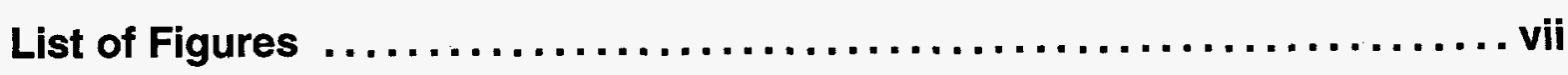

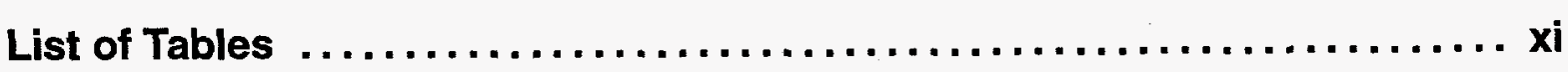

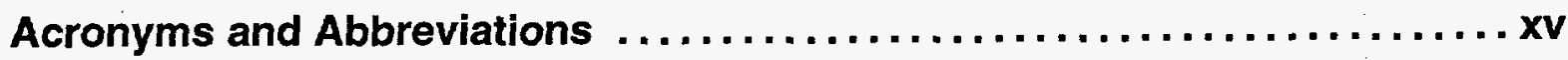

Sampling Location Abbreviations $\ldots \ldots \ldots \ldots \ldots \ldots \ldots \ldots \ldots \ldots \ldots \ldots \ldots \ldots \ldots \ldots \ldots \ldots$

Executive Summary $\ldots \ldots \ldots \ldots \ldots \ldots \ldots \ldots \ldots \ldots \ldots \ldots \ldots \ldots \ldots \ldots \ldots \ldots \ldots$

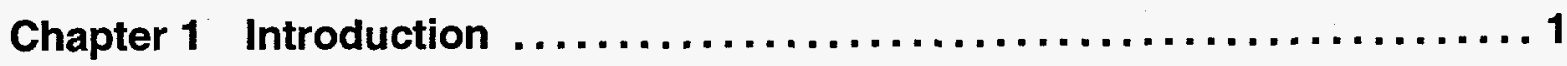

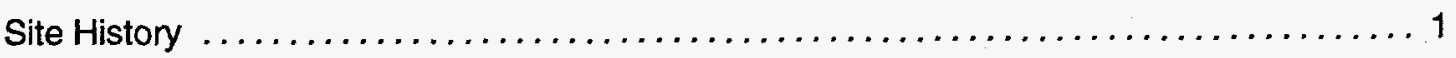

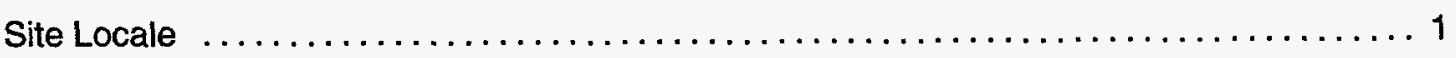

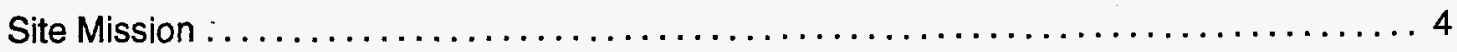

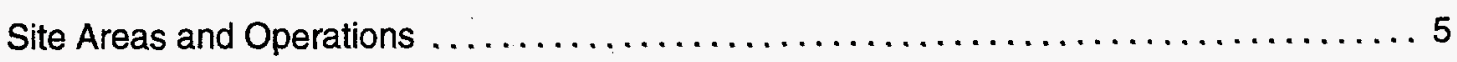

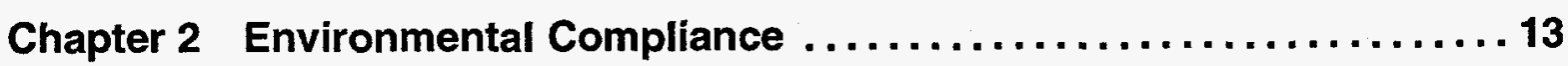

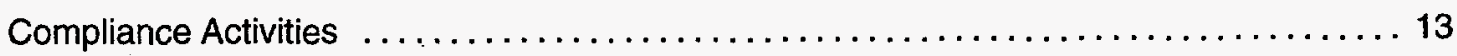

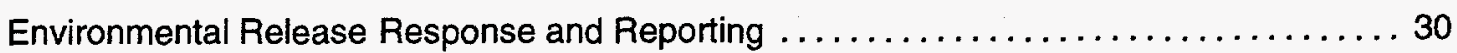

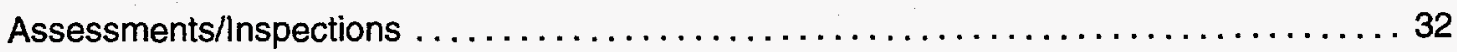

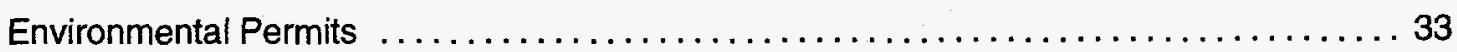

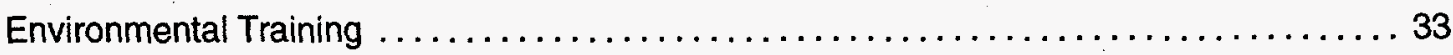

Transition and Decontamination and Decommissioning $\ldots \ldots \ldots \ldots \ldots \ldots \ldots \ldots \ldots$

Other Major Environmental Issues and Actions $\ldots \ldots \ldots \ldots \ldots \ldots \ldots \ldots \ldots \ldots \ldots \ldots \ldots$

Chapter 3 Environmental Program Information $\ldots \ldots \ldots \ldots \ldots \ldots \ldots \ldots 4$

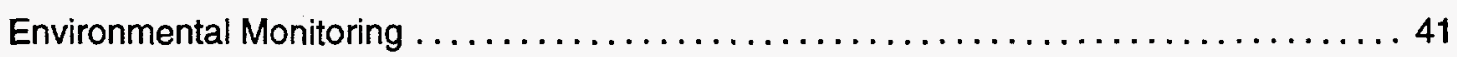

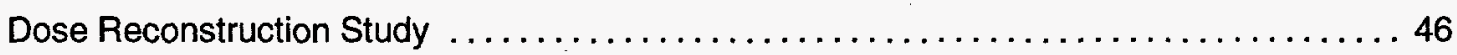

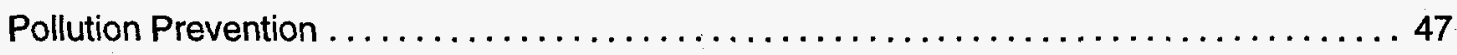

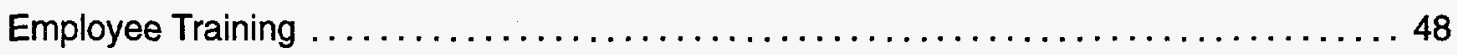

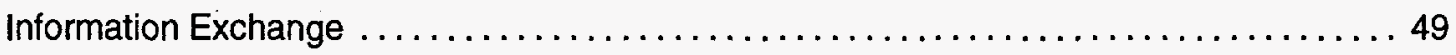

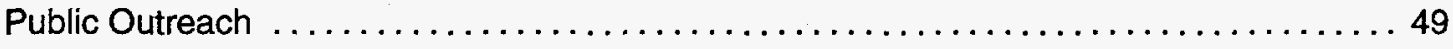


Chapter 4 Environmental Restoration and Waste Management .........51

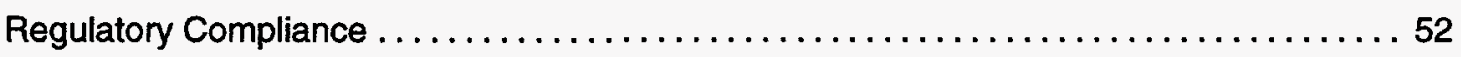

Environmental Restoration ..................................... 52

Solid Waste Management . . . . . . . . . . . . . . . . . . . . . . . . 54

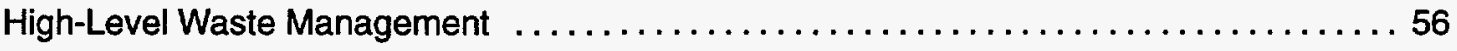

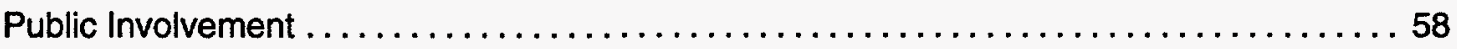

Chapter 5 Radiological Effluent Monitoring $\ldots \ldots \ldots \ldots \ldots \ldots \ldots \ldots \ldots \ldots \ldots \ldots \ldots$

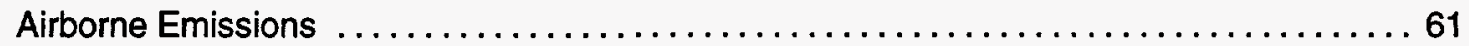

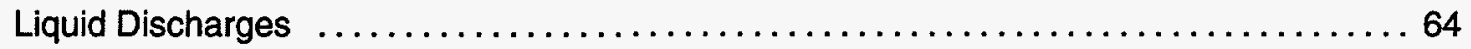

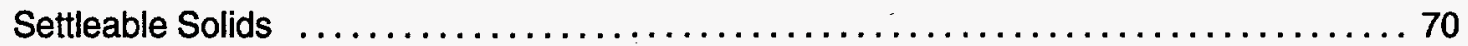

Chapter 6 Radiological Environmental Surveillance $\ldots \ldots \ldots \ldots \ldots \ldots \ldots 75$

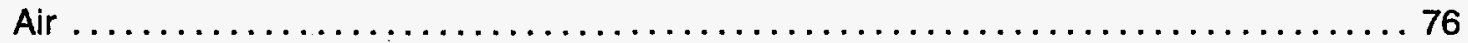

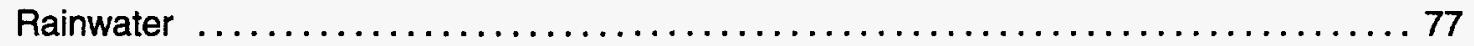

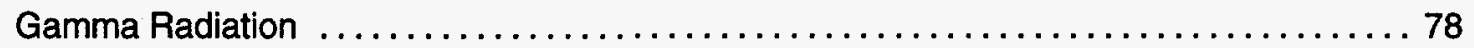

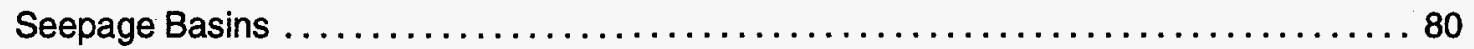

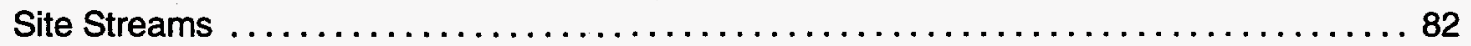

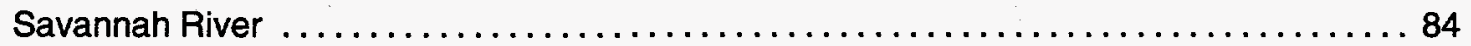

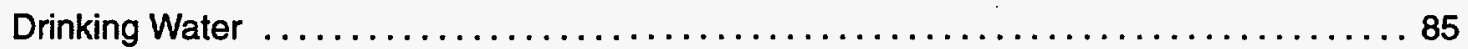

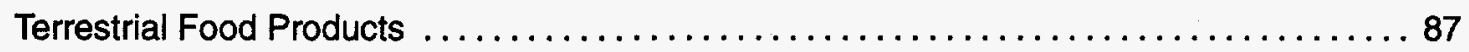

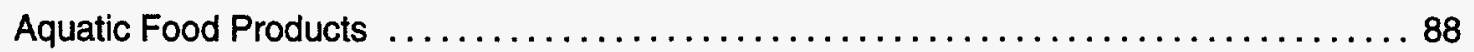

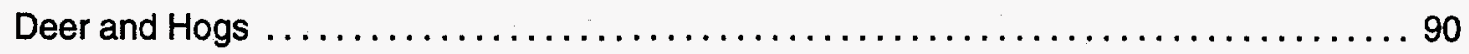

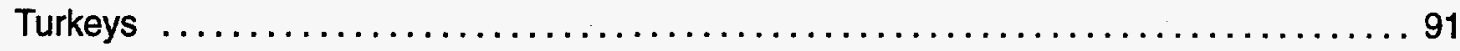

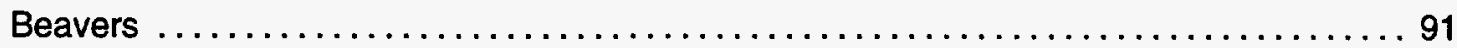

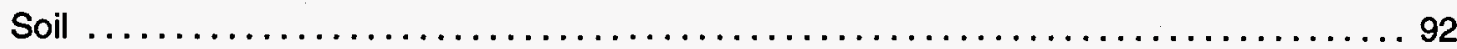

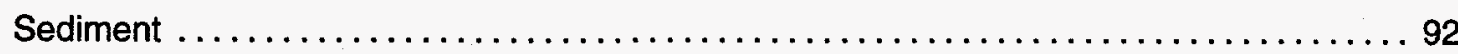

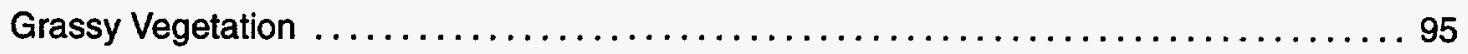

Chapter 7 Potential Radiation Doses ......................... 105

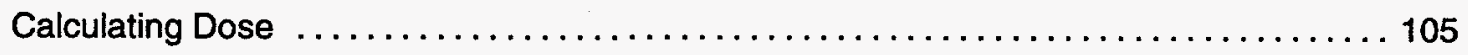

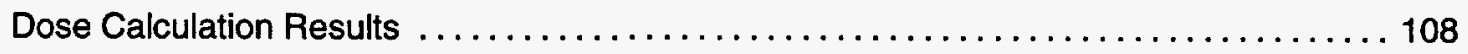

Radiological Assessment Program ................................ 120 
Chapter 8 Nonradiological Effluent Monitoring .................. 121

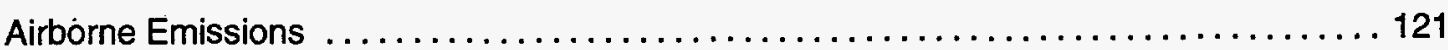

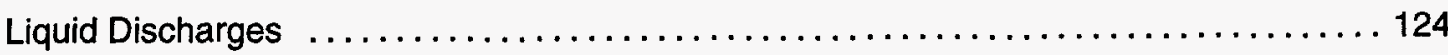

Chapter 9 Nonradiological Environmental Surveillance ............ 129

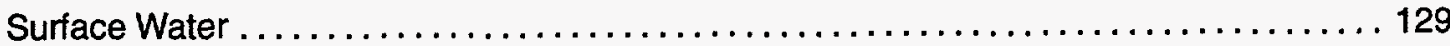

Drinking Water $\ldots \ldots \ldots \ldots \ldots \ldots \ldots \ldots \ldots \ldots \ldots \ldots \ldots \ldots \ldots \ldots \ldots \ldots \ldots \ldots \ldots \ldots \ldots, 130$

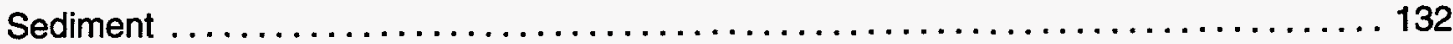

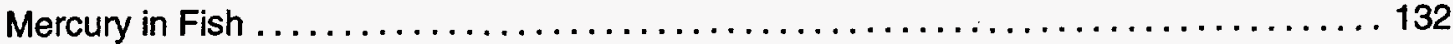

Chapter 10 Groundwater $. . \ldots \ldots \ldots \ldots \ldots \ldots \ldots \ldots \ldots \ldots \ldots \ldots \ldots \ldots, 135$

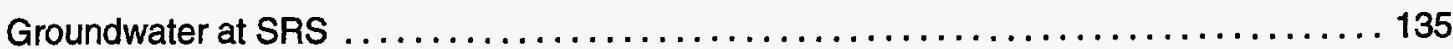

Description of the Groundwater Monitoring Program ...................... 139

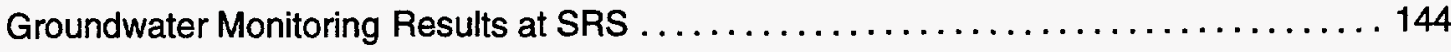

Chapter 11 Quality Assurance $\ldots \ldots \ldots \ldots \ldots \ldots \ldots \ldots \ldots \ldots \ldots \ldots \ldots, 169$

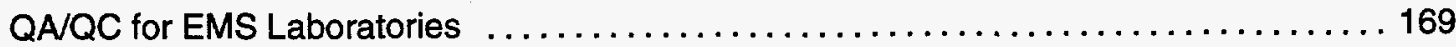

QA/QC for Subcontracted Laboratories ............................... 172

Chapter 12 Special Surveys and Projects $\ldots \ldots \ldots \ldots \ldots \ldots \ldots \ldots \ldots 177$

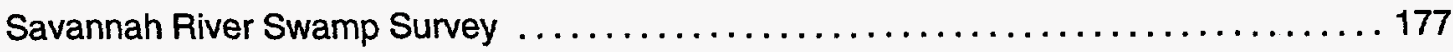

Mitigation Action Plan for Pen Branch Reforestation ....................... 179

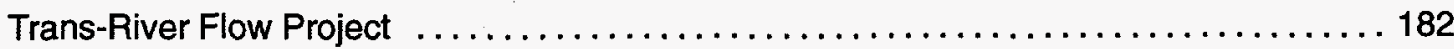

Academy of Natural Sciences of Philadelphia River Quality Surveys .............. 182

Appendix A Applicable Guidelines, Standards, and Regulations ...... 183

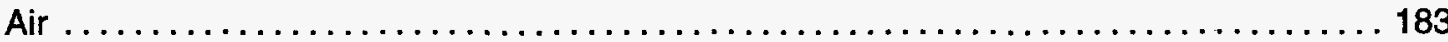

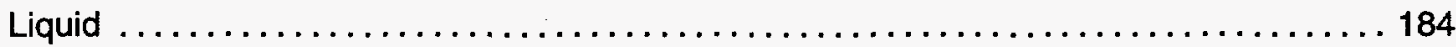

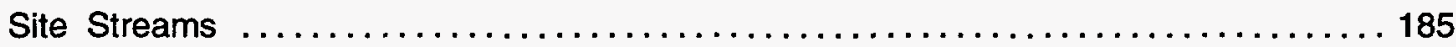

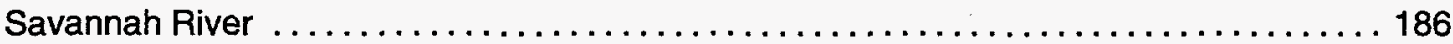

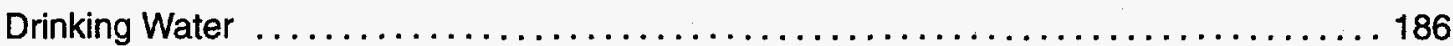

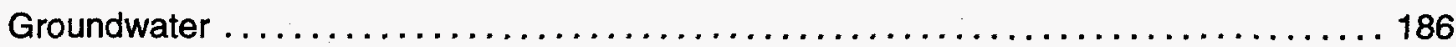

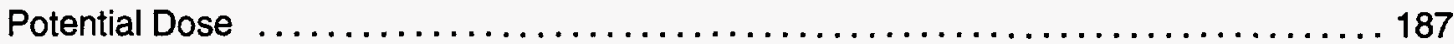

Environmental Restoration and Waste Management $\ldots \ldots \ldots \ldots \ldots \ldots \ldots \ldots \ldots \ldots \ldots \ldots \ldots$

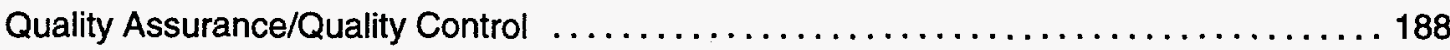


Appendix B SRS Environmental Permits $\ldots . \ldots \ldots \ldots \ldots \ldots \ldots \ldots \ldots . \ldots 189$

Appendix C Radionuclide and Chemical Nomenclature ............ 219

Appendix D Drinking Water Standards $\ldots \ldots \ldots \ldots \ldots \ldots \ldots \ldots \ldots \ldots \ldots \ldots \ldots \ldots \ldots$

Appendix E Environmental Monitoring Reports ................ 227

Appendix F Errata from 1995 Report $\ldots \ldots \ldots \ldots \ldots \ldots \ldots \ldots \ldots \ldots \ldots 229$

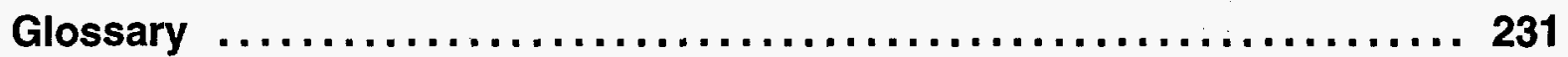

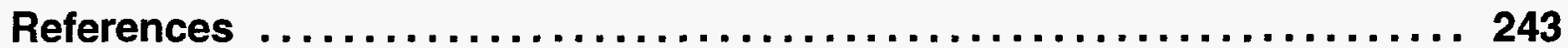

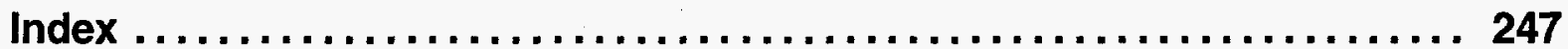




\section{List of Figures}

\section{Executive Summary}

Figure 1 SRS Maximum Potential Doses to the Maximally Exposed Individual ......xxiii

Figure 2 Ten-Year History of SRS Annual Atmospheric Tritium Releases . . . . . . . xxv

\section{Chapter 1 Site and Operations Overview}

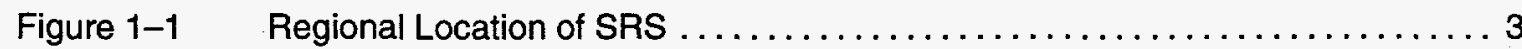

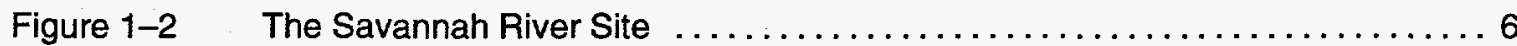

\section{Chapter 2 Environmental Compliance}

Figure 2-1 Total Toxic Chemical Releases at SRS, 1987-1995

\section{Chapter 3 Environmental Program Information}

Figure 3-1 Typical Airborne Effluent Monitoring and Environmental Surveillance $\ldots \ldots \ldots 43$

Figure 3-2 Typical Liquid Effluent Monitoring and Environmental Surveillance ........ 43

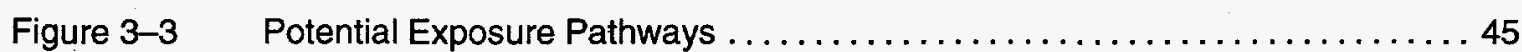

\section{Chapter 4 Environmental Restoration and Waste Management}

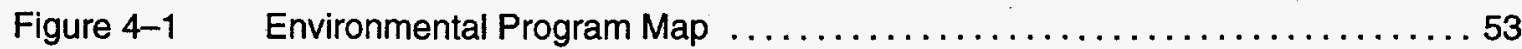

\section{Chapter 5 Radiological Effluent Monitoring}

Figure 5-1

SRS Annual Atmospheric Tritium Releases, 1987-1996

Figure 5-2

Direct Releases of Tritium to SRS Streams, 1988-1996

Figure 5-3

Tritium Migration from Seepage Basins and SWDF to SRS Streams, 1988-1996

Figure 5-4

Total Tritium Releases to SRS Streams (Direct Discharges and Migration), 1988-1996 .............................................68

Figure 5-5 Past, Current, and Projected Tritium Migration Releases to Four Mile Creek from the F-Area and H-Area Seepage Basins and SWDF

\section{Chapter 6 Radiological Environmental Surveillance}

Figure 6-1

Figure 6-2

Figure 6-3

Figure 6-4

Figure $6-5$

Figure 6-6
Radiological Air Surveillance Stations 77

Average Concentration of Tritium in Rainwater

Radiological Surface-Water Sampling Locations

Average Tritium Concentration in SRS Streams, 1988-1996

SRS Tritium Transport Summary, 1960-1996 86

SRS Fish Sampling Points on the Savannah River 
Figure $6-7 \quad$ Radiological Soil Sampling Locations $\ldots \ldots \ldots \ldots \ldots \ldots \ldots \ldots \ldots \ldots$

Figure 6-8 Radiological Sediment Sampling Locations $\ldots \ldots \ldots \ldots \ldots \ldots \ldots \ldots \ldots . \ldots 4$

Figure $6-9 \quad$ SRS Onsite Vegetation Sampling Locations $\ldots \ldots \ldots \ldots \ldots \ldots \ldots \ldots$

\section{Chapter 7 Potential Radiation Doses}

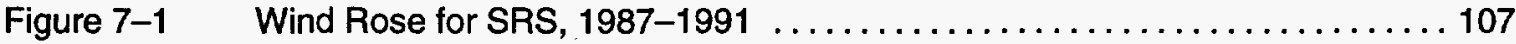

Figure 7-2 Annual Average Tritium Concentrations at River Mile 120, Beaufort-Jasper,

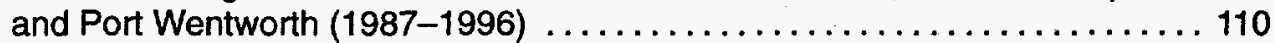

Figure 7-3 Sector-Specific Adult Maximally Exposed Individual Air Pathway Doses

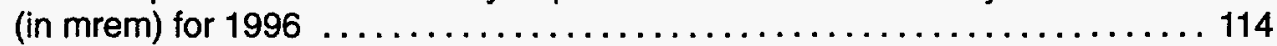

Figure 7-4 Ten-Year History of SRS Maximum Potential All-Pathway Doses to the Maximally Exposed Individual (Airborne plus Liquid Pathways) ...... 116

Figure $7-5 \quad$ Contributions to the U.S. Average Individual Dose $\ldots \ldots \ldots \ldots \ldots \ldots \ldots 116$

\section{Chapter 8 Nonradiological Effluent Monitoring}

\section{Chapter 9 Nonradiological Environmental Surveillance}

Figure 9-1 Nonradiological Surface Water Sampling Locations $\ldots \ldots \ldots \ldots \ldots \ldots \ldots 131$

Figure 9-2 Nonradiological Sediment Sampling Locations ................... 133

\section{Chapter 10 Groundwater}

Figure 10-1 Facilities Monitored by the SRS Monitoring Well Network, Including Areas Having Constituents Exceeding Drinking Water Standards in 1996 ....... 136

Figure 10-2 Groundwater at SRS

Figure 10-3

Potentiometric Surface and Horizontal Groundwater Flow Directions of the Middle Zone at SRS During the First Quarter of 1996

Figure 10-4 Potentiometric Surface and Horizontal Groundwater Flow Directions of the Lower Zone at SRS During the First Quarter of 1996

Figure 10-5 Extent of Groundwater Contamination Beneath A-Area and M-Area in 1996 and Location of Noteworthy Sources of Contamination Exceeding Drinking Water Standards

Figure 10-6 Extent of Groundwater Contamination Beneath C-Area in 1996 and Location of Noteworthy Sources of Contamination Exceeding

Drinking Water Standards

Figure 10-7 Extent of Groundwater Contamination Beneath D-Area and TNX in 1996 and Location of Noteworthy Sources of Contamination Exceeding Drinking Water Standards

Figure 10-8 Extent of Groundwater Contamination Beneath the General Separations and Waste Management Areas in 1996 and Location of Noteworthy Sources of Contamination Exceeding Drinking Water Standards ............. 153

Figure 10-9 Extent of Groundwater Contamination Beneath K-Area in 1996 and Location of Noteworthy Sources of Contamination Exceeding Drinking Water Standards 
Figure 10-10 Extent of Groundwater Contamination Beneath L-Area and the Chemicals, Metals, and Pesticides Pits in 1996 and Location of Noteworthy Sources of Contamination Exceeding Drinking Water Standards

Figure 10-11 Extent of Groundwater Contamination Beneath P-Area in 1996 and Location of Noteworthy Sources of Contamination Exceeding Drinking Water Standards

Figure 10-12 Extent of Groundwater Contamination Beneath R-Area in 1996 and Location of Noteworthy Sources of Contamination Exceeding Drinking Water Standards 164

Figure 10-13 Extent of Groundwater Contamination Beneath the Sanitary Landfill and B-Area in 1996 and Location of Noteworthy Sources of Contamination Exceeding

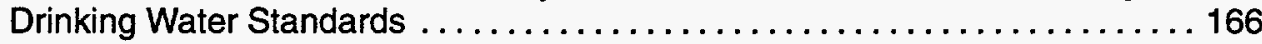

\section{Chapter 11 Quality Assurance}

Figure 11-1 SRS EM Program QAVC Document Hierarchy/Relevant Guidance Documents

\section{Chapter 12 Special Surveys and Projects}

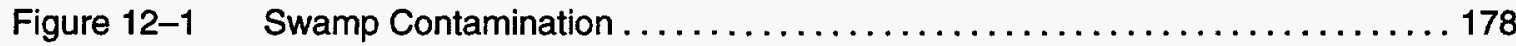

Figure 12-2 Savannah River Swamp Sampling Trails ..................... 179

Figure 12-3 Monthly Reptile and Amphibian Species Diversity in the

Pen Branch Corridor 



\section{List of Tables}

\section{Executive Summary}

Table 1

1996 Potential Radiation Doses from SRS Releases Compared with Applicable Dose Standards and Estimated Doses from Naturally Occurring Radiation xxii

\section{Chapter 2}

Table 2-1

Table 2-2

Table 2-3

Table 2-4

Table 2-5

Table 2-6

Table 2-7

Table 2-8

Table 2-9

\section{Chapter 5}

Table 5-1

Table 5-2

\section{Chapter 6}

Table 6-1

Table 6-2

Table 6-3

Table 6-4

Table 6-5

Table 6-6

Table 6-7

Table 6-8

\section{Environmental Compliance}

Identification and Location of RCRA-Regulated Units at SRS 18 Releases of Toxic Chemicals (in Pounds) by SRS During 1993, 1994, and 1995 Reporting Years (Reported Under EPCRA Section 313) ........ 20

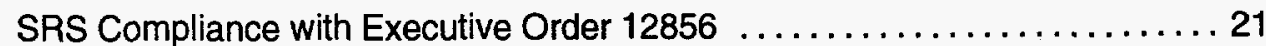

Types/Numbers of NEPA Activities at SRS During $1996 \ldots \ldots \ldots \ldots \ldots 21$

SRS Project NEPA Documentation Activities During $1996 \ldots \ldots \ldots \ldots \ldots \ldots 23$

CERCLA Releases Reported to Regulatory Agencies in 1996 ........... 31

Environmentally Related Unusual Occurrences Reported Through SIRIM

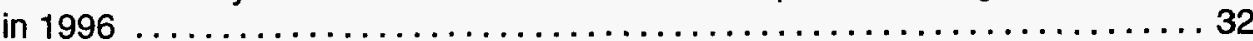

SRS Construction and Operating Permits $\ldots \ldots \ldots \ldots \ldots \ldots \ldots \ldots \ldots \ldots \ldots \ldots \ldots \ldots$

Examples of RCRA and RCRA/CERCLA Units at SRS $-1996 \ldots \ldots \ldots \ldots 36$

\section{Radiological Effluent Monitoring}

Radioactive Atmospheric Releases by Source $\ldots \ldots \ldots \ldots \ldots \ldots \ldots \ldots \ldots 71$

Radioactive Liquid Releases by Source (Including Direct and Seepage Basin Migration Releases) ..................................... 73

Radiological Environmental Surveillance

Average Gross Alpha and Gross Beta Measured in Air $(\mathrm{mCi} / \mathrm{mL})$, 1990-1996 ........................................... 78

1996 Gamma Radiation Surveillance Program Changes .............. 79

TLD Surveillance Results Summary for $1996 \ldots \ldots \ldots \ldots \ldots \ldots \ldots \ldots$

Average 1996 Concentration of Radioactivity in SRS and Surveillance Station

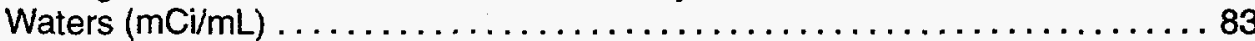

Average 1996 Concentration of Radioactivity in the

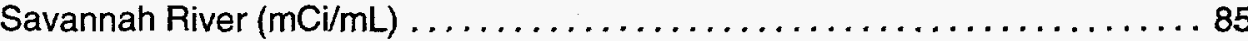

Maximum Radionuclide Concentrations in Vegetation from Quarterly

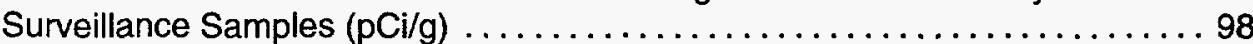

Maximum Radionuclide Concentrations in Vegetation from Chemical, Seepage,

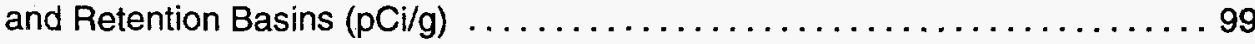

Maximum Radionuclide Concentrations in Vegetation from Outside the Solid Waste Disposal Facility (pCi/g) ............................. 99 
Table 6-9 Representative Lower Limits of Detection for Gamma Analysis of Water

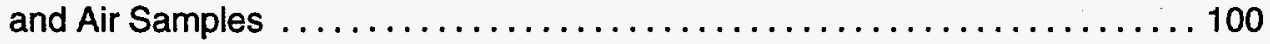

Table 6-10 Representative Lower Limits of Detection for Gamma Analysis of Soil, Food, Fish and Wildlife, and Vegetation Samples ................. 101

Table 6-11 Representative Lower Limits of Detection for Radiological Analysis of Plutonium and Uranium by Alpha Spectroscopy $\ldots \ldots \ldots \ldots \ldots \ldots \ldots . \ldots 102$

Table 6-12 Representative Lower Limits of Detection for Radiological Analysis by Gas-Flow Proportional Counters and by Liquid Scintillation ......... 103

\section{Chapter 7}

\section{Potential Radiation Doses}

Table 7-1

1996 Radioactive Liquid Release Source Terms and 12-Month Average Downriver Radionuclide Concentrations (Calculated Concentrations Are Based on Effective River Flow Rates)

Table 7-2

Potential Cose to the Maximally Exposed Individual from SRS Liquid Releases

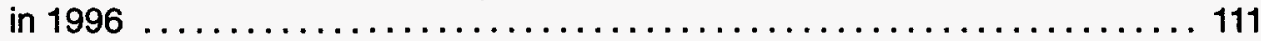

Table 7-3 Ten-Year History of SRS Atmospheric Tritium and Tritium Oxide Releases and Average Measured Tritium Oxide Concentrations in Air Compared to Calculated Concentrations in Air $\ldots \ldots \ldots \ldots \ldots \ldots \ldots \ldots \ldots \ldots \ldots \ldots \ldots$

Table 7-4 Potential Dose to the Maximally Exposed Individual from SRS Atmospheric

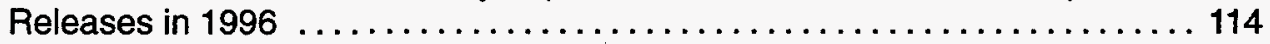

Table 7-5 1996 All-Pathway and Sportsman Doses Compared to the DOE All-Pathway

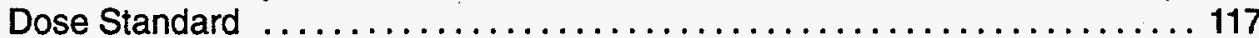

Table 7-6 Potential Lifetime Risks from the Consumption of Savannah River Fish Compared to Dose Standards (1993-1996)

\section{Chapter 8}

\section{Nonradiological Effluent Monitoring}

Table 8-1

Nonradiological Airborne Emissions Standards for SRS Coal-Fired Boilers .. 121

Table 8-2 SRS Power Plant Boiler Capacities 122

Table 8-3

Boiler Stack Test Results (D-Area, A-Area)

Table 8-4

SRS Package Steam Boiler Capacities

Table 8-5

1995 Criteria Pollutant Air Emissions

Table 8-6

Soil Vapor Extraction Unit (SVEU)/Catalytic Oxidation Stack Test Results

Chapter 10

Groundwater

Table 10-1

Environmental-Screening Constituents 142

Table 10-2

Constituent Groups Above Drinking Water Standards at A-Area and M-Area

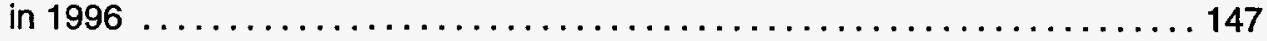

Table 10-3

Constituent Groups Above Drinking Water Standards at C-Area in 1996

Table 10-4 Constituent Groups Above Drinking Water Standards at D-Area and TNX in 1996 152

Table 10-5 Constituent Groups Above Drinking Water Standards at the General Separations and Waste Management Areas in 1996 ....................... 155

Table 10-6 Constituent Groups Above Drinking Water Standards at K-Area in 1996 . . . 157

Table 10-7

Constituent Groups Above Drinking Water Standards at L-Area and the Chemicals, Metals, and Pesticides Pits in 1996 
Table 10-8 Constituent Groups Above Drinking Water Standards at N-Area in 1996 . . . . 161

Table 10-9 Constituent Groups Above Drinking Water Standards at P-Area in 1996 . . . 163

Table 10-10 Constituent Groups Above Drinking Water Standards at R-Area in 1996 . . . 165

Table 10-11 Constituent Groups Above Drinking Water Standards at the Sanitary Landfill

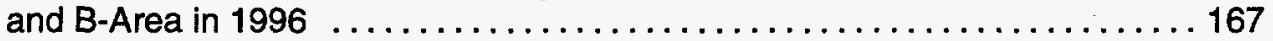

\section{Chapter 11}

Quality Assurance

Table 11-1 Subcontracted Laboratories for 1996 172 



\section{Acronyms and Abbreviations}

$$
\text { A }
$$

ALARA - As low as reasonably achievable

ANSP - Academy of Natural Sciences of Philadelphia

B.

BTU - British thermal unit

BSRI - Bechtel Savannah River, Inc.

C

CAA - Clean Air Act

CAAA - Clean Air Act Amendments of 1990

CAB - Citizens Advisory Board

CDC - Centers for Disease Control and Prevention

CERCLA - Comprehensive Environmental Response, Compensation, and Liability Act (Superfund)

CFC - Chlorofluorocarbon

CFR - Code of Federal Regulations

CIF - Consolidated Incineration Facility

CMP - Chemicals, metals, and pesticides

CSRA - Central Savannah River Area

CSWTF - Central Sanitary Wastewater Treatment Facility

CWA - Clean Water Act

CX - Categorical exclusion

$D$

D\&D - Decontamination and decommissioning
DCG - Derived concentration guide

DNC - Department National Environmental Policy Act Coordinator

DOE - U.S. Department of Energy

DOE-HQ - U.S. Department of Energy-Headquarters

DOE-SR - U.S. Department of Energy-Savannah River Operations Office

DWPF - Defense Waste Processing Facility

DWS - Drinking water standards

E

EA - Environmental Assessment

ECD - Environmental Compliance Division of the U.S. Department of Energy-Savannah River Operations Office

EIS - Environmental Impact Statement

EMCAP - Environmental Monitoring Computer Automation Project

EMS - Environmental Monitoring Section of the Environmental Protection Department (of Westinghouse Savannah River Company)

EPA - U.S. Environmental Protection Agency

EPCRA - Emergency Planning and Community Rightto-Know Act

EPD - Environmental Protection Department (of Westinghouse Savannah River Company)

ERDA - Education, Research and Development Association of Georgia Universities

ETF - Effluent Treatment Facility

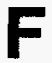

FAC - Forced activity concentrations 
FDA - U.S. Food and Drug Administration

FFA - Fèderal Facility Agreement

FFCA - Federal Facility Compliance Agreement

FFCAct - Federal Facility Compliance Act

FONSI - Finding of No Significant Impact

$\mathbf{G}$

GDNR - Georgia Department of Natural Resources

GOCO - Government-owned, contractor-operated

HBFC - Hydrobromofluorocarbon

HCFC - Hydrochlorofluorocarbon

HVAC - Heating, ventilation, and air conditioning

I

ICRP - International Commission on Radiological Protection

ITP - In-Tank Precipitation Facility

2

LDR - Land disposal restrictions

LETF - Liquid Effluent Treatment Facility

LLD - Lower limit of detection

LLRWDF-Low-Level Radioactive Waste Disposal Facility

M

MAP - Mitigation Action Plan

MDA - Minimum detectable activity

MDL - Minimum detectable limit
MRD - Mean relative difference

MWMF - Mixed Waste Management Facility

$\mathbf{N}$

NASA - National Aeronautics and Space Administration

NCRP - National Council on Radiation Protection and Measurements

NEPA - National Environmental Policy Act

NESHAP - National Emission Standards for Hazardous Air Pollutants

NOV - Notice of Violation

NPDES - National Pollutant Discharge Elimination System

NRC - U.S. Nuclear Regulatory Commission

ODS - Ozone-depleting substances

9

PAR Pond - Pond constructed at Savannah River Site in 1958 to provide cooling water for P-Reactor and RReactor (P and R; hence, PAR)

PCB - Polychlorinated biphenyl

PEIS - Programmatic Environmental Impact Statement

$\mathrm{pH}$ - Measure of the hydrogen ion concentration in an aqueous solution (acidic solutions, $\mathrm{pH}$ from $0-6$; basic solutions, $\mathrm{pH}>7$; and neutral solutions, $\mathrm{pH}=7$

PVC - Polyvinyl chloride

QA - Quality assurance

QAD - Quality Assurance Division (Environmental Protection Agency) 
QAP - Quality Assurance Program (Department of Energy)

QAVC - Quality assurance/quality control

QC - Quality control (in environmental monitoring, the routine application of procedures to obtain the required standards of performance in monitoring and measurement processes)

Di

RBOF - Receiving Basin for Offsite Fuel

RCO - Radiological Control Operations

RCRA - Resource Conservation and Recovery Act

RFIRI - RCRA Facility Investigation/Remedial Investigation

ROD - Record of Decision

RQ - Reportable quantity

RTF - Replacement Tritium Facility

$\infty$

SARA - Superfund Amendments and Reauthorization Act

SCDHEC - South Carolina Department of Health and Environmental Control

SCUREF - South Carolina Universities Research and Education Foundation

SDWA - Safe Drinking Water Act

SEA - Special Environmental Analysis

SEIS - Supplemental Environmental Impact Statement

SIRIM - Site Item Reportability and Issues Management
SRARP - Savannah River Archaeological Research Program

SREL - Savannah River Ecology Laboratory (University of Georgia)

SRFS - Savannah River Forest Station (U.S. Department of Agriculture Forest Service)

SRP - Savannah River Plant

SRS - Savannah River Site

SRTC - Savannah River Technology Center

SVEU - Soil Vapor Extraction Unit

SWDF - Solid Waste Disposal Facility

7

TLD - Thermoluminescent dosimeter

TRAC - Tracking Radioactive Atmospheric Contaminants

TRI - Toxic Release Inventory

TSCA - Toxic Substances Control Act

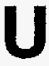

USGS - U.S. Geological Survey

UV - Ultraviolet

W

WIND - Weather Information and Display

WSI - Wackenhut Services Inc.

WSRC - Westinghouse Savannah River Company 


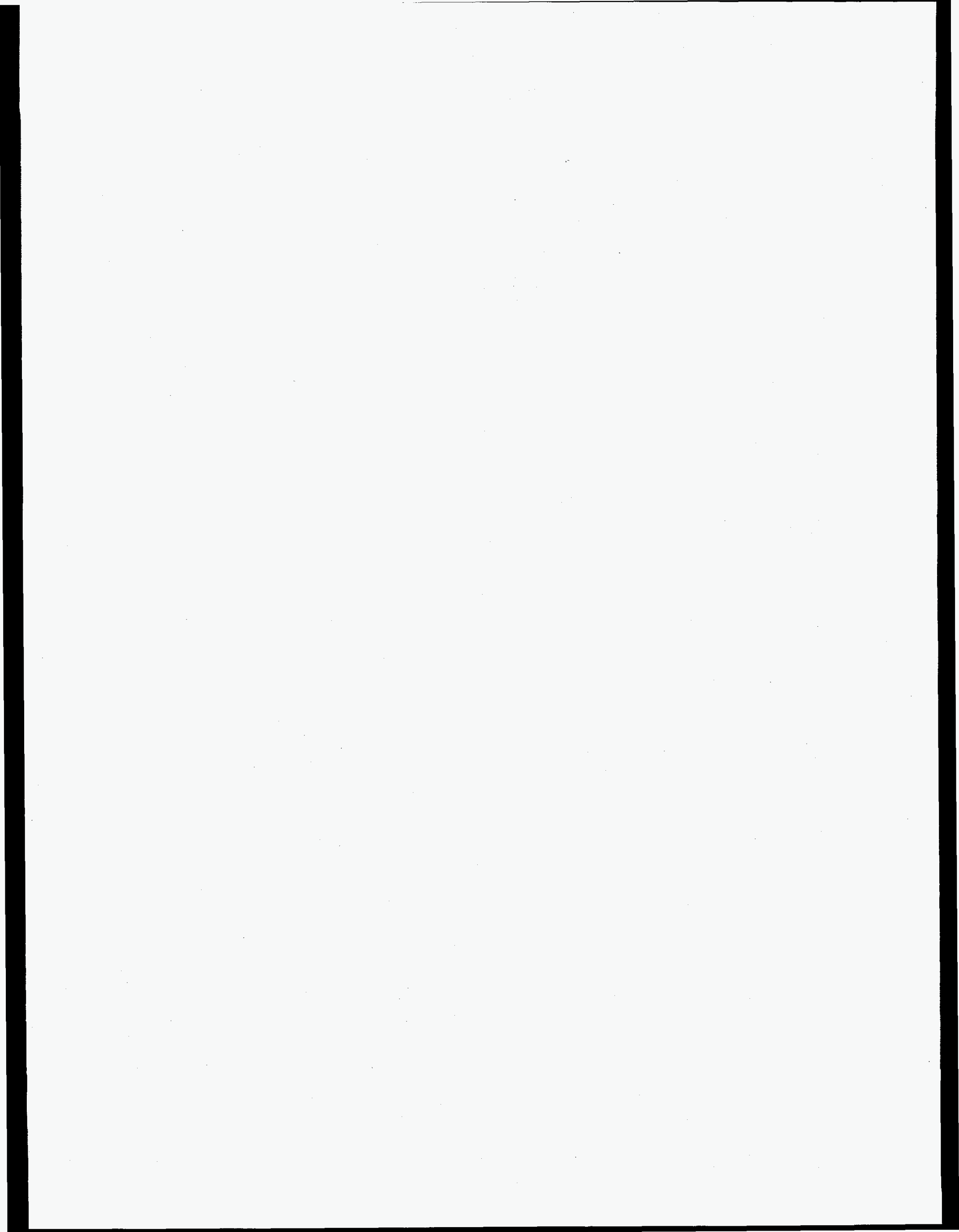




\section{Sampling Location Abbreviations}

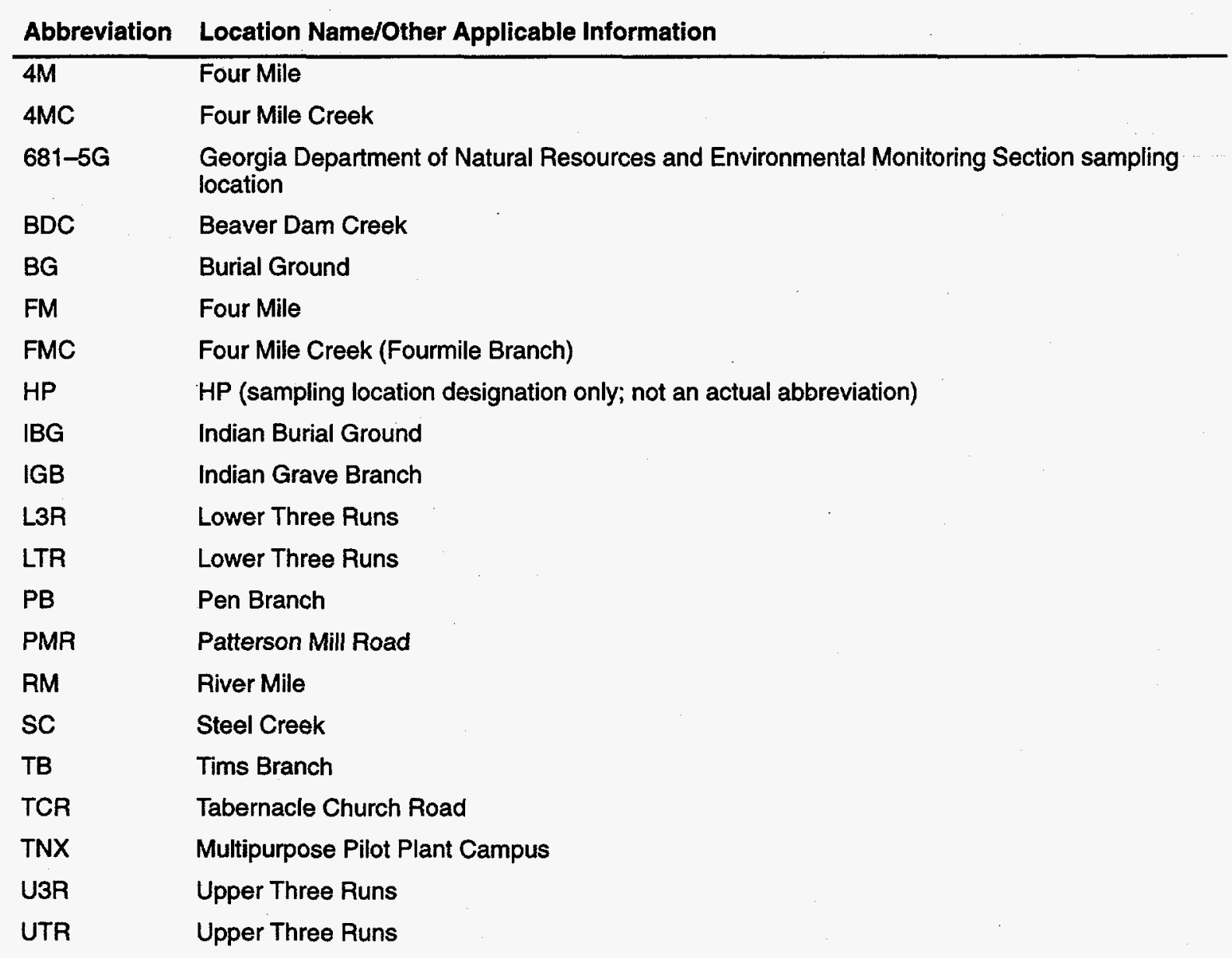

Sample Locations Known By More Than One Abbreviation

Beaver Dam Creek; 400-D

Four Mile Creek-6; FM-6; 4MC-6; Four Mile Creek at Leigh Road

Four Mile Creek at Road A7; FM-A7; 4M-A7

Lower Three Runs-2; L3R-2; L3R Creek and Patterson Mill

River Mile 120; RM-120; River 10; R-10

River Mile 140; RM-140; R-8A

River Mile 160; RM-160; River 2; R-2

Steel Creek-4; SC-4; Steel Creek-4 at Road A; SC and Highway 125

Tinker Creek at Kennedy Pond; TC/KP; TC-1

Upper Three Runs-4 at Road A; U3R-4; U3R-Rd A

Vogtle Discharge; River 3B; R-3B 



\section{Executive Summary}

$\mathrm{T}$ HE mission at the Savannah River Site (SRS) has changed from the production of nuclear weapons materials for national defense to the management of site-generated waste, restoration of the surrounding environment, and the development of industry in and around the site. However, SRSthrough its prime operating contractor, Westinghouse Savannah River Company (WSRC) - continues to maintain a comprehensive environmental monitoring program.

In 1996, effluent monitoring and environmental surveillance were conducted within a

31,000-square-mile area in and around SRS that includes neighboring cities, towns, and counties in Georgia and South Carolina and extends up to 100 miles from the site. Though the environmental monitoring program was streamlined in 1996-to improve its cost-effectiveness without compromising data quality or reducing its overall ability to produce critical information-thousands of samples of air, surface water, groundwater, food products, drinking water, wildlife, rainwater, soil, sediment, and vegetation were collected and analyzed for radioactive and nonradioactive contaminants.

\section{Potential Radiation Doses}

Table 1 shows the 1996 potential radiation doses from SRS releases compared with the applicable federal dose standards and with estimated doses from naturally occurring background radiation. Materials released from SRS reach the environment and people in a variety of ways. The routes that materials follow to get from an SRS facility to the environment and then to people are called exposure pathways. All potential radiation doses attributed to SRS in 1996 were below applicable regulatory standards.

\section{Potential Liquid Pathway Dose}

The potential dose to the maximally exposed individual from liquid releases of radioactivity to the Savannah River was estimated to be $0.14 \mathrm{mrem}$ $(0.0014 \mathrm{mSv})$, which was the same as the 1995 maximum potential dose. The dose remained the same-even though the amount of tritium oxide released from SRS during 1996 was about 21 percent less than during $1995(8,950 \mathrm{Ci}$ in 1996 versus $11,400 \mathrm{Ci}$ in 1995) - because of decreased dilution in the Savannah River due to a 10-percent increase in river flow during 1996.
Approximately 43 percent of this potential dose resulted from the ingestion of cesium-137 in Savannah River fish, and about 41 percent resulted from the ingestion (via drinking river water) of tritium oxide.

The 1996 collective dose from liquid releases was estimated to be 2.2 person-rem ( 0.022 person-Sv).

\section{Potential Drinking Water Pathway Dose}

Offsite doses were calculated for persons consuming drinking water from two water treatment plants located downriver of SRS near Beaufort, South Carolina, and Port Wentworth, Georgia. The maximum doses were $0.06 \mathrm{mrem}(0.0006 \mathrm{mSv})$ at Beaufort and at Port Wentworth. These doses are 1.5 percent of the drinking water standard of $4 \mathrm{mrem}$ per year $(0.04 \mathrm{mSv}$ per year). Tritium oxide in the drinking water represents about 74 percent of the dose.

\section{Potential Airborne Pathway Dose}

For 1996, the potential dose to the maximally exposed individual from airborne releases of radioactive materials was $0.05 \mathrm{mrem}(0.0005 \mathrm{mSv})$. This dose is 0.5 percent of the 10 -mrem per year (0.1-mSv per year) limit for exposure to airborne releases from a U.S. Department of Energy (DOE) facility. The 1996 dose was approximately 17 percent lower than the 1995 dose of 0.06 mrem $(0.0006 \mathrm{mSv})$-primarily because of a 26 -percent decrease in tritium oxide releases from 1995 to 1996.

Tritium oxide comprised approximately 68 percent of the potential airborne pathway dose.

The collective dose (population dose) to the 620,100 persons living within 80 kilometers ( 50 miles) of the center of the site was estimated to be 2.8 person-rem $(0.028$ person-Sv), which is less than 0.01 percent of the collective dose received from naturally occurring sources of radiation (about 186,000 person-rem).

\section{Potential All-Pathway Dose}

To demonstrate compliance with the DOE Order 5400.5 all-pathway dose standard of $100 \mathrm{mrem}$ per year $(1.0 \mathrm{mSv}$ per year), SRS conservatively combines the maximally exposed individual airborne pathway and liquid pathway dose estimates, even though the two doses are calculated for hypothetical individuals residing at different geographic locations. 
Table 11996 Potential Radiation Doses from SRS Releases Compared with Applicable Dose Standards and Estimated Doses from Naturally Occurring Radiation

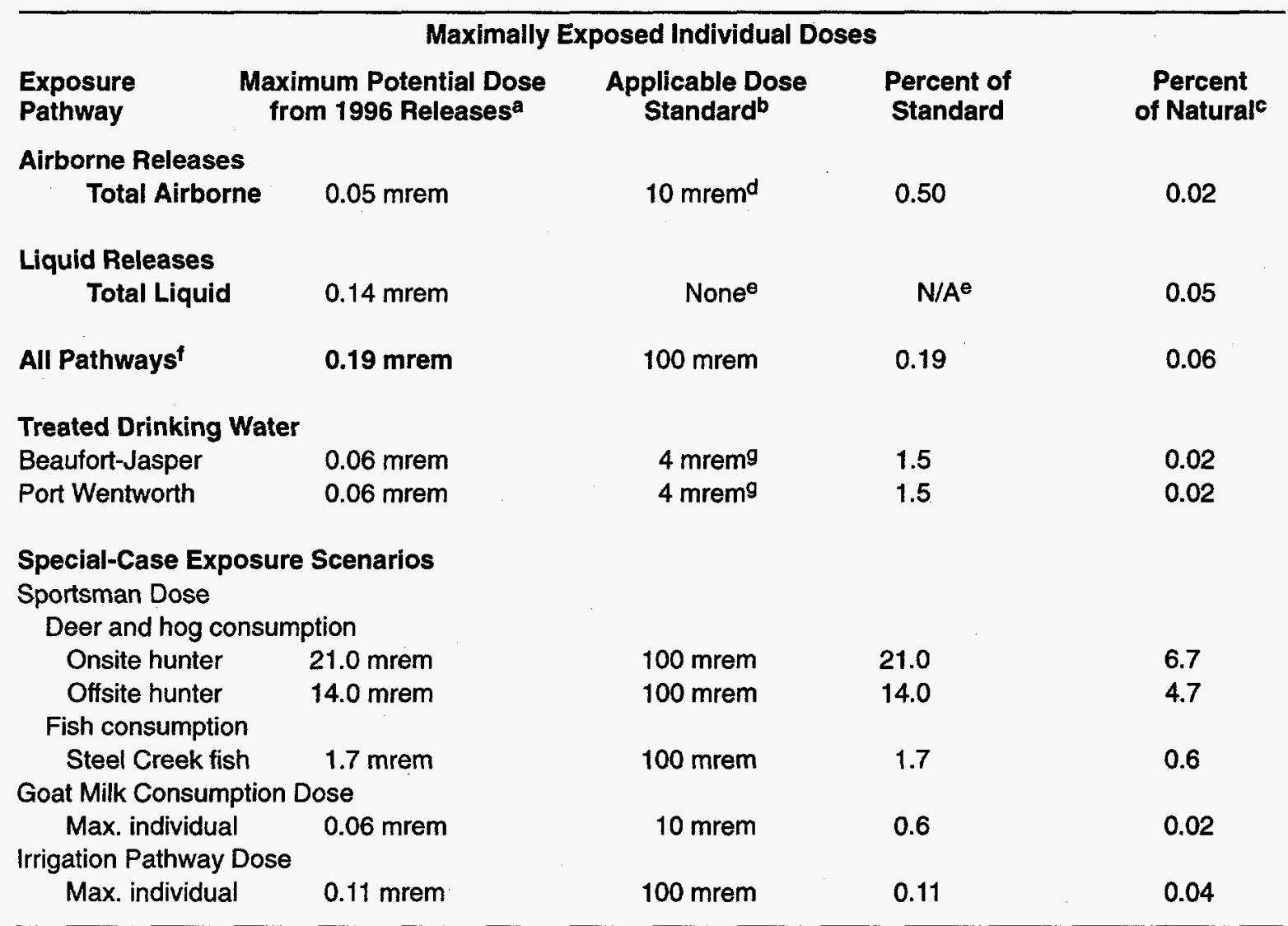

Population (Collective) Doses

$\begin{array}{lcccc}\begin{array}{l}\text { Exposure } \\ \text { Pathway }\end{array} \begin{array}{c}\text { Maximum Potential Dose } \\ \text { from 1996 Releases }\end{array} & \begin{array}{c}\text { Applicable Dose } \\ \text { Standard }^{\mathbf{b}}\end{array} & \begin{array}{c}\text { Percent of } \\ \text { Standard }\end{array} & \begin{array}{c}\text { Percent } \\ \text { of Naturalc }\end{array} \\ \begin{array}{c}\text { Airborne Releases } \\ \text { Total Airborne }\end{array} & 2.8 \text { person-rem } & \text { None }^{e} & \text { N/A } & 0.01 \\ \begin{array}{c}\text { Liquid Releases } \\ \text { Total Liquid }\end{array} & 2.2 \text { person-rem } & \text { None } & \text { N/A } & 0.01\end{array}$

a Committed effective dose equivalent.

b All the standards listed are given in DOE Order 5400.5, February 8, 1990, "Radiation Protection of the Public and the Environment."

c Estimate of average dose received from naturally occurring radiation is 300 mrem per year [NCRP, 1987]. The population (collective) dose due to naturally occurring radiation is estimated to be about 186,000 person-rem.

d The standard for airborne effluents applies to the sum of the doses from all airborne pathways: inhalation, submersion in a plume, exposure to radionuclides deposited on the ground surface, and consumption of foods contaminated as a result of the deposition of radionuclides.

e There is no separate standard for population dose or for all liquid pathways alone; liquid releases are included in the 100-mrem standard for all pathways.

$f$ The total airborne and liquid exposure pathways are added in order to compare maximum calculated doses from SRS releases with the DOE "all pathways" standard. This total includes the maximum airborne pathway dose of $0.05 \mathrm{mrem}$ $(0.0005 \mathrm{mSv})$ and the maximum liquid pathway dose of $0.14 \mathrm{mrem}(0.0014 \mathrm{mSv})$.

g The drinking water standard applies to public drinking water systems and to drinking water supplies operated by DOE or DOE contractors. 


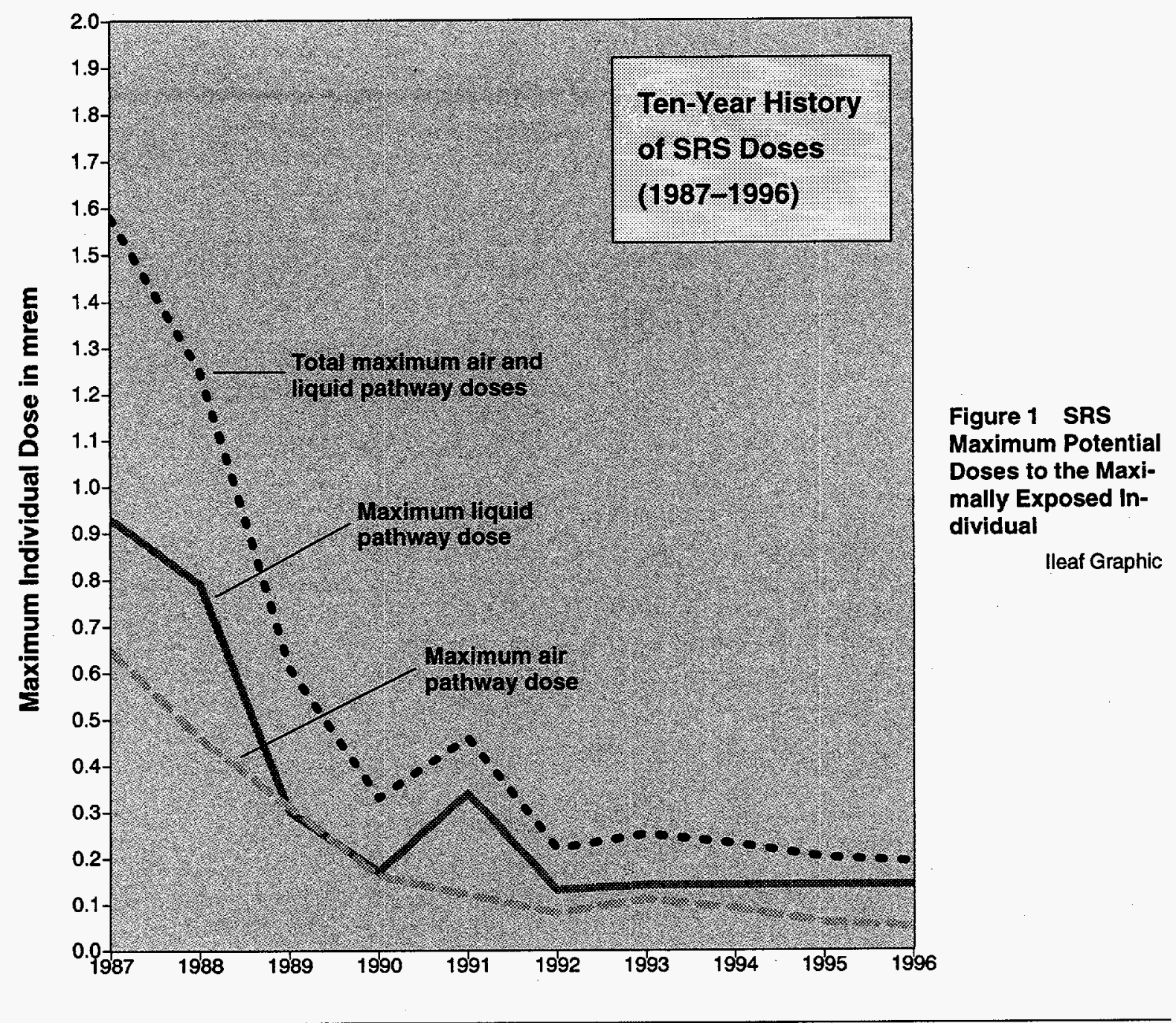

For 1996, the potential maximally exposed individual all-pathway dose was $0.19 \mathrm{mrem}(0.0019 \mathrm{mSv})$ ( $0.05 \mathrm{mrem}$ from airborne pathway plus $0.14 \mathrm{mrem}$ from liquid pathway). This dose is about 5 percent lower than the 1995 all-pathway dose of $0.20 \mathrm{mrem}$ $(0.0020 \mathrm{mSv})$, mainly because of the decrease in atmospheric tritium oxide releases during 1996. A history (since 1983) of SRS maximum potential all-pathway doses to the maximally exposed individual is depicted in figure 1.

\section{Potential Sportsman Dose}

In 1996, the maximum potential dose to an actual onsite hunter was $21 \mathrm{mrem}(0.21 \mathrm{mSv})$, which is 21 percent of DOE's 100 -mrem all-pathway dose standard. During the onsite deer hunts, this individual harvested 6 animals-the edible portion totaled about 111 kilograms (245 pounds) - and was assumed to have eaten all the meat himself.
If a hypothetical offsite hunter living near the site boundary consumed $81 \mathrm{~kg}$ (179 pounds) of meat-the annual maximum adult consumption rate for meat-taken from deer living on site prior to being harvested, the individual's maximum dose could have been $14 \mathrm{mrem}(0.14 \mathrm{mSv})$. This dose was based on the gross average concentration of cesium-137 $(4.5 \mathrm{pCi} / \mathrm{g})$ measured in animals harvested at SRS during 1996.

The potential maximum dose for a recreational fisherman was based on the consumption of $19 \mathrm{~kg}$ (42 pounds)-the maximum adult consumption rate for fish - of Savannah River fish having the highest measured concentrations of radionuclides. In 1996, bass caught at the mouth of Steel Creek had the highest concentrations. Consumption of these bass could have resulted in a dose of $1.7 \mathrm{mrem}$ (0.017 mSv). 


\section{Compliance Activities}

A major goal at SRS continues to be positive environmental stewardship and full regulatory compliance, with zero violations. The site's employees maintained progress toward achievement of this goal in 1996, as a vast majority of their efforts were successful. For example, under the Clean Water Act (CWA), the site's National Pollutant Discharge Elimination System (NPDES) compliance rate was 99.8 percent, and under the Clean Air Act (CAA), the compliance rate was 100 percent.

Compliance with environmental regulations and with DOE orders related to environmental protection is an integral part of the operations at SRS. Management of the environmental programs at SRS is a significant activity, and assurance that onsite processes do not impact the environment adversely is a top priority. All site activities are overseen by one or more regulatory agencies, including the U.S.

Environmental Protection Agency (EPA) and the South Carolina Department of Health and Environmental Control (SCDHEC).

A systematic effort is in place to identify and address all evolving regulatory responsibilities that concern SRS. As part of the process, communications are maintained with all appropriate regulatory agencies to emphasize the site's commitment to environmental compliance. SRS did not receive a Notice of Violation (NOV) from SCDHEC in 1996.

SRS operations in 1996 continued to involve a wide variety of processes and chemicals subject to compliance with an increasing number of environmental statutes, regulations, policies, and permits. (For example, SRS had 668 construction and operating permits in 1996 that specified operating levels for each permitted source.) Compliance with all requirements helps to ensure that the site, the public, and the surrounding environment are protected from adverse effects that could result from SRS operations. This section offers an overview of some of the environmental compliance issues with which the site was involved during 1996.

\section{High-Level Waste Tank Closure}

The mission of SRS high-level waste tank closure at the F-Area and H-Area tank systems is to close out tanks in a way that ensures protection of human health and the environment, and in a technically and economically prudent manner. The "Industrial Wastewater Closure Plan for F- and H-Area High-Level Waste Tanks" outlines the SRS/regulator protocol for closing all 51 high-level waste tanks on site. An Environmental Assessment (EA), which resulted in a Finding of No Significant Impact (FONSI), was issued in July 1996 to fulfill National Environmental Policy Act (NEPA) requirements for the closure action. EPA and SCDHEC approved the closure plan July 23 and July 31 , respectively.

Tank-specific closure modules will be developed for each tank system. These modules apply the general closure methodology to a specific tank system.

Modules are being drafted for the first two tanks to be closed (17F and 20F). Closure of these two tanks will involve filling them; a layer of reducing grout will be topped with controlled, low-strength material. Field work, already begun for the closure of the two tanks, should be completed in 1997.

\section{National Pollutant Discharge Elimination System}

The CWA created the NPDES program, which is regulated by SCDHEC under EPA authority. The program is designed to protect surface waters by limiting all nonradiological releases of effluents into streams, reservoirs, and other wetlands. (Radiological effluents are covered under other acts.) Discharge limits are set for each facility to ensure that SRS operations do not impact aquatic life adversely or degrade water quality.

SCDHEC issued SRS a new NPDES permit August 6,1996 to replace the expired but administratively extended SC0000175 and SC0044903 permits. The new permit recognizes 37 active outfalls and requires the analysis each year of approximately 5,800 parameters to demonstrate compliance. All monitoring was reported to SCDHEC in the monthly Discharge Monitoring Reports, as required by the permit [SRS Data, 1997].

\section{CAA - Title V Operating Program}

The CAA provides the basis for protecting and maintaining air quality. Some types of SRS air emissions, such as radioactive sources and ozone-depleting substances (ODS), are regulated by EPA, but most are regulated by SCDHEC, which must ensure that its air pollution regulations are at least as stringent as the CAA's. This is accomplished through SCDHEC Regulation 61-62, "Air Pollution Control Regulations and Standards."

The primary purpose of the Title $\mathrm{V}$ permitting program is to establish federally enforceable operating permits for major sources of air emissions. The implementation plan for this program, submitted to EPA in 1993 by the State of South Carolina and subsequently approved by EPA in June 1995 , required that $S R S$ submit an extensive application 


\section{Curies}

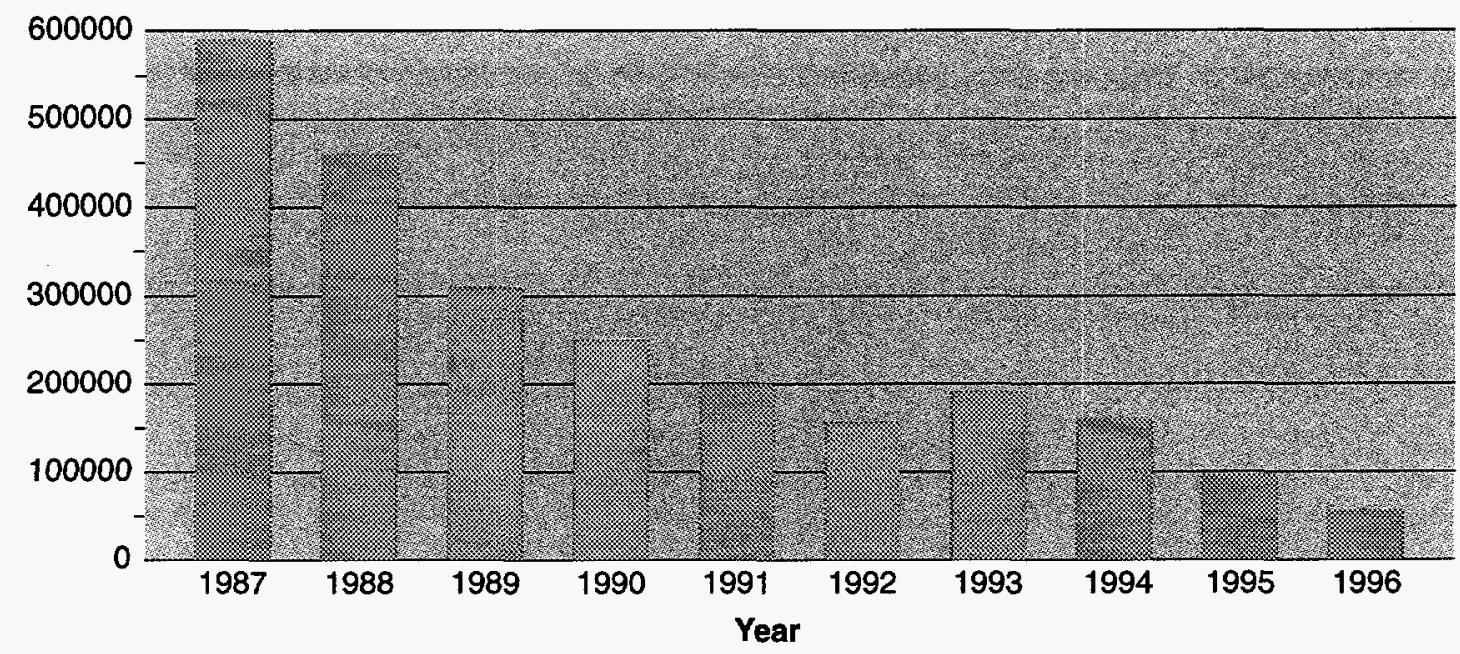

lleaf Graphic

Figure 2 Ten-Year History of SRS Annual Atmospheric Tritium Releases

package for air emission sources at the site by March 15, 1996; SRS submitted the Title V permit application before the deadline.

\section{CAA - NESHAP Asbestos Removal Program}

The site implemented an asbestos removal program in 1988. Asbestos is removed during maintenance and renovations of equipment and buildings. During 1996, SRS removed 12,547 square feet of transite panel, which contains asbestos. Also removed were 4,283 linear feet and 2,481 square feet of asbestos pipe and surface insulation. This compares with 9,253 square feet of transite panel and 3,486 linear feet and 1,678 square feet of asbestos pipe and surface insulation removed during 1995. Estimates of the percentage of total friable asbestos (a form that can be crumbled or pulverized with hand pressure when dry) removed from SRS cannot be accurately determined because it is not known exactly how much exists on site. SRS will continue to identify and remove such asbestos according to state (SCDHEC R.61-86.1) and federal (40 CFR 61, Subpart M) regulations and "best management practices."

\section{Radiological Effluent Monitoring}

During 1996, SRS collected and analyzed more than 4,400 effluent samples to quantify radiological releases to the environment from site operations. Tritium again was the major contributor to air and liquid releases, accounting for more than 90 percent of the total radioactivity released in 1996.

\section{Airborne Emissions}

Tritium was the primary radionuclide released to the atmosphere in 1996; approximately 55,700 curies $(2.1 \mathrm{E}+15 \mathrm{~Bq})$ were released. This compares with $96,700 \mathrm{Ci}(3.6 \mathrm{E}+15 \mathrm{~Bq})$ released in 1995 . The sharp (42 percent) decrease is attributed to (1) reduced throughput in the tritium facilities and (2) continued improvement in operations at the Replacement Tritium Facility (RTF). Figure 2 shows a 10-year history (1987-1996) of SRS tritium releases.

\section{Liquid Discharges}

Tritium constitutes more than 99 percent of the radioactivity released to the Savannah River from direct, seepage basin, and Solid Waste Disposal Facility (SWDF) migration discharges. In 1996, about 7,560 $\mathrm{Ci}(2.8 \mathrm{E}+14 \mathrm{~Bq})$ of tritium was released in liquid discharges from SRS, based on point-of-release concentrations and flow rates, compared to about $9,900 \mathrm{Ci}(3.7 \mathrm{E}+14 \mathrm{~Bq})$ in 1995 . The total amount of tritium released directly from process areas (i.e., reactor, separations, heavy water rework) to site streams during 1996 was $950 \mathrm{Ci}$ $(3.5 \mathrm{E}+13 \mathrm{~Bq})$, which was 29 percent less than the 1995 total of $1,340 \mathrm{Ci}(5.0 \mathrm{E}+13 \mathrm{~Bq})$.

\section{Radiological Environmental Surveillance}

The radiological environmental surveillance program at SRS surveys and quantifies any effects routine and nonroutine operations may have had on the site, the surrounding area, and those populations living in or 
near the site. Sampled media include air, seepage basins, site streams, the Savannah River, drinking water, rainwater, sediment, soil, vegetation, food products, fish, deer, hogs, turkeys, and beavers.

In 1996, approximately 10,000 radiological analyses were performed on approximately 5,000 samples, and measurements of gamma radiation levels were made at 131 locations on and off site. Activity levels generally were consistent with 1995 levels.

Radionuclide activity levels, such as tritium, cesium, and strontium, were at or slightly above their nominal lower limits of detection (LLD) and were consistent with observed historical levels in sampled media. In air and surface water, some onsite activity levels were, as expected, slightly higher than observed in offsite media. Because of production slowdown, most tritium transport in site streams, which has been decreasing in recent years, was attributed to contaminated groundwater-from retired seepage basins—outcropping at stream banks. No samples collected exceeded EPA drinking water standards.

As part of an overall comprehensive review of the environmental monitoring program, a number of changes were implemented during 1996, including reductions in radiological environmental surveillance programs covering ambient gamma, soil, vegetation, and water.

\section{Nonradiological Effluent Monitoring}

Nonradioactive airborne emissions of sulfur dioxide, oxides of nitrogen, carbon monoxide, and total particulate matter less than 10 microns released from SRS stacks were within applicable (SCDHEC) standards.

SRS maintained its NPDES compliance rating for liquid releases above 99 percent for the 11th straight year. Results from only 14 of the 5,737 analyses performed in 1996 exceeded permit limits. This resulted in a compliance rating of 99.8 percent-higher than the DOE-mandated rate of 98 percent.

\section{Nonradiological Environmental Surveillance}

The nonradiological environmental surveillance program at SRS involves sampling and analyzing surface waters (site streams and the Savannah River), drinking water, sediment, groundwater, and fish. In 1996 , more than 8,600 analyses for specific chemicals and metals were performed on more than 1,800 samples, not including groundwater.

The 1996 water quality data showed normal fluctuations expected for surface water. Comparison of the 1996 data with published historical data for site surface water monitoring did not indicate any abnormal deviations from past monitoring data. Analysis for pesticides, herbicides, and volatile organic compounds yielded positive results for a pesticide (dieldrin) at one location (Four Mile Creek-A7). All other analyses results were below the LLD. Coliform analysis results exceeded recommended standards 20 times in 1996 (17 in site streams and 3 in the river). The 20 exceedances represented a decrease from 1995, when site streams analysis results exceeded guides 36 times and river analysis results exceeded guides 13 times.

All SRS drinking water systems complied with SCDHEC chemical, bacteriological, lead and copper, chemical, synthetic organic, and volatile organic water quality standards in 1996.

In Savannah River and site stream sediment samples, no pesticides or herbicides were found to be above the practical quantitation limits in 1996. All sample results were below the LLD of the EPA analytical procedures used.

The mercury concentrations in fish analyzed from onsite waters ranged from a high of $1.70 \mu \mathrm{g} \mathrm{Hg} / \mathrm{g}$ in PAR Pond and Pond B bass to lows below the LLD at several locations. Mercury concentrations in offsite fish ranged from a high of $1.67 \mu \mathrm{g} \mathrm{Hg} / \mathrm{g}$ in a bass from the Stokes Bluff Landing area to lows below the LLD at several locations.

\section{Groundwater}

SRS monitors groundwater for radioactive and nonradioactive constituents to identify contamination that may have occurred because of site operations. Groundwater beneath 5 to 10 percent of the site has been contaminated by industrial solvents, tritium, metals, or other constituents used or generated by SRS operations. This report describes groundwater monitoring results for approximately 1,600 wells in 101 locations within designated areas at SRS. In 1996, approximately 49,000 radiological analyses and 328,000 nonradiolugical analyses were performed on groundwater samples.

Eight new sites were monitored during the year, and additional wells were installed at several more sites to improve detection monitoring and plume definition. Also, numerous wells were abandoned to accommodate closure activities in and around the 
Sanitary Landfill and the F-Area, H-Area, K-Area, and P-Area acid/caustic basins.

\section{Special Surveys}

\section{Savannah River Swamp}

During the 1960s, an area of the Savannah River Swamp was contaminated with approximately $25 \mathrm{Ci}$ of cesium- 137 and $1 \mathrm{Ci}$ of cobalt-60. The contamination resulted from failed fuel elements that leaked radioactivity into the P-Area storage basin; occasionally, this water was discharged to Steel Creek. Periodic radiological surveys of the swamp have been conducted since 1974 to characterize the amount and movement of this activity. A comprehensive survey scheduled for 1995 was delayed until 1996 because of safety concerns resulting from high water levels in the swamp.

The survey's results generally followed trends noted in previous surveys. Some changes with time in the spatial distribution of activity throughout the swamp were observed, which indicates the possibility of some localized movement of activity. However, results from sampling trails located at the downstream end of the swamp have changed little, indicating that activity is not migrating out of the identified contaminated area. Overall, the results show that, although some spatial and vertical migration of activity may be occurring, the activity has remained in the swamp area.

\section{Academy of Natural Sciences of Philadelphia River Quality Surveys}

The Environmental Research Division of the Academy of Natural Sciences of Philadelphia (ANSP) has been conducting biological and water quality surveys of the Savannah River since 1951. These surveys are designed to assess potential effects of SRS contaminants and warm water discharges on the general health of the river and its tributaries.

Results of the 1996 ANSP studies on the Savannah River have been delayed pending finalization of a new contract based on recommendations of the 1996 "Rock Hill Initiative \#2" review. It is expected that results of analyses of the 1996 data will be compiled after the new contract is placed-and that both 1996 and 1997 results will be reported in the SRS Environmental Report for 1997. 


\section{Chapter 1 \\ Introduction}

\author{
Margaret Arnett \\ Environmental Protection Department
}

To Read About ... . See Page ...

Site History . . . . . . . . . . . . . . . . . . . 1

Site Locale ...................... 1

Site Mission ......................4 4

Site Areas and Operations........... 5
$\mathrm{T}$ HE Savannah River Site (SRS), one of several facilities in the U.S. Department of Energy (DOE) complex, encompasses approximately 310 square miles in South Carolina, adjacent to the Savannah River.

The site was established by the U.S. Atomic Energy Commission (AEC) in 1950 to produce plutonium and tritium for national defense and additional special nuclear materials for other government uses and for civilian purposes. Production of these materials continued for more than 40 years, and the site became an integral financial and cultural part of the surrounding area and the state of South Carolina.

When the Cold War ended in 1991, DOE responded to changing world conditions and national policies by refocusing its missions. The site's priorities shifted toward waste management, environmental restoration, technology transfer, and economic development.

This chapter includes general information on the site's history; location, demographics, and environmental setting; mission; and areas and operations.

\section{Site History}

Responding to a 1950 directive from President Harry S. Truman to the AEC, E.I. du Pont de Nemours and Company and the commission negotiated a contract whereby Du Pont would design, construct, and operate what was to become the Savannah River Plant (SRP).

On November 22 of that year, the AEC approved the present site and purchased the land for approximately $\$ 19$ million. By February 1, 1951, construction had begun. The first facility to begin operating, the heavy water plant, started up August 17, 1952, and the first of five production reactors achieved criticality December 28, 1953. All five reactors had achieved criticality by March 1955. [Bebbington, 1990].

Until it was disbanded by the Energy Reorganization Act of 1974, the AEC oversaw and regulated site activities. In 1975, its functions were transferred to two newly established agencies: the Energy Research and Development Administration, overseeing government operations, and the Nuclear Regulatory Commission, overseeing commercial operations. By 1977, the Energy Research and Development Administration had evolved into DOE, which has overseen all facility activities since that time.

Du Pont operated SRP until March 31, 1989. On April 1, 1989, Westinghouse Savannah River Company (WSRC) became the prime operating contractor, and SRP became SRS.

Beginning October 1, 1996, the site was operated under a new contract by an integrated team led by WSRC. Under this contract, WSRC is responsible for the site's nuclear facility operations; Savannah River Technology Center (SRTC; more about SRTC can be found on page 9); environment, safety, health, and quality assurance; and all the site's administrative functions. Bechtel Savannah River, Inc. (whose parent company is Bechtel National, Inc.) is responsible for environmental restoration, project management, engineering, and construction activities. Babcock \& Wilcox Savannah River Company (whose parent company is Babcock \& Wilcox Government Group) is responsible for facility decontamination and decommissioning, and British Nuclear Fuels Savannah River Corporation (whose parent company is British Nuclear Fuels, Inc.) is responsible for the site's solid waste program [Fact Sheet, 1996a]. Wackenhut Services, Inc., provides security support services for SRS.

\section{Site Locale}

In 1950, the site was selected by applying the criteria developed to select the most suitable location in the country to carry out President Truman's directive:

- a large land area for safety and security

- a buffer zone large enough to provide land around each operating facility for protection of human health and the environment

- land somewhat isolated yet near communities that could handle construction and operations personnel

- access to adequate transportation 
- land not subject to floods and major storms

- the availability of millions of gallons of water, low in mineral content, for cooling and process use

- $\quad$ suitable terrain and topography

Du Pont, the AEC, and the U.S. Army Corps of Engineers considered 114 sites in 18 states before recommending the current site, which met all the established criteria.

\section{Location}

SRS covers 198,344 acres in Aiken, Allendale, and Barnwell counties of South Carolina and borders the Savannah River. The site is approximately 25 miles southeast of Augusta, Georgia, and 12 miles south of Aiken, South Carolina (figure 1-1 ). The average population density in the counties surrounding SRS is 85 people per square mile, with the largest concentration in the Augusta metropolitan area. Based on 1990 U.S. Census Bureau data, the population within a 50 -mile radius of SRS is approximately 620,100 .

About 70 percent of the site's employees live in South Carolina-primarily Aiken County-and 30 percent in Georgia.

SRS is included in the Central Savannah River Area, which is comprised of 18 counties surrounding Augusta. The counties are Aiken, Edgefield, Allendale, Barnwell, and McCormick in South Carolina and Richmond, Columbia, McDuffie, Burke, Emanuel, Glascock, Jenkins, Jefferson, Lincoln, Screven, Taliaferro, Warren, and Wilkes in Georgia.

mpicat aninate at sis

- Summer

Hot and hume

remperathes reach upper 90 s ( $\mathrm{C}$ )

33 percent ot annual rainall

1. Fall

Cool mornings, wam atternoons

Temporalures range rom $501076 . \mathrm{F}$

19 percent of annuaj rainall

U. $110 \mathrm{le}$

Wid, lasting November through March

Temperatures romally above 32 .

21 percent or annual rainall

3. 3.9119

Most Variable, colisnap often in Warch

Temperatures average $65 \%$

27 percent of annual rainfall
Various industrial, manufacturing, medical, and farming operations are conducted near the site. Major industrial and manufacturing facilities in the area include textile mills, polystyrene foam and paper products plants, chemical processing facilities, and a commercial nuclear power plant. Farming is diversified and includes crops such as cotton, soybeans, corn, and small grains.

\section{Climate}

SRS has a relatively mild climate, with an average frost-free season of approximately 246 days. The average annual rainfall, about 48 inches, is fairly evenly distributed throughout the year. There is no strong prevailing wind direction; however, there is a relatively high frequency of east-through-northeast winds during the summer and fall and of south-through-northwest winds during the late fall, winter, and spring [Hunter, 1990]. Except for the Savannah River, no unusual topographic features significantly influence the general climate.

\section{Geology and Hydrology}

SRS is on the Upper Coastal Plain of South Carolina. Coastal Plain deposits at SRS consist of 500 to 1,400 feet of sands, clays, and limestones of Tertiary and Cretaceous age. These sediments are underlain by sandstones of Triassic age and by older metamorphic and igneous rocks.

The sandy sediments of the Coastal Plain contain several productive aquifers, separated by clay-rich units, that drain into the Savannah River, its tributaries, and the Savannah River Swamp. The older, underlying rocks are nearly impermeable and are not a major water source.

\section{Water Resources}

SRS, bounded on its southwestern border by the Savannah River for about 35 river miles (as measured from the upriver boundary of the site, near Jackson, South Carolina, to the Lower Three Runs Creek corridor), is approximately 160 river miles from the Atlantic Ocean. Five major SRS streams feed into the river: Upper Three Runs Creek, Four Mile Creek (also referred to as Fourmile Branch), Pen Branch, Steel Creek, and Lower Three Runs Creek. These streams, which receive effluents from various onsite operations, are not commercial water sources.

The two main bodies of water on site, PAR Pond and L-Lake, are manmade. PAR Pond, constructed in 1958 to provide cooling water for P-Reactor and R-Reactor (hence the name PAR Pond), covers 2,640 acres and is approximately 60 feet deep. The 1,000-acre L-Lake was constructed in 1985 to receive heated cooling water from L-Reactor. 


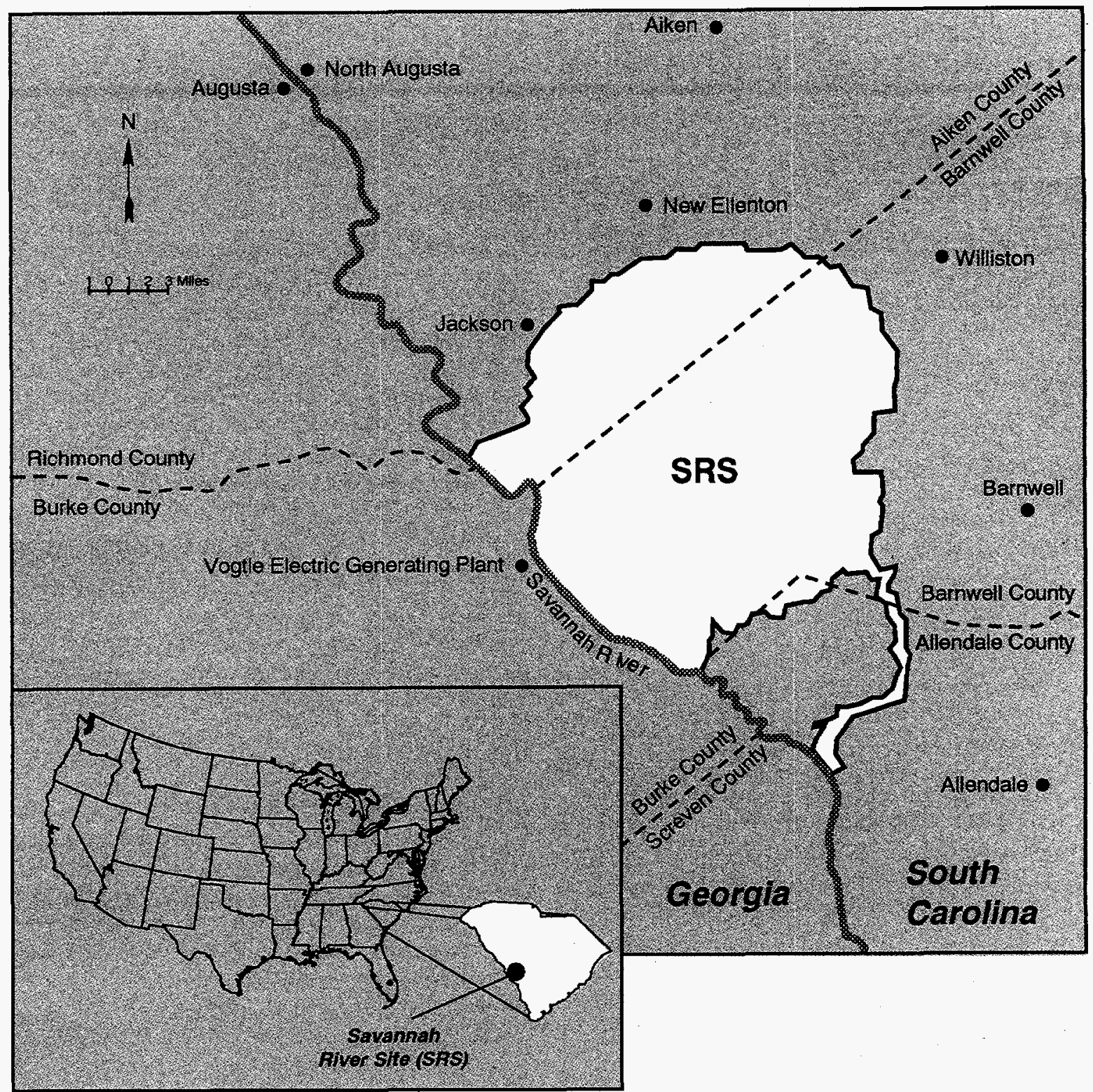

94X06608.06.AlL

Figure 1-1 Regional Location of SRS

SRS is about 25 miles southeast of Augusta, Georgia, and 12 miles south of Aiken, South Carolina. The site, approximately 310 square miles in area, covers about 1 percent of the state of South Carolina.

The Savannah River is used as a drinking water supply for approximately 56,000 residents downriver of SRS in Port Wentworth, Georgia, and near Beaufort, South Carolina (Beaufort and Jasper counties) [Fledderman, 1995]. The City of Savannah Industrial and Domestic Water Supply Plant intake, at Port Wentworth, is approximately 130 river miles from SRS; the Beaufort-Jasper Water Treatment Plant intake, near Beaufort, is approximately 120 river miles from SRS. The Savannah River also is used for commercial and sport fishing, boating, and other recreational activities. There is no known use of the river for irrigation by farming operations downriver of the site [Hamby, 1991]. SRS uses water from the river for some of its operations.

Approximately 200 Carolina bays exist on SRS, ranging in size from about 0.2 acre to 125 acres. Carolina bays are unique, naturally occurring wetlands found only on the southeastern Coastal Plain. They are elliptical in shape and oriented northwest to southeast along their long axes; their 
origin is unknown. Carolina bays are shallow and may dry up seasonally. At SRS, they provide important habitat and refuge for many plants and animals.

\section{Land Resources}

The SRS region is part of the Southern Bottomland Hardwood Swamp region, which extends south from Virginia to Florida and west along the Gulf of Mexico to the Mississippi River drainage basin. The main features are river swamps, rarely more than 5 miles wide.

\section{Plant and Animal Life}

In 1972, SRS was designated as the first National Environmental Research Park. These parks are used by government and university-related scientists as outdoor laboratories to study the impact of human activity on the environment. This designation has created a unique environment for preserving and studying vegetation and wildlife.

The site provides refuge for approximately 50 endangered, threatened, and sensitive species of plants and animals, such as the red-cockaded woodpecker, the southern bald eagle, the smooth purple coneflower, the Bachman's sparrow, the American alligator, the wood stork, the shortnose sturgeon, and the bog spice bush. Many site research projects are designed to protect and increase the populations of these species.

\section{Vegetation}

Most of the site's environs are rural. Approximately 40 percent of the countryside is forested with longleaf and loblolly pines and sweet gum, maple, birch, and various oak-hickory hardwood trees.
Major plant communities at SRS include cypress-gum and lowland hardwood swamps, sandhills, and old agricultural fields, as well as aquatic and semiaquatic areas. These habitats range from very sandy, dry hilltops to continually flooded swamps.

\section{Wildlife}

SRS is populated with more than 50 species of mammals, including deer, feral hogs (hogs that have reverted to the wild state from domestication), beavers, rabbits, foxes, raccoons, bobcats, river otters, and opossums. In 1952, there were fewer than three dozen white-tailed deer on site. Since then, however, the population has increased dramatically, and the site now is home to several thousand white-tailed deer [SRFS, 1982]. Since 1965, managed public deer hunts have been held annually on site to reduce the number of animal-vehicle accidents and to maintain the health of the herd.

More than 100 species of reptiles and amphibians-including turtles, alligators, lizards, snakes, frogs, and salamanders-and more than 200 species of birds also inhabit the site.

\section{Site Mission}

While the changing world has caused a downsizing of the site's original defense mission, the future of SRS lies in several areas: managing, stabilizing, and treating nuclear materials; continuing to clean up the site and managing the waste it has produced; transferring environmental technology to government and nongovernment entities; and forming economic and industrial alliances [Fact Sheet, 1996a]. Environmental activities related to SRS missions are introduced briefly in the following section.

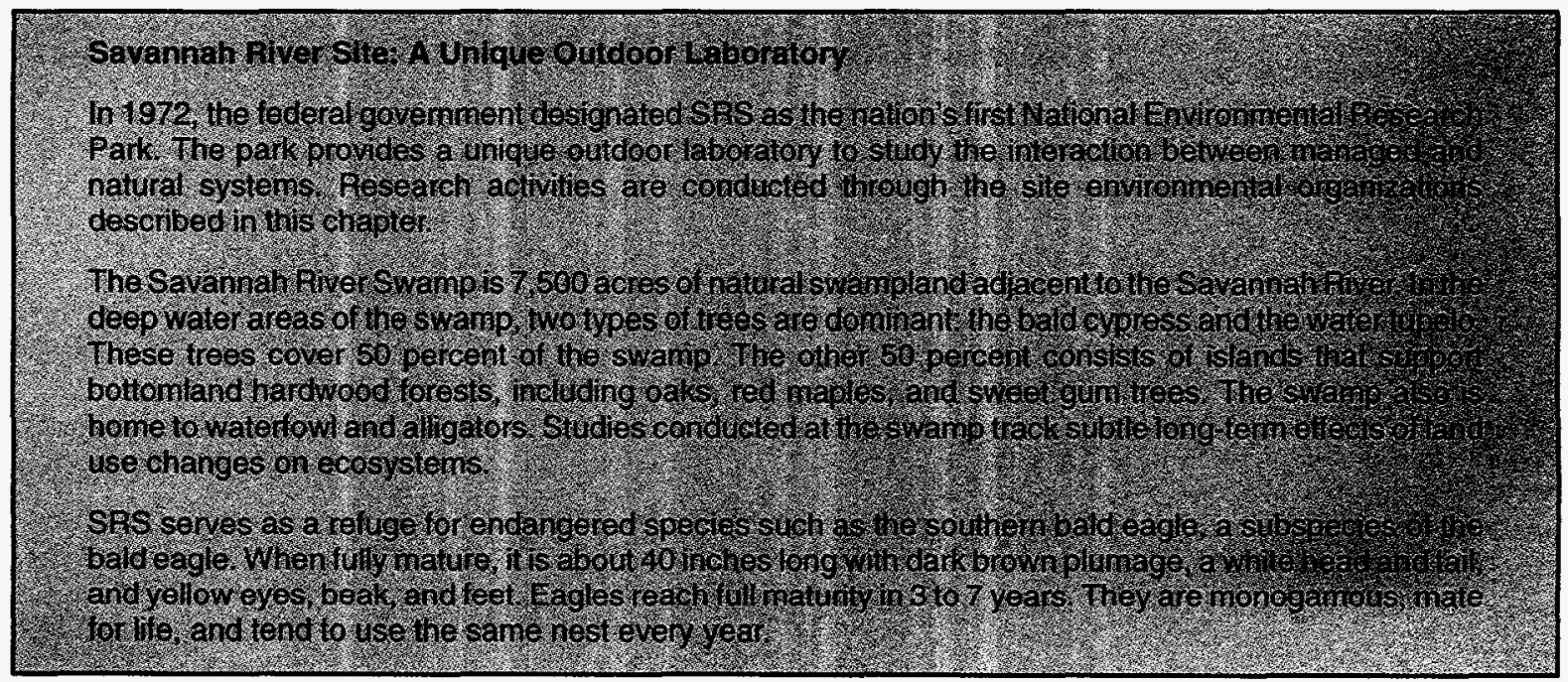




\section{Site Areas and Operations}

SRS was constructed to produce basic materials used in nuclear weapons, primarily tritium and plutonium-239. Five reactors were built to produce these materials by irradiating target materials with neutrons; also built were support facilities, including two chemical separations plants, a heavy water extraction plant, a nuclear fuel and target fabrication facility, and waste management facilities.

The production process began with the manufacture of fuel and target assemblies produced from a variety of nuclear and other materials such as enriched uranium and aluminum. The assemblies were transported to the reactor, where they were loaded into the reactor core and used to produce series of controlled nuclear reactions. During the reaction, neutrons from the fuel bombarded the target assemblies to produce the desired product.

The irradiated target assemblies and spent fuel assemblies then were moved to one of the chemical separations facilities-known as "canyons"-where the desired products were separated and waste products were processed.

After refinement, nuclear materials were shipped to other DOE sites for incorporating into nuclear weapons. SRS produced about 36 metric tons of plutonium from 1953 to 1988 .

SRS has adjusted to meet declining defense requirements. All five reactors are now shut down, a result of the end of the Cold War. However, until fresh supplies of tritium are available, recycling and reloading of tritium to maintain the nation's supply of nuclear weapons is a continuing site mission [Fact Sheet, 1996a].

SRS is divided into several areas, based on production and other functions (figure 1-2):

- reactor materials area $(M)$

- reactor areas (C, K, L, P, and R)

- heavy water reprocessing area (D)

- separations areas $(\mathrm{F}$ and $\mathrm{H})$

- waste management areas $(\mathrm{E}, \mathrm{F}, \mathrm{H}, \mathrm{S}$, and $\mathrm{Z})$

- administration area (A)

- other areas (B, N, G, and TNX)

In addition, environmental activities are conducted by SRTC, the Savannah River Ecology Laboratory (SREL), the Savannah River Forest Station (SRFS), and the Savannah River Archaeological Research Program (SRARP).

\section{Reactor Materials Area}

The reactor materials area (M-Area) consists of a fuel and target fabrication facility, three analytical laboratories, and the Liquid Effluent Treatment Facility (LETF).

The fuel fabrication facility produced fuel and target assemblies to be used in the reactors. Control rods and other reactor components also were manufactured in the facility.

The LETF treated wastewater generated by various M-Area processes and consolidated low-radioactivity residues from $\mathrm{M}$-Area processes for eventual disposal.

\section{Reactor Areas}

Production reactors are in five areas: $\mathrm{C}, \mathrm{K}, \mathrm{L}, \mathrm{P}$, and $R$. Each area houses one of the site's five heavy water reactors. The basis for the design of the reactors was derived in large part from experience and data generated at the Argonne National Laboratory in Argonne, Illinois. Argonne was the focal point for heavy water reactor research and development, and the facility had built and operated two such reactors by 1950 [Bebbington, 1990].

All five production reactors, (R-Reactor, P-Reactor, L-Reactor, K-Reactor, and C-Reactor) have been placed in cold shutdown.Although the areas are being used, as for moderator and fuel storage, no effort is being expended to maintain reactors.

R-Reactor went critical in December 1953 and has been permanently shut down because of reduced production demands.

P-Reactor was started in February 1954 and was shut down in August 1988 for maintenance. In February 1991, it was placed in cold standby and was to be used to provide spare parts for L-Reactor and $\mathrm{K}$-Reactor. P-Reactor has been permanently shut down.

L-Reactor went critical in August 1954 and was placed in cold standby in 1968. It was restarted in October 1985, after upgrading, and shut down for maintenance and safety upgrades in August 1988. It was placed in warm standby in December 1991 to be put into operation as a backup to K-Reactor, if necessary, but since has been permanently shut down.

C-Reactor went critical in March 1955 and was shut down in 1985 for maintenance. It was placed in cold 


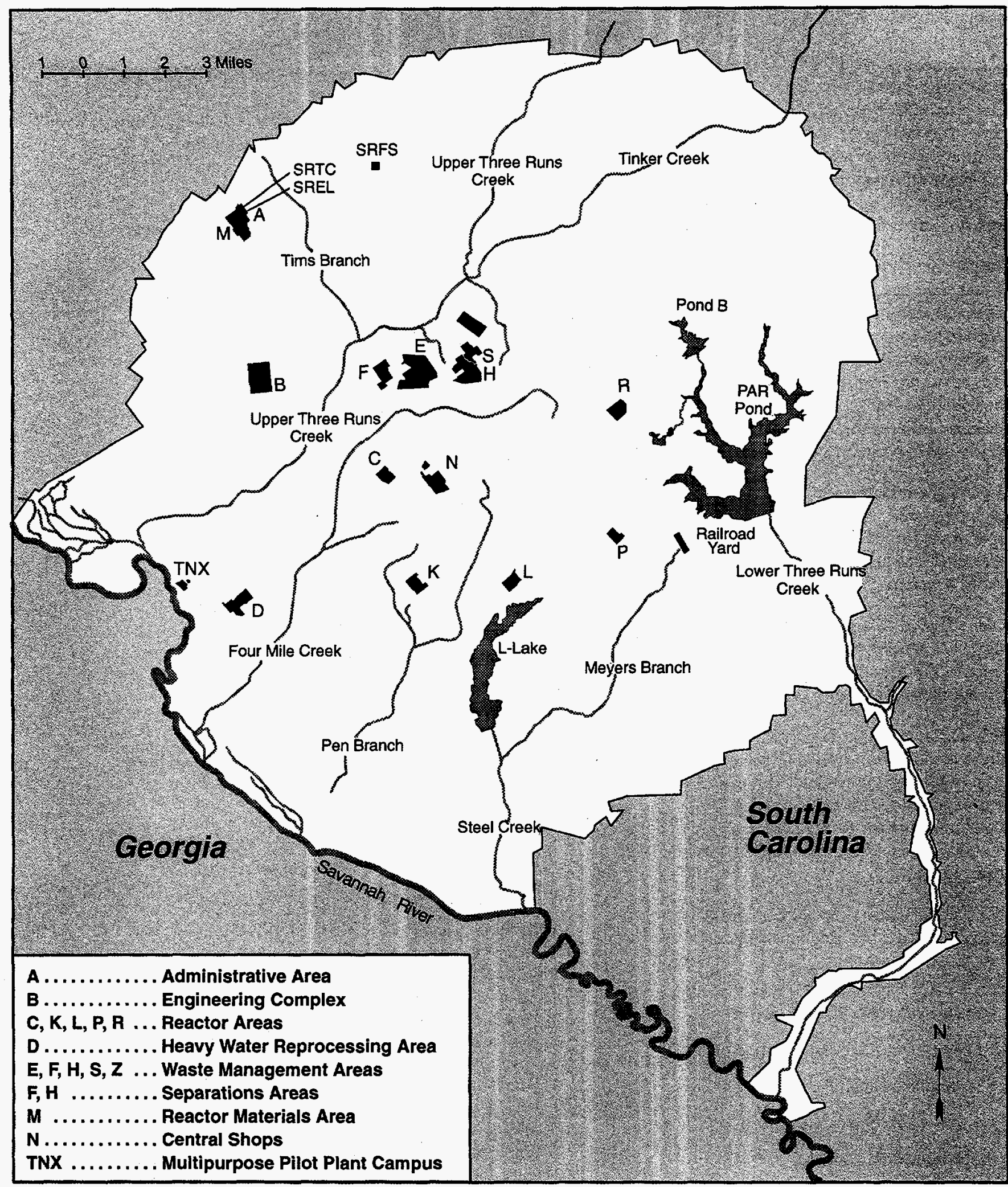

94X01678.04.EPS (modified)

Figure 1-2 The Savannah River Site

SRS includes nuclear materials production areas, which are primarily in the interior of the site, and several operating areas. The Savannah River Ecology Laboratory (SREL), the Savannah River Forest Station (SRFS), and the Savannah River Technology Center (SRTC) also are located on site. 
standby in 1987, when cracking was observed in the reactor vessel. C-Reactor has been permanently shut down.

K-Reactor went critical in October 1954 and was shut down in August 1988 for maintenance. Initial steps to restart K-Reactor began in December 1991.

Successful power ascension testing was completed in July 1992 . Following ascension testing, the reactor was taken offline to allow for the tie-in of a cooling tower. The tie-in was completed, and the operating permit was issued in December 1992. In 1993, the cooling tower was tested; however, the reactor was never restarted. K-Reactor was placed in cold standby, but the official status was changed in 1996 to cold shutdown.

\section{Heavy Water Reprocessing Area}

A heavy water production plant in D-Area began operations in 1953 to produce heavy water to moderate and cool the site's reactors. The plant separated heavy water, present in all water, from Savannah River water. Production was discontinued at the facility in 1981 because of a sufficient supply of heavy water.

Facilities operating in D-Area include a coal-fired power plant (leased by DOE to the South Carolina Electric and Gas Company effective

October 1, 1995), a laboratory facility that analyzes process effluent samples, and the Heavy Water Rework Facility. Through normal reactor operations, heavy water became diluted with light (ordinary) water. This degraded heavy water is sent to the Heavy Water Rework Facility, where light water is removed, and the heavy water is reconcentrated to 99.75-percent purity. Funding fluctuations caused decreases in rework operations during 1996. However, moderator purification and consolidation operations are continuing in D-Area.

\section{Separations Areas}

Reactor-generated products are processed in the separations facilities in F-Area and H-Area. Operations in the separations areas also include chemical separations, receipt of offsite fuel for processing, and tritium processing. Facilities include the canyon buildings (F-Canyon and $\mathrm{H}-\mathrm{Canyon}$ ), the FB-Line and the HB-Line (located atop the canyons), the Receiving Basin for Offsite Fuel (RBOF), and the Replacement Tritium Facility (RTF).

Nuclear materials historically have been chemically recovered and purified in the canyon buildings, the FB Line, and the HB Line. All processing work in the canyons, so called because of their long, narrow shapes-835 feet long, 122 feet wide, and 66 feet high - is remotely controlled to protect workers from the radioactive materials being processed [Fact Sheet, 1996d].

F-Canyon initiated recovery of plutonium-239 and uranium-238 from spent fuel rods from site reactors and other test and research reactors. Plutonium-239 was produced to support the nuclear weapons stockpile. Depleted uranium-238 was recovered as a by-product and remains stored at SRS [Fact Sheet, 1996d].

FB-Line historically converted plutonium solution produced in F Canyon from irradiated reactor targets to plutonium-239 metal for the support of defense programs [Fact Sheet, 1996e].

$\mathrm{H}$-Canyon historically recovered uranium-235, the fuel source for nuclear reactors, from spent rods from site reactors and other test research reactors. In addition, the canyon was equipped to recover plutonium-238, for use in power systems for deep space exploration, and neptunium-237, used to produce plutonium-238 [Fact Sheet, 1996f].

HB-Line was constructed to support the production of plutonium-238. Plutonium-238 has a unique combination of high heat output and long life, allowing space vehicle designers to keep weight at a minimum and still have a power supply that is effective for many years [Fact Sheet, 1996g]. In 1995 , the facility completed a 5-year campaign for the National Aeronautics and Space Administration (NASA) to supply plutonium-238 for the Cassini mission, an unmanned expedition to the planet Saturn.

The canyons and lines did not operate between 1992 and 1995, with the exception of the work mentioned above for NASA. In 1995, analyses showed that resuming processing operations was the best way to stabilize and manage most of the remaining inventory of plutonium-bearing and highly enriched uranium materials at SRS [Fact Sheet, 1996f; Fact Sheet, 1996h].

F-Canyon operations resumed in 1995, and the canyon is scheduled to operate until about 2002 to stabilize SRS materials. Most of these stabilization actions essentially will be the same as historic operations [Fact Sheet, 1996d].

Operations were restarted in 1996 in the FB Line to convert plutonium-bearing solutions into a metal form suitable for long-term storage and management. Stabilization of the approximately 80,000 gallons of 
existing plutonium-bearing solutions in F-Area was completẹd in April [Fact Sheet, 1996e].

$\mathrm{H}$-Canyon may be used to stabilize a number of plutonium solids currently stored in vaults. In addition, DOE has determined that $\mathrm{H}$-Canyon should be used to convert a large quantity of weapons-usable highly enriched uranium to low-enriched material-no longer weapons-usable, but suitable as fuel in commercial power reactors [Fact Sheet, 1996f].

Decisions announced between December 1995 and July 1996 by DOE concluded that HB Line should be used to stabilize plutonium-242 solution and may be used to stabilize other plutonium materials. The plutonium-242 campaign is in progress [Fact Sheet, 1996g].

Offsite fuel to be processed in the H-Area canyon building is stored and packaged in the RBOF. This facility receives and stores spent fuel from offsite research reactors, pending recovery operations or disposition.

Tritium, one of the materials produced by the site for national defense, has a half-life of 12.5 years and must be replenished. SRS is the nation's only facility for recycling tritium from nuclear weapons reservoirs returned from service. This recycling allows the United States to use its tritium supplies efficiently.

The SRS tritium facilities in H-Area consist of four main process buildings designed and operated to process tritium. The newest building is the one-acre-sized underground RTF. The main mission of the tritium facilities is to purify and maintain existing inventories of tritium for defense purposes.

With the SRS production reactors shut down, DOE began a search for a new source for tritium. The department is evaluating two options for tritium production: using an existing commercial reactor and constructing a linear accelerator. The more promising of the alternatives is expected to be selected in 1998 and designated the primary method of tritium production.

If the linear accelerator is selected, it will be constructed at SRS to take advantage of the site's long-standing expertise and capabilities in handling tritium. In either case, tritium extraction and loading will continue to be a site mission [Fact Sheet, 1996a].

\section{Waste Management Areas}

Waste management activities are conducted in the following areas: E, F, H, S, and Z. E-Area, between
F-Area and H-Area, eventually will include all the site's disposal and storage facilities.

Weapons material production at SRS has generated unusable byproducts, such as highly radioactive waste. About 34 million gallons of this high-level radioactive waste is stored in tanks on site [Fact Sheet, 1996a]. In addition, other wastes at the site include low-level solid and liquid radioactive wastes; transuranic waste (which contains alpha-emitting isotopes that have decay rates and concentrations exceeding specified levels); hazardous waste (which is any toxic, corrosive, reactive, or ignitable material that could affect human health or the environment); mixed waste (which contains both hazardous and radioactive components); and sanitary waste (which is neither radioactive nor hazardous). How the site manages this waste is discussed in chapter 4 , "Environmental Restoration and Waste Management."

Facilities in waste management areas are designed to store or treat the waste generated from onsite operations. These facilities include the Solid Waste Disposal Facility (SWDF)-formerly the Radioactive Waste Burial Grounds; the E-Area Vaults; the ETF; the high-level waste storage tanks in F-Area and H-Area ("tank farms"); the Extended Sludge Processing Facility; the In-Tank Precipitation Facility; the Defense Waste Processing Facility (DWPF); the Saltstone Facility; and the Consolidated Incineration Facility (CIF).

SWDF was a burial site for such items as protective clothing, tools, and equipment contaminated with small amounts of radioactive material. Such solid low-level waste now is disposed of permanently in the engineered concrete E-Area Vaults and thus is significantly more isolated from the environment.

Historically, seepage basins were used to dispose of wastewater from the separations facilities in F-Area and $\mathrm{H}$-Area. The ETF, located in H-Area, treats the low-level radioactive wastewater formerly sent to the seepage basins. The ETF removes radioactive and nonradioactive contaminants, except tritium, from process effluents and allows the water to discharge to Upper Three Runs Creek.

The F-Area and H-Area waste tank farms consist of large underground storage tanks that hold high-level liquid radioactive waste. The waste is contained in 29 tanks in H-Area and 22 tanks in F-Area. Sludge (which has settled to the bottom of the tanks) and saltcake must be removed from the tanks so the wastes can be processed for ultimate disposal.

The Extended Sludge Processing Facility washes the sludge to remove excess aluminum and salts before 
the sludge is ready to be fed to the DWPF. The In-Tank Precipitation Facility in H-Area separates the highly radioactive portion ("precipitate") of the saltcake from the low-level radioactive portion ("filtrate").

The DWPF, located in S-Area, immobilizes the high-level waste sludge and the precipitate by "vitrifying" it into a solid glass waste form. A component of the DWPF, the Saltstone Facility, treats and disposes of the filtrate by stabilizing it in a solid, cement-based waste form [Fact Sheet, 1996c]. The DWPF began radioactive operations in March.

The CIF, located adjacent to H-Area, is designed to safely burn certain hazardous, low-level radioactive, and mixed (both hazardous and radioactive) wastes. The CIF still is undergoing testing; operations are expected to begin in 1997.

\section{Administration Area}

The administration area (A-Area) contains organizations that provide direct support for SRS operations. DOE's Savannah River Operations Office and WSRC's administrative offices are located in A-Area, as are SRTC and SREL.

\section{Other Areas}

Other onsite and offsite facilities support SRS operations. Onsite areas include an engineering complex (B-Area); Central Shops (N-Area); and TNX (now called the Multipurpose Pilot Plant Campus), a research and development area. Locations not within areas designated for specific purposes are called G-Area, or general area. Activities conducted off site are administrative and do not involve radioactive or hazardous materials.

\section{Spent Fuel}

Beginning in the 1950s, as part of the "Atoms for Peace" program, the United States provided nuclear technology to foreign nations for peaceful applications in exchange for their promise to forego development of nuclear weapons. A major element of this program was the provision of research reactor technology and the highly enriched uranium needed in the early years to fuel the research reactors. Research reactors play a vital role in important medical, agricultural, and industrial applications. Nevertheless, the uranium initially used in the fuel elements for these reactors also can be used in nuclear weapons. Therefore,the used fuel elements ("spent nuclear fuel") were transported to the United States, where they were chemically separated to extract the uranium still remaining in the fuel. In this way, the United States maintained control over disposition of the highly enriched uranium that it provided to other nations.

For years, it was routine for the foreign researchers to return this U.S.-origin spent fuel to the United States under bilateral agreements and, from 1964 until 1988, the "Off-Site Fuels Policy." This policy expired in 1988 , and shipments no longer were accepted by the United States. The decision to return to this practice was made in 1996 [DOE, 1996], and the first shipment arrived on site in September from foreign research reactors [Fact Sheet, 1996a].

Spent nuclear fuel is managed in several locations at the site. Most of the spent nuclear fuel remaining from SRS reactor operations is in water-filled concrete storage basins, which originally were intended as an interim storage area. Fuel from domestic and foreign research reactors is stored in the RBOF (discussed on page 7). Interim storage will be a major issue for fuels that are not processed or that arrive after SRS reprocessing facilities are phased out. Many of the original storage facilities were not designed for the long interim storage period that may be required pending disposition. DOE is continuing with its integrated, long-term spent fuel management program, which addresses storage and treatment of all spent fuel until an ultimate disposition is determined.

\section{Environmental Restoration}

In 1981, SRS began inventorying waste sites (referred to as "units" for eventual restoration; there are about 460 inactive waste units included in the site's environmental restoration program. Waste sites range in size from a few square or cubic feet to tens of acres and include basins, pits, piles, burial grounds, landfills, tanks, and groundwater contamination areas.

To date, 90 acres of land have been remediated (assessed and cleaned up). Also, several billion gallons of groundwater have been treated, with hundreds of thousands of pounds of solvents removed. Even though the site has had success in cleaning up some areas, a tremendous amount of environmental restoration work remains [Fact Sheet, 1996a]. More about environmental restoration can be found in chapter 4, "Environmental Restoration and Waste Management."

\section{Research and Development}

SRTC is an applied research and development organization that provides technical support for the missions of SRS while working in partnership with site operations and interfacing with other government and private research organizations. SRTC is active in 
transferring technology to American industry, establishing industrial and academic partnerships and cooperative ventures, and supporting education programs.

The SRTC complex is comprised of 33 permanent buildings. Used in the past for nuclear materials production process development, the facilities now focus on developing, testing, and demonstrating equipment and techniques for nuclear materials processing, environmental remediation, environmental protection, waste processing, decontamination and decommissioning, and industrial uses of SRS technology.

Information about SRTC's outreach program can be found in chapter 3, "Environmental Program Information."

\section{Environment}

\section{Environmental Monitoring}

Onsite and offsite radiological and nonradiological environmental monitoring is conducted by the Environmental Monitoring Section (EMS) of WSRC's Environmental Protection Department (EPD). The environmental monitoring program is discussed briefly in chapter 3, "Environmental Program Information," and more thoroughly in chapters 5, ("Radiological Effluent Monitoring"), 6 ("Radiological Environmental Surveillance"), 8 ("Nonradiological Effluent Monitoring"), and 9 ("Nonradiological Environmental Surveillance").

Also, the Division of Environmental Research of the Academy of Natural Sciences of Philadelphia has performed biological and water quality surveys of the Savannah River since 1951. More about the academy's surveys can be found in chapter 12 ("Special Surveys and Projects").

\section{Savannah River Ecology Laboratory}

SREL is operated by The University of Georgia and funded by DOE to conduct research on the impact of site operations on the environment. Research programs are organized into four main categories-radioecology, environmental chemistry, ecotoxicology, and ecosystem health.

Radioecology research assesses the distribution, fate, and ecological risk associated with radionuclides in the environment, including the genetic effects on flora and fauna at SRS and more contaminated sites such as the Chernobyl site in the Ukraine.

Environmental chemistry research addresses the physical, chemical, and biological processes controlling the mobility of organic and inorganic contaminants in the environment, particularly in soils and water of SRS and other DOE sites. Research in ecotoxicology seeks to measure or predict bioaccumulation of contaminants in natural populations of organisms. The program also seeks to evaluate genetic and demographic markers in various species for use as possible indicators of responses to environmental contaminants. Objectives of the ecosystem health research are to identify patterns of biodiversity on the site and to understand the natural and anthropogenic processes that maintain or change them.

Additional studies are conducted on the site's deer herd, fish, reptiles, amphibians, waterfowl, and endangered species, such as the wood stork. Other studies evaluate the potential of various experimental approaches for remediating contaminated soils, Carolina bays, and other habitats.

Information about SREL's outreach program can be found in chapter 3. More information about all programs can be obtained by contacting SREL at 803-725-0156.

\section{Savannah River Forest Station}

The area of the site not used for nuclear materials production and production-related activities-about 175,000 acres-has been managed for several decades by SRFS, a unit of the U.S. Department of Agriculture (USDA) Forest Service. Because the site was farmland before it was purchased by the federal government, the Forest Service was asked in 1951 to establish a reforestation and forest management plan, which was written in 1952. In all, the Forest Service has planted more than 134 million trees (mainly pines) since 1953, covering almost 80 percent of the site. SRS maintains a forest management program to contribute to environmental protection and research.

Although SRFS originally was responsible only for timber management, its scope now includes management of the site's plants and wildlife, especially of threatened and endangered species; maintenance of the primary quality of the site's soil and water; and maintenance of the site's secondary roads and exterior boundaries. SRFS fire crews, which have primary responsibility for fighting wild fires and conducting controlled burns, coordinate their efforts with WSRC firefighters.

Information about SRFS's outreach program can be found in chapter 3 . Information about other programs can be obtained by contacting SRFS at 803-725-0237. 


\section{Savannah River Archaeological Research Program}

SRARP was formed in 1973 under a cooperative agreement with DOE and the South Carolina Institute of Archaeology and Anthropology, University of South Carolina. Its primary purpose is to make compliance recommendations to DOE that will facilitate the management of archaeological resources at SRS. Other functions include compliance activities involving reconnaissance surveys, general intensive watershed surveys, specific intensive surveys, data recovery, coordination with major land users, and reconstruction of the environmental history of the site. More information can be obtained by contacting SRARP at 803-725-3623.

\section{Economic Development}

The transfer of technology to private industry moves existing government-developed technologies into the commercial world, helping businesses sharpen their competitive edge and providing American taxpayers a second return on their investment. Through government/industry partnerships for the development of new technologies, the site also benefits from industry expertise in finding the best available solutions to the site's environmental restoration and waste management challenges [Fact Sheet, 1996a]. 



\section{Environmental Compliance}

\author{
Mary Dodgen, Pete Fledderman, \\ Phillip Miller, and Greg Peterson \\ Environmental Protection Department
}

To Read About . . .

See Page...

Compliance Activities .............. 13

Key-Regulations Summary . . . . . . . . . 15

Toxic Chemical Releases . . . . . . . . . . . 20

Safe Drinking Water ............... 22

NEPA Documentation Activities . .......23

Clean Air .......................26

CERCLA-Reportable Releases . . . . . . . 31

Construction/Operating Permits ........ 34

Transition/D\&D .................... 33

Other Major Issues/Actions . . . . . . . . . . 34
$\mathrm{S}$ AVANNAH River Site (SRS) operations in 1996 continued to involve a wide variety of processes and chemicals subject to compliance with environmental statutes, regulations, and policies. Such compliance ensures that SRS, the public, and the surrounding environment are protected from any adverse effects generated by site operations. This chapter addresses environmental compliance issues with which the site was involved during 1996.

SRS's goal-and that of the U.S. Department of Energy (DOE)-is positive environmental stewardship and full regulatory compliance, with zero violations. The site's employees maintained progress toward achievement of this goal in 1996, as is shown by examples in this chapter.

A systematic effort is in place to identify and address all evolving regulatory responsibilities that concern SRS. As part of the process, communications are maintained with all appropriate regulatory agencies to emphasize the site's commitment to environmental compliance.

The site's compliance efforts achieved a very high level of success in 1996. For example, under the Clean Water Act (CWA), almost 6,500 analyses were performed during the year to demonstrate compliance with the site's National Pollutant Discharge Elimination System (NPDES) permits; the site's compliance rate was 99.9 percent, calculated by dividing the number of exceedances by the number of parameters analyzed for permit compliance.

Under the Clean Air Act (CAA), the 1996 compliance rate was 100 percent. Other key regulations with which the site must comply - and the compliance status of each-are noted on page 15 .

\section{Compliance Activities}

Compliance with environmental regulations and with DOE orders related to environmental protection is a critical part of the operations at SRS. Assurance that onsite processes do not impact the environment adversely is a top priority, and management of the environmental programs at SRS is a major activity. All site activities are overseen by one or more regulatory bodies, including the U.S. Environmental Protection Agency (EPA) and the South Carolina Department of Health and Environmental Control (SCDHEC). Significant effort and funding have been dedicated to ensuring that site facilities and operations comply with all requirements.

\section{Resource Conservation and Recovery Act}

The Resource Conservation and Recovery Act (RCRA) was passed in 1976 to address the problem of solid and hazardous waste management. The law requires that EPA regulate the management of solid and hazardous wastes, such as spent solvents, batteries, and many other discarded substances deemed potentially harmful to human health and the environment. Amendments to RCRA regulate nonhazardous solid waste, and some underground storage tanks.

Under RCRA, hazardous waste generators are responsible for controlling every aspect of the generation, treatment, storage, and disposal of the waste; this is referred to as "cradle-to-grave control." Hazardous waste generators, including SRS, must follow specific requirements for handling these wastes. For many waste management activities, RCRA requires that owners and operators of operating or post-closure-care hazardous waste management facilities have a permit.

EPA is responsible for all hazardous waste regulations. However, EPA can delegate this authority 
to a state when the state passes laws and regulations that meet or exceed EPA regulations and the state plan is approved by EPA. SCDHEC has been delegated RCRA authority. The Federal Facility Compliance Act (FFCAct) gives the state authority to enforce land disposal restrictions (LDRs)/treatment standards for mixed wastes. Also, SCDHEC has been authorized by the FFCAct to play the key role in the implementation of FFCAct statutes, and was the lead regulatory agency for implementation of the SRS Site Treatment Plan (STP), which addresses storage and treatment of mixed waste. More information on waste management at SRS can be found in chapter 4, "Environmental Restoration and Waste Management."

\section{Federal Facility Compliance Act}

The FFCAct was signed into law in October 1992 as an amendment to the Solid Waste Disposal Act to add provisions concerning the application of certain requirements and sanctions to federal facilities. With respect to federal agencies, the FFCAct waives sovereign immunity from all civil and administrative penalties and fines; this includes waiver for both coercive and punitive sanctions for violations of the Solid Waste Disposal Act. For mixed waste, the FFCAct provided a 3-year delay (until October 1995) in the imposition of fines and penalties so that DOE sites could investigate mixed waste volumes in storage, evaluate treatment capacities, and develop STPs with schedules for mixed waste treatment for approval by their state or federal regulatory agencies.

On March 30, 1995, DOE's Savannah River Operations Office (DOE-SR) submitted a proposed STP-developed with State of South Carolina involvement-that addressed the development of capacities and technologies for treating SRS mixed wastes according to LDRs, as required by the FFCAct. This plan was approved with modifications, and the FFCAct consent order was issued September 29, 1995.

Also in association with the FFCAct, Westinghouse Savannah River Company (WSRC) submitted a mixed waste inventory report January 13, 1993, and DOE Headquarters (DOE-HQ) issued a complexwide report-U.S. Department of Energy Interim Mixed Waste Inventory Report: Waste Streams, Treatment Capacities, and Technologies-April 21, 1993, to state governors and to regulatory agencies in states that host DOE sites. This was followed by a comment period for the regulators and states. DOE-HQ provided an update to the mixed waste inventory report in April 1994. DOE-HQ and SRS will prepare regular updates of the mixed waste inventory report every September to support the STP.

\section{Land Disposal Restrictions}

The 1984 RCRA amendments established LDRs, often referred to as "land ban." LDRs do not allow storage of restricted hazardous wastes, except for the purpose of accumulating such quantities as are necessary to facilitate proper recovery, treatment, or disposal. The amendments require that, prior to land disposal, all wastes meet treatment standards based on the "best demonstrated available technology."

The same restrictions apply to mixed wastes, which are composed of a mixture of radioactive and hazardous wastes. Because SRS did not have the capability to comply with the applicable LDR requirements, a Federal Facility Compliance Agreement (FFCA) was signed in March 1991 between DOE-SR and EPA Region IV (Alabama, Florida, Georgia, Kentucky, Mississippi, North Carolina, South Carolina, and Tennessee). The goal of the FFCA was to address SRS mixed waste compliance with LDRs. Since then, the LDR FFCA has been amended. Commitments made under the amended FFCA allowed for a smooth transition to a new commitment in the STP and in the STP Consent Order, which enforced the STP commitments. The effective date of the STP and the STP Consent Order was September 29, 1995.

As required by the STP Consent Order, SRS issued an annual update to the STP on April 30, 1996. In the update were changes in the mixed waste treatment status, including the addition of new mixed waste streams. Information for STP updates was supplied in part from a Mixed Waste Inventory Report completed in September 1995. Updates of both the STP and Mixed Waste Inventory Report will continue to be produced annually unless the State of South Carolina changes the requirement.

Treatability variances are an option available to facilities for particular waste streams that either cannot be treated at the level specified in regulations-the appropriate treatment technology may not be available-or for which the treatment technology is inappropriate for the waste. SRS has identified some mixed waste streams that are potential candidates for a treatability variance. One variance-for in-tank precipitation filters-was granted in October 1993 by EPA Region IV. The STP references three additional treatability variances for mixed wastes with special problems that prevent treatment according to LDR standards. The three variances are for (1) tritiated water with mercury, (2) silver saddles (silver nitrate-coated berl saddles 
Some of the Key Regulations SRS Must follow

Legistation

nepus

Resource Conservation and Recovery Act (1976)

FFEAC:

Federal racity Compliance Act (1992)

\section{CERCIA,SARA}

Comprehensive Environnental Response. Compensation and Liability. AC( $(980)$.

Superfund Amendinents and Reautionzation Adt (1986)

\section{CERCLATILENIISPCRA)}

Energency Plannirg and Community

Right to-know Act (1986)

\section{NEPA}

National Envirom mental rolicy Act (1969)

\section{Sowa}

Sato Drinking Water Act (1974)

\section{CWA NPDES}

Nationat Pollutant Discharge Elimination System. Clean Water Act (1977):

\section{CAA, NESHAP}

Nationat Enission Stand dards for hazardous Air Pollitanis, Clean Ar Act $(1970)$.

TSCA

Toxic Substances Control Act (1976)

\section{What 1 Requiless Rs Compliance Status}

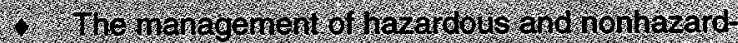
qus wastes and of underground storage lanks. contaning hazardous sibstances and porrolevm products it conpritance

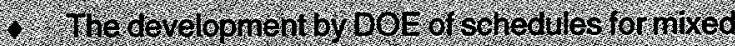
Waste toatinen to avoil waver of sovereign 17 .

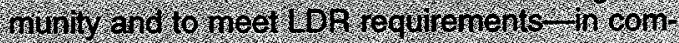
plianee

7. The estabisminent or liabilit, compensation. cleanipa, and energeney resjousso for hazardous substances released to the envionment SAS

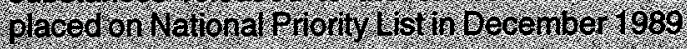

6. The reponing or hararious substanees bsed on stuv (and heir releases) 10 EPA. state, and local planing units. in complance

- The evatuation or he eotehtial environmentalin? pact or tederal activities and alternaties. 1 . 1996 WsafG condilcted 309 reviews for new proposed actions. incompliance

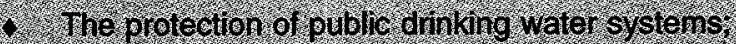
enacted 17 1974 amended in 1980 , 1986 . in Gortilaner

- The regulation of truine discharges at outralls (e.g. crains or pipes) that cary efluents to Stearis in complianee

- The estabish ment or ar quaniy standards for haz. ardols arrenissions, such as radiontulides and benzere tr complanco.

6. The regulation or use and disposal of PGBs tha. tion has na de quate disposal capacily tor radioac. trepers generated and currenty stored at SAS designed to take up iodine gas), and (3) lead acid batteries. EPA reviews of these variance requests are scheduled for September 1997 for the first two and September 1998 for the third. Schedules are included in the STP for preparation of variance request documents.

\section{Underground Storage Tanks}

Underground storage tanks at SRS house petroleum products, such as gasoline and diesel fuel, and hazardous substances (as defined by the Comprehensive Environmental Response, Compensation, and Liability Act, or CERCLA). All such tanks are regulated under Subtitle I of RCRA.

Underground storage tank regulations require that all regulated existing tanks be closed or upgraded to meet or comply with new tank standards by December 22, 1998. In 1996, WSRC closed two tanks by removal, initiated regulatory proceedings to close nine more, and performed tightness tests on 14 
tanks and their connective piping. Every tank that was tested passed.

The regulations set standards for upgrading existing tanks based on their age. Existing tanks must be monitored for leaks, and records must be kept for inventory control. In areas where underground tanks are still needed, WSRC will replace single-walled tanks with double-walled tanks that have leak detection systems. During 1996, of the 25 total operational petroleum storage tanks at SRS, 19 met the new tank standards, and the remaining six are to be upgraded, replaced, or abandoned to meet the December 1998 deadline.

\section{High-Level Waste Tank Closure}

The mission of the SRS high-level waste tank closure effort at the F-Area and H-Area tank systems is to close out tanks in a way that ensures protection of human health and the environment, and in a technically and economically prudent manner. A general tank closure plan for F-Area and H-Area was developed to outline the protocol for closure. SCDHEC has provided conditional approval of this general plan.

Tank-specific closure modules will be developed for each tank system. These modules apply the general closure methodology to a specific tank system.

Module $17 \mathrm{~F}$ has been drafted; module $20 \mathrm{~F}$ has been conditionally approved by SCDHEC. In addition, a tank closure plan has been developed and submitted to SCDHEC to meet an annual operating plan milestone. This document is a planning tool for managing high-level tank system closures, and it will be updated at least annually.

Closure for tanks $17 \mathrm{~F}$ and $20 \mathrm{~F}$ will involve filling the tanks; a layer of reducing grout inserted initially into the bottom of the tanks will be topped with controlled, low-strength material. Field work has begun for the closure of these two tanks and should be completed in 1997.

Environmental Protection Department (EPD) personnel participated during 1996 in a team effort with High-Level Waste Department personnel as writers/reviewers for the "Industrial Wastewater Closure Plan for F- and H-Area High-Level Waste Tanks." This document outlines the SRS/regulator protocol for closing all 51 high-level waste tanks on site. An Environmental Assessment (EA), which resulted in a Finding of No Significant Impact (FONSI), was issued in July 1996 to fulfill National Environmental Policy Act (NEPA) requirements for the closure action. EPA and SCDHEC approved the closure plan July 23, 1996, and July 31, 1996, respectively. EPD will continue to participate in this process as individual tank system closure modules are developed for closure of operational groupings of the SRS tank systems.

\section{RCRA 3004(u) Program}

The hazardous waste permit issued to SRS in September 1987 requires that the site institute a program for investigating and, if necessary, performing corrective action at solid waste management units under RCRA 3004(u). The RCRA 3004(u) requirements have been integrated with the CERCLA requirements because SRS is on the National Priority List-also known as the Superfund List. The integration of RCRA and CERCLA regulatory requirements will provide a more cost-effective and focused investigation and remediation process. The RCRA/CERCLA program status is detailed under the CERCLA section of this chapter.

\section{Waste Minimization Program}

The SRS Waste Minimization Program, a comprehensive plan to prevent pollution and minimize waste from all SRS operations, is designed to meet the requirements of RCRA, of DOE orders, and of applicable executive orders. The program focuses mainly on source reduction, on recycling, and on increasing employee awareness of and participation in pollution prevention. Since SRS initiated its formal Waste Minimization Program in 1991, the solid radioactive and hazardous waste generation volumes have decreased by about 70 percent. In addition, the types of materials collected for recycling and sale as salvageable materials have increased significantly, with more than 3,270 tons of scrap materials being diverted into the recycling market, versus disposal, during fiscal year 1996, and more than 95,000 pounds of excess chemicals being disbursed from the SRS Chemical Commodity Management Center for reuse. For more information on this program, refer to chapter 3, "Environmental Program Information," and chapter 4.

\section{Notice of Violation (RCRA)}

SCDHEC issued a Notice of Violation (NOV) to SRS October 14, 1993, alleging storage and disposal of mixed waste without a RCRA permit. The NOV was based on information reported to SCDHEC by SRS in September 1993, and-after continued discussions-the issue was resolved August 5, 1996, when SCDHEC executed Consent Order 96-30-HW. No NOV was issued to SRS under RCRA in 1996. 


\section{Comprehensive Environmental Response, Compensation, and Liability Act}

SRS was placed on the National Priority List in December 1989, thereby making the site subject to CERCLA (Public Law 96-510), as amended by the Superfund Amendments and Reauthorization Act (SARA, Public Law 99-499). CERCLA assigns liability and provides for compensation, cleanup, and emergency response for hazardous substances released to the environment.

In accordance with Section 120 of CERCLA, DOE, EPA Region IV, and SCDHEC entered into a Federal Facility Agreement (FFA), which became effective August 16, 1993. Declaration of the effective date results in the FFA being an enforceable agreement. The FFA, which sets the milestones for environmental remediation at SRS, consolidates site cleanup activities into one comprehensive strategy.

Releases or potential releases from RCRA/CERCLA waste management units are evaluated under the FFA. Work plans detailing the proposed investigations for the RCRA/CERCLA units must be approved by both EPA and SCDHEC prior to implementation. During 1996, six investigations were initiated according to approved work plans and the schedule in Appendix D of the FFA.

Remediation under CERCLA imposes requirements in addition to existing RCRA requirements. CERCLA requires remedial decisions to be based on the results of a baseline risk assessment, which examines present and future risk to human health and the environment from the waste unit, using conservative,

EPA-approved exposure scenarios.

CERCLA also requires public participation in the selection of remediation alternatives. A significant step in this process is the development of a Proposed Plan, which highlights key aspects of the remedial investigation and feasibility study. The plan also provides a brief analysis of remedial alternatives that were considered, identifies the preferred alternative, and tells the public how it can participate in the remedy selection process. After public comment is received, a Record of Decision (ROD) is issued that presents the selected remedy and provides the rationale for that selection. Also included in this process is the establishment of an administrative record file that documents the remediation alternatives and provides for public review of them.

RCRA Facility Investigation/Remedial Investigation (RFL/RI) field starts were initiated in Fiscal Year
1996 on three operable units: K-Area rubble pile, $\mathrm{K}$-Area burning/rubble pit, and a third unit made up of the four SRL seepage basins. The parties issued two Proposed Plans for public comment during Fiscal Year 1996: Old Radioactive Waste Burial Ground Interim Action and Burma Road Rubble Pit. Remedial Actions and Interim Remedial Actions were initiated on three units in Fiscal Year 1996: D-Area Oil Seepage Basin Interim Action, TNX Groundwater Interim Action, and Old Radioactive Waste Burial Ground Interim Action. Interim Remedial Actions were completed on one unit in Fiscal Year 1996: D-Area Oil Seepage Basin Interim Action.

The FFA also identifies more than 300 site evaluation units for which investigations are required. Site evaluation reports for 24 areas were submitted to EPA and SCDHEC during 1996, compared to 24 areas in 1995 and 28 areas in 1994.

\section{RCRAVCERCLA Units}

Table 2-9, beginning on page 36 , identifies

- examples of the 467 waste units and potential waste units at SRS (by location and building number)

- the 18 units that are RCRA-regulated and for which Interim Action or Final Records of Decision have been issued

Table 2-1 identifies units at SRS that are RCRA-regulated but that are not RCRA/CERCLA units.

\section{Emergency Planning and Community Right-to-Know Act}

The Emergency Planning and Community Right-to-Know Act (EPCRA) of 1986 was enacted as a provision to SARA. EPCRA requires facilities to notify state and local emergency planning units about their hazardous chemical inventories and to report releases of hazardous chemicals.

Under Section 312 of EPCRA, SRS completes an annual Tier II Inventory Report for all hazardous chemicals present at the site in excess of specified quantities during the calendar year. Hazardous chemical storage information is submitted to state and local authorities by March 1 for the previous calendar year.

Under Section 313 of EPCRA, SRS must file an annual Toxic Chemical Release Inventory report by July 1 . The site calculates chemical releases to the environment and reports aggregate quantities for each regulated chemical that exceeds established threshold 
Table 2-1 Identification and Location of RCRA-Regulated Units at SRS

\begin{tabular}{ll}
$\begin{array}{l}\text { Site and } \\
\text { Location }\end{array}$ & $\begin{array}{l}\text { Building or } \\
\text { Identification Number(s) }\end{array}$ \\
\hline $\begin{array}{l}\text { A-Area and M-Area } \\
\text { SRL Mixed Waste Storage Tanks }\end{array}$ & $776-\mathrm{A}$ \\
M-Area Mixed Waste Storage Shed & $316-\mathrm{M}$ \\
M-Area Process Waste Interim Treatment Storage Facility & $341-1 \mathrm{M}$ \\
M-Area Waste Storage Pad & $315-4 \mathrm{M}$ \\
$\quad$ Metallurgical Laboratory Hazardous Waste Management Facility & $904-110 \mathrm{G}$ \\
General Separations and Waste Management Areas (E-, F-, H-, S-, Y-, and Z-) & \\
Burial Ground Solvent Tanks (S23-S30) & \\
Consolidated Incineration Facility & $261-\mathrm{H}$ \\
$\quad$ DWPF Organic Waste Storage Facility & $430-1 S$ \\
$\quad$ Experimental TRU Waste Assay FacilityMaste Certification Facility & $724-8 \mathrm{E}$ \\
$\quad$ Mixed Waste Tritiated Oil Storage Tank (S-32) & $650-32 \mathrm{E}$ \\
$\quad$ Mixed Waste Storage Buildings (including Waste Storage Pads 20-22) & $643-29 \mathrm{E},-43 \mathrm{E}$ \\
TRU Waste Storage Pads 1-19 & $660-1 \mathrm{E},-5 \mathrm{E},-6 \mathrm{E},-19 \mathrm{E}$ \\
N-Area (formerly Central Shops) & \\
$\quad$ Hazardous Waste Storage Facility & $645-\mathrm{N},-2 \mathrm{~N}, 4 \mathrm{~N},-710-\mathrm{B}$ \\
Other & \\
$\quad$ Liquid Waste Solvent Tanks (S33-S36) & \\
\hline
\end{tabular}

amounts. The Pollution Prevention Act of 1990 expanded the Toxic Chemical Release Inventory reports to include source reduction and recycling activities. Pollution prevention information has been reported annually since 1991 .

Form $\mathrm{R}$ of the Toxic Chemical Release Inventory report for 1995 was submitted to EPA in June 1996. Six chemicals, with releases totaling 60,503 pounds, were reported to EPA for 1995 . This compares with eight chemicals $(85,658$ pounds of releases) reported during 1994 . Through 1995 , total toxic chemical releases had been reduced by about 98 percent compared to 1988 , with the sharpest drop occurring between 1988 and 1989. Figure 2-1 shows the overall reduction in total toxic chemical releases at SRS for the period 1987-1995. Several factors have contributed to this reduction. Pollution prevention programs have exerted downward pressure on the use and release of toxic chemicals, resulting in significant decreases for chemicals such as chlorine, lead, Freon 113, and 1,1,1-trichloroethane. Two primary contributors to the dramatic decline in reported totals during the late 1980s were as follows:

- EPA initially identified chemicals for reporting that did not meet the toxic criteria later devel- oped for EPCRA Section 313. For example, EPA delisted nontoxic chemicals such sodium sulfate; this resulted in a decline in reported releases for SRS.

- DOE curtailed nuclear production operations at SRS in 1989.

A breakdown of the comparison from 1993 through 1995 is presented in table $2-2$. Lead represented a significant portion of the 1995 totals, as indicated in the table. Ninety-nine percent of the lead reported that year was sent off site for recycling and was identified as an offsite transfer on Form R. Form R treats offsite transfers as releases, but they actually are transfers of waste to EPA-approved facilities for further treatment or for storage, disposal, or recycling.

\section{3/50 Pollution Prevention Program}

In September 1992, DOE became the first federal agency to agree formally to participate in EPA's $33 / 50$ Pollution Prevention Program. Under the agreement, DOE voluntarily adopted the program goals that are expected to reduce the use and release of 17 priority chemicals. The first goal, which called for a 50 -percent reduction by the end of 1995 , applied to SRS and other contractor-operated facilities that 
already were reporting the releases under EPCRA in 1992. The second goal, which calls for a 33-percent reduction by the end of 1997, applies to the other contractor-operated facilities that met the reporting criteria in 1992 but had not previously reported the releases under EPCRA.

By 1993, the DOE complex had met its 50-percent reduction goals. With its achievement of the $33 / 50$ goals, the DOE complex began to focus on reducing all toxic chemical releases, as identified in Executive Order 12856.

\section{Executive Order 12856}

Executive Order 12856 requires that all federal facilities comply with right-to-know laws and pollution prevention requirements. The order requires that federal facilities meet EPCRA reporting requirements and develop voluntary goals to reduce releases of toxic chemicals 50 percent on a DOE-wide basis by the end of 1999. SRS complies with the applicable requirements for EPCRA, as indicated in table $2-3$, and the site incorporates into its pollution prevention efforts all of the toxic chemicals on the Toxic Chemical Release Inventory report.

\section{National Environmental Policy Act}

The National Environmental Policy Act (NEPA) establishes policies and goals for the protection, maintenance, and enhancement of the human environment in the United States. The purpose of NEPA is to provide the federal government with a process for implementing these goals. The Act requires consideration of environmental factors during the planning process for all major federal activities that could significantly affect the quality of the environment. In practice, NEPA provides a means to evaluate the potential environmental impact of such proposed federal actions and to examine alternatives to those actions. Although implemented on site by the Energy Research and Development Administration during the $1970 \mathrm{~s}$, a formal management and operation contractor NEPA compliance group was not established at SRS until 1982. The ongoing mission of this group is to make recommendations regarding the level of NEPA review of a site-proposed action and to prepare draft

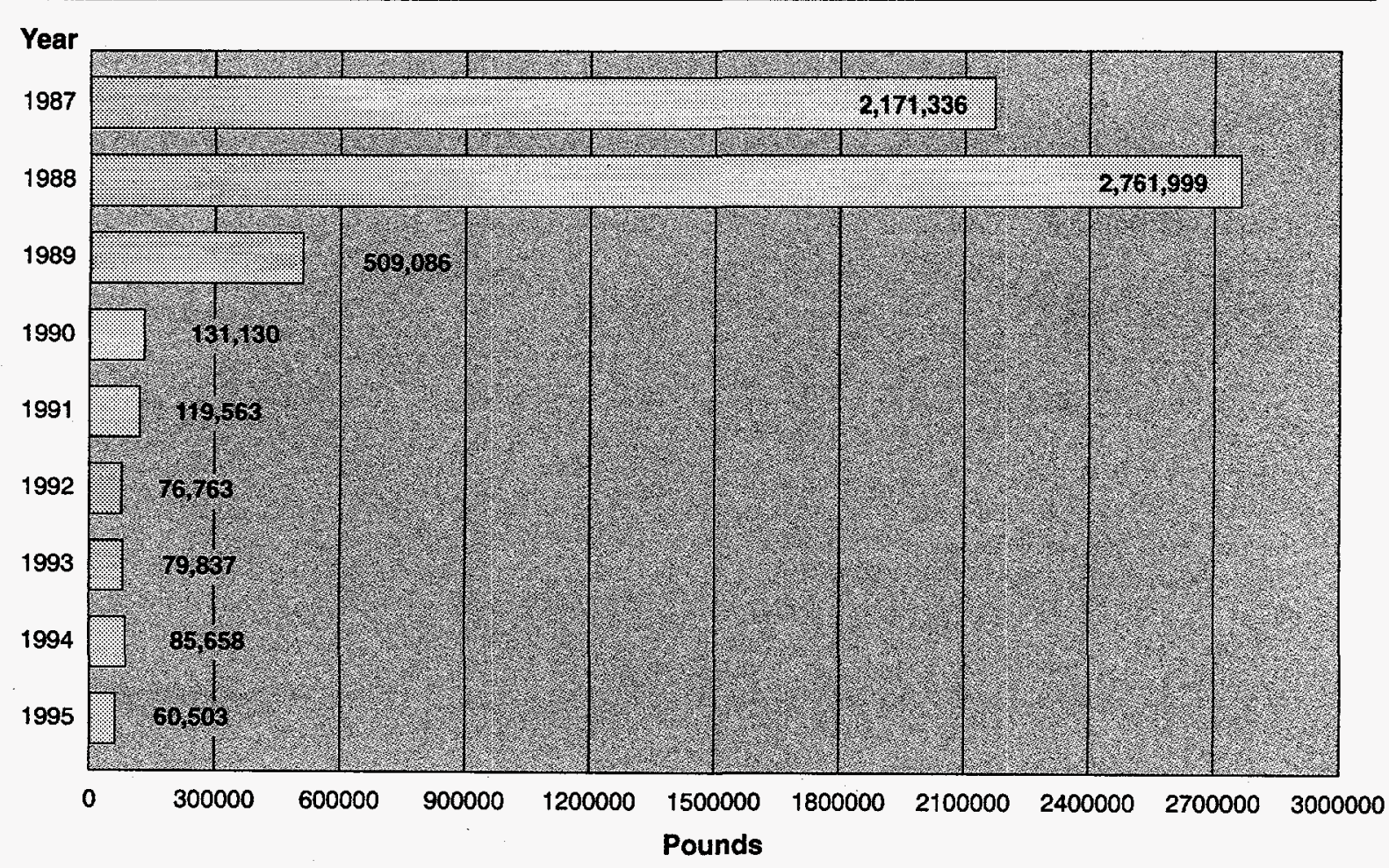

lieaf Graphic

Figure 2-1 Total Toxic Chemical Releases at SRS, 1987-1995

Through 1995, total toxic chemical releases have been reduced by about 98 percent when compared to 1988 . The sharpest drop occurred between 1988 and 1989, when EPA delisted nontoxic chemicals that did not meet toxic criteria for EPCRA Section 313. 
Table 2-2 Releases of Toxic Chemicals (in Pounds) by SRS During 1993, 1994, and 1995 Reporting Years (Reported Under EPCRA Section 313)

\begin{tabular}{lrcrrr}
1993 & $\begin{array}{l}\text { Air } \\
\text { Chemical }\end{array}$ & $\begin{array}{l}\text { Water } \\
\text { Emissions }\end{array}$ & $\begin{array}{l}\text { Land } \\
\text { Disposal }\end{array}$ & $\begin{array}{c}\text { Offsite } \\
\text { Transfers }\end{array}$ & Total \\
\hline Ammonia & 11,550 & 977 & 0 & 150 & 12,677 \\
Chlorine & 0 & 15 & 0 & 0 & 15 \\
Lead & 76 & 9 & 8,500 & 66 & 8,651 \\
Manganese compounds & 42 & 0 & 1,250 & 0 & 1,292 \\
Methyl ethyl ketone & 9,735 & 0 & 41 & 0 & 9,776 \\
Methyl tert-butyl ether & 540 & 0 & 0 & 0 & 540 \\
Nitric acid & 37,000 & 0 & 0 & 0 & 37,000 \\
Sulfuric acid & 0 & 0 & 0 & 1 & 1 \\
Toluene & 2,401 & 0 & 4 & 0 & 2,405 \\
Xylene & $\mathbf{7 , 4 2 8}$ & 0 & 52 & 0 & 7,480 \\
Totals & $\mathbf{6 8 , 7 7 2}$ & $\mathbf{1 , 0 0 1}$ & $\mathbf{9 , 8 4 7}$ & $\mathbf{2 1 7}$ & $\mathbf{7 9 , 8 3 7}$
\end{tabular}

1994

\begin{tabular}{lrcrrr} 
Chemical & $\begin{array}{l}\text { Air } \\
\text { Emissions }\end{array}$ & $\begin{array}{l}\text { Water } \\
\text { Discharges }\end{array}$ & $\begin{array}{l}\text { Land } \\
\text { Disposal }\end{array}$ & $\begin{array}{r}\text { Offsite } \\
\text { Transfers }\end{array}$ & Total \\
\hline Benzene & 5,878 & 0 & 4 & 9,276 & 15,158 \\
Chlorodifluoromethane & 19,500 & 0 & 5 & 0 & 19,505 \\
Lead & 8 & 172 & 10,000 & 2 & 10,182 \\
Manganese compounds & 31 & 53 & 1,499 & 23 & 1,606 \\
Nitric acid & 32,050 & 0 & 120 & 168 & 32,338 \\
Sulfuric acid & 0 & 0 & 0 & 15 & 15 \\
Toluene & 1,780 & 0 & 7 & 440 & 2,227 \\
Xylene & 3,950 & 0 & 17 & 660 & 4,627 \\
Totals & $\mathbf{3 3 , 1 9 7}$ & $\mathbf{2 2 5}$ & $\mathbf{1 1 , 6 5 2}$ & $\mathbf{1 0 , 5 8 4}$ & $\mathbf{8 5 , 6 5 8}$
\end{tabular}

1995

\begin{tabular}{lrrrrr} 
Chemical & $\begin{array}{l}\text { Air } \\
\text { Emissions }\end{array}$ & $\begin{array}{l}\text { Water } \\
\text { Discharges }\end{array}$ & $\begin{array}{l}\text { Land } \\
\text { Disposal }\end{array}$ & $\begin{array}{r}\text { Offsite } \\
\text { Transfers }\end{array}$ & Total \\
\hline Benzene & 7,600 & 0 & 0 & 1,724 & 9,324 \\
Formic Acid & 33 & 0 & 0 & 0 & 33 \\
Lead & 1 & 13 & 240 & 43,426 & 43,680 \\
Sodium Nitrite & 0 & 0 & 0 & 0 & 0 \\
Nitric acid & 224 & 0 & 0 & 0 & 224 \\
Nitrate Compounds & 2 & 7,240 & 0 & 0 & 7,242 \\
Totals & $\mathbf{7 , 8 6 0}$ & $\mathbf{7 , 2 5 3}$ & $\mathbf{2 4 0}$ & $\mathbf{4 5 , 1 5 0}$ & $\mathbf{6 0 , 5 0 3}$
\end{tabular}


Table 2-3 SRS Compliance with Executive Order 12856

\begin{tabular}{llc}
\hline $\begin{array}{l}\text { EPCRA } \\
\text { Citation }\end{array}$ & $\begin{array}{l}\text { Activity } \\
\text { Regulated }\end{array}$ & $\begin{array}{c}\text { Applicable } \\
\text { Requirement }\end{array}$ \\
\hline $302-303$ & Planning Notification & No \\
304 & $\begin{array}{l}\text { Extremely Hazardous Substances } \\
\text { Release Notification }\end{array}$ & No \\
$311-312$ & $\begin{array}{l}\text { Material Safety Data Sheet } \\
\text { Chemical Inventory }\end{array}$ & Yes \\
313 & Toxic Release Inventory Reporting & Yes \\
\hline
\end{tabular}

documentation in support of DOE compliance with NEPA at SRS. In 1996, 309 reviews of new proposed actions were conducted at SRS and formally documented through Categorical Exclusions (CXs), Notices of NEPA Approval, or EAs. WSRC also provided technical support to DOE-SR for the preparation of Supplement Analyses (SAs), Environmental Impact Statements (EISs), Supplemental Environmental Impact Statements (SEISs), and Programmatic Environmental Impact Statements (PEISs).

The types and numbers of NEPA activities conducted at SRS during 1996 are presented in table 2-4.

Among the specific activities were the following:

- On February 8, DOE issued a second Record of Decision (ROD) related to the Interim Management of Nuclear Materials EIS. This ROD describes the DOE's decision to process Mark-16 and Mark-22 fuels and blend the uranium down to low-enriched uranium using the SRS canyon facilities. DOE also decided to process the other aluminum-clad targets using a canyon facility and to vitrify the resulting solutions to a glass form at the site's Defense Waste Processing Facility (DWPF). A third ROD for this EIS was issued September 6 . This more recent document described DOE's decision to stabilize neptunium solutions and targets, as well as the plutonium solutions stored in H-Canyon. The plutonium will be processed into metal, while the neptunium will be vitrified at DWPF.

- The final PEIS on the Proposed Policy for the Acceptance of U.S. Origin Foreign Research Reactor Spent Nuclear Fuel was issued February 16. The ROD for this programmatic document was signed May 13.

- In April, DOE announced that the Notice of Intent to prepare an EIS on a proposed upgrade of the canyon exhaust systems at SRS had been withdrawn. This decision was based on a substantial scope reduction of the proposed upgrade. DOE decided to replace in-kind equipment that has reached the end of its service life or that does not comply with current regulations.

- On June 12, DOE issued a Notice of Intent to prepare an EIS on the proposed shutdown of the SRS river water system. The draft EIS was issued for public review and comment November 8. Public hearings were held in December. The proposed action would result in the cessation of river water input to L-Lake and PAR Pond,

Table 2-4 Types/Numbers of NEPA Activities at SRS During 1996

\begin{tabular}{lr} 
Type of NEPA Documentation & Number \\
\hline Categorical Exclusion (CX) & 3 \\
Recommendation & 294 \\
Sitewide Categorical Exclusion/ & 8 \\
Routine Insignificant Actions & 9 \\
Tiered by Previous NEPA Documentation & 8 \\
Environmental Assessment (EA) & 3 \\
Environmental Impact Statement (EIS) & \\
Supplement Analysis & 1 \\
Supplemental Environmental & 5 \\
Impact Statement (SEIS) & \\
Programmatic Environmental & 331 \\
Impact Statement (PEIS) & \\
\hline Total & \\
& \\
\hline a Includes 309 reviews of new proposed actions in & \\
\hline$\quad 1996$ and 22 activities continued from 1995
\end{tabular}


formerly used as reactor cooling water reservoirs. More information on the river water system shutdown project can be found on page 34 .

- The final EA and FONSI on the Closure of Fand H-Area High-Level Waste Tanks at SRS were issued on July 31 . The EA assesses the potential impacts associated with the proposed emptying of 51 tanks holding approximately 34 million gallons of high-level waste. This EA included a preliminary evaluation of five proposed closure alternatives. DOE further developed a tank closure plan in support of the proposed action.

- A supplement analysis of Seismic Activity on F-Canyon was approved August 20. An earlier review of safety documentation indicated that this site facility might not be resistant to seismic activity, as assumed in the F-Canyon Safety Analysis Report. Detailed analyses revealed that the response of the facility to seismic activity would be well within the bounds of the aforementioned Safety Analysis Report and the analysis presented in the F-Canyon Plutonium Solutions EIS. Therefore, DOE determined that a supplemental EIS would not have to be prepared at this time.

- On September 5, DOE issued a Notice of Intent to prepare an EIS on the Accelerator Production of Tritium at SRS. Public scoping meetings in support of this EIS were held in December. The Accelerator Production of Tritium EIS will evaluate the potential impacts associated with the construction and operation of a linear accelerator for the production of tritium for nuclear stockpile purposes.

- A Notice of Intent to prepare an EIS on the construction and operation of a Tritium Extraction Facility at SRS was published in the Federal Register September 5. The Tritium Extraction Facility would extract tritium gas from targets irradiated in a commercial light water reactor or an accelerator. Public scoping meetings were held in December for the EIS.

- A revised FONSI was approved by DOE November 8 to change the scope of the proposed action described in the EA on Domestic Water Supply Upgrades and Consolidation at SRS (DOE/EA-0943). This scope change involved the siting, construction, and operation of a new domestic water line along an existing cleared right-of-way between two of the SRS operations areas.

- The final PEIS on Stockpile Stewardship and Management was distributed to the public November 8 . A ROD signed by DOE December 23 appeared in the Federal Register December 26. This PEIS describes and analyzes alternatives to maintain the safety and reliability of the reduced nuclear weapons stockpile in the absence of underground nuclear testing. Based on the decisions described in the ROD, a small amount of stockpile material would be transferred from SRS to the Los Alamos National Laboratory.

- On December 23, DOE signed a Notice of Intent to prepare an EIS on spent nuclear fuel activities at SRS. Initiated by decisions made on the PEIS prepared by DOE on the spent nuclear fuel issue, this site-specific EIS would address alternatives related to SRS facilities to support the management of both domestic and foreign research reactor SN.

Table 2-5 contains a complete list of NEPA documentation activities at SRS during 1996.

The revised SRS sitewide procedure (Environmental Compliance Manual 3Q, Procedure 5.1, "Implementation of the National Environmental Policy Act") was issued at the end of December. Eleven new department NEPA coordinators completed the SRS certification program during 1996. SRS had 31 certified department NEPA coordinators within its various contractor organizations as of December.

SRS has the DOE-approved use of $53 \mathrm{CXs}$ for sitewide routine insignificant actions on site. These CXs require approval only at the department NEPA coordinator level in the field prior to project implementation. SRS was the first site in the DOE complex to be granted such authority within the NEPA compliance process.

The site is continuing to revise its computerized database/tracking system for both completed and ongoing SRS NEPA documentation. This database was developed for reporting and analysis purposes. An SRS NEPA Home Page also was developed and is available to offsite computer users by means of the Internet.

As a result of the DOE NEPA secretarial policy issued in 1994, the site implemented several actions during 1995 that continued through 1996 and resulted in a more streamlined SRS NEPA process. A DOE comparison of EAs prepared throughout the complex indicated that SRS produces these NEPA documents more quickly and cost-effectively than the other DOE sites.

\section{Safe Drinking Water Act}

The federal Safe Drinking Water Act (SDWA) - enacted in 1974 to protect public drinking water sys- 
Table 2-5 SRS Project NEPA Documentation Activities During 1996

Project Name

Level of NEPA

Acceptance of U.S. Origin Foreign Research Reactor Spent Nuclear Fuel

Documentation

Disposition of Surplus Highly Enriched Uranium

PEIS

PEIS

DOE Waste Management

PEIS

Stockpile Stewardship and Management

PEIS

Storage and Disposition of Weapons-Usable Fissile Materials

PEIS

Accelerator Production of Tritium at SRS

EIS

Interim Management of Nuclear Materials

EIS

Shutdown of the SRS River Water System

EIS

SRS Spent Nuclear Fuel

EIS

SRS Waste Management

EIS

Disposition of Rocky Flats Plutonium Scrap

EIS

Tritium Extraction Facility at SRS

EIS

Upgrade of Canyon Exhaust System

EIS

Waste Isolation Pilot Plant

SEIS

Saltstone Disposal Alternative Design

$S A$

Seismic Activity on F Canyon

$S A$

Seismic Activity on $\mathrm{H}$ Canyon $\quad$ SA

Closure of $\mathrm{F}$ and $\mathrm{H}$ Area High-Level Waste Tanks EA

Commercial Wood Products Facility on SRS EA

Domestic Water Supply Upgrades and Consolidation

EA

Expansion and Operation of Central Shops Borrow Pit (was "Central Services Works Engineering

Borrow Pit" in 1995 Report)

EA

Offsite Processing of Depleted Uranium

EA

SRS Wetland Mitigation Bank Program

EA

Transportation of Radiological Materials

EA

Tritium Extraction Furnace Prototype

EA

Tritium Facility Modernization and Consolidation (was "Tritium Facility Upgrades" in 1995 Report)

\footnotetext{
Key: EA - Environmental Assessment

SA - Supplement Assessment

EIS - Environmental Impact Statement

PEIS - Programmatic Environmental Impact Statement

SEIS - Supplemental Environmental Impact Statement
}

tems-was amended in 1980, 1986, and 1996. The SRS drinking water supply is from groundwater sources, which support 26 domestic water systems. The number of systems (originally 28 ) was reduced by two in 1996 by connecting D-Area and TNX Area and shutting down the P-Area water system. Eleven of the systems on site regularly serve more than 25 people each and meet the requirements for nontransi- ent, noncommunity systems, which are regulated by SCDHEC. The remaining 15 systems, each of which serves fewer than 25 people, are classified as "state" systems by SCDHEC and receive a lesser degree of regulatory oversight.

SRS provides drinking water to the majority of its employees through the 11 nontransient, 
noncommunity systems, which the site continues to work toward upgrading. Approval of the SRS Domestic Water Consolidation Preliminary Engineering Report was issued by SCDHEC May 24, 1993. The report recommended consolidation of the major site drinking water systems into three systems through the installation of

- $\quad$ three elevated storage tanks

- looped distribution piping

- a centralized water treatment facility

Plans had been to reclassify the L-Area system as a "state" system by September 1997, but because of a new mission in L-Area, this system now must be upgraded and will be tied to the K-Area system in 1997. Drinking water system consolidation, scheduled for completion by September 1997, replaces the upgrade plan submitted to SCDHEC in October 1991.

As of December 1996, the consolidation project was 8 months ahead of schedule. The following projects have been completed as part of system consolidation:

- K-Area water system (elevated storage tank, treatment, piping)

- D-Area water system (wells, elevated storage tank, treatment)

- A-Area Elevated Storage Tank

- D-Area and TNX-Area Connection

- C-Area/N-Area Elevated Storage Tank

- $\quad$ Piping upgrades in the following areas: A, B, C, $\mathrm{D}, \mathrm{N}$, Forestry, and TNX

On November 15, 1993, WSRC received analysis results indicating that lead and copper concentrations in the Forestry Area domestic water system exceeded SDWA regulatory action levels. As a result of this exceedance, and in accordance with Lead and Copper Rule requirements, WSRC installed a soda ash feed system ( $\mathrm{pH}$ adjustment) in May 1995 as a corrosion control measure, although primarily bottled water is consumed in this area. Since the installation of this treatment system, the Forestry Area has received satisfactory samples from two consecutive 6-month monitoring periods and has been approved by SCDHEC to proceed with sampling under a reduced monitoring plan.

During 1996, lead and copper compliance sampling was performed under an SCDHEC-approved reduced-monitoring plan for $S R S$ small domestic water systems in the following areas: B, C, D, F, H, $\mathrm{K}, \mathrm{L}, \mathrm{N}, \mathrm{P}, \mathrm{S}$, and TNX. A-Area has been approved for ultrareduced monitoring and is not required to sample until 1998.

None of these systems exceeded the lead and copper action levels in the 90th percentile during 1996. The National Primary Drinking Water Regulations specify that treatment technique requirements are triggered by exceedances of the lead and copper action levels measured in the 90 th percentile.

\section{Clean Water Act}

\section{NPDES}

The CWA of 1972 created the NPDES program, which is administered by SCDHEC under EPA authority. The program is designed to protect surface waters by limiting releases of effluents into streams, reservoirs, and wetlands. Radiological effluents are limited under DOE orders. Discharge limits are set for each facility to ensure that SRS operations do not adversely impact water quality.

SRS had five NPDES permits for most of 1996-two for industrial wastewater discharge (SC0000175 and SC0044903), two for general stormwater discharge (SCR000000 and SCR100000), and one for land application (ND0072125). Permits SC0000175 or SC0044903 regulated 83 active and inactive NPDES outfalls at SRS during much of 1996. Based on repermitting activities that take into account current circumstances at SRS, SCDHEC issued SRS a single new permit August 6 to replace the expired but administratively extended SC0000175 and SC0044903 permits. This new permit recognizes 37 active outfalls and requires the analysis each year of approximately 5,800 parameters to show compliance. All monitoring was reported to SCDHEC in the monthly Discharge Monitoring Reports, as required by the permit. [SRS Data, 1997].

A list of exceedances, including outfall locations, probable causes, and corrective actions, can be found in chapter 8, "Nonradiological Effluent Monitoring."

In October 1996, SCDHEC personnel conducted a 2-week audit in which SRS wastewater facilities were inspected and the permitted NPDES outfalls were sampled. All the facilities passed the operations/maintenance part of the audit. Sample analytical results indicated that the facilities had no problems and that there were two exceedances, which were explained in the October Discharge Monitoring Report.

Because of the new NPDES permit, many of the outfalls covered under the old permit have been reevaluated and now are covered under general stormwater permit SCR000000 for stormwater 
discharges associated with industrial activity, excluding construction activity. The permit requires that the stormwater discharges be sampled and that the data generated be compiled and evaluated. Under the old NPDES permit, 11 outfalls were monitored as representative of the 48 stormwater outfalls listed. With the new permit, many of the outfalls that were covered have been reevaluated as being stormwater only and will be covered under the SCR000000 permit. These are being evaluated, and those that qualify will be added to the stormwater program, with representative outfalls to be chosen for sampling. The stormwater outfalls represent a wide range of SRS activities, including

- $\quad$ storage, use, or disposal of EPCRA Section 313 chemicals

- $\quad$ land disposal units

- steam electric generation

- chemical and allied product manufacturing

- borrow pits

As required by the general permit, a pollution prevention plan was developed and implemented in 1993 and updated in 1996 for the identified stormwater outfalls. The plan identifies facility areas where "best management practices" and/or "best available technology" should be implemented to prevent or mitigate the release of pollutants with stormwater runoff.

All construction activity that would result in a land disturbance of 5 or more acres must be permitted. Currently, the 15 land areas associated with industrial activity from construction activity are permitted as required under Permit SCR100000. The pollution prevention plan for this permit also requires a sediment reduction and erosion control plan.

Under the federal Oil Pollution Prevention regulation (40 CFR 112), SRS must report petroleum product discharges of 1,000 gallons or more into or upon the navigable waters of the United States, or petroleum product discharges in harmful quantities that result in oil sheens. No such incidents occurred at the site during 1996.

SRS has an agreement with SCDHEC to report petroleum product discharges of 25 gallons or more to the environment. Two such incidents occurred at the site during 1996.

\section{Dredge and Fill; Rivers and Harbors}

The Clean Water Act, Section 404, "Dredge and Fill Permitting," as amended, and the Rivers and Harbors
Act, Sections 9 and 10, "Construction Over and Obstruction of Navigable Waters of the United States," protect U.S. waters from dredging and filling and construction activities by permitting of such projects. Through implementation of regulations in 33 CFR and 40 CFR, dredge and fill operations in U.S. waters are defined, permitted, and controlled. In 1996, seven projects were permitted under $33 \mathrm{CFR}$ 330 (a general permit under Section 404) of the nationwide permit (NWP) program. The domestic water upgrade was permitted under NWP 12, "Utility Line Backfill and Bedding." Bridges over Upper Three Runs Creek at Road F and Road 8-1, Fourmile Branch at Road 4, and Lower Three Runs Creek at Road B were permitted under NWP 3,

"Maintenance." Also, three erosion control projects of less than one acre each were permitted under NWP 26, "Headwaters and Isolated Waters Discharges." These projects were located near F-Area and Z-Area.

\section{Construction in Navigable Waters}

SCDHEC Regulation 19-450, "Permit for Construction in Navigable Waters," protects the state's navigable waters through the permitting of any dredging, filling, construction, or alteration activity in, on, or over state navigable waters, in or on the beds of state navigable waters, or in or on land or waters subject to a public navigational servitude. The only state navigable waters at SRS are Upper Three Runs Creek (through the entire site) and Lower Threes Runs Creek (upstream to the base of the PAR Pond Dam). In 1996, several SRS projects were permitted under Regulation 19-450. On Upper Three Runs, permits were received for the pipe bridge crossing at Road F and the traffic bridges at Roads C, F, 2-1, and 8-1. On Lower Three Runs, a permit was received for construction of the bridge at Road $B$.

\section{Federal Insecticide, Fungicide, and Rodenticide Act}

The Federal Insecticide, Fungicide, and Rodenticide Act restricts the application of pesticides through a state-administered certification program. SRS's pesticide procedure provides guidelines for pesticide use and requires that applicators be state certified. A pesticide-use task group evaluates planned pesticide programs to ensure that they are acceptable and that appropriate pesticides are used so that any impact on the environment is minimal. The task group also

- maintains records of pest control activities

- assists in communicating information about pesticide use to other site contractors 
- contacts offsite utility companies to determine the pesticide applications they plan for right-ofway maintenance on SRS property

SRS pesticide programs typically include such activities as the maintenance of roadways and fence lines through the use of herbicides.

\section{Clean Air Act}

\section{Regulation, Delegation, and Permits}

The CAA provides the basis for protecting and maintaining air quality. Some types of SRS air emissions, such as radioactive sources and ozone-depleting substances (ODS), are regulated by EPA, but most are regulated by SCDHEC, which must ensure that its air pollution regulations are at least as stringent as the CAA's. This is accomplished through SCDHEC Regulation 61-62, "Air Pollution Control Regulations and Standards."

Under the CAA and as defined in federal regulations, SRS is classified as a "major source" and, as such, is assigned one permit number (0080-0041) by SCDHEC. In this permit, each emission source is identified by the area designation, by a point identification number, and by a source description. SRS holds operating and construction permits from SCDHEC's Bureau of Air Quality Control, which regulates nonradioactive toxic and criteria pollutant emissions from approximately 192 point sources, several of which have specific emission limits. As of May 1994, SCDHEC had completed renewal of all SRS operating permits, which are valid for 5 years. Of the 192 point sources, 155 were in operation in some capacity during 1996 . The remaining 37 sources either were under construction or were being maintained in a "cold standby" status.

During 1996, SCDHEC conducted 192 source compliance inspections at SRS, including biennial stack tests, initial operation inspections following completion of construction, and annual compliance inspections. As indicated earlier, the 1996 compliance rate was 100 percent, and the site received no NOVs.

\section{National Emission Standards for Hazardous Air Pollutants}

The National Emission Standards for Hazardous Air Pollutants (NESHAP) is a CAA-implementing regulation that sets air quality standards for air emissions containing hazardous air pollutants, such as radionuclides, benzene, and asbestos. The NESHAP regulations found in 40 CFR 61 are divided into subparts based on specific hazardous pollutant categories, such as Subpart $H$ for radionuclides and Subpart M for asbestos. The Clean Air Act
Amendments (CAAA) of 1990 revised the original list of hazardous air pollutants. The revised list of 189 air pollutants includes all radionuclides as a single item. Regulation of these pollutants, except for radionuclides, has been delegated to SCDHEC; EPA Region IV regulates radionuclides.

SRS, like most South Carolina industrial complexes, uses a number of chemicals identified by SCDHEC as toxic air pollutants and by EPA as hazardous air pollutants. These include many common consumer products-e.g., off-the-shelf bug sprays, correction fluids, paints, sealers, janitorial cleaning supplies, gasoline for vehicles, etc. - as well as a number of typical industrial chemicals, such as degreasers, solvents, metals, batteries, and diesel fuel. But SRS has at least one category, radionuclides, not found in typical industrial settings. During the course of normal operations, some radionuclides are released to the air.

NESHAP Radionuclide Program The SRS NESHAP radionuclide program continues to change to incorporate sampling, monitoring, and dose assessment practices that meet or exceed the requirements of $40 \mathrm{CFR} 61$, Subpart $H$. The radionuclide FFCA was signed October 31, 1991; the first amendment to the FFCA for radionuclide NESHAP was signed by EPA Region IV on August 16, 1993. This amendment provided SRS an extension of the original FFCA through February 10, 1995 , to accomplish monitoring equipment upgrades to several additional sources. These upgrades were completed on time, and the FFCA was officially closed by EPA Region IV on May 10, 1995.

During 1996, the maximally exposed individual effective dose equivalent, calculated using the NESHAP-required CAP88 computer code, was estimated to be $0.06 \mathrm{mrem}(0.0006 \mathrm{mSv})$, which is 0.6 percent of the 10 -mrem-per-year (0.10-mSv-per-year) EPA standard (chapter 7, "Potential Radiation Doses").

NESHAP Nonradionuclide Program SRS uses many chemicals identified as toxic or hazardous air pollutants, but the majority of these chemicals are not regulated under the CAA or under federal NESHAP regulations. Except for asbestos, SRS facilities and operations do not fall into any of the "categories" listed in the subparts. Under Title III of the federal CAAA of 1990, EPA in December 1993 issued a final list of hazardous air pollutant-emitting source categories potentially subject to maximum achievable control technology standards. These standards are being developed and issued over a 10 -year period that will end in the year 2000 , based on a schedule arranged according to 
- the effects of each pollutant

- the industry group source category

- the abatement technology available

In an attempt to regulate hazardous or toxic air pollutants in South Carolina, SCDHEC established Air Pollution Control Regulation 61-62.5, Standard No. 8, "Toxic Air Pollutants," in June 1991. To demonstrate compliance with this standard, SRS completed and submitted an air emissions inventory and air dispersion modeling data for all site sources in 1993. The submitted data demonstrated compliance by computer modeling the accumulated ambient concentration of individual toxic air pollutants at the boundary line and comparing them to the Standard No. 8 maximum allowable concentrations. To ensure continued compliance with Standard No. 8, new sources of toxic air pollutants must be permitted, which requires submittal of appropriate air permit applications and air dispersion modeling. Sources with emissions below a threshold of 1,000 pounds per month of any single toxic air pollutant may be exempted from permitting requirements. During 1996 , seven sources of toxic air pollutants either were issued a construction permit or exempted from permitting requirements.

NESHAP Asbestos Removal Program Asbestos insulation, considered one of the best boiler and piping insulators, can be found in older buildings throughout SRS. This is because people were unaware of the danger of airborne asbestos fibers in the early 1950 s, when SRS was constructed. Today, however, it is known that asbestos can cause cancer in humans. The site implemented an asbestos removal program in 1988.

Asbestos is removed during maintenance and renovations of equipment and buildings. During 1996, SRS removed 12,547 square feet of transite panel, which contains asbestos. Also removed were 4,283 linear feet and 2,481 square feet of asbestos pipe and surface insulation. This compares with 9,253 square feet of transite panel and 3,486 linear feet and 1,678 square feet of asbestos pipe and surface insulation removed during 1995. Estimates of the percentage of total friable asbestos (a form that can be crumbled or pulverized with hand pressure when dry) removed from SRS cannot be accurately determined because it is not known exactly how much exists on site. SRS will continue to identify and remove such asbestos according to state (SCDHEC R.61-86.1) and federal (40 CFR 61, Subpart M) regulations and "best management practices."
Other CAA Requirements Only a few of the major sections of the CAA and its 1990 amendments and regulations have had-or are expected to have-a significant impact on SRS sources and facilities. These include Title V, "Operating Permit Program," and Title VI, "Stratospheric Ozone Protection." The other regulations impacting SRS facilities are implemented primarily in SCDHEC Regulation 61-62 and existing operating or construction permits.

Air Emissions Inventory SCDHEC Regulation 61-62.1, Section III, "Emissions Inventory," requires compilation of an air emissions inventory. To demonstrate compliance, SRS personnel conducted a comprehensive air emissions inventory of all site facilities in 1993. Other purposes of this inventory were

- to ensure that all radiological and nonradiological sources had been accounted for

- to better characterize emission points from site processes

- to provide data for air dispersion modeling that had been required for compliance with Regulation 61-62.5, Standard No. 2 ("Ambient Air Quality Standards") and Standard No. 8.

Guidelines and procedures were written to ensure documentation of all vents and stacks for each building and to calculate emissions based on design capacity, maximum potential emissions, and actual emissions for a selected period of time.

The inventory identified approximately 5,300 radiological and nonradiological air emissions sources. Air emissions data from 1990 established the SRS baseline emissions. Calculations from the 1990 data demonstrated that SRS complied with Standard No. 8. The information from this inventory for all emission sources will be used as input into SRS's Title V permit application, as well as to meet other SCDHEC requirements. One such requirement is that inventory data must be recorded annually and reported every other year. Data from 1995 were reported in 1996. Compilation of 1996 data will be completed in 1997.

Title V Operating Program As previously indicated, the CAAA of 1990 also include, under Title V, a major new permitting section expected to have a significant impact on the site. The primary purpose of the Title $\mathrm{V}$ permitting program is to establish federally enforceable operating permits for major sources of air emissions. The implementation plan for this program, submitted to EPA in 1993 by the State of South Carolina and subsequently approved by EPA in June 1995, required that SRS submit an extensive application package for air 
emission sources at the site by March 15, 1996; SRS submitted the Title $\mathrm{V}$ permit application before the deadline. The full impact on the site is not yet known because the source information and regulation applicability still are being determined. In addition to sources already on existing SCDHEC operating or construction permits, the new permit resulting from Title V may include sources previously "grandfathered" by existing regulations, and it is expected to add a number of new regulatory requirements.

Ozone-Depleting Substances The CAAA of 1990 contained a chapter under Title VI addressing stratospheric ozone protection. This law requires that EPA establish a number of regulations to phase out the production and consumption of ODS. The substances commonly are used as refrigerants in air conditioning and cooling systems; as degreasers and cleaners; as spray can propellants; as fire suppressants (Halon); and as laboratory extractions; and in many other common consumer products.

Several sections of Title VI of the CAAA of 1990, along with recently established EPA regulations, apply to the site. The ODSs are regulated in two general categories: Class I substances-chlorofluorocarbons (CFCs), Halon, carbon tetrachloride, methyl chloroform, methyl bromide, and hydrobromofluorocarbons (HBFCs)-and Class II substances, or hydrochlorofluorocarbons (HCFCs). Class I ODSs are about 10 times more ozone-depleting than HCFCs and thus are more strictly regulated. As required by the CAAA of 1990 , most Class I Halon was phased out of production by January 1, 1994, and other Class I ODSs were phased out by January 1,1996 . This means that several very important refrigerants (CFC 11, 12, 114, and 502) used on site essentially may become unavailable for purchase. Many of the large chillers on site that use these refrigerants are being scheduled for total replacement or for retrofits that will use HCFCs or other chemical substitutes. The site also is scheduling fire suppression (Halon) system replacements. Many common degreasers are Class I ODSs and have been targeted for replacement. Most major degreasing applications already have been eliminated or replaced with non-ODS. Smaller ODS degreasing applications, such as those in maintenance and electrical shops, are being targeted for phaseout. ODSs used in laboratory extraction procedures will be replaced when EPA approves newly developed processes that use non-ODSs.

The SRS CAAA of 1990 Title $V$ air permit application includes ODS emission sources. All large (greater than or equal to 50-pound charge) heating, ventilation, and air conditioning (HVAC)/chiller systems for which there are recordkeeping requirements are included as fugitive emission sources.

In 1994, the site formed a CFC steering committee of participants from all the major users of these substances to provide initial direction in the phaseout of Class I ODSs on the site. A number of technical subcommittees also were initiated at that time to address particular applications, such as refrigeration, fire suppression, degreasers, laboratory applications, and environmental compliance. The ODS

Subcommittee of the Central Environmental Committee was created in 1995 to communicate to site organizations-through field representatives-any changes in Title VI regulations that could affect established programs. The "Savannah River Site Refrigerant Management Plan," completed and issued in September 1994, provides guidance to assist SRS and DOE in the phaseout of $\mathrm{CFC}$ refrigerants and equipment.

The site has

- purchased certified recycling equipment

- trained and certified technicians where required

- implemented required recordkeeping and leaktracking for large cooling systems

- implemented proper labeling and other recordkeeping requirements

In 1996, SRS let a subcontract for the offsite reclamation of used refrigerants. The site also eliminated the use of CFC-114 by completing replacement of the 789-A chiller plant with a new plant that uses a non- $\mathrm{CFC}$ refrigerant. The 55,000 pounds of CFC-114 will be sold as part of a decontamination and decommissioning (D\&D) contract. Additionally, Executive Order 12856 requires a 50-percent reduction in CFC usage by the end of 1999, based on 1993 data. SRS surpassed the 21,116-pound 1999 goal in 1996 by reducing CFC refrigerant usage to 12,570 pounds.

Three other central refrigerant plant projects-for tritium facilities, F-Canyon, and H-Canyon-were initiated in 1996 to further reduce the site's dependence on Class I ODSs.

\section{Toxic Substances Control Act}

The Toxic Substances Control Act (TSCA) gives EPA comprehensive authority to identify and control chemical substances manufactured, imported, processed, used, or distributed in commerce in the United States. Reporting and recordkeeping are mandated for new chemicals and for any chemical 
that may present a substantial risk of injury to human health or the environment. EPD and the Industrial Hygiene Section coordinate reporting and recordkeeping requirements under TSCA.

Polychlorinated biphenyls (PCBs), which are chemicals specifically regulated under 40 CFR 761 of TSCA, have been used in the past in various SRS processes. PCBs were used on site in pre-1979 electrical equipment in the form of transformers, small capacitors, and fluorescent light ballasts. The site has a well-structured PCB program that complies with TSCA regulation 40 CFR 761, with DOE orders, and with WSRC policies. The 1995 PCB Annual Document Log was completed prior to the July 1,1996 , deadline in full compliance with the regulations. Disposal of PCBs from SRS is conducted at EPA-approved disposal facilities within the regulatory time frame.

In August 1993, PCBs were confirmed to be present as a component of dense nonaqueous phase liquids in samples from two groundwater monitoring wells around the M-Area hazardous waste management facility. Regulators were notified and a modification to the RCRA Part B Permit Application to address the discovery of PCBs was submitted to SCDHEC in December 1993. Any waste generated was handled according to the appropriate TSCA and RCRA requirements. Savannah River Technology Center (SRTC) continues to study ways to remediate the dense nonaqueous phase liquids.

Certain PCB waste generated by SRS during the late 1970 s and early 1980 s was radioactively contaminated. Most of the radioactively contaminated waste resulted from a 1978 spill of PCBs from a failed electrical capacitor inside a nuclear materials processing area. TSCA regulations call for annual disposal of PCB waste, but there is insufficient capacity for disposal off site of radioactive PCB waste. A request to conduct a treatability study on this waste was approved by EPA in August 1995, and work continued on the study from late 1995 until May 1996. The study included the evaluation of three chemical dechlorination technologies and one thermal desorption/vacuum extraction technology. The chemical dechlorination technologies were unsuccessful in treating the waste below TSCA thresholds. The test of the thermal desorption/vacuum extraction process was terminated prior to its conclusion because of vendor equipment malfunction and the shutdown of the vendor facility. The residuals from the study subsequently were returned to SRS for storage. SRS now is working to ship the waste to the Oak Ridge TSCA incinerator, but this process is not expected to be completed until 1998 at the earliest.
In 1996, PCBs were detected in certain painted surfaces and electrical cable at the Heavy Water Components Test Reactor. The materials were analyzed as part of the predemolition characterization of the building. Subsequently, varying amounts of PCBs were detected in painted surfaces in two other site facilities. Prior to this discovery, the use of PCBs in paints and other solid items at SRS was unrecognized. The site is investigating the issue of PCBs in solids in older, pre-TSCA structures and is working with EPA on the appropriate path forward.

During 1996, SRS completed the reclassification as non-PCB of 20 electrical transformers that previously contained PCBs. At this time, all the site's electrical transformers are non-PCB. Also during 1996, SRS ended its investigation into the source of PCBs detected in 1994 in the R-Reactor disassembly basin sediment and water. Analyses of several items identified as possible sources did not reveal PCBs.

\section{Endangered Species Act}

The Endangered Species Act of 1973, as amended, provides for the designation and protection of wildlife, fish, and plants in danger of becoming extinct. The act also protects and conserves the ecosystems on which such species depend.

Several threatened and endangered species exist at SRS. The site conducts research on the wood stork, the red-cockaded woodpecker, the bald eagle, the shortnose sturgeon, and the smooth purple coneflower. A study of the bald eagle at PAR Pond and L-Lake was completed in 1996 to comply with the Endangered Species Act, as requested by the U.S. Fish and Wildlife Service. Programs designed to enhance the habitat of such species also are in place.

NEPA documentation was prepared and reviewed for several new projects at SRS in 1996. A biological assessment conducted for the Enviro-Comp site found no activities that would significantly impact endangered species. A biological assessment for the River Water System Shutdown EIS concluded that the proposed action could affect the bald eagle, the alligator, and the wood stork. This conclusion resulted in ongoing consultations with U. S. Fish and Wildlife Services personnel, as pursuant to Section 7, "Interagency Cooperation," of the Act.

\section{National Historic Preservation Act}

The National Historic Preservation Act of 1966 , Section 106, governs the protection and preservation of archaeological and historical resources. SRS ensures that the site is in compliance with this act through the site-use process. All sites being considered for activities such as construction are 
evaluated by the University of South Carolina's archaeology group to ensure that archaeological or historic sites are not impacted. NEPA reviews were conducted for numerous new projects at SRS during 1996; only one project - the Three Rivers Landfill Project-was found to have activities of significant impact in terms of the National Historic Preservation Act. This project contained four sites eligible for nomination to the National Registry for Historic Places. The landfill was located so that impacts to three of the four sites can be avoided; the four site was excavated to preserve artifacts.

\section{Floodplains and Wetlands}

Under DOE General Provisions, 10 CFR, Part 1022

("Compliance with Floodplains/Wetlands

Environmental Review Requirements"), establishes policies and procedures for implementing DOE's responsibilities in terms of compliance with Executive Orders 11988 ("Floodplain Management") and 11990 ("Protection of Wetlands"). Part 1022

includes DOE policies regarding the consideration of floodplains/wetlands factors in planning and decision making. It also includes DOE procedures for identifying proposed actions involving floodplains/wetlands, providing early public reviews of such proposed actions, preparing floodplains/wetlands assessments, and issuing statements of findings for actions in floodplains.

\section{Executive Order 11988, "Floodplain Management"}

Executive Order 11988, "Floodplain Management," was established to avoid long- and short-term impacts associated with the occupancy and modification of floodplains. Evaluation of impacts to SRS floodplains is ensured through the NEPA Evaluation Checklist and the site-use system. Site-use applications are reviewed for potential impacts by WSRC, DOE-SR, SRFS, and the Savannah River Ecology Laboratory (SREL), as well as by professionals from other organizations. NEPA reviews of new projects at SRS in 1996 found no activities of significant impact with respect to Executive Order 11988.

\section{Executive Order 11990, "Protection of Wetlands"}

Executive Order 11990, "Protection of Wetlands," was established to mitigate adverse impacts to wetlands caused by destruction and modification of wetlands and to avoid new construction in wetlands wherever possible. Avoidance of impact to SRS wetlands is ensured through the site-use process, various departmental procedures and checklists, and project reviews by the SRS Wetlands Task Group.
Many groups and individuals, including scientists at SRTC, SREL, and EPD, review site-use applications to ensure that proposed projects do not impact wetlands. NEPA reviews of new projects at SRS in 1996 found no activities of significant impact with respect to Executive Order 11990. Potential impacts outlined in the River Water System Shutdown EIS will be mitigated as necessary for SRS to fulfill the DOE policy of "no net loss" of wetlands.

\section{Environmental Release Response and Reporting}

\section{Response to Unplanned Releases}

The SRS environmental monitoring program extends beyond routine effluent monitoring and environmental surveillance activities. Upon request by area operations personnel, the Environmental Monitoring Section (EMS) is prepared to respond to unplanned environmental releases-both radiological and nonradiological.

In 1996, there were a number of unplanned environmental releases, but area operations personnel did not require the sampling and analysis services of EMS. If the services of EMS personnel are requested, the samples collected are given priority in preparation and, if radiological in nature, priority in the count room. Data are validated and a determination is made as to whether there has been an actual release. If there has, then consequences to the public and the environment are determined.

\section{Occurrences Reported to Regulatory Agencies}

"Federally permitted" releases comply with legally enforceable licenses, permits, regulations, or orders. Under the Atomic Energy Act, for example, releases of SRS radionuclides are federally permitted as long as public dose standards in DOE orders are not exceeded.

If a nonpermitted release to the environment of a reportable quantity (RQ) or more of a hazardous substance (including radionuclides) occurs, CERCLA requires notification of the National Response Center. Also, the CWA ren!ires that the National Response Center be notified if an oil spill causes a "sheen" on navigable waters of the United States, such as rivers, lakes, or streams. Reporting of oil spills was reinforced with liability provisions in CERCLA's National Contingency Plan.

Other CERCLA provisions allow exemptions from reporting a release of an $\mathrm{RQ}$ or more of a hazardous substance if the release is covered by a 
Table 2-6

CERCLA Releases Reported to Regulatory Agencies in 1996

\begin{tabular}{|c|c|c|c|}
\hline Date & $\begin{array}{l}\text { Applicable Regulation/ } \\
\text { Reason for Notification }\end{array}$ & $\begin{array}{l}\text { Agencies } \\
\text { Notified }\end{array}$ & Description \\
\hline Jan. 23 & Exceeded RQ of 1 pound & EPA/SCDHEC & $\begin{array}{l}\text { Released to ground about } 8 \text { pounds of } \\
\text { condensate liquid (suspected of being } \\
\text { hazardous waste but later determined to } \\
\text { contain less than the RQ of hazardous } \\
\text { constituents) }\end{array}$ \\
\hline Feb. 14 & Exceeded RQ of 1 pound & EPA/SCDHEC & $\begin{array}{l}\text { Released to ground 14-22 pounds of } \\
\text { condensate liquid (suspected of being } \\
\text { hazardous) }\end{array}$ \\
\hline
\end{tabular}

continuous-release notification or if it is federally permitted. A continuous-release notification provides an exemption from reporting each release of a specific hazardous substance greater than an $R Q$. The site submitted two continuous-release notifications in 1992 - for ethylene glycol and for asbestos, each of which had a statutory RQ of 1 pound. SRS withdrew the request for continuous-release notification status for ethylene glycol in 1995, when EPA made an adjustment to that $R Q$. The asbestos continuous-release notification request is still active.

During 1996, SRS notified regulatory agencies of two CERCLA reportable releases, which are described in table 2-6. This performance compares with four such releases reported during 1995 , two during 1994 , zero during 1993, three during 1992, and four during 1991.

Also, SRS made six notifications to SCDHEC in 1996 based on agreements with the state. Three were for sewage releases of more than 100 gallons; two were for petroleum spills of more than 25 gallons; and one was a permit exceedance.

EPCRA (40 CFR 355.40) requires that reportable releases of extremely hazardous substances or CERCLA hazardous substances be reported to any local emergency planning committees and state emergency response commissions likely to be affected by the release. There were no EPCRA reportable releases in 1996.

It is SRS policy to notify SCDHEC and the Georgia Department of Natural Resources (GDNR) of any occurrence that may interest state regulatory agencies. Although not required by law, these "courtesy notifications" enhance environmental protection objectives. SRS made eight such notifications to SCDHEC in 1996.

\section{Site Item Reportability and Issues Management (SIRIM) Program}

The Site Item Reportability and Issues Management (SIRIM) program, mandated by DOE Order 232.1 (which superceded DOE Order 5000.3B), "Occurrence Reporting and Processing of Operations Information," is designed to "... establish a system for reporting of operations information related to DOE-owned or operated facilities and processing of that information to provide for appropriate corrective action ...." It is the intent of the order that DOE be “... kept fully and currently informed of all events which could: (1) affect the health and safety of the public; (2) seriously impact the intended purpose of DOE facilities; (3) have a noticeable adverse effect on the environment; or (4) endanger the health and safety of workers."

The SIRIM program at SRS is designed to meet the requirements of $\mathrm{DOE}$ Order 232.1 by ensuring that

- all occurrences specified are identified in a timely manner, categorized, and reported

- proper corrective actions are taken in a timely manner

- all reportable occurrences are reviewed to assess significance and root causes

- occurrence reports to DOE operations are disseminated to prevent the recurrence of similar events

All SIRIM events are classified in one of the following categories: (1) facility condition; (2) environmental; (3) personnel safety; (4) personnel radiation protection; (5) safeguards and security; (6) transportation; (7) value-based reporting; 8) facility status; or 9) cross-group items. The impact-or the anticipated impact - of each event is categorized as follows (based on criteria in site procedures): 
Table 2-7

Environmentally Related Unusual Occurrences Reported Through SIRIM in 1996

\begin{tabular}{lll}
\hline $\begin{array}{l}\text { Discovery } \\
\text { Date }\end{array}$ & Occurrence & $\begin{array}{l}\text { Report No. } \\
\text { (SR-WSRC-) }\end{array} \quad$ Cause/Explanationa \\
\hline
\end{tabular}

Feb. 7 About 135 gallons of fuel oil spilled wVIT-1996-0003 to the ground at Bldg. 292-S, Diesel Fuel Storage Tank \#2

Attributed to suspected clogged filters; investigation nearing completion at yearend

Feb. 14

Fourteen to 22 pounds (about 2 gallons) of condensate liquid, suspected of being hazardous, leaked to the ground from an off-gas system filter compartment housing at the Consolidated Incineration Facility (Bldg. 261-H)

Mar. $22 \quad$ Waste filter housings received from off site was potentially inaccurately characterized

Nov. 11 About 150 gallons of diesel fuel spilled from a logging truck along about 24 miles of SRS roads
CIF-1996-0009

Attributed to human error and design deficiency; corrected by installing drain lines to bottom of filter compartment housing

SLDHZD-1995-0013

Attributed to failure to take into consideration cadmium-plated, cold-rolled steel used as construction material

CSWE-1996-0009 Investigation in progress at year-end

a SRS takes followup corrective actions to minimize the impact on the environment.

- Emergency - the most serious event; requires increased alert status for onsite and, in specific cases, offsite authorities

- Unusual occurrence - a nonemergency event that has significant impact or potential for impact on safety, environment, health, security, or operations

- Off-normal occurrence - an abnormal or unplanned event or condition that deviates from established standards or specifications

In 1996, of the approximately 532 SIRIM-reportable events, 25 were categorized as primarily environmental. Of these 25 events, none were classified as emergencies, four were classified as unusual occurrences, and 21 were classified as off-normal occurrences. Table 2-7 lists the four unusual occurrences reported through SIRIM in 1996.

\section{Assessments/Inspections}

The SRS environmental program is overseen by a number of organizations, both outside and within the DOE complex. In 1996, the WSRC environmental appraisal program consisted of self and independent assessments. The new program employs total-quality management concepts that support the site's four imperatives of safety, disciplined operations, continuous improvement, and cost effectiveness. It also ensures recognition of noteworthy practices, identification of performance deficiencies, and initiation and tracking of associated corrective actions until they are satisfactorily completed. The primary objectives of the WSRC assessment program are to ensure compliance with regulatory requirements and to foster continuous improvement.

In addition to the assessment program, DOE-SR's Environmental Quality \& Management Division (EQMD) ensures - through independent reviews of SRS environmental protection programs and activities - that SRS contractors comply with federal and state environmental regulations, applicable DOE orders, and accepted industry standards.

EQMD operates under the Comprehensive Environmental Protection Assessment Program to identify proficiencies and deficiencies in SRS environmental protection programs and activities according to DOE Order 5482.1B, "Environment, Safety, and Health Appraisal Program," and other environmental requirements. Scheduled assessments have met with positive results; routine 1996 assessments promoted improvement and helped ensure the adequacy of environmental programs and 
operations at SRS. The assessments-programmatic and sitewide in scope-are the functional equivalent of appraisals, as defined in DOE Order 5482.1B.

Among the environmental activities assessed by EQMD in 1996 were

- PCB management

- asbestos management

- management of wastes generated during D\&D activities

- compliance with STP requirements

- environmental restoration activities monitoring, tracking, and reporting

- EMS program management

- NEPA program

- environmental restoration materials control and accountability

- Spill Prevention and Control Countermeasures/ Best Management Practices program

SCDHEC also inspects the SRS environmental program for regulatory compliance. SCDHEC representatives performed three comprehensive compliance inspections in 1996, as follows:

- During the period April 22-25, annual air compliance inspections were conducted for 66 of the site's 155 operating permitted air emission sources. The air emission sources were in compliance.

- The 1996 Comprehensive Monitoring Evaluation (a RCRA inspection) of SRS was conducted September 16-27. Although no deficiencies were cited during the inspection, the letter from SCDHEC on the 1996 Comprehensive Monitoring Evaluation noted one problem-the failure of DWPF to RCRA-train 29 individuals whose work could involve hazardous waste responsibilities-which SRS reported to SCDHEC in June 1996. This issue was referred to the SCDHEC Enforcement Section; no enforcement action was taken, and the 29 individuals were either trained or reassigned.

- During the period October 14-24, annual CWA NPDES operation and maintenance inspections were performed at SRS wastewater treatment facilities, and grab and composite samples were collected at site NPDES discharge points. No deficiencies were noted at the time of the inspection, but SCDHEC is expected to issue a final report-including category ratings-in early 1997.
SCDHEC also performed monthly compliance inspections during the year, with no deficiencies noted.

Two expired NPDES permits were renewed into a single permit, SCO000175, which became effective on October 1, 1996, and expires September 30, 2001. The new permit reduces the number of NPDES outfalls from 81 to 37 , which is considered more representative of current SRS activities.

\section{Environmental Permits}

SRS has 668 construction and operating permits that specify operating levels for each permitted source. This compares with 643 such permits in 1995, 608 in 1994,608 in 1993, and 498 in 1992. Table 2-8 summarizes the permits held by the site during the past 5 years. Appendix B ("SRS Environmental Permits") of this report provides a comprehensive list of the permits, including the permit number, type of permit, and permitted source.

\section{Environmental Training}

The site's environmental training program identifies training activities to teach job-specific skills that protect the employee and the environment while satisfying regulatory training requirements. Chapter 3 contains more information about the training program.

\section{Transition and Decontamination and Decommissioning}

As missions at SRS continue to shift from national defense to cleanup and environmental restoration, selected site facilities are transitioned to responsibility of the Environmental Restoration Division of DOE. As part of this process, existing D\&D activities continue, and new D\&D activities are initiated.

On October 1, 1996, Babcock \& Wilcox joined the Westinghouse management team, establishing B\&W Savannah River Company and providing three senior managers for WSRC's new Facilities Decommission Division. Such organizational realignment is indicative of a renewed emphasis on D\&D. The new division's charter is to manage SRS excess facilities - from completion of operations shutdown through final disposition-in a manner that minimizes life cycle costs without compromising health, safety, or environmental quality.

Since early 1995 at SRS, B\&W Nuclear Environmental Services, Inc., has been actively decontaminating building 232-F (an idle tritium 
processing facility) on a fixed-price subcontract to WSRC. As of December 31, 1996, after 23 months of work at the facility, a number of milestones had been accomplished, including the following:

- removal and packaging for disposal of all hazardous materials

- removal, packaging, and transportation (to the E-Area vaults) of tritium-contaminated process equipment

- removal of interior and exterior walls and deconstruction of structural steel and concrete

Another significant $D \& D$ project now under Facilities Decommission Division management is the Heavy Water Components Test Reactor. The project's characterization phase, along with a decommissioning alternatives study, were completed in December 1996. This included a 30-day public comment period. The Request for Proposal for the D\&D of the Heavy Water Components Test Reactor will be prepared for distribution by late January 1997 , and a subcontract for the D\&D is scheduled to be let in the spring or early summer of 1997.

\section{Other Major Environmental Issues and Actions}

Key SRS compliance issues addressed during 1996 included a shutdown of the site's river water system.

The SRS river water system was constructed in the late 1950s to pump large quantities of cooling water from the Savannah River to five nuclear reactors located on site. Because all the reactors are shut down, no cooling water is required and the system is identified in the SRS Strategic Plan as potential surplus infrastructure.

DOE proposes to shut down the river water system and place all or part of it in a standby condition. The department published the draft EIS in November and accepted comments from the public and government agencies; it plans to issue the final EIS in May 1997. A Record of Decision will be made in July 1997. Under the "standby" alternative, portions of the river water system would be placed in a variety of conditions. For example, surplus portions of the system could be shut down and deactivated; the deactivated portions would not be capable of being

Table 2-8

SRS Construction and Operating Permits

\begin{tabular}{lrrrrr} 
Type of Permit & \multicolumn{5}{c}{ Number of Permits } \\
\hline & 1992 & 1993 & 1994 & 1995 & 1996 \\
Air & 134 & 172 & 189 & 200 & 196 \\
U.S. Army Corps of Engineers 404 & 1 & 1 & 1 & 0 & 0 \\
Army Corps of Engineers Nationwide Permit & $\mathrm{a}$ & $\mathrm{a}$ & $\mathrm{a}$ & $\mathrm{a}$ & 8 \\
Domestic Water & 127 & 146 & 152 & 165 & 178 \\
Industrial Wastewater & 75 & 79 & 83 & 90 & 87 \\
NPDES-Discharge & 2 & 2 & 2 & 2 & 2 \\
NPDES-No Discharge & 0 & 1 & 1 & 1 & 1 \\
NPDES-Stormwater & 1 & 2 & 2 & 2 & 2 \\
RCRA & 1 & 1 & 1 & 1 & 1 \\
Sanitary Wastewater & 119 & 120 & 133 & 133 & 135 \\
SCWRC 401 & 1 & 1 & 1 & 1 & 1 \\
SCDHEC Navigable Waters & $\mathrm{a}$ & $\mathrm{a}$ & $\mathrm{a}$ & $\mathrm{a}$ & 4 \\
Solid Waste & 6 & 6 & 6 & 6 & 6 \\
Underground Injection Control & 3 & 6 & 7 & 13 & 18 \\
Underground Storage Tanks & $29^{\mathrm{a}}$ & $31^{\mathrm{a}}$ & $31^{\mathrm{a}}$ & $29^{\mathrm{a}}$ & 29 \\
Totals & 498 & 567 & 608 & 643 & 668 \\
& & & &
\end{tabular}

a Formal tracking of these permits was initiated in 1996.

b Additional underground storage tank permits not previously reported were identified in 1996. 
restarted. Other portions would be placed in a "layup" condition to ensure that they could be restarted (for future missions or potential environmental mitigation, if necessary).

The EIS evaluates the impacts of two other alternatives. The first-the no-action alternative-would continue current river water system operation, under which the river water system would continue to provide makeup water to L-Lake (and PAR Pond, if necessary). The second alternative would shut down and deactivate the entire river water system. Under this alternative, other water sources (such as from groundwater) would be needed to provide for minor nonreactor cooling requirements (air conditioning, small equipment cooling, etc.). The cessation of river water input to $\mathrm{L}$-Lake would result in the gradual disappearance of the lake and its return to original creek conditions over a period of about 10 years.

The EIS also evaluates a number of environmental impacts, such those as from exposed sediments in the L-Lake bed and from the loss of wildlife habitat as the lake recedes to the original creek condition. It also covers the following:

- impacts to PAR Pond if the lake level drops below 195 feet mean sea level

- the maintenance of minimum flows in Steel Creek and Lower Three Runs Creek

- the classification of L-Lake bed as a potential CERCLA unit, and possible remediation

- the evaluation of various river water system standby alternatives 
Table 2-9 Examples of RCRA and RCRA/CERCLA Units at SRS - 1996

Page 1 of 5

\begin{tabular}{|c|c|c|}
\hline Site and Location & $\begin{array}{l}\text { Building or Identification } \\
\text { Number(s) }\end{array}$ & Additional Information \\
\hline \multicolumn{3}{|l|}{ A-Area and M-Area } \\
\hline A-Area Burning Rubble Pits & $731-A,-1 A$ & \\
\hline A-Area Coal Pile Runoff Basin & $788-3 A$ & \\
\hline A-Area Miscellaneous Rubble Pile & $731-6 A$ & \\
\hline A-Area Rubble Pit & $731-2 A$ & \\
\hline A-Area Stormwater Outfalls & $A-001,-002,-024, A-013$ & \\
\hline 716-A Motor Shop Seepage Basin & $904-101 G$ & \\
\hline $\begin{array}{l}\text { M-Area Hazardous Waste Management } \\
\text { Facility (HWMF) including }\end{array}$ & $904-51 \mathrm{G}, 904-112 \mathrm{G}$ & RCRA-regulated \\
\hline AM Groundwater Portion & $904-110$ & $\begin{array}{l}\text { RCRA-regulated; Interim Action } \\
\text { ROD issued }\end{array}$ \\
\hline $\begin{array}{l}\text { M-Area HWMF Settling Basin Inactive } \\
\text { Process Sewers to Manhole } 1\end{array}$ & $081-M$ & RCRA-regulated \\
\hline M-Area HWMF Vadose Zone & & $\begin{array}{l}\text { RCRA-regulated; Interim Action } \\
\text { ROD issued }\end{array}$ \\
\hline M-Area West & $631-21 G$ & \\
\hline Met Lab Basin/Carolina Bay & $904-110$ & $\begin{array}{l}\text { RCRA-regulated; Interim Action } \\
\text { ROD issued }\end{array}$ \\
\hline $\begin{array}{l}\text { Miscellaneous Chemical Basin/ } \\
\text { Metals Burning Pits }\end{array}$ & $731-4 A,-5 A$ & \\
\hline Silverton Road Waste Site & $731-3 A$ & \\
\hline SRL Seepage Basins & $904-53 G 1,-53 G 2,-54 G,-55 G$ & \\
\hline SRL 904-A Process Trench & $904-A$ & \\
\hline \multicolumn{3}{|l|}{ C.Area } \\
\hline C-Area Burning/Rubble Pit & $131-C$ & \\
\hline C-Area Coal Pile Runoff Basin & $189-\mathrm{C}$ & \\
\hline C-Area Reactor Seepage Basins & 904-066G, -067G, -068G & \\
\hline C-Area Stormwater Outfall & C-004 & \\
\hline Tank 105-C & & $\begin{array}{l}\text { RCRA-regulated; Final ROD } \\
\text { issued }\end{array}$ \\
\hline \multicolumn{3}{|l|}{$\begin{array}{l}\text { General Separations and Waste Managenent: } \\
\text { Areas (E. F. If. S. Y. and Z) }\end{array}$} \\
\hline \multicolumn{3}{|l|}{ Burial Ground Complex comprised of } \\
\hline $\begin{array}{l}\text { Low Level Radioactive Waste Disposal } \\
\text { Facility (nonhazardous portion) }\end{array}$ & 643-7E & RCRA-regulated \\
\hline Mixed Waste Management Facility & $643-28 E$ & $\begin{array}{l}\text { RCRA-regulated; Final ROD } \\
\text { issued }\end{array}$ \\
\hline Old Radioactive Waste Burial Ground & 643-E & Interim Action ROD issued \\
\hline Solvent Tanks S01-S22 & & RCRA-regulated \\
\hline
\end{tabular}


Table 2-9 Examples of RCRA and RCRAVCERCLA Units at SRS - 1996

Page 2 of 5

\begin{tabular}{|c|c|c|}
\hline Site and Location & $\begin{array}{l}\text { Building or Identification } \\
\text { Number(s) }\end{array}$ & Additional Information \\
\hline \multicolumn{3}{|l|}{ Burial Ground Complex Groundwater } \\
\hline Burma Road Rubble Pit & $231-4 F$ & Final ROD issued \\
\hline 211-FB Pu-239 Release & $081-F$ & \\
\hline F-Area Acid/Caustic Basin & $904-47 G$ & RCRA-regulated \\
\hline F-Area Burning/Rubble Pits & $231-F,-1 F,-2 F$ & \\
\hline F-Area Canyon Groundwater & & $\begin{array}{l}\text { Unit added during Fiscal Year } \\
1996\end{array}$ \\
\hline F-Area Coal Pile Runoff Basin & $289-F$ & \\
\hline \multicolumn{3}{|l|}{ F-Area Groundwater } \\
\hline $\begin{array}{l}\text { F-Area Hazardous Waste Management } \\
\text { Facility }\end{array}$ & $904-41 G,-42 G,-43 G$ & $\begin{array}{l}\text { RCRA-regulated; Final ROD } \\
\text { issued }\end{array}$ \\
\hline $\begin{array}{l}\text { F-Area Inactive Process Sewer Lines } \\
\text { from Building to Security Fence }\end{array}$ & $081-1 F$ & \\
\hline F-Area Retention Basin & $281-3 F$ & $\begin{array}{l}\text { RCRA permit modification } \\
\text { not required }\end{array}$ \\
\hline $\begin{array}{l}\text { F-Area Seepage Basin Groundwater } \\
\text { Operable Unit }\end{array}$ & $904-44 F$ & $\begin{array}{l}\text { RCRA-regulated; Interim Action } \\
\text { ROD issued }\end{array}$ \\
\hline $\begin{array}{l}\text { F-Area Tank Farm Groundwater } \\
\text { Operable Unit }\end{array}$ & & $\begin{array}{l}\text { Unit added during Fiscal Year } \\
1996\end{array}$ \\
\hline H-Area Acid/Caustic Basin & $904-75 G$ & RCRA-regulated \\
\hline H-Area Coal Pile Runoff Basin & $289-\mathrm{H}$ & \\
\hline H-Area Ditch to Outfall H-012 & $\mathrm{H}-012$ & \\
\hline \multicolumn{3}{|l|}{ H-Area Groundwater } \\
\hline $\begin{array}{l}\text { H-Area Hazardous Waste Management } \\
\text { Facility }\end{array}$ & $904-44 G,-45 G,-46 G,-59 G$ & $\begin{array}{l}\text { RCRA-regulated; Final ROD } \\
\text { issued }\end{array}$ \\
\hline $\begin{array}{l}\text { H-Area Inactive Process Sewer Lines } \\
\text { from Building to the Security Fence }\end{array}$ & $081-H$ & \\
\hline $\mathrm{H}$-Area Retention Basin & $281-3 \mathrm{H}$ & $\begin{array}{l}\text { RCRA permit modification } \\
\text { not required }\end{array}$ \\
\hline $\begin{array}{l}\text { H-Area Seepage Basin Groundwater } \\
\text { Operable Unit }\end{array}$ & & $\begin{array}{l}\text { RCRA-regulated; Interim Action } \\
\text { ROD issued }\end{array}$ \\
\hline H-Area Stormwater Outfall & $\mathrm{H}-013$ & \\
\hline \multicolumn{3}{|l|}{$\begin{array}{l}\text { H-Area Tank Farm Groundwater } \\
\text { Operable Unit }\end{array}$} \\
\hline Old F Area Seepage Basin & $904-49 G$ & \\
\hline Tank 16 & $241-\mathrm{H}$ & \\
\hline Tank 37 CTS Line Leak & $081-1 \mathrm{H}$ & \\
\hline Warner's Pond & $685-23 G$ & $\begin{array}{l}\text { RCRA permit modification } \\
\text { not required }\end{array}$ \\
\hline
\end{tabular}


Table 2-9 Examples of RCRA and RCRACERCLA Units at SRS - 1996

Page 3 of 5

\begin{tabular}{|c|c|c|}
\hline Site and Location & $\begin{array}{l}\text { Building or Identification } \\
\text { Number(s) }\end{array}$ & Additional Information \\
\hline \multicolumn{3}{|l|}{ Kariea } \\
\hline K-Area Acid/Caustic Basin & $904-080 G$ & RCRA-regulated \\
\hline K-Area Bingham Pump Outage Pit & $643-1 \mathrm{G}$ & $\begin{array}{l}\text { RCRA permit modification } \\
\text { not required }\end{array}$ \\
\hline K-Area Burning/Rubble Pit & $131-K$ & \\
\hline K-Area Coal Pile Runoff Basin & $189-K$ & \\
\hline K-Area Reactor Seepage Basin & $904-65 G$ & $\begin{array}{l}\text { RCRA permit modification } \\
\text { not required }\end{array}$ \\
\hline K-Area Rubble Pile & $631-20 G$ & \\
\hline K-Area Sludge Land Application Site & $761-4 G$ & \\
\hline K-Area Stormwater Outfall & $K-011$ & \\
\hline K-Area Tritium Anomaly & & $\begin{array}{l}\text { RCRA permit modification } \\
\text { not required }\end{array}$ \\
\hline \multicolumn{3}{|l|}{ L-Area } \\
\hline Chemicals, Metals, and Pesticides Pits & $\begin{array}{l}080-17 G,-17.1 G,-18 G,-19 G \\
-18.1 G,-18.2 G,-18.3 G\end{array}$ & \\
\hline Gas Cylinder Disposal Facility & $131-2 L$ & \\
\hline L-Area Bingham Pump Outage Pits & $643-2 G,-3 G$ & $\begin{array}{l}\text { RCRA permit modification } \\
\text { not required }\end{array}$ \\
\hline L-Area Burning Rubble Pit & $131-L$ & \\
\hline L-Area Hot Shop & $717-G$ & \\
\hline $\begin{array}{l}\text { L-Area Oil/Chemical Basin and L-Area } \\
\text { Acid/Caustic Basin }\end{array}$ & $904-83 G,-77 G$ & \\
\hline L-Area Rubble Pile & $131-3 L$ & \\
\hline L-Area Rubble Pits & $131-1 \mathrm{~L},-4 \mathrm{~L}$ & \\
\hline \multicolumn{3}{|l|}{ L-Area Southern Groundwater } \\
\hline L-Area Stormwater Outfall & $\mathrm{L}-012$ & \\
\hline \multicolumn{3}{|l|}{ N-Area (Central Shops) } \\
\hline Central Shops Burning/Rubble Pits & $631-G,-3 G,-5 G,-6 G$ & \\
\hline Central Shops Sludge Lagoon & $080-24 G$ & \\
\hline \multicolumn{3}{|l|}{ PिArea = } \\
\hline P-Area Acid/Caustic Basin & $904-78 G$ & RCRA-regulated \\
\hline P-Area Bingham Pump Outage Pits & $643-G$ & $\begin{array}{l}\text { RCRA permit modification } \\
\text { not required }\end{array}$ \\
\hline P-Area Burning/Rubble Pit & $131-P$ & \\
\hline P-Area Coal Pile Runoff Basin & $189-P$ & \\
\hline P-Area Stormwater Outfall & $P-010$ & \\
\hline
\end{tabular}


Table 2-9 Examples of RCRA and RCRACERCLA Units at SRS - 1996

Page 4 of 5

\begin{tabular}{|c|c|c|}
\hline Site and Location & $\begin{array}{l}\text { Building or Identification } \\
\text { Number(s) }\end{array}$ & Additional Information \\
\hline \multicolumn{3}{|l|}{ frarea } \\
\hline Overflow Basin & $108-4 R$ & $\begin{array}{l}\text { RCRA permit modification } \\
\text { not required }\end{array}$ \\
\hline $\begin{array}{l}\text { PAR Pond (including pre-cooler ponds } \\
\text { and canals) }\end{array}$ & $685-G$ & Interim Action ROD issued \\
\hline PAR Pond Sludge Land Application Site & $761-5 \mathrm{G}$ & \\
\hline R-Area Acid/Caustic Basin & $904-79 G$ & \\
\hline R-Area Bingham Pump Outage Pits & $643-8 G,-9 G,-10 G$ & $\begin{array}{l}\text { RCRA permit modification } \\
\text { not required }\end{array}$ \\
\hline R-Area Burning/Rubble Pits & $131-R,-1 R$ & \\
\hline R-Area Reactor Seepage Basins & $\begin{array}{l}904-57 G,-58 G,-59 G,-60 G \\
-103 G,-104 G\end{array}$ & $\begin{array}{l}\text { RCRA permit modification } \\
\text { not required }\end{array}$ \\
\hline R-Area Rubble Pile & $631-25 G$ & \\
\hline \multicolumn{3}{|l|}{ Sanitary Landfill: } \\
\hline Sanitary Landfill & $740-G$ & Portions RCRA-regulated \\
\hline Sanitary Landfill Groundwater & & RCRA-regulated \\
\hline \multicolumn{3}{|l|}{ TNX and D-Areas: } \\
\hline D-Area Oil Seepage Basin & $631-\mathrm{G}$ & Interim Action ROD issued \\
\hline D-Area Ash Basin & 488-D & \\
\hline D-Area Burning/Rubble Pits & $431-D,-1 D$ & \\
\hline D-Area Coal Pile Runoff Basin & 489-D & \\
\hline D-Area Waste Oil Facility & 484-D & \\
\hline New TNX Seepage Basin & $904-102 G$ & \\
\hline Old TNX Seepage Basin & $904-076 G$ & \\
\hline TNX Burying Ground & $643-5 G$ & \\
\hline TNX Groundwater & $082-G$ & Interim Action ROD issued \\
\hline West of SREL "Georgia Fields" Site & $631-19 G$ & \\
\hline \multicolumn{3}{|l|}{ Other } \\
\hline Fire Department Hose Training Facility & 904-113G & \\
\hline Ford Building Seepage Basin & $904-91 G$ & \\
\hline Ford Building Waste Site & $643-11 G$ & $\begin{array}{l}\text { RCRA permit modification } \\
\text { not required }\end{array}$ \\
\hline \multicolumn{3}{|l|}{ Fourmile Branch Integrator Operable Unit } \\
\hline G-Area Oil Seepage Basin & $761-13 G$ & \\
\hline Grace Road Site & $631-22 G$ & \\
\hline Gunsite 113 Access Road & $631-24 G$ & \\
\hline Gunsite 218 Rubble Pile & $631-23 G$ & \\
\hline
\end{tabular}


Table 2-9 Examples of RCRA and RCRAVERCLA Units at SRS - 1996

Page 5 of 5

\begin{tabular}{|c|c|c|}
\hline Site and Location & $\begin{array}{l}\text { Building or Identification } \\
\text { Number(s) }\end{array}$ & Additional Information \\
\hline Gunsite 720 Rubble Pit & $631-16 G$ & \\
\hline Hydrofluoric Acid Spill & $631-4 G$ & $\begin{array}{l}\text { RCRA permit modification } \\
\text { not required }\end{array}$ \\
\hline \multicolumn{3}{|c|}{ Lower Three Runs Integrator Operable Unit } \\
\hline \multicolumn{3}{|c|}{ Pen Branch Integrator Operable Unit } \\
\hline Road A Chemical Basin & $904-111 \mathrm{G}$ & \\
\hline \multicolumn{3}{|c|}{ Savannah River Integrator Operable Unit } \\
\hline \multicolumn{3}{|c|}{$\begin{array}{l}\text { Savannah River Floodplain Swamp } \\
\text { Integrator Operable Unit }\end{array}$} \\
\hline SRL Oil Test Site & $080-16 \mathrm{G}$ & \\
\hline \multicolumn{3}{|c|}{ Steel Creek Integrator Operable Unit } \\
\hline \multicolumn{3}{|c|}{ Steel Pond } \\
\hline \multicolumn{3}{|c|}{ Upper Three Runs Integrator Operable Unit } \\
\hline X-001 Outfall Drainage Ditch & $x-001$ & \\
\hline
\end{tabular}




\section{Environmental Program Information}

To Read About ...

Turn to Page ...

Environmental Monitoring ...........4 41

Dose Reconstruction Study ........... 46

Pollution Prevention ................ 47

Employee Training ............... 48

Information Exchange ............. 49

Public Outreach ................... 49

\author{
Mary Dodgen and Greg Peterson \\ Environmental Protection Department
}

Various site operating groups-including Westinghouse Savannah River Company's (WSRC) Environmental Protection Department (EPD), Radiological Control Operations (RCO), Savannah River Technology Center (SRTC), Savannah River Ecology Laboratory (SREL), Savannah River Forest Station (SRFS), and Savannah River Archaeological Research Program (SRARP) - have environmental programs. SRTC, SREL, SRFS, and SRARP are discussed in chapter 1 .

\section{Environmental Monitoring}

SRS environmental monitoring, which includes both onsite and offsite activities, is the responsibility of EPD's Environmental Monitoring Section (EMS). Also, the Division of Environmental Research of the Academy of Natural Sciences of Philadelphia has performed biological and water quality surveys of the Savannah River since 1951.

Though much of the environmental monitoring program focuses on radioactive materials, considerable effort also is dedicated to nonradioactive materials. The primary purpose of the nonradiological monitoring program is to demonstrate that the levels of airborne and liquid releases remain within federal and state standards.

Additional environmental monitoring information in this report is provided in chapters dealing specifically with

- radiological effluent monitoring (chapter 5)

- radiological environmental surveillance (chapter 6)

- nonradiological effluent monitoring (chapter 8)

- nonradiological environmental surveillance (chapter 9)

- groundwater monitoring (chapter 10)

- $\quad$ special surveys and projects (chapter 12) 
Efluent Monitoring Versus Eavirongental Surveillance

Pet DOE Order 5400.5 . Radiation Prolection of the public and the Envionment:

Etivent monitoring is the collection and analysis of samples or measurements of liquid and gaseois.

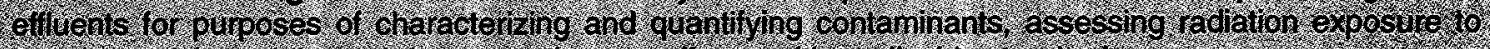
inembers of the public, and de monstrating compliance with applicable standards:

Environ mental survelliance is the collection and analysis or samples of air water soi, foodstufts biota, and other nedia from DOE sites and their envicons and the measurement of external radiation tor punios s 5 of demonstrating compliance with applicable standards, assessing radiation exposures to members of the peiblic, and assessing the eftects, ff any, on the local envirominent.

Monitoring occurs at the point of oischarge, sugh as an air stack or drainage pipe, surveillance involves looking for contaminants in the environment.

\section{Effluent Monitoring}

Effluent monitoring is conducted by collecting and analyzing onsite samples of liquid and airborne effluents taken at or very near their points of discharge to the environment. Radiological effluent monitoring meets regulatory requirements and provides source terms for calculating potential offsite radiation doses. More information about these calculations can be found in chapter 7, "Potential Radiation Doses." In 1996, more than 4,400 samples were taken at 86 points of discharge.

RCO and EMS share the responsibility for radiological effluent monitoring. $\mathrm{RCO}$ collects and screens air and liquid samples from regulated (radiologically controlled) areas and maintains monitoring equipment on stacks and at some liquid effluent discharge points. EMS collects and analyzes most liquid effluent samples. Following validation, results of these analyses are recorded in a monthly radioactive releases report. Data from the monthly reports are summarized in an annual data publication (in 1996, SRS Environmental Data for 1996, WSRC-TR-97-0077).

Because SRS handles plutonium, tritium, and other special nuclear materials, much of the site's environmental monitoring effort is focused on collecting samples of airborne and liquid effluents released during routine operations-and analyzing the samples for radioactive materials. A typical setup for airborne effluent monitoring is illustrated in figure 3-1. As shown, radioactive materials are monitored at their points of discharge, and air monitoring stations are located strategically to track-and to quantify - the dispersion of any released material into the surrounding environment. Monitoring may be performed at any or all of the identified locations as determined by the rationale discussed on page 44 .
Monitoring for nonradioactive contaminants in airborne effluents at SRS is designed to show compliance with permits issued by the South Carolina Department of Health and Environmental Control (SCDHEC). These permits are discussed further in chapter 2, "Environmental Compliance," and listed in appendix B, "SRS Environmental Permits." The major nonradiological airborne emissions of concern from SRS stacks include sulfur dioxide, oxides of nitrogen, total particulate matter, and toxic air pollutants, such as tetrachloroethylene (TCE), perchloroethylene (PCE), benzene, and hydrochloric acid. As part of a network associated with the federal Clean Air Act, Georgia and South Carolina environmental agencies verify permit compliance by monitoring ambient air quality near SRS. Clean Air Act Amendments, implemented in 1990, require federal facilities, such as SRS, to comply with provisions of the act.

Nonradioactive liquid effluents generally are sampled at National Pollutant Discharge Elimination System (NPDES) outfalls (points of discharge) and reported to SCDHEC in a monthly discharge monitoring report, as required by the Clean Water Act. Monitoring requirements for liquids may vary at each outfall, depending on the type of facility and the known characteristics of the wastewater. A typical setup for liquid effluent monitoring is shown in figure 3-2.

\section{Environmental Surveillance}

Environmental surveillance is conducted by collecting and analyzing onsite and offsite samples taken at various distances from points of discharge. In 1996 , approximately 10,000 radiological analyses were performed on approximately 5,000 samples (not including groundwater). Data from radiological environmental surveillance are evaluated to

- determine the effects, if any, of SRS releases 


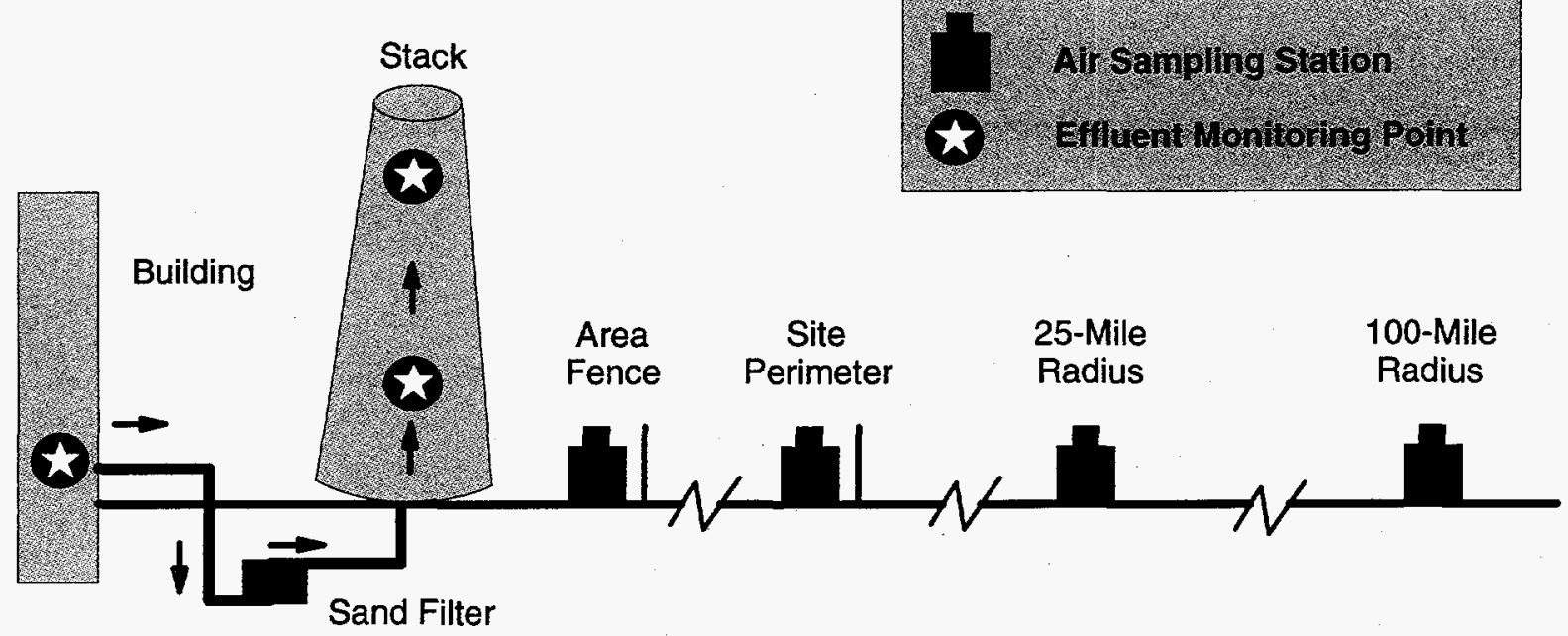

9700407.01.AlL (modified)

Figure 3-1 Typical Airborne Effluent Monitoring and Environmental Surveillance

Effluents are monitored at points of discharge. Released materials of concern are tracked in the environment.

- $\quad$ provide a way to verify dose calculations and predictions from mathematical models

Because most contaminants are released in such small amounts that they cannot be readily measured in environmental samples, SRS uses mathematical models to estimate contaminant concentrations in environmental media. The data obtained at the point of discharge (e.g., stack, pipe, or outfall)-where the concentration would be highest if a contaminant were present-is used to calculate the estimated contaminant concentration in sampled media, such as water, soil, or vegetation. More information about modeling can be found in chapter 7 .

Nonradiological environmental surveillance is conducted by collecting and analyzing samples from site streams and the Savannah River to verify the outfall sampling data and to ensure the detection and characterization of materials that could adversely

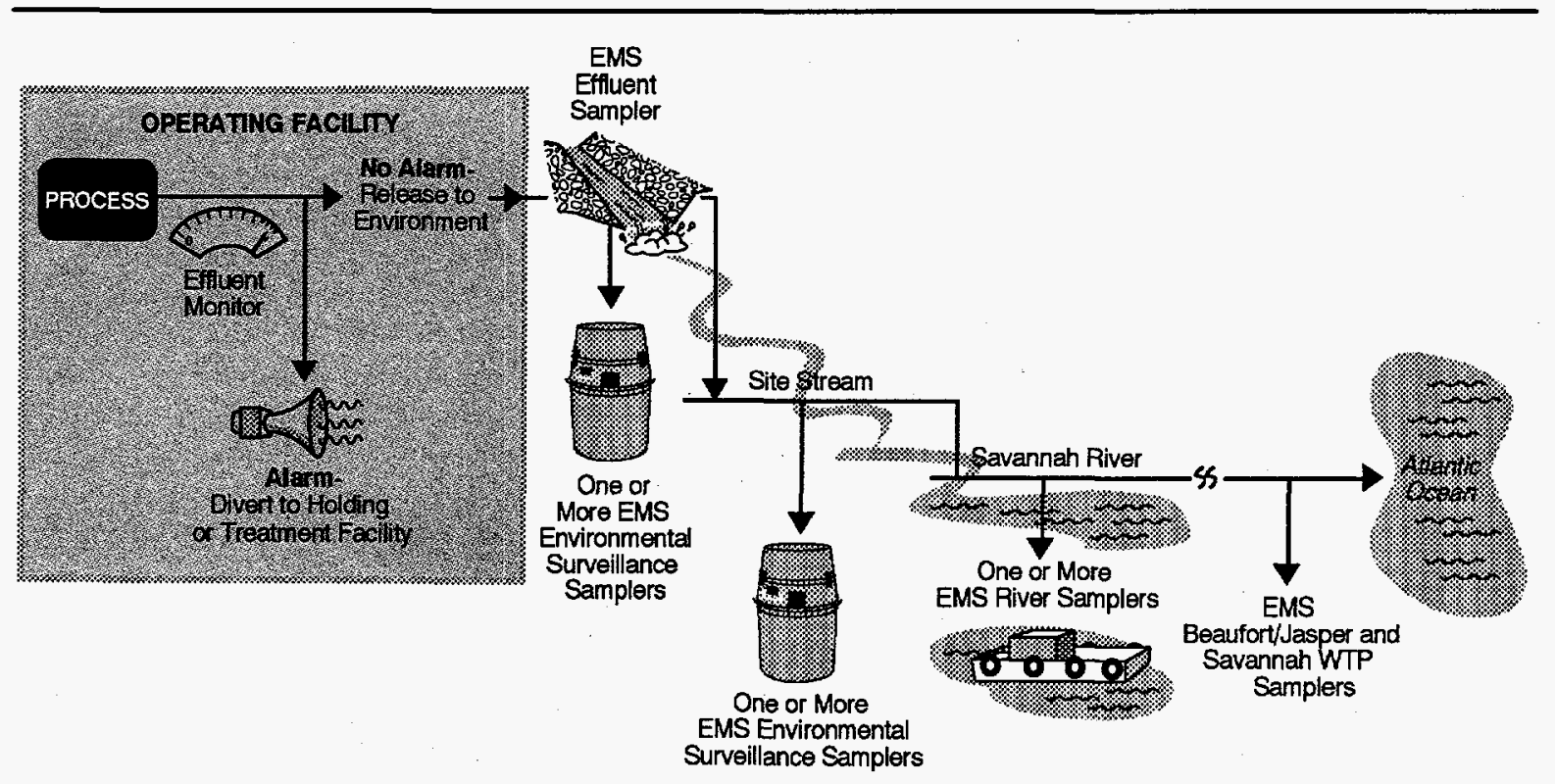

94X06608.57.AlL

Figure 3-2 Typical Liquid Effluent Monitoring and Environmental Surveillance

Effluents are monitored at points of discharge. Released materials of concern are tracked in the environment. 
affect the environment. Adverse conditions resulting from the presence of such materials are identified and evaluated to provide a basis for corrective action.

\section{Policy}

SRS policy requires an environmental monitoring program designed to

- establish effluent and ambient levels of radionuclides and other discharges

- determine trends in these releases

- provide a basis for assessment of dose to humans and the environment

- provide information needed to detect and correct problems

SRS is committed to sharing this information with the public and its representatives.

\section{Objectives}

The purpose of many environmental regulations is to protect human health and the environment. In support of this purpose, the SRS environmental monitoring objectives are to

- assess actual or potential exposures of radioactive and nonradioactive materials to critical groups and populations from normal site operations or from accidents

- demonstrate compliance with authorized limits and regulatory requirements

- verify the adequacy of each facility in containing radioactivity and controlling effluents

- notify appropriate officials of unusual or unforeseen conditions and, if necessary, to activate a special environmental monitoring program

- communicate accurate and effective EMS monitoring results to DOE, to other government agencies, and to the general public

- maintain an accurate and continuous record of the effects of SRS operations on the environment

- determine concentrations of radioactive and nonradioactive contaminants in environmental media for the purpose of assessing the immediate and long-term consequences of normal and accidental releases

- distinguish between environmental contamination and effects from SRS operations and those from other sources

- evaluate and revise the environmental monitoring program in response to changing conditions in transport pathways
- provide site-specific data for risk assessment for human populations near SRS

- conduct scientific studies on the transfer pathways of radioactive and nonradioactive contaminants in the environment

- assess the validity and effectiveness of models used to predict the concentration of pollutants in the environment

- determine the long-term buildup of-and predict environmental trends from-site-released contaminants

- establish baselines of environmental quality so that trends in the physical, chemical, and biological condition of environmental media can be characterized

- identify and quantify new or existing environmental quality problems, then assess the need for corrective actions or mitigation measures

- pinpoint exposure pathways in which contaminants are accumulated and transmitted to the public

These objectives incorporate the recommendations of the International Commission on Radiological Protection ("Principles of Monitoring for the Radiation Protection of the Public," ICRP Publication 42), of DOE Order 5400.1 ("General Environmental Protection Program"), and of DOE/EH-0173T ("Environmental Regulatory Guide for Radiological Effluent Monitoring and Environmental Surveillance").

\section{Rationale}

Many factors are considered in the determination of monitoring activities at SRS, including responsible environmental stewardship. Sampling locations, sample media, sampling frequency, and types of analysis are selected on the basis of environmental regulations, exposure pathways, public concerns, and measurement capabilities. More detailed information about the site's environmental monitoring program is documented in sections 1101-1111 (SRS EM Program) of the SRS Environmental Monitoring Section Plans and Procedures, WSRC-3Q1-2, Volume 1, which was issued in June 1995. This document is reviewed annually and updated every 3 years.

\section{Environmental Regulations}

Environmental monitoring at SRS is designed to meet state and federal regulatory requirements for radiological and nonradiological programs. These requirements are stated in DOE orders 5400.1 and 5400.5 ("Radiation Protection of the Public and the 
Figure 3-3 Potential Exposure Pathways

Airborne and liquid materials released from SRS operations can reach people in a variety of ways. These ways, or routes, are called exposure pathways.

94X01185.39.AlL

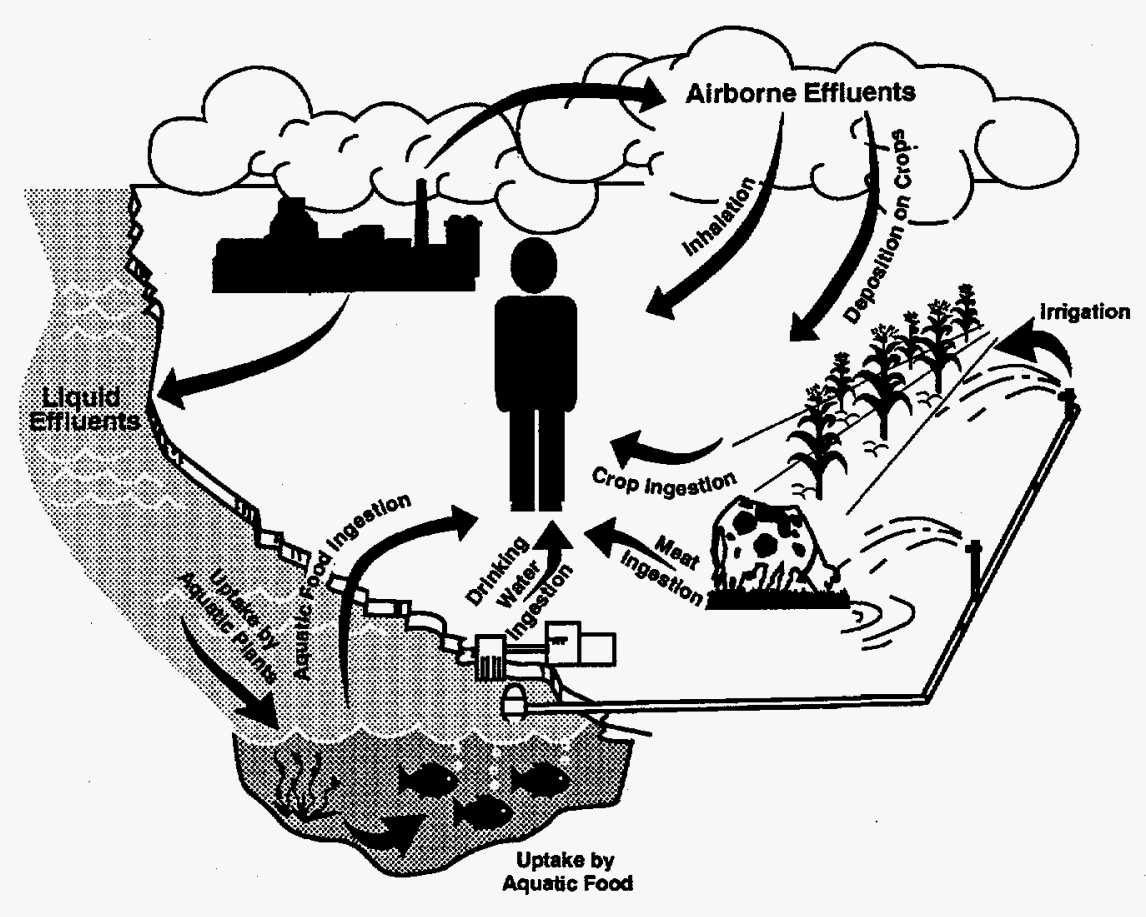

Environment"); in the Clean Air Act-for example, National Emission Standards for Hazardous Air Pollutants (NESHAP); in the Comprehensive Environmental Response, Compensation, and Liability Act (CERCLA-also known as the Superfund); in the Resource Conservation and Recovery Act (RCRA); and in the Clean Water Act-for example, NPDES. SCDHEC, the U.S. Environmental Protection Agency (EPA), and DOE conduct audits to verify that the site complies with environmental regulations. Chapter 2 summarizes the site's compliance status for 1996.

\section{Exposure Pathways}

Materials released from SRS reach the environment and people in a variety of ways. The routes that materials follow to get from an SRS facility to the environment and then to people are called exposure pathways. Some potential exposure pathways are illustrated in figure $3-3$, which shows that airborne effluents can be ingested directly by inhalation or indirectly as a result of their deposition on crops, followed by ingestion of the crops. Liquid effluents can be ingested directly from drinking water or indirectly by eating aquatic food that previously had taken up the effluents.

The method used to determine exposure pathways is called a critical pathways analysis. In a limited critical pathways analysis completed in 1993, nine radionuclides released each year from SRS facilities were identified as potentially significant contributors to offsite doses; that is, they each represented more than 1 percent of the total dose [Arnett, 1993]. These radionuclides were tritium; strontium-90; iodine-129; iodine-131; cesium-137; uranium-235,238; plutonium-238; and plutonium-239.

A more complete and thorough critical contaminant/critical pathways analysis was initiated in October 1995 by SRTC's Environmental Dosimetry Group in response to a request from DOE's Savannah River Operations Office (DOE-SR). Initially, this analysis was expected to be completed by October 1996; however, because of reduced resources, the projected completion date was extended to February 1997.

Critical pathways analysis results are used in the site's environmental monitoring activities to make decisions about sampling locations, sample media, and sampling frequency. Results from modeling an exposure pathway can help

- verify that a sampling network performs as required

- make the best use of available resources for sampling and analysis

\section{Public Concerns}

Public concerns influence the site's environmental monitoring activities. The public wants to know about releases and their potential health effects. One aspect of environmental monitoring that addresses a public concern is the placement of thermoluminescent dosimeters (TLDs) in offsite 
locations. These devices, used to measure external gamma radiation, provide a quick, reliable method of determining the dose from gamma-emitting radionuclides in the event of an unplanned release of radioactive material.

\section{Measurement Capabilities}

Many materials released from SRS exist in such low concentrations in the environment that they cannot be readily measured Thus, measurement capabilities become significant factors in the rationale for monitoring certain materials. In these cases, modeling with nationally accepted computer programs is used to predict or estimate concentration levels. More information on modeling can be found in chapter 7 , more on measurement capabilities, in SRS

Environmental Data for 1996.

\section{Program Changes}

The types, frequencies, and locations of environmental measurements are reviewed annually to determine how best to structure the monitoring program. If a clear rationale for a measurement no longer exists, the measurement is deleted from the program. Likewise, the program is modified as new sampling/analytical methods and needs evolve.

While elements of individual monitoring programs are reviewed annually, it became apparent in 1995 that the overall site monitoring program could benefit from a holistic, comprehensive review of the entire effort that takes into account current and evolving site missions, regulatory trends, and potential program element efficiencies. This review, known as "Rock Hill Initiative \#2," was completed in June 1996. Objectives of this review were to define a reasonable environmental monitoring program for the site given current site status and regulatory requirements and to identify cost reductions associated with the program. The review focused on identifying monitoring activities that could be eliminated without compromising the essential information desired and on identifying any risks and consequences associated with the proposed reductions.

Sixty-nine discrete program elements were identified and evaluated by participants from site organizations-DOE-SR, WSRC, SREL, SRFS, and Wackenhut Services Inc. (WSI, contractor for site security) - with assistance from the Environmental Advisory Committee. (The Environmental Advisory Committee is discussed on page 49.) As a result of the review, five elements were eliminated, 43 were reduced in scope, 3 were increased in scope, and 18 were unchanged. Since completion of the review, all nonregulatory changes have been implemented.
Rationale to implement acceptable decreases in permit conditions and regulatory monitoring requirements are being prepared for submission to the regulators.

Details of the Rock Hill Initiative \#2 review are documented in Comprehensive Review of Environmental Monitoring Programs at Savannah River Site $(U)$, WSRC-RP-96-308. Specific programmatic changes implemented in 1996 are detailed in subsequent chapters of this report.

\section{Dose Reconstruction Study}

SRS has conducted environmental monitoring of radioactive materials and chemicals released to the environment since the beginning of site operations in the early 1950 s. Historical data from this environmental monitoring and from site operations are being evaluated independently by the federal Centers for Disease Control and Prevention (CDC) in Atlanta, Georgia, as part of the SRS Dose Reconstruction Study, to determine the effects these materials may have had on people living near the site.

Phase I of the SRS Dose Reconstruction Study began in October 1992. Its purpose was to locate and review records-from SRS and other sources-that could be used in the dose reconstruction process. This phase was completed in June 1995. More than 34,000 boxes of documents were searched, with more than 260,000 pages of potentially useful documents identified.

Two reports were published to summarize the evaluation of materials released from SRS and to identify environmental monitoring and research data:

- Savannah River Site Dose Reconstruction Project, Phase I, Data Retrieval and Assessment, Task 3, Evaluation of Materials Released from the Savannah River Site

- Savannah River Site Dose Reconstruction Project, Phase I, Data Retrieval and Assessment, Task 4, Identifying Sources of Environmental Monitoring and Research Data

The Task 3 report describes methods used to qualitatively characterize the historical use and potential release of chemicals and radionuclides at SRS since the beginning of site operations. The Task 4 report identifies, vatalogs, and evaluates historical environmental and research information-in terms of usefulness, limitations, and quality-that could be used to support a dose reconstruction. Copies of these reports are available to the general public in the DOE Reading Room at the University of South Carolina-Aiken.

During Phase II of the study, which began in September 1995, the CDC will estimate the amount 
of materials released (the source term) since SRS began operations in 1952 and will reconstruct - through pathways analyses and dose assessments - the doses that the public has received from these materials. This information will be used to assess the possibility of health effects, attributable to site operations, in the population around the site. Phase II is expected to be completed in 1997.

Inquiries can be made about the study by writing to Centers for Disease Control and Prevention, 4770 Buford Highway NE, MS F35, Atlanta, GA 30341-3724; by calling 770-488-7040; or by faxing $770-488-7044$.

\section{Pollution Prevention}

Pollution prevention at SRS is designed to reduce the impact of site operations on the environment. Pollution prevention at the site includes

- $\quad$ source reduction activities

- recycling of potential wastes and pollutants

- reduction in the use of materials, energy, water, and other resources

- protection of human health and of natural resources through conservation or more efficient use

- disposal of waste in an environmentally safe manner

Pollution prevention programs are a major focus of many activities, organizations, and implementation teams. Improvements in the coordination of and communication between these program areas are ongoing, and employee awareness of - and management emphasis on-pollution prevention is increasing. The WSRC Waste Minimization and Pollution Prevention Plan (WSRC-RP-95-36) provides program details. Highlights of some of the 1996 SRS pollution prevention activities are discussed in the following paragraphs.

\section{Waste Minimization}

The SRS waste minimization program continued in 1996 to reduce the generation of solid wastes that require costly treatment, storage, and disposal. The annualized solid radioactive waste generation volumes decreased by about 70 percent, or almost 680,000 cubic feet, from 1991 to 1996 . (In calendar year 1991, 969,650 cubic feet of radioactive solid waste was generated. In fiscal year 1996, 290,323 cubic feet of radioactive solid waste was generated.) The decrease is attributed largely to waste minimization efforts initiated as a site program in
1991 , but also is the result of changing site missions. In 1996, solid waste generators identified more than 125 waste reduction initiatives with potential to reduce forecasted waste generation by more than 145,000 cubic feet on an annualized basis. Key initiatives included incorporation of commercial radioactive waste reduction practices; emphasis on reduction in the size of radioactive contamination areas; and increased use of recyclable-versus disposable- materials for radioactive jobs.

\section{Solid Waste Recycling}

Sanitary waste volumes were reduced by recycling initiatives. In fiscal year 1996, more than 3,250 tons of nonradioactive materials were recycled at SRS, including 810 tons of paper and cardboard. A consolidated office waste recycling contract implemented during the year should increase employee participation in recycling by making the recycling option more convenient.

\section{Energy Conservation}

Reducing site demand for energy in turn reduces emissions and conserves resources (e.g., coal) associated with energy production. A comprehensive energy conservation program and site mission changes helped drive down facility energy consumption in British thermal units (BTU) per gross square foot by more than 51 percent from 1985 through 1996.

\section{Reduction of Chemical Releases}

Under Section 313 of the Emergency Planning and Community Right-to-Know Act (EPCRA), SRS has filed Toxic Chemical Release Inventory reports annually since 1987 . The site calculates chemical releases to the environment and reports aggregate quantities for each regulated chemical that exceeds threshold amounts. Between 1987 and 1995 , reportable release quantities have declined by 97 percent. More about Toxic Chemical Release Inventory reports can be found in chapter 2 .

\section{Affirmative Procurement of Recycled Products}

The SRS Affirmative Procurement Program promotes the purchase of products made from recycled materials to help conserve natural resources. The program follows federal guidance for implementing affirmative procurement requirements at DOE sites. The program expanded the purchasing in several areas during fiscal year 1996, including recycled building insulation and retread tire and re-refined oil use for site fleet vehicle maintenance. The program is 
implemented as part of federal Executive Order 12873, "Federal Acquisition, Recycling and Waste Prevention," and RCRA Section 6002.

\section{Excess-Chemical Management}

The Chemical Commodity Management Center was created and staffed in 1994 to ensure environmentally sound, safe, and cost-effective acquisition, distribution, and reuse of chemicals/excess chemical products for the site. An "excess chemical product" is defined as any reusable material requiring a material safety data sheet and in the original form and concentration as received as a stock supply item from a supplier. Some accomplishments included implementing reviews of all chemical procurement requests prior to purchase, coordinating the site's annual EPCRA Tier II chemical inventory (chapter 2) and developing a sitewide chemical management program.

\section{Ozone-Depleting Substances}

The Clean Air Act Amendments of 1990 require that EPA publish a number of regulations to phase out the production and consumption of ozone-depleting substances. SRS has produced an internal guidance document designed to assist the site in the phaseout

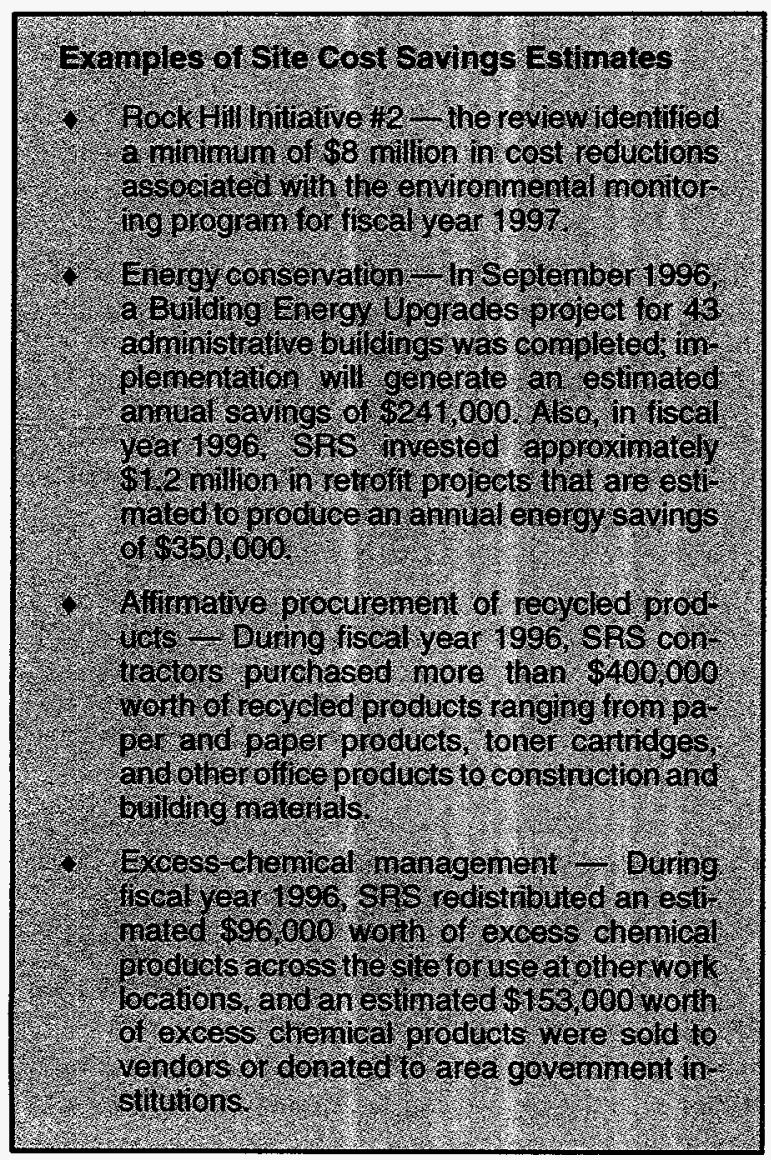

of these substances. The main objective of the plan is to reduce the use of chlorofluorocarbon (CFC) refrigerants by replacement and retrofit of CFC equipment and by sound refrigerant containment practices.

During 1996, the A-Area Chiller Replacement project was completed, replacing four CFC chiller units. Future projects will replace or refit 37 major CFC chiller and heating, ventilation, and air conditioning systems throughout the site as funding becomes available.

\section{Employee Training}

SRS environmental training programs help achieve environmental goals at the site. SRS is committed, as a matter of policy, to maintaining its facilities and conducting its operations in full compliance with all applicable laws and regulations for the protection of the environment and of the health and safety of its employees and the general public. The training program identifies training activities to teach job-specific skills that protect the environment and satisfy regulatory requirements.

Environmental training at SRS addresses federal and state regulations. The focus is on required training and recommended education courses for employees (based on responsibility) involved with environmental oversight, hazardous materials, and waste management at the site.

Environmental training activities in 1996 included the following:

- Fourteen site environmental protection coordinators were trained in responsibilities for reporting occurrences having environmental consequences. Training also was provided for DOE and environmental coordinator representatives.

- Seventy-two site workers received Water/Wastewater Continuing Education training.

- More than 200 persons attended environmental training through subcontracted courses.

- Eight hundred twelve site workers attended Hazardous Waste Operations courses (29 CFR 1910.120), which provide health and safety training in hazardous-waste cleanup activities and in working at RCRA treatment, storage, and disposal facilities.

- About 1,880 site workers attended RCRA training.

- More than 15,100 site workers took the Consolidated Annual Training course to meet general training requirements, including some environmental training. 


\section{Information Exchange}

SRS has opened several avenues of exchange with state and federal regulators, other government-owned, contractor-operated (GOCO) facilities, and scientists to improve and update its environmental monitoring and research programs.

DOE-SR representatives attend DOE Headquarters (DOE-HQ)-sponsored technical information exchange workshops, which provide a way to enhance the exchange of technical information among DOE sites.

Environmental awareness and information exchange tours are conducted for many special-interest groups, including environmental activists and representatives of other GOCOs, of DOE-HQ, of Westinghouse Electric Corporation, of EPA, and of SCDHEC. Tours are designed to meet the needs of a particular group. For example, EPA and SCDHEC tours might focus on regulatory issues, while tours for other GOCOs might cover activities applicable to their programs.

Initiated in 1996, the Interagency Information Exchanges are public forums that enable state and federal regulators and SRS to address environmental compliance issues. At these forums, EPA, SCDHEC, and SRS representatives discuss cleanup plans and draft RCRA permit changes while soliciting public comments. Public input is considered by the agencies and used to develop final remedial approaches.

The Citizens Advisory Board (CAB) for SRS provides recommendations to DOE, EPA, and SCDHEC on environmental remediation, waste management, and related issues. The $\mathrm{CAB}$ is composed of 25 South Carolina and Georgia individuals who reflect the cultural diversity of the population affected by SRS. Information about their 1996 recommendations is presented in chapter 4 , "Environmental Restoration and Waste Management." Additional information can be obtained by calling $800-249-8155$.

The Environmental Advisory Committee, which is comprised of nationally recognized consultants from the fields of biology, ecology, hydrogeology, health physics, environmental restoration, and economics, meets quarterly to review site environmental programs and make recommendations. In 1996, this group formally reviewed the SRS Environmental Report for 1995 (WSRC-TR-96-0075) and SRS Environmental Data for 1995 (WSRC-TR-96-0077).

SRS hosted a training exercise in May called Handshake II to help refine the skills of field monitoring teams and data assessment personnel who respond to major radiological emergencies. Taking part in the exercise were about 200 persons-including 20 field monitoring teams-and four mobile laboratories from the DOE Region 3 states-North Carolina, South Carolina, Georgia, Florida, and Alabama. In addition, observers from across the nation and visitors from Brazil, Bulgaria, and Canada were present to view new equipment, its use, and integration of response teams from all levels of government. Also, a separate exercise using specialized equipment and night-operations procedures for designated participants was carried out to support the National Aeronautics and Space Administration's Cassini mission.

The Central Savannah River Area Radiological Environmental Monitoring Program is a data exchange program involving representatives of SCDHEC, the Georgia Department of Natural Resources, Georgia Power Company, Chem-Nuclear Systems, DOE, and WSRC. This group has met semiannually since 1987 to share technical environmental program information and data. These meetings provide an open forum in which to review and possibly improve each organization's monitoring program.

\section{Public Outreach}

SRS public outreach activities-such as public meetings, the Visitors Program, the Speakers Bureau, and the Traveling Lecturers Program-provide communication channels between the site and the public. Local newspaper, television, and radio advertisements also inform the public about environmental activities. More information can be obtained by contacting the WSRC Media and Community Relations Department at 800-603-0970.

When topics involve unusually complex issues, DOE may conduct workshops that give special-interest groups or citizens the opportunity to meet with site representatives.

In 1996, DOE-SR initiated the first effort in the DOE complex to integrate feasible environmental justice principles set forth in Executive Order 12898, "Environmental Justice Strategy," into SRS operations. DOE's plan reflects a commitment to participate in efforts to advance the well-being of people in surrounding communities by

- taking an integrated approach to formulating strategies based on clear priorities and tangible benefits and actions that address programmatic, legislative, and regulatory responsibilities 
- emphasizing community participation and empowering stakeholders and communities

- refocusing research agendas to reflect a new recognition of various health issues

- encouraging modified approaches for structuring models for occupational and environmental science research for high-risk communities and workers

- embracing interagency coordination to ensure environmental justice

- including plans to heighten the sensitivity of management and staff to environmental justice options within DOE's infrastructure.

As part of the Environmental Justice Strategy effort, a grant was awarded to a group of United Negro College Fund schools for a fish subsistence/consumption survey. Results of the survey are scheduled to be presented to the CAB in January 1997. Another grant was awarded to the Medical University of South Carolina in Charleston with researchers examining concerns about such issues as air and water quality and cancer held by people living near the site (phase 1) and addressing these concerns (phase 2). Presentations on this study also are scheduled to be given in January 1997.

Various regulations require that SRS notify the public of its environmental plans and activities. RCRA, CERCLA, the National Environmental Policy Act (NEPA), and the Clean Water Act mandate regulatory public notice requirements. SRS meets these requirements by using various community involvement tools, including notices to contiguous landowners, to media, to local and state government agencies, and to any other interested stakeholders. Such notices-and the status of documentation-typically are sent in a newsletter called the Environmental Bulletin. Appendix B of this report lists the construction and operating permits held by SRS, and chapter 2 lists 1996 SRS project NEPA documentation activities.

Several groups on site are involved in efforts to educate students and teachers. Information about SRS educational outreach programs can be accessed via the SRS Home Page on the Internet at http://www.srs.gov.

WSRC assists in conducting competitions such as the Central Savannah River Area Science and Engineering Fair and the DOE Savannah River Regional Science Bowl to encourage student interest in engineering, science, and mathematics. Education and career fairs that emphasize requirements for advanced skills and education are held in elementary, middle, and high schools. WSRC's EPD offers teacher resource kits and miscellaneous materials to assist teachers in a variety of environmental areas. Tabulations on the 1995-96 school year show that WSRC reached more than 40,000 students in the surrounding communities through a variety of programs and events in science and mathematics.

SRFS has community outreach programs that include Smokey Bear, Woodsy Owl, Earth Day, and the Senior Community Service Program. SRFS environmental awareness programs are shared with visitors. Also, the Natural Resources Environmental Education Program at SRFS aims to increase student awareness of the role of science and mathematics in solving natural resource and environmental problems. The program is a cooperative effort between DOE and the University of South Carolina-Aiken. Another program, a cooperative effort of SRFS, DOE, and South Carolina State University in Orangeburg, was begun at SRS in 1996. This environmental science field education program provides undergraduate students from historically black colleges and universities hands-on field and laboratory experiences in science and engineering. More information about SRFS outreach can be obtained by calling 803-725-2441.

SREL's Environmental Outreach and Education Program was shared with an estimated 60,000 people during 1996. The program emphasizes the importance of environmental awareness in decision making regarding ecological problems. Environmental awareness is promoted through tours of the laboratory; lectures to students and civic and special interest groups; teacher workshops; and various exhibits [Fact Sheet, 1996b]. Presentation topics include animal ecology, outdoor safety, plants and wetlands, the environment, conservation, and careers in ecology and research. More information can be obtained by contacting SREL at 803-725-0156.

SRARP expanded its heritage education activities in 1996 with a full schedule of classroom education, public outreach, and onsite tours. Volunteer excavations at SRS's Tinker Creek site were continued with the Augusta Archaeological Society and other avocational groups, while offsite excavations provided a variety of opportunities for field experience. Some 99 presentations, displays, and tours were provided for schools, historical societies, civic groups, and environmental and historical awareness day celebrations. Also, SRARP personnel taught four anthropology courses at area colleges. More information can be obtained by contacting SRARP at 803-725-3623. 


\section{Chapter 4 \\ Environmental Restoration and Waste Management}

\author{
Dean Campbell \\ Public Relations Department \\ Lou Davis and Nordette Lawrence \\ Environmental Restoration Department \\ Helen Villasor \\ Solid Waste/Environmental Restoration Division
}

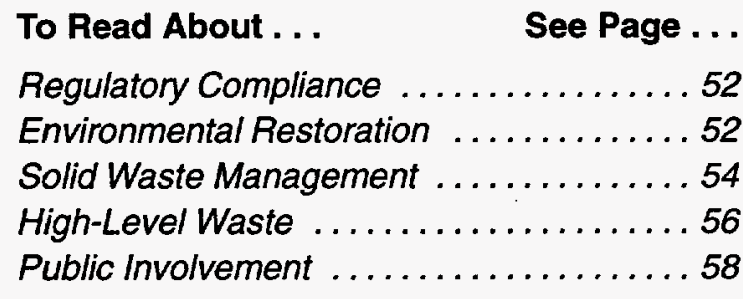

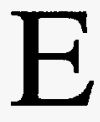
NVIRONMENTAL restoration and waste management programs at Savannah River Site (SRS) continued to make significant progress on environmental cleanup in 1996. This chapter presents a brief overview of the programs, describes some of their major milestones during the year, and summarizes their shift from initial concept and formulation to the achievement of results in the field in an open, responsive, and accountable manner.

The U.S. Department of Energy (DOE) uses the term "environmental restoration" to mean the assessment and cleanup of inactive waste units and groundwater (remediation). "Cleanup" means actions taken to deal with the release or potential release of hazardous substances. This may refer to complete removal of a substance, or it may mean stabilizing, containing, or otherwise treating the substance so it does not affect human health or the environment [DOE EM, 1991]. Determining the most environmentally sound methods of cleaning up waste units is a major component of the environmental restoration program at SRS.

In 1996, for example, environmental restoration accomplishments included

- placement of a composite geosynthetic closure cap-the first approved by the South Carolina Department of Health and Environmental Control (SCDHEC) for a hazardous waste closureover the Nonradioactive Waste Disposal Facility

- completion of a geosynthetic closure cap over two sections, totaling five acres, of the Low Level Radioactive Waste Disposal Facility

- removal of more than 350,000 pounds of waste organic solvents from over 2.3 billion gallons of groundwater by the continuous operation of the M-1 Air Stripper

- installation of a 60-foot-tall A-2 air stripper in A-Area/M-Area (in the northeast part of the site) that has more than five times the capacity of the former A-1 stripper-to accelerate cleanup of groundwater contaminated by volatile organic compounds (VOCs)

- continuous operation of vacuum extraction vadose zone units that increased the removal rate of VOCs by 500 percent, and installation of automated control systems that allow remote operations to increase efficiency and reduce operating costs

- removal of more than $\mathbf{5 0}$ drums of contaminants at the D-Area oil seepage basin, which reduced the immediate health and environmental contact potential of the contaminant source.

- initial operation of four recovery wells and a low-profile air stripping unit at the TNX Area to provide the capacity to treat groundwater from the downgradient edge of the contaminant plume at a rate of 80 gallons per minute

- completion of removal of 260,000 pounds of radioactive vegetation from 4.5 acres at the $\mathrm{H}$-Area retention basin, Warner's Pond, and the HP-52 outfall and placement of erosion controls to protect the basins until remediation is complete

- completion of (1) a time-critical removal action consisting of soil and asphalt covers designed to contain and reduce the spread of contamination and (2) maintenance of the R-Reactor seepage basins

DOE uses the term "waste management" to refer to the safe, effective management of various kinds of nonhazardous, hazardous, and radioactive waste generated on site. Identifying the need for appropriate 
waste management facilities and ensuring their availability have been major components of the SRS waste management program.

Waste management highlights during 1996 included

- the pollution prevention/waste minimization programs, which earned national awards for their activities for the second straight year

- the transuranic waste management program's successful management of legacy waste from a weapons production mission by safely venting sealed drums containing potentially explosive gases

- the safe removal and transfer of 40,000 pounds of highly radioactive solvent from old singlewalled tanks in the Burial Ground complex to new double-walled tanks near the Consolidated Incineration Facility

- continuation of preparations for a pretrial burn (conducted in December) at the Consolidated Incineration Facility

\section{Regulatory Compliance}

Two major federal statutes govern the site's environmental restoration and waste management activities, which were begun in 1981: the Resource Conservation and Recovery Act (RCRA) and the Comprehensive Environmental Response, Compensation, and Liability Act (CERCLA). RCRA addresses the management of regulated hazardous waste and requires that permits be obtained for DOE facilities that treat, store, or dispose of hazardous or mixed waste. It also requires that DOE facilities perform appropriate corrective action. CERCLA (also known as Superfund) addresses releases of hazardous substances and the cleanup of inactive waste disposal sites. This act establishes a National Priority List of sites targeted for assessment and, if necessary, for remediation. SRS was placed on the list December 21, 1989 [Fact Sheet, 1995]. Complete information on SRS compliance activities can be found in chapter 2, "Environmental Compliance."

\section{Environmental Restoration}

SRS began its remediation program in 1981, before many of the regulations requiring environmental restoration were written. However, the site's current Environmental Restoration program was not officially established and developed until 1990 . Since then, 467 inactive waste and contaminated groundwater sites have been identified (figure 4-1). The program achieved its goals during 1996 through

- groundwater remediation
- the use of preventive measures and removal actions to reduce contamination risks

- the deployment of innovative technologies

In 1996, all regulatory commitments were met by the program, and Environmental Restoration placed an additional 160 acres of waste sites into remediation-an increase of 178 percent over 1995. In addition, within A-Area and M-Area area during 1996 , more than 80,000 pounds of organic solvents were removed from the soil and groundwater (a 74-percent increase over 1995) through vacuum extraction-a technology 500 percent more efficient than pump and treat. Vacuum extraction pulls toxins from the vadose zone-the layer of soil above the groundwater table.

Treatment of contaminated groundwater in F-Area and H-Area accelerated during 1996 with the installation of 30 extraction wells and 20 injection wells. The entire treatment system, which will be in full operation in 1997, employs water treatment units that use reverse osmosis technology. Through this system, contaminated groundwater is treated at a combined rate (for both F-Area and H-Area) of 350 gallons per minute. Solid-waste contaminants are extracted and stored in vaults above ground, and the treated water is sent to underground injection wells for storage. The wells have been designed to control tritium seepage into the wetlands from the groundwater.

Effective remediation of contaminated groundwater sites cannot be achieved without an effective groundwater monitoring system. Successful onsite field testing was conducted in the summer of 1996, and approval-by SCDHEC and the U.S.

Environmental Protection Agency (EPA), for use at SRS —of a new system for retrieving protocol samples on clean wells and handling the reinjection of purge water is expected in 1997. Technical support has concluded that the well sampling methodology used by the new purge water management system will

- reduce purge water handling

- eliminate the need for treatment of contaminated water

The use of the purge water management system at wells where purge water contains radioactive waste, mixed waste, or listed waste is expected to reduce worker risks significantly.

Also in 1996, engineers began protective capping at a 76-acre tract known as the Old Radioactive Waste Burial Ground. This is part of the largest and highest priority waste area at SRS; low-level radioactive waste was buried there from 1952 until 1972. The area is being covered with special soil as an interim 


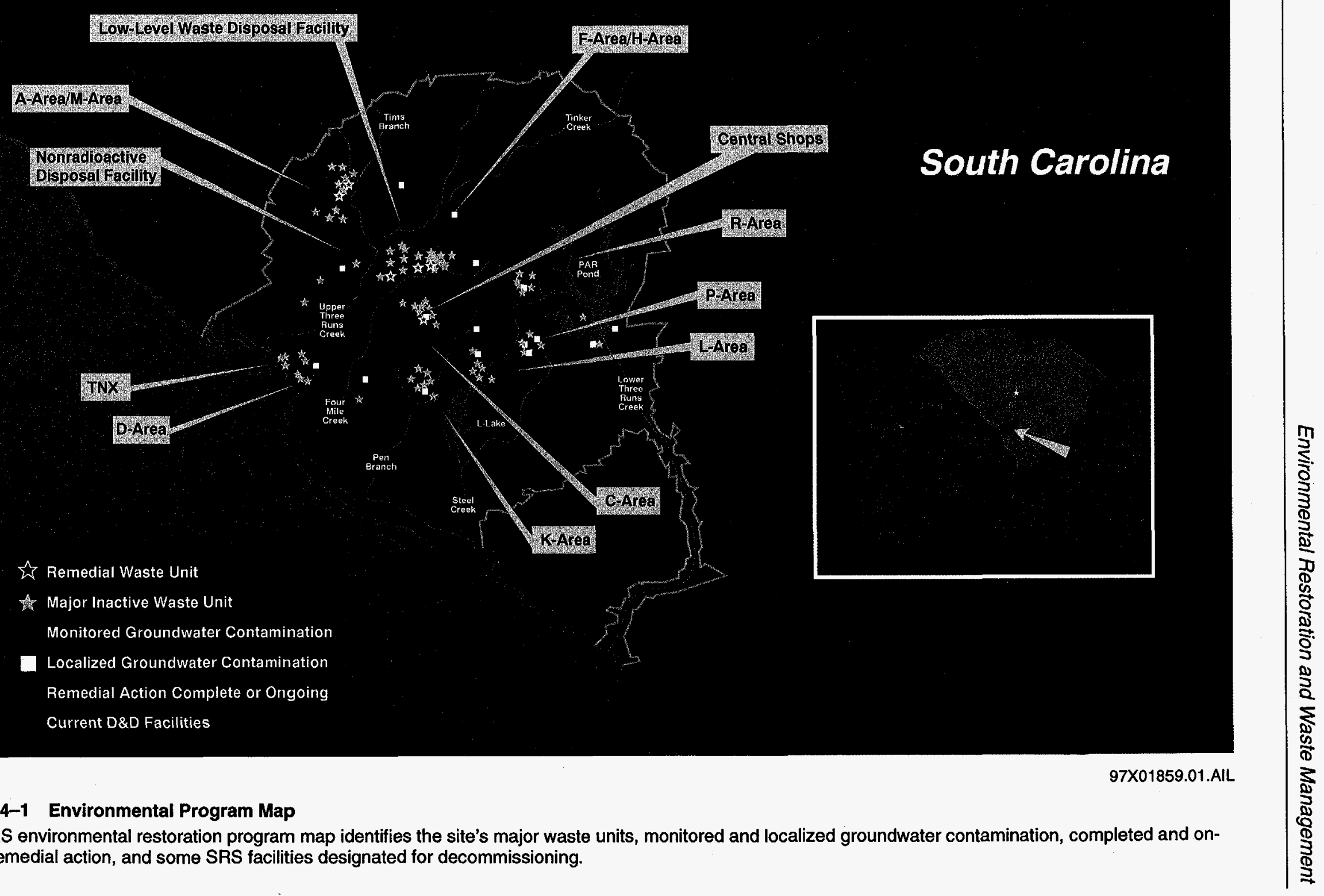


action to help stop the infiltration of rainwater, which can flush contamination into the groundwater. This prevention measure provides groundwater protection until a final remediation design is developed.

Another action that will prevent rainwater infiltration at waste sites is the deployment of geosynthetic cap closure technology. The SRS Environmental Restoration program used geosynthetic caps to cover 60 acres of waste sites in 1996. These were the first closure plans that used geosynthetic capping approved for hazardous waste sites by the state of South Carolina. Both the Nonradioactive Waste Disposal Facility and the Low-Level Radioactive Waste Disposal Facility were chosen for a geosynthetic cap versus the traditional kaolin clay cap design because of geosynthetic capping's many advantages, including

- added flexibility

- reduction in cap height by 4 feet

- ease of installation

- less construction time

Unlike traditional kaolin clay caps, geosynthetic caps do not crack and, therefore, do not allow rainwater to seep into waste sites. Thus, they provide greater protection for groundwater than traditional kaolin clay caps.

An important part of restoring the environment at SRS involves removing contaminated vegetation. Vegetation removal at the H-Area retention basin was completed during 1996, and contaminated trees were reduced in size for disposal to a vendor for treatment. All H-Area retention basin vegetation and most Warner's Pond vegetation has been transported off site for incineration; the total is approximately 260,000 pounds.

In D-Area, 58 contaminated drums were removed during April and May 1996 following expedited site sampling and characterization. The area then was backfilled with soil and covered by vegetation to minimize rainwater infiltration and erosion. The drum removal action eliminated the source of contamination at the D-Area oil seepage basin, thus reducing the immediate health and environmental contact potential with the contaminant source.

SRS continues to use new environmental remediation technologies. BaroBall ${ }^{\mathrm{TM}}-$ a passive remediation device-was designed by Savannah River Technology Center researchers and deployed in August 1996 under the environmental restoration program to remove solvent vapors underground through wells. Using natural atmospheric pressure fluctuations, BaroBall ${ }^{\mathrm{TM}}$ can remove volatile organic compounds from the vadose zone. During low-pressure weather patterns, the BaroBall ${ }^{\mathrm{TM}}$ device releases vapor in low but safe concentrations. This technology was deployed in A-Area and M-Area; however, it may be applied to any site where volatile substances have contaminated the vadose zone.

\section{Solid Waste Management}

In 1996, SRS's solid waste program faced the challenge of reducing the volume of waste generated sitewide and of safely treating, storing, and disposing of the waste in the most cost-effective manner possible.

The program's major focus involved shifting from a production phase to cleanup activities by managing large volumes of backlog wastes at various site facilities. Proper handling of the waste requires first that the waste be categorized as sanitary, low-level, transuranic, hazardous, mixed, or high-level (high-level waste discussion begins on page 56).

\section{Sanitary Waste}

Sanitary waste includes office waste, food, garbage, refuse, and other solid wastes that can be disposed of in landfills. SRS has privatized the collection, hauling, and disposal of its sanitary waste, which consists primarily of food and office wastes. In 1996, 6,700 tons of the site's sanitary waste were disposed of at a permitted offsite commercial facility, according to Solid Waste Certification and Minimization Records.

\section{Low-Level Waste}

Low-level waste is any radioactive waste not classified as high-level waste or transuranic waste. Examples of SRS low-level wastes include protective clothing, job control waste, equipment, tools, filters, rags, and papers. All certified low-level wastes are stored or disposed of in the E-Area Vaults. During 1996, the Solid Waste Management Department accepted 252,908 cubic feet of low-level waste for storage or disposal in these vaults, according to the site's Computerized Radioactive Waste Burial Records Analysis System and Waste Information Tracking System. The department also began shipping low-level waste to an offsite vendor to reduce volume, prolong the life of the vaults, and reduce costs.

\section{Transuranic Waste}

Transuranic waste is radioactive waste contaminated with certain isotopes that have decay rates and activities exceeding defined levels. It contains 
manmade elements that are heavier than uranium and that decay slowly, thus requiring thousands of years of isolation. At SRS, transuranic wastes can include contaminated equipment, protective clothing, and tools. In $1996,5,815$ cubic feet of solid transuranic waste were accepted for storage on transuranic waste pads, according to the site's Computerized

Radioactive Waste Burial Records Analysis System.

\section{Hazardous Waste}

According to RCRA, hazardous waste is any toxic, corrosive, reactive, or ignitable material that could damage the environment or negatively affect human health. Examples of SRS hazardous wastes include oils, solvents, acids, metals, and pesticides. In 1996, the Solid Waste Management Department accepted 3,519 cubic feet of hazardous waste for storage at the site's hazardous waste storage facilities, according to Solid Waste Certification and Minimization records.

\section{Mixed Waste}

Mixed waste is both radioactive and hazardous and is subject to regulations governing both waste types. In 1996, the Solid Waste Management Department accepted 801 cubic feet of mixed waste for storage at SRS's mixed waste storage buildings, according to Solid Waste Certification and Minimization records.

\section{Addressing the Legacy}

Management strategy for each type of waste often depends on consent orders and agreements-in-principle that DOE enters into with host states and EPA-largely according to RCRA requirements. For example, DOE is complying with Federal Facility Compliance Act (FFCAct) requirements for mixed waste-including high-level waste, most transuranic waste, and low-level waste with hazardous constituents. This act requires that DOE develop and submit site treatment plans to EPA or state regulators for approval.

Through established SRS protocol, the solid waste program provides opportunities for its representatives to listen to stakeholders and discuss and share information with them. This is designed to ensure strong public participation in decision-making processes.

Near-term program emphasis has been placed on the establishment of new facilities for

- solidification of high-level waste

- treatment of stored transuranic waste in preparation for future permanent storage at a federal repository
- incineration of low-level, hazardous, and mixed wastes

Each type of waste requires a different management strategy, as each has specific requirements for treatment, storage, and disposal.

These ongoing waste management programs are supplemented by a waste certification program through which SRS waste generators must demonstrate compliance with the waste acceptance criteria of the site's various waste management facilities. Other 1996 solid waste program activities involved continued hazardous waste shipments, the site treatment plan for mixed wastes, and the RCRA Part B permit renewal.

\section{Accomplishments}

Solid waste program activities for 1996 included accomplishments in the following areas:

- pollution prevention/waste minimization

- transuranic waste management

- solvent storage tank closures

- vendor partnerships

- the Waste Management Environmental Impact Statement

- Consolidated Incineration Facility startup preparations

Noteworthy results are described in the paragraphs that follow.

\section{Pollution Prevention/Waste Minimization}

Comprehensive, integrated sitewide pollution prevention/waste minimization programs achieved substantial reductions in waste during 1996 and earned recognition for sitewide recycling efforts. Senior management support and source reduction actions-part of a long-term effort that includes controlled-area rollbacks, decontamination, the use of reusable anticontamination materials, and other pollution control programs-contributed to a waste generation reduction in 1996 of about 180,000 cubic feet of low-level waste and more than 3,600 cubic feet of hazardous, mixed, and transuranic wastes, according to Pollution Prevention-Everybody's Business, a booklet produced for SRS's Solid Waste Division [SWD, 1997].

Projects such as beneficial reuse and office and industrial products recycling contributed to SRS's already exceeding Secretary of Energy 1999 goals for recycling and radioactive waste reduction. In 1996, the beneficial reuse program established and began implementing a method to convert the site's 
contaminated stainless steel scrap into metals that could be used at SRS and other DOE facilities. Also, the site recycled more than 3,200 tons of material through its salvage yard and more than 74,000 pounds of chemicals and chemical products through the excess operations function of the SRS Chemical Commodity Management Center, according to Pollution Prevention-Everybody's Business.

The pollution prevention and waste minimization programs earned four DOE awards in 1996 (to be presented in 1997) for

- incorporating pollution prevention/waste minimization initiatives into environmental restoration activities

- $\quad$ solid waste recycling

- reduction in the size of contamination areas

- development and use of prefabricated radiological containment huts

\section{Transuranic Waste Management}

In 1996, SRS managed more than 10,000 cubic meters of transuranic and mixed transuranic waste, generated by the site's former weapons production mission. An automated vent and purge system safely released combustible gas from stored drums, and portable equipment was used to assay transuranic waste. SRS reduced risk by dewatering, retrieving, inspecting, and repacking transuranic drums and moving them to covered storage pads. The solid waste program is developing strategies to stabilize transuranic waste for disposal at the Waste Isolation Pilot Plant in Carlsbad, New Mexico.

\section{Solvent Storage Tank Closures}

On October 25, 1996, a week ahead of schedule, approximately 40,000 pounds of solvent were removed from two tanks at SRS's old burial ground complex and transferred by cask to new double-lined tanks at the Consolidated Incineration Facility.

To further reduce risk at the complex, a closure plan submitted to SCDHEC in 1996 authorized a complete cleanup of the solvent tank storage site, and the process of filling the two tanks with grout began. Final plans call for turning the site over to the Environmental Restoration Division for capping. The site then will become a part of the Low Level Radioactive Waste Disposal Facility, which is expected to be closed in 1999.

\section{Vendor Partnerships}

In 1996, SRS continued to implement various waste stream treatments developed from the 1994 Supplier
Environmental and Waste Management Information Exchange with commercial vendors. The ongoing shredding of filter paper take-up rolls prepared mixed waste for incineration at the Consolidated Incineration Facility. The shredding process further reduces the volume of mixed waste, enabling it to fit inside the facility's incineration boxes. The shredding technology was expanded to treat five additional SRS waste streams in 1996. Other demonstrations successfully decontaminated cadmium-coated filter frames and radioactive lead for recycling.

\section{Waste Management Environmental Impact Statement}

The Final Waste Management Environmental Impact Statement (EIS) was issued to the public July 28, 1995, and the first of two National Environmental Protection Act (NEPA) Records of Decision was approved September 22, 1995. The second NEPA Record of Decision, originally expected to be issued in 1996, now is targeted for issue in 1997. The EIS

- forecasts the next 30 years of SRS waste management activities

- provides waste generation estimates for various waste streams

- describes treatment, storage, and disposal options available for managing wastes

\section{Consolidated Incineration Facility}

Construction of the Consolidated Incineration Facility — completed in 1995-was followed by preparations for a pretrial burn, which was conducted in December 1996. A self assessment was conducted in late 1995 in preparation for an expected readiness verification in 1997. Pending another pretrial burn, the facility is scheduled for startup in 1997; it will incinerate solid and liquid forms of radioactive, hazardous, and mixed wastes and is expected to reduce waste volume at an average ratio of 20 to 1 . Ash formed in the rotary kiln will be loaded into drums and solidified with concrete into a waste form called "ashcrete," which will be disposed of in onsite waste disposal facilities.

\section{High-Level Waste Management}

"High-level waste" is highly radioactive waste material that results primarily from the reprocessing of spent nuclear fuel. It contains liquid waste produced directly in reprocessing, any solid waste derived from that liquid, and both transuranic waste and fission products in concentrations requiring permanent isolation from the environment.

High-level waste from the F-Area and H-Area canyons is segregated according to radionuclide and 
heat content. High-heat waste, generated primarily during the first extraction cycle in SRS's Separations canyons, contains a major portion of the radioactivity. Low-heat waste is generated primarily from the second and subsequent canyon extraction cycles.

The major waste streams into the F-Area and H-Area tank farms include transfers from the canyons, receipts from the Receiving Basin for Offsite Fuels (RBOF), and a recycle stream from the Defense Waste Processing Facility (DWPF).

SRS continues to manage approximately 34 million gallons of high-level liquid radioactive waste (about 496 million curies); this waste is stored in 51 massive storage tanks grouped into two "tank farms."

Twenty-nine tanks are located in the H-Area Tank Farm, 22 in the F-Area Tank Farm. All SRS tanks are built of carbon steel inside reinforced concrete containment vaults.

\section{High-Level Waste Facilities}

Each tank farm has one operating evaporator system used to concentrate high-level waste received from the canyons. These evaporators reduce the waste to about 25 percent of its original volume. SRS has successfully conducted this dewatering operation in the tank farms since the early 1960s. Since the first evaporator facilities began operation in 1960 , approximately 105 million gallons of space have been reclaimed.

Without these evaporator systems, SRS would have required 70 additional waste storage tanks-at $\$ 50$ million apiece - to store waste produced over the site's lifetime. A new evaporator, the replacement high level waste evaporator, is under construction to enable the tank farms to process future waste loads. This new evaporator will have twice the processing capacity of the existing two evaporators.

The In-Tank Precipitation Facility (ITP) is a volume reduction/pretreatment operation for DWPF. It will process the majority (about 90 percent) of the "liquid salt" waste in tanks, splitting that waste into two distinct streams. The highly radioactive portion, called "precipitate," will go to DWPF for vitrification, while the remainder, called "filtrate" (about 90 percent of the salt waste), will be low-level waste that will be grouted into a solid form at the Saltstone Facility.

\section{Accomplishments}

In 1996, SRS continued to effectively manage its high-level waste facilities in support of the integrated high-level waste removal program. DWPF began radioactive operations and had produced 64 canisters of immobilized radioactive waste by the end of the fiscal year. Also, SRS gained regulatory approval of its general closure plan for high-level waste tanks-the first such plan developed and approved in the DOE complex.

\section{Tank Farms}

The tank farm evaporators recovered more than 2 million gallons of tank space in 1996 through evaporation of the watery "supernate" that floats atop the sludge in the tanks. The 2-H evaporator system, which recovered more than 1.5 million gallons, set a single-month tank space gain record for SRS in July, creating 338,000 gallons of storage space with an availability of 97 percent during the month. This was accomplished through improved planning and predictive maintenance techniques and by performing routine maintenance during scheduled outages to minimize unplanned outages. An outage of the 2-F evaporator during the summer of 1996 enabled personnel to focus on problem areas and incorporate improvements demonstrated on the $2-\mathrm{H}$ evaporator.

Processing strategies were developed to extend evaporator operations and improve DWPF wastewater processing flexibility. The strategies provide a 9-month contingency for unexpected evaporator outages without impacting DWPF operations by

- selectively choosing the waste streams fed to the 2-H evaporator

- modifying operating parameters for the $2-\mathrm{H}$ evaporator based on tank chemistry and DWPF receipt rates

Actions were completed during the summer of 1996 to activate the interarea line between $\mathrm{H}$-Area and F-Area tank farms. This line will transfer feed to the ITP and provide feed to the 2-F evaporator as part of the integrated waste removal program.

Approximately 15,000 gallons of high-level waste material were transferred from F-Area to H-Area during 1996 as part of the project; this culminated several years of preparation of the line for operation.

\section{Waste Tank Closure}

SCDHEC and EPA approved SRS's general closure plan for high-level waste tanks-the first in the DOE complex -in July 1996, after public hearings. The plan represents a cooperative effort between Westinghouse Savannah River Company, DOE, and the regulators. All aspects of the SRS program to place high-level waste in an environmentally acceptable form through DWPF, the ITP, and the Saltstone Facility now have been demonstrated.

A plan to close empty waste tanks also was developed in 1996. The tanks are being filled with 
grout and a low-release reduction material to ensure that the remaining radioactivity in them cannot contaminate the environment. This program eliminates the need for extensive, high-cost decontamination and/or disassembly of the tanks.

\section{In-Tank Precipitation}

Progress was made in 1996 toward understanding and resolving a benzene generation rate problem identified during startup of the ITP in 1995. Excess benzene was successfully removed from the facility, and generation rates were stabilized at lower levels.

A process verification testing safety evaluation developed by the Regulatory Programs group of High-Level Waste Engineering to demonstrate resolution of all safety issues was approved by DOE in October 1996.

\section{DWPF}

DWPF personnel began processing radioactive sludge in March 1996 and had poured 64 canisters through the end of the fiscal year, surpassing their goal of 60 canisters. Filling the canisters with sludge culminated a lengthy testing process involving "waste qualification runs" that were completed in November 1995. These runs included the filling of 71 canisters with a high-quality glass form that met all projected quality and environmental requirements to contain SRS's waste. Nonradioactive chemicals were used to simulate the properties of the waste throughout the testing process.

In early 1996, DWPF began its final review before requesting approval to begin radioactive operations: a thorough operational readiness review by a DOE-Headquarters team. This process is similar to Nuclear Regulatory Commission review and licensing at a commercial nuclear facility. The operational readiness review process is an indepth critique of the facility and its processes, along with face-to-face interviews of personnel.

\section{Saltstone Facility}

A component of DWPF, the Saltstone Facility plays a vital role in treating and disposing of low-level radioactive salt solutions that are the byproduct of the high-level waste treatment process at SRS.

After the salt solutions are received at the facility, they are mixed with cement, fly ash, and furnace slag to form a grout. The grout then is pumped into a large concrete vault divided into sections, or cells. Here, it cures into a stable form called "saltstone." After it is filled, the vault will be capped with clean grout to isolate it from rain and weathering. Final closure of the vault disposal area will include covering each vault with a clay cap and backfilling it with earth.

Radioactive operations began at the Saltstone Facility in June 1990; through the end of 1996, the facility had processed approximately 2.1 million gallons of salt solutions, creating about 3.4 million gallons of "saltstone."

\section{Public Involvement}

One of the hallmarks of all environmental management programs, including DOE's, following the end of the Cold War is the involvement of various stakeholders in environmental management decisions and resulting activities.

Stakeholder involvement in the development of environmental management decisions and subsequent actions is required by law and encouraged by DOE and SRS beyond the bare legal requirements. The SRS credibility-and-trust target initiative encompasses stakeholder involvement in environmental restoration and facilitates the decision-making process while responding to needs, ideas, and concerns of communities and entities impacted by the site.

During 1996, SRS's public involvement program continued to support the SRS Citizens Advisory Board (CAB), an independent group whose members provide recommendations to DOE, EPA, and SCDHEC. Among major issues addressed by the 14 CAB recommendations from 1996 were

- establishment of criteria to close the tank farms by the end of 1996 and the drafting of a closure plan to meet tank farm criteria

- $\quad$ simplification of the waste management programmatic environmental impact statement and elaboration on worker risks for treatment alternatives

- provision of the highest budget priority recommendations on the FY 1998 budget to address the health and safety of workers and the public and to protect the environment

- implementation of a Blue Ribbon Panel Report recommendation for an urgent budget request to treat SRS transuranic waste

- establishment of a preferred alternative, placement of a soil cover over the old Burial Ground, as an interim action

- focus by SRS on the safe and secure interim storage of surplus plutonium

- $\quad$ support of SRS plans to remediate the old F-Area seepage basin for the cleanup of contaminated groundwater 
- evaluation of the environmental restoration program for remediation of the highest risks first, and exploration of ways to shorten the remediation-particularly the design phase

- provision of input to the SRS Ten Year Plan in an effort to accelerate elimination of the most urgent site risks

- establishment of an alternative disposal method at the Saltstone Facility

- a January 1997 startup of the Consolidated Incineration Facility

- chemical processing alternatives for spent nuclear fuel

- revisions to enhance the Management Action Plan
The three agencies substantially concurred with all the 1996 recommendations [CAB, 1994-1995].

Attendance at meetings and feedback from stakeholders increased during 1996, and stakeholders provided DOE with more specific recommendations on various $S R S$ activities. The $C A B$ provided information to the public on nuclear material-related issues through educational forums, and meetings were held in a variety of geographic locations to involve stakeholders who had not participated in the past. Other initiatives were implemented to increase public knowledge, including editorials and presentations to civic and governmental organizations. 



\section{Radiological Effluent Monitoring}

\author{
Brian Crandall, Mary Dodgen, \\ and Stuart Stinson \\ Environmental Protection Department \\ Timothy Jannik \\ Savannah River Technology Center
}

To Read About ...

See Page ...

Airborne Emissions . . . . . . . . . . 61

Liquid Discharges .................6 64

Settleable Solids ................. 70
$\mathrm{T}$ HIS chapter describes the Savannah River Site (SRS) radiological effluent monitoring program and summarizes the 1996 effluent monitoring data results. Objectives and rationale for the SRS radiological effluent monitoring program are discussed in chapter 3, "Environmental Program Information."

Radiological effluent monitoring results are a major component in determining compliance with applicable dose standards, which can be found in chapter 7, "Potential Radiation Doses," and in appendix A, "Applicable Guidelines, Standards, and Regulations." Also, SRS management philosophy is that potential exposures to members of the public be kept as far below regulatory standards as is reasonably achievable. This philosophy is known as the "as low as reasonably achievable" (ALARA) concept.

SRS airborne and liquid effluents that potentially contain radionuclides are monitored at their points of discharge by a combination of direct measurement and/or sample extraction and analysis. Radiological Control Operations (RCO) and the Environmental Protection Department's Environmental Monitoring Section (EMS) share most of the radiological effluent monitoring responsibilities. RCO personnel collect and screen air and liquid samples from regulated (radiologically controlled) areas and maintain monitoring equipment on stacks and at some liquid effluent discharge points. EMS personnel collect and analyze most liquid effluent samples. Results of these analyses are compiled and reported in monthly radioactive releases reports.

Of the more than 4,400 radiological effluent samples collected and analyzed during 1996, 17 (0.4 percent) were not collected and/or analyzed because of sampling equipment failure or inadvertent loss of, or damage to, the sample media. The radioactive releases attributed to these samples were accounted for in the annual release totals by using either historical process knowledge or less sensitive on-line monitoring results.

A complete description of the EMS sampling and analytical procedures used for radiological effluent monitoring can be found in sections 1102 and 1103 of the Savannah River Site Environmental Monitoring Section Plans and Procedures, WSRC-3Q1-2, Volume 1 (SRS EM Program), which was issued in June 1995. A summary of data results is presented in this chapter; however, more detailed data can be found in SRS Environmental Data for 1996 (WSRC-TR-97-0077).

\section{Airborne Emissions}

Process area discharge stacks that release or have the potential to release radioactive materials are monitored continuously by applicable on-line monitoring (for tritium and noble gases) and/or sampling systems [SRS EM Program, 1995]. Filter paper samples, used to collect radioactive particles, generally are gathered daily and screened initially for radioactivity by RCO personnel. Charcoal canisters, used to collect radioiodines, are gathered weekly. RCO personnel routinely transfer the charcoal canisters and filter paper samples on a weekly basis to EMS sampling personnel for transport to, and analysis in, the EMS laboratories.

Depending on the processes involved, discharge stacks also may be monitored with "real-time" instrumentation by area operations and/or RCO personnel to determine instantaneous and cumulative atmospheric releases to the environment. Tritium is one of the radionuclides monitored with continuous real-time instrumentation. 


\section{Description of Monitoring Program}

\section{Sample Collection Systems}

Sample collection systems vary from facility to facility, depending on the nature of the radionuclides being discharged. Generally, RCO personnel are responsible for ensuring that the sampling systems are maintained and for collecting the filter papers and charcoal filter samples.

The following effluent sampling and monitoring changes were made during 1996:

- Reporting of "forced activity concentrations" was implemented for gamma spectroscopy data processed after January 5 . Forced activity concentration values are now quantified for potassium- 40 , cobalt -60 , and cesium- 137 , whether the values are significant or not, i.e., above or below minimum detectable concentrations. These three radionuclides were selected because of their importance in dose calculations and analytical trending. Also, availability of these data allows for trending of activities below method detection limits. Less-than-detectable data will produce numerical measurements with values below the detection limit and sometimes negative values. All actual values, including negative ones, are included in the statistical analyses. Practices such as assigning a zero, the detection limit value, or some in-between value to the below-detectable data point, or discarding those data points, severely biases the resulting parameter estimates.

- Sampling at several locations that are no longer radiological release points was discontinued. These locations include: 717-C Hot Shop Stack, 230-H Lag Stack, 230-H Process Stack, 299-H Building Stack, 299-H HP Exhaust Hood, and Low Point Drain Tank Stack.

- M-Area Vendor Treatment Facility (in Building $341-8 \mathrm{M}$ ) was identified as a potential source of radiological air emissions in late 1995; the first sample result from this location was reported in June 1996. Due to sample collection and delivery complications, not all data are available for this location. However, omitted data will be included in the SRS Environmental Report for 1997.

- Modification of the C-Area Decontamination Facility air monitoring system began in mid-1996. The release point, "C-Area Decon Facility Stack," was retired in August and will be replaced by three new release points in 1997.

- Effective February 26, and with U.S. Environmental Protection Agency (EPA) approval, use of the 321-M machine room isokinetic sampler, which had been in service since 1994, was discontinued. By May 26, the simpler E.P. 927 sampler (the former 321-M machine room system) was placed back into service.

- Early in 1996, sampling with charcoal canisters used to collect radioiodines was discontinued for reactor air effluent streams because use of this method is not required during reactor shutdown.

\section{Continuous Monitoring Systems}

SRS reactor and tritium facilities use real-time instrumentation to determine instantaneous and cumulative atmospheric releases of tritium and noble gas radioisotopes. All other monitored radionuclides are sampled using filter papers, charcoal filters, or other air effluent sampling media.

\section{Laboratory Analysis}

EMS provides most of the necessary radioanalytical laboratory services required to conduct the site airborne effluent monitoring program. However, the Savannah River Technology Center (SRTC) environmental laboratory performs iodine-129 and carbon-14 analyses on certain air effluent samples because they have the sensitive instrumentation capable of detecting low levels of these radionuclides.

\section{Effluent Flow Rates}

Stack effluent flows generally are determined with hot-wire anemometers, Pitot tubes, or fan capacity calculations. Sample line flow rates usually are determined with in-line rotameters or hot-wire anemometers. Flow rates are used to determine the total quantity of radioactive materials released.

\section{Diffuse and Fugitive Sources}

An estimate of radionuclide releases from unmonitored diffuse and fugitive sources also is included in the SRS radioactive release totals. These unmonitored sources include punds, contaminated land areas, and structures without ventilation-or with ventilation but without well-defined release points. The sources were included in the overall SRS source terms for the first time in 1991, as required by the U.S. Department of Energy (DOE).

\section{Monitoring Results}

The total amount of radioactive material released to the environment is quantified by using data obtained from continuously monitored airborne effluent releases points and estimates of diffuse and fugitive sources in conjunction with calculated release estimates of unmonitored radionuclides from the separations areas. These unmonitored radionuclides 
are fission product tritium, carbon-14, and isotopes of krypton. These radionuclides cannot be measured in the effluent streams; therefore, the values are calculated on an annual basis. Total SRS atmospheric releases for 1996 are shown by source in table 5-1, page 71 .

The data shown in table 5-1 are a major component in the determination of offsite dose estimations from SRS operations. The calculated individual and collective doses from atmospheric releases are presented in chapter 7, as is a comparison of these offsite doses to EPA and DOE dose standards.

For dose calculation purposes, values for unidentified beta- and alpha-emitting radionuclides in airborne releases are summed with the values reported for strontium- 89,90 and plutonium-239, respectively. Accounting for the unidentified beta- and alpha-emitting radionuclides in this way, a conservative approach, generates an overestimated dose attributable to releases from SRS because

- strontium-89,90 and plutonium-239 have the highest dose factors among the common betaand alpha-emitting radionuclides

- a part of the unidentified activity probably is from naturally occurring radionuclides, such as potassium- 40 and radon-222 progeny, which have less dose consequence

In 1996, because this methodology was used, unidentified beta-emitting radionuclides accounted for 98 percent of the reported total strontium- 89,90 and unidentified alpha-emitting radionuclides accounted for 43 percent of the reported total plutonium-239 (table 5-1).

Tritium in elemental and oxide forms accounts for more than 90 percent of the total radioactivity released to the atmosphere from SRS operations. About 10 percent of the total radioactivity released to the atmosphere is krypton- 85 (based on calculated release estimates of unmonitored radionuclides) (table 5-1). As an isotope of hydrogen, tritium acts the same as hydrogen chemically and physically and thus is extremely difficult to remove from air effluent streams. During 1996, about 55,300 Ci

$(2.05 \mathrm{E}+15 \mathrm{~Bq})$ of tritium was released from SRS, compared to about $96,700 \mathrm{Ci}(3.6 \mathrm{E}+15 \mathrm{~Bq})$ in 1995 .

The amount of tritium (and other atmospheric radionuclides) released has been reduced throughout the history of SRS, with changes in the site's mission and improvements in facilities, processes, and operations. During the early years at SRS, large quantities of tritium were discharged to the atmosphere. The maximum yearly release of
2.4 million $\mathrm{Ci}(8.9 \mathrm{E}+16 \mathrm{~Bq})$ of tritium occurred during 1958. From 1987 through 1992, the amount of tritium released from SRS decreased approximately 20 percent per year (figure 5-1). In 1993, an increase in tritium released was attributed to increased loading and unloading of reservoirs in the tritium facilities. The 43-percent decrease in the amount of tritium released in 1996-compared to 1995 - is attributed to (1) reduced throughput in the tritium facilities, (2) reduced maintenance and layup activities in the reactor facilities, and (3) continued improvements in Replacement Tritium Facility (RTF) operation.

\section{Comparison of Average Concentrations in Airborne Emissions to DOE Derived Concentration Guides}

Average concentrations of radionuclides in airborne emissions are calculated by dividing the yearly release total of each radionuclide from each stack by the yearly stack flow quantities. These average concentrations then can be compared to the DOE derived concentration guides (DCGs), which are found in DOE Order 5400.5, "Radiation Protection of the Public and the Environment," for each radionuclide.

DCGs are used as reference concentrations for conducting environmental protection programs at all DOE sites. Based on a 100-mrem exposure, DCGs are applicable at the point of discharge (prior to dilution or dispersion) under conditions of continuous exposure (assumed to be an average inhalation rate of 8,400 cubic meters per year). This means that the DOE DCGs are based on the highly conservative assumption that a member of the public has direct access to- and continuously breathes, or is immersed in - the actual air effluent 24 hours a day, 365 days a year. However, because of the distance between most SRS operating facilities and the site boundary, and because the wind rose at SRS shows no strong prevalence (chapter 7), this scenario is improbable.

Average annual radionuclide concentrations in SRS air effluents can be referenced to DOE DCGs as a screening method to determine if existing effluent treatment systems are proper and effective.

Most of the SRS radiological stacks/facilities release small quantities of radionuclides at concentrations below the DOE DCGs [SRS Data, 1997]. However, certain radionuclides-such as (1) tritium (in the oxide form) from the heavy water rework facilities, the reactor facilities, and the tritium facilities, and (2) plutonium isotopes from the F-Area and H-Area separations facilities-were emitted at concentration levels above the DCGs. Because of the extreme difficulty involved in removing tritium and because 


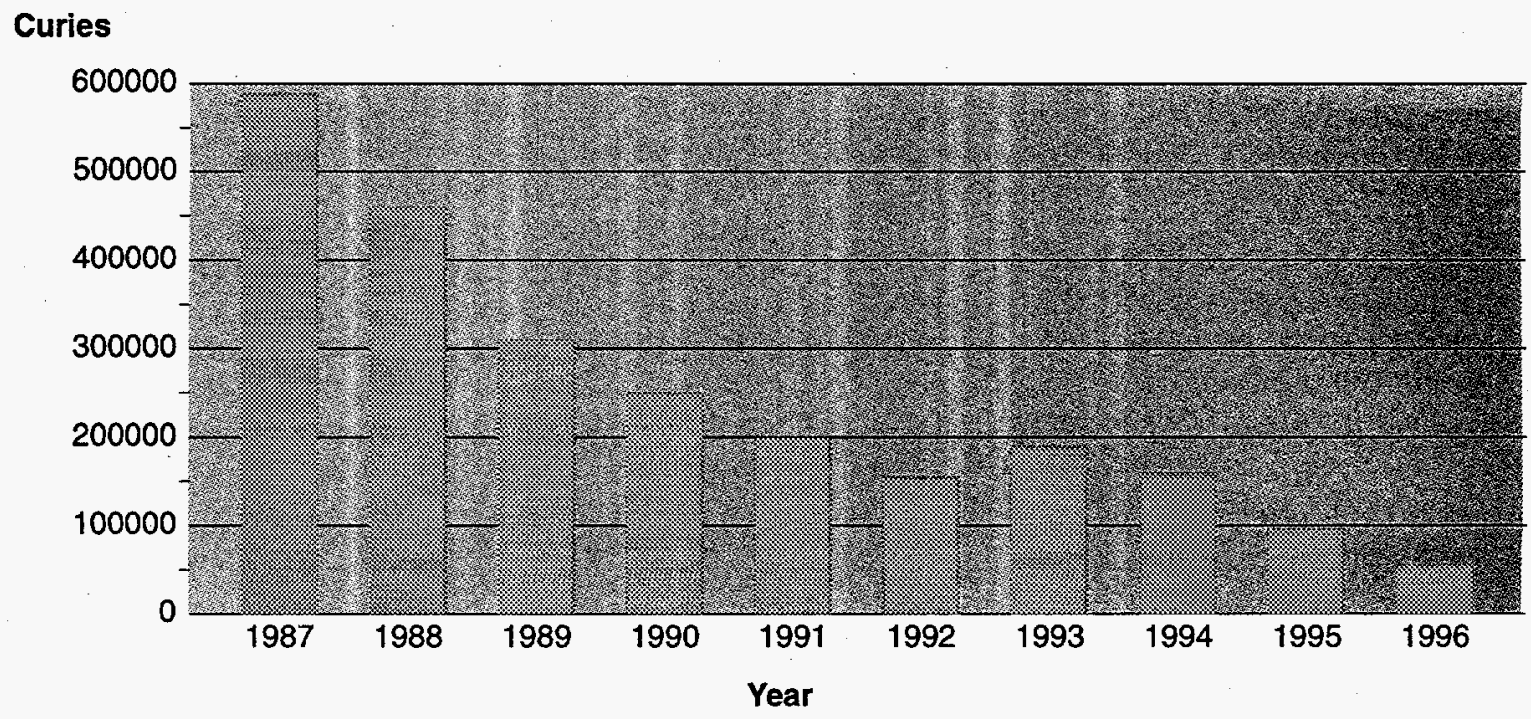

Ileaf Graphic

Figure 5-1 SRS Annual Atmospheric Tritium Releases, 1987-1996

of current facility designs, site missions, and operational considerations, this situation is unavoidable. However, the dose consequences from all SRS atmospheric releases during 1996 were 0.5 percent of the DOE and EPA annual atmospheric pathway dose standard of $10 \mathrm{mrem}(0.1 \mathrm{mSv})$ (chapter 7).

\section{Liquid Discharges}

Each process area liquid effluent discharge point that releases or has potential to release radioactive materials is sampled routinely and analyzed for radioactivity [SRS EM Program, 1995]. The radiological liquid effluent sampling locations at SRS are shown, along with the surface water surveillance sampling locations, in chapter 6, "Radiological Environmental Surveillance" (page 81, figure 6-3).

Site streams also are sampled upstream and downstream of seepage basins to obtain data to calculate the amount of radioactivity migrating from the basins. These results are important in calculating the total amount of radioactivity released to the Savannah River as a result of SRS operations.

\section{Description of Monitoring Program}

\section{Sample Collection Systems}

Liquid effluents are sampled continuously at, or very near, their points of discharge to the receiving streams. Three primary systems are used-paddlewheel samplers, Brailsford motor pumps, and Isco samplers. EMS personnel normally collect the liquid effluent samples weekly and transport them to the EMS laboratory for analysis.

The following effluent sampling and monitoring changes were made during 1996:

- Sampling at the $\mathrm{H}-004$ location (for the purpose of radiological effluent monitoring) began in January 1996 to obtain baseline data before startup of the Consolidated Incinerator Facility (CIF). This sampling location will be the official pointof-discharge for CIF liquid discharges when this facility becomes operational.

- Sampling at the K-008 outfall location, which is no longer a radiological release point, was discontinued.

- Liquid discharge sampling schedules were revised as a result of Rock Hill Initiative \#2 (described in chapter 3, page 46), which involved a comprehensive evaluation of site environmental programs with the objectives of ceasing unnecessary monitoring and reducing programmatic costs. Samples will continue to be collected at effluent monitoring locations weekly, while samples will be collected at surveillance locations biweekly.

\section{Continuous Monitoring Systems}

Depending on the processes involved, liquid effluents also may be monitored by area operations and/or $\mathrm{RCO}$ personnel with real-time instrumentation to ensure that instantaneous releases stay within established limits. However, because of 
instrumentation detection capabilities, on-line monitoring systems are not used to quantify liquid radioactive releases from SRS.

\section{Laboratory Analysis}

EMS provides most of the necessary radioanalytical laboratory services required to conduct the site liquid effluent monitoring program. However, specific low-level analyses for iodine-129 and technetium-99 are performed by SRTC environmental laboratory personnel.

\section{Flow Rate Measurements}

Liquid effluent flows generally are determined by one of four methods: U.S. Geological Survey (USGS) flow stations, stream velocity measurements, Isco sampler flow meters, or pump capacity calculations. Effluent flow rates are used to determine the total radioactivity released.

\section{Monitoring Results}

Data from continuously monitored liquid effluent discharge points are used in conjunction with site seepage basin and Solid Waste Disposal Facility (SWDF) migration release estimates to quantify the total radioactive material released to the Savannah River from SRS operations. SRS liquid radioactive releases for 1996 are shown by source in table 5-2, page 73 .

The data shown in this table are a major component in the determination of offsite dose consequences from SRS operations. The calculated individual and collective doses from site liquid releases are presented in chapter 7, as is a comparison of these offsite doses to EPA and DOE dose standards.

For dose calculation purposes, values for unidentified beta- and alpha-emitting radionuclides in liquid discharges are summed with the values reported for strontium-89,90 and plutonium-239, respectively.

Accounting for the unidentified beta- and alpha-emitting radionuclides in this way, a conservative approach, generates an overestimated dose attributable to releases from SRS because

- $\quad$ strontium-89,90 and plutonium-239 have the highest dose factors among the common betaand alpha-emitting radionuclides

- a part of the unidentified activity probably is from naturally occurring radionuclides, such as potassium-40 and radon-222 progeny, which have less dose consequence

In 1996, because this methodology was used, unidentified beta-emitting radionuclides accounted for 60 percent of the reported total strontium- 89,90 and unidentified alpha-emitting radionuclides accounted for 99 percent of the reported total plutonium-239 (table 5-2).

As with airborne releases, strontium-90 and plutonium-239 have the highest dose factors of the common beta- and alpha-emitting radionuclides found in liquid releases. Therefore, summing the unidentified beta and alpha emissions this way maintains conservatism of the highest dose being represented. In addition, some of the unidentified beta and alpha activity probably originates from naturally occurring radionuclides, such as potassium- 40 and radon-222 progeny. This also adds a degree of conservatism to the dose calculations.

Tritium constitutes more than 99 percent of the radioactivity released to the Savannah River from site streams. Tritium reaches site streams as a result of direct discharges from facilities and from groundwater migration beneath seepage basins and SWDF. In 1996, about 7,560 Ci $(2.80 \mathrm{E}+14 \mathrm{~Bq})$ of tritium was released in liquid discharges from SRS, based on point-of-release concentrations and flow rates, compared to about $9,900 \mathrm{Ci}(3.7 \mathrm{E}+14 \mathrm{~Bq})$ in 1995 [SRS Data, 1997]. SRS tritium transport data for 1960-1996 are summarized in chapter 6 (page 86 , figure 6-5). For conservatism, the slightly higher SRS river transport value of $8,950 \mathrm{Ci}(3.31 \mathrm{E}+14 \mathrm{bq})$ was used for dose calculations and is discussed in chapter 7 .

\section{Direct Discharges of Liquid Effluents}

As discussed previously, tritium is the major radionuclide released in SRS liquid effluents. The total amount of tritium released directly from process areas (i.e., reactor, separations, heavy water rework) to site streams during 1996 was $949 \mathrm{Ci}$ $(3.51 \mathrm{E}+13 \mathrm{~Bq})$, which was 29 percent less than the 1995 total of $1,340 \mathrm{Ci}(5.0 \mathrm{E}+13 \mathrm{~Bq})$. The heavy water rework area (400-D) releases decreased 71 percent, from $628 \mathrm{Ci}$ in 1995 to $183 \mathrm{Ci}$ in 1996. In the reactor area (P-Area, L-Area, $\mathrm{K}$-Area, and $\mathrm{C}$-Area), releases decreased 19 percent (542 $\mathrm{Ci}$ in 1995 ; $437 \mathrm{Ci}$ in 1996), while in the separations area, releases increased by about 96 percent $(168 \mathrm{Ci}$ in 1995; $329 \mathrm{Ci}$ in 1996).

Direct releases of tritium to site streams for the years 1988-1996 are shown in figure 5-2.

\section{Comparison of Average Concentrations in Liquid Releases to DOE Derived Concentration Guides}

In addition to dose standards, DOE Order 5400.5 imposes other control considerations on liquid 


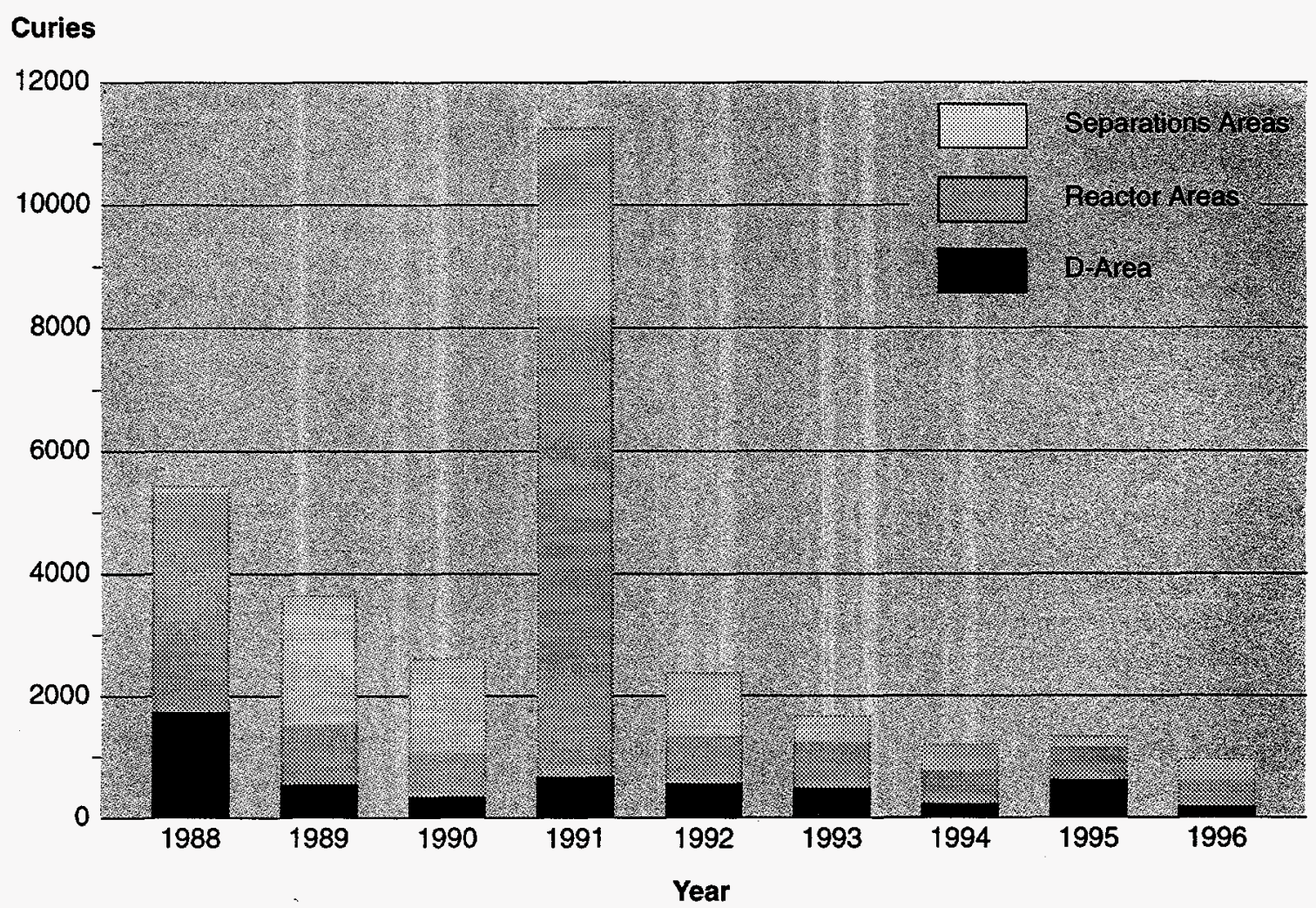

lleaf Graphic

Figure 5-2 Direct Releases of Tritium to SRS Streams, 1988-1996

The 1991 total includes an accidental release in December of 5,700 Ci from K-Reactor.

releases. These considerations are applicable to direct discharges but not to seepage basin and SWDF migration discharges. The DOE order lists DCG values for most radionuclides. DCGs are used as reference concentrations for conducting environmental protection programs at all DOE sites. These DCG values are not release limits but screening values for "best available technology" investigations and for determining whether existing effluent treatment systems are proper and effective.

According to DOE Order 5400.5 , exceedance of the DCGs at any discharge point may require an investigation of "best available technology" waste treatment for the liquid effluents. Tritium in liquid effluents is specifically excluded from "best available technology" requirements; however, it is not excluded from other ALARA considerations. DOE DCG compliance is demonstrated when the sum of the fractional DCG values for all radionuclides detectable in the effluent is less than 1.00 , based on consecutive 12-month average concentrations.

DCGs, based on a 100-mrem exposure, are applicable at the point of discharge from the effluent conduit to the environment (prior to dilution or dispersion). They are based on the highly conservative assumption that a member of the public has continuous direct access to the actual liquid effluent and consumes 2 liters of the effluent every day, 365 days a year. However, because of security controls and the distance between most SRS operating facilities and the site boundary, this scenario is improbable.

For each site facility that releases radioactivity, EMS compares the monthly liquid effluent concentrations and 12-month average concentrations against the DOE DCGs. The 1996 liquid effluent 12-month average concentrations, their comparisons against the DOE DCGs, and the quantities of radionuclides released are provided, by discharge point, in $S R S$ Environmental Data for 1996.

The data show that the U3R-2A ETF outfall at the Road C discharge point exceeded the DCG guide for 12-month average tritium concentrations during 1996. However, as noted previously, DOE

Order 5400.5 specifically exempts tritium from "best available technology" waste treatment investigation requirements. This is because there is no practical 
technology available for removing tritium from dilute liquid waste streams. In 1992, in consideration of ALARA principles for tritium discharges and while reviewing, analyzing, and modifying the process for controlling liquid releases of radioactive effluents, SRS identified several options and alternatives to continuing with these discharges at the U3R-2A ETF outfall. None of these alternatives was considered viable on a cost/benefit basis. No other discharge points exceeded the DOE DCGs in 1996.

\section{Seepage Basin and SWDF Migration Results}

To incorporate the migration of radioactivity to site streams into total radioactive release quantities, EMS monitors and quantifies the migration of radioactivity from site seepage basins and the SWDF. During 1996, tritium, strontium-89,90, and iodine-129 were detected in migration releases [SRS Data, 1997].

Figure $5-3$ is a graphical representation of releases of tritium via migration to site streams for the years 1988-1996. During 1996, the total quantity of tritium migrating from the seepage basins and SWDF was about $6,610 \mathrm{Ci}(2.45 \mathrm{E}+14 \mathrm{~Bq})$, compared to $8,560 \mathrm{Ci}$ $(3.2 \mathrm{E}+14 \mathrm{~Bq})$ in 1995 .
Figure 5-4 shows 1988-1996 total combined tritium releases from direct discharges and seepage basin and SWDF migration.

\section{Migration of Radioactivity from the K-Area Drain} Field and Seepage Basin Liquid purges from the $\mathrm{K}$-Area disassembly basin were released to the K-Area seepage basin in 1959 and 1960. Since 1960, purges from the K-Area disassembly basin have been discharged to a percolation field below the $\mathrm{K}$-Area retention basin. A total tritium migration of $1,290 \mathrm{Ci}$ $(4.77 \mathrm{E}+13 \mathrm{~Bq})$ was calculated from weekly flow measurements and tritium concentrations measured in Indian Grave Branch (a tributary of Pen Branch) during 1996. The sample location used-beginning in 1995-to determine tritium migration from the $\mathrm{K}$-Area seepage basin was changed to $\mathrm{K}-018$ because stream flow is more easily measured there than at IGB-21, which has a lower flow rate. The 1996 migration total represents a 22-percent increase from the $1650 \mathrm{Ci}(6.1 \mathrm{E}+13 \mathrm{~Bq})$ recorded in 1995 .

\section{Migration of Radioactivity from F-Area and H-Area Seepage Basins Although seepage basins in} $\mathrm{F}$-Area and $\mathrm{H}$-Area no longer are used, radioactivity previously deposited in them continues to migrate via

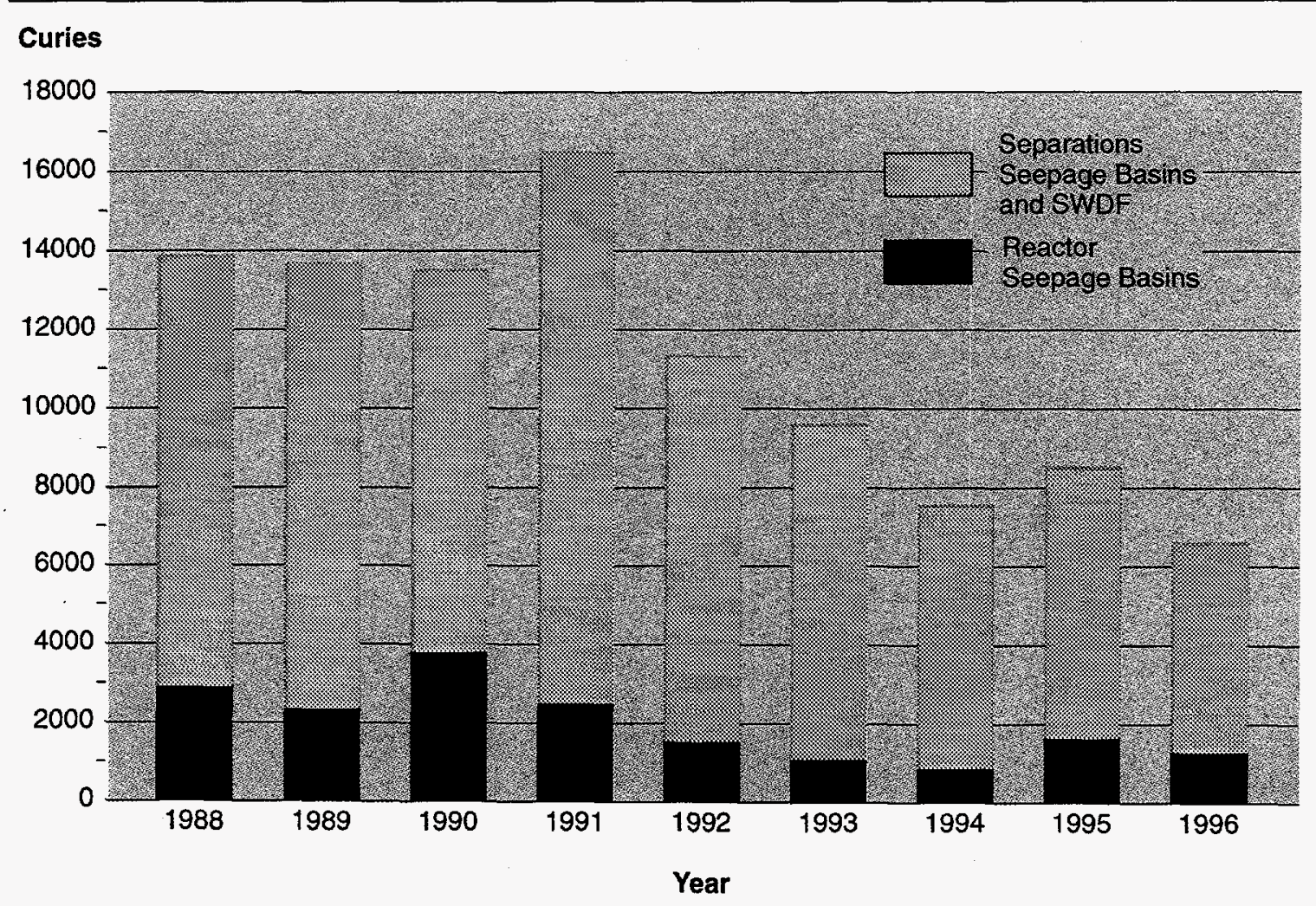

lleaf Graphic

Figure 5-3 Tritium Migration from Seepage Basins and SWDF to SRS Streams, 1988-1996 


\section{Curies}

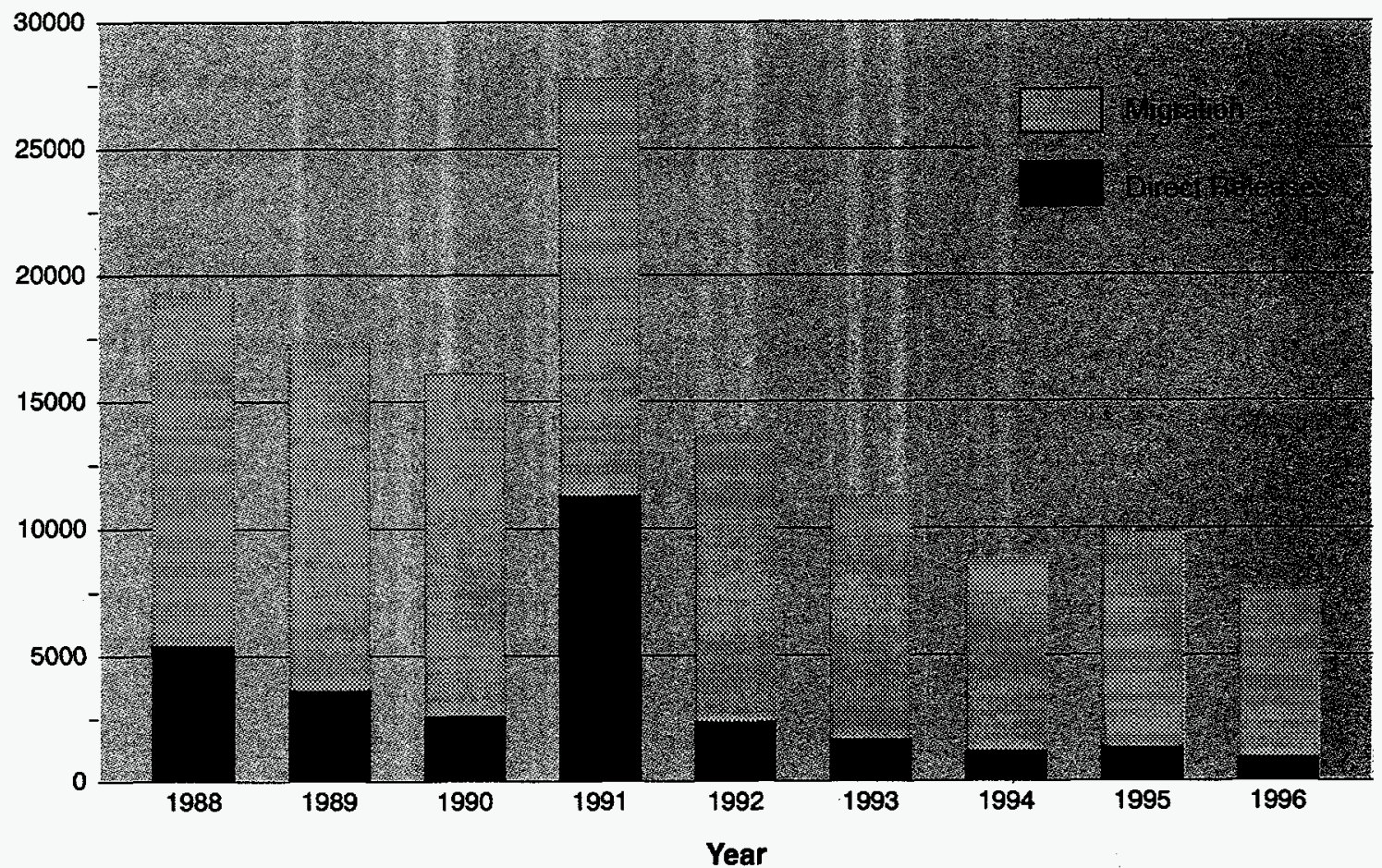

lleaf Graphic

Figure 5-4 Total Tritium Releases to SRS Streams (Direct Discharges and Migration), 1988-1996

the groundwater and to outcrop into Four Mile Creek. (also known as Fourmile Branch).

Migration of radioactivity from F-Area and $\mathrm{H}$-Area seepage basins is measured with continuous samplers and flow recorders in Four Mile Creek. Groundwater from the F-Area seepage basins enters Four Mile Creek between sampling locations FM-3A, FM-2B, and FM-A7. Four Mile Creek sampling locations are shown in chapter 6, (page 81, figure 6-3).

Most of the outcropping from $\mathrm{H}$-Area seepage basins 1, 2, and 3 occurs between FM-1C and FM-2B. Outcropping from $\mathrm{H}$-Area seepage basin 4 and SWDF occurs between FM-3 and FM-3A. Radioactivity from $\mathrm{H}$-Area seepage basin 4 and SWDF mixes during groundwater migration to Four Mile Creek. Therefore, radioactivity from the two sources cannot be distinguished at the outcrop point.

Measured migration of tritium from F-Area seepage basins was $1,620 \mathrm{Ci}(5.99 \mathrm{E}+13 \mathrm{~Bq})$ in 1996. This is nearly a 32 percent decrease from the 1995 total of $2,370 \mathrm{Ci}(8.8 \mathrm{E}+13 \mathrm{~Bq})$. The measured migration from $\mathrm{H}$-Area seepage basin 4 and SWDF was $3,200 \mathrm{Ci}(1.18 \mathrm{E}+14 \mathrm{~Bq})$, a 20 -percent decrease from the 1995 total of $4,010 \mathrm{Ci}(1.5 \mathrm{E}+14 \mathrm{~Bq})$. The measured migration from $\mathrm{H}$-Area seepage basins 1,2 , and 3 was $505 \mathrm{Ci}(1.87 \mathrm{E}+13 \mathrm{~Bq})$, a 4-percent decrease from the 1995 total of $528 \mathrm{Ci}(2.0 \mathrm{E}+13 \mathrm{~Bq})$ [SRS Data, 1997].

Past, current, and computer model-projected tritium migration releases from $\mathrm{F}$-Area and $\mathrm{H}$-Area seepage basins and SWDF are shown in figure 5-5. Generally, and as the data show, tritium migration from the F-Area and $\mathrm{H}$-Area seepage basins, which were closed in 1988, has been declining and is projected to continue to decline. However, tritium migration from SWDF has remained relatively stable during the past 10 years. Furthermore, based on the operational history of SWDF and the geology and hydrology of the site, it is anticipated that, with no corrective actions, SWDF tritium migration to Four Mile Creek is expected to remain at about $4,500 \mathrm{Ci}(1.7 \mathrm{E}+14 \mathrm{~Bq})$ per year for at least the next 10 to 20 years [Looney et al, 1993].

As required by the Resource Conservation and Recovery Act (RCRA) Part B Permit, SRS is developing SWDF groundwater corrective action plans for South Carolina Department of Health and Environmental Control (SCDHEC) approval. Portions of SWDF also are regulated under the 
Comprehensive Environmental Response,

Compensation, and Liability Act (CERCLA).

CERCLA characterization and assessment continued in 1996. Reduction of tritium migration releases is one of the factors being considered during the development of these RCRA/CERCLA groundwater corrective action plans. Low-permeability caps, waste form stabilization, groundwater barriers, groundwater pump-treat-reinjection, and other technologies are under consideration as relevant components of SWDF remediation.

The amount of strontium-89,90 entering Four Mile Creek during 1996 was estimated to be $68 \mathrm{mCi}$ $(2.52 \mathrm{E}+09 \mathrm{~Bq})$ from the F-Area seepage basins. This was a 39-percent decrease from the 1995 level of $111 \mathrm{mCi}(4.11 \mathrm{E}+09 \mathrm{~Bq})$. In addition, $31 \mathrm{mCi}$ $(1.15 \mathrm{E}+09 \mathrm{~Bq})$ of strontium-89,90 was estimated to have migrated from the H-Area seepage basins. This was a 22-percent decrease from the 1995 level of $40 \mathrm{mCi}(1.5 \mathrm{E}+09 \mathrm{~Bq})$ [SRS Data, 1997]. Like tritium migration, strontium migration is expected to continue to decline from these closed seepage basins.

In addition, a total of $78 \mathrm{mCi}(2.89 \mathrm{E}+09 \mathrm{~Bq})$ of iodine- 129 and $47 \mathrm{mCi}(1.74 \mathrm{E}+09 \mathrm{~Bq})$ of cesium- 137 migrated from the F-Area and $\mathrm{H}$-Area seepage basins and from SWDF in 1996.

Because of the low dose consequence and radioanalytical difficulties associated with technetium-99, this radionuclide cannot be detected-using common radioanalytical methods-in dilute streams. Measurement for this radionuclide, which was begun in 1994, was discontinued in 1996.

\section{Migration of Radioactivity from P-Area, C-Area,} and L-Area Seepage Basins Liquid purges from the P-Area, L-Area, and C-Area disassembly basins have been released periodically to their respective seepage basins since 1978. Purge water is released to the seepage basins to allow a significant part of the tritium to decay before the water outcrops to surface streams and flows into the Savannah River. The delaying action of the basins reduces the dose that users of water from downriver water treatment plants receive from SRS tritium releases. The seepage basins were used for purging the disassembly basins from the 1950s until 1970, but disassembly basin purge water was released directly to SRS streams between 1970 and 1978. The earlier experience with

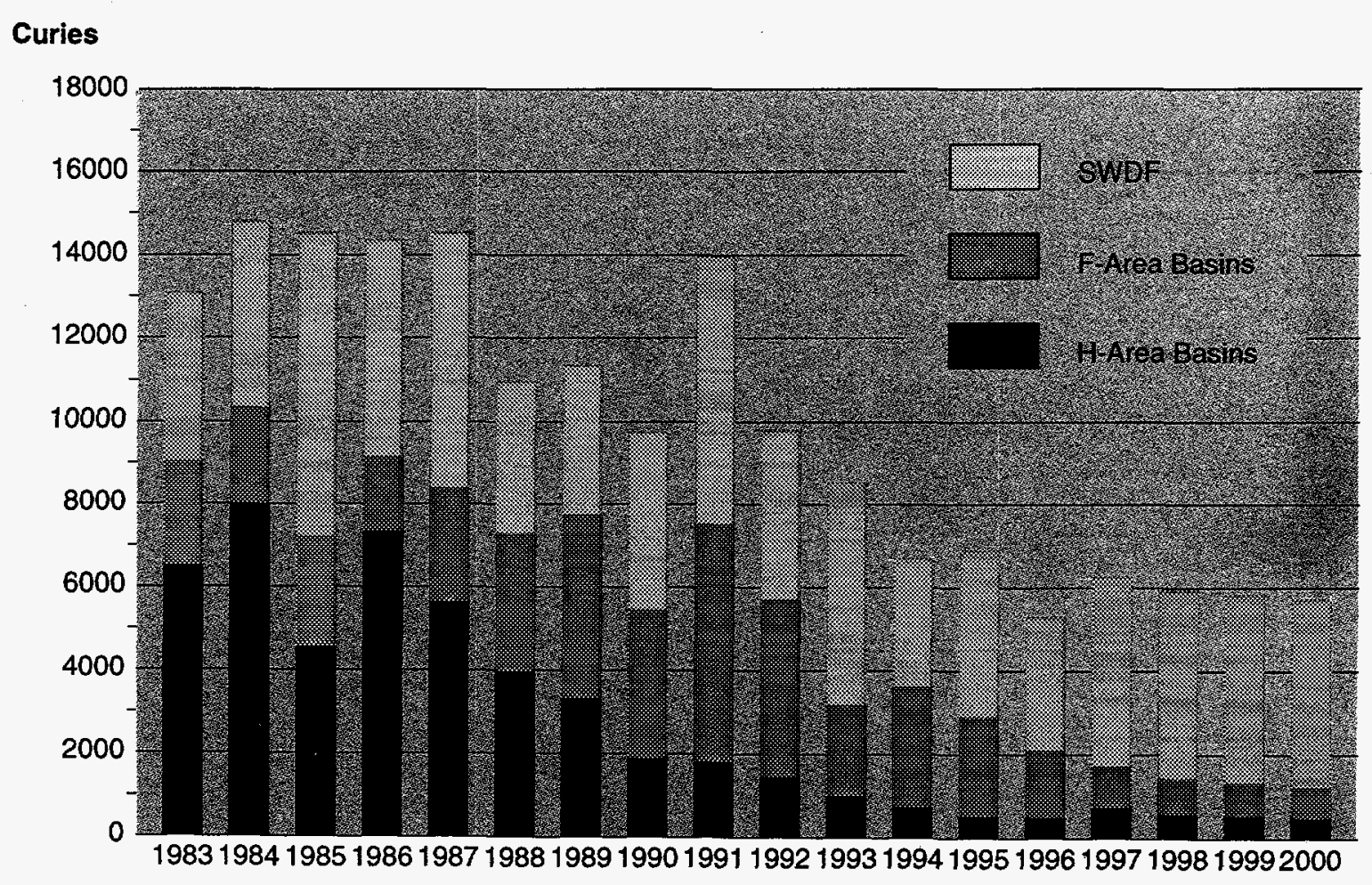

Year

lleaf Graphic

Figure 5-5 Past, Current, and Projected Tritium Migration Releases to Four Mile Creek from the F-Area and H-Area Seepage Basins and SWDF 
seepage basins indicated that the extent of radioactive decay during the holdup was sufficient to recommend that the basins be used again in P-Area, L-Area, and C-Area. However, no purges to the basins occurred during 1996.

No radionuclide migration was attributed to the C-Area seepage basin in 1996. The failure of the Twin Lakes Dam in 1991 made the determination of migration more difficult in this area. Results from a sampler installed on Steel Creek above L-Lake indicated that $320 \mathrm{Ci}(1.18 \mathrm{E}+13 \mathrm{~Bq})$ of tritium migrated from the P-Area seepage basin during 1996, slightly less than the $355 \mathrm{Ci}(1.3 \mathrm{E}+13 \mathrm{~Bq})$ of tritium in 1995 [SRS Data, 1997]. No migration of radionuclides from the L-Area seepage basin was detected in site streams.

\section{Transport of Actinides in Streams}

In 1996, a new and more sensitive actinide method was implemented for the analysis of uranium, plutonium, americium, and curium. As a result of the increased sensitivity, trace amounts of uranium and plutonium were detected at the stream transport locations FM-6, PB-3, L3R-2, and U3R-4. Consequently, these small amounts were incorporated into the source term used for the calculation of the annual dose.

\section{Settleable Solids}

In 1996, the settleable solids program was incorporated into the radiological environmental surveillance program for sediments. This was done to provide a more reliable and cost-effective method for determining the buildup of radioactivity in sediments. Eight additional sample sites were added to the sediment program to compensate for the loss of the settleable solids sampling program. Additional information on the sediment sampling program can be found in chapter 6 . 
Table 5-1

Radioactive Atmospheric Releases by Source

Page 1 of 2

\begin{tabular}{|c|c|c|c|c|c|c|c|c|}
\hline \multirow[b]{2}{*}{$\begin{array}{l}\text { Radio- } \\
\text { nuclide }\end{array}$} & \multirow[b]{2}{*}{ Half-life } & \multicolumn{7}{|c|}{ Curies $^{a}$} \\
\hline & & Reactors & $\begin{array}{l}\text { Separa- } \\
\text { tions }^{b}\end{array}$ & $\begin{array}{l}\text { Reactor } \\
\text { Materials }\end{array}$ & $\begin{array}{l}\text { Heavy } \\
\text { Water }\end{array}$ & SRTCC & $\begin{array}{l}\text { Diffuse } \\
\text { and } \\
\text { Fugitived }^{d}\end{array}$ & Total \\
\hline \multicolumn{9}{|c|}{ Blank spaces indicate no quantifiable activity; $h=$ hour, $d=$ day, $y=$ year } \\
\hline \multicolumn{9}{|c|}{ 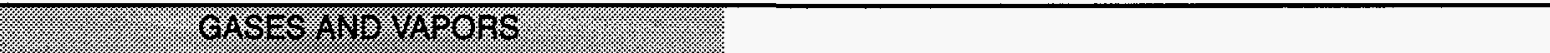 } \\
\hline H-3 (oxide) & $12.3 y$ & $1.10 \mathrm{E}+04$ & $2.85 E+04$ & & $3.29 \mathrm{E}+02$ & & $2.23 \mathrm{E}+02$ & $4.01 E+04$ \\
\hline $\mathrm{H}-3$ (elem) & $12.3 y$ & & $1.51 \mathrm{E}+04$ & & & & & $1.51 E+04$ \\
\hline H-3 Total & $12.3 y$ & $1.10 \mathrm{E}+04$ & 4.37E+04 & & $3.29 E+02$ & & $2.23 E+02$ & $5.53 E+04$ \\
\hline C-14 & $5.73 E 3 y$ & & $8.11 E+00$ & & & & $5.88 \mathrm{E}-09$ & $8.11 E+00$ \\
\hline Kr-85 & $10.73 y$ & & $5.47 \mathrm{E}+03$ & & & & & $5.47 E+03$ \\
\hline $1-129$ & $1.57 E 7 y$ & & $1.04 \mathrm{E}-02$ & & & & 3.83E-06 & $1.04 E-02$ \\
\hline $\mid-131$ & $8.040 \mathrm{~d}$ & & $5.74 \mathrm{E}-05$ & & & $2.98 E-05$ & & $8.72 E-05$ \\
\hline $1-133$ & $20.8 \mathrm{~h}$ & & & & & $5.94 E-04$ & & $5.94 E-04$ \\
\hline Xe-135 & $9.10 \mathrm{~h}$ & & & & & $1.20 E-03$ & & $1.20 E-03$ \\
\hline \multicolumn{9}{|c|}{ 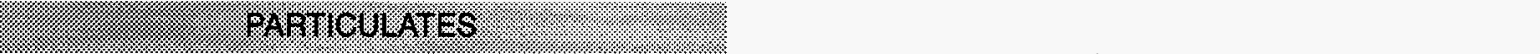 } \\
\hline Co-57 & $271.8 d$ & & $5.76 \mathrm{E}-09$ & & & & & $5.76 \mathrm{E}-09$ \\
\hline Co-60 & 5.271 y & & $3.85 \mathrm{E}-07$ & & & $8.55 E-06$ & $4.71 E-07$ & $9.41 E-06$ \\
\hline $\mathrm{Ni}-59$ & $7.6 E 4 y$ & & & & & & $2.51 \mathrm{E}-08$ & $2.51 E-08$ \\
\hline $\mathrm{Zn}-65$ & $243.8 d$ & & & & & & $1.46 \mathrm{E}-16$ & $1.46 \mathrm{E}-16$ \\
\hline Se-79 & $6.5 \mathrm{E} 4 \mathrm{y}$ & & & & & & $2.47 \mathrm{E}-08$ & $2.47 E-08$ \\
\hline Sr-90e,f & $29.1 y$ & $1.05 E-03$ & $1.46 E-03$ & $4.04 \mathrm{E}-05$ & $9.48 \mathrm{E}-05$ & $g$ & $4.75 \mathrm{E}-04$ & $3.12 \mathrm{E}-03$ \\
\hline Zr-95 & $64.02 d$ & & & & & & $2.13 E-05$ & $2.13 E-05$ \\
\hline $\mathrm{Nb}-95$ & $34.97 \mathrm{~d}$ & & & & & & $1.55 \mathrm{E}-15$ & $1.55 \mathrm{E}-15$ \\
\hline TC-99 & $2.13 E 5 y$ & & & & & & $2.65 \mathrm{E}-08$ & $2.65 E-08$ \\
\hline Ru-106 & $1.020 y$ & & $9.18 \mathrm{E}-07$ & & & & $7.00 \mathrm{E}-02$ & $7.00 E-02$ \\
\hline Sn-126 & $1 E 5 y$ & & & & & & $6.79 \mathrm{E}-09$ & $6.79 E-09$ \\
\hline Sb-125 & $2.758 y$ & & $2.61 \mathrm{E}-07$ & & & & $2.28 E-04$ & $2.28 E-04$ \\
\hline Cs-134 & $2.065 y$ & & $1.97 E-07$ & & & & $2.49 E-15$ & $1.97 \mathrm{E}-07$ \\
\hline Cs-137 & $30.17 y$ & $1.76 E-05$ & $4.82 E-04$ & $3.94 E-07$ & $1.11 E-06$ & $1.22 \mathrm{E}-06$ & 4.33E-03 & $4.83 E-03$ \\
\hline $\mathrm{Ce}-144$ & $284.6 \mathrm{~d}$ & & $6.77 E-07$ & & & & $7.36 \mathrm{E}-06$ & $8.04 E-06$ \\
\hline Pm-147 & $2.623 y$ & & & & & & $6.75 E-06$ & $6.75 E-06$ \\
\hline Eu-154 & $8.59 \mathrm{y}$ & & $1.87 E-07$ & & & & $6.42 \mathrm{E}-06$ & $6.61 \mathrm{E}-06$ \\
\hline
\end{tabular}

a One curie equals $3.7 \mathrm{E}+10$ Becquerels.

b Includes separations, waste management, and tritium facilities

c Savannah River Technology Center

d Estimated releases from minor unmonitored diffuse and fugitive sources

e Includes unidentified beta emissions

f Includes Sr-89

g No unidentified emissions 
Table 5-1

Radioactive Atmospheric Releases by Source

Page 2 of 2

\begin{tabular}{|c|c|c|c|c|c|c|c|c|}
\hline \multirow[b]{2}{*}{$\begin{array}{l}\text { Radio- } \\
\text { nuclide }\end{array}$} & \multirow[b]{2}{*}{ Half-life } & \multicolumn{7}{|c|}{ Curies $^{a}$} \\
\hline & & Reactors & $\begin{array}{c}\text { Separa- } \\
\text { tions }{ }^{\mathbf{b}}\end{array}$ & $\begin{array}{l}\text { Reactor } \\
\text { Materials }\end{array}$ & $\begin{array}{l}\text { Heavy } \\
\text { Water }\end{array}$ & SRTCC & $\begin{array}{c}\text { Diffuse } \\
\text { and } \\
\text { Fugitived }^{d}\end{array}$ & Total \\
\hline Eu-155 & $4.71 y$ & & 8.33E-07 & & & & $1.66 \mathrm{E}-06$ & $1.66 E-06$ \\
\hline Th-232 & $1.40 \mathrm{E} 10 \mathrm{y}$ & & & & & & $1.28 \mathrm{E}-08$ & $1.28 E-08$ \\
\hline $\mathrm{Pa}-231$ & $3.28 E 4 y$ & & & & & & $1.00 \mathrm{E}-09$ & $1.00 \mathrm{E}-09$ \\
\hline U-233 & $1.592 E 5 y$ & & & & & & $1.62 \mathrm{E}-08$ & $1.62 E-08$ \\
\hline$U-234$ & $2.46 E 5 y$ & & $2.44 E-04$ & $6.81 E-06$ & & & $2.93 \mathrm{E}-07$ & $2.51 E-04$ \\
\hline$U-235$ & 7.04E8 y & & $4.67 E-05$ & $1.06 \mathrm{E}-06$ & & & $4.10 \mathrm{E}-05$ & $8.88 E-04$ \\
\hline$U-236$ & 2.342E7 y & & & & & & $5.79 E-08$ & $5.79 \mathrm{E}-08$ \\
\hline$U-238$ & 4.47E9 $y$ & & $1.37 \mathrm{E}-03$ & $1.09 \mathrm{E}-06$ & & & $1.35 \mathrm{E}-06$ & $1.37 \mathrm{E}-03$ \\
\hline Np-237 & $2.14 E 6 y$ & & & & & & $4.66 \mathrm{E}-08$ & $4.66 \mathrm{E}-08$ \\
\hline Np-239 & $2.35 \mathrm{~d}$ & & & & & & 2.17E-07 & 2.17E-07 \\
\hline Pu-238 & $87.7 y$ & & $4.79 \mathrm{E}-04$ & $2.23 E-09$ & & & $5.19 \mathrm{E}-06$ & $4.84 \mathrm{E}-04$ \\
\hline Pu-239e & $2.410 \mathrm{E} 4 \mathrm{y}$ & $6.74 \mathrm{E}-05$ & $2.65 E-04$ & $2.78 E-05$ & $6.39 \mathrm{E}-06$ & $6.67 \mathrm{E}-06$ & $1.83 E-04$ & 5.57E-04 \\
\hline Pu-240 & $6.56 \mathrm{E} 3 \mathrm{y}$ & & & & & & $2.11 \mathrm{E}-07$ & $2.11 E-07$ \\
\hline Pu-241 & $14.4 y$ & & & & & & 3.75E-06 & $3.75 E-06$ \\
\hline Am-241 & $432.7 y$ & & $1.27 E-05$ & $1.06 \mathrm{E}-08$ & & & $4.20 \mathrm{E}-07$ & $1.31 E-05$ \\
\hline Am-243 & 7.37E3 y & & & & & & $1.76 \mathrm{E}-05$ & $1.76 \mathrm{E}-05$ \\
\hline $\mathrm{Cm}-242$ & $162.8 \mathrm{~d}$ & & & & & & $2.03 E-16$ & $2.03 E-16$ \\
\hline $\mathrm{Cm}-244$ & $18.1 y$ & & $4.47 E-06$ & $2.43 E-09$ & & & $1.28 \mathrm{E}-04$ & $1.32 \mathrm{E}-04$ \\
\hline
\end{tabular}

One curie equals $3.7 \mathrm{E}+10$ Becquerels.

Includes separations, waste management and tritium facilities

Savannah River Technology Center

Estimated releases from minor unmonitored diffuse and fugitive sources

Includes unidentified alpha emissions 
Table 5-2

Radioactive Liquid Releases by Source

(Including Direct and Seepage Basin Migration Releases)

Page 1 of 1

\begin{tabular}{|c|c|c|c|c|c|c|c|}
\hline \multirow[b]{2}{*}{$\begin{array}{l}\text { Radio- } \\
\text { nuclide }\end{array}$} & \multirow[b]{2}{*}{ Half-life } & \multicolumn{6}{|c|}{ Curies $^{a, b}$} \\
\hline & & Reactors & $\begin{array}{c}\text { Separa- } \\
\text { tionsc }\end{array}$ & $\begin{array}{c}\text { Reactor } \\
\text { Materials }\end{array}$ & $\begin{array}{c}\text { Heavy } \\
\text { Water/TNX }\end{array}$ & $\begin{array}{c}\text { Savannah } \\
\text { River } \\
\text { Technology } \\
\text { Center } \\
\end{array}$ & Total \\
\hline \multicolumn{8}{|c|}{ Notes: Blank spaces indicate no quantifiable activity; $h=$ hour, $d=$ day, $y=$ year } \\
\hline H-3 (oxide) & $12.3 y$ & $2.73 E+03$ & $5.81 E+03$ & & $1.83 E+02$ & $8.78 \mathrm{E}-01$ & $8.95 E+03^{d}$ \\
\hline $\mathrm{Sr}-90^{\oplus, \mathrm{f}}$ & $29.1 \mathrm{y}$ & $1.35 \mathrm{E}-01$ & $1.21 \mathrm{E}-01$ & $g$ & $5.38 \mathrm{E}-03$ & $9.31 \mathrm{E}-04$ & $2.62 E-01$ \\
\hline $\mid-129$ & $1.6 \mathrm{E} 7 \mathrm{y}$ & & 7.82E-02 & & & & $7.82 E-02$ \\
\hline Cs-137 & $30.2 y$ & $2.30 \mathrm{E}-02$ & $9.35 E-02$ & & & & $1.17 \mathrm{E}-01^{\mathrm{h}}$ \\
\hline Pm-147 & $2.6 y$ & & $4.80 \mathrm{E}-04$ & & & & $4.80 E-04$ \\
\hline U-234 & 2.46E5 y & $1.19 \mathrm{E}-03$ & $6.90 \mathrm{E}-03$ & $3.55 \mathrm{E}-05$ & $7.45 \mathrm{E}-07$ & $5.06 \mathrm{E}-05$ & $8.18 E-03$ \\
\hline U-235 & $7.04 E 8$ y & $1.81 \mathrm{E}-05$ & $2.08 \mathrm{E}-04$ & & & $1.43 E-06$ & $2.28 \mathrm{E}-04$ \\
\hline U-238 & 4.47E9 $y$ & $8.21 E-04$ & $9.59 E-03$ & $5.83 E-05$ & $1.75 E-06$ & $5.00 \mathrm{E}-05$ & $1.05 E-02$ \\
\hline Pu-238 & $87.7 y$ & $1.36 \mathrm{E}-04$ & $2.61 E-03$ & $4.01 E-05$ & $1.97 \mathrm{E}-06$ & $6.71 E-06$ & $2.79 E-03$ \\
\hline Pu-239i & $2.410 \mathrm{E} 4 \mathrm{y}$ & $1.07 E-02$ & $1.52 \mathrm{E}-02$ & $\mathbf{g}$ & $4.19 \mathrm{E}-04$ & $3.41 E-04$ & 2.67E-02 \\
\hline Am-241 & $432.7 y$ & & $4.03 E-06$ & $6.72 E-05$ & & & $7.12 \mathrm{E}-05$ \\
\hline $\mathrm{Cm}-244$ & $18.1 y$ & & $6.23 E-07$ & $1.19 \mathrm{E}-05$ & & & $1.25 E-05$ \\
\hline
\end{tabular}

\footnotetext{
One curie equals $3.7 E+10$ Becquerels.

Blank spaces indicate no quantifiable activity.

Includes separations, waste management, and tritium facilities

For conservatism, the slightly higher river transport number $(8.95 \mathrm{E}+03 \mathrm{Ci})$ was used for dose calculations.

Includes unidentified beta

Includes Sr-89

No quantifiable unidentified releases

$\mathrm{h}$ For conservatism, the higher release number (1.55E-01 Ci), calculated from River Mile 120 fish concentrations, was used for dose calculations (chapter 7, "Potential Radiation Doses").

Includes unidentified alpha
} 

Air ......................... 76

Rainwater ..................... 77

Gamma Radiation ................ 78

Seepage Basins . . . . . . . . . . . 80

Site Streams .................... 82

Savannah River ................... 84

Drinking Water .................. 85

Mary Dodgen, Pete Fledderman, Bill Littrell, and Stuart Stinson Environmental Protection Department

Terrestrial Food Products . . . . . . . . . . 87

Aquatic Food Products .............. 88

Deer and Hogs . . . . . . . ............ 90

Turkeys ....................... 91

Beavers ...................... 91

Soil ......................... 92

Sediment....................... 92

Grassy Vegetation ................ 95

$\mathrm{T}$ HE Savannah River Site (SRS) radiological environmental surveillance program is designed to survey and quantify any effects that routine and nonroutine operations might have on the site and on the surrounding area and population. The program represented an extensive network in 1996 that covered approximately 2,000 square miles and extended up to 25 miles from the site. In conjunction with the radiological effluent monitoring program (chapter 5, "Radiological Effluent Monitoring"), the program enables SRS to monitor ambient radiological conditions and determine site contributions of radioactive materials to the environment.

Routine Radiological surveillance activities are performed by the Environmental Protection Department's Environmental Monitoring Section (EMS) and by the Savannah River Technology Center (SRTC). The Savannah River also is monitored by other groups, including the South Carolina Department of Health and Environmental Control (SCDHEC) and the Georgia Department of Natural Resources (GDNR).

As part of the radiological surveillance program, routine surveillance of all radiation exposure pathways (ingestion, inhalation, immersion, and submersion) is performed on all environmental media that may lead to a measurable annual dose at the site boundary. This chapter summarizes surveillance results of the atmosphere (air and rainwater), surface water (seepage basins, site streams, and the Savannah River), drinking water, food products (terrestrial and aquatic), wildlife, soil, sediment, and vegetation. Also summarized are results of extensive monitoring of ambient gamma radiation levels performed on site, at the site boundary, and in population centers (surrounding communities). A description of the surveillance program and 1996 results for groundwater can be found in chapter 10 , "Groundwater."

All results discussed in this chapter are based on available samples and/or analyses. Because of sampling and/or analytical difficulties, some sample analyses may be missing. Problems may have arisen with sample collection, such as loss of power to the sampling site or inaccessibility to the sampling site (locked gates, flooding, etc.) Results for collected samples can be rejected after analysis for such reasons as insufficient sample volume, low chemical yield, or equipment failure.

The \pm value reported with individual results is a counting uncertainty; the \pm value reported with averages (means) is a standard deviation. The lower limit of detection (LLD) often varies because of counting times and other factors. Nominal LLDs for the types of analyses being performed on the various environmental surveillance media are presented in tables 6-9 through 6-12, which can be found at the end of this chapter.

In 1996, approximately 10,000 radiological analyses were performed on approximately 5,000 samples (not including groundwater) Analytical results from 1996 appear in SRS Environmental Data for 1996 (WSRC-TR-97-0077). Information on the rationale for the radiological environmental surveillance program can be found in chapter 3, "Environmental Program Information." Data from earlier years can be found in previous SRS environmental reports and data publications. Document numbers for these can 
be found in appendix E, "Environmental Monitoring Reports."

A complete description of the SRS radiological environmental surveillance program can be found in section 1105 of the Savannah River Site Environmental Monitoring Section Plans and Procedures, WSRC-3Q1-2, Volume 1 (SRS EM Program). Changes in the site's missions led to a comprehensive review of the radiological surveillance program in 1995. As a result, adjustments were implemented in several parts of the program that year and in 1996-without reducing the overall ability of the program to produce critical information. Details about specific changes are presented in the discussions of the affected program areas.

\section{Air}

\section{Description of Surveillance Program}

EMS maintains an extensive network of 23 sampling stations in and around SRS to monitor the concentration of radioactive materials in the air. These locations are divided into four subgroups, as follows:

- onsite

- $\quad$ site perimeter

- a control location at 25 miles

- $\quad$ selected major population centers at 25 and 100 miles

Figure 6-1 shows all the sampling locations except the 25- and 100-mile stations.

The air surveillance program helps determine the impact (if any) of site operations on the environment and evaluates trends in airborne radionuclide concentrations. The program also is used to verify atmospheric transport models and to support emergency response activities in the event of an unplanned release of radioactive material to the atmosphere.

\section{Surveillance Results}

Chapter 5 details the types and quantity of radioactive material released to the environment from SRS activities in 1996. Except for tritium, specific radionuclides were not routinely detectable at the site perimeter. Both onsite and site perimeter/offsite activity concentrations were similar to levels observed in previous years.

\section{Gross Alpha and Gross Beta}

Gross alpha and gross beta activity analyses are performed on glass fiber filter papers. Although they cannot provide concentrations of specific radionuclides, these measurements are useful in providing information for trending of the total activity in an air sample or in screening samples.

A summary of the monitoring results from 1990-1996 is presented in table 6-1. Although both the average gross alpha and average gross beta results are slightly lower than the 1995 results, they are still consistent with historical trends. As observed in previous years, no significant difference was observed between the average concentration measured on site near the operating facilities and the average concentration observed at the site perimeter.

\section{Gamma-Emitting Radionuclides}

Glass fiber filters and activated charcoal canisters are collected weekly and analyzed for gamma-emitting radionuclides. In 1996, no manmade gamma-emitting radionuclides were observed above the nominal LLD. These results are consistent with historical results, which indicate a small number of samples with detectable activity.

\section{Tritium}

Tritium-in-air analyses are conducted on biweekly silica gel samples. Tritium is released as part of routine SRS operations and becomes part of the natural environment. Monitoring assures that it poses no health risk to the surrounding population. Consistent with the SRS source term, tritium concentrations generally decrease with increasing distance from the tritium facilities near the center of the site. In addition, the analytical results agree with the predictions of the SRS transport and dose assessment model, as detailed in Chapter 7, "Potential Radiation Doses."

\section{Plutonium and Strontium}

Glass fiber filters are composited either weekly or monthly and analyzed for plutonium isotopes (plutonium-238 and plutonium-239) and total strontium (strontium-89,90). These radionuclides are released in small quantities as part of routine site operations-primarily from the separations areas. The observed concentrations of the radionuclides were similar to historical levels; most locations were near or below the nominal LLD. Likewise, the distribution pattern of the isotopes was similar to that observed in previous years-the concentrations generally were higher near the center of the site, as expected from the source term. The concentrations 


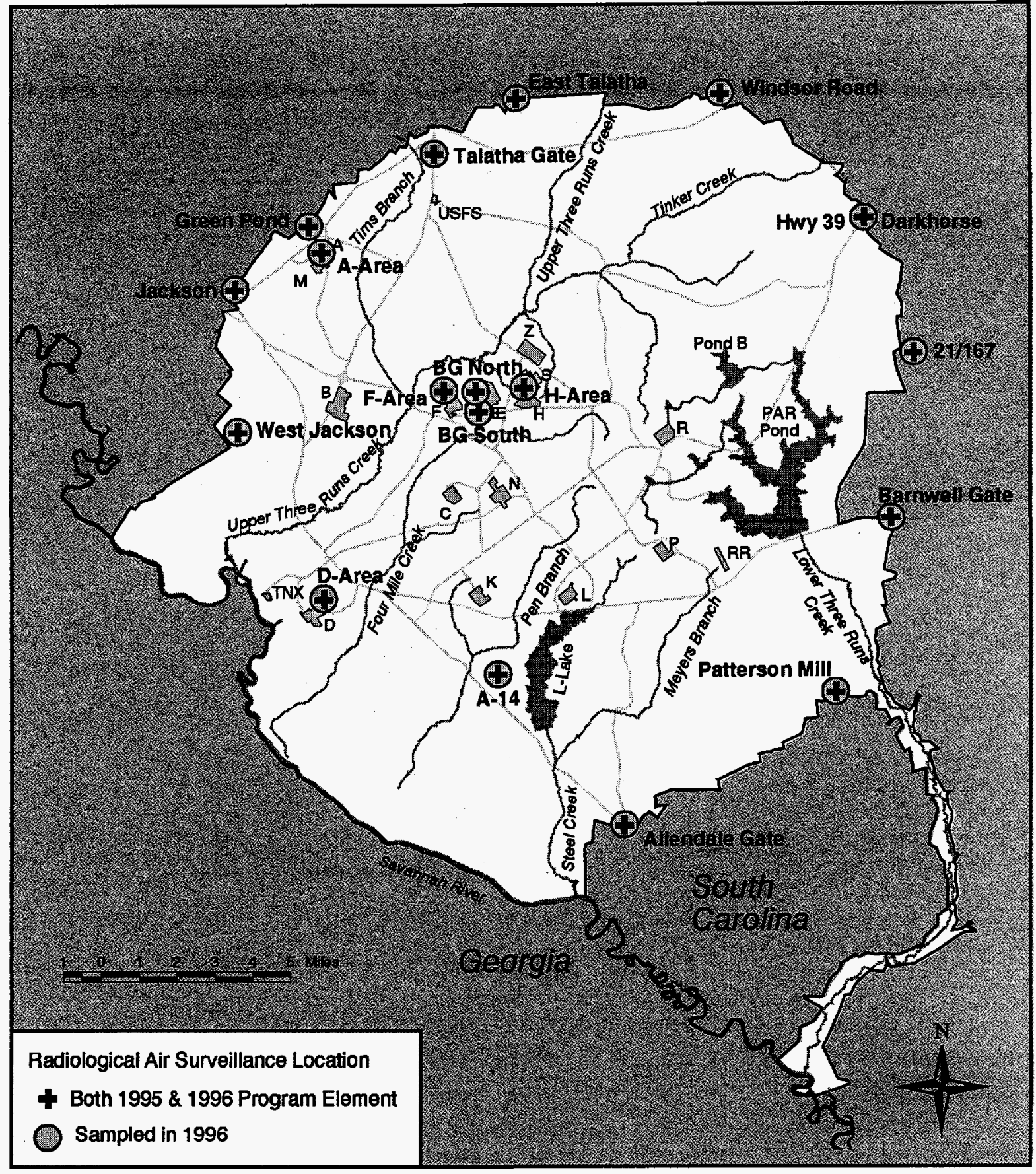

EPD/GIS Map

\section{Figure 6-1 Radiological Air Surveillance Stations}

The SRS air surveillance program consists of 19 stations located on site or along the site perimeter, as well as (not shown) three stations approximately 25 miles from the site perimeter (located at the Highway 301 Bridge over the Savannah River, the Augusta Lock and Dam, and the Aiken airport) and one approximately 100 miles from the site perimeter (at Savannah, Georgia).

then showed a decrease to background levels or detection limits at the site boundary and beyond.

\section{Rainwater}

SRS maintains a network of rainwater sampling sites as part of the air surveillance program. These stations 
Table 6-1

Average Gross Alpha and Gross Beta Measured in Air ( $\mu \mathrm{Ci} / \mathrm{mL}), 1990-1996$

\begin{tabular}{lccccccc}
\hline & \multicolumn{7}{c}{ Average Gross Alpha } \\
Locations & 1990 & 1991 & 1992 & 1993 & 1994 & 1995 & 1996 \\
On site & $1.3 \mathrm{E}-15$ & $2.5 \mathrm{E}-15$ & $1.8 \mathrm{E}-15$ & $1.9 \mathrm{E}-15$ & $1.4 \mathrm{E}-15$ & $1.5 \mathrm{E}-15$ & $1.1 \mathrm{E}-15$ \\
Site perimeter & $1.1 \mathrm{E}-15$ & $2.6 \mathrm{E}-15$ & $1.8 \mathrm{E}-15$ & $1.8 \mathrm{E}-15$ & $1.4 \mathrm{E}-15$ & $1.4 \mathrm{E}-15$ & $1.0 \mathrm{E}-15$ \\
25-mile radius & $1.0 \mathrm{E}-15$ & $2.5 \mathrm{E}-15$ & $1.7 \mathrm{E}-15$ & $1.8 \mathrm{E}-15$ & $1.4 \mathrm{E}-15$ & $1.4 \mathrm{E}-15$ & $1.0 \mathrm{E}-15$ \\
100-mile radius & $1.3 \mathrm{E}-15$ & $2.6 \mathrm{E}-15$ & $1.7 \mathrm{E}-15$ & $2.0 \mathrm{E}-15$ & $1.8 \mathrm{E}-15$ & $1.6 \mathrm{E}-15$ & $9.4 \mathrm{E}-16$ \\
& & \multicolumn{7}{c}{ Average Gross Beta } & & & \\
Locations & 1990 & 1991 & 1992 & 1993 & 1994 & 1995 & 1996 \\
On site & $1.8 \mathrm{E}-14$ & $1.8 \mathrm{E}-14$ & $1.9 \mathrm{E}-14$ & $1.8 \mathrm{E}-14$ & $1.7 \mathrm{E}-14$ & $1.8 \mathrm{E}-14$ & $1.5 \mathrm{E}-14$ \\
Site perimeter & $1.8 \mathrm{E}-14$ & $1.8 \mathrm{E}-14$ & $1.9 \mathrm{E}-14$ & $1.9 \mathrm{E}-14$ & $1.8 \mathrm{E}-14$ & $1.8 \mathrm{E}-14$ & $1.5 \mathrm{E}-14$ \\
25-mile radius & $1.8 \mathrm{E}-14$ & $1.8 \mathrm{E}-14$ & $1.8 \mathrm{E}-14$ & $1.8 \mathrm{E}-14$ & $1.8 \mathrm{E}-14$ & $1.8 \mathrm{E}-14$ & $1.6 \mathrm{E}-14$ \\
100-mile radius & $1.9 \mathrm{E}-14$ & $1.8 \mathrm{E}-14$ & $1.7 \mathrm{E}-14$ & $2.0 \mathrm{E}-14$ & $1.8 \mathrm{E}-14$ & $1.8 \mathrm{E}-14$ & $1.4 \mathrm{E}-14$ \\
\hline
\end{tabular}

are used to measure deposition of radioactive materials.

\section{Description of Surveillance Program}

Rainwater collection pans are located at each routine air surveillance station (figure 6-1). Ion-exchange resin columns are placed at 10 of these locations. At each of these locations, rain collected in the pan passes through the column and into a collection bottle. Both the ion-exchange resin column and the collected liquid is returned to the laboratory for analysis. The column is analyzed for gamma-emitting radionuclides, gross alpha, gross beta, plutonium-238, plutonium-239, and strontium- 89,90 , while the rainwater is analyzed for tritium. At all other locations, the collected rainwater is returned to the laboratory and analyzed for tritium only. Ion-exchange column sampling is performed monthly, while rainwater sampling is performed biweekly.

\section{Surveillance Results}

\section{Gamma-Emitting Radionuclides}

As in 1995, no detectable manmade gamma-emitting radionuclides were observed.

\section{Gross Alpha and Gross Beta}

The gross alpha and gross beta results were consistent with those of 1995; no increasing or decreasing trend was evident. This implies that the observed values are natural background and do not indicate any contribution directly attributable to SRS.

\section{Plutonium}

As in 1995, no detectable levels of plutonium-238 or plutonium-239 were observed.

\section{Strontium}

As in 1995, no detectable levels of strontium-89,90 were observed.

\section{Tritium}

Tritium-in-rain values were highest at those locations near the center of the site and at D-Area. This is consistent with the H-Area and D-Area effluent release points that routinely release tritium. As with tritium in air, concentrations generally decreased as distance from the effluent release point increased (figure 6-2); this observation also is consistent with the source term and with atmospheric transport.

\section{Gamma Radiation}

\section{Description of Surveillance Program}

Ambient gamma exposure rates in and around SRS are monitored by an extensive network of dosimeters. The site uses the thermoluminescent dosimeter (TLD) to quantify integrated gamma exposure on a quarterly basis. The TLD performs this function accurately, reliably, and relatively inexpensively.

SRS has been monitoring ambient environmental gamma exposure rates with TLDs since 1965 . The information provided by this program is used primarily to determine the impact (if any) of site operations on the gamma exposure environment and to evaluate trends in environmental exposure levels. Other potential uses include 


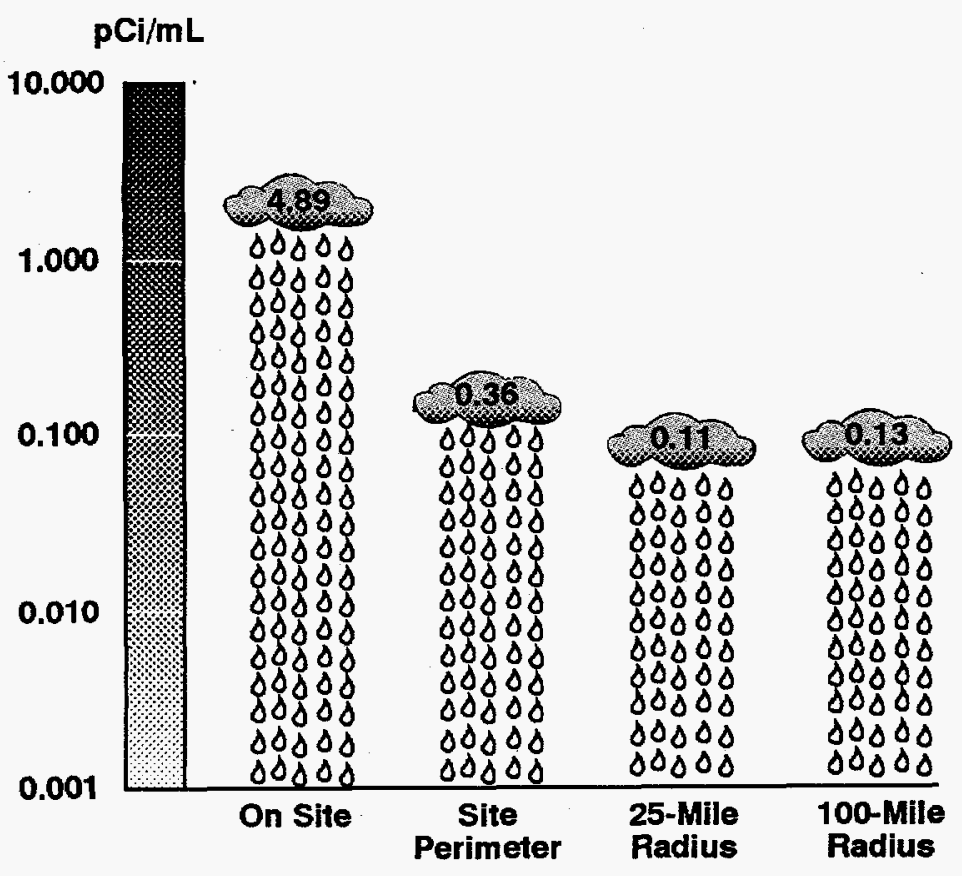

Figure 6-2 Average Concentration of Tritium in Rainwater

Tritium concentrations in rainwater (shown here in $\mathrm{pCi} / \mathrm{mL}$ ), generally decrease as the distance from the site increases.

97X00957.02.AlL

\section{Location}

- $\quad$ support of routine and emergency response dose calculation models

- assistance in determining protective action recommendations in the event of an unplanned release of gamma-emitting radionuclides

- confirmatory accident assessment

The SRS ambient gamma radiation monitoring program is divided into five subprograms, as follows: onsite operating areas, site perimeter stations, population centers, air surveillance stations, and NRC/Vogtle (stations co-located with Nuclear Regulatory Commission and Georgia Power Company locations that monitor potential exposures from Georgia Power's Vogtle Electric Generating Plant). All TLDs are exchanged quarterly.
A second technical evaluation of the radiological environmental surveillance program-conducted in 1996 because of continuing changes in site missions and as part of an overall comprehensive review of the WSRC environmental monitoring program-resulted in extensive changes to the gamma radiation surveillance program. Most of the changes were implemented in midyear, as 196 of 327 monitoring stations were eliminated (table 6-2).

As a result of these modifications, most gamma exposure monitoring is conducted on site and at the site perimeter. Monitoring continues to be conducted in population centers within approximately 9 miles $(15 \mathrm{~km})$ of the site boundary, but only limited monitoring is conducted beyond this distance and at the 25- and 100-mile air surveillance stations.

Table 6-2

1996 Gamma Radiation Surveillance Program Changes

\section{Subprogram}

Site operating areas

Site perimeter stations

Population centers

Air surveillance stations

NRC/Nogtle

\section{Change(s)}

Eliminate 26 locations (70 remaining)

Eliminate 170 locations (nine remaining)

No changes (nine remaining)

No changes (25 remaining)

No changes (18 remaining) 
Table 6-3

TLD Surveillance Results Summary for 1996

\section{Monitoring Subprogram}

\author{
Mean Exposure \\ (mrem per year)
}

Maximum Exposure

(mrem per year)
Maximum-Exposure Location

$\begin{array}{llrl}\text { On site } & 99 & 252 & \text { N-Area \#5 } \\ \text { Site perimeter } & 85 & 99 & \text { Perimeter \#42 } \\ \text { Air surveillance } & 78 & 116 & \text { BG North } \\ \text { Population centers } & 87 & 108 & \text { Williston, SC } \\ \text { NRC } / \text { Vogtle } & 64 & 85 & \text { NRC \#5 }\end{array}$

\section{Surveillance Results}

In general, 1996 gamma radiation surveillance program results indicated gamma exposure rates consistent with those observed in 1995 . As expected, results from several onsite monitoring locations showed clearly elevated exposure rates. As in 1995, the maximum annual exposure was observed on site at Location 5 in N-Area; this location is near facilities where work is performed on steam generators. The 1996 exposure at this location was approximately 252 mrem. The remainder of the onsite locations were no greater than levels measured at the site perimeter or off site. This follows a long-term trend.

Site perimeter and offsite locations were consistent with previously published historical results. The exposures at these locations show some variation based on normal site-to-site and year-to-year differences in the components of natural ambient gamma exposure levels. This phenomena also is observed at a majority of the onsite monitoring locations because operations in many areas have been reduced or discontinued. Table 6-3 summarizes the 1996 surveillance results.

\section{Seepage Basins}

During previous years of operation, SRS discharged liquid effluent to seepage basins to allow for the decay and natural removal of radioactivity in the water before it reached onsite streams. The practice of discharging water to the seepage basins was discontinued in 1988 , but water accumulating in the basins from other sources continues to be monitored by EMS because of potential contamination from the basin soil.

\section{Description of Surveillance Program}

Seepage basin water is analyzed for gross alpha, gross beta, and tritium content. Analyses for specific radionuclides are determined by the makeup of previous releases to the basins.

In 1996, aqueous samples were scheduled to be collected annually from the TNX seepage basin, monthly from the Solid Waste Disposal Facility (SWDF), and quarterly from the A-Area, C-Area, L-Area, and P-Area seepage basins. As part of the E-Area expansion plan, EMS also monitors two basins, E-Basin North and E-Basin South, on a monthly basis. Because of dry conditions, not all scheduled samples were collected from the C-Area, L-Area, and P-Area basins, the SWDF basin, and E-Basin South. Seepage basin surveillance locations are shown in figure 6-3.

Seepage basin water is analyzed for gross alpha, gross beta, tritium, strontium, and gamma-emitting radionuclides. Analyses for specific radionuclides are determined by the makeup of previous releases to the basins.

\section{Surveillance Results}

Sampling results from 1996 for seepage basin water were similar to those from previous years, largely because liquid effluents no longer introduce new activity to the basins. For most samples, results from 1996 are slightly lower than results from 1995. Tritium results were slightly lower in 1996 than in 1995 for three of six locations. Tritium values for 1996 at the C-Area, L-Area, and P-Area basins were only slightly higher than in 1995, with the P-Area basin containing the highest activity. The C-Area basin contained the highest beta activity, the majority of which was identified as cesium-137 and cobalt- 60 . Activity levels for cobalt and cesium were lower at all locations than those reported in 1995. Analysis of uranium/plutonium activities by alpha spectroscopy began in July 1995; this allows results to be reported for individual isotopes of uranium and plutonium. Average uranium and plutonium activities reported in 

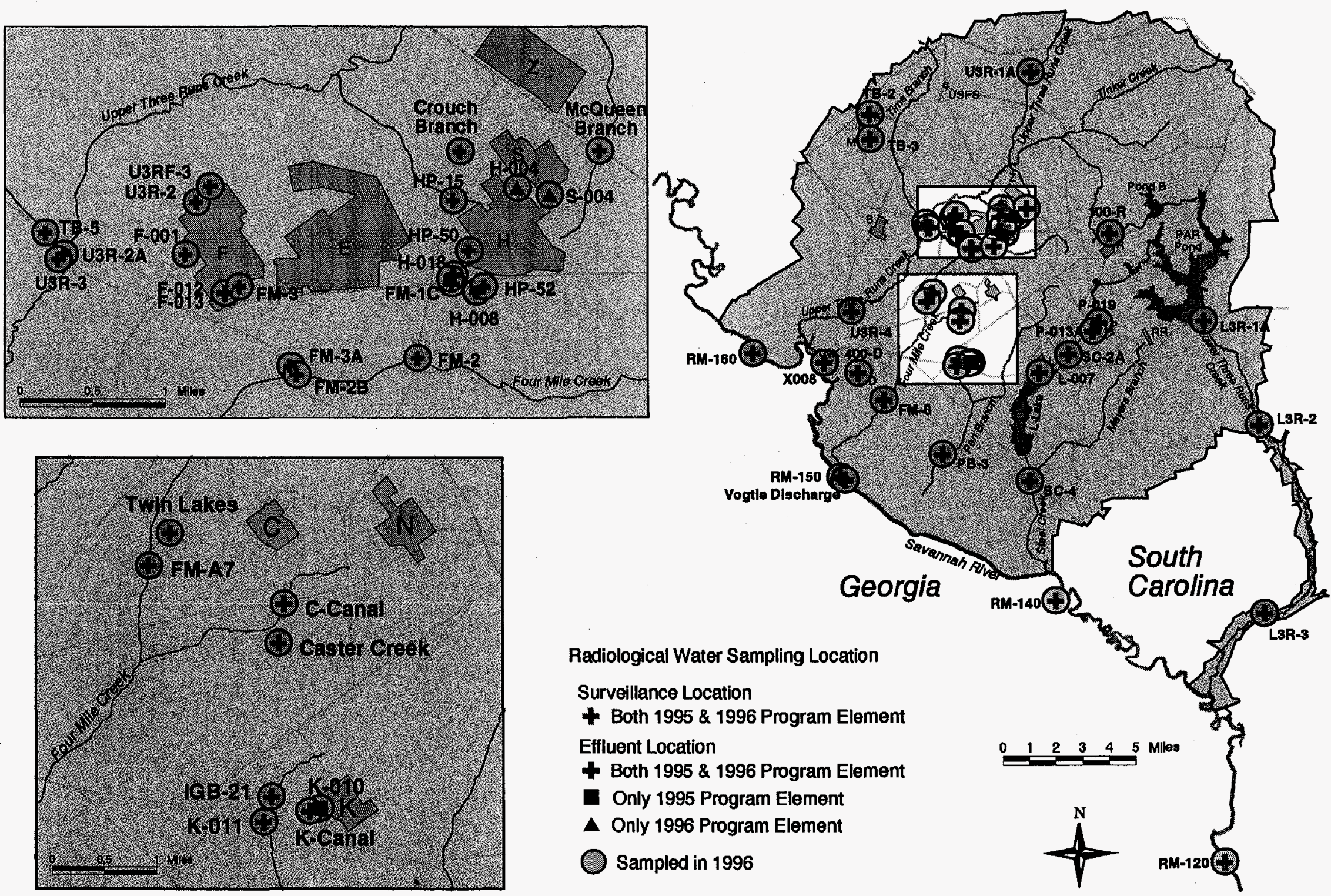

Radiological Water Sampling Location

Surveillance Location

+ Both 1995 \& 1996 Program Element Effluent Location

+ Both 1995 \& 1996 Program Element

- Only 1995 Program Element

A Only 1996 Program Element

C Sampled in 1996

EPD/GIS Graphic

Figure 6-3 Radiological Surface-Water Sampling Locations

Surveillance and effluent sampling points are located on SRS seepage basins and streams and on the Savannah River. 
1996 were lower at the TNX seepage basin than those reported in 1995. Strontium levels in the L-Area basin also were lower than those reported in 1995.

\section{Site Streams}

Continuous surveillance is used on several SRS streams, including Tims Branch, Upper Three Runs Creek, Four Mile Creek (also known as Fourmile Branch), Pen Branch, Steel Creek, and Lower Three Runs Creek. Stream water sampling locations that monitor below process areas serve to detect and quantify levels of radioactivity in liquid effluents that are being transported to the Savannah River. In 1996, 23 samplers on SRS streams served as environmental surveillance points. Stream surveillance locations are shown in figure 6-3.

\section{Description of Surveillance Program}

From January through June 1996, stream samples were collected weekly and analyzed as either weekly, biweekly, or monthly composites. From July through December, stream samples were collected every other week and analyzed as either biweekly or monthly composites. Frequency and types of analyses performed on each sample are based on the potential quantity and type of radionuclides likely to be present in the water at the surveillance station. Generally, tritium determinations, gamma and alpha spectroscopy, and gross alpha and gross beta screening are performed on stream water. Monthly composites also are analyzed for strontium-89,90 - another likely byproduct of SRS operations. Analytical schemes for particular stream locations are documented in the SRS EM Program. The site implemented a new sample reporting regime in 1996 that requires the laboratory to report all gamma spectroscopy results for cobalt-60 and cesium-137 and all alpha spectroscopy results for uranium-234, 235, and 238 and plutonium-238 and 239 , even though the results may be below the approximate detection limits listed on tables 6-9, "Representative Lower Limits of Detection for Gamma Analysis of Water and Air Samples," and 6-11, "Representative Lower Limits of Detection for Radiological Analysis of Plutonium and Uranium by Alpha Spectroscopy."

\section{Surveillance Results}

The average gross alpha, gross beta, and tritium concentrations at downstream locations near the creek mouths are presented in table 6-4. A graph showing the average tritium concentration over a 9 -year period is presented in figure 6-4. The locations of these stations, well below all points at which radioactivity is introduced into the respective streams, ensure that adequate mixing has taken place and that a representative sample is being analyzed. Concentrations at surveillance station U3R-1A (above process effluents and runoff locations on Upper Three Runs Creek) and at an Edisto River surveillance station in the Aiken State Park above SRS are listed for comparison purposes in table 6-4. Sampling at the Edisto River surveillance station was discontinued in July 1996 as part of the reduction in the radiological surveillance program. The following sections contain discussions of surveillance results from each of the major SRS creeks.

\section{Tims Branch}

A tributary of Upper Three Runs Creek, Tims Branch receives effluents from $M$-Area and SRTC. A surveillance point on Tims Branch, TB-5, is located downstream of all release points and before entry into Upper Three Runs Creek. Tritium was below the nominal short count LLD in Tims Branch in 1996, and gross alpha and beta measurements, while above the detection limits, are comparable to levels seen above SRS at the U3R-1A and the Edisto sampling locations.

\section{Upper Three Runs Creek}

Upper Three Runs Creek receives discharges from the Effluent Treatment Facility (ETF), flow from Tims Branch, effluent from the Naval Fuels Facility, and stormwater runoff from F-Area and $\mathrm{H}$-Area. Tritium, the predominant radionuclide detected in Upper Three Runs Creek, is discharged primarily from the ETF. The average concentration of tritium in 1996 at U3R-4, located on SRS Road A, was $(2.42 \pm 2.01) \mathrm{E}-06 \mu \mathrm{Ci} / \mathrm{mL}$, which was 12.1 percent of the $2.00 \mathrm{E}-05-\mu \mathrm{Ci} / \mathrm{mL}$ EPA drinking water standard for tritium - up slightly from 11 percent in 1995. Gross alpha concentrations in Upper Three Runs Creek were consistent with 1995 levels. Average cobalt- 60 concentrations were less than the nominal LLD and average cesium-137 concentrations were only slightly above the nominal LLD. Average concentrations for isotopes of uranium (uranium-234, 235 , and 238) were slightly above the nominal LLD, and average concentrations for isotopes of plutonium (plutonium-238 and 239) all were below the nominal LLD.

\section{Four Mile Creek}

Four Mile Creek receives effluents from F-Area, $\mathrm{H}$-Area, and C-Area, as well as from water that has migrated from seepage basins and is outcropping into the stream. Four Mile Creek transported the majority of radioactivity present in SRS streams in 1996, mostly in the form of gross beta-gamma activity and 
Table 6-4

Average 1996 Concentration of Radioactivity in SRS and Surveillance Station Waters $(\mu \mathrm{Ci} / \mathrm{mL})$

Locationa

Lower Limits of Detection
Gross Alpha

6.23E-10

\section{Gross Beta \\ $1.55 \mathrm{E}-09$}

Tritium

$1.30 \mathrm{E}-06^{\mathrm{b}}$

Onsite Downstream Locations

Tims Branch (TB-5)

$(1.94 \pm 1.60) E-09$

Upper Three Runs (U3R-4)

Four Mile Creek (FMC-6)

$(1.84 \pm 1.68) \mathrm{E}-09$

$(4.52 \pm 5.10) \mathrm{E}-10$

Pen Branch (PB-3)

$(3.07 \pm 7.36) \mathrm{E}-10$

$(2.48 \pm 3.27) \mathrm{E}-10$

Steel Creek (SC-4)

$(3.70 \pm 4.15) E-10$

Lower Three Runs (L3R-2)

Onsite Surveillance Station (for comparison purposes)

Upper Three Runs (U3R-1A) (2.14 \pm 1.01$) \mathrm{E}-09$

Lower Limit of Detection

Offsite Surveillance Station (for comparison purposes)

Edisto River $\quad(7.43 \pm 3.61) E-10$
$(2.21 \pm 1.00) E-09$

$(1.43 \pm 1.28) E-09$

$(8.66 \pm 3.77) \mathrm{E}-09$

$(1.20 \pm 0.80) E-09$

$(1.42 \pm 0.81) E-09$

$(1.70 \pm 0.72) E-09$

$(1.16 \pm 0.71) E-09$

$(1.12 \pm 0.39) \mathrm{E}-09$
$(4.60 \pm 2.92) \mathrm{E}-07$

4.07E-0 $\mathrm{C}$

$(8.89 \pm 2.78) \mathrm{E}-07$

$(2.42 \pm 2.01) E-06$

$(2.10 \pm 0.17) \mathrm{E}-04$

$(6.22 \pm 1.15) \mathrm{E}-05$

$(7.54 \pm 0.86) \mathrm{E}-06$

$(1.12 \pm 0.30) E-06$

$(1.94 \pm 0.97) E-07$

a Site surveillance locations are near mouths of streams.

b Lower limit of detection for tritium by short count

c Lower limit of detection for tritium by long count

tritium. The gross beta-gamma is made up of strontium-89,90 (outcropping from retired seepage basins) and cesium-137 (from direct releases and resuspension of activity deposited in the streambed). The amount of tritium transported in Four Mile Creek was approximately 58 percent of the total amount reaching the Savannah River in 1996. Because the highest tritium concentrations are present at surveillance points along Four Mile Creek, and not at the stations monitoring direct releases, most of the tritium transport is due to outcropping activity from retired seepage basins and from the SWDF. This activity has decreased significantly since the F-Area and H-Area seepage basins were closed in 1988 (figure 6-4).

\section{Pen Branch}

Pen Branch receives discharges from K-Area and flow from a tributary, Indian Grave Branch. Because K-Reactor has not operated since 1992, tritium detected in Pen Branch was due to water entering from Indian Grave Branch, which carries tritium outcropping from the K-Area percolation field and seepage basins. The average tritium concentration at $\mathrm{PB}-3$ in 1996 was $(6.22 \pm 1.15) \mathrm{E}-05 \mu \mathrm{Ci} / \mathrm{mL}$, which was consistent with 1995 levels. Because 1995 concentrations had shown a significant increase over those of 1994, an investigation was conducted in 1996 to determine the cause of the increase; the study identified a previously unmonitored groundwater tritium migration source that enters the stream above PB-3. Average cobalt- 60 concentrations were less than the nominal LLD and average cesium-137 concentrations were only slightly above it. Average concentrations for uranium-234 and 238 were slightly above the nominal LLD, while average concentrations for uranium-235 were below the nominal LLD. Average concentrations for isotopes of plutonium all were below the nominal LLD. Average strontium concentrations were lower than those reported in 1995.

\section{Steel Creek}

Steel Creek receives releases from L-Area effluents and tritium migration from P-Area seepage basins. When P-Area diverts water away from PAR Pond to Steel Creek, the area's discharges are transported to the stream. All releases enter L-Lake, water from which overflows into Steel Creek and is monitored at $\mathrm{SC}-4$. Gross alpha and beta concentrations at $\mathrm{SC}-4$ were below the nominal LLD in 1996. The average tritium concentration at $\mathrm{SC}-4$ was $(7.54 \pm 0.86) \mathrm{E}-06 \mu \mathrm{Ci} / \mathrm{mL}$. Because the highest 


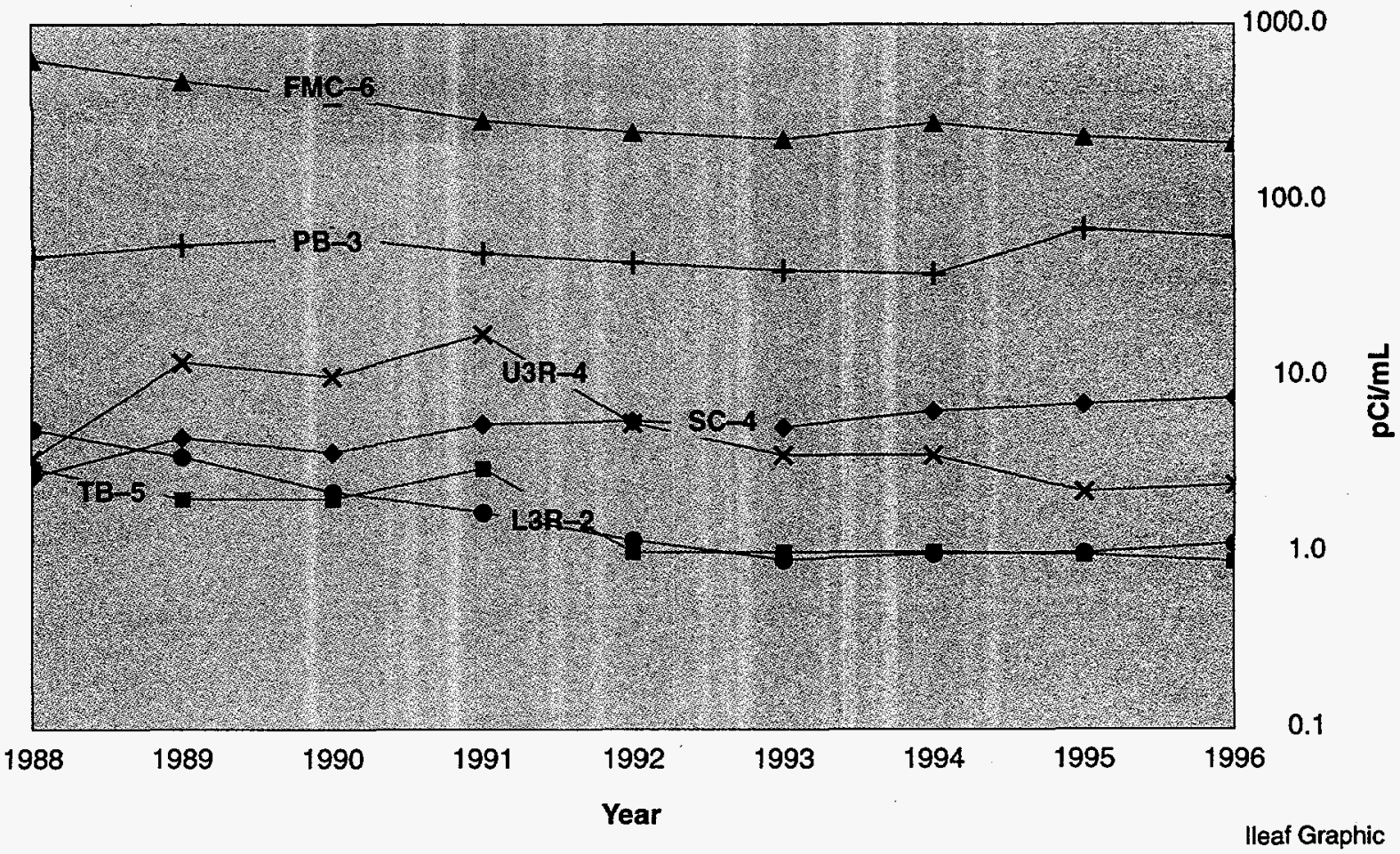

Figure 6-4 Average Tritium Concentration in SRS Streams, 1988-1996

Stream water analysis shows a decrease in the concentration of tritium in most SRS streams.

tritium concentration, $(4.07 \pm 0.08) \mathrm{E}-05 \mu \mathrm{Ci} / \mathrm{mL}$, was measured at the surveillance station at SC-2A, and not at the direct-release monitoring stations in L-Area and P-Area, activity being transported in Steel Creek is attributed to outcropping from the P-Area seepage basins.

\section{Lower Three Runs Creek}

Lower Three Runs Creek receives overflow from PAR Pond, a manmade pond that receives discharges from P-Area. Gross beta concentrations in PAR Pond and Lower Three Runs Creek are above the nominal LLD; this is attributable to low concentrations of cesium-137 from previous releases during P-Area and R-Area operations. Average gross alpha and tritium concentrations are below the nominal LLD. Average concentrations for cobalt-60 and cesium-137 in 1996 were slightly above the nominal LLD. Average concentrations for isotopes of uranium were slightly above the nominal LLD, and average concentrations for isotopes of plutonium all were below the nominal LLD. Average strontium concentrations at L3R-2 were slightly higher than 1995 concentrations. Average strontium concentrations at L3R-1A and L3R-3 were lower than 1995 concentrations.

\section{Savannah River}

Continuous surveillance is performed along the Savannah River at points above and below SRS and below the point at which Plant Vogtle liquid discharges enter the river. In 1996, five locations along the river served as environmental surveillance points. River sampling locations are shown in figure 6-3.

\section{Description of Surveillance Program}

The Savannah River, which provides SRS its western boundary for a 35-mile stretch, is analyzed to determine what effect the site's effluents have on the river water. Gross screening for alpha and beta emitters, along with determinations of specific radionuclides, such as tritium and gamma emitters, is performed on weekly, biweekly, and monthly composites. The analysis of strontium- 89,90 samples collected on the Savannah River during 1996 was omitted in 1996 because of a scheduling error.

\section{Surveillance Results}

\section{Gross Alpha, Gross Beta, and Tritium}

The average concentrations of gross alpha, gross beta, and tritium at river locations are presented in table 
$6-5$. The order of the locations begins at $\mathrm{RM}-160$, above the site, and ends at RM-120, after all site streams enter the Savannah River. Samplers situated between RM-160 and RM-120 are located at regular intervals along the SRS boundary and where Plant Vogtle discharges feed into the river.

Tritium is the predominant radionuclide detected above background levels in the Savannah River. The highest average concentration in 1996, $(1.47 \pm 0.77) \mathrm{E}-06 \mu \mathrm{Ci} / \mathrm{mL}$, was measured at RM-150. The average concentration above SRS, measured at RM-160, was $(0.95 \pm 1.42) \mathrm{E}-07 \mu \mathrm{Ci}$ / $\mathrm{mL}$. The average concentration at RM-120, located on U.S. Highway 301 below SRS, was $(1.16 \pm 0.39) \mathrm{E}-06 \mu \mathrm{Ci} / \mathrm{mL}$. The RM-120 concentration was less than 6 percent of the $2.00 \mathrm{E}-05-\mu \mathrm{Ci} / \mathrm{mL}$ drinking water standard set by EPA for tritium in drinking water. The average tritium concentrations were lower at all sampling locations than in 1995.

\section{Tritium Transport in Streams and River}

Tritium is introduced into SRS streams and the Savannah River from production areas on site. Because of the mobility of tritium in water and the quantity of the radionuclide released during the years of SRS operations, a tritium balance has been performed annually since 1960 . The balance is evaluated among the following alternative methods of calculation:

- tritium releases from effluent release points and calculated seepage basin and SWDF migration (direct releases)

- tritium transport in SRS streams and the last sampling point before entry into the Savannah River (stream transport)
- tritium transport in the Savannah River downriver of SRS after subtraction of any measured contribution above the site (river transport)

Figure 6-5 shows graphic and numeric summaries of the last 37 years of direct releases, stream transport, and river transport determined by EMS.

In 1996, tritium transport decreased for direct releases and stream and river transport to the lowest levels in the past 37 years.

General agreement between the three calculational methods of annual tritium transport-measurements at the source, stream transport, and river transport-serves to validate SRS sampling schemes and counting results. Differences between the various methods can be attributed to uncertainties arising in the collection and analytical processes, including determinations of water flows and varying transport times. Because of the close agreement, and because it can be independently verified by offsite agencies, the river transport value has been chosen for use in annual environmental dose calculations.

\section{Drinking Water}

EMS collects drinking water samples from locations at SRS and at water treatment facilities that use Savannah River water. Potable water is analyzed at offsite treatment facilities to ensure that SRS operations are not adversely affecting the water supply and to provide voluntary assurance that drinking water is below EPA drinking water standards for radionuclides. Analysis in surrounding towns and communities was discontinued in 1996 as part of the reduction in the radiological surveillance program.

\section{Description of Surveillance Program}

Sampling on site consists of monthly grab samples at production areas and quarterly grab samples at nonproduction and perimeter stations. Collected monthly are samples from

Table 6-5

Average 1996 Concentration of Radioactivity in the Savannah River $(\mu \mathrm{Ci} / \mathrm{mL})$

\begin{tabular}{llcr}
\hline $\begin{array}{l}\text { Location } \\
\text { Lower Limits of Detection }\end{array}$ & $\begin{array}{c}\text { Gross Alpha } \\
6.23 E-10\end{array}$ & $\begin{array}{c}\text { Gross Beta } \\
1.55 E-09\end{array}$ & $\begin{array}{c}\text { Tritium } \\
4.07 E-07\end{array}$ \\
\hline RM-120 & $(1.07 \pm 2.41) \mathrm{E}-10$ & $(1.81 \pm 0.51) \mathrm{E}-09$ & $(1.16 \pm 0.39) \mathrm{E}-06$ \\
RM-140 & $(1.24 \pm 3.17) \mathrm{E}-10$ & $(1.92 \pm 0.69) \mathrm{E}-09$ & $(1.44 \pm 0.60) \mathrm{E}-06$ \\
RM-150 & $(2.71 \pm 3.21) \mathrm{E}-10$ & $(1.80 \pm 0.50) \mathrm{E}-09$ & $(1.47 \pm 0.77) \mathrm{E}-06$ \\
Vogtle discharge & $(2.67 \pm 3.72) \mathrm{E}-10$ & $(1.85 \pm 0.65) \mathrm{E}-09$ & $(9.96 \pm 8.73) \mathrm{E}-07$ \\
RM-160 & $(1.43 \pm 2.40) \mathrm{E}-10$ & $(1.96 \pm 0.62) \mathrm{E}-09$ & $(0.95 \pm 1.42) \mathrm{E}-07$
\end{tabular}




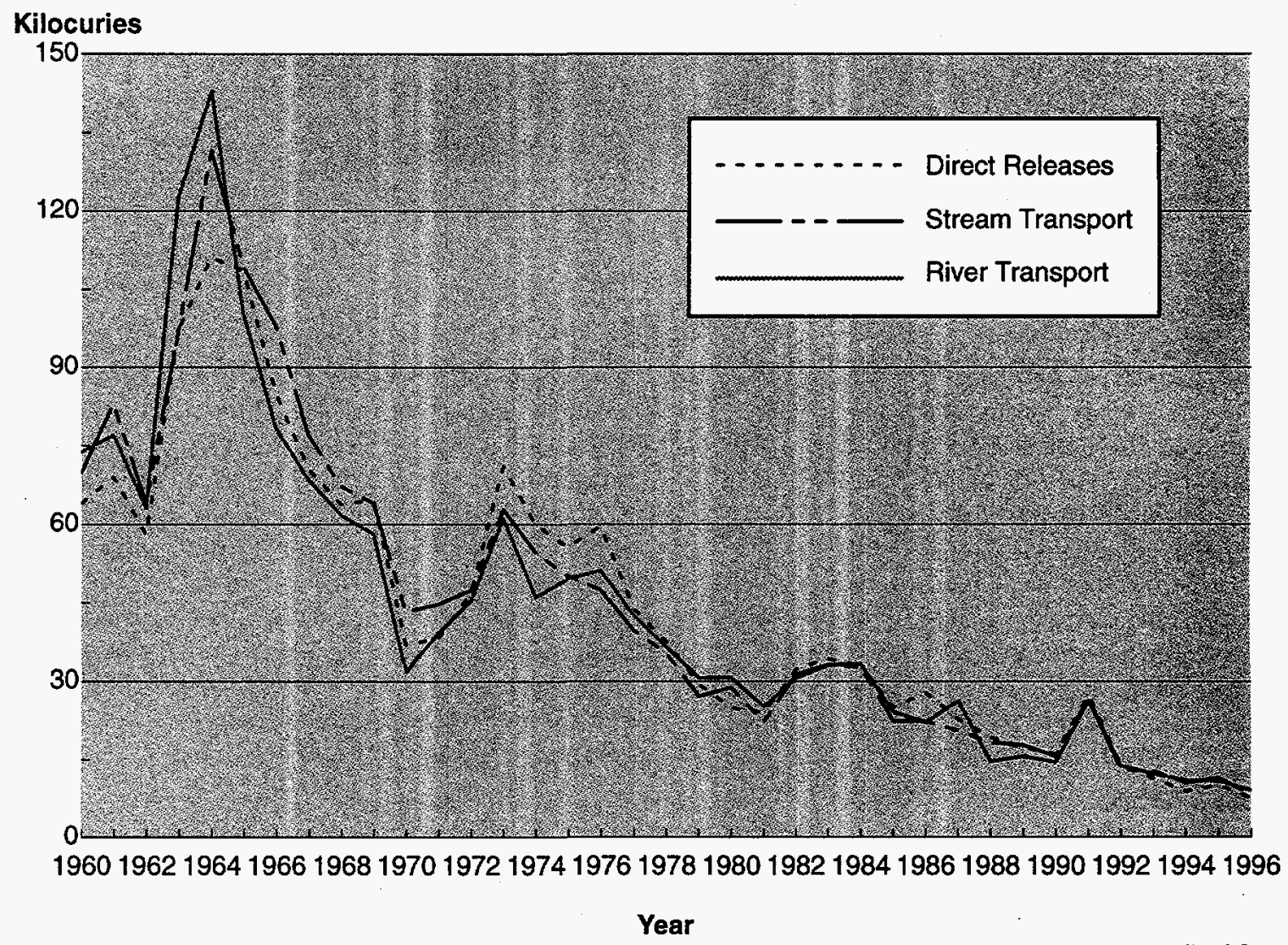

Figure 6-5 SRS Tritium Transport Summary, 1960-1996

SRS has maintained a tritium balance of direct releases, stream transport, and river transport since 1960 in an effort to account for and trend tritium releases in liquid effluents from the site. The general downward slope over time indicates that tritium transport has decreased as production has slowed and effluent controls have been developed.

- two water treatment plants downriver of SRS that supply treated Savannah River water to Beaufort and Jasper counties in South Carolina and to Port Wentworth, Georgia

- the North Augusta (South Carolina) Water Treatment Plant

- the D-Area treatment facility on site

At all these facilities, raw and finished water samples are collected daily and composited for analysis by EMS. All drinking water samples are screened for alpha and beta emitters and analyzed specifically for tritium. Drinking water samples are analyzed at least once a year for strontium-89,90; however analysis of the 1996 samples was omitted inadvertently.

\section{Surveillance Results}

\section{Gross Alpha and Gross Beta}

All drinking water samples collected by EMS are screened for gross alpha and gross beta concentrations to determine if activity levels warrant further analysis. No samples collected in 1996 exceeded EPA's $1.50 \mathrm{E}-08-\mu \mathrm{Ci} / \mathrm{mL}$ alpha activity limits or $5.00 \mathrm{E}-08-\mu \mathrm{Ci} / \mathrm{mL}$ beta activity limits. As in previous years, the highest average alpha concentration- $(1.39 \pm 0.13) \mathrm{E}-09 \mu \mathrm{Ci} / \mathrm{mL}$ at the 701-5G Aiken Barricade (Talatha Gate) — has been characterized for specific alpha activity, with at least a partial source of activity due to radium- 226 . No sample's average exceeded $8.00 \mathrm{E}-09 \mu \mathrm{Ci} / \mathrm{mL}$ of beta activity. This concentration is the EPA limit for strontium-90, which is the most restrictive beta-emitting radionuclide. 


\section{Strontium}

No drinking water samples collected and analyzed by EMS for strontium- 89,90 exceeded the $1.90 \mathrm{E}-09-\mu \mathrm{Ci} / \mathrm{mL}$ detection limit of the EMS laboratories. This limit is approximately 25 percent of the EPA drinking water standard for strontium-90.

\section{Tritium}

No drinking water samples collected and analyzed by EMS exceeded the $2.00 \mathrm{E}-05-\mu \mathrm{Ci} / \mathrm{mL}$ EPA tritium limit. Detectable levels of tritium were present in the drinking water samples collected monthly from the Beaufort-Jasper and Port Wentworth water treatment facilities. These levels reflect the introduction of tritium from SRS operations into the Savannah River. The average tritium concentration in finished water at Beaufort-Jasper in 1996, $(9.16 \pm 2.74) \mathrm{E}-07 \mu \mathrm{Ci} / \mathrm{mL}$, was 5 percent of the EPA drinking water limit. The average tritium concentration at Port Wentworth, $(9.88 \pm 2.77) \mathrm{E}-07 \mu \mathrm{Ci} / \mathrm{mL}$, was 5 percent of the EPA drinking water limit.

\section{Terrestrial Food Products}

The terrestrial food products surveillance program consists of radiological analyses of food product samples typically found in the Central Savannah River Area (CSRA). Because radioactive materials can be transported to man through the consumption of milk and other food products containing radioactivity, food product samples are analyzed to determine what effects, if any, SRS operations have on them. Data from the food product surveillance program are not used to show direct compliance with any dose standard; however, the data can be used as required to verify dose models and determine environmental trends.

\section{Description of Surveillance Program}

\section{Meat, Fruit, and Greens}

The food products surveillance program divides the area that surrounds the site, approximately nine miles $(15 \mathrm{~km})$ beyond its perimeter, into four quadrants: northeast, southeast, southwest, and northwest. Samples of food-including meat (beef or chicken), fruit (peaches or melons), green vegetables (collards), and milk - are collected from one location within each of the quadrants and from a control location within an extended (to 25 miles beyond the perimeter) southeast quadrant. All food samples are collected annually except milk, which is collected monthly for analysis of tritium and gamma-emitting radionuclides and quarterly for analysis of strontium-90. During 1996, fruit was unavailable for collection from two locations-northwest and southwest.

The EMS analysis of food products changed in 1996 to allow for the measurement of specific isotopes of plutonium (plutonium-238 and plutonium-239). This replaced the previously used nonspecific uranium/plutonium procedure. Food samples also are analyzed for gamma-emitting radionuclides, tritium, and strontium- 89,90 .

\section{Milk}

During 1996, EMS collected milk samples at five dairies within a 25-mile radius of SRS and from locally produced inventories of a major distributor.

Milk samples are analyzed for tritium and gamma-emitting radionuclides, primarily cesium- 137 and iodine-131. Additional milk samples are collected quarterly and analyzed for strontium-90; however, the collection of one of the quarterly milk samples for strontium-90 analysis was omitted inadvertently in 1996.

\section{Surveillance Results}

\section{Gamma-Emitting Radionuclides}

The only manmade gamma-emitting radionuclide detected in food products, excluding milk, was cesium-137. The maximum concentration, $(4.79 \pm 0.49) \mathrm{E}-02 \mathrm{pCi} / \mathrm{g}$, was measured in beef from the $15-\mathrm{km}$ northwest quadrant. Cesium- 137 concentrations at the control location were below the nominal LLD. Generally, concentrations of cesium-137 in indicator samples were similar to those measured at the control location, although some locations showed detectable activity. These concentrations were similar to those observed in previous years.

Cesium-137 also was the only manmade gamma-emitting radionuclide detected in milk samples during 1996. Measured average concentrations ranged from a high of $(4.16 \pm 1.50) \mathrm{E}-03 \mathrm{pCi} / \mathrm{mL}$ to a low below the nominal LLD. The mean concentrations measured in 1996 were similar to those measured in 1995.

Iodine-131 was not detected in any 1996 milk samples. Because of its short physical half-life ( 8 days), iodine-131 generally is not detected, except shortly after tests of nuclear weapons or in the wake of events such as the Chernobyl incident. There were no announced nuclear weapons tests or other major nuclear incidents in 1996. 


\section{Tritium}

Tritium concentrations ranged from a high of $(1.68 \pm 0.45) \mathrm{E}-01 \mathrm{pCi} / \mathrm{g}$, measured in beef from the $15-\mathrm{km}$ southeast quadrant, to below the nominal LLD in several samples. The concentrations were similar to those measured in 1995.

Tritium in milk and other samples is attributed to releases from SRS. Milk from most dairies showed detectable concentrations of tritium at some point during 1996. The maximum concentration, $(6.69 \pm 1.28) \mathrm{E}-01 \mathrm{pCi} / \mathrm{mL}$, was measured at a Jackson, South Carolina, location. The minimum concentration from other local sampling locations was below the nominal LLD. Tritium concentrations measured in milk in 1996 were similar to those in 1995 and generally reflected atmospheric releases from the site.

\section{Strontium}

All strontium-89,90 concentrations in food products, excluding milk, were below the nominal LLD and generally were within the ranges observed during past years.

Strontium- 90 analysis was performed on milk from the six sampling locations. Measured concentrations ranged from a high of $(9.22 \pm 2.67) \mathrm{E}-03 \mathrm{pCi} / \mathrm{mL}$ in the Denmark, South Carolina, area to a low below the LLD. The mean concentrations measured in 1996 were similar to those measured in 1995.

\section{Plutonium}

Concentrations of plutonium-238 in food products, excluding milk, during 1996 ranged from a high of $(4.42 \pm 0.42) \mathrm{E}-03 \mathrm{pCi} / \mathrm{g}$, measured in fruit collected from the $15-\mathrm{km}$ northeast quadrant to a low below the nominal LLD. Plutonium-239 concentrations in food products all were below the nominal LLD.

Plutonium-238 and plutonium-239 concentrations in food products, excluding milk, during 1996 were similar to the 1995 concentrations.

\section{Aquatic Food Products}

\section{Description of Surveillance Program}

The aquatic food product surveillance program consists of both fish (freshwater and marine) and shellfish. To determine the potential dose and risk to the public from consumption of these fish, both are sampled.
Nine surveillance points for the collection of fish are located on the Savannah River (figure 6-6). These include

- the Augusta Lock and Dam area (control location), above the site

- five areas where site streams enter the Savannah River

- the U.S. Highway 301 bridge, below the site

- Stokes Bluff Landing, below the site

- the U.S. Highway 17A bridge area, below the site

Nine surveillance points for fish collection also are located within the SRS boundary. These points include PAR Pond, L-Lake, Pond B, Lower Three Runs Creek, Upper Three Runs Creek, Beaver Dam Creek, Pen Branch, Steel Creek, and Four Mile Creek. In 1996, not enough fish could be collected for composite samples (five from the same category per location) from Upper Three Runs Creek, Four Mile Creek, Pen Branch, Lower Three Runs Creek at Patterson Mill, or Beaver Dam Creek.

Freshwater fish are grouped into one of three categories: bass, panfish (bream or crappie), or catfish. Marine (saltwater) fish, collected from the U.S. Highway $17 \mathrm{~A}$ bridge area, also are grouped into one of three categories: predatory fish, filter feeders, or bottom-dwelling fish. Sea trout and bass were placed in the predatory group; mullet in the filter feeder group; and catfish and flounder in the bottom-dwelling group. The fish are grouped in this manner because they are the most sought-after fish in the Savannah River, according to the latest creel survey conducted by the Fisheries Management Section of the Georgia Department of Natural Resources Wildlife Resources Division.

For analysis purposes, five fish from each category at each collection location are combined to create a composite. Composites are divided into edible (meat fillet only) and nonedible. (scales, skin, head, fins, viscera, bone) portions and analyzed for gross alpha and gross beta for all locations. Fish collected from Augusta Lock and Dam downstream through the U.S. Highway 301 bridge also are analyzed for strontium-89,90; plutonium-238 and plutonium-239; tritium; and gamma-emitting radionuclides.

In the shellfish surveillance program, samples of oysters and crabs are collected on the coast near Savannah, Georgia. The shellfish are analyzed for gross alpha, gross beta, strontium-89,90, and gamma-emitting radionuclides.

Calculations of risk from the consumption of fish from the Savannah River can be found in chapter 7 . 


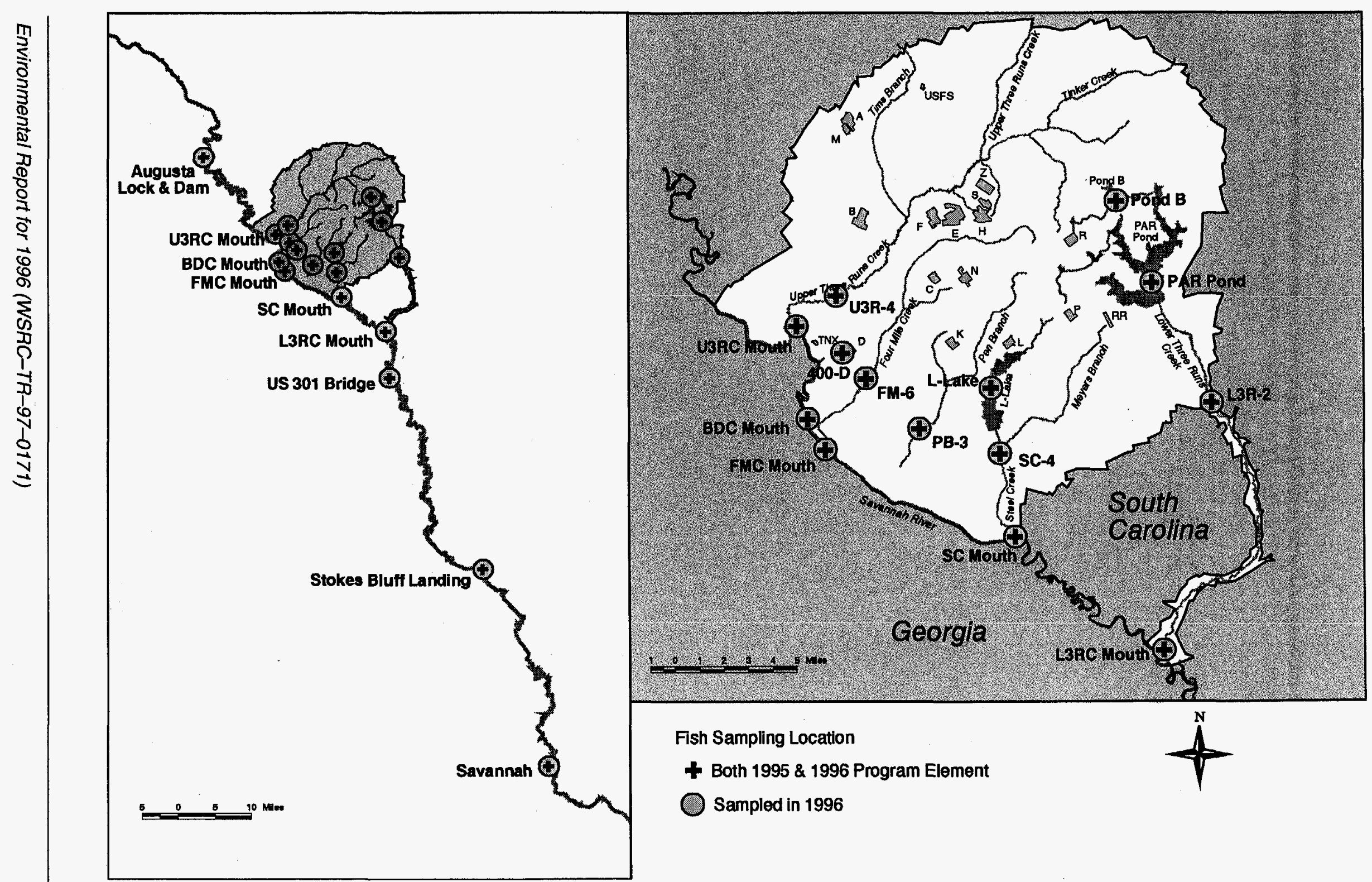

EPD/GIS Graphic

Figure 6-6 SRS Fish Sampling Points on the Savannah River

SRS collects fish (for both radiological and nonradiological analyses) from the Savannah River above, adjacent to, and below the site, as well as at Stokes Bluff Landing and near Savannah, Georgia. 


\section{Surveillance Results}

In the following surveillance results discussion, uncertainty values are provided because most measurements were at or near the LLD.

\section{Freshwater Fish}

Savannah River In 1996, for the first time, all categories of fish from all nine Savannah River locations were collected. Composites of each category were analyzed for gross alpha and gross beta.

Gross alpha activities in the offsite edible composites ranged from a high of $(4.62 \pm 2.08) \mathrm{E}-01 \mathrm{pCi} / \mathrm{g}$ in a bass from Stokes Bluff Landing to a low below the LLD. The maximum gross alpha activity- $(9.15 \pm$ 7.45)E-01 pCi/g, in a nonedible composite-was measured in a catfish from the Steel Creek river mouth location.

The maximum edible gross beta activity from the Savannah River, $(4.97 \pm 0.55) \mathrm{E}+00 \mathrm{pCi} / \mathrm{g}$, was measured in a bass composite from the mouth of Steel Creek. This concentration was slightly lower than the maximum nonedible gross beta activity, $5.08 \pm 0.69 \mathrm{E}+00 \mathrm{pCi} / \mathrm{g}$, measured in a bass from the mouth of Four Mile Creek.

Cesium-137 and cobalt- 60 were the only manmade, gamma-emitting radionuclides detected in 1996 fish composites. The maximum cesium-137 activity in edible fish from the Savannah River, $(2.99 \pm 0.08) \mathrm{E}+00 \mathrm{pCi} / \mathrm{g}$, was measured in a bass composite from the mouth of Steel Creek. The maximum cesium-137 concentration in nonedible fish from off site, $(1.53 \pm 0.06) \mathrm{E}+00 \mathrm{pCi} / \mathrm{g}$, was measured in a bass composite from the mouth of Steel Creek.

In 1996, both edible and nonedible composite portions were analyzed for strontium-89,90. The maximum strontium- 89,90 concentration was $(2.61 \pm 0.05) \mathrm{E}+00 \mathrm{pCi} / \mathrm{g}$ in a nonedible bass from the mouth of Four Mile Creek.

The maximum tritium concentration at the control location (Augusta Lock and Dam, upstream of SRS) was $(7.08 \pm 4.92) \mathrm{E}-02 \mathrm{pCi} / \mathrm{g}$, measured in a bream composite. The maximum tritium concentration downstream and/or adjacent to the site, $(2.67 \pm 0.01) \mathrm{E}+01 \mathrm{pCi} / \mathrm{g}$, was found in a bass composite from the mouth of Four Mile Creek.

Onsite Streams and Ponds Gross alpha and gross beta analyses were performed on edible fish composites collected from SRS streams and ponds. Gross alpha concentrations ranged from a high of $(0.54 \pm 1.22) \mathrm{E}-01 \mathrm{pCi} / \mathrm{g}$ in a PAR Pond bream to lows below the nominal LLD in other composites. Gross beta concentrations ranged from a high of $(1.44 \pm 0.06) \mathrm{E}+01 \mathrm{pCi} / \mathrm{g}$ in a Pond B bream to lows below the nominal LLD in other composites.

Cesium- 137 and cobalt- 60 were the only manmade, gamma-emitting radionuclides detected in fish from onsite streams and ponds. The maximum cesium-137 concentration in an onsite edible composite, $(3.87 \pm 0.08) \mathrm{E}+01 \mathrm{pCi} / \mathrm{g}$, came from a Pond $\mathrm{B}$ bream composite; the minimum, $(3.06 \pm 0.38) \mathrm{E}-01 \mathrm{pCi} / \mathrm{g}$, came from a bream from the Steel Creek at Road A location.

Cobalt-60 was detected at $(5.20 \pm 2.38) \mathrm{E}-02 \mathrm{pCi} / \mathrm{g}$ in a bass sample from Pond $B$.

\section{Marine Fish}

Bass, catfish, and mullet were collected in 1996 from the U.S. Highway 17A bridge area. The gross alpha concentrations ranged from a high of

$(0.73 \pm 1.64) \mathrm{E}-01 \mathrm{pCi} / \mathrm{g}$ in a bass to a low below the LLD in other composites; the gross beta concentrations ranged from a high of $(2.13 \pm 0.35) \mathrm{E}+00 \mathrm{pCi} / \mathrm{g}$ in a catfish to a low below the LLD in other composites.

\section{Shellfish}

A sample of oysters and a sample of crabs-both from near the mouth of the Savannah River-were collected in 1996. Analytical results showed that no manmade radionuclides above the nominal LLD were present in the samples.

\section{Deer and Hogs}

\section{Description of Surveillance Program}

Annual hunts, open to members of the general public, are conducted at SRS to control the site's deer and feral hog populations and to reduce animal-vehicle accidents. Before any animal is released to a hunter, EMS uses portable sodium iodide detectors to perform field analysis for cesium-137. The resulting dose from consumption is calculated for each animal, and each hunter's cumulative total is tracked. Media samples (muscle and/or bone) are collected periodically for laboratory analysis based on a set frequency, on cesium-137 levels, and/or on exposure limit considerations.

\section{Surveillance Results}

During 1996, 1,685 deer and 109 feral hogs were taken from the site as part of the controlled hunt program. This compares with 1,152 deer and 47 feral hogs taken during the 1995 hunts. The number of hunts was increased from 12 to 14 in 1996 as part of the site's ongoing wildlife management program. 
One animal-a deer-was confiscated in 1996. The cesium- 137 activity in the animal, as measured by field instruments, was $166 \mathrm{pCi} / \mathrm{g}$. This measurement was verified by post-hunt laboratory analysis, which indicated a concentration of $150 \mathrm{pCi} / \mathrm{g}$. Because consumption of the edible portion of this deer by an individual would result in an exposure exceeding DOE's annual individual dose limit for members of the general public $(100 \mathrm{mrem})$, the deer was retained by SRS personnel. The discussion below summarizes results from animals released to hunters during 1996; therefore, it does not include the confiscated animal described above.

\section{Gamma-Emitting Radionuclides}

In 1996, the maximum field measurement of cesium-137 in deer muscle was approximately 21 $\mathrm{pCi} / \mathrm{g}$, while the mean cesium- 137 concentration was approximately $5 \mathrm{pCi} / \mathrm{g}$. In feral hogs, the maximum field measurement of cesium-137 in muscle was approximately $16 \mathrm{pCi} / \mathrm{g}$, while the mean concentration was approximately $4 \mathrm{pCi} / \mathrm{g}$.

Each animal is monitored prior to release, and the field measurements are supplemented by laboratory analyses. Samples are collected from approximately 10 percent of the animals processed, including every 10th animal monitored and any animal that results in a hunter's annual dose exceeding $25 \mathrm{mrem}-\mathrm{either}$ alone or in combination with previous animals killed by the hunter. In 1996, 192 samples from 169 animals were collected and analyzed for gamma-emitting radionuclides; tables in SRS Environmental Data for 1996 include measurements only from these animals.

As observed during previous hunts, cesium- 137 was the only manmade gamma-emitting radionuclide detected during laboratory analysis. Generally, the cesium- 137 concentrations measured by the field and lab methods were comparable. Field measurements ranged from approximately $1 \mathrm{pCi} / \mathrm{g}$ to $16 \mathrm{pCi} / \mathrm{g}$, while lab measurements ranged from approximately $1 \mathrm{pCi} / \mathrm{g}$ to $15 \mathrm{pCi} / \mathrm{g}$.

\section{Strontium}

Strontium levels are determined in some of the animals analyzed for cesium-137. Typically, muscle and bone samples are collected for analysis from the same animals checked for cesium-137, and the samples are analyzed for strontium-89,90.

In 1996, 47 muscle samples from 24 animals were collected for strontium analysis. Only two of the samples showed detectable strontium-89,90-one at $0.04 \mathrm{pCi} / \mathrm{g}$ and the other at $0.05 \mathrm{pCi} / \mathrm{g}$. These results are consistent with those observed during previous hunts-most animals do not have detectable strontium-89,90 in muscle tissue, and generally only low levels are present in the remainder of the animals.

In addition, 23 bone samples were collected from 23 animals for strontium- 89,90 analysis. As observed in previous hunts, the analytical results indicated a wide range of strontium-89,90 concentrations, with levels ranging from a minimum of approximately $3 \mathrm{pCi} / \mathrm{g}$ to a maximum of approximately $92 \mathrm{pCi} / \mathrm{g}$. Generally, the strontium- 89,90 concentrations in bone tissue appear to be slightly higher than those observed in 1995. As expected, the concentrations in bone tissue were significantly higher than in muscle. This is because strontium, whether stable or radioactive, is chemically similar to calcium and thus tends to accumulate in bone.

\section{Turkeys}

\section{Description of Surveillance Program}

Wild turkeys are trapped on site by the South Carolina Wildlife and Marine Resources Department and used to repopulate South Carolina game areas. All turkeys are monitored for cesium-137 with portable sodium iodide detectors before leaving SRS. No turkey above $25 \mathrm{pCi} / \mathrm{g}$ is released off site.

\section{Surveillance Results}

EMS monitored 68 turkeys in 1996. Concentrations of cesium-137 generally were similar to those measured in the past, with all results $5.0 \mathrm{pCi} / \mathrm{g}$ or less. This compares to a maximum concentration in 1995 of $1.0 \mathrm{pCi} / \mathrm{g}$ and a maximum in 1994 of $10 \mathrm{pCi} / \mathrm{g}$ (with a minimum of $1 \mathrm{pCi} / \mathrm{g}$ ).

\section{Beavers}

\section{Description of Surveillance Program}

The U.S. Forest Service administers a contract for the trapping of beavers in selected areas within the SRS perimeter. The purpose of trapping is to reduce the beaver population in specific areas of the site and thereby minimize dam-building activities that can result in flood damage to timber stands, primary and secondary roads, and railroad beds. All beavers are monitored for cesium-137 with a portable sodium iodide detector and disposed of in the SRS sanitary landfill.

\section{Surveillance Results}

EMS monitored 84 beavers in 1996. The maximum cesium- 137 concentration was $10.5 \mathrm{pCi} / \mathrm{g}$ (the same as in 1995), measured in an animal trapped on Pen 
Branch. The minimum concentration was $1.0 \mathrm{pCi} / \mathrm{g}$ (also the same as in 1995). These results compare with a 1994 maximum of $22 \mathrm{pCi} / \mathrm{g}$ and minimum of 1 pCi/g, and with a 1993 maximum and minimum of 47 $\mathrm{pCi} / \mathrm{g}$ and $1 \mathrm{pCi} / \mathrm{g}$, respectively.

\section{Soil}

The SRS soil monitoring program provides

- data for long-term trending of radioactivity deposited from the atmosphere (both wet and dry)

- information on the concentrations of radioactive materials in the environment

Routine and nonroutine SRS atmospheric releases, as well as worldwide fallout, are monitored in this program. The concentrations of radionuclides in soil vary greatly among locations because of differences in rainfall patterns and in the mechanics of retention and transport in different types of soils. Because of this program's design, a direct comparison of data from year to year is not appropriate.

\section{Description of Surveillance Program}

Soil samples were collected in 1996 from four uncultivated and undisturbed locations in F-Area, $\mathrm{H}$-Area, Z-Area, and E-Area (burial ground)-one sample from each area-and from four onsite quadrant locations near the site perimeter, as shown in figure 6-7. One location approximately 100 miles from SRS-Savannah, Georgia-also was sampled. Changes implemented in 1995 as part of the overall comprehensive review of the environmental monitoring program reduced the total number of sampling locations from 24 that year to nine in 1996. Additional changes-implemented in September 1996-further reduced the number of locations to five for 1997.

Hand augers or other similar devices are used in sample collection. The samples are analyzed for gamma-emitting radionuclides, strontium- 89,90 , plutonium-238, and plutonium-239. The rationale for each sampling site is explained in the SRS EM Program.

\section{Surveillance Results}

\section{Gamma-Emitting Radionuclides}

Cesium-137 was observed at levels above the nominal LLD in 1996 at seven of the eight onsite locations and at the offsite location. The highest concentration detected on site, $(5.91 \pm 0.40) \mathrm{E}-01$ $\mathrm{pCi} / \mathrm{g}$, was in a sample taken from the northwest quadrant, and the lowest was below the nominal
LLD. The concentration at the 100-mile-radius location was $(2.82 \pm 0.23) \mathrm{E}-01 \mathrm{pCi} / \mathrm{g}$.

\section{Plutonium}

Plutonium-238 was observed above the nominal LLD at four of the eight onsite locations and at the offsite location. The highest onsite concentration was $(7.84 \pm 1.60) \mathrm{E}-03 \mathrm{pCi} / \mathrm{g}$, in the northwest quadrant; the lowest was below the nominal LLD.

Plutonium-239 was observed above the nominal LLD at six of the eight onsite locations and at the offsite location. The highest onsite concentration was $(2.05 \pm 0.26) \mathrm{E}-02$ in the northwest quadrant; the lowest was below the nominal LLD. The offsite concentration was $(1.84 \pm 0.60) \mathrm{E}-03 \mathrm{pCi} / \mathrm{g}$.

\section{Strontium}

Soil samples from all locations were analyzed for strontium-89,90, and all were below the nominal LLD.

\section{Sediment}

Sediment sample analysis measures the movement, deposition, and accumulation of long-lived radionuclides in stream beds and in the Savannah River bed. Because of the continuous deposition and remobilization occurring in the stream and river beds, significant year-to-year differences may be evident, but the data obtained can be used to observe long-term environmental trends.

\section{Description of Surveillance Program}

Sediment samples are collected annually at 15 locations: nine in the Savannah River and six in site streams (figure 6-8). Samples are obtained from the top $8 \mathrm{~cm}$ of sediment in areas where fine sediment accumulates and most radionuclides concentrate. Sediments are analyzed for gamma-emitting fission and activation products, strontium-89,90, plutonium-238, and plutonium-239.

\section{Surveillance Results}

Concentrations of radionuclides in river sediment during 1996 were similar to those detected upriver in the control sample from Demiere's Landing. Maximum activities were observed in samples obtained from Steel Creek, Four Mile Creek, and Pen Branch.

\section{Gamma-Emitting Radionuclides}

Cesium- 137 and Cobalt- 60 were the only manmade gamma-emitting radionuclides observed in river and stream sediments during 1996.

The highest cesium- 137 concentration, $(4.25 \pm 0.45) \mathrm{E}-01 \mathrm{pCi} / \mathrm{g}$, was detected in sediment 


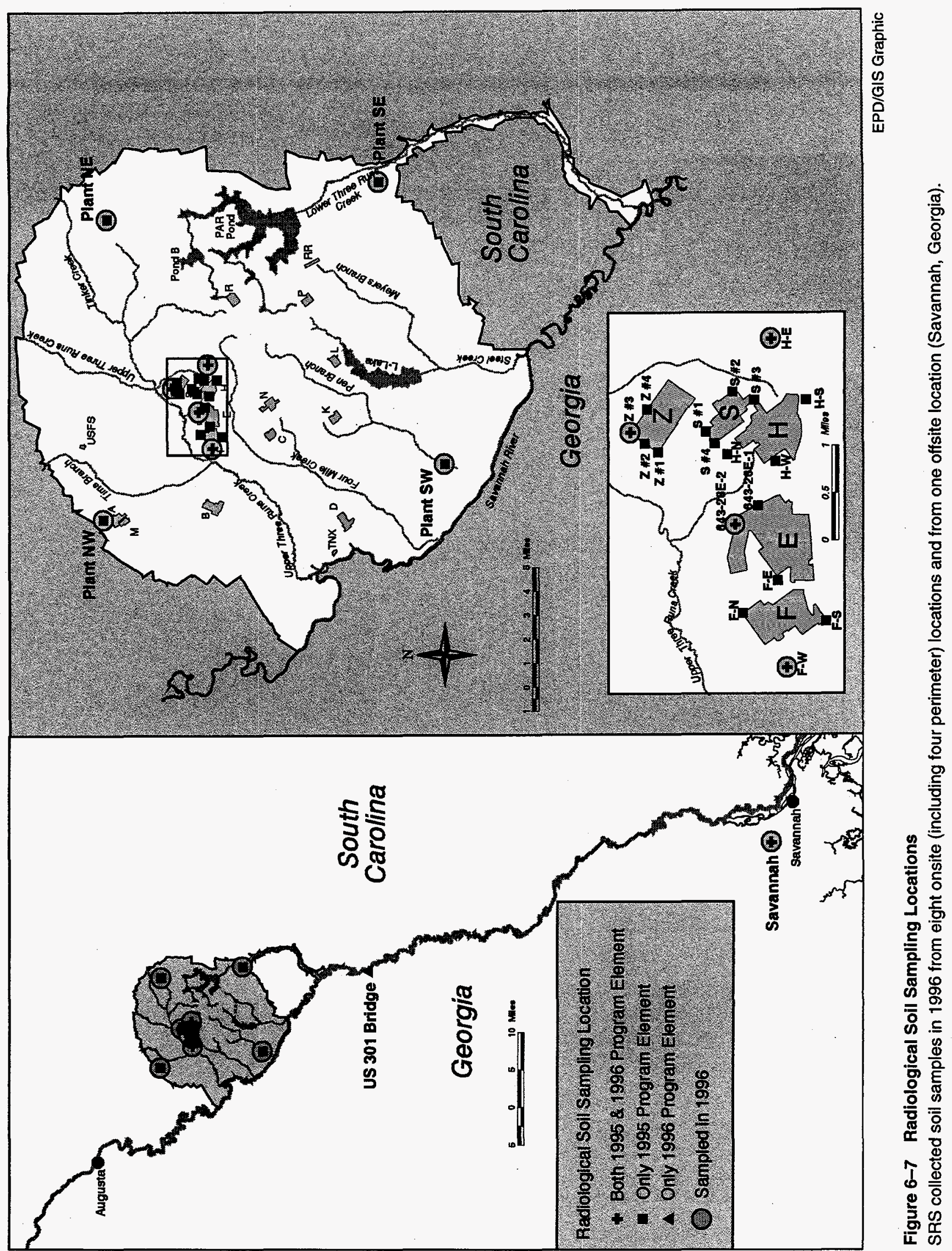




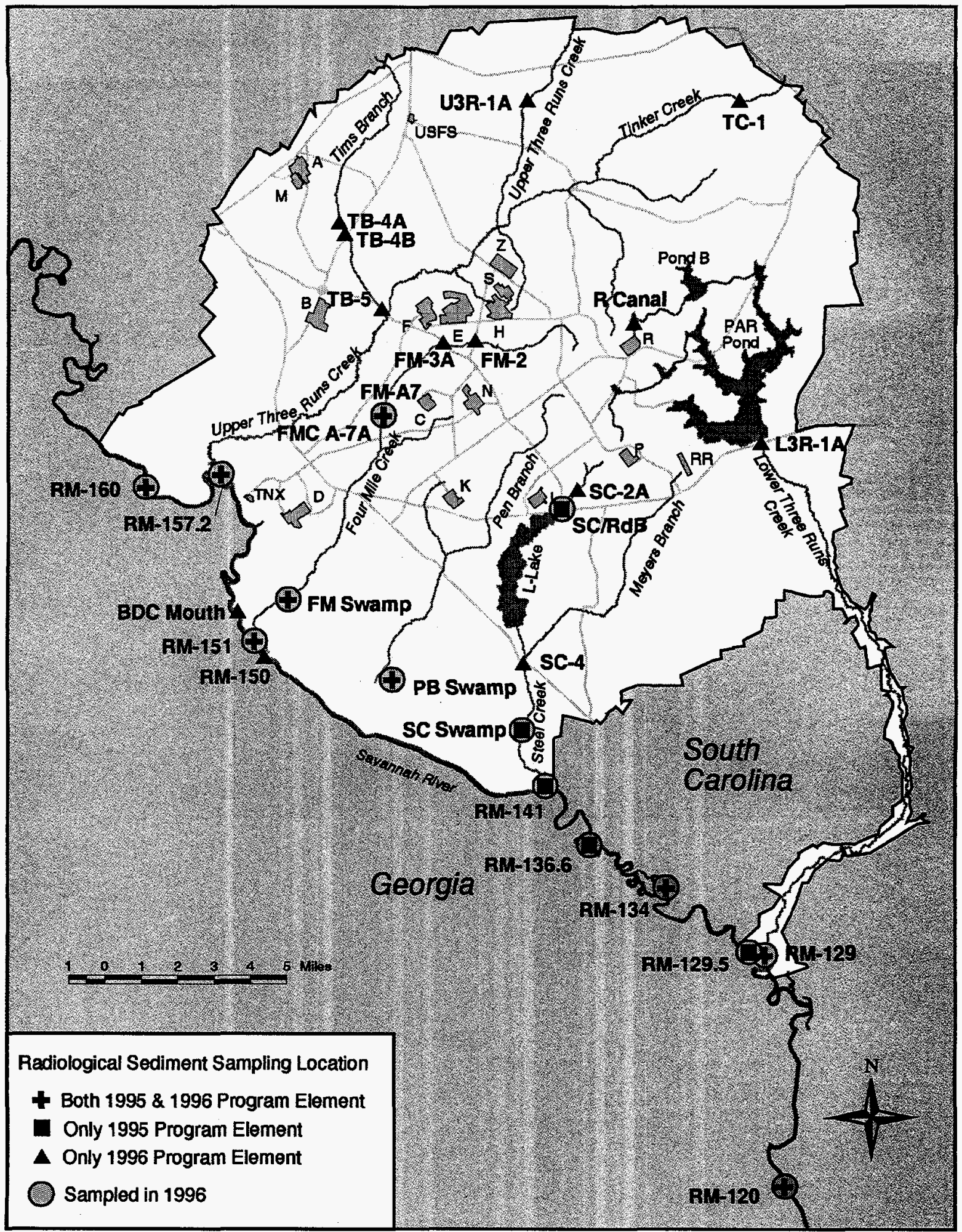

EPD/GIS Graphic

Figure 6-8 Radiological Sediment Sampling Locations

Sediment samples were collected in 1996 at nine Savannah River locations-upriver of, adjacent to, and downriver of the site-and six site stream locations. 
taken from below Four Mile Creek; the lowest was below the nominal LLD. Also, the Lower Three Runs Creek Mouth location reflected more typical concentrations in 1996 than it had during the previous 3 years, when higher than normal concentrations could have been caused by changes in PAR Pond. Generally, cesium- 137 concentrations were slightly higher in stream sediments than in river sediments. This is to be expected because the streams receive radionuclide-containing liquid effluents from the site. Most radionuclides settle out and deposit on the stream bed before reaching the river.

Cobalt- 60 was detected in sediment from the following locations:

- Steel Creek Swamp Discharge

- Pen Branch Swamp Discharge

- Four Mile A-7A

- River Mile 129.5 and River Mile 134

- Control Location (River Mile 160.5, Demiere's Landing)

The highest concentration, $(1.92 \pm 0.12) \mathrm{E}-01 \mathrm{pCi} / \mathrm{g}$, was measured at Four Mile A-7A; the lowest was below the nominal LLD.

\section{Plutonium}

Concentrations of plutonium-238 in sediment ranged from a high of $(2.09 \pm 0.14) \mathrm{E}-01 \mathrm{pCi} / \mathrm{g}$ at the Four Mile A-7A location to a low below the nominal LLD. Concentrations of plutonium-239 ranged from a high of $(7.18 \pm 0.56) \mathrm{E}-02$-also at the Four Mile A-7A location-to a low below the nominal LLD. As expected, concentrations of these isotopes in streams generally were higher than concentrations in the river. Changes observed when these data are compared to previous years probably are due to the effects of resuspension and deposition, which occur constantly in sediment media.

\section{Strontium}

The maximum strontium- 89,90 concentration in sediment in $1996,(1.32 \pm 0.24) \mathrm{E}-01 \mathrm{pCi} / \mathrm{g}$, which occurred on Four Mile Creek at Road A-7, is lower than the results reported in 1994 and 1995. The change in magnitude probably is due to the year-to-year variations cited earlier. The minimum strontium concentration was below the nominal LLD.

\section{Grassy Vegetation}

The radiological program for grassy vegetation is designed to collect and analyze samples from onsite and offsite locations to determine radionuclide concentrations. Vegetation samples are obtained to complement the soil and sediment samples in order to determine the environmental accumulation of radionuclides and help confirm the dose models used by SRS. Furthermore, the program provides information that can be used to determine the effect, if any, of various radioactive material operations on the surrounding vegetation.

Typically, grasses are collected for vegetation because of their year-round availability. Bermuda grass is preferred because of its importance as a pasture grass for dairy herds.

\section{Description of Surveillance Program}

Vegetation samples are obtained from

- locations containing soil radionuclide concentrations that are expected to be higher than normal background levels

- locations receiving water that may have been contaminated

Until mid-1995, these samples were collected at 174 locations in and around SRS, including four "areas," 13 basins, the burial ground (outside and inside), the site perimeter, and the 25 - and 100-mile-radius locations near the environmental air monitoring stations. As a result of the comprehensive review of the environmental monitoring program, and because data from previous years indicated little or no contamination, all four 25-mile-radius and three of four 100-mile-radius sampling locations were retired in 1995. The 25-mile-radius locations were used to accumulate trending data, while the 100 -mile-radius locations served as control locations and provided historical baseline information. In 1996, SRS continued to collect quarterly samples at the 100-mile-radius location in Savannah, Georgia.

In 1996, sampling was discontinued on site at inside-burial ground and area locations, and the sampling frequency at outside-burial ground and site perimeter locations was reduced from quarterly to annually. Figure 6-9 shows the 116 locations sampled on site during 1996. By the end of 1996, the vegetation surveillance program was designed to collect samples annually at 100 onsite locations and one offsite location (Savannah)-a 40-percent reduction from the 174 locations sampled in early 1995.

Onsite sampling locations encircle burial ground and basin locations. Site perimeter air monitoring stations provide sampling within each 30 -degree sector around the site boundary. The offsite sampling 

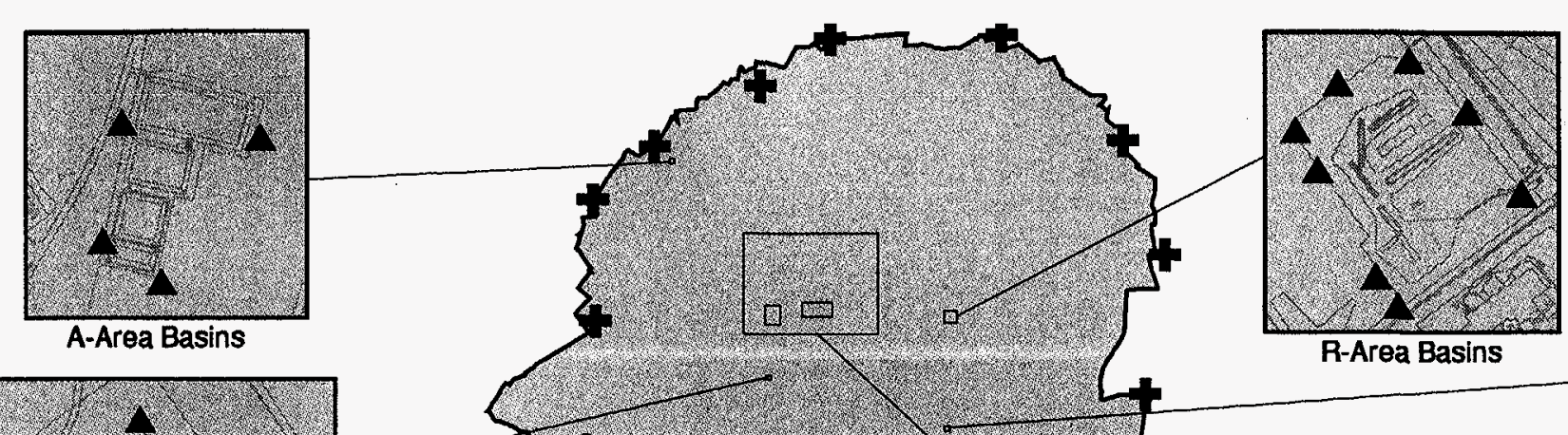

R-Area Basins

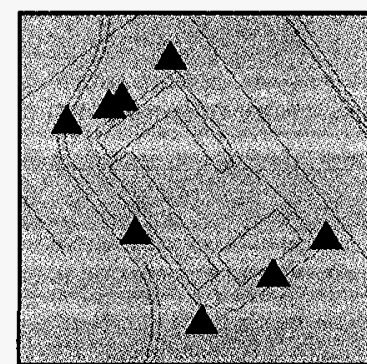

C-Area Basins

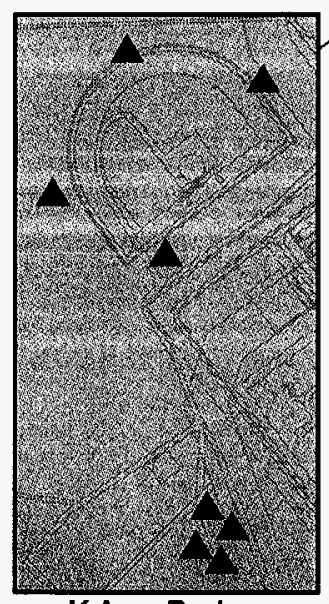

K-Area Basins

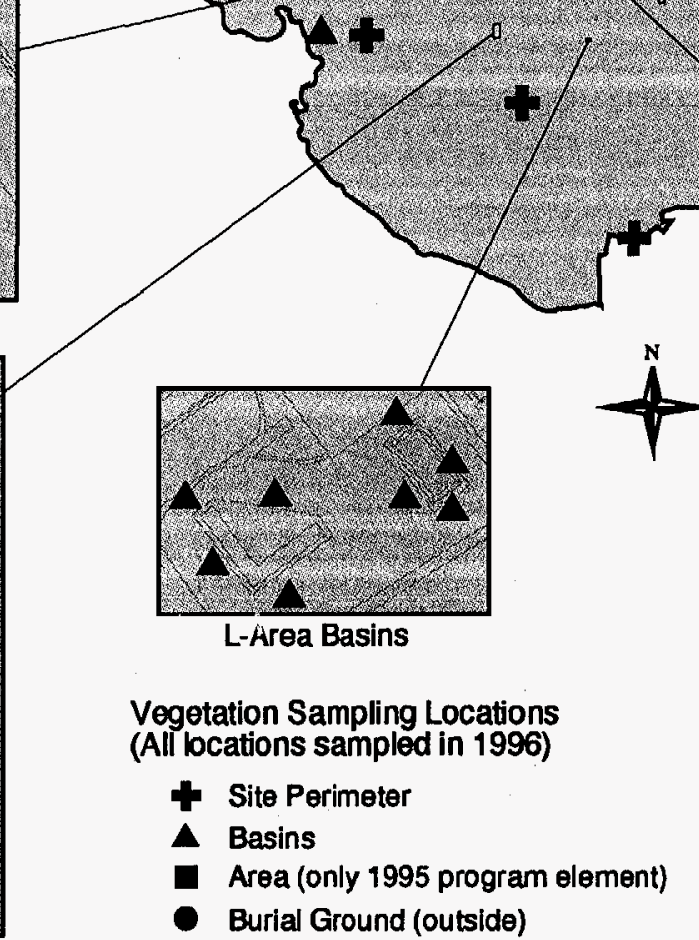

- Burial Ground (outside)
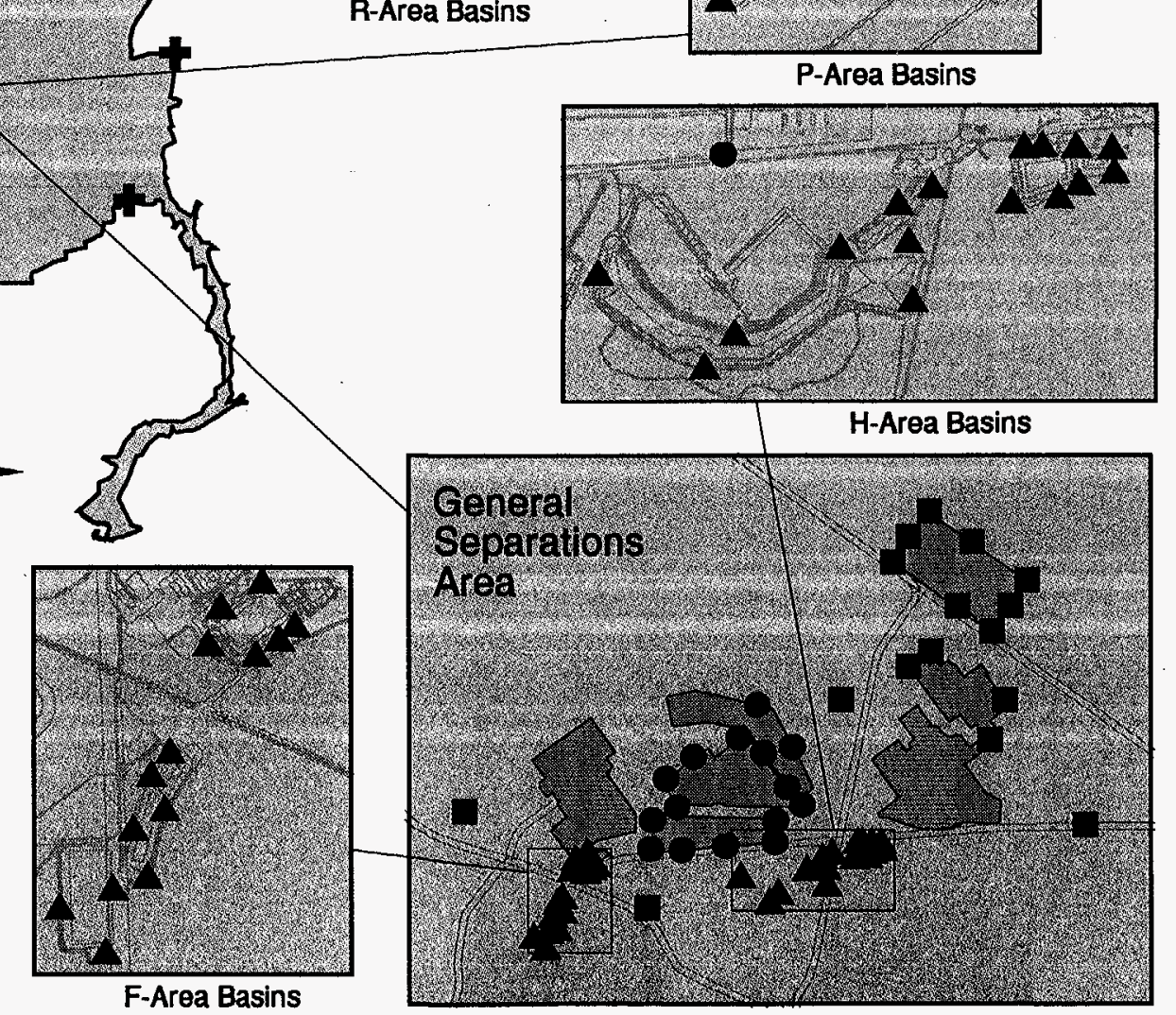

Figure 6-9 SRS Onsite Vegetation Sampling Locations

Vegetation samples were collected for radiological analysis from 116 onsite locations and one offsite (Savannah, Georgia) in 1996. 
location, selected as a control site, is near the environmental air monitoring station in Savannah.

Vegetation samples are analyzed for gross alpha and gross beta, gamma-emitting radionuclides, tritium, and strontium because vegetation can be contaminated externally by the deposition of airborne radioactive contaminants (i.e., from fallout) and internally by uptake, from soil or water, by the roots. While the program makes no attempt to differentiate between contributions of the external and internal contaminations, contributions can be approximated when naturally occurring radionuclide concentrations in local soils are known.

The sampling and analysis programs for grassy vegetation are documented in WSRC-3Q1-2, Volume 1, Section 1105.3.10.2. Operational details of sample collection are in procedure manual WSRC-3Q1-3, while analytical procedures are in WSRC -3 Q1-4 and WSRC-3Q1-6.

\section{Surveillance Results}

Before 1996, the vegetation surveillance program was divided into three broad areas: quarterly surveillance samples, annual basin samples (chemical, retention, and seepage), and quarterly and annual SWDF (burial ground) samples. Because all program changes were not fully implemented until mid-year, surveillance results are discussed on the basis of these three areas. All results are based on dry weight.

\section{Quarterly Surveillance Samples}

Sixty percent fewer vegetation samples were collected at the 16 onsite and 14 site perimeter quarterly surveillance sampling locations during 1996. (The 16 onsite locations are down from 18 in 1995 , when samples from two locations were grouped with SWDF.) Analytical results are summarized in table 6-6.

Gross Alpha and Gross Beta The 1996 gross alpha levels detected in onsite, site perimeter, 25-mile-radius, and 100-mile-radius samples generally are comparable to 1995 gross alpha levels. An examination of the gross beta values revealed no significant difference between the onsite surveillance locations and the offsite locations.

Many of the gross alpha results (from both onsite and offsite samples) were at or below the LLD, as indicated by the relatively large analytical uncertainties and negative concentrations. Even though many of the gross alpha concentrations are present at the LLD, it is appropriate to state that the data are comparable to those of previous years because the methods for collection, preparation, and analysis have not changed since 1992 . Variations in worldwide fallout patterns and in concentrations of naturally occurring radionuclides in the soil contribute to the differences in the gross beta concentrations.

Gamma-Emitting Radionuclides Most vegetation samples are composited for analysis of gamma-emitting radionuclides. Samples are composited by area (F-Area, H-Area) and by radius (perimeter, 25-mile, and 100-mile). S-Area and $Z$-Area samples are not composited but are analyzed individually.

An abundance of naturally occurring radionuclides, such as potassium- 40 , were detected in vegetation samples, which is to be expected. Cesium-137, the only manmade gamma-emitting radionuclide detected in the 1996 quarterly vegetation samples, was detected in samples from most locations, but most of the results were only slightly above the typical cesium-137 LLD.

Strontium The relatively low levels of strontium-89,90 detected in 1996 are similar to the levels detected since 1993. The differences in the results from year to year can be attributed to the variable strontium distribution in the surrounding soils.

As was the case with the gross alpha results, some of the strontium-89,90 levels were at or below the LLD, as indicated by the large analytical uncertainty or negative concentrations.

Tritium Onsite and site perimeter tritium concentrations generally were higher than the concentrations in vegetation samples collected from the 100-mile-radius location. These higher concentrations on site and at the site perimeter are attributed to atmospheric tritium releases from SRS.

\section{Chemical, Retention, and Seepage Basin Samples}

Vegetation samples are collected annually in the vicinity of the chemical, retention, and seepage basins. All samples from a specific operating area are composited for analysis of gross alpha, gross beta, gamma-emitting radionuclides, and strontium- 89,90 . Maximum concentrations are presented in table 6-7.

Gross Alpha and Gross Beta Gross alpha activity levels in vegetation samples taken at basin locations were below the LLD. Generally, the levels were consistent with the background levels observed off site and on the site perimeter.

Gross beta activity was detected in all vegetation samples analyzed. In general, the gross beta activity 
Table 6-6

Maximum Radionuclide Concentrations in Vegetation from Quarterly Surveillance Samples (pci/g)

\begin{tabular}{|c|c|c|}
\hline Surveillance Ring & Maximum & Location \\
\hline \multicolumn{3}{|l|}{ Gross Alpha } \\
\hline Onsite & $(3.16 \pm 1.19) E+00$ & $200-F \# 13$ \\
\hline Site Perimeter & $(3.41 \pm 2.05) E+00$ & Windsor Road \\
\hline 100-Mile Radius & $(1.33 \pm 3.50) E-01^{a}$ & Savannah, $\mathrm{GA}^{\mathrm{b}}$ \\
\hline \multicolumn{3}{|l|}{ Gross Beta } \\
\hline Onsite & $(2.86 \pm 0.12) E+01$ & Z-Area \#6 \\
\hline Site Perimeter & $(2.35 \pm 0.17) \mathrm{E}+01$ & Jackson \\
\hline 100-Mile Radius & $(8.13 \pm 1.28) E+00$ & Savannah, $\mathrm{GA}^{\mathrm{b}}$ \\
\hline Cobalt -60 & 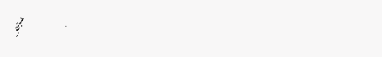 & \\
\hline Onsite & $(5.27 \pm 4.18) E-02^{a}$ & S-Area \#3 \\
\hline Site Perimeter & $(6.52 \pm 2.72) E-02^{a}$ & (Composite) \\
\hline 100-Mile-Radius & $(1.04 \pm 2.37) E-02^{a}$ & ${\text { (Composite })^{b}}^{b}$ \\
\hline \multicolumn{3}{|l|}{ Cesium-137 } \\
\hline Onsite & $(8.73 \pm 0.75) E-01$ & Z-Area \#2 \\
\hline Site Perimeter & $(6.31 \pm 0.40) E-01$ & (Composite) \\
\hline 100-Mile-Radius & $(1.26 \pm 0.41) E-01$ & $(\text { Composite })^{b}$ \\
\hline \multicolumn{3}{|l|}{ Strontium } \\
\hline Onsite & $(7.89 \pm 1.40) E-01$ & Z-Area \#1 (Composite) \\
\hline Site Perimeter & $(7.95 \pm 1.62) E-01$ & (Composite) \\
\hline 100-Mile-Radius & $(4.67 \pm 1.55) E-01^{a}$ & Savannah, GA ${ }^{b}$ \\
\hline \multicolumn{3}{|l|}{ Tritium } \\
\hline Onsite & $(7.98 \pm 0.10) E+01$ & $200-H \# 10$ \\
\hline Site Perimeter & $(1.33 \pm 0.03) E+00$ & East Talatha \\
\hline 100-Mile-Radius & $(5.12 \pm 3.44) E-02$ & Savannah, GA ${ }^{b}$ \\
\hline
\end{tabular}

detected was at or near background levels observed off site and on the site perimeter.

Gamma-Emitting Radionuclides As in 1995, cesium-137 was the only manmade gamma-emitting radionuclide detected in basin samples; it was present in a majority of the retention and seepage basin vegetation samples. Generally, the concentrations were present at levels comparable to those detected at the site perimeter, but slightly greater than the offsite levels.

Strontium Strontium-89,90 was detected in about half the samples; concentrations in the basin vegetation generally were greater than in the site perimeter and offsite vegetation. However, most values were near or slightly lower than last year's values.

The year-to-year variability of the results probably is attributable to the variable strontium distribution in the surrounding soils and the fact that the vegetation could have been collected from a slightly different location within the immediate area.

\section{Solid Waste Disposal Facility Samples}

When vegetation is available, samples are collected annually outside the SWDF to determine if there is significant uptake of radioactivity from the buried waste. During 1996, samples were collected at 13 of 15 locations immediately outside the SWDF fence; vegetation was not available for sampling at two 
Table 6-7

Maximum Radionuclide Concentrations in Vegetation from Chemical, Seepage, and Retention Basins (pCi/g)

Maximum Location

$\begin{array}{lll}\text { Gross Alpha } & \begin{array}{l}(7.21 \pm 6.09) \mathrm{E}-01^{\mathrm{a}} \\ (7.21 \pm 6.51) \mathrm{E}-01^{\mathrm{a}}\end{array} & \begin{array}{c}\text { A-Area Seepage } \\ \text { L-Area Chemical }\end{array} \\ \text { Gross Beta } & (2.47 \pm 0.18) \mathrm{E}+01 & \text { H-Area Retention } \\ \text { Cobalt-60 } & (4.39 \pm 1.71) \mathrm{E}-02^{\mathrm{a}} & \text { L-Area Chemical } \\ \text { Cesium-137 } & (3.87 \pm 0.20) \mathrm{E}+00 & \text { F-Area Retention } \\ \text { Strontium } & (1.04 \pm 0.04) \mathrm{E}+01 & \text { H-Area Retention }\end{array}$

a Activity is less than the lower limit of detection.

Table 6-8

Maximum Radionuclide Concentrations in Vegetation from Outside the Solid Waste Disposal Facility (pCi/g)

Maximum Location

$\begin{array}{lcc}\text { Gross Alpha } & (4.57 \pm 1.64) \mathrm{E}+00 & \text { OBG-1 } \\ \text { Gross Beta } & (2.43 \pm 0.27) \mathrm{E}-01 & \text { OBG-7 } \\ \text { Cobalt-60 } & (9.48 \pm 9.63) \mathrm{E}-01^{\mathrm{a}} & 643-26 \mathrm{E}-1 \\ \text { Cesium-137 } & (1.90 \pm 0.23) \mathrm{E}+00 & \text { OBG-9 } \\ \text { Strontium } & (2.79 \pm 1.78) \mathrm{E}-01 & 643-26 \mathrm{E}-1\end{array}$

a Activity is less than the lower limit of detection.

locations because of construction activity. SWDF samples are analyzed for gross alpha, gross beta, and gamma-emitting radionuclides. Maximum concentrations are presented in table 6-8. Generally, sample results were comparable to or slightly lower than results since 1993, and all activity was at or near levels detected at the site perimeter. These results indicated no significant uptake of radioactivity from the buried waste. 
Table 6-9

Representative Lower Limits of Detection for Gamma Analysis of Water and Air Samples ${ }^{a}$

Page 1 of 1

\begin{tabular}{|c|c|c|c|c|}
\hline \multirow[b]{2}{*}{ Nuclide } & \multicolumn{2}{|c|}{ pCi/L } & \multirow{2}{*}{$\frac{\mathrm{pCi} / \mathrm{m}^{2}}{\text { Rainwater }}$} & \multirow{2}{*}{$\frac{\mathrm{pCi} / \mathrm{m}^{3}}{\text { Air Filter }}$} \\
\hline & River Water & Stream Water. & & \\
\hline $\mathrm{Ce}-141$ & 0.8 & 8 & 36 & 12 \\
\hline $\mathrm{Ce}-144$ & 2.9 & 29 & 125 & 33 \\
\hline $\mathrm{Co}-58$ & 0.6 & 7 & 29 & 10 \\
\hline Co-60 & 1.0 & 9 & 32 & 11 \\
\hline $\mathrm{Cr}-51$ & 5.8 & 56 & 246 & 93 \\
\hline Cs-134 & 0.7 & 6 & 27 & 8 \\
\hline Cs-137 & 0.7 & 7 & 26 & 8 \\
\hline $\mid-131$ & 1.2 & 16 & 72 & 16 \\
\hline$M n-54$ & 0.7 & 7 & 32 & 11 \\
\hline $\mathrm{Nb}-95$ & 0.8 & 10 & 36 & 14 \\
\hline$R u-103$ & 0.6 & 7 & 28 & 10 \\
\hline Ru-106 & 5.5 & 59 & 278 & 88 \\
\hline Sb-125 & 1.8 & 15 & 63 & 19 \\
\hline $\mathrm{Zn}-65$ & 1.4 & 17 & 64 & 22 \\
\hline Zr-95 & 1.4 & 12 & 55 & 19 \\
\hline
\end{tabular}

a The lower limits of detection (LLDs) are calculated at the $95 \%$ confidence level with Canberra Industries Inc.'s VAXNMS gamma spectroscopy software. The values are based on a background measurement using a $32 \%$ relative efficiency high purity germanium detector and typical decay times and counting intervals. Chemical recoveries are assumed to be $100 \%$. Air filter values are for a single $47 \mathrm{~mm}$ particulate filter with a flow rate of approximately 2.5 cubic feet per minute (CFM) for 7 days (I-131 value is obtained from a charcoal cartridge). Rainwater values are for a collection area of $0.031 \mathrm{~m}^{2}$. The sample size for stream water is $1 \mathrm{~L}$ and for river water is $10 \mathrm{~L}$. The LLDs for actual samples may be different because of variations in the sample preparation, size, and content, and because of variations in the chemical recoveries, counting efficiencies, decay times, and instrument backgrounds. 
Table 6-10

Representative Lower Limits of Detection for Gamma Analysis of Soil, Food, Fish and Wildlife, and Vegetation Samples ${ }^{a}$

Page 1 of 1

\begin{tabular}{|c|c|c|c|c|c|}
\hline \multirow[b]{2}{*}{ Nuclide } & \multicolumn{3}{|c|}{$\mathrm{fCl} / \mathrm{g}$} & \multirow{2}{*}{$\frac{\mathrm{pCl} / \mathrm{g}}{\text { Vegetation }}$} & \multirow{2}{*}{$\frac{\mathrm{pCl} / \mathrm{L}}{\text { Milk }}$} \\
\hline & Soil & Foods & $\begin{array}{c}\text { Fish and } \\
\text { Wildlife }\end{array}$ & & \\
\hline $\mathrm{Ce}-141$ & 97 & 98 & 158 & 0.4 & 3 \\
\hline $\mathrm{Ce}-144$ & 139 & 40 & 227 & 0.5 & 12 \\
\hline Co-58 & 42 & 21 & 74 & 0.2 & 2 \\
\hline Co-60 & 29 & 7 & 52 & 0.1 & 3 \\
\hline Cr-51 & 771 & 979 & 1,322 & 2.9 & 19 \\
\hline Cs- 134 & 26 & 7 & 45 & 0.1 & 2 \\
\hline Cs- 137 & 24 & 7 & 42 & 0.1 & 3 \\
\hline $\mid-131$ & 3,939 & Decayed & 6,790 & 15.0 & 3 \\
\hline$M n-54$ & 32 & 8 & 57 & 0.1 & 2 \\
\hline $\mathrm{Nb}-95$ & 84 & 74 & 147 & 0.3 & 3 \\
\hline Ru-103 & 60 & 49 & 104 & 0.2 & 2 \\
\hline Ru-106 & 279 & 72 & 486 & 1.1 & 23 \\
\hline Sb-125 & 61 & 18 & 106 & 0.2 & 6 \\
\hline$Z n-65$ & 66 & 21 & 117 & 0.3 & 5 \\
\hline Zr-95 & 83 & 39 & 145 & 0.3 & 4 \\
\hline
\end{tabular}

a The lower limits of detection (LLDs) are calculated at the $95 \%$ confidence level with Canberra Industries Inc.'s VAXIVMS gamma spectroscopy software. The values are based on a background measurement using a $32 \%$ relative efficiency high purity germanium detector and typical decay times and counting intervals. Chemical recoveries are assumed to be $100 \%$. Sample sizes are $700 \mathrm{~g}$ for soll, $1,000 \mathrm{~g}$ for foods, $200 \mathrm{~g}$ for fish and wildlife, $100 \mathrm{~g}$ for vegetation, and $1 \mathrm{~L}$ for milk. The LLDs for actual samples may be different because of variations in the sample preparation, size, and content, and because of variations in the chemical recoveries, counting efficiencies, decay times, and instrument backgrounds. 
Table 6-11

Representative Lower Limits of Detection for Radiological Analysis of Plutonium and Uranium by Alpha Spectroscopya

Page 1 of 1

\begin{tabular}{llcllll}
\hline Sample Type & Units & Pu-239 & Pu-238 & U-238 & U-234 & U-235 \\
\hline Air filter & $\mu \mathrm{Ci} / \mathrm{m}^{3}$ & $2.4 \mathrm{E}-11$ & $4.3 \mathrm{E}-11$ & $2.4 \mathrm{E}-11$ & $2.8 \mathrm{E}-11$ & $2.9 \mathrm{E}-11$ \\
Rainwater & $\mu \mathrm{Ci} / \mathrm{m}^{2}$ & $3.3 \mathrm{E}-7$ & $5.8 \mathrm{E}-7$ & $3.1 \mathrm{E}-7$ & $3.5 \mathrm{E}-7$ & $3.6 \mathrm{E}-7$ \\
Stream water & $\mu \mathrm{Ci} / \mathrm{mL}$ & $1.0 \mathrm{E}-11$ & $1.8 \mathrm{E}-11$ & $9.5 \mathrm{E}-12$ & $1.1 \mathrm{E}-11$ & $1.1 \mathrm{E}-11$ \\
River water & $\mu \mathrm{Ci} / \mathrm{mL}$ & $1.0 \mathrm{E}-12$ & $1.8 \mathrm{E}-12$ & $9.5 \mathrm{E}-13$ & $1.1 \mathrm{E}-12$ & $1.1 \mathrm{E}-12$ \\
Foodstuff & $\mu \mathrm{Ci} / \mathrm{g}$ & $1.5 \mathrm{E}-10$ & $1.4 \mathrm{E}-10$ & & & \\
Soil and sediment & $\mu \mathrm{Ci} / \mathrm{g}$ & $5.9 \mathrm{E}-10$ & $7.3 \mathrm{E}-10$ & & & \\
Vegetation & $\mu \mathrm{Ci} / \mathrm{g}$ & $7.3 \mathrm{E}-11$ & $1.1 \mathrm{E}-10$ & & & \\
Tissue & $\mu \mathrm{Ci} / \mathrm{g}$ & $2.4 \mathrm{E}-10$ & $1.7 \mathrm{E}-10$ & & &
\end{tabular}

a The lower limits of detection (LLDs) are calculated at the $95 \%$ confidence level with Canberra Industries Inc.'s VAXNMS alpha management spectroscopy software. The values are based on the average regent blank activity, detector efficiency, and chemical recovery for each sample matrix. The counting time is 1,000 minutes. Air filter values are for one-half of a single $47 \mathrm{~mm}$ particulate filter with a flow rate of approximately 2.5 cubic feet per minute (CFM) for 7 days. The rainwater values are for a collection area of $0.031 \mathrm{~m}^{2}$. The other sample sizes are $1 \mathrm{~L}$ for stream water, 10 $L$ for river water, $10 \mathrm{~g}$ for soil and sediment, and $100 \mathrm{~g}$ for foodstuff, vegetation, and tissue. The LLDs for actual samples may be different because of variations in the sample preparation, size, and content, and because of variations in the chemical recoveries, counting efficiencies, batch reagent blanks, and instrument backgrounds. 
Table 6-12

Representative Lower Limits of Detection for Radiological Analysis by Gas-Flow Proportional Counters ${ }^{a}$ and by Liquid Scintillation ${ }^{b}$

Page 1 of 1

Analysis of Gross Alpha, Nonvolatile Beta, Strontium-89,90, and Strontium-90 by Gas-Flow Proportional Counters

Nuclide

Gross alpha

Nonvolatile beta

Strontium-89, 90

Strontium-90
Typical Lower Limit of Detection ( $\mu$ Ci/sample)

$$
6.8 \mathrm{E}-7
$$

$1.52 E-6$

$2.38 \mathrm{E}-6$

$1.89 \mathrm{E}-6$

Analysis for Weak Beta Emitters by Liquid Scintillation

\section{Sample}

Tritiume

Tritium ${ }^{d}$

Promethium-147
Typical Lower Limit Of Detection $(\mu \mathrm{Ci} / \mathrm{mL})$

1.3E-6

4.7E-7

8.6E-9

a The instrument lower limits of detection (LLD) values for the gas-flow proportional counter were calculated at the $95 \%$ confidence level using the formula given in the section, "Lower Limits of Detection," in chapter 4 of the Savannah River Site Environmental Report for 1991 . The counting efficiencies were $28 \%$ for alpha and $40 \%$ for beta, strontium- 90 , and strontium-89,90. The LLD for the actual sample is variable because of the effects of sample aliquot size, sample preparation, chemical recovery, counting efficiency, and radioactive decay. The sample counting time was 20 minutes.

b Instrumental LLD values for the liquid scintillation counter were calculated at the $95 \%$ confidence level using the formula given in the section, "Lower Limits of Detection," in chapter 4 of the Savannah River Site Environmental Report for 1991 . The average counting efficiencies were $37 \%$ for tritium and $88 \%$ for promethium-147. The LLD for the actual sample is variable because of the effects of sample preparation, sample aliquot size, chemical recovery, counting efficiency, counting time, and radioactive decay.

c Routine environmental samples (e.g. stream samples and silica gels) are analyzed for tritium using a 20-minute count.

d Environmental samples such as drinking water, foodstuffs, and rainwater are analyzed using a 150 -minute count. 

Calculating Dose ................. 105

Dose Calculation Results ............. 108

Potential Risk from Consumption

of SRS Creek Mouth Fish ............ 117

Radiological Assessment Program ..... 120

\author{
Bill Carlton, Timothy Jannik, \\ and Ali Simpkins \\ Savannah River Technology Center
}

$\mathrm{T}$ HIS chapter presents the potential doses to offsite individuals and the surrounding population from 1996 Savannah River Site (SRS) atmospheric and liquid radioactive releases. Additionally, potential doses from special-case exposure scenarios-such as deer meat, fish, and goat milk consumption and crops irrigated with Savannah River water-are documented.

Unless otherwise noted, the generic term "dose" used in this report includes both the committed effective dose equivalent (50-year committed dose) from internal deposition of radionuclides and the effective dose equivalent attributable to sources external to the body. Use of the effective dose equivalent allows doses from different types of radiation and to different parts of the body to be expressed on the same relative basis.

Many parameters- -such as radioactive release quantities, population distribution, meteorological conditions, radionuclide dose factors, human consumption rates of food and water, and environmental dispersion - are considered in the dose models used to estimate offsite doses at SRS.
Descriptions of the effluent monitoring and environmental surveillance programs discussed in this chapter can be found in chapter 5, "Radiological Effluent Monitoring," and chapter 6, "Radiological Environmental Surveillance." A complete description of how potential doses are calculated can be found in section 1108 of the Savannah River Site

Environmental Monitoring Section Plans and Procedures, WSRC-3Q1-2, Volume 1 (SRS EM Program). Tables containing all potential dose calculation results are presented in $S R S$ Environmental Data for 1996 (WSRC-TR-97-0077).

Applicable dose regulations can be found in Appendix A, "Applicable Guidelines, Standards, and Regulations," of this document.

\section{Calculating Dose}

Potential offsite doses from SRS effluent releases of radioactive materials (atmospheric and liquid) are calculated for the following scenarios:

- maximally exposed individual

- 80-kilometer (50-mile) population

\title{
Dose to the Mrainally Exposed indithethi
}

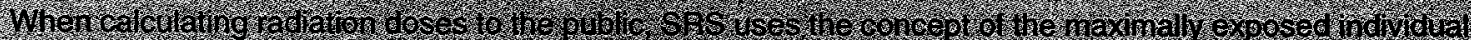

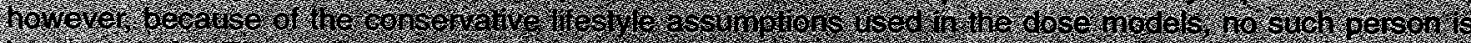

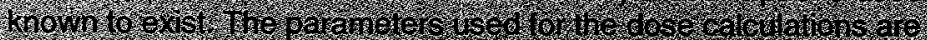

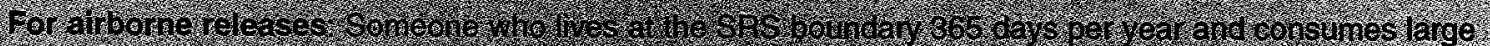

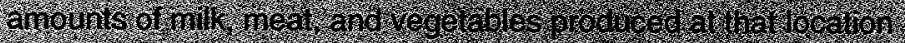

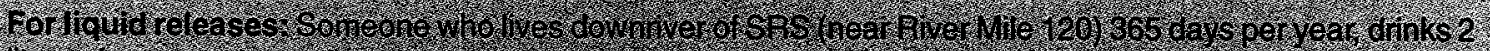

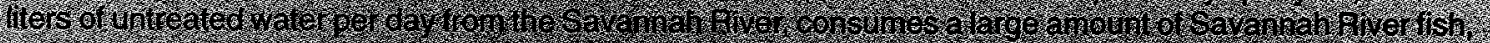

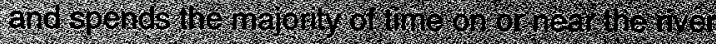

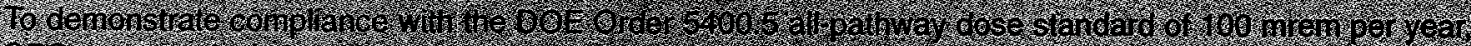

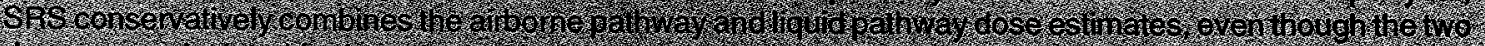

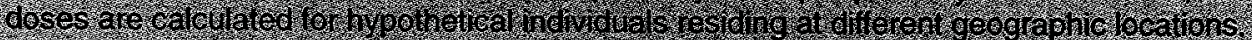


Because the U.S. Department of Energy (DOE) has adopted dose factors only for adults, SRS calculates maximally exposed individual and collective doses as if the entire 80-kilometer population consisted of adults [DOE, 1988].

The International Commission on Radiological Protection (ICRP), in its Publications \#56 and \#67, has established age-specific dose factors for six age groups, ranging from 3-month-old infants to adults. However, dose factors for only a select group of radioisotopes were published, and these are applicable to only the ingestion pathway. In general, for most radioisotopes, the dose to an infant is higher than to an adult. For the radioisotopes that constitute most of SRS's radioactive releases (i.e., tritium and cesium-137), the dose to infants would be approximately two to three times higher than to adults. The dose to older children becomes progressively closer to the adult dose.

When the ICRP completes age-specific dose factors for all radioisotopes and develops an age-specific lung model for inhalation, and when DOE adopts these factors and models, doses will be calculated for the various age groups.

SRS also uses adult consumption rates for food and drinking water and adult usage parameters to estimate intakes of radionuclides [SRS Data, 1997]. These intake values and parameters were developed specifically for SRS based on an intensive regional survey [Hamby, 1991]. The survey includes data on agricultural production, consumption rates for food products, and use of the Savannah River for drinking water and recreational purposes.

\section{Dose Calculation Models}

To calculate annual offsite doses, SRS uses radiation transport and dose models developed for the commercial nuclear industry [NRC, 1977]. The models are implemented at SRS in the following computer programs [SRS EM Program, 1996]:

- MAXIGASP: calculates maximum and average doses to offsite individuals from atmospheric releases.

- POPGASP: calculates collective doses from atmospheric releases.

- LADTAPII: calculates maximum and average doses to offsite individuals and the population from liquid releases.

- CAP88: calculates doses to offsite individuals from atmospheric releases to demonstrate compliance with the National Emission Standards for
Hazardous Air Pollutants (NESHAP) under the Clean Air Act.

The CAP88 computer code is required under the Clean Air Act to calculate offsite doses from atmospheric releases from existing and proposed facilities. SRS uses the CAP88 dose estimates to show NESHAP compliance, but not for routine dose calculations. Both the CAP88 and the MAXIGASP codes use modeling based on U.S. Nuclear Regulatory Commission Regulatory Guide 1.109.

\section{Meteorological Database}

Meteorological data are used as input for the atmospheric transport and dose models.

For 1996, all potential offsite doses from releases of radioactivity to the atmosphere were calculated with quality-assured meteorological data for A-Area (located near the northwest SRS boundary), D-Area (located near the west-southwest site boundary), and $\mathrm{H}$-Area (located near the center of the site).

Meteorological data for A-Area (used for A-Area and $M$-Area releases) and D-Area (used for D-Area releases) were added in 1996 to improve the accuracy of the dose estimates. All of the databases were compiled for the period 1987-1991 [SRS

Data, 1997]. A 5-year average database is used instead of the actual annual data because of the difficulty of compiling, inputting, and validating all the data in time to be used for the current-year dose calculations, and because there is little year-to-year variation in the meteorology at SRS [Hamby and Parker, 1991].

The wind rose developed from the 1987-1991 database is shown in figure 7-1. As can be seen, there is no prevailing wind at SRS, which is typical for the lower midlands of South Carolina. The maximum frequency that the wind blew in any one direction was 9.1 percent of the time, which occurred from the northeast blowing towards the southwest sector.

The meteorological measurements include all dispersion conditions observed during the 5-year period, ranging from unstable (considerable turbulence, which leads to rapid dispersion) to very stable (very little turbulence, which produces a narrow, undispersed plume). The data for 1987-1991 indicate that the SRS area experiences stable conditions (atmospheric stability classes E, F, G) about 21 percent of the time.

\section{Population Database and Distribution}

Collective, or population, doses from atmospheric releases are calculated for the population within a 80 -kilometer (50-mile) radius of SRS. 

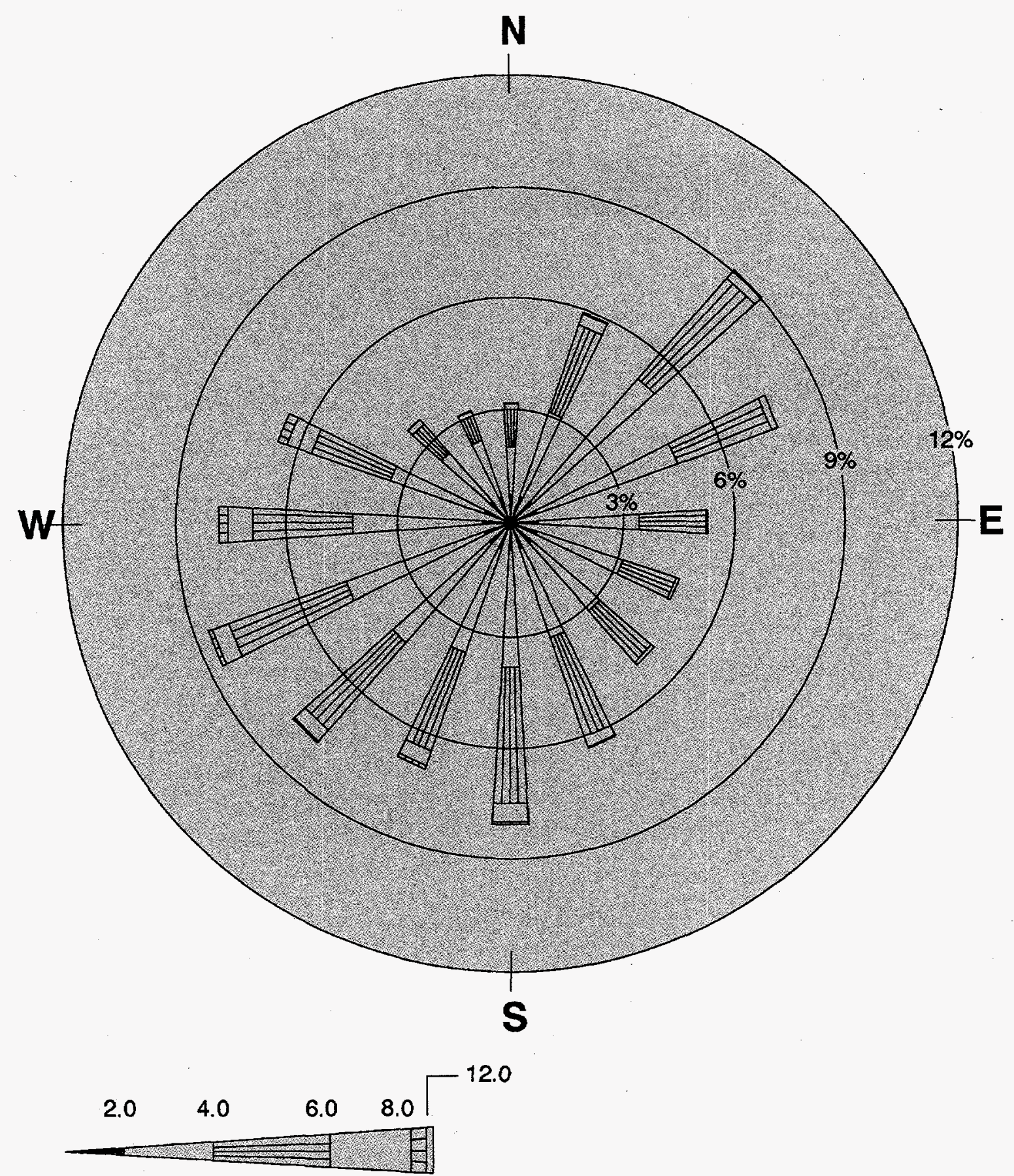

Wind Speed Class Boundaries

(Meters/Second)

$94 \times 01185.32$

Figure 7-1 Wind Rose for SRS, 1987-1991

The wind rose plot shows the percent of occurrence frequencies of wind direction and speed at SRS. The plot is based on hourly averaged wind data from the SRS meteorological tower network for the 5-year period 1987-1991. Measurements were taken 200 feet above the ground. Directions indicated are from which the wind blows. 
For 1996 dose calculations, the 1990 population database prepared by the University of South Carolina was used. This database distributes the population into a grid of cells one-second latitude by one-second longitude. This database is transformed by the POPGASP Code into polar coordinates of 16 compass sectors and varying radial distances out to 80 kilometers. The POPGASP Code can prepare a polar coordinate database for any release point put into the code in polar coordinates. A separate, fixed-polar-coordinate database was prepared for use with the CAP88 Code, which does not have the capability of transforming the grid into polar coordinates. The population database generated by the POPGASP Code is centered on the geographical center of SRS [SRS Data, 1997].

Within the 80-kilometer radius, the total population for 1990 was 620,100 , compared to 555,200 for 1980 , a 12-percent population growth in 10 years.

Some of the collective doses resulting from SRS liquid releases are calculated for the populations served by the City of Savannah Industrial and Domestic Water Supply Plant (formerly Cherokee Hill Water Treatment Plant), near Port Wentworth, Georgia, and by the Beaufort-Jasper Water Treatment Plant, near Beaufort, South Carolina. In 1996, according to the treatment plant operators, the population served by the Port Wentworth facility declined from about 15,000 to approximately 10,000 persons, and the population served by the Beaufort-Jasper facility rose from about 50,000 to approximately 60,000 persons.

\section{River Flow Rate Data}

Offsite dose from liquid effluents varies each year with the amount of radioactivity released and the amount of dilution (flow rate) in the Savannah River. Although flow rates are recorded at U.S. Geological Survey (USGS) gauging stations at the SRS boat dock and near River Mile 120 (U.S. Highway 301 bridge), these data are not used directly in dose calculations. This is because weekly river flow rates fluctuate widely (i.e., short-term dilution varies from week to week). Used instead are "effective" flow rates, which are based on measured concentrations of tritium in Savannah River water and measured concentrations in water used at the downstream water treatment plants. However, the USGS-measured flow rates are used for comparison to these calculated values.

For 1996, the River Mile 120 calculated (effective) flow rate of 8,640 cubic feet per second was used in determining doses to maximally exposed individuals, population doses from recreation and fish consumption, and potential doses from crops irrigated with river water. This flow rate was about 13 percent less than the 1995 effective flow rate of 9,973 cubic feet per second. For comparison, during 1996 the USGS-measured flow rate at River Mile 120 was 11,467 cubic feet per second, which was about 10 percent less than the 1995 measured rate of 12,750 cubic feet per second. Therefore, the calculated value is more conservative because it accounts for less dilution.

The 1996 calculated (effective) flow rate for the Beaufort-Jasper facility was 10,941 cubic feet per second, which was about 29 percent less than the 1995 rate of 15,474 cubic feet per second. This indicates that less dilution occurred in the Beaufort-Jasper canal during 1996 than during 1995.

The 1996 calculated (effective) flow rate for the Port Wentworth facility was 10,144 cubic feet per second, which was about 22 percent less than the 1995 rate of 13,000 cubic feet per second. This indicates that less dilution occurred in Abercorn Creek during 1996 than during 1995.

The 1996 calculated Savannah River estuary flow rate (12,680 cubic feet per second) was used only for calculation of dose from consumption of salt water invertebrates.

\section{Uncertainty in Dose Calculations}

Radiation doses are calculated using the best available data. If adequate data are unavailable, then site-specific parameters are selected that would result in a conservative estimate of the maximum dose.

All radiation data and input parameters have an uncertainty associated with them, which causes uncertainty in the dose determinations. For example, there is uncertainty in the assumption that an individual eats $81 \mathrm{~kg}$ (179 pounds) of meat each year. Obviously, a few people will eat more than $81 \mathrm{~kg}$, but most probably will eat less. Uncertainties can be combined mathematically to create a distribution of doses rather than a single number. While the concept is simple, the calculation is quite difficult. A detailed technical discussion of the method of estimating uncertainty at SRS was published in the July 1993 issue of Health Physics [Hamby, 1993].

\section{Dose Calculation Results}

Liquid and air pathway doses are calculated for the maximally exposed individual and for the surrounding population. In addition, a sportsman dose is calculated separately for consumption of fish, deer, and feral hogs, which are nontypical exposure pathways. Finally, a dose is calculated for the aquatic biota found in SRS streams. 
Table 7-1

1996 Radjoactive Liquid Release Source Terms and 12-Month Average Downriver Radionuclide Concentrations (Calculated Concentrations Are Based on Effective River Flow Rates)

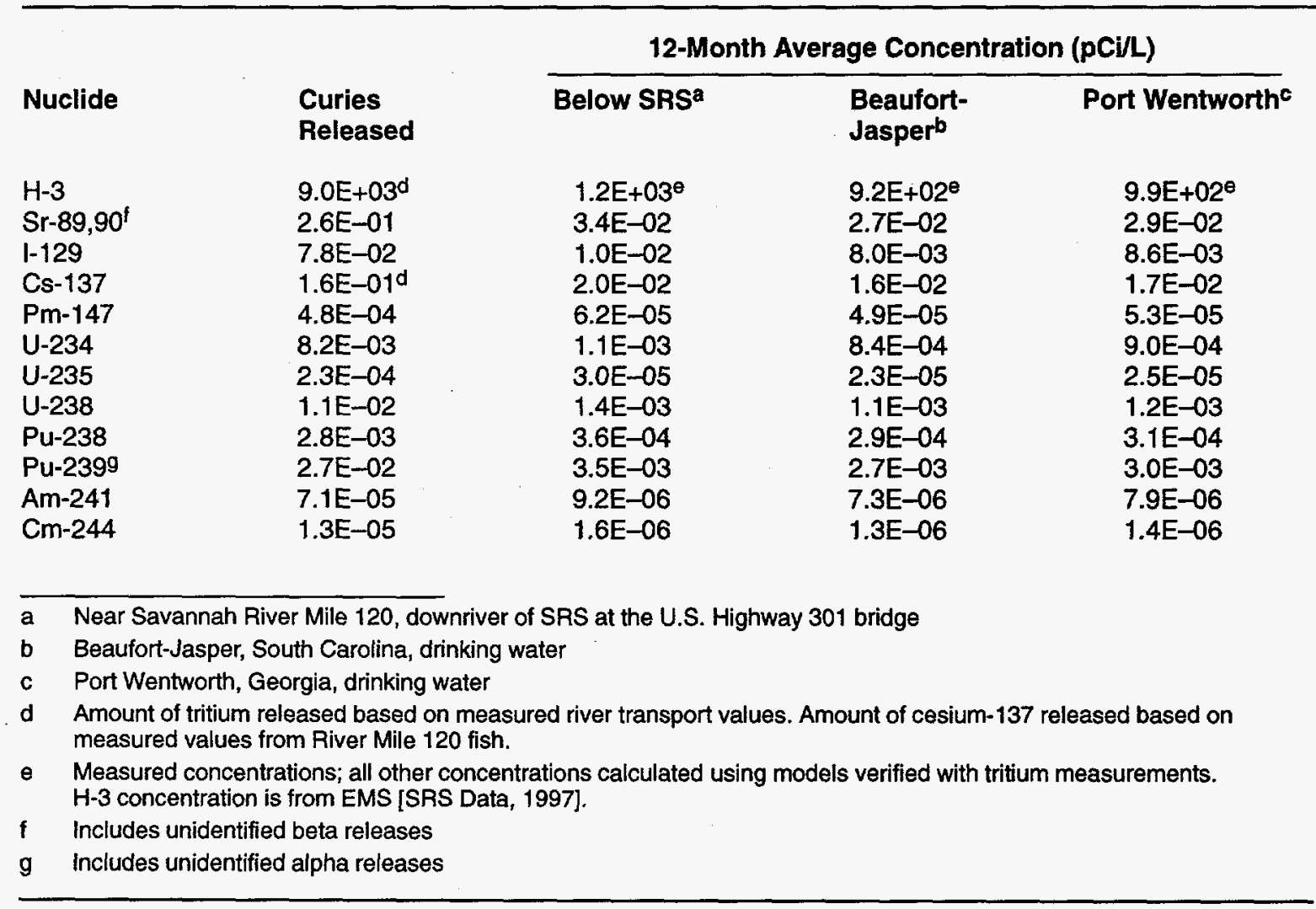

\section{Liquid Pathway}

This section contains information on liquid release quantities used as source terms in SRS dose calculations, including a discussion about radionuclide concentrations in Savannah River fish. The calculated dose to the maximally exposed individual, the calculated collective (population) dose, and the potential dose from agricultural irrigation are presented.

\section{Liquid Release Source Terms}

The 1996 radioactive liquid release quantities used as source terms in SRS dose calculations are presented in chapter 5 and summarized by radionuclide in table 7-1. In order to maintain conservatism, the river transport tritium release total of $8,950 \mathrm{Ci}$

$(3.3 \mathrm{E}+14 \mathrm{~Bq})$, which was the highest value of the three alternative tritium release calculation methods employed at SRS (chapter 6), was used in the dose calculations.

As discussed in chapter 5, for dose calculations, releases of unidentified beta-gamma emitters were summed with strontium $-89,90$ releases, and unidentified alpha emitters were summed with releases of plutonium-239.

For use in dose determinations and model comparisons, concentrations of radionuclides in Savannah River water and fish were measured at several locations along the river. The measured concentrations of tritium oxide in the Savannah River near River Mile 120 and at the Beaufort-Jasper and Port Wentworth water treatment facilities are shown in table 7-1, as are the LADTAPII computer code-determined concentrations for the other released radionuclides.

The 12-month average tritium oxide concentrations measured in the Savannah River near River Mile 120 $(1,160 \mathrm{pCi} / \mathrm{L})$, and at the Beaufort-Jasper $(916 \mathrm{pCi} / \mathrm{L})$ and Port Wentworth ( $988 \mathrm{pCi} / \mathrm{L}$ ) water treatment plants, remained below the U.S. Environmental Protection Agency (EPA) and DOE concentration standards of $20,000 \mathrm{pCi} / \mathrm{L}$ and $80,000 \mathrm{pCi} / \mathrm{L}$, respectively.

The 1996 River Mile 120 concentration was just 9 percent less than the 1995 concentration of 1,280 $\mathrm{pCi} / \mathrm{L}$, even though the amount of tritium oxide 


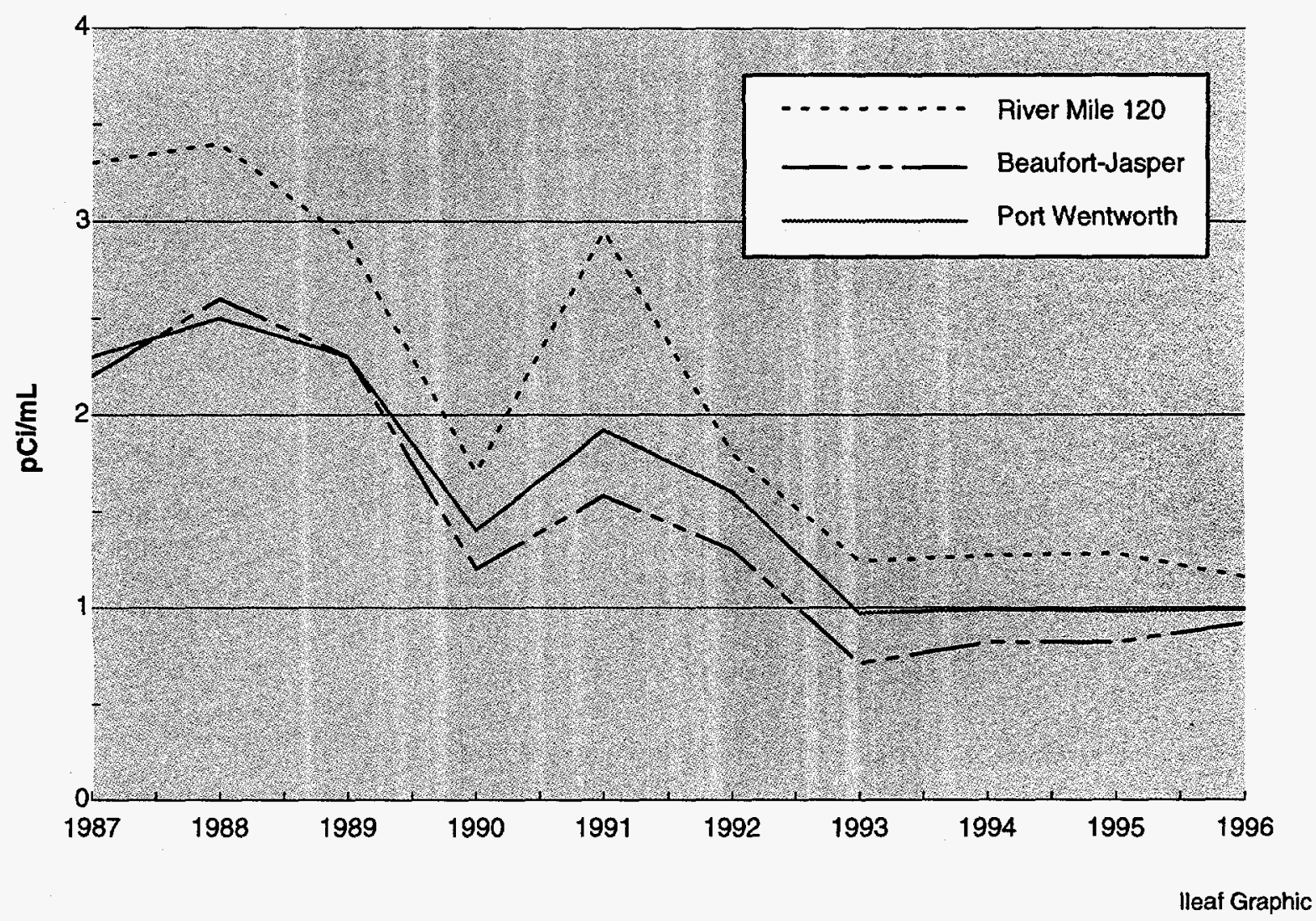

Figure 7-2 Annual Average Tritium Concentrations at River Mile 120, Beaufort-Jasper, and Port Wentworth (1987-1996)

released from SRS during 1996 was about 21 percent less than the amount released during $1995(8,950$ curies in 1996 versus 11,400 curies in 1995). This is because the effective River Mile 120 flow rate was about 13 percent less in 1996 than in 1995 , causing less dilution to occur.

A 10-year history of annual average tritium concentrations measured at River Mile 120 and at the Beaufort-Jasper and Port Wentworth facilities is shown in figure 7-2. The data for Beaufort-Jasper and Port Wentworth are the tritium concentrations measured in the finished drinking water at each facility.

As can be seen in the figure, the water treatment plant concentrations increased slightly in 1996 because the effective river flow rates for the treatment plants was more than 20 percent lower in 1996 than in 1995. Additional information about the river's flow rates can be found in the River Flow Rate Data section of this chapter (page 108).

Radionuclide Concentrations in River Fish At SRS, a major dose pathway for the maximally exposed individual is from the consumption of fish.
Fish exhibit a high degree of bioaccumulation for certain contaminants. For the element cesium (including radioactive isotopes of cesium), the bioaccumulation factor for Savannah River fish is approximately 3,000 . That is, the concentration of cesium found in fish flesh is about 3,000 times greater than the concentration of cesium found in the water in which the fish live.

Because of this high bioaccumulation factor, cesium-137 is more easily detected in fish flesh than in river water. Therefore, the fish pathway dose from cesium-137 is based directly on the radioanalysis of the fish collected near Savannah River Mile 120 , which is the assumed location of the hypothetical maximally exposed individual [SRS Data, 1997]. The fish pathway dose from all other radionuclides is based on the calculated concentrations determined by the LADTAPII code. A consumption rate of $19 \mathrm{~kg}$ ( 42 pounds) of fish per year is used in the maximally exposed individual dose calculation [Hamby, 1991]. Some fraction of this estimated dose is due to cesium-137 from worldwide fallout and from neighboring Vogtle Electric Generating Plant; 
however, that amount is difficult to determine and is not subtracted from the total.

The dose determinations are accomplished in the LADTAPII code by substituting a cesium- 137 release value that would result in the measured concentration in river fish, assuming the site-specific

bioaccumulation factor of 3,000. A weighted average concentration (based on the number of fish in each composite analyzed) of cesium-137 in River Mile 120 fish was used for maximally exposed individual and population dose determinations. Using the above factors, the cesium- 137 release value used for LADTAPII input was $0.16 \mathrm{Ci}(5.9 \mathrm{E}+09 \mathrm{~Bq})$, which is more conservative than the measured release value of $0.12 \mathrm{Ci}(4.4 \mathrm{E}+09 \mathrm{~Bq})$.

\section{Dose to the Maximally Exposed Individual}

The potential liquid pathway dose to the hypothetical maximally exposed individual living downriver of SRS, near River Mile 120, was determined based on intake parameters discussed earlier in this chapter.

As shown in table 7-2, the highest potential dose to the maximally exposed individual from liquid releases in 1996 was estimated at $0.14 \mathrm{mrem}$ $(0.0014 \mathrm{mSv})$. This dose is 0.14 percent of DOE's 100-mrem all-pathway dose standard for annual exposure.

The 1996 potential maximally exposed individual dose was the same as the 1995 dose of $0.14 \mathrm{mrem}$ $(0.0014 \mathrm{mSv})$. The potential dose remained the same even though the amount of tritium oxide released from SRS during 1996 was more than 21 percent less than during 1995. This was because of decreased dilution in the Savannah River due to the 13-percent decrease in the effective river flow during 1996.

Approximately 43 percent of the dose to the maximally exposed individual at the site perimeter resulted from the ingestion of cesium-137, mainly from the consumption of fish, and about 41 percent resulted from the ingestion (via drinking water) of tritium oxide [SRS Data, 1997].

Drinking Water Pathway Persons downriver of SRS may receive a radiation dose by consuming drinking water that contains radioactivity as a result of liquid releases from the site. In 1996, tritium oxide in downriver drinking water represented the majority of the dose (about 75 percent) received by persons at downriver water treatment plants.

The calculated doses to maximally exposed individuals whose entire daily intake of water is supplied by the Beaufort-Jasper and Port Wentworth water treatment facilities, located downriver of SRS, were determined for maximum ( 2 liters per day for a year) water consumption rates [SRS Data, 1997].

At the Beaufort-Jasper Water Treatment Plant, the potential dose for maximum water consumption rates during 1996 was $0.06 \mathrm{mrem}(0.0006 \mathrm{mSv})$; at the City of Savannah Industrial and Domestic Water Supply Plant (Port Wentworth), the potential dose also was $0.06 \mathrm{mrem}(0.0006 \mathrm{mSv})$.

As shown in table 7-2, the maximum dose of $0.06 \mathrm{mrem}(0.0006 \mathrm{mSv})$ is 1.5 percent of the DOE and EPA standard of 4 mrem per year from public water supplies. The 1996 maximum potential

Table 7-2

Potential Dose to the Maximally Exposed Individual from SRS Liquid Releases in 1996

\begin{tabular}{lll}
$\begin{array}{l}\text { Committed } \\
\text { Dose }\end{array}$ & $\begin{array}{l}\text { Applicable } \\
\text { Standard }\end{array}$ & $\begin{array}{l}\text { Percent } \\
\text { of Standard }\end{array}$ \\
\hline
\end{tabular}

\section{Maximally Exposed Individual}

\section{At Site Boundary}

(untreated river water)

At Port Wentworth

(public water supply only)

At Beaufort-Jasper

(public water supply only)
0.14 mrem

100 mrem $^{\mathrm{a}}$

0.14

0.06 mrem

$4 \mathrm{mrem}^{\mathrm{b}}$

1.5

$0.06 \mathrm{mrem} \quad 4 \mathrm{mrem}^{\mathrm{b}}$
1.5

a All-pathway dose standard: 100 mrem per year (DOE Order 5400.5)

b Drinking water pathway standard: 4 mrem per year (DOE Order 5400.5 and EPA, 1975) 
drinking water dose was slightly more than the 1995 maximum dose of $0.05 \mathrm{mrem}(0.0005 \mathrm{mSv})$. This increase in dose is attributed to the decrease in effective Savannah River flow during 1996.

\section{Collective (Population) Dose}

The collective drinking water consumption dose is calculated for the discrete population groups at Beaufort-Jasper and Port Wentworth. The collective dose from other pathways is calculated for a diffuse population that makes use of the Savannah River. However, it cannot be described as being in a specific geographical location.

Potential collective doses were calculated, by pathway and radionuclide, using the LADTAPII computer code [SRS Data, 1997]. In 1996, the collective dose from SRS liquid releases was estimated at 2.2 person-rem ( 0.022 person-Sv). This was more than the 1995 collective dose of 1.7 personrem $(0.017$ person-Sv). This increase in dose is attributed to the decrease in effective Savannah River flow during 1996.

\section{Potential Dose from Agricultural Irrigation}

The 1990 update of land- and water-use parameters [Hamby, 1991] revealed that there is no known use of river water downstream of SRS for agricultural irrigation purposes. However, in response to public concerns, potential doses from this pathway are calculated for information purposes only and are not included in calculations of the official maximally exposed individual or collective doses. A potential offsite dose of $1.1 \mathrm{mrem}(0.011 \mathrm{mSv})$ to the maximally exposed individual and a collective dose of 7.6 person-rem ( 0.076 person-Sv) were estimated for this exposure pathway. As in previous years, collective doses from agricultural irrigation were calculated for 1,000 acres of land devoted to each of four major food types - vegetation, leafy vegetation, milk, and meat [SRS Data, 1997].

\section{Air Pathway}

This section describes the atmospheric source terms and concentrations used for dose determinations and presents the calculated dose to the maximally exposed individual, as well as the calculated collective (population) dose. Also included is a discussion about how SRS demonstrates NESHAP compliance.

\section{Atmospheric Source Terms}

The 1996 radioactive atmospheric release quantities used as source terms in SRS dose calculations are presented in chapter 5. For dose calculation purposes, releases of unidentified beta emitters were summed with strontium- 89,90 releases and releases of unidentified alpha emitters were summed with plutonium-239 releases [SRS Data, 1997].

Estimates of unmonitored diffuse and fugitive source terms were considered, as required for demonstrating compliance with NESHAP regulations. Most of the estimated diffuse and fugitive releases occurred at the separations areas, the reactor areas, and the Solid Waste Disposal Facility.

Atmospheric source terms are grouped by major release points for dose calculations. For the MAXIGASP code, five release locations with specific release heights were used [SRS Data, 1997].

The CAP88 code can calculate doses from collocated release heights but cannot combine calculations for releases at different geographical locations.

Therefore, for CAP88 calculations, source terms were grouped for elevated releases (61 meters) and ground-level releases ( 0 meters), and the geographical center of the site was used as the release location for both [SRS Data, 1997].

\section{Atmospheric Concentrations}

The MAXIGASP and CAP88 codes calculate average and maximum concentrations of all released radionuclides at the site perimeter. These calculated concentrations are used for dose determinations instead of measured concentrations. This is because most radionuclides released from SRS cannot be measured, using standard methods, in the air samples collected at the site perimeter and offsite locations. However, the concentrations of tritium oxide at the site perimeter locations usually can be measured and are compared with calculated concentrations as a verification of the dose models.

The average tritium oxide concentration in air measured at the 14 site perimeter locations during 1996 was $11 \mathrm{pCi} / \mathrm{m}^{3}\left(0.41 \mathrm{~Bq} / \mathrm{m}^{3}\right)$, which is a 31 percent decrease from the 1995 measured value of $16 \mathrm{pCi} / \mathrm{m}^{3}$ $\left(0.6 \mathrm{~Bq} / \mathrm{m}^{3}\right)$. The 1996 measured value compares favorably with the MAXIGASP and CAP88 computer code values of $11 \mathrm{pCi} / \mathrm{m}^{3}\left(0.41 \mathrm{~Bq} / \mathrm{m}^{3}\right)$ and $10 \mathrm{pCi} /$ $\mathrm{m}^{3}\left(0.37 \mathrm{Bg} / \mathrm{m}^{3}\right)$, respectively.

The maximum tritium oxide concentration measured in air at the site perimeter was $19 \mathrm{pCi} / \mathrm{m}^{3}(0.70 \mathrm{~Bq} /$ $\mathrm{m}^{3}$ ), which occurred at the D-Area location. This value is less than, but compares favorably with, the MAXIGASP calculated value of $23 \mathrm{pCi} / \mathrm{m}^{3}(0.85 \mathrm{~Bq} /$ $\left.\mathrm{m}^{3}\right)$.

The CAP88 code calculated a maximum site perimeter concentration of $15 \mathrm{pCi} / \mathrm{m}^{3}\left(0.55 \mathrm{~Bq} / \mathrm{m}^{3}\right)$. This 
Table 7-3

Ten-Year History of SRS Atmospheric Tritium and Tritium Oxide Releases and Average Measured Tritium Oxide Concentrations in Air Compared to Calculated Concentrations in Air

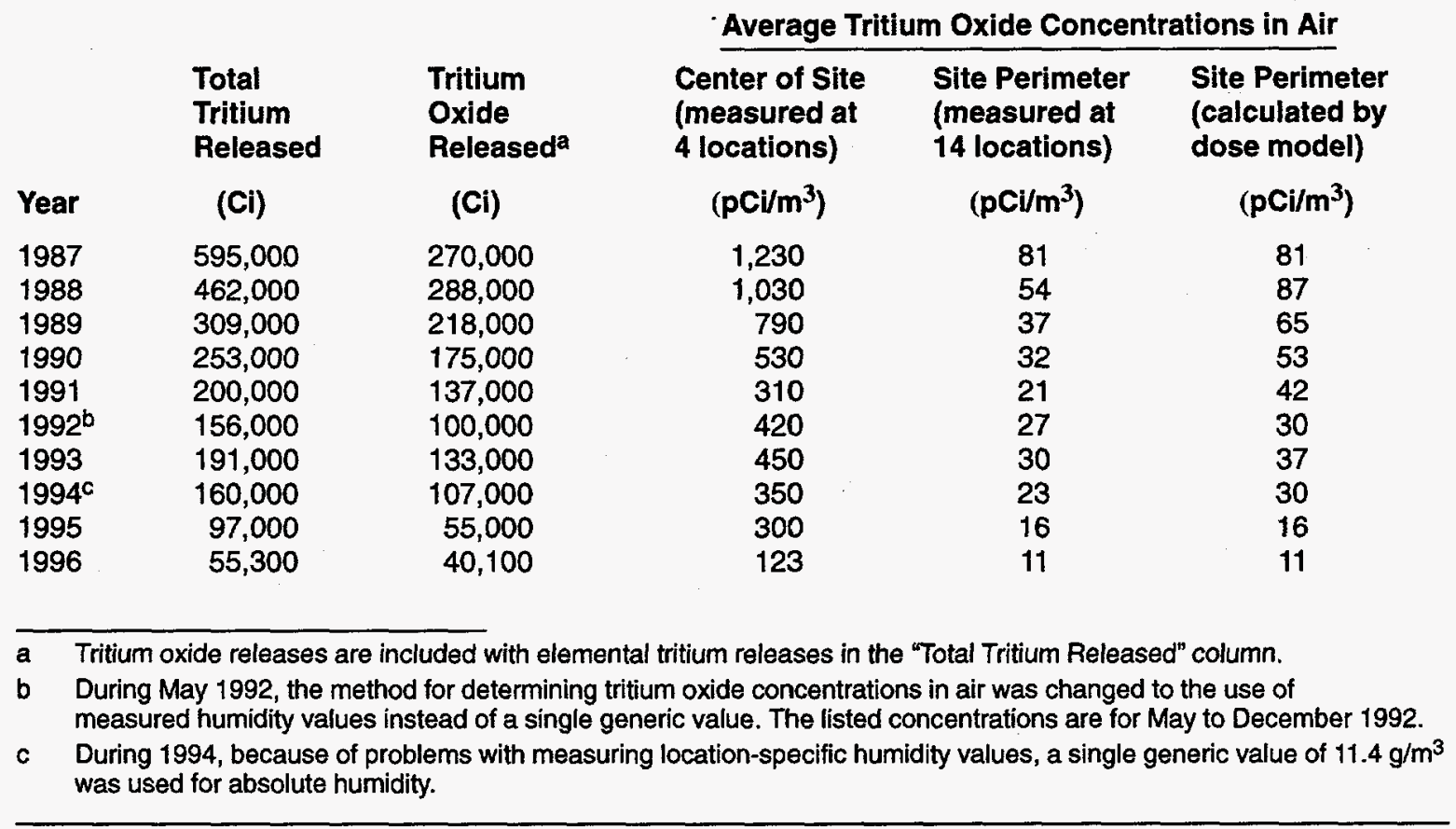

value is lower than the MAXIGASP code value because the CAP88 code assumes that all releases occurred from only one point, which is located at the center of the site.

In table 7-3, the average 1987-1996 tritium oxide concentrations in air-measured at four locations near the center of the site (F-Area, H-Area, SWDF North, and SWDF South) and at 14 locations along the site perimeter-are compared to the average concentrations calculated for the site perimeter, using the MAXIGASP code. These data show that the calculated site-perimeter tritium oxide concentrations are conservative in that they are higher than or equal to the measured site-perimeter concentrations. However, they consistently and reasonably approximate the measured values and therefore are appropriate for use in dose determinations.

Also shown in table 7-3 are the total tritium and tritium oxide releases from SRS for the same years. As can be seen, there is a correlation between the quantity of tritium oxide released and the measured concentration of tritium oxide in air at the monitoring locations. The 27-percent decrease in tritium oxide releases during 1996 is attributed primarily to continued improvements in operations at the state-of-the-art Replacement Tritium Facility and to decreases in tritium processing activities.

\section{Dose to the Maximally Exposed Individual}

The potential air pathway dose to a hypothetical maximally exposed individual located at the site perimeter was determined using the MAXIGASP computer code [SRS Data, 1997]. The parameters used for the calculations were discussed earlier in this chapter.

In 1996, the estimated dose to the maximally exposed individual was $0.05 \mathrm{mrem}(0.0005 \mathrm{mSv})$, which is about 0.5 percent of the DOE Order 5400.5

("Radiation Protection of the Public and the Environment") standard of 10 mrem per year. This dose was approximately 17 percent lower than the 1995 dose of 0.06 mrem $(0.0006 \mathrm{mSv})$ because of the 21-percent decrease in tritium oxide releases from 1995 to 1996 (chapter 5). Tritium oxide releases accounted for about 68 percent of the dose to the maximally exposed individual. Table 7-4 compares the maximally exposed individual's dose with the DOE standard.

For 1996, the MAXIGASP code determined that the west-southwest sector of the site was the location of the maximally exposed individual. Figure $7-3$ shows 
Table 7-4

Potential Dose to the Maximally Exposed Individual from SRS Atmospheric Releases in 1996

\begin{tabular}{lll}
\hline & MAXIGASP & CAP88 (NESHAP) \\
\cline { 2 - 3 } Calculated dose & $0.05 \mathrm{mrem}$ & $0.06 \mathrm{mrem}$ \\
Applicable standard & $10 \mathrm{mrem} \mathrm{m}^{\mathrm{a}}$ & $10 \mathrm{mrem}^{\mathrm{b}}$ \\
Percent of standard & $0.5 \%$ & $0.6 \%$ \\
& & \\
\hline b DOE: DOE Order 5400.5, February 8, 1990 & & \\
b EPA: (NESHAP) 40 CFR 61 Subpart H, December 15, 1989 & \\
\hline
\end{tabular}

the potential dose to the maximally exposed individual residing at the site boundary for each of the 16 compass point directions around SRS.

The major pathways contributing to the dose to the maximally exposed individual from atmospheric releases were from inhalation ( 38 percent) and from consumption of vegetation ( 40 percent), cow milk (12 percent), and meat ( 8 percent).

Additional calculations of the dose to the maximally exposed individual were performed substituting a goat milk pathway for the customary cow milk pathway. The maximum potential dose using the goat milk pathway was estimated at 0.06 mrem $(0.0006 \mathrm{mSv})$, which is slightly more than the cow milk pathway dose.

Most of this difference is from tritium oxide because the transfer factor (fraction of the daily intake of the nuclide that appears in each liter of milk) for tritium is 17 times higher for goat milk than for cow milk [NRC, 1977]. However, because goat milk consumption is less common, the dose calculated from cow milk consumption will continue to be the

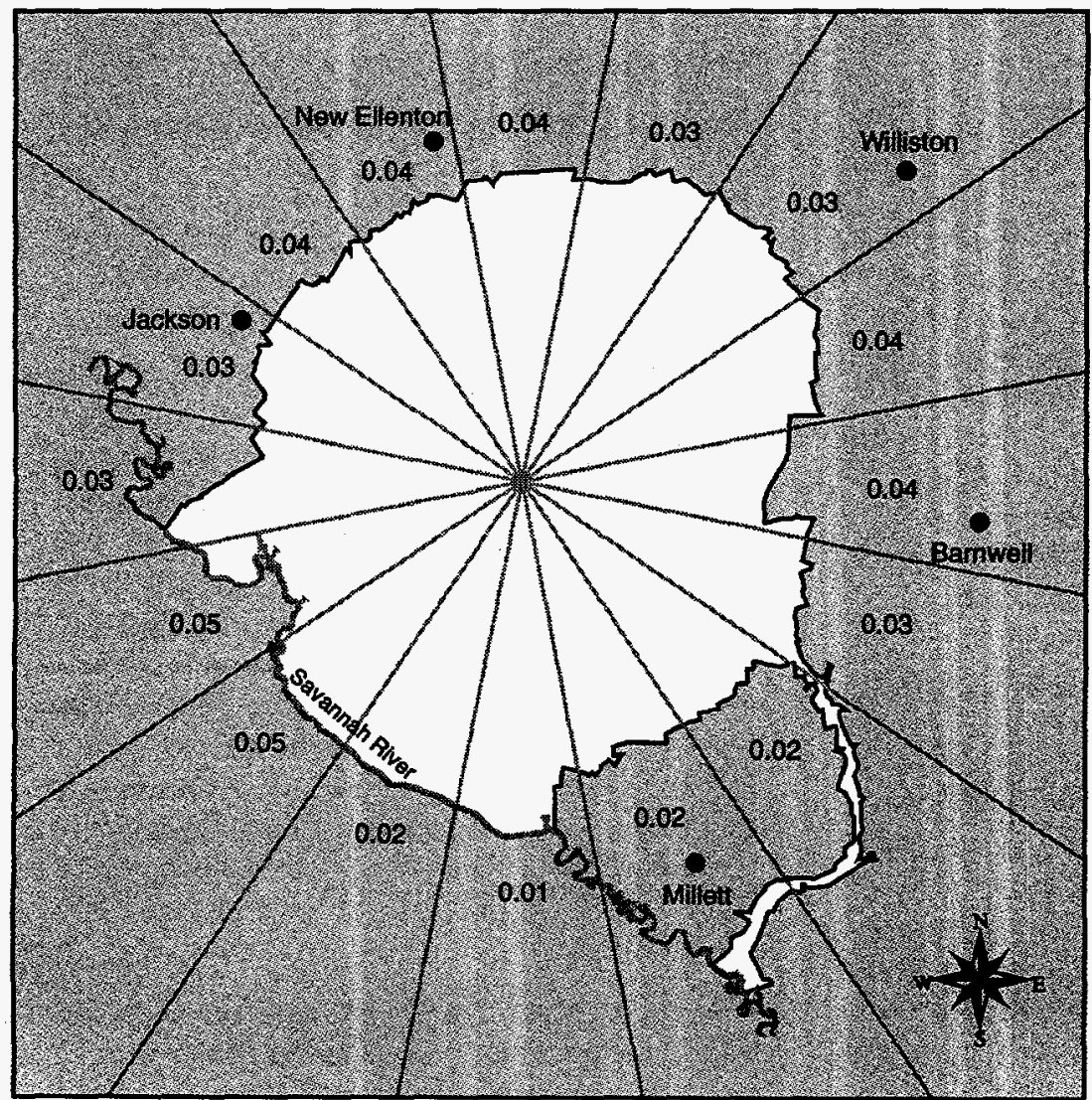

Figure 7-3 Sector-Specific Adult Maximally Exposed Individual Air Pathway Doses (in mrem) for 1996 Maximally exposed individual site boundary doses from airborne releases are shown for each of the 16 compass point directions surrounding SRS. As indicated by the dose totals for 1996, the west-southwest sector was the location of the highest maximally exposed individual dose.

EPD/GIS Map 
primary dose used for demonstrating compliance with dose standards.

\section{Collective (Population) Dose}

Potential doses also were calculated, by pathway and radionuclide, using the POPGASP computer code for the population $(620,100$ people) residing within 80 kilometers of the center of SRS [SRS Data, 1997]. In 1996, the collective dose was estimated at 2.8 person-rem $(0.028$ person-Sv), which is less than 0.01 percent of the collective dose received from natural sources of radiation (about 186,000 person-rem). The 1996 collective dose was approximately 20 percent lower than the 1995 collective dose of 3.5 person-rem ( 0.035 person-Sv)-again, mainly because of the 21-percent decrease in tritium oxide releases from 1995 to 1996 . Tritium oxide releases accounted for about 75 percent of the 1996 collective dose.

\section{NESHAP Compliance}

To demonstrate compliance with NESHAP (Clean Air Act, 40 CFR 61, Subpart $H$ ) regulations, maximally exposed individual and collective doses were calculated, and a percentage of dose contribution from each radionuclide was determined using the CAP88 computer code [SRS Data, 1997].

The dose to the maximally exposed individual, calculated with CAP88, was estimated at 0.06 mrem $(0.0006 \mathrm{mSv})$, which is 0.6 percent of the 10-mrem-per-year EPA standard, as shown in table 7-4. Tritium oxide releases accounted for almost 92 percent of this dose.

The CAP88 collective dose was estimated at 6.4 person-rem ( 0.064 person-Sv). Tritium oxide releases accounted for about 92 percent of this dose.

As the data show, the CAP88 code estimates a higher dose than do the MAXIGASP and POPGASP codes. Most of the differences occur in the tritium dose estimated from food consumption. The major cause of this difference is the CAP8 8 code's use of 100 -percent equilibrium between tritium in air moisture and tritium in food moisture, whereas the MAXIGASP and POPGASP codes use 50-percent equilibrium values, as recommended by the Nuclear Regulatory Commission [NRC, 1977]. A recent publication indicates that the 50-percent value is correct for the atmospheric conditions at SRS [Hamby and Bauer, 1994].

Because tritium oxide dominates the doses determined using the CAP88 code, and because the CAP88 code is limited to a single, center-of-site release location, other radionuclides (such as iodine-129, plutonium-239, and ruthenium-106) are less important - on a percentage-of-dose basis-for the CAP88 doses than for the MAXIGASP and POPGASP doses.

\section{All-Pathway Dose}

To demonstrate compliance with the DOE Order 5400.5 all-pathway dose standard of 100 mrem per year (1.0 mSv per year), SRS conservatively combines the maximally exposed individual airborne pathway and liquid pathway dose estimates, even though the two doses are calculated for hypothetical individuals residing at different geographic locations.

Figure 7-4 shows a 10-year history of SRS's all-pathway doses (airborne pathway plus liquid pathway doses to the maximally exposed individual).

For 1996, the potential maximally exposed individual all-pathway dose was $0.19 \mathrm{mrem}$ $(0.0019 \mathrm{mSv})-0.05 \mathrm{mrem}$ from airborne pathway plus 0.14 mrem from liquid pathway. This dose is 5 percent lower than the 1995 all-pathway dose of $0.20 \mathrm{mrem}(0.0020 \mathrm{mSv})$, primarily because of the decrease in atmospheric tritium oxide releases during 1996.

Figure 7-5 shows that the 1996 maximum potential all-pathway dose attributable to SRS operations ( 0.19 mrem) contributed less than 0.1 percent of the average annual radiation dose received by a typical Central Savannah River Area (CSRA) resident.

As shown in table 7-5, the 1996 potential all-pathway dose of 0.19 mrem $(0.0019 \mathrm{mSv})$ is 0.19 percent of the 100-mrem-per-year DOE dose standard.

\section{Sportsman Dose}

DOE Order 5400.5 specifies radiation dose standards for individual members of the public. The dose standard of 100 mrem per year, which applies to all members of the public, includes doses a person receives from routine DOE operations through all exposure pathways. Nontypical exposure pathways, not included in the standard calculations of the doses to the maximally exposed individual, are considered and quantified separately. This is because they apply to low-probability scenarios, such as consumption of fish caught exclusively from the mouths of SRS streams, or to unique scenarios, such as volunteer deer hunters.

\section{Deer and Hog Consumption Pathway}

For approximately 6 weeks each year, controlled hunts of deer and feral hogs are conducted at SRS. Hunt participants are volunteers. Before any harvested animal is released to a hunter, SRS 


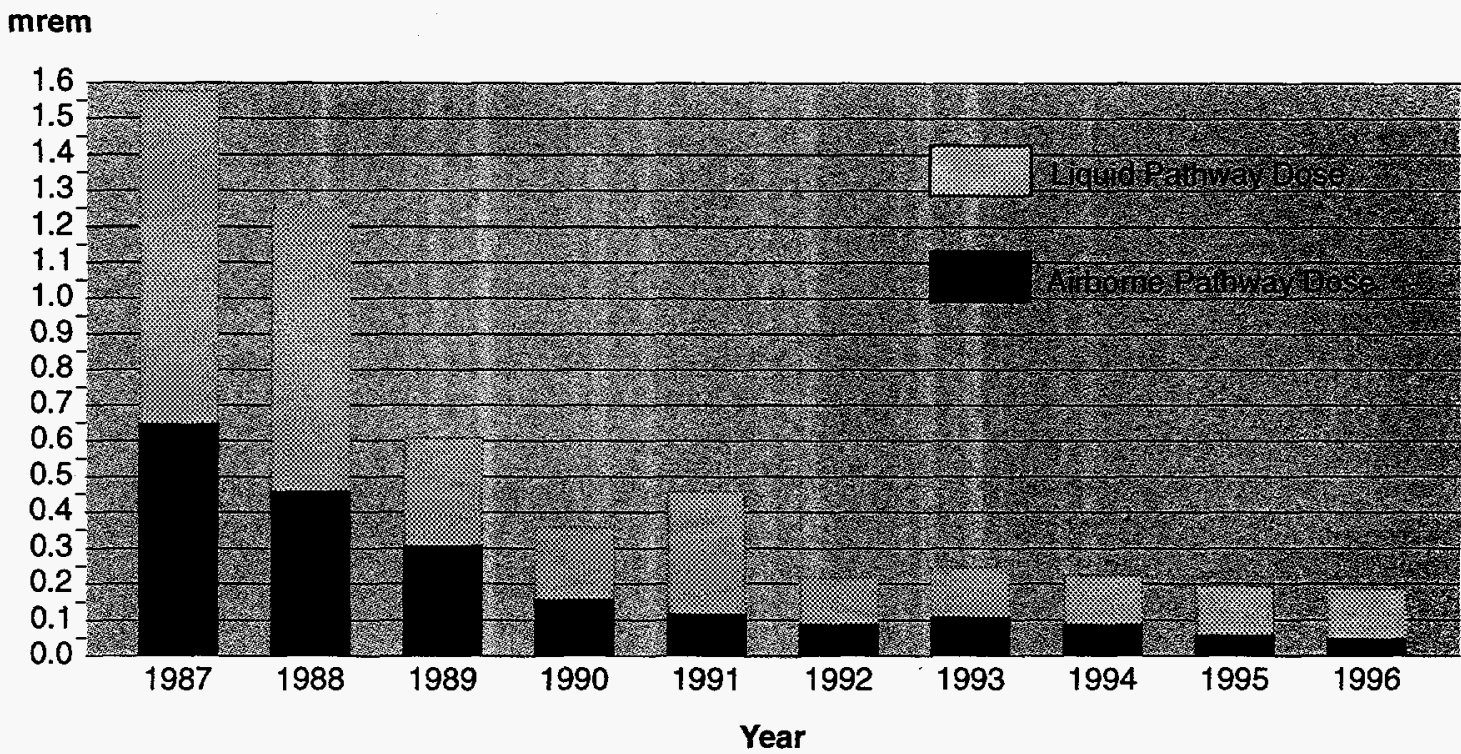

Ileaf Graphic

Figure 7-4 Ten-Year History of SRS Maximum Potential All-Pathway Doses to the Maximally Exposed Individual (Airborne plus Liquid Pathways)

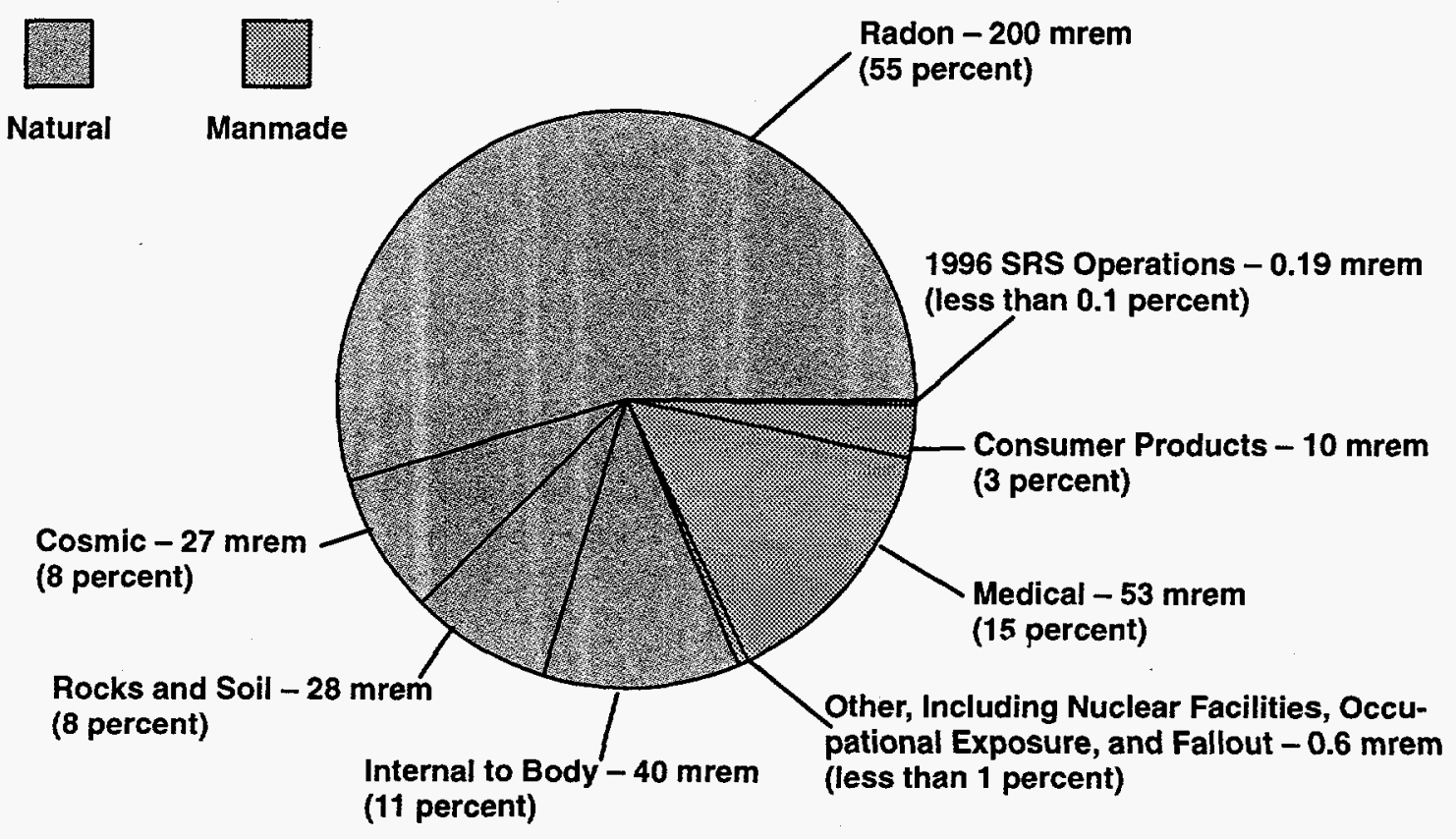

Heaf Graphic

Figure 7-5 Contributions to the U.S. Average Individual Dose

The major contributor to the annual average individual dose in the United States, including residents of the CSRA, is naturally occurring radiation (about $300 \mathrm{mrem}$ ) [NCRP, 1987]. During 1996, SRS operations potentially contributed a maximum individual dose of $0.19 \mathrm{mrem}$, which is less than 0.1 percent of the $360-\mathrm{mrem}$ total annual average dose (natural plus manmade sources of radiation). 
Table 7-5

1996 All-Pathway and Sportsman Doses Compared to the DOE All-Pathway Dose Standard

\begin{tabular}{lccc}
\hline & $\begin{array}{c}\text { Committed } \\
\text { Dose (mrem) }\end{array}$ & $\begin{array}{c}\text { Applicable } \\
\text { Standarda (mrem) }\end{array}$ & $\begin{array}{c}\text { Percent } \\
\text { of Standard }\end{array}$ \\
\cline { 2 - 4 } $\begin{array}{l}\text { Maximally Exposed Individual Dose } \\
\begin{array}{l}\text { All-Pathway } \\
\text { (Liquid Plus Airborne Pathway) }\end{array}\end{array}$ & 0.19 & 100 & 0.19 \\
$\begin{array}{l}\text { Sportsman Doses } \\
\text { Creek Mouth Fisherman } \\
\text { Onsite Hunter } \\
\text { Offsite Hunter }\end{array}$ & 1.7 & 100 & 1.7 \\
\hline A & 21 & 100 & 21 \\
\hline
\end{tabular}

personnel perform a field analysis for cesium-137 on the deer and hogs at the hunt site, using portable sodium iodide detectors. Like fish, deer and hogs have a high bioaccumulation factor for cesium.

The estimated dose from consumption of the harvested deer or hog meat is determined for each hunter. During 1996, the maximum potential dose that could have been received by a hunter was estimated at $21 \mathrm{mrem}(0.21 \mathrm{mSv})$, or 21 percent of DOE's 100-mrem all-pathway dose standard (table 7-5). This dose was determined for a hunter who had harvested six animals during the 1996 hunts. The hunter-dose calculation is based on the conservative assumption that the hunter individually consumed the entire edible portion-approximately $111 \mathrm{~kg}$ ( 245 pounds) - of the animals he harvested from SRS.

An additional deer meat consumption pathway considered was for a hypothetical offsite individual whose entire intake of meat during the year was deer meat. It was assumed that this individual harvested deer that had resided on SRS, but then moved off site. The estimated dose was based on the maximum annual meat consumption rate for an adult of $81 \mathrm{~kg}$ per year [Hamby, 1991].

Based on these low-probability assumptions and on the gross average concentration of cesium-137 (4.5 pCi/g) in deer harvested from SRS during 1996, the potential maximum dose from this pathway was estimated at $14 \mathrm{mrem}(0.14 \mathrm{mSv})$. As shown in table $7-5$, this potential dose is 14 percent of DOE's 100-mrem all-pathway dose standard. This dose was slightly less than the 1995 dose of 15 mrem $(0.15 \mathrm{mSv})$.

\section{Fish Consumption Pathway}

For 1996, analyses were conducted of fish taken from the mouths of five SRS streams, and the subsequent estimated doses from the maximum consumption of $19 \mathrm{~kg}$ per year [Hamby, 1991] of these fish were determined [SRS Data, 1997]. Fish flesh was composited by species for each location and analyzed for tritium, strontium-90, cesium-137, plutonium-238, and plutonium-239.

As shown in table 7-5, the maximum potential dose from this pathway was estimated at $1.7 \mathrm{mrem}$ $(0.017 \mathrm{mSv})$ from the consumption of bass collected at the mouth of Steel Creek. This hypothetical dose is based on the low-probability scenario that, during 1996, a fisherman consumed $19 \mathrm{~kg}$ of bass caught exclusively from the mouth of Steel Creek. More than 99 percent of this potential dose was from cesium-137. Again, some fraction of this cesium-137 is from worldwide fallout and from neighboring Vogtle Electric Generating Plant; however, that amount is difficult to determine and is not subtracted from the total.

\section{Potential Risk from Consumption of SRS Creek Mouth Fish}

During 1991 and 1992, in response to a U.S. House of Representative Appropriations Committee request for a plan to evaluate risk to the public from fish collected from the Savannah River, SRS developed-in conjunction with the Georgia Department of Natural Resources (GDNR), the South Carolina Department of Health and Environmental Control (SCDHEC), and EPA - and implemented the WSRC/EMS Fish Monitoring Plan [SRS EM Program, 1996]. Part of the reporting requirements of this plan are to perform 
an assessment of radiological risk from the consumption of Savannah River fish, and to summarize the results in the annual SRS Environmental Report. The following sections discuss the potential radiological risks from the consumption of Savannah River fish, using SRS-published data from 1993 through 1996. Potential radiological risks are determined using both the ICRP-60 [ICRP, 1990] and the EPA [EPA, 1991] methods.

Exposure Scenario In EPA's risk assessment guidance document [EPA, 1991], two fish consumption pathways are considered - the recreational fisherman scenario and the subsistence fisherman scenario. Because there are no known permanent residences adjacent to, or immediately downriver of, SRS, the recreational fisherman scenario-as opposed to the subsistence fisherman scenario--is considered the more reasonable exposure scenario and is used in this assessment.

It is assumed that a recreational fisherman fishes for a single species of fish (either panfish, predators, or bottom dwellers) from the mouth of a single worstcase SRS stream. Access to upstream portions of SRS streams is prohibited by postings, fencing (where possible), and periodic patrols.

Per EPA guidance [EPA, 1991], the maximum consumption rate that should be used for determining risk to the recreational fisherman is 19 kilograms ( 42 pounds) per year. This is the same as the consumption rate used by SRS for demonstrating dose compliance [Hamby, 1991].

The EPA guidance document requires that critical subpopulations and fish species be considered in risk assessments. Currently, there are no known sensitive subpopulations (e.g., Native Americans) in the immediate SRS region who are known to regularly consume whole fish (edible and nonedible portions) as part of their typical diet. Also, there are no known species of fish, such as smelt, in the SRS region of the Savannah River that are commonly eaten whole. Therefore, it is reasonably assumed that the recreational fisherman consumes only the edible (fillet only) portion of the fish caught.

Risk Factors For the EPA method, estimates of potential risk are calculated directly by multiplying the amount of each radionuclide ingested by the appropriate risk (slope) factors provided in EPA's Health Effects Assessment Summary Tables (HEAST) [EPA, 1996]. The HEAST ingestion slope factors are best estimates of potential, age-averaged, lifetime excess cancer incidence (fatal and nonfatal) risk per unit of activity ingested.
For the ICRP-60 method, estimates of potential risk are determined first by calculating a radiation dose attributable to the amount of radionuclides ingested and then multiplying that dose by the ICRP-60 coefficient of risk of severe detriment of 7.3E-07 per mrem [ICRP, 1990]. Stated another way, if a group of $10,000,000$ people each received a radiation dose of $1 \mathrm{mrem}$, during their collective lifetimes there would theoretically be 7.3 additional severe detrimental incidences (fatal/nonfatal cancer or severe hereditary effects), which is small compared to the $2,000,000$ or more expected fatal cancer incidences from other causes during their lifetimes [BEIR V, 1990].

The ICRP-60 risk coefficient includes factors for

- fatal cancers $(5.0 \mathrm{E}-07$ per mrem)

- nonfatal cancers (1.0E-07 per mrem)

- hereditary effects (1.3E-07 per mrem)

Exposure Duration According to guidance provided by EPA, the upper bound value of 30 years can be used for exposure duration when calculating reasonable maximum residential exposures. However, the guidance states that other site-specific exposure durations may be used at the discretion of the risk assessor. This assessment compares the potential risks of exposure durations of 1 year, 30 years, and 50 years. The 30-year and 50-year exposure duration risks are simply 30 times and 50 times the 1-year exposure duration risk, respectively.

Risk Comparisons The maximum potential lifetime risks from the consumption of SRS creek mouth fish for 1-year, 30-year, and 50-year exposure durations are shown in table 7-6. Also shown are the potential radiation doses. For each year, the maximum recreational fisherman dose was caused by the consumption of bass collected at the mouth of Steel Creek. More than 98 percent of the doses are attributable to cesium- 137 .

Table 7-6 includes a comparison of radiation risks associated with the DOE Order 5400.5 all-pathway dose standard of $100 \mathrm{mrem}(1.0 \mathrm{mSv})$ per year. The associated EPA-method risks were determined using the slope factor for cesium- 137 .

As indicated in table 7-6, for the ICRP-60 method, the 50-year maximum potential lifetime risks from consumption of SRS creek mouth fish range between $4.4 \mathrm{E}-05$ and $6.2 \mathrm{E}-05$, which are below the 50-year risk associated with the dose standard.

According to EPA practice, if a potential risk is calculated to be less than $1.0 \mathrm{E}-06$ (i.e., one additional case of cancer over what would be expected in a group of $1,000,000$ people), then the risk is 
Table 7-6

Potential Lifetime Risks from the Consumption of Savannah River Fish Compared to Dose Standards (1993-1996)

\begin{tabular}{|c|c|c|c|}
\hline & $\begin{array}{l}\text { Committed } \\
\text { Dose (mrem) }\end{array}$ & $\begin{array}{l}\text { ICRP-60 } \\
\text { Risk Method }\end{array}$ & $\begin{array}{l}\text { EPACERCLA } \\
\text { Risk Method }\end{array}$ \\
\hline \multicolumn{4}{|c|}{1996 Savannah River Fish } \\
\hline 1-Year Exposure & 1.7 & $1.2 E-06$ & $1.1 E-06$ \\
\hline 30-Year Exposure & 51 & 3.7E-05 & 3.3E-05 \\
\hline 50-Year Exposure & 85 & $6.2 \mathrm{E}-05$ & $5.5 \mathrm{E}-05$ \\
\hline \multicolumn{4}{|c|}{1995 Savannah River Fish } \\
\hline 1-Year Exposure & 1.2 & $8.8 E-07$ & $7.4 E-07$ \\
\hline 30-Year Exposure & 36 & $2.6 \mathrm{E}-05$ & 2.2E-05 \\
\hline 50-Year Exposure & 60 & 4.4E-05 & 3.7E-05 \\
\hline \multicolumn{4}{|c|}{1994 Savannah River Fish } \\
\hline 1-Year Exposure & 1.3 & $9.5 E-07$ & 8.2E -07 \\
\hline 30-Year Exposure & 39 & $2.8 \mathrm{E}-05$ & $2.5 E-05$ \\
\hline 50-Year Exposure & 65 & $4.7 E-05$ & $4.1 E-05$ \\
\hline \multicolumn{4}{|c|}{1993 Savannah River Fish } \\
\hline 1-Year Exposure & 1.3 & $9.5 \mathrm{E}-07$ & $7.9 \mathrm{E}-07$ \\
\hline 30-Year Exposure & 39 & $2.8 E-05$ & $2.4 E-05$ \\
\hline 50-Year Exposure & 65 & $4.7 E-05$ & $4.0 \mathrm{E}-05$ \\
\hline \multicolumn{4}{|l|}{ Dose Standard } \\
\hline \multicolumn{4}{|c|}{ 100-mrem/year All Pathway } \\
\hline 1-Year Exposure & 100 & $7.3 E-05$ & $6.3 E-05$ \\
\hline 30-Year Exposure & 3,000 & $2.2 E-03$ & $1.9 E-03$ \\
\hline 50-Year Exposure & 5,000 & $3.7 E-03$ & $3.2 E-03$ \\
\hline
\end{tabular}

considered minimal and the corresponding contaminant concentrations are considered negligible. If a calculated risk is greater than 1.0E-04 (one additional case of cancer in a population of 10,000), then some form of corrective action or remediation usually is required. However, if a calculated risk falls between $1.0 \mathrm{E}-04$ and $1.0 \mathrm{E}-06$, which is the case with the maximum potential lifetime risks from the consumption of Savannah River fish, then the risks are considered acceptable if they are kept as low as reasonably achievable (ALARA).

At SRS, the following programs are in place to ensure that the potential risk from site radioactive liquid effluents (and, therefore, from consumption of Savannah River fish) are kept ALARA:

- radiological liquid effluent monitoring program (chapter 5)

- radiological environmental surveillance program (chapter 6)
- environmental ALARA program [SRS EM Program, 1996]

\section{Dose to Aquatic Animal Organisms}

DOE Order 5400.5 establishes an interim dose standard for protection of native aquatic animal organisms. The absorbed dose limit to these organisms is 1 rad per day (0.01 Gy per day) from exposure to radioactive material in liquid effluents released to natural waterways.

Hypothetical doses to aquatic biota in SRS streams are calculated annually to demonstrate compliance with this 1-rad-per-day (0.01-Gy-per-day) dose standard. Upper-limit doses are calculated with measured radioactivity transport and minimum flow rates for each surface stream. Flow rates are chosen to maximize the biota dose. Source terms (stream transport) are provided by the site's Environmental Monitoring Section (EMS) [SRS Data, 1997]. 
The CRITR computer code [Soldat et al., 1974], incorporated as part of the LADTAPII code, calculates internal and external doses to aquatic biota and to higher trophic levels that depend on aquatic biota for food. The CRITR Code is one of the three aquatic biota dose codes recommended by $\mathrm{DOE}$ [DOE, 1991]. External doses are calculated with the same external dose factors used for man [DOE, 1988]. Internal doses are based on the physical size of the biota (effective radius) and on effective energies provided for each radionuclide for each radius. The maximum dose to biota was estimated at $0.019 \mathrm{rad}$ per day ( 0.00019 Gy per day), which occurred in ducks in Four Mile Creek. This is 1.9 percent of the 1-rad-per-day (0.01-mGy-per-day) DOE dose limit.

\section{Radiological Assessment Program}

The preparation of documents describing the effects of SRS operations on the environment began in 1988. The format chosen was a separate document for each major radionuclide or group of similar radionuclides. The documents describe the operating history of the site with respect to the production, storage, and release of each radionuclide. The transport of the radionuclide in air, surface water, and groundwater is explained, and a calculation of the dose estimate to individuals and the population surrounding SRS is presented. As of December 31, 1996, the following 11 documents had been published ${ }^{\mathrm{a}}$ :
- Assessment of Tritium in the Savannah River Site Environment, WSRC-TR-93-214

- Cesium in the Savannah River Site Environment, WSRC-RP-92-250

- Uranium in the Savannah River Site Environment, WSRC-RP-92-315

- Radioiodine in the Savannah River Site Environment, WSRC-RP-90-424-2

- Assessment of Radiocarbon in the Savannah River Site Environment, WSRC-TR-93-215

- Assessment of Technetium in the Savannah River Site Environment, WSRC-TR-93-217

- Assessment of Strontium in the Savannah River Site Environment, WSRC-RP-92-984

- Plutonium in the Savannah River Site Environment, WSRC-RP-92-879, Rev. 1

- Assessment of Mercury in the Savannah River Site Environment, WSRC-TR-94-0218ET

- Assessment of Noble Gases in the Savannah River Site Environment, WSRC-TR-95-0219

- Assessment of Activation Products in the Savannah River Site Environment, WSRCTR-95-0422

A document for selected fission products is scheduled for publication in 1997.

a Copies of these documents can be obtained from the National Technical Information Service, U.S. Department of Commerce, 5285 Port Royal Road, Springfield, VA 22161. 


\author{
Carl Cook, Larry Eldridge, \\ and Stuart Stinson \\ Environmental Protection Department
}

$\mathrm{N}$ ONRADIOACTIVE air emissions originating at Savannah River Site (SRS) facilities are monitored at their points of discharge by direct measurement, sample extraction and measurement, or process knowledge. Air monitoring is used to determine whether all emissions and ambient concentrations are within applicable regulatory standards.

Nonradiological liquid effluent monitoring encompasses sampling and analysis and is performed by the Environmental Protection Department's Environmental Monitoring Section (EMS) and the Savannah River Technology Center (SRTC).

A complete description of EMS sampling and analytical procedures used for nonradiological monitoring can be found in sections 1101-1111 (SRS EM Program) of the Savannah River Site Environmental Monitoring Section Plans and Procedures, WSRC-3Q1-2, Volume 1, which was issued in June 1995. A summary of data results is presented in this chapter; more complete data can be found in SRS Environmental Data for 1996 (WSRC-TR-97-0077).

\section{Airborne Emissions}

The South Carolina Department of Health and Environmental Control (SCDHEC) regulates nonradioactive air emissions-both criteria pollutants and toxic air pollutants-from SRS sources. Each source is permitted by SCDHEC, with specific limitations identified, as outlined in various South Carolina air pollution control regulations and standards. Many of the applicable standards are source dependent, i.e., Emissions from Fuel Burning Operations, Waste Combustion and Reduction, Emissions from Process Industries, etc. However, the primary standards that govern all sources for criteria air pollutants and ambient air quality are identified in SCDHEC Air Pollution Control Regulation 61-62.5,

\section{Table 8-1 \\ Nonradiological Airborne Emissions Standards for SRS Coal-Fired Boilers}

Sulfur dioxide

Total suspended particulates Opacity

\section{$3.5 \mathrm{lb} / 10^{6} \mathrm{BTU}^{\mathrm{a}}$ \\ $0.6 \mathrm{lb} / 10^{6} \mathrm{BTU}$ $40 \%$}

Standard No. 2, and Regulation 61-62.5, Standard No. 8, for toxic air pollutants. Standard No. 2 lists eight criteria air pollutants commonly used as indices of air quality (e.g., sulfur dioxide, nitrogen dioxide, and lead) and provides an allowable site boundary concentration for each pollutant. Standard No. 8 identifies 257 toxic air pollutants and their respective allowable site boundary concentrations. Specific permits for operating facilities are listed in appendix B, "SRS Environmental Permits."

Airborne emission standards for each SRS permitted source may differ, based on size and type of facility, type and amount of expected emissions, and the year the facility was placed into operation. For example, for powerhouse boilers constructed before February 11,1971 , the particulate emission limit is 0.6 pounds per million BTU (British thermal unit) of boiler fuel heat input. Boilers constructed after 1971 must meet more stringent standards, identified in 40 CFR 60 , "New Source Performance Standards," in addition to the SCDHEC requirements. For process and diesel engine stacks in existence prior to January 1, 1986, and powerhouse stacks built before February 11, 1971 , the opacity standard is 40 percent. For new sources placed into operation after these dates, the opacity standard typically is 20 percent. Table $8-1$ shows typical standards for criteria pollutants from SRS coal-fired boilers, which were built before 1971 . 
At SRS, there are 192 permitted/exempted nonradiological air emission sources, 155 of which were in operation in some capacity during 1996 . The remaining 39 sources either were being maintained in a "cold standby" status or were under construction.

\section{Description of Monitoring Program}

Major nonradiological emissions of concern from stacks at SRS facilities include sulfur dioxide, carbon monoxide, oxides of nitrogen, particulate matter smaller than 10 microns, volatile organic compounds, and toxic air pollutants. Stacks that have such emissions at SRS include those associated with diesel engine-powered equipment, package steam generators, powerhouse boilers, the Defense Waste Processing Facility (DWPF), the in-tank precipitation process, groundwater air strippers, and various other process facilities. Emissions from SRS sources are determined during an annual emissions inventory from calculations using source operating parameters such as fuel oil consumption rates, total hours of operation, and the emission factors provided in EPA's "Compilation of Air Pollution Emission Factors," AP-42. The calculation for boiler sulfur dioxide emissions also uses the average sulfur content of the coal and assumes 100 percent liberation of sulfur and 100 percent conversion to sulfur dioxide. Most of the processes at SRS are nonstandard-type sources requiring complex calculations that use process chemical or material throughputs, hours of operation, chemical properties, etc., to determine actual emissions. In addition to the annual emissions inventory, compliance with various standards is determined in several ways, as follows:

At the SRS powerhouses, stack compliance tests are performed every 2 years for each boiler by airborne emission specialists under contract to SRS. The tests include

- sampling of the boiler exhaust gases to determine particulate emission rates and carbon dioxide and oxygen concentrations

- laboratory analysis of coal for sulfur content, ash content, moisture content, and BTU output

Sulfur content and BTU output are used to calculate sulfur dioxide emissions. SCDHEC also conducts visible-emissions observations during the tests to verify compliance with opacity standards. The day-to-day control of particulate matter smaller than 10 microns is demonstrated by opacity meters in all SRS powerhouse stacks.

For the package steam generating boilers in K-Area and P-Area, compliance with sulfur dioxide standards is determined by analysis of the fuel oil purchased from the offsite vendor. The percent of sulfur in the fuel oil must be below 0.5 and is reported to SCDHEC each quarter. Compliance with particulate emission standards is demonstrated by mass-balance calculations rather than stack emission tests.

Compliance by SRS diesel engines and other process stacks is determined during annual compliance inspections by the local SCDHEC district air manager. These inspections include a review of operating parameters, an examination of continuous-emission monitors (where required for process or boiler stacks), and a visible-emissions observation for opacity.

Compliance by all toxic air pollutant and criteria pollutant sources also is determined by using U.S. Environmental Protection Agency (EPA)-approved air dispersion models. Air dispersion modeling is extremely conservative unless refined models are used. The Industrial Source Complex Version No. 2 model was used to predict maximum ground-level concentrations occurring at or beyond the site boundary for new sources permitted during 1996. Some site sources of toxic air pollutants also are required to be stack tested every 2 years.

\section{Monitoring Results}

As noted earlier, emissions are calculated each year as part of an annual emissions inventory. In 1996, operating data were compiled and emissions were calculated for 1995 operations for all site air emission sources. Because this process, which begins in January, requires up to 6 months to complete, this report will provide a more comprehensive examination of total 1995 emissions, with only limited discussion of available 1996 monitoring results. Actual emissions for 1996 will be compiled and reported in depth in the SRS Environmental Report for 1997.

Two coal-fired power plants with five boilers are operated by Westinghouse Savannah River Company (WSRC) at SRS. The location, number of boilers, and capacity of each boiler for these plants are listed in table 8-2. The A-Area and $\mathrm{H}$-Area boilers are overfeed stoker fed and use coal as their only fuel. The A-Area No. 1, H-Area No. 1, and H-Area No. 3 boilers were stack tested in 1996 . The results are

Table 8-2

SRS Power Plant Boiler Capacities

\begin{tabular}{lcc}
\hline Location & $\begin{array}{l}\text { Number of } \\
\text { Boilers }\end{array}$ & $\begin{array}{c}\text { Capacity } \\
\text { (BTU/hr) }\end{array}$ \\
A-Area & 2 & $71.7 \mathrm{E}+06$ \\
H-Area & 3 & $71.1 \mathrm{E}+06$ \\
\hline
\end{tabular}


Table 8-3

Boiler Stack Test Results (D-Area, A-Area)

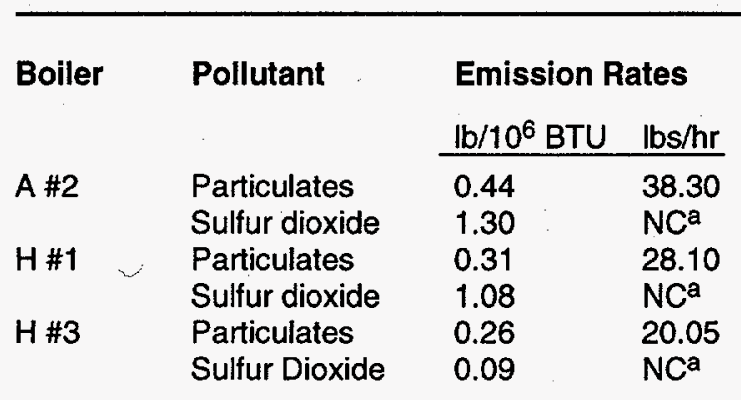

a Not calculated

shown in table 8-3, and all are within the required emission standards presented in table 8-1.

SRS also has four package steam generating boilers fired by No. 2 fuel oil. These boilers are used primarily to heat buildings during cold weather. If necessary, they are used during process facility operation. The location, number of boilers, and capacity of each boiler are shown in table 8-4. During 1996 only the $76.8-$ and $38.0-\mathrm{mmBTU} / \mathrm{hr}$ boilers were operated. The percent of sulfur in the fuel oil burned during the year was certified by the vendor to meet the requirements of the permit.

At SRS, 125 permitted sources, both portable and stationary, are powered by internal combustion diesel engines. These sources include portable air compressors, diesel generators, emergency cooling water pumps, and fire water pumps ranging in size from 150 to 2050 kilowatts for generators and 200 to 520 horsepower for air compressor and pump engines. Fuel oil consumption for the diesel engines operated in 1996 was 805,425 gallons. Total fuel consumption for 1996 will be included in the report for calendar year 1997.

Another significant source of criteria pollutant emissions at SRS is the burning of forestry areas across the site. The Savannah River Forest Station (SRFS), a unit of the U.S. Department of Agriculture

Table 8-4

SRS Package Steam Boiler Capacities

\begin{tabular}{lcc}
\hline Location & $\begin{array}{c}\text { Number of } \\
\text { Boilers }\end{array}$ & $\begin{array}{l}\text { Capacity } \\
\text { (BTU/hr) }\end{array}$ \\
K-Area & 1 & $76.8 \mathrm{E}+06$ \\
K-Area & 1 & $38.0 \mathrm{E}+06$ \\
Portable & 2 & $17.0 \mathrm{E}+06$ \\
\hline
\end{tabular}

Table 8-5

1995 Criteria Pollutant Air Emissionsa

\section{Pollutant Name}

Actual Tons/Year

Sulfur dioxide

Total suspended particulates

$8.73 E+02$

PM10 (particulate matter $<10$ microns)

Carbon monoxide

$2.41 \mathrm{E}+00$

Ozone (volatile organic compounds)

$2.25 \mathrm{E}+02$

$4.21 E+03$

$5.05 \mathrm{E}+04$

Gaseous fluorides (as hydrogen fluoride) 1.47E-01

Nitrogen dioxide (NOX)

Lead

$5.21 \mathrm{E}+02$

$1.49 \mathrm{E}-02$

a From all SRS sources (permitted and nonpermitted)

Forest Service, periodically conducts controlled burning of vegetation and undergrowth as a means of preventing uncontrolled forest fires. During 1995, SRFS personnel burned a total of 15,593 acres across the site.

Other sources of criteria pollutants, such as sulfur dioxide, oxides of nitrogen, carbon monoxide, particulate matter, and volatile organic compounds, at SRS are too numerous to discuss here by type. Table $8-5$ provides the 1995 atmospheric emissions results for all permitted SRS sources, as determined by the air emissions inventory conducted in 1996. All calculated emissions were within applicable SCDHEC standards and permit limitations during 1995.

Thirty-five of the SRS permitted sources are permitted for toxic air pollutants; 29 of these were operated during 1996. Only eight of the operable toxic air pollutant sources are required to be stack tested. During 1996, two air stripper units and one soil vapor extraction/catalytic oxidation unit were stack tested to determine compliance with their respective permitted emission rates. Table $8-6$ shows the test results and the permitted emission rates. The results indicate that all permit limits have been met.

Total toxic air pollutant emissions at SRS are determined annually in tons per year for each pollutant [SRS Data, 1997]. It should be noted that some toxic air pollutants regulated by SCDHEC also are, by nature, volatile organic compounds (VOCs). As such, the total for VOCs in table 8-5 includes toxic air pollutant emissions.

\section{Ambient Air Quality}

SRS does not conduct onsite monitoring for ambient air quality; however, as a result of regulatory requirements, the site is required to show compliance with various air quality standards. To accomplish this, 
Table 8-6

Soil Vapor Extraction Unit (SVEU)/Catalytic Oxidation Stack Test Results

\begin{tabular}{llcc}
\hline SVEU & Pollutant & $\begin{array}{l}\text { Result } \\
\text { Ib/hr }\end{array}$ & $\begin{array}{r}\text { Permitted } \\
\text { Emission } \\
\text { Ib/hr }\end{array}$ \\
A-2 & HCL & 0.150 & 4.000 \\
& PCE & 0.028 & 6.400 \\
M-1 & TCE & 0.017 & 6.400 \\
& HCL & 1.380 & 5.612 \\
$782-7 M$ & PCE & 0.106 & 0.122 \\
& TCE & 0.064 & 0.214 \\
& HCL & 0.250 & 3.750 \\
& PCE & 0.061 & 0.130 \\
& TCE & 0.010 & 0.100 \\
\hline
\end{tabular}

air dispersion modeling was conducted during 1996 for new emission sources as part of the sources' construction permitting process. The modeling analysis showed that SRS air emission sources were in compliance with applicable regulations.

South Carolina and Georgia continue to monitor ambient air quality near SRS as part of the network associated with the Clean Air Act.

\section{Liquid Discharges}

\section{Description of Monitoring Program}

From January 1 through September 30, 1996, SRS discharged water into site streams and the Savannah River under four NPDES permits: two for industrial wastewater (SC0000175 and SC0044903) and two for stormwater runoff-SCR000000 (industrial discharge) and SCR100000 (construction discharge). A fifth NPDES permit-a no-discharge permit (ND0072125) - was issued to cover land application of sludge generated at onsite sanitary waste treatment plants. Industrial permit SC0000175 expired in 1988 and industrial permit SC0044903 expired in November 1995, but because SRS had applied for a new NPDES permit, discharges were allowed to continue under the expired permits until October 1 , 1996, when the new permit (also numbered SC0000175) was issued. The new permit, which will not expire until September 30,2001, includes the discharge points covered under the two expired industrial permits (SC0000175 and SC0044903).

Stormwater industrial permit SCR000000 covers 48 discharge locations sorted into 11 groups. A representative site from each group was sampled, as required by the permit. Construction permit SCR 100000 does not require sampling unless requested by SCDHEC to address specific discharge issues at a given construction site. SCDHEC did not request any such sampling in 1996.

NPDES discharge points are sampled according to applicable permit requirements. The samples are preserved in the field according to 40 CFR 136 , the federal document that lists specific sample collection, preservation, and analytical methods acceptable for the type of pollutant to be analyzed. Chain-of-custody procedures are followed after collection and during transport to the analytical laboratory. The samples then are accepted by the laboratory and analyzed according to procedures listed in 40 CFR 136 for the parameters required by the permit.

The effectiveness of the NPDES monitoring program is documented by a surveillance program involving chemical and biological evaluation of the waters to which effluents have been discharged. More monitoring information can be found in chapters 9 , "Nonradiological Environmental Surveillance," and 12 ,"Special Surveys and Projects."

\section{Monitoring Results}

SRS reports analytical results to SCDHEC through a monthly discharge monitoring report, which includes a list of exceedances or locations at which analyses showed the discharge did not meet permit requirements.

From January 1 through September 30, 1996 (under the expired NPDES permits), 68 of the 83 permitted outfalls discharged; 11 did not discharge; and 4 were not in service. From October 1 through December 31, 1996 (under the new permit), 34 of 37 permitted outfalls discharged and three did not discharge. Results from 14 of the 5,737 discharge-sample analyses performed during 1996 exceeded permit limits because of process upsets-such as overheated UV light bulbs, which caused erosion of galvanized pipes at Outfall G-010). Even with these exceedances, the site achieved a 99.8-percent compliance rate-higher than the 98-percent rate mandated by DOE. A list of the 1996 exceedances under the old permits appears in table 8-7, beginning on page 126; exceedances under the new permit appear in table 8-8, page 127. Figure 8-1 shows the NPDES exceedances at SRS from 1986 through 1996. SCDHEC has not mandated permit limits for stormwater outfalls. 
Number

of Exceedances

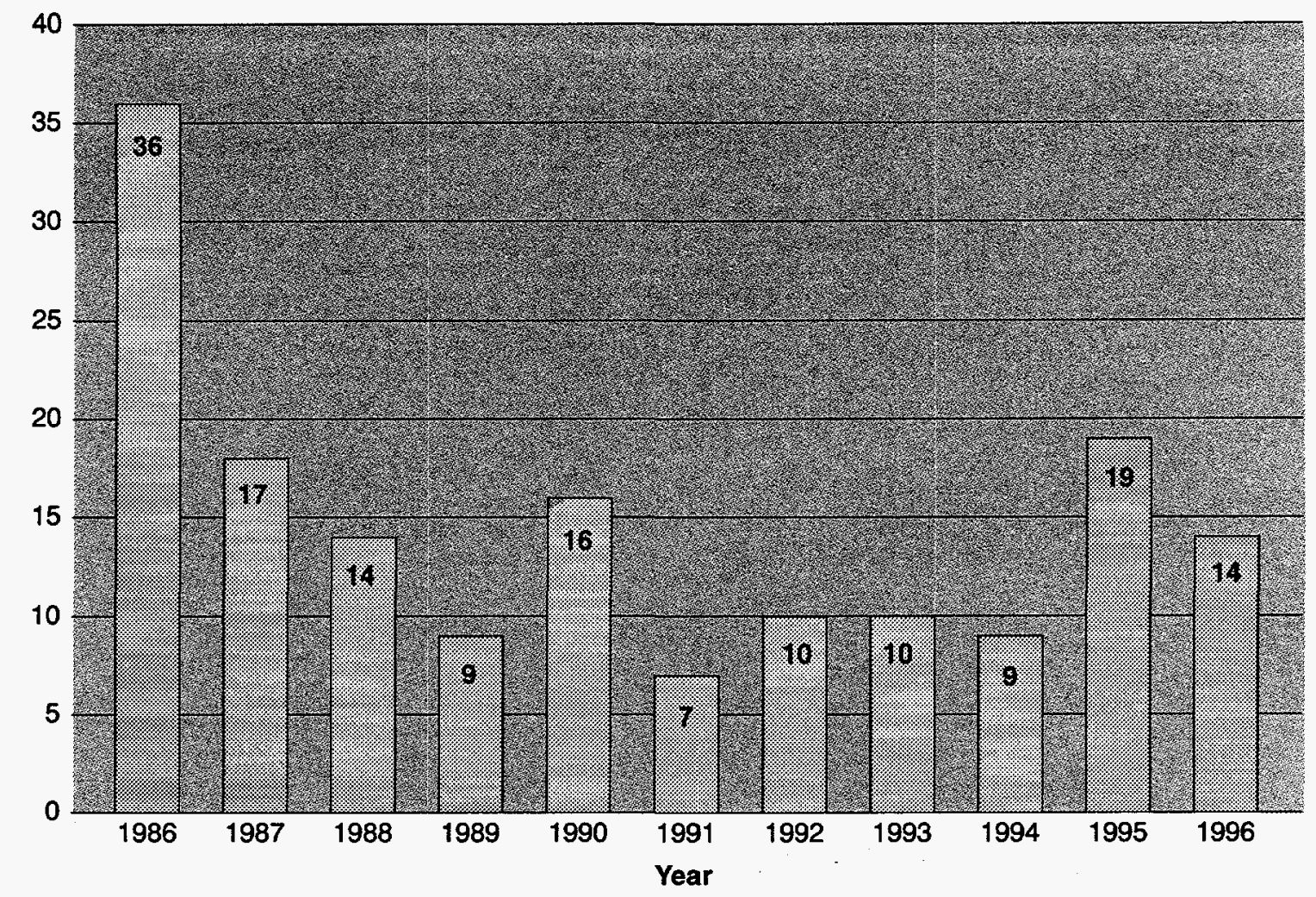

Number of Analyses

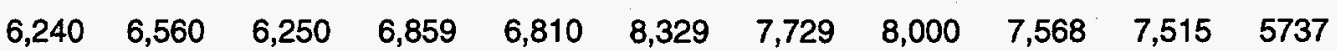

Compliance Rate

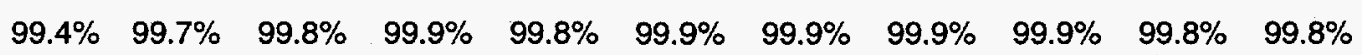

Ileaf Graphic

Figure 8-1 History of NPDES Exceedances, 1986-1996

To determine the compliance rate, the number of analyses not exceeding limits for a given year is divided by the total number of analyses. For example, 5,737 analyses were performed in 1996, with 14 exceedances. To calculate the compliance rate for that year, divide $5,723(5,737$ minus 14$)$ by 5,737 for a quotient of .9975 , or 99.8 , percent. 
Table 8-7

1996 NPDES Exceedances Under Old Permits (January 1 through September 30)

Page 1 of 1

\begin{tabular}{|c|c|c|c|c|c|c|}
\hline Department & Outfall & Date & Analysis & Result & Possible Cause & Corrective Action \\
\hline SSD/SUD & $\mathrm{G}-010$ & Jan. 15 & $\begin{array}{l}\text { Acute } \\
\text { Toxicity }\end{array}$ & Fail & Unknown & $\begin{array}{l}\text { None; toxicity } \\
\text { stopped prior to } \\
\text { discovery of source }\end{array}$ \\
\hline SSD/SUD & $\mathrm{G}-010$ & Jan. 17 & $\begin{array}{l}\text { Chronic } \\
\text { Toxicity }\end{array}$ & Fail & Unknown & $\begin{array}{l}\text { None; toxicity } \\
\text { stopped prior to } \\
\text { discovery of source }\end{array}$ \\
\hline SSD/SUD & $G-010$ & Jan. 23 & $\begin{array}{l}\text { Chronic } \\
\text { Toxicity }\end{array}$ & Fail & Unknown & $\begin{array}{l}\text { None; toxicity } \\
\text { stopped prior to } \\
\text { discovery of source }\end{array}$ \\
\hline CSWE & $A-005$ & Feb. 27 & TSS & 45 mg/L (avg) & Unknown & $\begin{array}{l}\text { None; investigation } \\
\text { revealed no pro- } \\
\text { cess upsets; no } \\
\text { cause determined }\end{array}$ \\
\hline RWMD & $L-008$ & Mar. 4 & TSS & $\begin{array}{l}100 \mathrm{mg} / \mathrm{L} \text { (avg } \\
\text { and } \mathrm{max} \text { ) }\end{array}$ & Unknown & $\begin{array}{l}\text { None; investigation } \\
\text { revealed no pro- } \\
\text { cess upsets; no } \\
\text { cause determined }\end{array}$ \\
\hline ER & $A-01 A$ & May 13 & $\mathrm{pH}$ & $4.3 \mathrm{SU}(\mathrm{min})$ & $\begin{array}{l}\text { Algal reduction } \\
\text { of } T C E \text { and } P C E\end{array}$ & Under investigation \\
\hline SSD/SUD & $\mathrm{G}-010$ & June 12 & $\begin{array}{l}\text { Fecal } \\
\text { coliform }\end{array}$ & $\begin{array}{l}1,960 \mathrm{col} / 100 \\
\mathrm{~mL} \text { (avg and } \\
\max \text { ) }\end{array}$ & $\begin{array}{l}\text { Bulbs over- } \\
\text { heated; fuse } \\
\text { blew }\end{array}$ & $\begin{array}{l}\text { Cleaned intake } \\
\text { screens to ensure } \\
\text { water flow }\end{array}$ \\
\hline SSD/SUD & $G-010$ & July 10 & $\begin{array}{l}\text { Fecal } \\
\text { coliform }\end{array}$ & $\begin{array}{l}1,400 \mathrm{col} / 100 \\
\mathrm{~mL} \text { (avg and } \\
\text { max) }\end{array}$ & $\begin{array}{l}\text { Electrical } \\
\text { problems }\end{array}$ & $\begin{array}{l}\text { Resolved electrical } \\
\text { problems }\end{array}$ \\
\hline RWMD & $\mathrm{P}-013$ & Aug. 9 & O\&G & $\begin{array}{l}58 \mathrm{mg} / \mathrm{L} \text { (avg } \\
\text { and } \max \text { ) }\end{array}$ & $\begin{array}{l}\text { Analytical result } \\
\text { is in question; } \\
\text { duplicate analy- } \\
\text { sis was } \\
<1.0 \mathrm{mg} / \mathrm{L}\end{array}$ & $\begin{array}{l}\text { None; upset attrib- } \\
\text { uted to analytical } \\
\text { error }\end{array}$ \\
\hline
\end{tabular}

Key: O\&G - Oil and Grease

PCE - Tetrachloroethylene

SU - Standard Units

TCE - Trichloroethylene

TSS - Total Suspended Solids 
Table 8-8

1996 NPDES Exceedances Under New Permit (October 1 through December 31)

Page 1 of 1

\begin{tabular}{|c|c|c|c|c|c|c|}
\hline Department & Outfall & Date & Analysis & Result & Possible Cause & Corrective Action \\
\hline SSD/SUD & $D-1 A$ & Oct. 16 & $\begin{array}{l}\text { Fecal } \\
\text { coliform }\end{array}$ & $\begin{array}{l}8,000 \mathrm{col} / 100 \\
\mathrm{~mL}\end{array}$ & $\begin{array}{l}\text { UV bulbs } \\
\text { burned out }\end{array}$ & UV bulbs replaced \\
\hline SSD/SUD & $D-1 A$ & Oct. 17 & $\begin{array}{l}\text { Fecal } \\
\text { coliform }\end{array}$ & $\begin{array}{l}1,800 \mathrm{col} / 100 \\
\mathrm{~mL}\end{array}$ & $\begin{array}{l}\text { UV bulbs } \\
\text { burned out }\end{array}$ & UV bulbs replaced \\
\hline SSD/SUD & $K-12$ & Nov. 16 & Flow & $\begin{array}{l}0.025 \text { MGD } \\
(\max )\end{array}$ & $\begin{array}{l}\text { Two flush valves } \\
\text { stuck open }\end{array}$ & Valves fixed \\
\hline LOD & $x-04$ & Dec. 5 & $\mathrm{pH}$ & $4.6 \mathrm{SU}$ & $\begin{array}{l}\text { Stormwater } \\
\text { pumped to outfall }\end{array}$ & $\begin{array}{l}\text { Check sump pH } \\
\text { prior to discharge }\end{array}$ \\
\hline SEP & $F-08$ & Dec. 11 & TSS & $100 \mathrm{mg} / \mathrm{L}(\mathrm{min})$ & $\begin{array}{l}\text { Well cleaning } \\
\text { wastewater } \\
\text { discharged } \\
\text { to outfall }\end{array}$ & $\begin{array}{l}\text { Well cleaning } \\
\text { discharges routed } \\
\text { to sanitary sewer }\end{array}$ \\
\hline
\end{tabular}

Key: MGD - Millions of Gallons per Day

SU - Standard Units

TSS - Total Suspended Solids 



\title{
Nonradiological Environmental Surveillance
}

\author{
Bill Littrell and Stuart Stinson \\ Environmental Protection Department \\ Robert Turner \\ Engineering Services Department
}

Surface Water .................. 129

Drinking Water .................. 130

Sediment..................... 132

Fish ........................ 132

$\mathrm{N}$ ONRADIOACTIVE environmental surveillance at the Savannah River Site (SRS) involves the sampling and analysis of surface waters (six onsite streams and the Savannah River), drinking water, sediment, groundwater, and fish. A description of the surveillance program and 1996 results for groundwater can be found in chapter 10 , "Groundwater."

The Environmental Protection Department's Environmental Monitoring Section (EMS) and the Savannah River Technology Center (SRTC) perform nonradiological surveillance activities. The Savannah River also is monitored by other groups, including the South Carolina Department of Health and Environmental Control (SCDHEC) and the Georgia Department of Natural Resources (GDNR). In addition, the Academy of Natural Sciences of Philadelphia conducts special environmental surveys on the Savannah River through a program that began in 1951. The Academy's studies for 1996 are discussed in chapter 12, "Special Surveys and Projects."

A complete description of the EMS sample collection and analytical procedures used for nonradiological surveillance can be found in section 1105 of the Savannah River Site Environmental Monitoring Section Plans and Procedures, WSRC-3Q1-2, Volume 1 (SRS EM Program), which was issued in June 1995. A summary of data results is presented in this chapter; however, more complete data can be found in SRS Data for 1996 (WSRC-TR-97-0077). Information on the rationale for the nonradiological environmental surveillance program can be found in chapter 3, "Environmental Program Information."

In 1996, approximately 8,600 nonradiological analyses for specific chemicals and metals were performed on about 1,800 samples, not including groundwater.

SRS currently does not conduct onsite surveillance for ambient air quality. However, to ensure compliance with SCDHEC air quality regulations and standards, SRTC conducted air dispersion modeling for all site sources of criteria and toxic air pollutants in 1993. This modeling indicated that all the SRS sources were in compliance with the air quality regulations and standards. Since that time, additional modeling conducted for new sources of criteria and toxic air pollutants has demonstrated continued compliance by the site with these regulations and standards. The states of South Carolina and Georgia continue to monitor ambient air quality near the site as part of a network associated with the federal Clean Air Act.

\section{Surface Water}

SRS streams and the Savannah River are classified as "Freshwaters" by SCDHEC. Freshwaters are defined as surface water suitable for

- primary-and secondary-contact recreation and as a drinking water source after conventional treatment in accordance with SCDHEC requirements

- fishing and survival and propagation of a balanced indigenous aquatic community of fauna and flora

- industrial and agricultural uses

Appendix A, "Applicable Guidelines, Standards, and Regulations," provides some of the specific guides used in water quality surveillance, but because some of these guides are not quantifiable, they are not tracked in response form (i.e., amount of garbage found). 


\section{Description of Surveillance Program}

EMS samples site streams and the Savannah River monthly for various chemicals, metals, and physical and biological properties to ensure that water quality criteria are met [SRS EM Program, 1995]. Stream nonradiological surveillance is conducted for any evident degradation that could be attributed to the water discharges regulated by site National Pollutant Discharge Elimination System (NPDES) permits. This also helps detect materials that may be released inadvertently from sources other than routine release points.

Each SRS stream receives varying amounts of treated wastewater and rainwater runoff from site facilities. Stream locations are sampled for water quality at weekly and monthly frequencies by the conventional grab-collection technique. Each grab sample shows the water quality at the time of sampling only.

River sampling sites are located upriver of, adjacent to, and downriver of the site to compare the SRS contribution of pollutants with background levels of chemicals from natural sources and from coniaminants produced by municipal sewage plants, medical facilities, and other upriver industrial facilities. Nonradiological surveillance of the river also checks for any degradation that could be attributed to the water discharges regulated by site NPDES permits.

To monitor the water quality and to ensure that water quality criteria are met, field measurements for conductivity, dissolved oxygen, $\mathrm{pH}$, and temperature are taken monthly and laboratory analyses are conducted for other water quality parameters, such as metals, chemicals, and physical and biological properties.

During 1996, changes in the nonradiological water quality surveillance program were implemented following a comprehensive review of the SRS environmental monitoring program. This review, known as "Rock Hill Initiative \#2," is discussed in chapter 3 . The review resulted in a change in the number of sampling locations from 7 stream and 2 river to 11 stream and 5 river, effective September 1.

Pesticides and herbicides have been monitored at SRS since 1976 to assess their concentrations in surface waters from site streams and the Savannah River. Prior to the Rock Hill review, annual water samples from seven stream and two river locations were analyzed for 21 pesticides and herbicides. These samples had not been collected in 1996 prior to the review, and the review discontinued these annual samples/analyses.

However, EMS samples from four SCDHEC stream locations were analyzed monthly in 1996 (until September) for the same pesticides and herbicides and also for three volatile organic compounds. Under the new program, pesticides will be analyzed quarterly at all surveillance locations. Because of an error during implementation of the new program, fourth quarter samples were not collected.

Surface water sampling locations are shown in figure 9-1.

\section{Surveillance Results}

The 1996 water quality data showed normal fluctuations expected for surface water. Comparison of the 1996 data with published historical data for site surface water monitoring did not indicate any abnormal deviations from past monitoring data. Analysis for pesticides, herbicides, and volatile organic compounds yielded positive results for a pesticide (dieldrin) at one location (Four Mile Creek-A7). All other analyses results were below detection limits. Coliform analysis results exceeded recommended standards 20 times in 1996 (17 in site streams and 3 in the river). The exceedances decreased in number from 1995, when site streams analysis results exceeded guides 36 times and river analysis results exceeded guides 13 times.

\section{Drinking Water}

\section{Description of Surveillance Program}

All 26 drinking water systems at SRS utilize well water pumped from the McBean, Congaree, Black Creek, and Middendorf formations. Some of the well water supplies require treatment to meet SCDHEC drinking water quality standards. Sodium hydroxide or soda ash is added for $\mathrm{pH}$ control, sodium hypochlorite for bacteriological control, and phosphates for corrosion control.

The following testing is performed to ensure compliance with SCDHEC water quality standards:

- The concentrations of chemicals added are monitored at least daily.

- All systems are monitored either monthly or quarterly for total coliform bacteria. The sampling frequency depends upon the population served.

- All systems are monitored semiannually for chlorocarbon concentrations.

- The 13 larger systems are monitored for lead and copper concentrations. The sampling fre- 


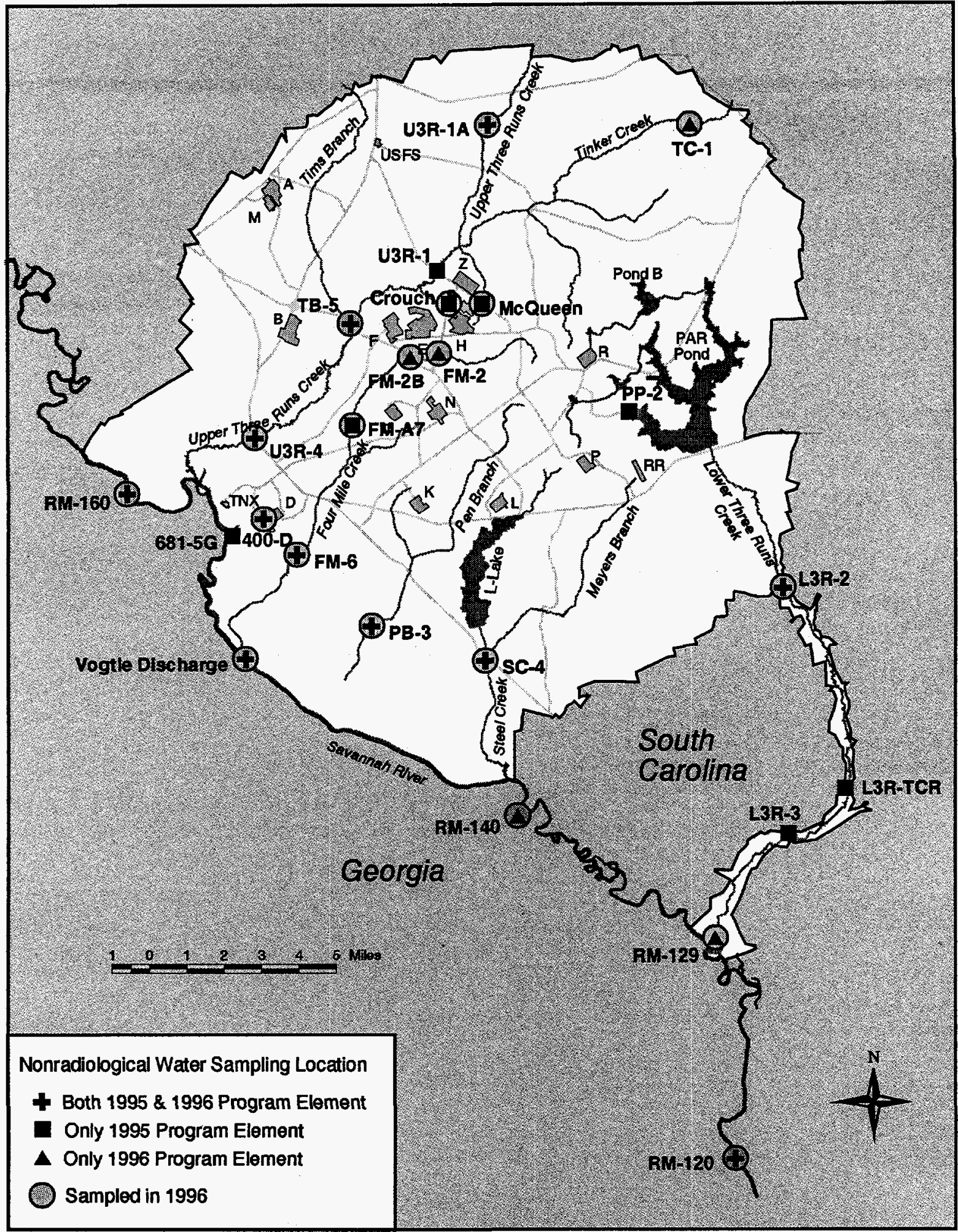

EPD/GIS Map

Figure 9-1 Nonradiological Surface Water Sampling Locations

Surface water samples are collected from Savannah River and SRS stream locations. Steel Creek-4 (SC-4), Tims Branch-5 (TB-5), Four Mile Creek at Road A7 (FM-A7), and Upper Three Runs-4 (U3R-4) are EMS and SCDHEC sampling locations, from which samples also are analyzed for volatile organic compounds. 
quency varies from annually to once every 3 years, depending upon SCDHEC requirements.

- SCDHEC periodically collects samples from the 18 largest systems to determine compliance with bacteriological, chemical, synthetic organic, and volatile organic water quality limits.

\section{Surveillance Results}

All SRS drinking water systems were in compliance with SCDHEC bacteriological, lead and copper, chemical, synthetic organic, and volatile organic water quality standards in 1996.

\section{Sediment}

EMS's nonradiological sediment surveillance program provides a method of determining the deposition, movement, and accumulation of nonradiological contaminants in stream systems.

\section{Description of Surveillance Program}

The surveillance of pesticides and herbicides and of inorganic contaminants, such as metals, make up the two major activities of the nonradiological sediment surveillance program.

Pesticides and herbicides were used at the location of SRS before 1950, when the U.S. Government obtained the land. Pesticides and herbicides also have been used since then as part of the site's forestry management program and for ongoing landscape and roadside maintenance.

A pesticide and herbicide surveillance program was established in 1976 to ensure that there is no buildup of these materials in the sediments of site streams or the Savannah River. Sediment samples from seven site stream and two Savannah River locations were

Perspective on mercun

Wercurint te envionment can come from natural sources. such as volkanoes and Veniting of the earths erust, and trom manmade sources and processes, such as tingicides and tossit tuel conbustion byproduets and the nanufacture of chlorine, sodium hydroxide, plastics, and electi. ealapparatus

Ar iripontant source in the SRS region nay bo in releases upriver ol the sito. Mich of the merculy gefected in SRS ish has been altibuited to ofsite sources such as Savannah hiver Water leavis et at. 19891. Savannah River water is pumped onto the site tor use as coding water and subsequenty is released into sitestreams and lates: to be analyzed for pesticides and herbicides during 1996. Due to error, samples from two site stream and the two river locations were not analyzed for pesticides and herbicides [SRS Data, 1997].

The inorganics area of the program was designed in 1993 to document the buildup, if any, of inorganic contaminants over time. Sampling locations were chosen at six site streams, two Savannah River locations, and three background locations (two stream locations and one river location). However, in 1996, one stream location, U3R-1, inadvertently was sampled in place of a river location (Vogtle Discharge). Sediment sampling locations are shown in figure 9-2.

"Rock Hill Initiative \#2," discussed on page 130, brought about changes in the nonradiological sediment sampling program. This review resulted in a change in sampling locations to $11-8$ stream and 3 river. The changes will be instituted in 1997.

\section{Surveillance Results}

No pesticides or herbicides were found to be above the practical quantitation limits in 1996 in sediment samples. All sample results were below the detection limits of the U.S. Environmental Protection Agency (EPA) analytical procedures used. All inorganic contaminants results were within normal fluctuations.

\section{Mercury in Fish}

Mercury is a naturally occurring metal that cycles between land, water, and air. The major sources of atmospheric mercury are as follows:

- Natural - Degassing of the earth's crust generates 2,700 to 6,000 tons of mercury a year (WHO, 1990).

- Manmade - Burning of fossil fuels releases an estimated 5,000 tons of mercury per year [Klaassen et al., 1986]; industrial and other discharges account for an undetermined amount.

As mercury enters streams and rivers through rainfall, runoff, and discharges, it is converted to the chemical compound methylmercury by bacterial and other processes. As part of the natural cycling, some mercury is absorbed by plants and animals into their tissues. Fish absorb methylmercury from food they ingest and from water as it passes over their gills; the methylmercury then is bound in their tissues.

Consumption, by people, of fish containing methylmercury completes the food cycle to man. The amount of fish that can be safely eaten varies with (1) the level of methylmercury found in the fish, (2) the amount of methylmercury consumed at 


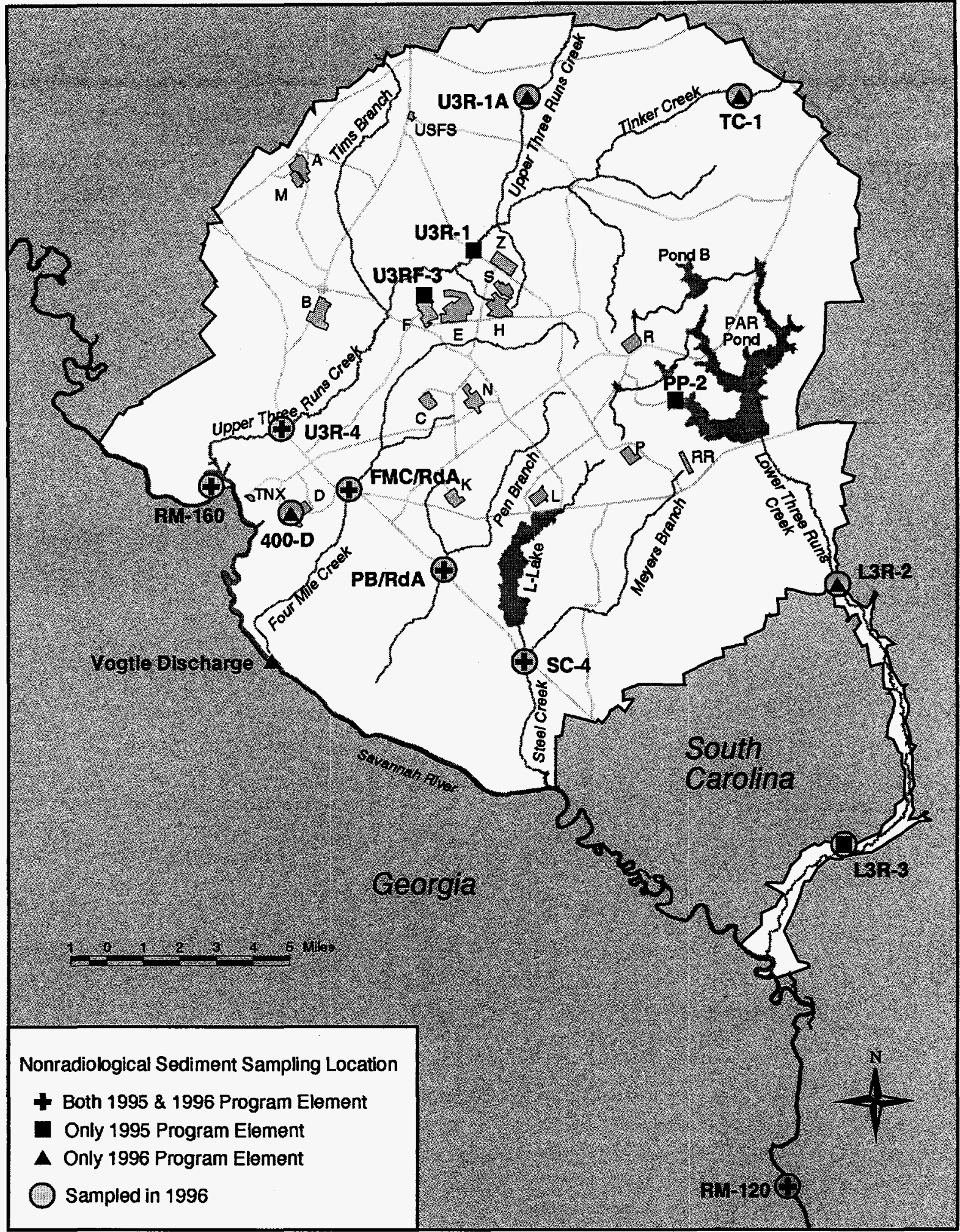

EPD/GIS

Figure 9-2 Nonradiological Sediment Sampling Locations

Sediment is sampled from SRS streams and the Savannah River for nonradiological contaminants, including pesticides, herbicides, and inorganic contaminants. 
any given sitting, and (3) the frequency of consumption of fish containing methylmercury during a given period of time. These three (primary) factors, and others, are the basis of calculations performed during "risk analysis," which is a method used to determine how much fish can be consumed safely. State and federal regulatory agencies calculate the health risk associated with the consumption of fish and other organisms, then recommend consumption guidelines based on that risk. Adherence to these guidelines can effectively control one's exposure to methylmercury. A list of fish advisories and/or recommended consumption limits can be obtained from state environmental agencies.

\section{Description of Surveillance Program}

EMS analyzes the flesh of fish caught from onsite streams and ponds and from the Savannah River to determine concentrations of mercury in the fish [SRS EM Program, 1996]. The fish analyzed represent the most common edible species of fish in the Central Savannah River Area (CSRA), an 18-county area in Georgia and South Carolina that surrounds Augusta, Georgia, and includes SRS.

(Sampling locations for fish are depicted in a map in chapter 6, "Radiological Environmental Surveillance," page 89.)

\section{Surveillance Results}

In 1996, 193 fish from SRS streams and ponds and the Savannah River were collected and analyzed for mercury [SRS Data, 1997].

The mercury concentrations in fish analyzed from onsite waters ranged from a high of $1.70 \mu \mathrm{g} \mathrm{Hg} / \mathrm{g}$ in PAR Pond and Pond $B$ bass to lows below the reporting limit $(0.33 \mu \mathrm{g} \mathrm{Hg} / \mathrm{g})$ at several locations.

Mercury concentrations in offsite fish ranged from a high of $1.67 \mu \mathrm{g} \mathrm{Hg} / \mathrm{g}$ in a bass from the Stokes Bluff Landing area to lows below the reporting limit $(0.33 \mu \mathrm{g} \mathrm{Hg} / \mathrm{g})$ at several locations. 


\title{
Groundwater
}

To Read About ... $\quad$ See Page ...

Groundwater at SRS .............. 135

Description of Groundwater

Monitoring Program .............. 139

\author{
William Fay, Linda VanSickle, \\ and Jen Williams \\ Exploration Resources, Inc.
}

Groundwater Monitoring Program

Changes During 1996 .............. 143

Groundwater Monitoring Results . ...... 144

$\checkmark$ roundwater beneath an estimated five to 10 percent of the Savannah River Site (SRS) has been contaminated by industrial solvents, tritium, metals, or other constituents used or generated by operations at SRS. Groundwater in areas indicated on figure 10-1 contains one or more of these constituents at or above the levels of Safe Drinking Water Act primary drinking water standards (DWS) of the U.S. Environmental Protection Agency (EPA).

This chapter summarizes the groundwater monitoring results for approximately 1,600 wells in 101 locations (figure 10-1) within designated areas at SRS. Only results exceeding the DWS are presented in figures and tables in this report. Most constituents are compared to the final federal primary DWS. In some cases, comparison is to the proposed primary DWS. or the interim final primary DWS. (See appendix A, "Applicable Guidelines, Standards, and Regulations," for additional information about applicable monitoring standards and appendix D, "Drinking Water Standards," for the DWS.) Some information about additional constituents is discussed in the text of this chapter.

Detailed groundwater monitoring results are presented in the following public documents: The
Savannah River Site's Groundwater Monitoring Program, First Quarter 1996 (ESH/EMS/960056); The Savannah River Site's Groundwater Monitoring Program, Second Quarter 1996 (ESH/EMS/950057);

The Savannah River Site's Groundwater Monitoring Program, Third Quarter 1996 (ESH/EMS/960058); and The Savannah River Site's Groundwater Monitoring Program, Fourth Quarter 1996 (ESH/EMS/960059). Full results for each well sampled during a quarter are presented alphabetically in the quarterly reports.

Another public document, the Environmental Protection Department's Well Inventory (ESH/EMS/960488), contains detailed maps of the wells at each monitored location.

\section{Groundwater at SRS}

When rain falls, part of the rainwater runs off of the surface of the earth into streams, and part of it soaks into the soil (figure 10-2). The water that runs off of the surface into the creeks is called direct runoff, and the water that soaks in and infiltrates the soil is called groundwater. Groundwater moves through the soil and eventually reappears at the surface in springs, swamps, rivers, or wells. Potentially hazardous substances in the soil may dissolve as the

\section{Overall Summary of 1996 Shs Ground water Monitoring Results}

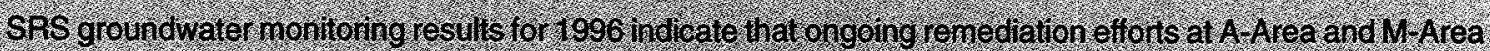
have slowed he spread of contanination (primarily organes and hetals) in those areas.

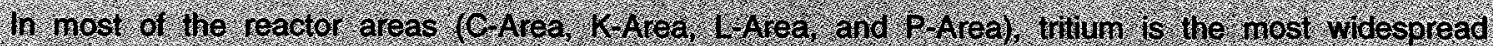

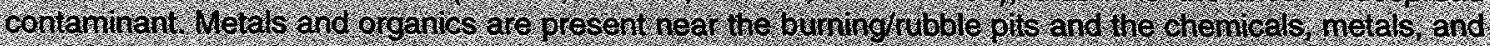

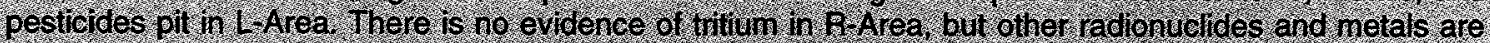
present in the ground water

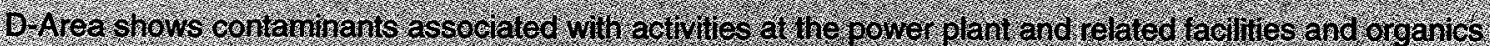

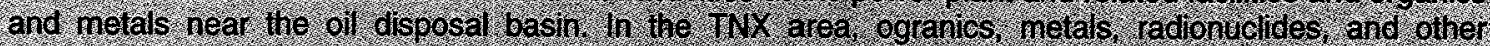

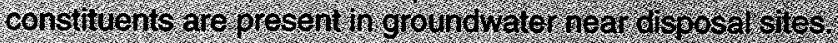

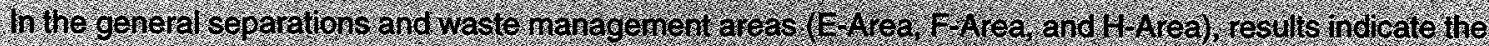

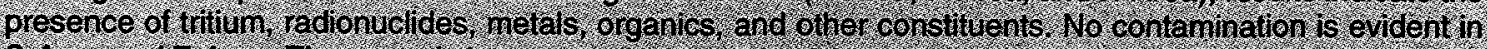

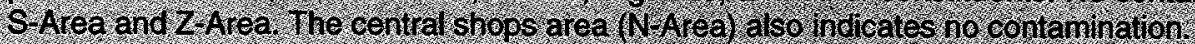

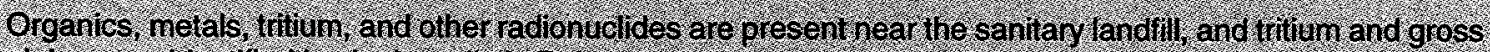
apha were ientified in single wels in B.Area. 


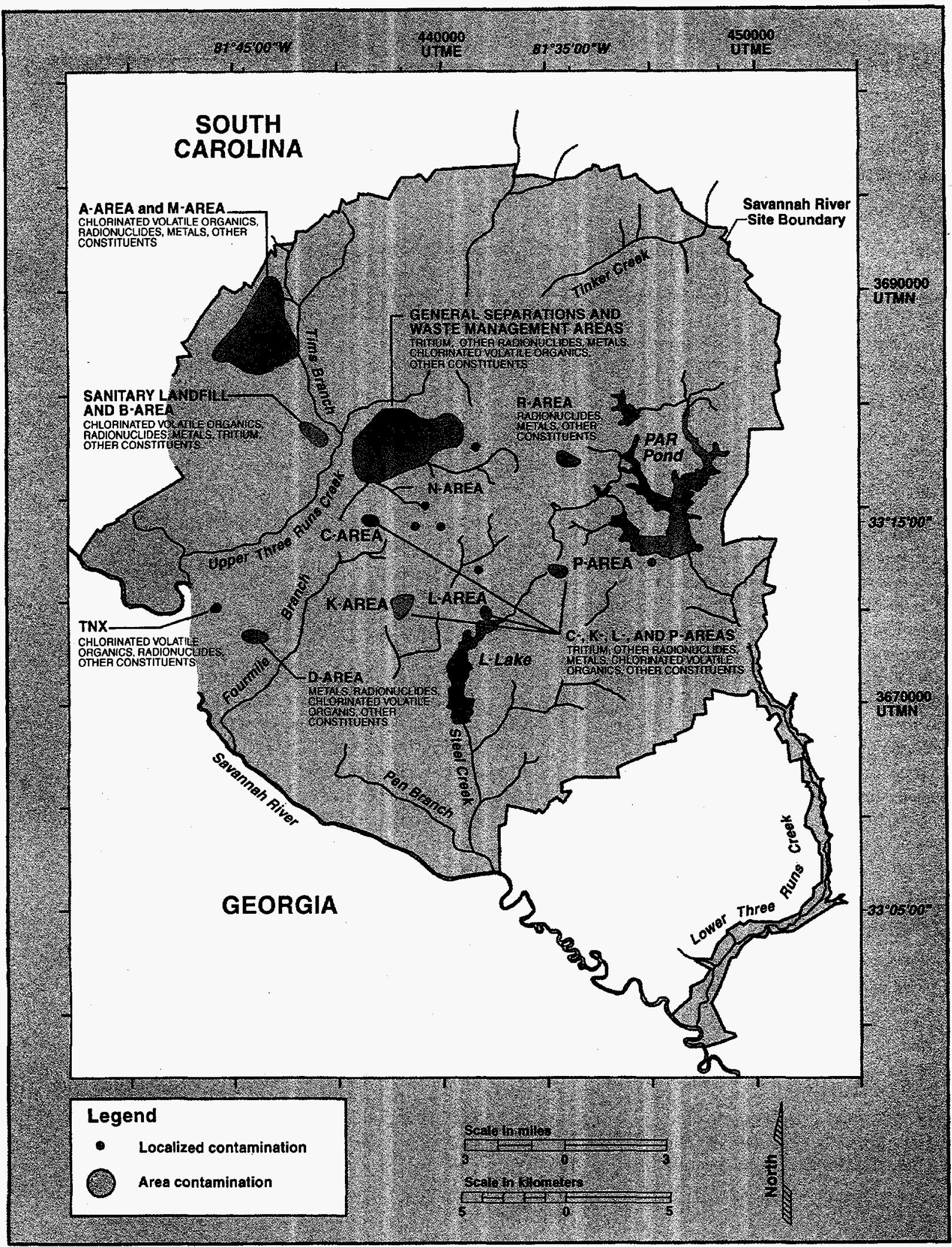

Exploration Resources, Inc.

Figure 10-1 Facilities Monitored by the SRS Monitoring Well Network, Including Areas Having Constituents Exceeding Drinking Water Standards in 1996 


\section{A-Area and M-Area}

- A-Area and M-Area Plume Monitoring

- A-Area Background Well Near Firing Range

- A-Area Burning/Rubble Pits and A-Area Ash Pile

- A-Area Coal Pile Runoff Containment Basin

- A-Area Metals Burning Pits

- A-Area and M-Area Recovery Well Network

- Flowing Springs Site

- M-Area Hazardous Waste Management Facility

- Metallurgical Laboratory Seepage Basin

- Miscellaneous Chemical Basin

- Motor Shop Oil Basin

- Savannah River Laboratory Seepage Basins

- Silverton Road Waste Site

General Separations and Waste Management Areas (E-Area, F-Area, H-Area, S-Area, and Z-Area)

- Burial Ground Expansion (E-Area Vaults)

- Burma Road Rubble Pit

- E-Area Vaults

- F-Area Acid/Caustic Basin

- F-Area Ash Basin

- F-Area Buming/Rubble Pits

- F-Area Canyon Building and A-Line Uranium Recovery Facility

- F-Area Coal Pile Runoff Containment Basin

- F-Area Effluent Treatment Cooling Water Basin

- F-Area Microbiology Wells

- F-Area Seepage Basins and Inactive Process Sewer Line

- F-Area Sanitary Sludge Land Application Site

- F-Area Tank Farm

- H-Area Acid/Caustic Basin

- H-Area Coal Pile Runoff Containment Basin

- H-Area Auxiliary Pump Pit

- H-Area Canyon Building

- H-Area Effluent Treatment Cooling Water Basin

- H-Area Retention Basins

- H-Area Sanitary Sludge Land Application Site

- H-Area Seepage Basins and Inactive Process Sewer Line

- H-Area Tank Farm

- Old Burial Ground

- Old F-Area Seepage Basin

- S-Area Facilities

- S-Area Vitrification Building

- Waste Solidification and Disposal Facility

- Z-Area Low-Point Drain Tank

- Z-Area Saltstone Facility Background Wells

\section{C-Area}

- Bioremediation Facility

- C-Area Burning/Rubble Pit

- C-Area Coal Pile Runoff Containment Basin

- C-Area Disassembly Basin

\section{K-Area}

- K-Area Acid/Caustic Basin

- K-Area Ash Basin

- K-Area Bingham Pump Outage Pit

- K-Area Burning/Rubble Pit

- K-Area Coal Pile Runoff Containment Basin

- K-Area Disassembly Basin

- K-Area Reactor Seepage Basin
- K-Area Retention Basin

- K-Area Sludge Land Application Site

- K-Area Tritium Sump

\section{L-Area}

- L-Area Acid/Caustic Basin and L-Area Oil and Chemical Basin

- L-Area Burning/Rubble Pit

- L-Area Disassembly Basin

- L-Area Reactor Seepage Basin

- L-Area Research Wells

\section{P-Area}

- P-Area Acid/Caustic Basin

- P-Area Burning/Rubble Pit

- P-Area Coal Pile Runoff Containment Basin

- P-Area Disassembly Basin

- P-Area Microbiology Wells

- P-Area Reactor Seepage Basins

\section{R-Area}

- R-Area Acid/Caustic Basin

- R-Area Background Wells

- R-Area Bedrock Exploration Hydrology Wells

- R-Area Burning/Rubble Pits

- R-Area Coal Pile

- R-Area Disassembly Basin

- R-Area Reactor Seepage Basins

Sanitary Landfill and B-Area

- B-Area Microbiology Wells

- Sanitary Landfill and Interim Sanitary Landfill

\section{Central Shops (N-Area)}

- Chemicals, Metals, and Pesticides Pits

- Ford Building Seepage Basin

- N-Area Burning/Rubble Pits

- $\quad$ N-Area Burning/Rubble Pit South

- N-Area Diesel Spill

- $\quad$ N-Area Fire Department Training Facility

- $\quad$-Area Fuel Oil Site

- $\quad \mathrm{N}$-Area Hydrofluoric Acid Spill

\section{D-Area and TNX}

- D-Area Burning/Rubble Pits

- D-Area Coal Pile Runoff Containment Basin and Ash Basins

- D-Area Oil Seepage Basin

- New TNX Seepage Basin

- Old TNX Seepage Basin

- TNX-Area Assessment Wells

- TNX-Area Background Wells

- TNX-Area Operable Unit Wells

- TNX-Area Recovery Wells

- TNX-Area Well Points along Seepline

- TNX Burying Ground

\section{Other Sites}

- Background Well near Hawthorne Fire Tower

- Hazardous Waste/Mixed Waste Disposal Facility

- Interim Waste Technology Site Characterization Wells

- PAR Pond Sludge Land Application Site

- Potential New Production Reactor Site Characterization Wells

- Second PAR Pond Borrow Pit Sewage Sludge Application Site 


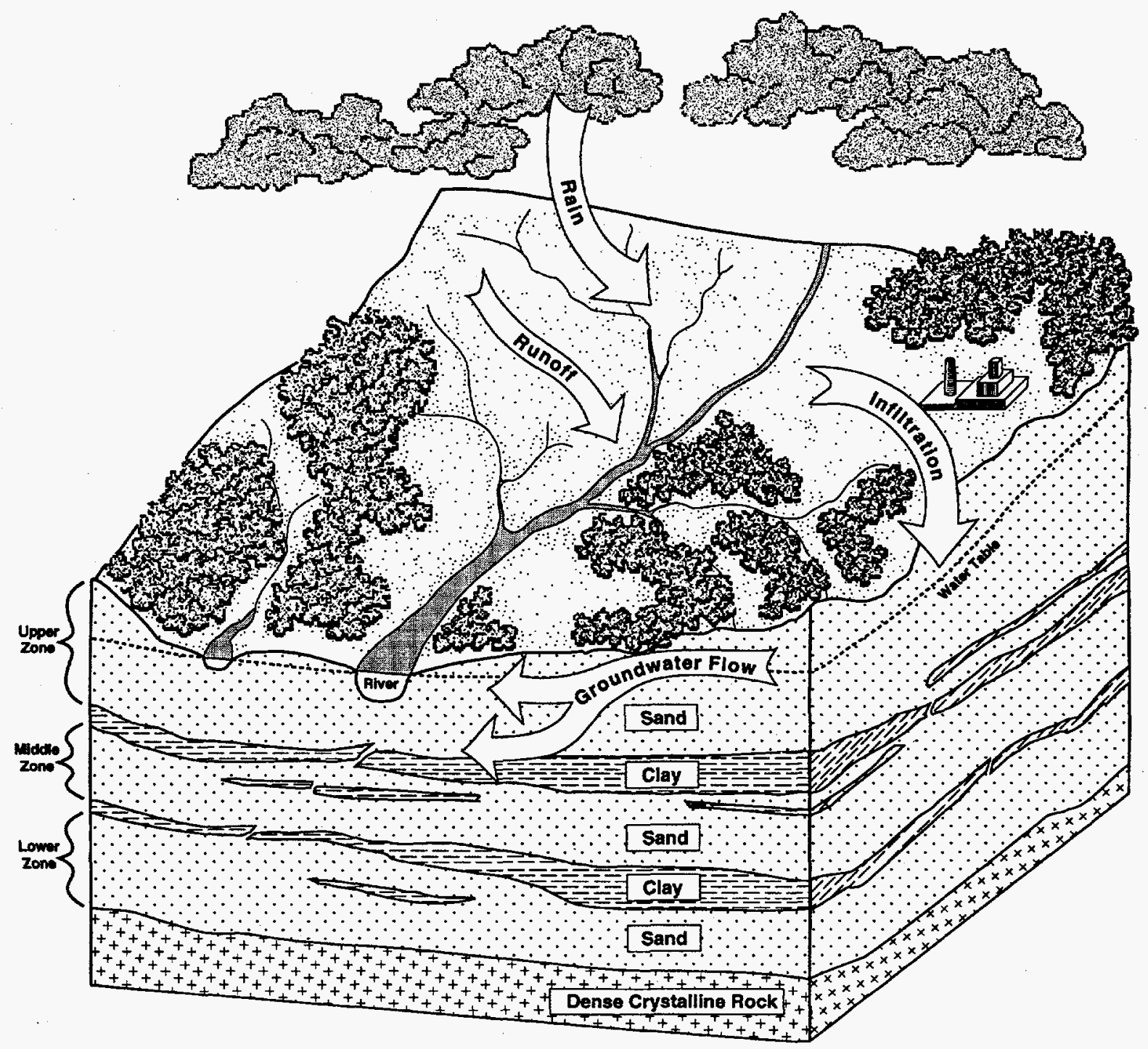

Exploration Resources, Inc.

Figure 10-2 Groundwater at SRS

groundwater infiltrates and moves down through the soil to the water table. In this way, contaminants in the soil can move with the groundwater and may become a health risk.

SRS is built on a 700-1,200-foot stack of sediments composed of sand, clayey sand, and clay, with a small amount of limestone. Dense crystalline rock lies under the sediments. The groundwater in the vicinity moves through the sediments, mostly in the sand layers. The clay layers allow very little groundwater to flow through them; therefore, their presence between sand layers helps direct the flow of groundwater and contaminants.
At SRS, groundwater moves in several sandy zones that are separated by less permeable clay layers. The upper zone comprises the rainwater that moves down from the surface. Water in this zone moves either laterally to discharge or downward into lower zones. Beneath the upper zone is a clay layer that retards the water moving downward into the lower zones. In some areas of SRS, this clay layer is thick and undisturbed and is effective in preventing the upper zone of groundwater from moving downward. In other areas, this clay layer is thin, broken, or missing, and the groundwater from the top zone can readily move into lower zones. 
Below the upper zone is another zone of sand where the water moves relatively freely. Water in this middle zone is used for domestic water supplies. Below the middle zone is another clay layer and then a lower zone of groundwater. The lowest zone is the most important aquifer in the region and supplies water to domestic and industrial users.

Groundwater beneath SRS flows slowly-at rates ranging from inches to several hundred feet per year-toward streams and swamps on site and into the Savannah River. Figures 10-3 and 10-4 illustrate the potentiometric contours and horizontal-flow directions of the middle and lower zones beneath SRS. Similar to contour lines on a weather map that connect points of equal barometric pressure, the figures' potentiometric surface contour lines connect below-ground regions of equal hydraulic head (elevation of the water in a well or piezometer). Horizontal-flow directions of groundwater within these zones are indicated on figures $10-3$ and 10-4 by bold arrows perpendicular to the contour lines. In both zones, the direction of flow beneath monitored waste sites generally is toward the Savannah River, the Savannah River Swamp, Upper Three Runs Creek, or Lower Three Runs Creek. Surface water in the swamp and creeks eventually flows into the Savannah River.

The upper zone is the most affected in general by activity at SRS. The middle zone is known to be contaminated in several areas. Contamination in the lowest zone has been identified only in A-Area and M-Area.

Monitoring wells are used extensively at SRS to assess the effect of site activities on groundwater quality. Most of the wells monitor the highest groundwater zone, although wells in lower zones are present at the sites with the larger groundwater contamination plumes.

\section{Description of the Groundwater Monitoring Program}

The groundwater monitoring program at SRS gathers information to determine the effect of site operations on groundwater quality. The program is designed to

- assist SRS in complying with environmental regulations and U.S. Department of Energy (DOE) directives

- provide data to identify and monitor constituents in the groundwater
- permit characterization of new facility locations to ensure that they are suitable for the intended facilities

- support basic and applied research projects

The groundwater monitoring program at SRS is conducted by the Environmental Geochemistry Group (EGG) of the Environmental Protection Department/Environmental Monitoring Section (EPD/EMS) of Westinghouse Savannah River Company (WSRC). To assist other departments in meeting their responsibilities, EGG provides the services for installing monitoring wells, collecting and analyzing samples, and reporting results.

The Savannah River Site Environmental Monitoring Plan (WSRC-3Q1-2, Section 2000) provides details about the following aspects of the groundwater monitoring program:

- well siting, construction, maintenance, and abandonment

- sample planning

- sample collection and field measurements

- analysis

- data management

- related publications, files, and databases

The next four sections of this chapter present overviews of several of these topics, along with information specific to 1996.

\section{Sample Scheduling and Collection}

EMS schedules groundwater sampling either in response to specific requests from SRS personnel or as part of its ongoing groundwater monitoring program. These groundwater samples provide data for reports required by federal and state regulations and for internal reports and research projects. The groundwater monitoring program schedules wells to be sampled at intervals ranging from quarterly to triennially.

- Groundwater from new wells added to the program is analyzed for environmental-screening constituents (table 10-1) for 4 consecutive quarters for only the wells identified in the Savannah River Site Screening Program Wells (ESHEMS-950409).

- Environmental-screening analyses are conducted once every 3 years for only the wells identified in the Savannah River Site Screening Program Wells (ESH-EMS-950409).

- If their environmental-screening constituent concentrations are above certain limits, wells identi- 


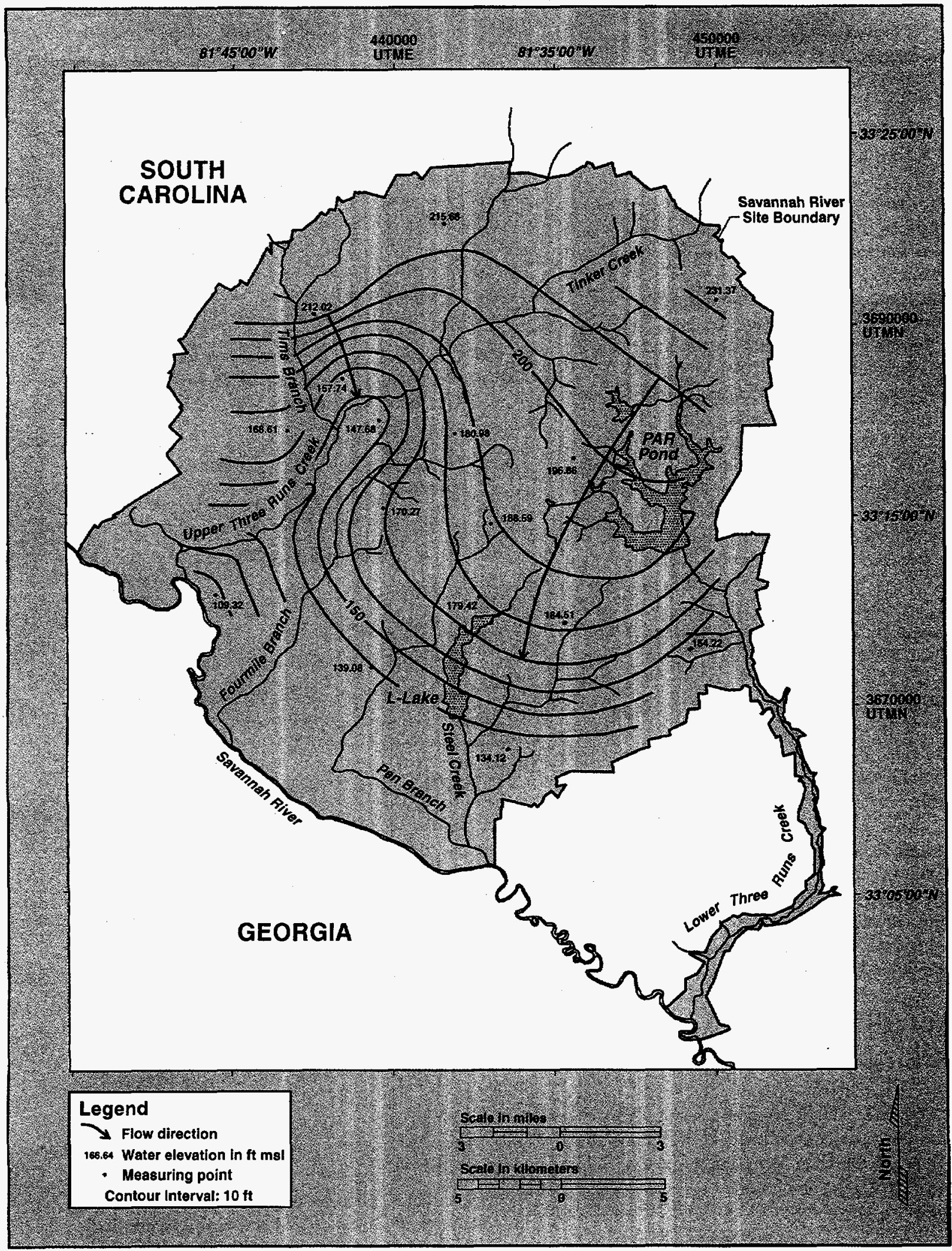

Exploration Resources, Inc.

Figure 10-3 Potentiometric Surface and Horizontal Groundwater Flow Directions of the Middle Zone at SRS During the First Quarter of 1996 


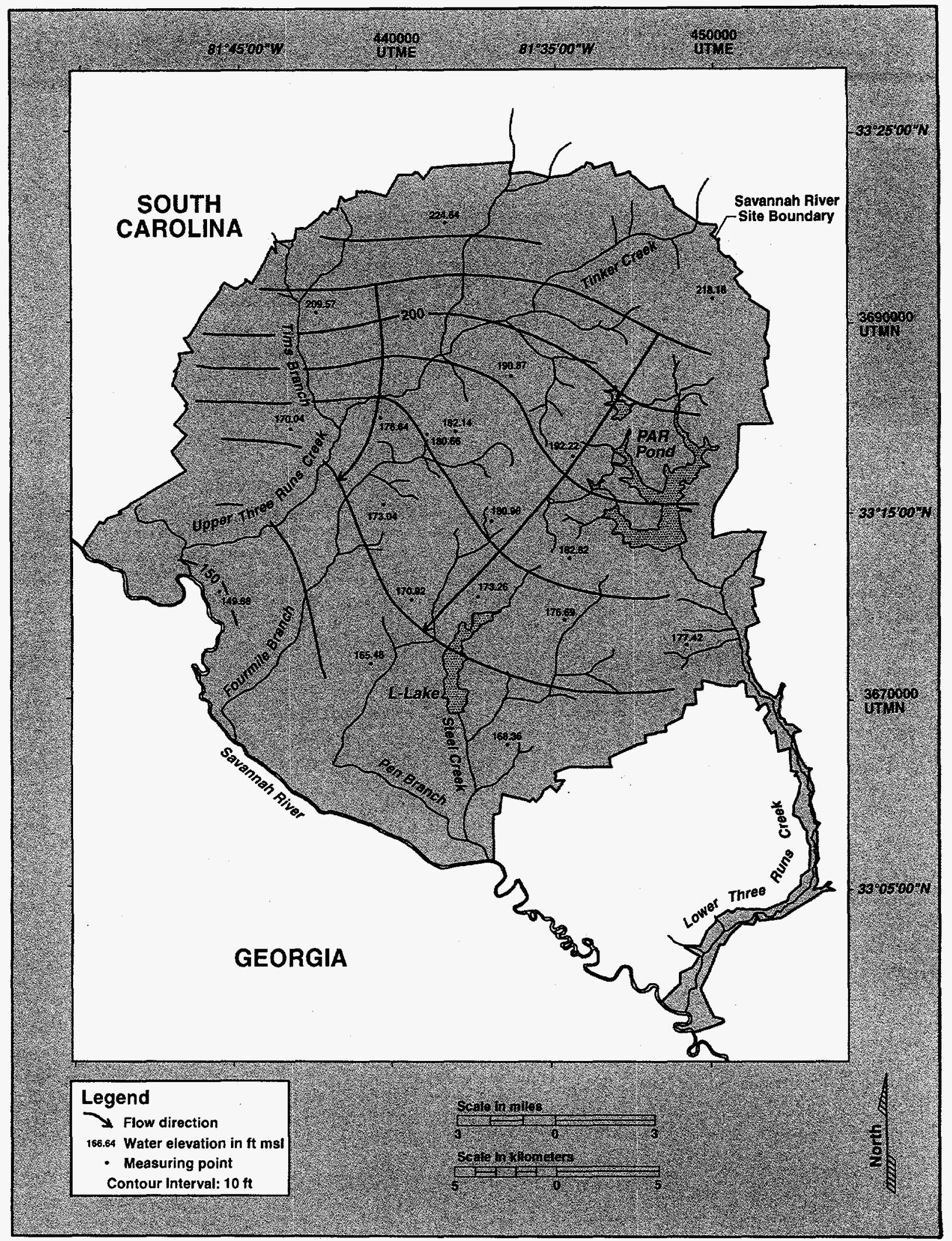

Exploration Resources, Inc.

Figure 10-4 Potentiometric Surface and Horizontal Groundwater Flow Directions of the Lower Zone at SRS During the First Quarter of 1996 


\section{Table 10-1 Environmental-Screening} Constituents

\author{
Aluminum \\ Arsenic \\ Barium \\ Boron \\ Cadmium \\ Calcium \\ Chloride \\ Chromium \\ Fluoride \\ Gross alpha \\ Iron \\ Lead \\ Lithium \\ Magnesium \\ Manganese \\ Mercury \\ Nitrate-nitrite as nitrogen \\ Nonvolatile beta \\ Potassium \\ Selenium \\ Silica \\ Silver \\ Sodium \\ Sulfate \\ Total dissolved solids \\ Total organic carbon \\ Total organic halogens \\ Total phosphates (as P) \\ Tritium
}

fied in the Savannah River Site Screening Program Wells (ESH-EMS-950409) are then sampled annually.

Personnel outside EMS may request sample collection as often as weekly. In addition to environmental-screening constituents, constituents that may be analyzed by request include suites of herbicides, pesticides, additional metals, volatile organics, and others. Radioactive constituents that may be analyzed by request include gamma emitters, iodine-129, strontium- 90 , radium-228, uranium isotopes, and other alpha and beta emitters.

Groundwater samples are collected from monitoring wells, generally with either pumps or bailers dedicated to the well to prevent cross-contamination among wells. Occasionally, portable sampling equipment is used; this equipment is decontaminated between wells.

Sampling and shipping equipment and procedures are consistent with EPA, South Carolina Department of Health and Environmental Control (SCDHEC), and U.S. Department of Transportation (DOT) guidelines.
EPA-recommended preservatives and sample-handling techniques are used during sample storage and transportation to both onsite and offsite analytical laboratories. Potentially radioactive samples are screened for total activity (alpha and beta emitters) prior to shipment to determine appropriate packaging and labeling requirements.

Deviations (caused by dry wells, inoperative pumps, etc.) from scheduled sampling and analysis for 1996 are enumerated in the SRS quarterly groundwater monitoring reports cited on the first page of this chapter.

In 1996, approximately 49,000 radiological analyses and 328,000 nonradiological analyses were performed on groundwater samples collected from approximately 1,600 monitoring wells.

\section{Analytical Procedures}

In 1996, General Engineering Laboratories of Charleston, South Carolina, performed most of the groundwater analyses. Roy F. Weston, Inc., of Lionville, Pennsylvania, also performed groundwater analyses. The contracted laboratories are certified by SCDHEC to perform specified analyses.

The EMS radiological laboratory at SRS screened potentially radioactive samples for total activity prior to shipment. General Engineering Laboratories subcontracted radiological analyses to Environmental Physics of Charleston; Roy F. Weston, Inc., subcontracted radiological analyses to TMA/Eberline of Oak Ridge, Tennessee, and Analytical Technologies, Inc., of Ft. Collins, Colorado.

Full lists of constituents analyzed, analytical methods used, and the laboratories' estimated quantitation limits are given in the SRS quarterly groundwater reports referenced earlier.

\section{Evaluation of Groundwater Data}

EMS receives analytical results and field measurements as reports and as ASCII files that are loaded into databases at SRS. Logbooks track receipt and transfer of data to the Geochemical Information Management System (GIMS) database, and computer programs present the data in a format that can be validated.

Quality control practices include the following:

- verification of well names and sample dates for field and analytical data

- verification that all analyses requested on the chain-of-custody forms were completed by each laboratory 
- identification of data entry problems (e.g., duplicate records, incorrect units)

- comparison of analytical data to historical data and review of the data for transcription, instrument, or calculation errors

- comparison of blind replicates and laboratory in-house duplicates for inconsistencies

- identification of laboratory blanks and blind blanks with elevated concentrations

Possible transcription errors and suspect results are documented and submitted to the appropriate laboratory for verification or correction. No changes are made to the database until the laboratory documents the problem and solution. Changes to the database are recorded in a logbook.

The quarterly groundwater monitoring reports identify queried results verified by the laboratory and list groundwater samples associated with blanks having elevated results. These reports also present the results of intralaboratory and interlaboratory quality assurance comparisons (chapter 11, "Quality Assurance").

\section{Changes to the Groundwater Monitoring Program during 1996}

\section{Well Abandonments and Additions to the Sampling Schedule}

During 1996, 43 wells were abandoned for the following reasons:

- One well at the Mixed Waste Management Facility was abandoned and replaced at the Burial Ground in preparation for the closure of the Low-Level Radioactive Waste Disposal Facility.

- Seventeen wells in the Sanitary Landfill were abandoned to accommodate a closure cap. Five wells were replaced in locations that would not interfere with the cap.

- Ten wells were abandoned in the F-Area acid/ caustic basin because SCDHEC approved clean closure of the basin.

- Three wells in the H-Area acid/caustic basin were abandoned because SCDHEC approved clean closure of the basin.

- Seven wells in the K-Area acid/caustic basin were abandoned because SCDHEC approved clean closure of the basin.

- Four wells in the P-Area acid/caustic basin were abandoned because SCDHEC approved clean closure of the basin.
- One well in the miscellaneous chemical basin was abandoned and replaced because it did not produce enough water for sampling.

The following 71 wells were monitored for the first time in 1996:

- Four new wells were installed at the A-Area metals burning pit for sampling in conjunction with the Resource Conservation and Recovery Act (RCRA) Facility Investigation/Remedial Investigation (RFI/RI) project in the miscellaneous chemical basin/metals burning pit.

- Five new wells in the A/M recovery well network were monitored for the first time in compliance with the RCRA permit.

- One new well was installed in the C-Area burning/rubble pit for RFI/RI characterization.

- Two new wells were installed in the chemicals, metals, and pesticides pits for RFI/RI characterization.

- Three new wells were installed at the old F-Area seepage basin to comply with RFI/RI requirements.

- Two new wells were installed in the K-Area Bingham pump outage pit to be sampled in compliance with requests from EPA and SCDHEC.

- Three new wells were installed in the K-Area burning/rubble pit to comply with RFI/RI characterization requirements.

- Two new wells were installed in the K-Area seepage basin to comply with the RFI/RI project at the basin.

- Five replacement wells were installed in the Sanitary Landfill in compliance with South Carolina Hazardous Waste Management Regulations, Solvent Rag Settlement (91-51-SW), and the 1995 version of the Groundwater Quality Assurance Plan.

- Ten new wells were installed in the miscellaneous chemical basin for sampling in conjunction with the RFI/RI project in the miscellaneous chemical basin/metals burning pit.

- One new replacement well was installed at the M-Area Hazardous Waste Management Facility in compliance with the RCRA permit.

- Two new wells were installed in N-Area to determine if fuel oil had reached the uppermost aquifer.

- Seven new wells were installed at the R-Area reactor seepage basins as part of an RFI/RI project. 
- One new well was installed at the Savannah River Ecology Laboratory flowing springs site to monitor a previous diesel fuel tank site.

- Nine new wells were installed at the TNX Operative Unit to support RFI/RI characterization and future investigative studies.

- Ten TNX well points along the seepline were monitored to support the RFI/RI process.

- Four new recovery wells were installed in TNX to comply with provisions of the TNX Effectiveness Monitoring Strategy.

\section{Changes in Scheduling Policy}

During 1996, herbicides/pesticides, phenols, $\mathrm{pH}$, and specific conductance laboratory analyses were no longer included as environmental-screening constituents. These analyses will be conducted only as special requests. Herbicides/pesticides and phenols are contaminants that historically have not been found at SRS. They were removed from the list of environmental screening constituents to reduce costs. Specific conductance and $\mathrm{pH}$ are measured in the field. In addition, to meet the goal of providing background data on groundwater quality, only new wells that have been designated as groundwater screening program wells will be assigned four quarters of environmental screening. All other wells will be sampled only by special request.

\section{Changes in Scheduling Procedures}

During 1996, the only constituents scheduled for analyses based on previous concentrations above certain limits were environmental-screening analyses and gas chromatographic volatile organic analyses (table 10-1). These were to be scheduled only for wells in the environmental-screening program (Savannah River Site Screening Program Wells (ESH-EMS-950409).

\section{Groundwater Monitoring Results at SRS}

This section summarizes groundwater monitoring results during the first three quarters of 1996 for each of the following areas at SRS:
- A-Area and M-Area

- C-Area

- D-Area and TNX

- General separations and waste management areas (E-Area, F-Area, H-Area, S-Area, and Z-Area)

- K-Area

- L-Area and chemicals, metals, and pesticides pits

- N-Area

- P-Area

- R-Area

\section{- Sanitary Landfill and B-Area}

Groundwater monitoring results for each area in the above list are (1) illustrated with a figure showing the extent of contamination, (2) described in the text, and (3) summarized with a table.

The figure (from each area) that shows facilities of interest at or near the site and illustrates areas of notable contamination above DWS is presented first. The figures do not specify every contaminant identified through groundwater monitoring, but they illustrate contamination above DWS.

Each figure is followed by a brief description of the sites and facilities of interest in the area, an explanation of groundwater flow, and the nature of contamination in the area.

The description of contamination at each area concludes with a table that summarizes the following information:

- major groups of constituents

- percent of wells sampled that contained constituents above drinking water standards

- number of wells sampled for each constituent group

- sources of contamination

Substantial areas of contamination identified in the tables are illustrated in more detail, in some cases, in the accompanying figures. For example, a table may identify metals contamination, and the figure may show that most of that contamination is lead. 


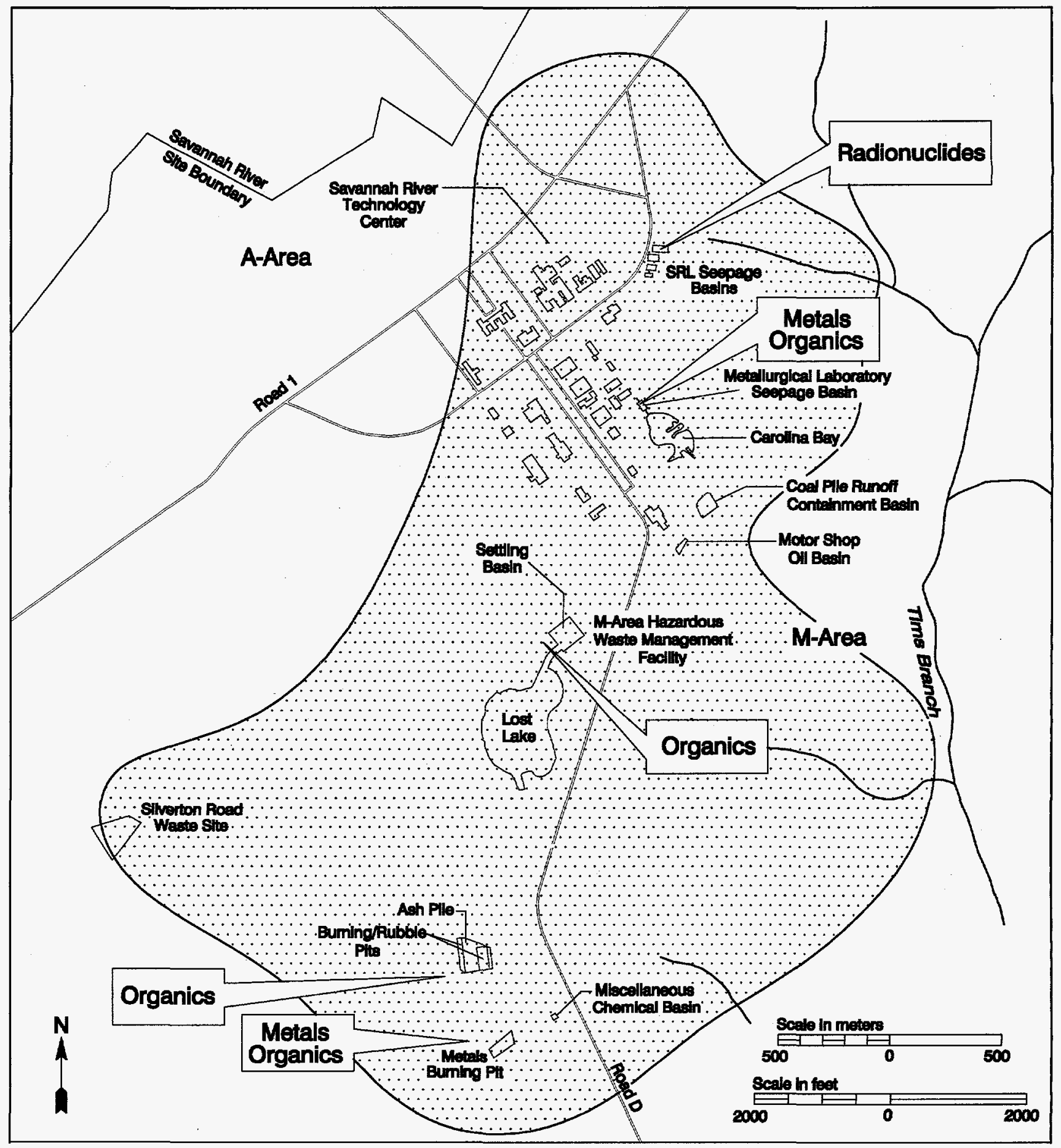

Exploration Resources, Inc.

Figure 10-5 Extent of Groundwater Contamination Beneath A-Area and M-Area in 1996 and Location of Noteworthy Sources of Contamination Exceeding Drinking Water Standards 


\section{Groundwater Contamination at A-Area and M-Area}

\section{Location and Facilities}

The administration and manufacturing areas, A-Area and M-Area, are located in the northwest portion of SRS. A-Area houses administrative and research facilities, including the Savannah River Technology Center. M-Area was used for production of nuclear fuels, targets, and other reactor components.

A-Area and M-Area include the following facilities associated with the groundwater monitoring program:

- A-Area burning/rubble pits

- A-Area ash pile

- A-Area coal pile runoff containment basin

- A-Area metals burning pit

- M-Area Hazardous Waste Management Facility

- Metallurgical Laboratory seepage basin

- Miscellaneous chemical basin

- Motor Shop oil basin

- Savannah River Laboratory seepage basins

- M-Area settling basin

- Silverton Road waste site

\section{Nature of Contamination}

Surface drainage in A-Area and M-Area is toward Tims Branch, approximately to the east, and toward valleys to the northwest and southwest that lead to the Savannah River.

The water table in this vicinity slopes to the southeast, south, and southwest toward Tims Branch and other discharge points. Most of the water of the upper saturated zone migrates downward into lower water-bearing zones.

Figure 10-5 shows the extent of contamination and the location of the various contaminant groups at A-Area and M-Area. There is a large groundwater contamination plume under and downgradient of A-Area and M-Area. Organic constituents-the primary contaminants-are found throughout the area and account for the largest percentage of contaminated wells. Trichloroethylene, tetrachloroethylene, and other organic compounds were used as degreasers during manufacturing and research. After use, organic wastes, metals, and other contaminants were placed into unlined basins, from which they slowly seeped into the groundwater. Contaminants also entered the groundwater as the result of spills or leaking pipes.

The highest concentrations of organics and metals generally are found beneath seepage and settling basins in central and southern portions of the area. The entire contaminant plume covers approximately 3 square miles and is approximately one-third mile from the SRS boundary.

Due to the chemical nature of trichloroethylene and tetrachloroethylene and the groundwater conditions in the upper aquifer zone, the contaminant movement generally is downward into deeper aquifers. Once in the deeper aquifers, these contaminants may be moved horizontally by faster groundwater flow rates.

Table 10-2 summarizes 1996 groundwater monitoring results for A-Area and M-Area.

\section{Remediation}

Ongoing remediation efforts have substantially altered the groundwater and contaminant flow patterns in the upper, middle, and lower aquifer zones beneath A-Area and M-Area. Remediation efforts include capping the basins and extracting and processing volatile organics from the groundwater. At the end of second quarter 1996, approximately 2.3 billion gallons of groundwater had been pumped and approximately 312,000 pounds of volatile organics removed. Remediation efforts also included pumping contaminated air to five units, where the volatile organic compounds were destroyed. At the end of second quarter 1996, approximately 37,000 pounds of degreaser solvent had been removed. While ongoing remediation never will clean up contaminated groundwater zones completely, it can slow the spread of contamination and minimize the impact to the environment. 
Table 10-2 Constituent Groups Above Drinking Water Standards at A-Area and M-Area in 1996

\begin{tabular}{llll}
\hline Constituent Groups & $\begin{array}{l}\text { Percent of Wells } \\
\text { with Results } \\
\text { above Standards }\end{array}$ & $\begin{array}{l}\text { Number } \\
\text { of Wells } \\
\text { Sampled }\end{array}$ & Sources of Contamination \\
\hline $\begin{array}{l}\text { Dioxins/furans } \\
\text { Metals }\end{array}$ & 0 & 14 & None \\
Organics & $7 \%$ & 294 & $\begin{array}{l}\text { Burning/rubble pit, Met Lab, metals burning } \\
\text { pit, several basins } \\
\text { Burning/rubble pits, Met Lab seepage basin, } \\
\text { several basins }\end{array}$ \\
Pesticides/PCBs & $57 \%$ & 296 & $\begin{array}{l}\text { None } \\
\text { Tritium }\end{array}$ \\
Other radionuclides & 0 & 73 & $\begin{array}{l}\text { Burning/rubble pits } \\
\text { Coal pile runoff containment basin, SRL } \\
\text { seepage basin }\end{array}$ \\
Other constituents & $2 \%$ & 295 & Several basins
\end{tabular}

Note: Drinking Water Standards refer to federal final primary DWS, proposed primary DWS, and interim final primary DWS. 


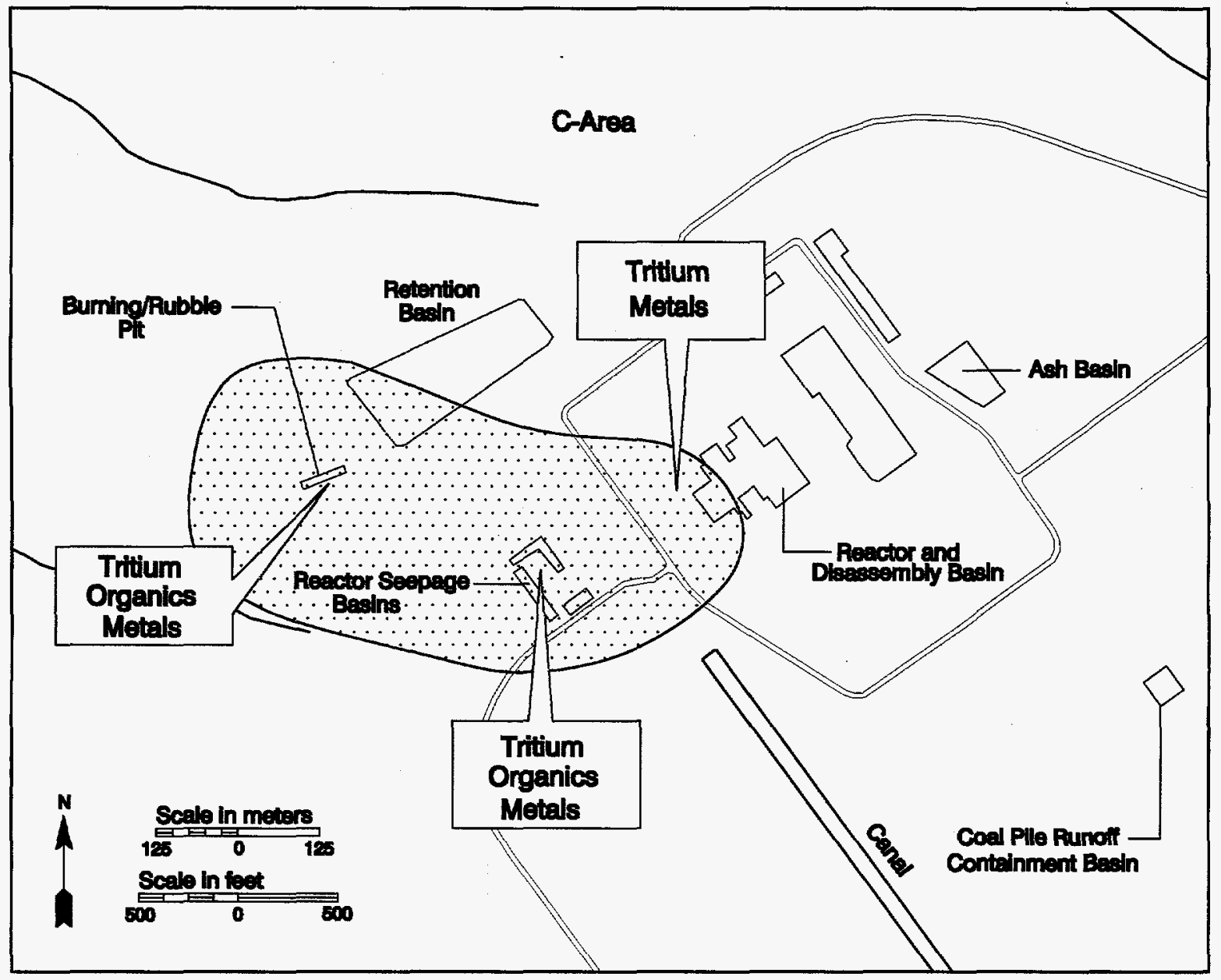

Exploration Resources, Inc.

Figure 10-6 Extent of Groundwater Contamination Beneath C-Area in 1996 and Location of Noteworthy Sources of Contamination Exceeding Drinking Water Standards

\section{Groundwater Contamination at C-Area}

\section{Location and Facilities}

C-Area, which is in the west-central part of SRS, contains the $\mathrm{C}$-Area reactor. The $\mathrm{C}$-Area reactor achieved criticality in March 1955 and was shut down in 1985 for maintenance. It was placed on cold standby in 1987, followed by cold shutdown.

C-Area includes the following facilities associated with the groundwater monitoring program:

- C-Area ash basin

- C-Area burning/rubble pit

- C-Area coal pile runoff containment basin

- C-Area disassembly basin

- C-Area reactor
- C-Area reactor seepage basins

- C-Area retention basin

\section{Nature of Contamination}

Groundwater flow beneath C-Area tends to be strongly influenced by incised creeks near the area. Horizontal flow generally is west toward Four Mile Creek (also known as Fourmile Branch), and surface drainage is predominantly west toward a tributary of Four Mile Creek.

During routine reactor operations, the radioactivity level from tritium built up in the disassembly basins that held activated target rods. Periodically, the water from these basins was purged to limit worker exposure. During different time periods, the water was discharged to the reactor seepage basins or to surface streams. Tritium also escaped from the disassembly basins. 
The C-Area burning/rubble pit and basins also received materials that could cause groundwater contamination.

Figure 10-6 shows the extent of contamination and the location of the various contaminant groups at C-Area. Tritium is the most widespread contaminant; the highest activities are in the groundwater downgradient of the reactor seepage basins. Lead and trichloroethylene also are present in many wells. Thallium is present in wells near the burning/rubble pits, and other constituents are elevated in a few wells. Monitoring results are consistent with those of previous years.

Table 10-3 summarizes 1996 groundwater monitoring results for $\mathrm{C}$-Area.

Table 10-3 Constituent Groups Above Drinking Water Standards at C-Area in 1996

\begin{tabular}{|c|c|c|c|}
\hline Constituent Groups & $\begin{array}{l}\text { Percent of Wells } \\
\text { with Results } \\
\text { above Standards }\end{array}$ & $\begin{array}{l}\text { Number } \\
\text { of Wells } \\
\text { Sampled }\end{array}$ & Sources of Contamination \\
\hline Dioxins/furans & - & - & \\
\hline Metals & $63 \%$ & 19 & $\begin{array}{l}\text { Burning/rubble pit, disassembly basin, } \\
\text { reactor seepage basins }\end{array}$ \\
\hline Organics & $56 \%$ & 18 & Burning/rubble pit, reactor seepage basins \\
\hline Pesticides/PCBs & 0 & 12 & None \\
\hline Tritium & $56 \%$ & 18 & $\begin{array}{l}\text { Burning/rubble pit, disassembly basin, } \\
\text { reactor seepage basins }\end{array}$ \\
\hline Other radionuclides & $9 \%$ & 11 & $\begin{array}{l}\text { Burning/rubble pit, disassembly basin, } \\
\text { reactor seepage basins }\end{array}$ \\
\hline Other constituents & 0 & 12 & $\begin{array}{l}\text { Burning/rubble pit, disassembly basin, } \\
\text { reactor seepage basins }\end{array}$ \\
\hline
\end{tabular}

Notes: Drinking Water Standards refer to federal final primary DWS, proposed primary DWS, and interim final primary DWS.

Dioxins/furans were not sampled at C-Area during 1996. 


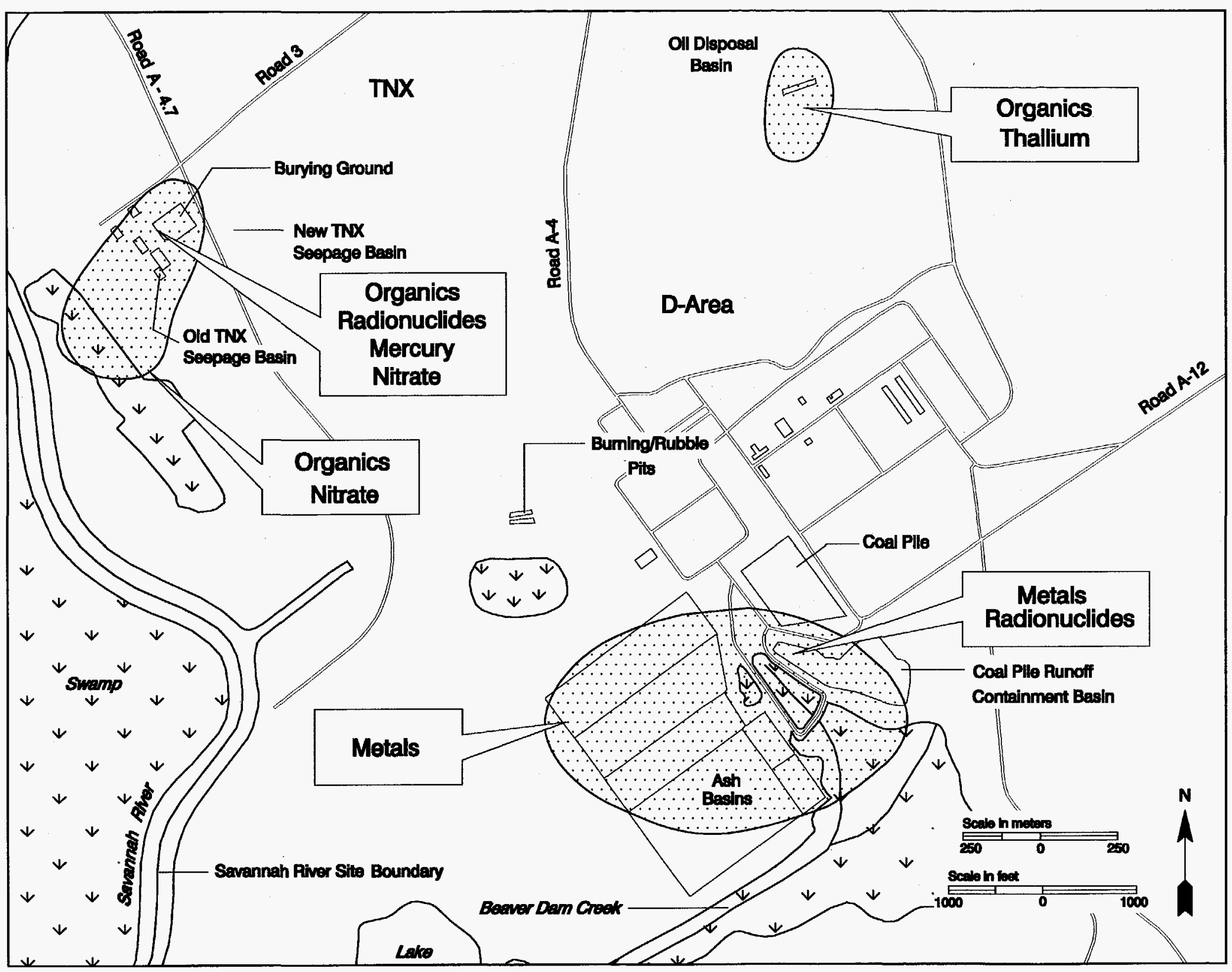

Exploration Resources, Inc.

Figure 10-7 Extent of Groundwater Contamination Beneath D-Area and TNX in 1996 and Location of Noteworthy Sources of Contamination Exceeding Drinking Water Standards 


\section{Groundwater Contamination at D-Area and TNX}

\section{Location and Facilities}

D-Area, located in the southwest part of SRS, includes a large coal-fired power plant and the inactive heavy-water facilities.

D-Area includes the following facilities associated with the groundwater monitoring program:

- D-Area burning/rubble pits

- D-Area coal pile, coal pile runoff containment basin, and ash basins

- D-Area oil disposal basin

TNX, also located in the southwest part of SRS-and operated by the Savannah River Technology Center-tests equipment prior to installation and develops new designs. The nearest SRS boundary is the Savannah River, approximately one-quarter mile to the west.

Facilities in TNX include the following:

- New TNX seepage basin

- Old TNX seepage basin

- TNX burying ground

\section{Nature of Contamination}

The water table in D-Area discharges to the Savannah River and to a nearby swamp along Beaver Dam
Creek. The water table surface in the vicinity of the coal pile runoff containment basin in D-Area is very close to the ground surface and drains to Beaver Dam Creek, which flows into the Savannah River Swamp.

Figure 10-7 shows the extent of contamination and the location of the various contaminant groups at D-Area and TNX. There is substantial contamination of the groundwater near the coal pile, the coal pile runoff containment basin, and the ash basins. The water is characterized by high conductivity and total dissolved solids. Elevated levels of metals, alpha-emitting radionuclides, sulfate, and fluoride are present. The contamination is consistent with the leaching of coal and coal ash.

A separate plume of contaminated groundwater is present near the D-Area oil disposal basin. Volatile organics and thallium have been detected above DWS.

The water table in TNX discharges to the Savannah River and the nearby Savannah River Swamp.

There is a plume of contaminated groundwater underneath much of TNX and downgradient into the Savannah River Swamp. Volatile organic compounds and nitrate are the most widely distributed contaminants. Mercury and alpha-emitting radionuclides also are present near the known disposal sites.

Table 10-4 summarizes 1996 groundwater monitoring results for D-Area and TNX. 
Table 10-4 Constituent Groups Above Drinking Water Standards at D-Area and TNX in 1996

\begin{tabular}{llll}
\hline Constituent Groups & $\begin{array}{l}\text { Percent of Wells } \\
\text { with Results } \\
\text { above Standards }\end{array}$ & $\begin{array}{l}\text { Number } \\
\text { of Wells } \\
\text { Sampled }\end{array}$ & Sources of Contamination \\
\hline $\begin{array}{l}\text { Dioxins/furans } \\
\text { Metals }\end{array}$ & 0 & 8 & None \\
Organics & $20 \%$ & 76 & $\begin{array}{l}\text { D-Area coal facilities, oil disposal basin, TNX } \\
\text { burying ground }\end{array}$ \\
Pesticides/PCBs & $40 \%$ & 75 & $\begin{array}{l}\text { Oil disposal basin, old TNX seepage basin, } \\
\text { TNX burying ground }\end{array}$ \\
$\begin{array}{l}\text { Tritium } \\
\text { Other radionuclides }\end{array}$ & 0 & 59 & $\begin{array}{l}\text { None } \\
\text { Other constituents }\end{array}$ \\
\hline $12 \%$ & 60 & $\begin{array}{l}\text { None } \\
\text { Coal pile runoff containment basin, TNX } \\
\text { burying ground }\end{array}$ \\
\hline
\end{tabular}

Note: Drinking Water Standards refer to federal final primary DWS, proposed primary DWS, and interim final primary DWS. 


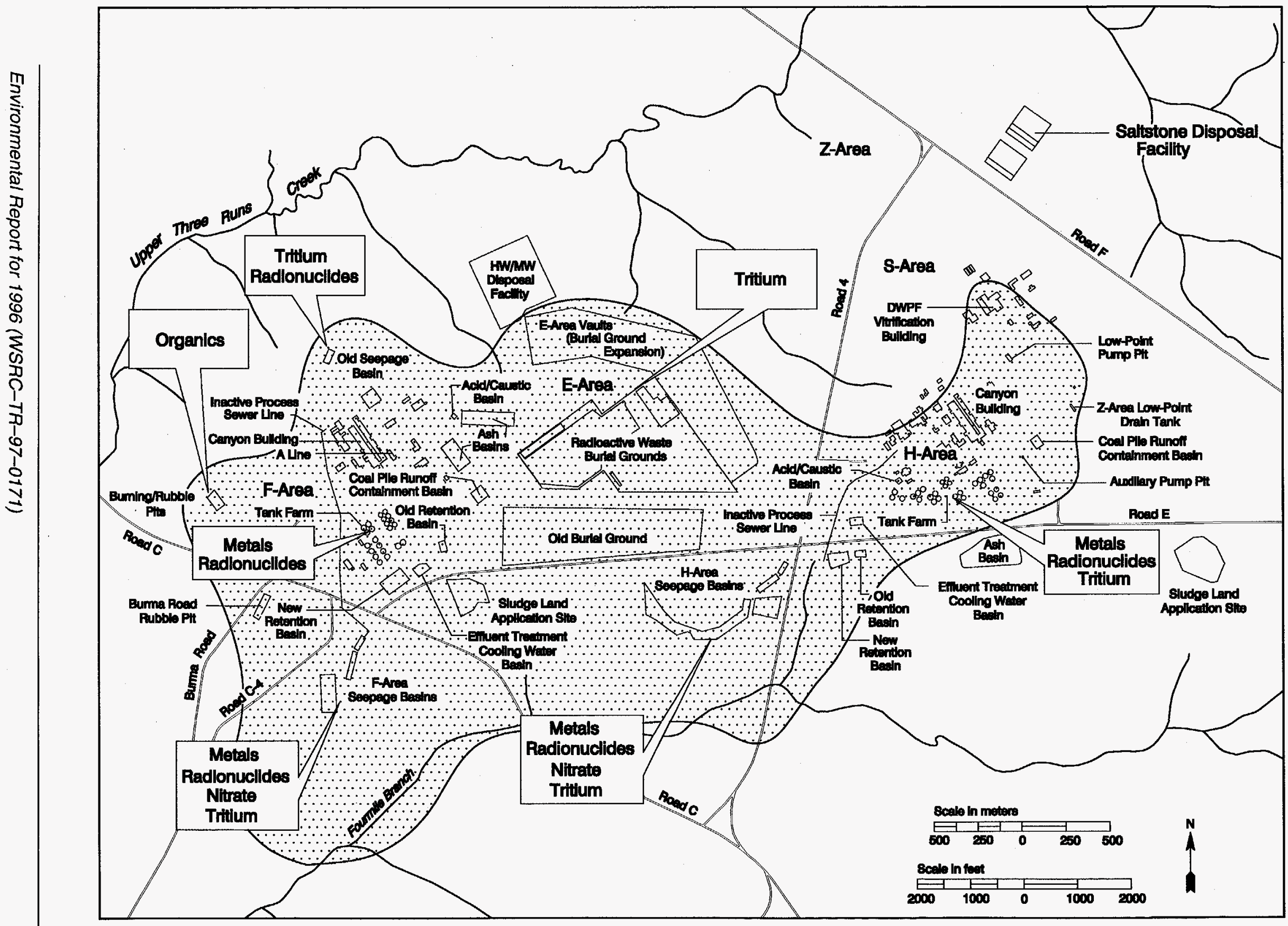

Figure 10-8 Extent of Groundwater Contamination Beneath the General Separations and Waste Management Areas in 1996 and Location of Noteworthy Sources of Contamination Exceeding Drinking Water Standards 


\section{Groundwater Contamination at the General Separations and Waste Management Areas}

\section{Location and Facilities}

The separations and waste management areas, which include E-Area, F-Area, H-Area, S-Area, and Z-Area, are located in the central part of SRS.

Reactor-produced materials are processed in the chemical separations plants in F-Area and H-Area, where uranium, plutonium-238, and plutonium-239 are separated from each other and from fission products. These areas also have facilities for purification and packaging of tritium and for storage of fission wastes.

The separations and waste management areas include the following facilities associated with the groundwater monitoring program:

\section{E-Area}

- Burial Ground expansion (E-Area Vaults)

- E-Area Hazardous Waste/Mixed Waste Disposal Facility

- Old Burial Ground

- Radioactive Waste Burial Ground (also known as Solid Waste Disposal Facility)

\section{F-Area}

- F-Area acid/caustic basin

- F-Area Burma Road rubble pit

- F-Area burning/rubble pits

- F-Area canyon building and A-Line Uranium Recovery Facility

- F-Area coal pile runoff containment basin and ash basins

- F-Area effluent treatment cooling water basin

- F-Area retention basin

- F-Area seepage basins and inactive process sewer line

- F-Area sludge land application site

- F-Area tank farm

- Old F-Area retention basin

- Old F-Area seepage basin

H-Area

- H-Area acid/caustic basin

- H-Area auxiliary pump pit
- H-Area canyon building

- H-Area coal pile runoff containment basin and ash basin

- H-Area effluent treatment cooling water basin

- H-Area retention basin

- H-Area seepage basins and inactive process sewer line

- H-Area sludge land application site

- H-Area tank farm

- Old H-Area retention basin

S-Area

- Defense Waste Processing Facility

- S-Area auxiliary pump pit

- S-Area low-point pump pit

Z-Area

- Z-Area low-point drain tank

- Z-Area Saltstone Disposal Facility

\section{Nature of Contamination}

Surface drainage in these areas of SRS is to Four Mile Creek to the south and Upper Three Runs Creek and its tributaries to the north and west.

E-Area, F-Area, and H-Area are located on the groundwater divide between Four Mile Creek and Upper Three Runs Creek. Near-surface groundwater in the southern portions of these areas discharges to Four Mile Creek and its tributaries. Near-surface groundwater in the northern portions of these areas discharges to Upper Three Runs Creek and its tributaries to the north.

S-Area and Z-Area are located on the groundwater divide between Upper Three Runs Creek and its tributaries to the west.

Figure 10-8 shows the extent of contamination and the location of the various contaminant groups at the general separations areas. The facilities at E-Area, F-Area, and H-Area have been sources of substantial groundwater pollution. In the past, the seepage and retention basins in F-Area and $\mathrm{H}$-Area have been used to dispose of liquids containing radionuclides, metals, organics, and nitrates. Radioactive liquids have leaked into the groundwater below the tank farms. Tritium and metals have leached from materials buried in E-Area. Several stabilization and closure programs have been implemented to reduce the impact of the sources of groundwater contamination. The newer facilities in S-Area and Z-Area are not known to produce any groundwater pollution. 
Many groundwater contamination plumes overlap in the area. Plumes from the Old Burial Ground and the F-Area and $\mathrm{H}$-Area seepage basins discharge radionuclides, metals, and nitrates into Four Mile Creek. An extensive tritium plume is migrating north from the Solid Waste Disposal Facility. Other plumes are under the buildings, tank farms, and other waste disposal areas.

Table 10-5 summarizes 1996 groundwater monitoring results for the general separations and waste management areas.

Table 10-5 Constituent Groups Above Drinking Water Standards at the General Separations and Waste Management Areas in 1996

\begin{tabular}{|c|c|c|c|}
\hline Constituent Groups & $\begin{array}{l}\text { Percent of Wells } \\
\text { with Results } \\
\text { above Standards }\end{array}$ & $\begin{array}{l}\text { Number } \\
\text { of Wells } \\
\text { Sampled }\end{array}$ & Sources of Contamination \\
\hline Dioxins/furans & 0 & 14 & None \\
\hline Metals & $24 \%$ & 414 & Seepage basins, tank farms \\
\hline Organics & $12 \%$ & 376 & $\begin{array}{l}\text { Burial Ground, burning/rubble pit, canyon } \\
\text { buildings, seepage basins }\end{array}$ \\
\hline Pesticides/PCBs & 0 & 31 & None \\
\hline Tritium & $54 \%$ & 435 & $\begin{array}{l}\text { Burial Ground, canyon buildings, seepage } \\
\text { basins }\end{array}$ \\
\hline Other radionuclides & $39 \%$ & 422 & $\begin{array}{l}\text { Burning/rubble pit, canyon buildings, } \\
\text { seepage basins, tank farms }\end{array}$ \\
\hline Other constituents & $28 \%$ & 339 & Seepage basins \\
\hline
\end{tabular}

Note: Drinking Water Standards refer to federal final primary DWS, proposed primary DWS, and interim final primary DWS. 


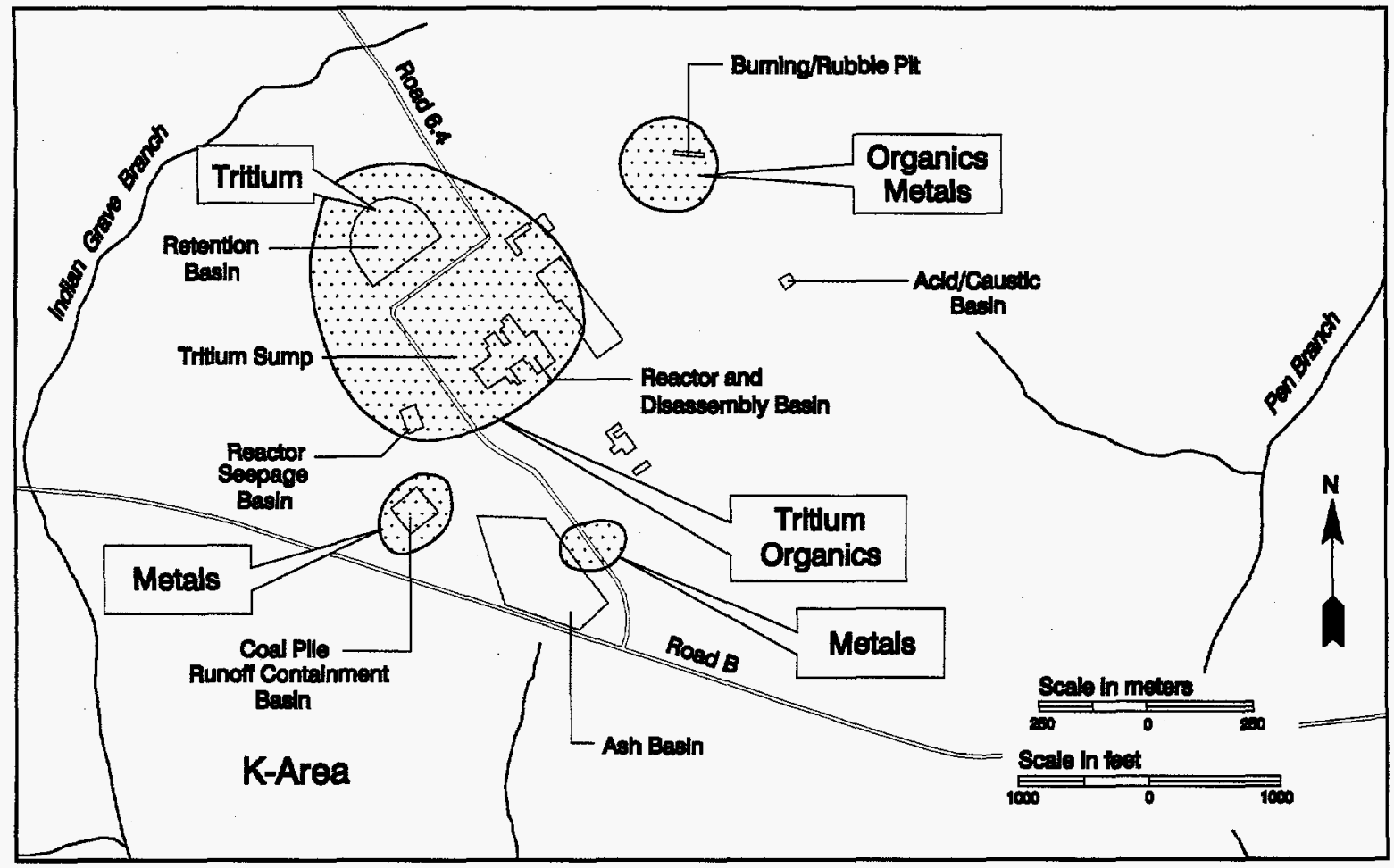

Exploration Resources, Inc.

Figure 10-9 Extent of Groundwater Contamination Beneath K-Area in 1996 and Location of Noteworthy Sources of Contamination Exceeding Drinking Water Standards

\section{Groundwater Contamination at K-Area}

\section{Location and Facilities}

$\mathrm{K}$-Area is in the south-central part of SRS and contains the K-Area reactor, which achieved criticality in 1954 and was shut down in 1988 for maintenance. The reactor was placed in cold shutdown in February 1996.

$\mathrm{K}$-Area includes the following facilities associated with the groundwater monitoring program:

- K-Area acid/caustic basin

- K-Area ash basin

- K-Area Bingham pump outage pit

- K-Area burning/rubble pit

- K-Area coal pile runoff containment basin

- K-Area diesel tank spill

- K-Area disassembly basin

- K-Area reactor

- K-Area reactor seepage basin

- $\mathrm{K}$-Area retention basin
- K-Area sludge land application site

- K-Area tritium sump

\section{Nature of Contamination}

The bisection of Pen Branch and Indian Grave Branch isolates the near-surface groundwater. Deeper groundwater flows toward the Savannah River.

Figure 10-9 shows the extent of contamination and the location of the various contaminant groups in $\mathrm{K}$-Area. Several plumes of contaminated groundwater are at K-Area. The largest plume consists of tritium-contaminated water around the disassembly basin, the reactor seepage basin, and the retention basin. As described in the C-Area discussion, these sites are known sources of tritium. Low levels of volatile organics are detected in some wells that monitor this plume.

Some groundwater under and near the ash basin and the coal pile runoff containment basin have metals and gross-alpha contamination. These are typical contaminants leached from coal and coal ash.

The groundwater underneath the burning/rubble pit is contaminated with tetrachloroethylene, and lead and thallium were detected above the DWS.

Table 10-6 summarizes 1996 groundwater monitoring results for K-Area. 
Table 10-6 Constituent Groups Above Drinking Water Standards at K-Area in 1996

\begin{tabular}{llll}
\hline Constituent Groups & $\begin{array}{l}\text { Percent of Wells } \\
\text { with Results } \\
\text { above Standards }\end{array}$ & $\begin{array}{l}\text { Number } \\
\text { of Wells } \\
\text { Sampled }\end{array}$ & Sources of Contamination \\
\hline $\begin{array}{l}\text { Dioxins/furans } \\
\text { Metals }\end{array}$ & - & - & \\
Organics & $18 \%$ & 33 & $\begin{array}{l}\text { Ash basin, coal pile runoff containment basin } \\
\text { Burning/rubble pit, disassembly basin, } \\
\text { reactor seepage basin, retention basin }\end{array}$ \\
Tritium & $31 \%$ & 16 & $\begin{array}{l}\text { None } \\
\text { Other radionuclides }\end{array}$ \\
Other constituents & $4 \%$ & 5 & $\begin{array}{l}\text { Disassembly basin, reactor seepage basin, } \\
\text { retention basin }\end{array}$ \\
\hline
\end{tabular}

Notes: Drinking Water Standards refer to federal final primary DWS, proposed primary DWS, and interim final primary DWS.

Dioxins/furans were not sampled at K-Area during 1996. 


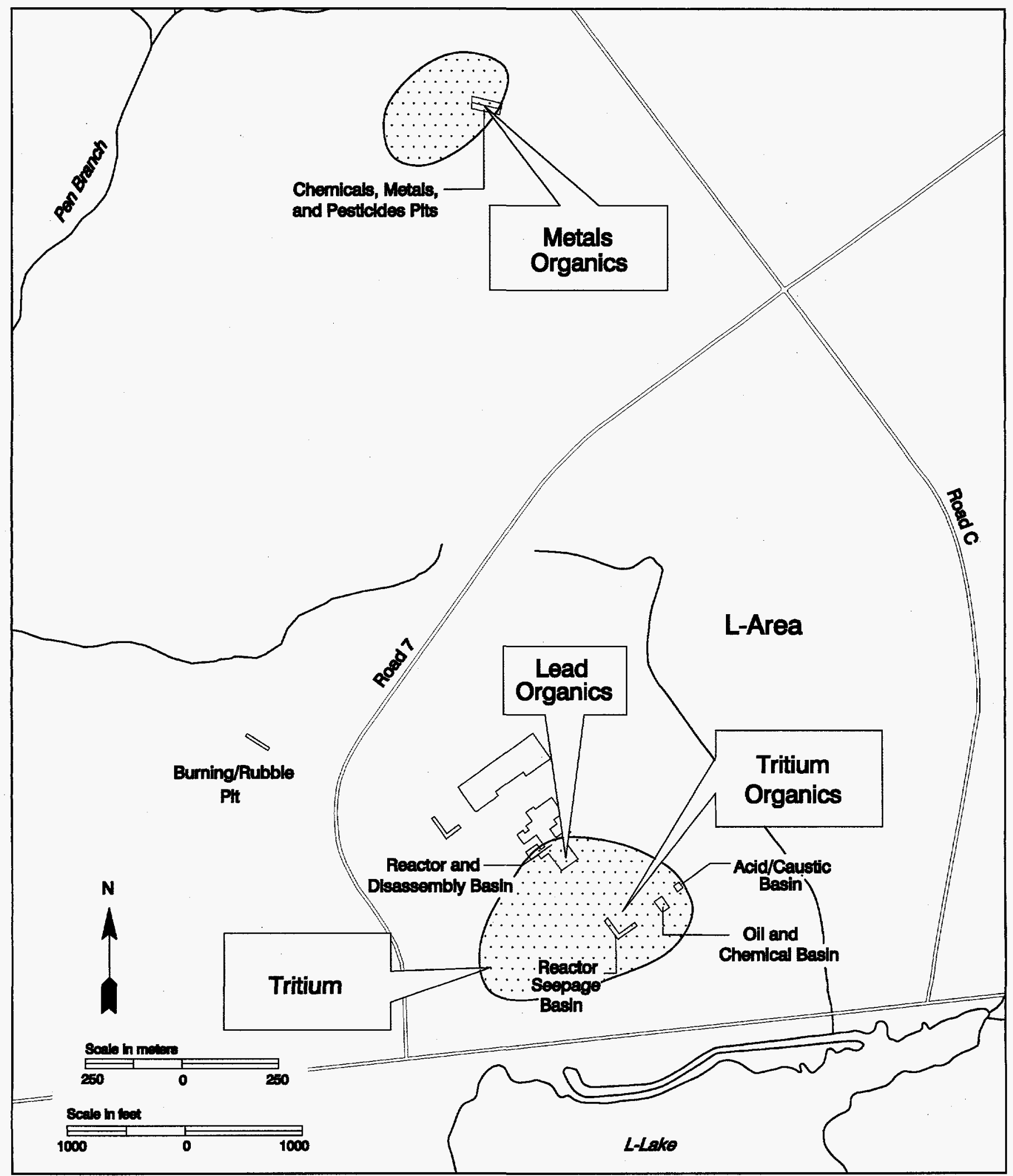

Exploration Resources, Inc.

Figure 10-10 Extent of Groundwater Contamination Beneath L-Area and the Chemicals, Metals, and Pesticides Pits in 1996 and Location of Noteworthy Sources of Contamination Exceeding Drinking Water Standards 


\section{Groundwater Contamination at L-Area and the Chemicals, Metals, and Pesticides Pits}

\section{Location and Facilities}

L-Area is in the south-central part of SRS and contains the L-Area reactor, which achieved criticality in 1954 and continued production until 1968 , when it was placed in warm standby. It subsequently operated from 1985 until 1988, when it was shut down for maintenance. It was placed in warm standby in December 1991 to be put into operation as a backup to K-Reactor, if necessary, but since has been placed in cold shutdown.

L-Area includes the following facilities associated with the groundwater monitoring program:

- L-Area acid/caustic basin

- L-Area Bingham pump outage pit

- L-Area burning/rubble pit

- L-Area disassembly basin

- L-Area oil and chemical basin

- L-Area reactor

- L-Area reactor seepage basin

The chemicals, metals, and pesticides (CMP) pits are near the head of Pen Branch. The pits were used from 1971 to 1979 to dispose of waste consisting of drummed oil, organic solvents, and small amounts of pesticides and metals. In 1984, the pits were excavated to form two trenches, backfilled, and capped. During excavation, most of the contaminated material was removed to the Hazardous Waste Storage Facility.

\section{Nature of Contamination}

Figure 10-10 shows the extent of contamination and the location of the various contaminant groups at L-Area and the CMP pits. There is a plume of contaminated groundwater downgradient between the $\mathrm{L}$-Area reactor buildings and L-Lake. Tritium is the most extensive contaminant, and lead and volatile organics are present in low concentrations. Tritium activity in a monitoring well about 1,000 feet southwest of the reactor building has increased substantially since 1994 . Volatile organic compounds are present near the disassembly basin and the oil and chemical basin.

Several small tributaries of Steel Creek receive surface drainage from L-Area. The near-surface groundwater discharges to Steel Creek and Pen Branch.

A plume of groundwater underneath the CMP pits is contaminated with volatile organics and metals.

Monitoring results from 1996 were similar to those of previous years.

Surface drainage at the CMP pits is to the north toward Pen Branch and to the south toward a tributary of Pen Branch. Groundwater flows downward and horizontally away from the pits.

Table 10-7 summarizes 1996 groundwater monitoring results for L-Area and the CMP pits. 
Table 10-7 Constituent Groups Above Drinking Water Standards at L-Area and the Chemicals, Metals, and Pesticides Pits in 1996

\begin{tabular}{|c|c|c|c|}
\hline Constituent Groups & $\begin{array}{l}\text { Percent of Wells } \\
\text { with Results } \\
\text { above Standards }\end{array}$ & $\begin{array}{l}\text { Number } \\
\text { of Wells } \\
\text { Sampled }\end{array}$ & Sources of Contamination \\
\hline Dioxins/furans & - & - & \\
\hline Metals & $19 \%$ & 26 & CMP pits, disassembly basin \\
\hline Organics & $25 \%$ & 20 & $\begin{array}{l}\text { CMP its, disassembly basin, oil and } \\
\text { chemical basin }\end{array}$ \\
\hline Pesticides/PCBs & 0 & 13 & None \\
\hline Tritium & $25 \%$ & 24 & $\begin{array}{l}\text { Disassembly basin, oil and chemical basin, } \\
\text { reactor seepage basin }\end{array}$ \\
\hline Other radionuclides & 0 & 18 & None \\
\hline Other constituents & 0 & 13 & None \\
\hline
\end{tabular}

Notes: Drinking Water Standards refer to federal final primary DWS, proposed primary DWS, and interim final primary DWS.

Dioxins/furans were not sampled at L-Area or the CMP pits during 1996. 


\section{Groundwater Contamination at $\mathrm{N}$-Area}

\section{Location and Facilities}

$\mathrm{N}$-Area, also called the Central Shops area, is located in the central part of SRS and provides supply, maintenance, and other support services.

$\mathrm{N}$-Area includes the following facilities associated with the groundwater monitoring program:

- Fire Department Training Facility

- Ford Building seepage basin
- $\quad \mathrm{N}$-Area burning/rubble pits

- $\quad \mathrm{N}$-Area diesel spill

- Hydrofluoric acid spill

Surface drainage in N-Area is to tributaries of Four Mile Creek to the north, west, and south and to tributaries of Pen Branch to the east. Four Mile Creek, Upper Three Runs Creek, and several other incised creeks are located between $\mathrm{N}$-Area and the SRS boundary and are areas of groundwater discharge.

Groundwater monitoring results for 1996, shown in table 10-8, indicate no evidence of contamination.

Table 10-8 Constituent Groups Above Drinking Water Standards at N-Area in 1996

\begin{tabular}{llll}
\hline Constituent Groups & $\begin{array}{l}\text { Percent of Wells } \\
\text { with Results } \\
\text { above Standards }\end{array}$ & $\begin{array}{l}\text { Number } \\
\text { of Wells } \\
\text { Sampled }\end{array}$ & Sources of Contamination \\
\hline Dioxins/furans & - & - & \\
Metals & 0 & 8 & None \\
Organics & 0 & 1 & None \\
Pesticides/PCBs & - & - & \\
Tritium & 0 & 6 & None \\
Other radionuclides & 0 & 3 & None \\
Other constituents & 0 & 3 & None
\end{tabular}

Notes: Drinking Water Standards refer to federal final primary DWS, proposed primary DWS, and interim final primary DWS.

Dioxins/furans and pesticides/PCBs were not sampled at N-Area during 1996. 


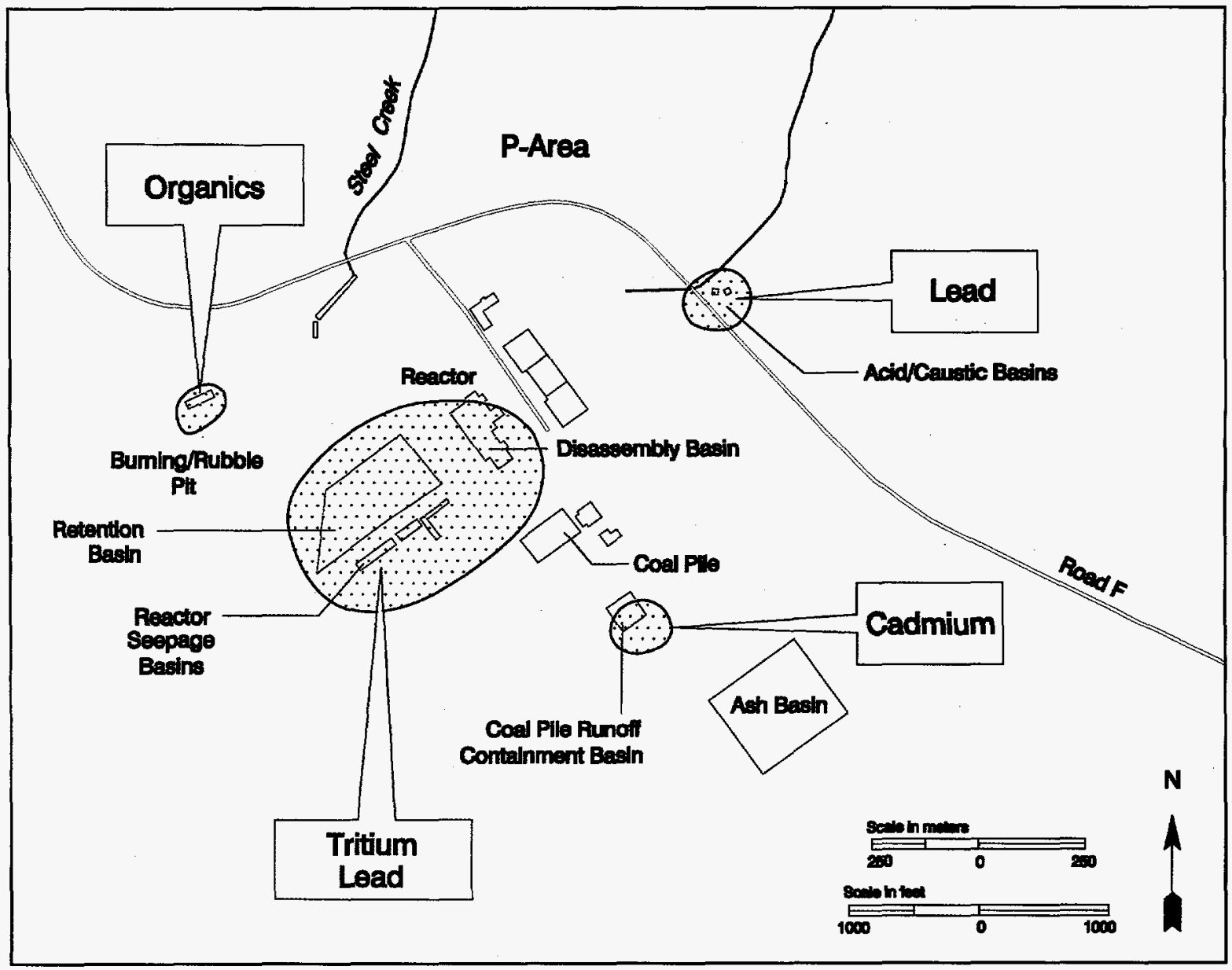

Exploration Resources, Inc.

Figure 10-11 Extent of Groundwater Contamination Beneath P-Area in 1996 and Location of Noteworthy Sources of Contamination Exceeding Drinking Water Standards

\section{Groundwater Contamination at P-Area}

\section{Location and Facilities}

P-Area, located in the south-central part of SRS, houses the P-Area reactor, which achieved criticality in 1954, was shut down for maintenance in 1987 , and has since been placed in cold shutdown.

P-Area includes the following facilities associated with the groundwater monitoring program:

- P-Area acid/caustic basins

- P-Area ash basin

- P-Area Bingham pump outage pit

- P-Area burning/rubble pit

- P-Area coal pile and coal pile runoff containment basin
- P-Area disassembly basin

- P-Area reactor

- P-Area reactor seepage basins

- P-Area retention basin

\section{Nature of Contamination}

Lower Three Runs Creek to the east, Steel Creek to the southwest, and Meyers Branch to the south and east isolate the near-surface groundwater in P-Area. The horizontal hydraulic gradients vary across P-Area and increase near a tributary to PAR Pond.

The horizontal gradients also increase near a tributary to Steel Creek to the southeast.

Figure 10-11 shows the extent of contamination and the location of various contaminant groups at P-Area. The largest plume of contaminated groundwater in P-Area consists of tritium contamination near the disassembly basin and the reactor seepage basins. 
Lead was elevated in a few wells near the seepage basins. These results are consistent with past years and are expected, based on the tritium disposal at these sites.

As in the past, low levels of trichloroethylene were detected in the groundwater near the burning/rubble pits. Also, lead was detected above the DWS near the acid/caustic basins, and cadmium was elevated near the coal pile runoff containment basin.

Table 10-9 summarizes 1996 groundwater monitoring results for P-Area.

Table 10-9 Constituent Groups Above Drinking Water Standards at P-Area in 1996

\begin{tabular}{llll}
\hline Constituent Groups, & $\begin{array}{l}\text { Percent of Wells } \\
\text { with Results } \\
\text { above Standards }\end{array}$ & $\begin{array}{l}\text { Number } \\
\text { of Wells } \\
\text { Sampled }\end{array}$ & Sources of Contamination \\
\hline $\begin{array}{l}\text { Dioxins/furans } \\
\text { Metals }\end{array}$ & - & - & \\
Organics & $20 \%$ & 20 & $\begin{array}{l}\text { Acid/caustic basin, coal pile runoff contain- } \\
\text { ment basin, seepage basin }\end{array}$ \\
Pesticides/PCBs & $25 \%$ & 4 & Burning/rubble pit \\
Tritium & - & - & Disassembly basin, seepage basin \\
Other radionuclides & 0 & 15 & None \\
Other constituents & 0 & 6 & None \\
\hline
\end{tabular}

Notes: Drinking Water Standards refer to federal final primary DWS, proposed primary DWS, and interim final primary DWS.

Dioxins/furans and pesticides/PCBs were not sampled at P-Area during 1996. 


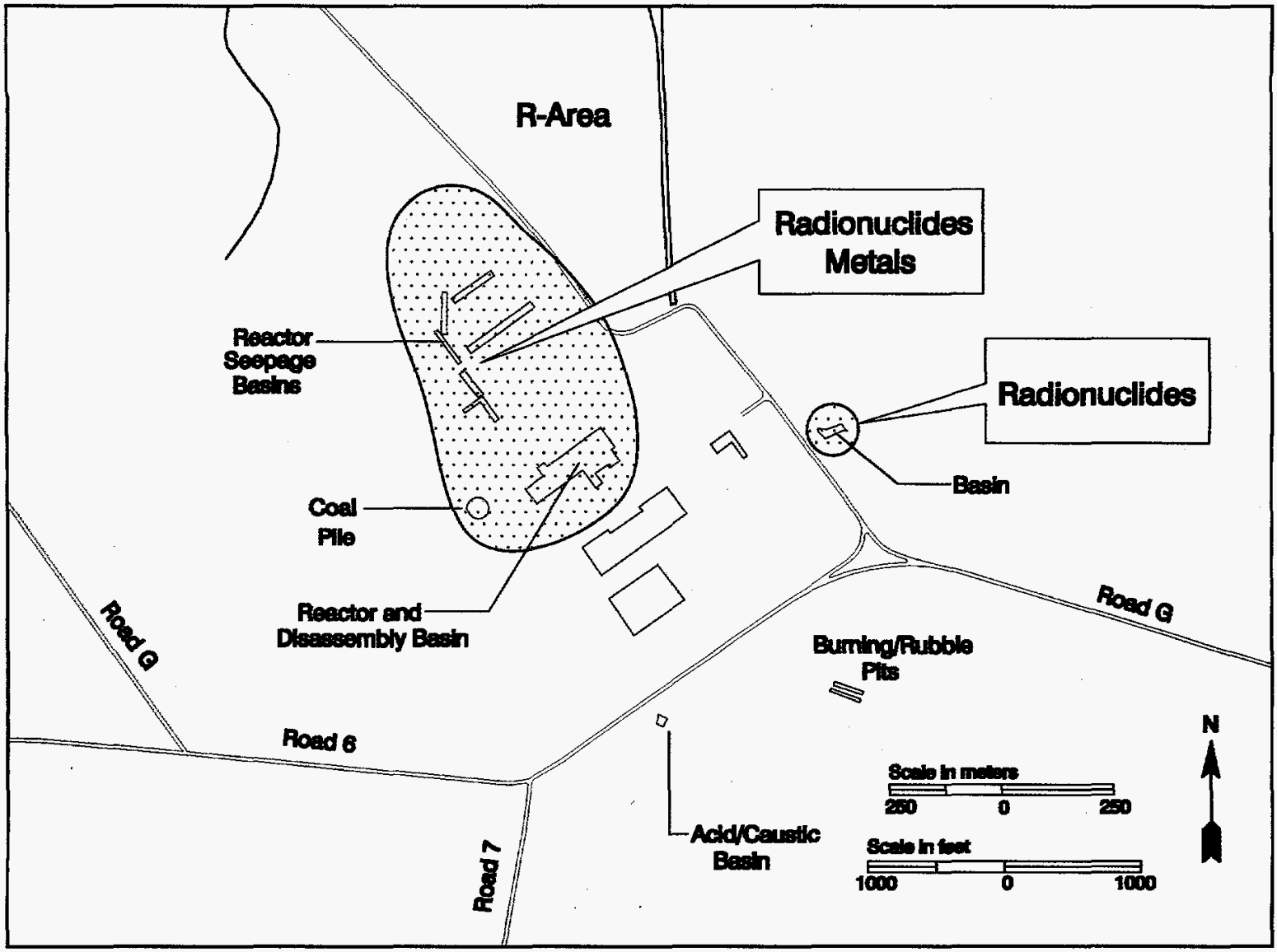

Exploration Resources, Inc.

Figure 10-12 Extent of Groundwater Contamination Beneath R-Area in 1996 and Location of Noteworthy Sources of Contamination Exceeding Drinking Water Standards

\section{Groundwater Contamination at R-Area}

\section{Location and Facilities}

R-Area, located in the east-central part of SRS, houses the R-Reactor, which achieved criticality in 1953 and was shut down permanently in 1964.

R-Area includes the following facilities associated with the groundwater monitoring program:

- R-Area acid/caustic basin

- R-Area Bingham pump outage pit

- R-Area burning/rubble pits

- R-Area coal pile

- R-Area disassembly basin

- R-Area reactor

- $\mathrm{R}$-Area reactor seepage basins

\section{Nature of Contamination}

Surface drainage in R-Area is to the northwest and northeast toward Mill Creek and Pond A and to the southeast and southwest toward tributaries of Pond 4 and Pond 2.

Incised tributaries, streams, and PAR Pond separate near-surface groundwater at R-Area from the site boundary to the east. R-Area is near a groundwater divide between Mill Creek and PAR Pond. The groundwater just north of R-Area naturally discharges to Mill Creek to the northwest and to the R-Area Canal of Pond A to the northeast. The groundwater from the southern part of R-Area naturally discharges to a tributary of Pond 4 south of R-Area.

Figure 10-12 shows the extent of contamination and the location of various contaminant groups at $\mathbf{R}$-Area. The only substantial groundwater contamination at R-Area consists of radionuclides, cadmium, and other metal contamination surrounding the reactor disassembly basin and the seepage basins. This 
contamination is consistent with that of previous years and with the history of the site.

On November 8, 1957, an experimental fuel element failed during a calorimeter test in the emergency section of the R-Area disassembly basin. Following this incident, the original seepage basin received approximately $2,700 \mathrm{Ci}$ of gross beta activity, including strontium-90 and cesium-137, each of which has a half-life of about 30 years. Much of the released radioactivity was contained in that basin, which was backfilled in December 1957. Five more basins were placed in operation in 1957 and 1958 to assist in containing the radioactivity.

Table 10-10 summarizes 1996 groundwater monitoring results for R-Area.

Table 10-10 Constituent Groups Above Drinking Water Standards at R-Area in 1996

\begin{tabular}{llll}
\hline Constituent Groups & $\begin{array}{l}\text { Percent of Wells } \\
\text { with Results } \\
\text { above Standards }\end{array}$ & $\begin{array}{l}\text { Number } \\
\text { of Wells } \\
\text { Sampled }\end{array}$ & Sources of Contamination \\
\hline Dioxins/furans & - & - & Disassembly basin, reactor seepage basin \\
Metals & $25 \%$ & 16 & None \\
Organics & 0 & 6 & None \\
Pesticides/PCBs & 0 & 6 & None \\
Tritium & 0 & 13 & Disassembly basin, reactor seepage basin \\
Other radionuclides & $18 \%$ & 17 & Disassembly basin, reactor seepage basin \\
\hline
\end{tabular}

Notes: Drinking Water Standards refer to federal final primary DWS, proposed primary DWS, and interim final primary DWS.

Dioxins/furans were not sampled at R-Area during 1996. 


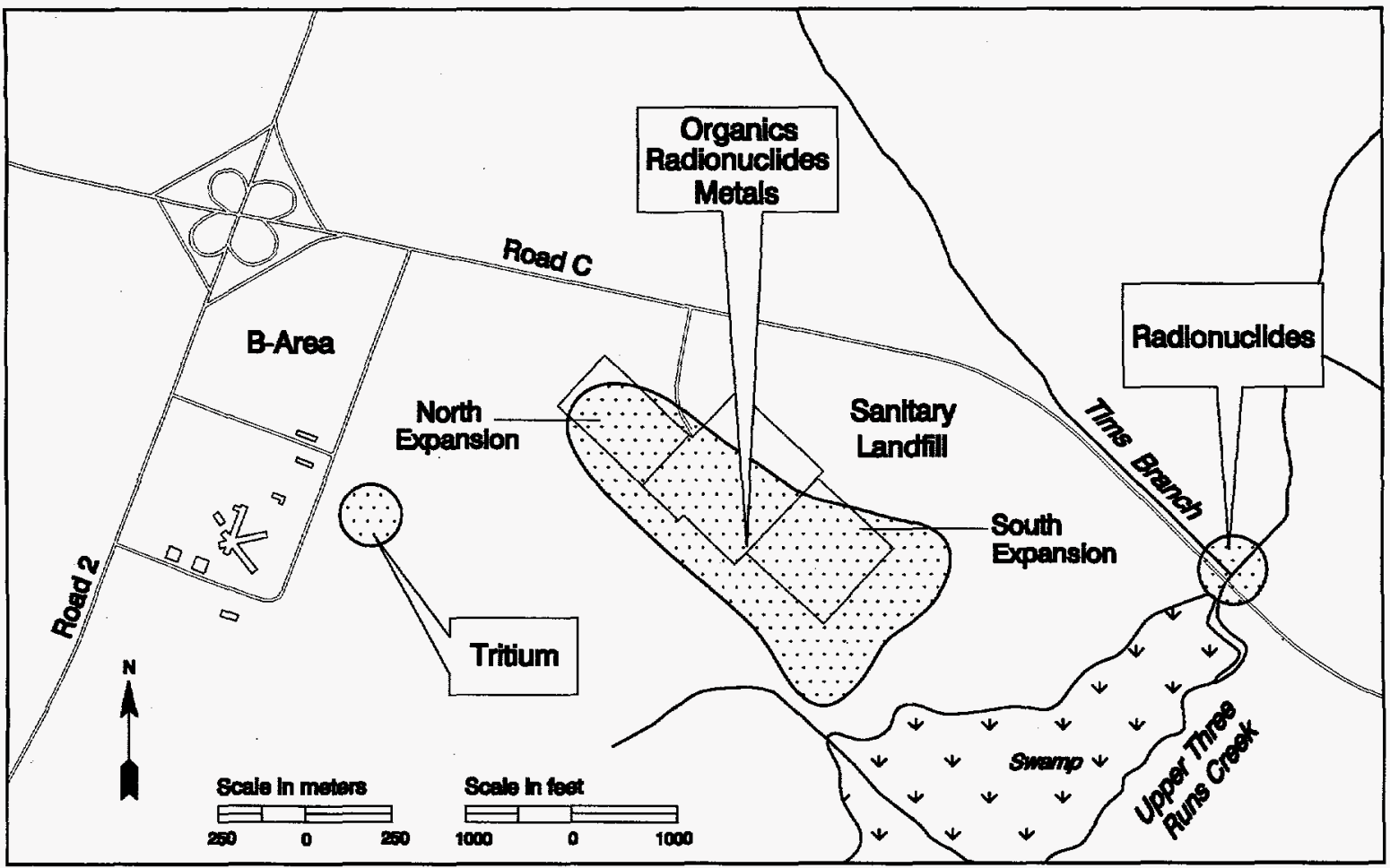

Exploration Resources, Inc.

Figure 10-13 Extent of Groundwater Contamination Beneath the Sanitary Landfill and B-Area in 1996 and Location of Noteworthy Sources of Contamination Exceeding Drinking Water Standards

\section{Groundwater Contamination at the Sanitary Landfill and B-Area}

\section{Location and Facilities}

The Sanitary Landfill is south of Road C, about midway down the slope from the Aiken Plateau to Upper Three Runs Creek.

The Sanitary Landfill began receiving waste from office, cafeteria, and industrial activities during 1974. Materials such as paper, plastics, rubber, wood, cardboard, rags, metal debris, pesticide bags, empty cans, carcasses, asbestos in bags, and sludge from SRS's wastewater treatment plant were placed in unlined trenches and covered daily with soil or a fabric substitute. The original section of the landfill and its southern expansion, with a total area of approximately 54 acres, have been filled. The portion of approximately 16 acres known as the northern expansion, or the interim sanitary landfill, ceased operations in November 1994.

\section{Nature of Contamination}

Surface drainage at the Sanitary Landfill is to the south-southeast, toward Upper Three Runs Creek.
Horizontal groundwater flow is to the southeast, toward Upper Three Runs Creek.

Sanitary landfills are intended to receive only nonradioactive, nonhazardous waste. However, until October 1992, some hazardous wastes (specifically, solvent-laden rags and wipes used for cleaning, decontamination, and instrument calibration) were buried in portions of the original 32-acre landfill and its southern expansion.

Figure 10-13 shows the extent of contamination and the location of various contaminant groups at the Sanitary Landfill and near B-Area. There is a substantial plume of contaminated groundwater under and downgradient of the Sanitary Landfill. Organic compounds are the most widespread contaminants, but metals, tritium, and other radionuclides also are present.

Tritium was detected in one well above the DWS near B-Area. Gross alpha was elevated in one well near Upper Three Runs Creek.

Table 10-11 summarizes the 1996 groundwater monitoring results for the Sanitary Landfill and B-Area. 
Table 10-11 Constituent Groups Above Drinking Water Standards at the Sanitary Landfill and B-Area in 1996

\begin{tabular}{llll}
\hline Constituent Groups & $\begin{array}{l}\text { Percent of Wells } \\
\text { with Results } \\
\text { above Standards }\end{array}$ & $\begin{array}{l}\text { Number } \\
\text { of Wells } \\
\text { Sampled }\end{array}$ & Sources of Contamination \\
\hline Dioxins/furans & 0 & 4 & None \\
Metals & $10 \%$ & 51 & Sanitary Landfill \\
Organics & $21 \%$ & 61 & Sanitary Landfill \\
Pesticides/PCBs & 0 & 45 & None \\
Tritium & $11 \%$ & 45 & B-Area, Sanitary Landfill \\
Other radionuclides & $7 \%$ & 45 & Sanitary Landfill \\
Other constituents & $2 \%$ & 47 & Sanitary Landfill
\end{tabular}

Note: Drinking Water Standards refer to federal final primary DWS, proposed primary DWS, and interim final primary DWS. 



\section{Chapter 11 Quality Assurance}

\author{
Bob Henderson, Moheb Khalil, \\ Walt Kubilius, and Stuart Stinson \\ Environmental Protection Department
}

To Read About ...

See Page ... .

QAVQC for EMS Laboratories ......... 169

Internal QA Program .............. 169

External QA Program ............. 171

QA/QC for Subcontracted Laboratories . 172

Nonradiological Liquid Effluents ....... 173

Stream and River Water Quality . . . . . . . 173

Groundwater .................... 174

Soil/Sediment ........................ 175
$\mathrm{T}$ HE Environmental Monitoring Section (EMS) of the Savannah River Site's (SRS) Environmental Protection Department maintains a quality assurance/quality control (QA/QC) program to continuously verify the integrity of data generated by its own environmental monitoring program and by its subcontracted laboratories. Each aspect of the monitoring program, from sample collection to data reporting, must address QA, QC, and quality assessment standards defined in the Savannah River Site Environmental Monitoring Program Quality Assurance Plan, section 8000 , WSRC-3Q1-2. This chapter summarizes the QA/QC program. Tables containing the 1996 QA/QC data can be found in SRS Environmental Data for 1996, WSRC-TR-97-0077. A more complete description of the EMS QA/QC program can be found in section 1110 of the Savannah River Site Environmental Monitoring Section Plans and Procedures, WSRC-3Q1-2, Volume 1 (SRS EM Program).

Guidelines and applicable standards for the QA/QC environmental monitoring program can be found in appendix A, "Applicable Guidelines, Standards, and Regulations," of this document. Figure 11-1 illustrates the hierarchy of relevant guidance documents that support the EMS QAVQC program. Detailed information about federal, state, and local QA regulations and standards can be found in the SRS EM Program.

\section{QAVQC for EMS Laboratories}

General objectives of the QA/QC program include validity, traceability, and reproducibility of reported results; comparability of results within data bases; representativeness of each sample to the population or condition being measured; and accuracy and precision.

\section{Training for Personnel}

EMS personnel must understand and comply with all requirements applicable to the activities with which they are involved. Consequently, appropriate training courses nurture the employees' understanding and fulfillment of their responsibilities. Courses include training on applicable QA procedures, Occupational Safety and Health Administration-mandated training, and General Employee Training. Regulations and procedures that govern the environmental monitoring program are emphasized.

EMS technicians begin with specific training determined by job assignment. The section's technical work is based on procedures in the WSRC-3Q1 series of manuals:

- "Environmental Sampling Procedures," WSRC-3Q1-3

- "Environmental Radiochemistry Procedures," WSRC-3Q1-4

- "Environmental Water Quality Procedures," WSRC-3Q1-5

- "Environmental Counting Room Procedures," WSRC-3Q1-6

- "Environmental Data Management and Computer Support Procedures," WSRC-3Q1-10

\section{Internal QA Program}

Specific QA checks and accepted practices are conducted by each EMS group, as described in the following paragraphs.

\section{Field Sampling Group}

Blind Sample Program EMS routinely conducts a blind sample program for field measurements of $\mathrm{pH}$ and conductivity to assess the quality and reliability of field data measurements. Conductivity and $\mathrm{pH}$ measurements are taken in the field using the same equipment as is used for routine measurements.

During 1996, blind $\mathrm{pH}$ field measurements were taken for 33 samples, and blind conductivity field measurements were taken for 25 samples. All field $\mathrm{pH}$ measurements were within the U.S. Environmental Protection Agency's (EPA) suggested 


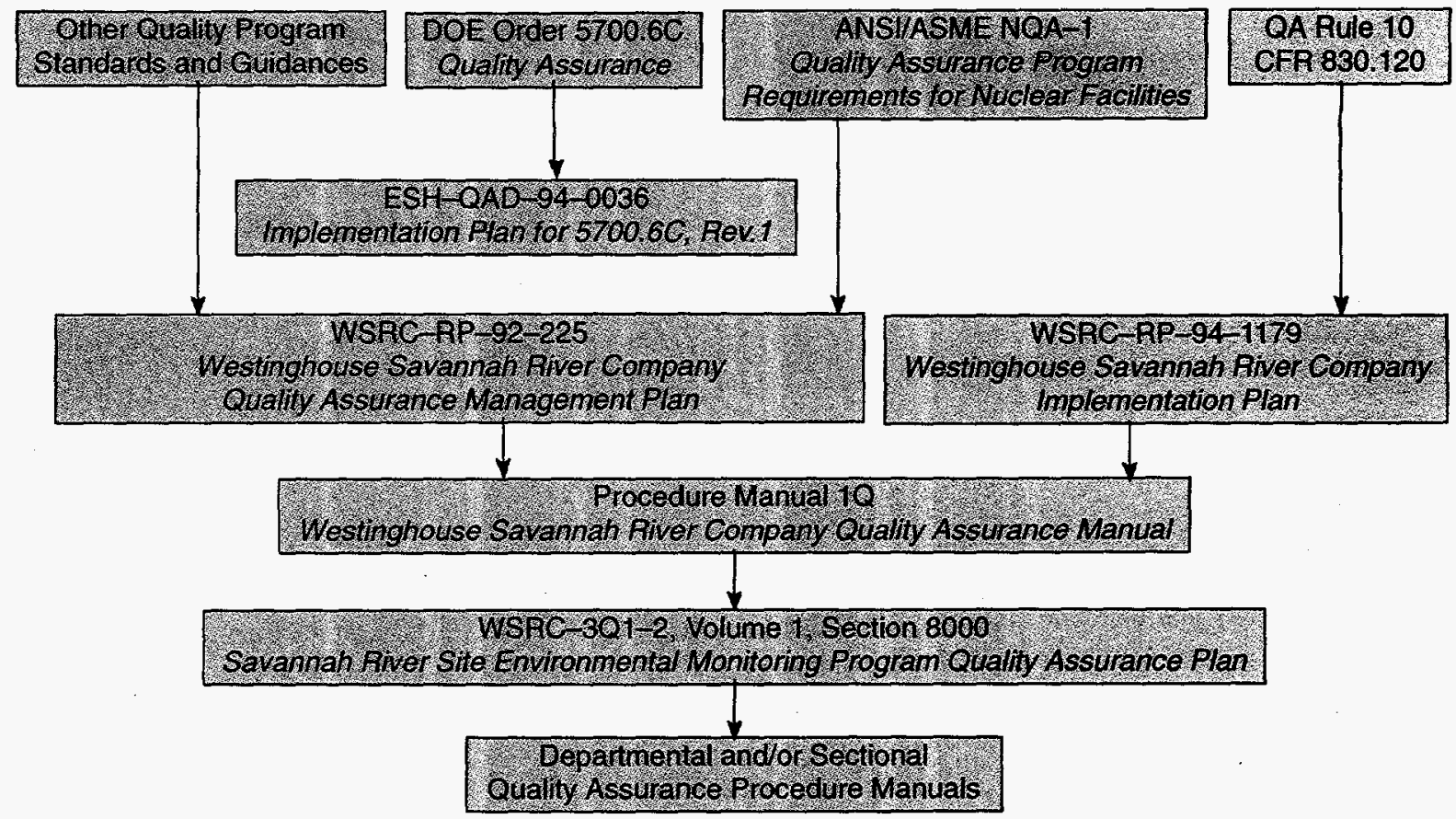

\section{Guidance Documents that Support Programs}

- International Organization for Standardization (ISO) 9000 Series of Standards

- Specifications and Guidelines for Environmental Data Collection and Environmental Technology Programs, ANSI/ASQC E-4

- General Requirements for the Competence of Calibration and Testing Laboratories ISO/IEC Guide 25-1990

Figure 11-1 SRS EM Program QAVC Document Hierarchy/Relevant Guidance Documents

acceptable control limit of $\pm 0.4 \mathrm{pH}$ units of the true (known) value. All field conductivity measurements differed from the true value by less than 15 percent, which is the EMS internal QAVQC control limit.

Instrumentation Calibration EMS personnel also measure chlorine, dissolved oxygen, and temperature in water samples; but because of the difficulties in providing field standards, these measurements are not suitable for a blind sample program. Therefore, quality control of these analyses relies instead on instrumentation calibration, per the WSRC $-3 \mathrm{Q} 1$ procedure series.

\section{Chemistry and Counting Laboratories}

Laboratory performance is evaluated through instrument checks, control charts, and data analyses. In the chemistry group, graphical and numerical trending is conducted on technician and method performance, with reports generated for sample results that exceed warning limits. The Counting Laboratory runs source checks and instrument backgrounds and performs calibrations regularly to monitor and characterize instrumentation.

Routine samples prepared and counted in EMS laboratories are subject to a variety of QC checks to assess and ensure validity. These checks make up 30 percent of the analytical workload. The Environmental Chemistry and Analysis group prepares spikes, blanks, duplicates, and blind samples to check the performance of routine analyses. Spikes and blanks are used to calculate a recovery efficiency of an analytical method, to adjust for background radiation, and to evaluate counting equipment performance.

Blind samples, the radionuclide composition of which is unknown to the technicians preparing or counting the samples, provide a constant check on the proficiency of the chemistry and counting laboratories. Based on matrix availability, blind and spiked samples are prepared from National Institute of Standards and Technology-traceable material or standardized against National Institute of Standards and Technology material. Upon completion of 


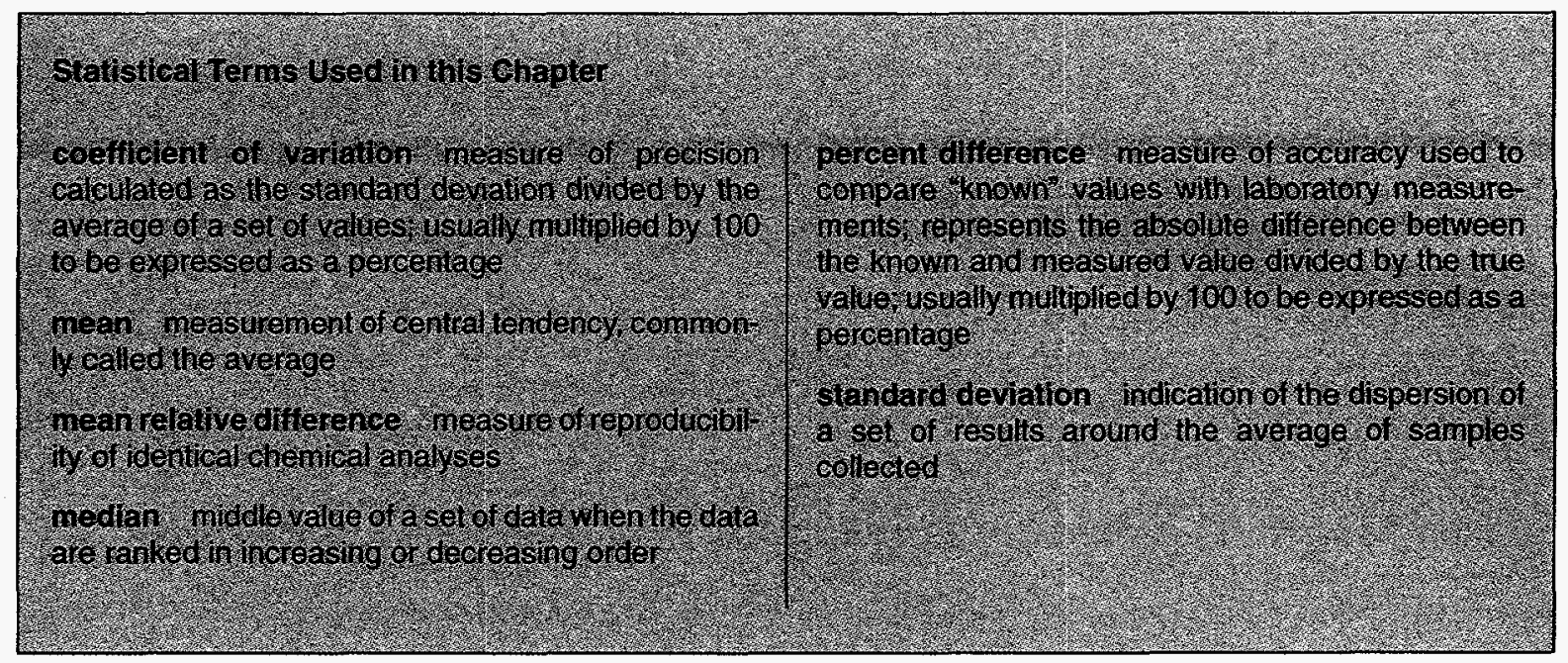

analyses, ratios between the measured and true values are calculated, and the results are added to control charts to identify trends. To address the high relative error of radioactive measurements at low levels, the difference between measured and true values is evaluated against standard deviation units of the true value. During 1996, blind samples were analyzed for tritium and gamma-emitting radionuclides. All tritium data were within the control limits except one, whose low-activity level was near the EMS minimum detectable activity. All gamma data were within the control limits. The results of these blind samples were used to validate analytical work in the chemistry and counting laboratories.

\section{Data Verification and Validation}

Results received from the Counting Laboratory are electronically evaluated by the Environmental Monitoring Computer Automation Project (EMCAP). Sample parameters-such as air flows, counting aliquots, and decay times-are flagged if values exceed preset limits or vary significantly from previous entries. Also, maximum and minimum radioactive acceptance levels, based on historical results, are calculated for all routine environmental samples. Sample results outside the acceptance range are submitted for individual review, which frequently results in analytical reruns, recounts, recalculations, or resampling for verification.

Before data are reported, they must be reviewed and validated by qualified personnel. Electronic verification is performed on 100 percent of the data stored in EMS data bases. Through this verification, data anomalies are removed or data are rejected if there is disagreement with EMS QAVQC policies. The validation methods and criteria are documented in QAP 21-1 of WSRC-1Q and in the EMS

"Environmental Geology Procedures,"
WSRC-3Q1-7. Quality control requirements for managing, evaluating, and publishing environmental monitoring data are defined in WSRC $-3 Q 1-2$, section 8250 .

\section{External QA Program}

The EMS laboratory participates in three interlaboratory comparison programs to track performance accuracy. Under these programs, the U.S. Department of Energy (DOE) and EPA send samples to participating laboratories throughout the year and compare the laboratories' results to true values. These comparisons not only test the accuracy of procedures, but compare SRS with other laboratories nationwide.

The DOE Quality Assurance Program (QAP) tests the quality of environmental data reported to DOE by its contractors. Reference samples for this program-including soil/sediment, water, vegetation, and air filter samples - are prepared by the DOE/EML (Environmental Measurements Laboratory) and sent to participating laboratories. Analytical results are reported to EML within 90 days and compared with the test results of other laboratories. The DOE/EML evaluates the results and distributes them to the participating laboratories.

The second program is administered by the Quality Assurance Division (QAD) of the EPA

Environmental Monitoring System Laboratory in Las Vegas. This division is responsible for QC of environmental radiological measurements. EPA provides participating laboratories with water, air filter, and milk samples that contain a variety of radionuclides with activity concentrations near environmental background levels. The QAD program enables EMS to document the accuracy of radiological analysis data, to identify instrument and 
procedural problems, and to compare analysis performance with other participating laboratories.

Control charts are maintained for the QAD results according to EPA control limits. For QAP results, the control charts are maintained according to DOE/EML control limits. Historical trends alert EMS to a method bias that may be occurring in its laboratories.

Most of the results reported by EMS in the QAD program were within EPA control limits. The results reported by EMS in the QAP program generally fell within the DOE/EML control limits. The results generally showed the greatest bias in samples with low activity levels and in difficult matrices for chemical separation. Air filter samples for strontium showed low bias, and the problem is being investigated. Both the QAD and QAP programs indicate that 95 percent of the EMS analyses fall within the applicable limits, according to the standards of intercomparison agencies, and that they compare favorably with those of other environmental laboratories.

The third intercomparison program, Gamma Spectrometry Data Validation, begun in 1996, provides DOE an assessment of the capabilities of the participating laboratories in performing routine gamma-ray spectra analysis required for EML projects and site characterizations. Previous studies have demonstrated that gamma-ray spectrometry software supplied by commercial manufacturers when tested with complex spectra may provide spurious results.

Participants in the program receive a data disk or tape containing synthetic spectra designed to test the sensitivity and capability of the spectrometry analysis system. The disk/tape contains sample spectra, which the spectroscopist is asked to identify and quantify accurately. The synthetic spectra includes calibration, background, and sample spectra. Participating laboratories are asked to identify and quantify the sample spectra. The spectra tests both the gamma-ray spectrometry software and the ability of the user to use the software properly. Participants' results must be reported to EML within 60 days. The expected results are compiled after the reporting deadline, and an evaluation report is issued within 90 days.

The first set of data in this program, composed of synthetic data simulating spectra obtained from air filters, was analyzed during July 1996 . The resulting evaluation shows that EMS successfully identified and quantified the sample spectra. The evaluation also shows the capability and sensitivity of the EMS high-purity germanium (HPGe) spectrometry
Table 11-1

Subcontracted Laboratories for 1996

General Engineering Laboratories

groundwater

soil/sediment

waste characterization

Roy F. Weston, Inc.

groundwater

soil/sediment

metals analyses for SRS streams

and the Savannah River

waste characterization

Environmental Physics

groundwater radiological analyses

soil/sediment

waste characterization

ThermoNUtech

subcontracted groundwater radiological analyses for Roy F. Weston, Inc.

soillsediment

waste characterization

Shealy Environmental Services

NPDES analyses

metals analyses for SRS streams

and the Savannah River

soil/sediment

domestic water analysis

PROCOUNT data reduction system in producing accurate results.

One gamma line in the synthetic spectra was not identified in the evaluation report; however, it produced two false positive identifications in the EMS analysis. Four isotopes were not detected because they were not included in the EMS gamma analysis library.

\section{QAVC for Subcontracted Laboratories}

Subcontracted laboratories providing analytical services must have a documented $Q A / Q C$ program and meet the quality requirements defined in WSRC-1Q. The subcontracted laboratories used during 1996 and the types of analyses performed are listed in table 11-1. 
EMS personnel perform an annual evaluation of each subcontracted laboratory to ensure that the laboratories maintain technical competence and follow the required QA programs. Each evaluation includes an examination of laboratory performance with regard to sample receipt, instrument calibration, analytical procedures, data verification, data reports, records management, nonconformance and corrective actions, and preventive maintenance. EMS provides reports of the findings and recommendations to each laboratory and conducts followup evaluations as necessary.

\section{Nonradiological Liquid Effluents}

Nonradiological liquid effluent samples are collected at each permitted SRS outfall according to requirements in the National Pollutant Discharge Elimination System (NPDES) permit issued by the South Carolina Department of Health and Environmental Control (SCDHEC). Effluent samples are analyzed by EMS for temperature, $\mathrm{pH}$, dissolved oxygen, and chlorine and by a subcontracted laboratory for other constituents, such as fecal coliform, metals, organics, and oil and grease. Shealy Environmental Services was the primary subcontractor for the NPDES program throughout 1996.

\section{Interlaboratory Comparison Program}

Interlaboratory comparison studies are used to compare the quality of results between laboratories performing the same analyses. During 1996, Shealy and EMS participated in interlaboratory comparison studies conducted by EPA.

\section{All subcontracted laboratories analyzing NPDES samples must participate in the EPA Discharge Monitoring Report Laboratory Performance Evaluation program. Under this program, EPA sends - to participating laboratories-performance samples containing constituents normally found in industrial and municipal wastewaters.}

These water samples have known chemical parameters, such as chemical oxygen demand, and contain known concentrations of constituents, such as total suspended solids, oil and grease, and certain trace metals. EPA provides a final comprehensive report to the program participants. The report contains a statistical analysis of all data, as well as documentation of the known sample value, with stated acceptance limits and warning limits. Accepted variations from the known sample value depend on a variety of factors, including the precision of the analysis and the extent to which the results can be reproduced.
In 1996, Shealy ran analyses for 32 parameters under the EPA program. EMS performed analyses for only three of the EPA parameters-chlorine, total suspended solids, and $\mathrm{pH}$. Shealy was outside acceptance limits for two analyses-beryllium and cyanide. EMS was outside acceptance limits for $\mathrm{pH}$. EMS performed additional analyses for $\mathrm{pH}$ and is waiting for results from EPA.

\section{Intralaboratory Comparison Program}

The intralaboratory program compares performance within a laboratory by analyzing duplicate and blind samples throughout the year. Shealy analyzed 471 duplicates samples for various parameters during 1996. Percent difference calculations showed that 398 of these samples were within the EMS internal QA/QC requirements of 20 percent. Forty-nine exceedances involved either total suspended solids, oil and grease, or biological oxygen demand, the analyses of which typically produce highly variable results. Thirteen exceedances occurred because results at or near the analytical detection limit produce large percent variations for small differences in actual data. The remaining 11 exceedances appeared to be related to analytical error at the subcontracted laboratories, sample contamination, or improper sampling technique.

Shealy also analyzed 53 blind samples submitted by EMS. Percent difference calculations showed that 46 of these samples were within the acceptable range of 20 percent. Of the seven exceedances, four were for biological oxygen demand and oil and grease; one other-for zinc-was the result of data at or near the analytical detection limit; and the remaining two-for ammonia and zinc-appeared to be related to analytical error at the subcontracted laboratory, sample contamination, or improper sampling technique.

\section{Stream and River Water Quality}

Metals analyses of samples from SRS streams and the Savannah River are also performed by a subcontracted laboratory. The water quality program requires quality checks of 10 percent of the samples to verify the analytical results. Split samples were sent for metals analyses to subcontractor laboratory Shealy and to verifying laboratory Roy F. Weston, Inc. (Weston). For the first quarter, the results from Shealy for aluminum, manganese, sodium, and zinc were significantly less than the results from Weston. For the second quarter, the results from Shealy for calcium, sodium, and zinc were significantly less than the results from Weston. For the third quarter, the results from Shealy for aluminum, copper, iron, and zinc were significantly less than the results from 
Weston. This consistent pattern indicates a systematic bias between the two laboratories.

In response to a continued trend of result discrepancies between the subcontract laboratory and the verifying laboratory, blind certified test samples were sent to both laboratories as part of an investigation to determine the cause of the discrepancies. Shealy was outside acceptance limits on 60 percent of analytes for the first blind sample and 80 percent for the second blind sample. All results were lower than the actual values of the blind samples. An audit of Shealy was performed to identify the root cause of the errors. The primary finding was that the subcontract laboratory and verifying laboratory were using different sample digestion methods. Shealy used an aggressive digestion - as required by NPDES analytical methods-that can result in loss of analyte in the sample. Environmental Resource Associates, the vendor that provided the blind sample, verified that aggressive digestion should not be performed on the blind sample. Secondary factors included blank contamination of reagent blanks and an incorrect application of interelement correction factors. After performing corrective actions for the identified problems, More than 80 percent of Shealy's results on subsequent blind samples have been within acceptance limits. The EMS QA/QC program will be modified to prevent future occurrences of error due to incorrect digestion methodology.

Laboratory methodology and analysis reproducibility between the subcontracted and the verifying laboratories were checked during the first three quarters of 1996. For the first two quarters, water samples from all EMS water quality field locations were composited into one sample, then split into three duplicates for the subcontracted laboratory and three for the verifying laboratory. For the third quarter, program changes were instituted that reduced the amount of sample available for compositing. As a result, only two duplicates were sent to each laboratory for analysis. For all three quarters, each sample was analyzed for a group of 12 metals. No samples were submitted for the fourth quarter because of programmatic changes. The subcontracted laboratory was Shealy and the verifying laboratory was Weston.

Mean relative difference (MRD) calculations exceeded 20 percent in 10 instances, indicating a lack of agreement between the subcontracted and verifying laboratories. Metals found not in agreement included aluminum and sodium for all three quarters and copper and zinc for the second and third quarters.
In general, the average percent coefficient of variation was below 10 percent for both the subcontracted laboratory and the verifying laboratory throughout the year, indicating that result reproducibility was satisfactory. The one exception occurred in the subcontract laboratory's (Shealy) first-quarter results, producing a percent coefficient of variation of 15.14 percent. For individual analyses, there were four instances in the first quarter and two instances in the second and third quarters in which the coefficient of variation exceeded 20 percent. In four instances, the actual analytical data were at or near the detection limit for the analyses. Small differences in results at or near the detection limit can cause large statistical calculation fluctuations that do not actually indicate a problem with reproducibility. Duplicate instances occurred for aluminum (Shealy in the first and third quarters and Weston in the second quarter) and for zinc (Weston in the first and second quarters and Shealy in the third quarter).

\section{Groundwater}

Groundwater analyses at SRS are performed by subcontracted laboratories. During 1996, General Engineering Laboratories and Weston were the primary subcontractors for nonradiological analyses. Environmental Physics and ThermoNUtech were the primary subcontractors for radiological analyses.

During 1996, approximately 5 percent of the samples collected (radiological and nonradiological) were submitted to the primary laboratory for analysis as blind duplicates and to a different laboratory as a QA check. Blind blanks, representing 5 percent of the samples sent to each laboratory, were submitted to General Engineering and Weston. The laboratories' results were evaluated on the basis of the percentage within an acceptable concentration range of certified values.
A statistical measure, the MRD, is calculated to assess result reproducibility and laboratory performance. The laboratories also analyze approximately 10 percent of samples as intralaboratory QA checks. Interlaboratory comparisons were conducted between General Engineering/Weston and Environmental Physics/ThermoNUtech.

As in past years, General Engineering and Weston results for QC standard samples were within the 80-percent acceptance range utilized by the EMS QA/QC program. Laboratories that fall outside this range are reevaluated by EMS.

During 1996, General Engineering and Weston participated in EPA water pollution studies. Of 75 samples analyzed for the studies, General 
Engineering reported one sample of chloride outside the acceptable range. During 1996, Weston analyzed 79 different constituents as part of its water pollution studies and reported that all were within the acceptable range.

Full results for all these QA/QC evaluations, including MRD calculations where appropriate, can be found in the following groundwater reports:

- The Savannah River Site's Groundwater Monitoring Program, First Quarter 1996 (ESH-EMS-960056)

- The Savannah River Site's Groundwater Monitoring Program, Second Quarter 1996 (ESH-EMS-960057)

- The Savannah River Site's Groundwater Monitoring Program, Third Quarter 1996 (ESH-EMS-960058)

- The Savannah River Site's Groundwater Monitoring Program, Fourth Quarter 1996 (ESH-EMS-960059)

\section{Soil/Sediment}

Environmental investigations of soils, sediments, and surface waters, primarily for Resource Conservation and Recovery Act (RCRA)/Comprehensive Environmental Response, Compensation, and Liability Act (CERCLA) units, are performed by subcontracted laboratories. Table 11-1 (page 172) lists the primary subcontractors for soil/sediment analyses.

EMS personnel validated and managed approximately 600,000 analytical records during soil/sediment investigations in 1996. Data are validated according to EPA/CERCLA validation guidelines for Definitive Data (formerly QA Objective 3 Data) unless specified otherwise by site customers. EMS delivered 26 project summary reports in 1996; each included

- a project QA/QC summary

- a discussion of validation findings

- tables of validated and qualified data

Although Data Quality Objectives Process for Superfund (EPA-540-R-93-071) identifies QA issues to be addressed, it does not formulate a procedure for how to evaluate these inputs, nor does it propose pass/fail criteria to apply to data and documents. Hence, the validation program necessarily contains elements from-and is influenced by-several sources, including

- Data Quality Objectives Process for Superfund, EPA final guidance, EPA-540-R-93-071

- $\quad Q A / Q C$ Guidance for Removal Activities, interim final guidance, EPA-540-G-90-004

- National Functional Guidelines for Organic Data Review, Multi-Media, Multi-Concentration (OLM 01.0), and Low Concentration Water (OLC 01.0), draft, June 1991

- Test Methods for Evaluating Solid Waste, EPA, November 1986, SW-846, Third Edition

- Data Validation Procedures for Radiochemical Analysis, WHC-SD-EN-SPP-001

Data management personnel in the soil/sediment program perform additional functions to ensure the quality of the data released by EMS. Two people enter the data for each entry to help eliminate errors, and all field, shipping, invoice, and analytical data are 100 percent verified.

Relative percent difference for the soil/sediment program is calculated for field duplicates and laboratory duplicates. A summary of this information can by found in each project report prepared by the Environmental Geochemistry Group of EMS, through which the reports are available upon request. A detailed description of the activities performed during validation of soil/sediment data can be found in the Environmental Geochemistry Group Operating Handbook, ESH-EMS-950061.

\section{Laboratory Data Record Reviews}

In addition to an annual evaluation, laboratory data record reviews are performed once per quarter for groundwater and once per project for soil/sediment. A predetermined percentage of the analyses for the indicated time frame is selected for inspection by a team of validators. The samples selected for review usually have been flagged by the electronic verification of the data. At the review, analyses with quality assurance deficiencies are identified and flagged appropriately. Results for record reviews are included as a section in the project reports delivered to the customer. A description of the activities performed during a record review, an example check list, and a report description can be found in the Environmental Geochemistry Group Operating Handbook, mentioned above. 



\section{Special Surveys and Projects}

\author{
Pete Fledderman and Chet Nichols \\ Environmental Protection Department \\ Eric Nelson \\ Environmental Sciences Section \\ Robin Davis \\ Academy of Natural Sciences of Philadelphia
}

I $\mathrm{N}$ addition to routine sampling and special sampling during nonroutine environmental releases, special sampling for radiological and nonradiological surveys is conducted on and off site by personnel from the Savannah River Site (SRS)

Environmental Protection Department's Environmental Monitoring Section (EMS) and from other groups, such as the Savannah River Technology Center (SRTC) the Academy of Natural Sciences of Philadelphia (ANSP), and the U.S. Geological Survey (USGS).

Both short- and long-term radiological and nonradiological surveys are used to monitor the effects of SRS effluents on the environment at SRS and in the site's immediate vicinity

All conclusions discussed in this chapter are based on samples and analyses that have been completed. Because of sampling and/or analytical difficulties, some sample analyses may be missing, but these analyses typically represent only a very small number of samples overall. Details about the number of samples analyzed and the results of those analyses appear in SRS Environmental Data for 1996

(WSRC-TR-97-0077).

\section{Savannah River Swamp Survey}

In the 1960s, an area of the Savannah River Swamp between Steel Creek Landing and Little Hell Landing was contaminated by failed fuel elements that leaked activity into the P-Area storage basin; occasionally, this water was discharged to Steel Creek (figure 12-1). During high river flow, Steel Creek flowed along the lowlands comprising the swamp and discharged into the Savannah River at Little Hell Landing. Consequently, approximately $25 \mathrm{Ci}$ of cesium-137 and $1 \mathrm{Ci}$ of cobalt-60 were deposited into the swamp. The contaminated area extends beyond the SRS boundary into private property known as Creek Plantation; this area is uninhabited and not easily accessible.

In 1974, 10 sampling trails were established so that specific locations could be monitored to determine changes in the amount or distribution of radioactivity in the swamp (figure 12-2). Fifty-four locations were established along these trails and are identified by distance (in feet) from the river bank.

Surveys have been conducted annually (water levels permitting) since 1974 and are divided into two types: comprehensive and cursory. Comprehensive surveys provide analysis of samples collected at all 54 monitoring locations, while cursory surveys provide interim monitoring through analysis of samples from a subset (one location per trail) of the 54 locations. Comprehensive surveys are performed at 5-year intervals, cursory surveys during the interim years. The comprehensive survey scheduled for 1995 , however, had to be delayed until 1996 because of high water levels in the swamp.

During the 1996 comprehensive survey, shallow soil (0-3 inches) and vegetation samples were scheduled for collection from each of the 54 monitoring locations, but could not be collected from all locations. Also, 12-inch core samples were collected from one location per trail; these locations correspond to the cursory survey sampling locations and are those areas on each trail that historically have exhibited the highest activity levels. The core samples were divided into 3-inch segments for analysis; this provides an indication of the vertical distribution of activity. All samples were analyzed for gamma-emitting radionuclides and strontium-89,90. 


\section{Gamma-Emitting Radionuclides}

In both soil and vegetation samples, cesium-137 was the predominant manmade gamma-emitting radionuclide quantified. It was detected in 80 of the 81 soil samples and 40 of the 46 vegetation samples. The maximum observed cesium-137 concentrations were $98.8 \mathrm{pCi} / \mathrm{g}$ in soil and $63.8 \mathrm{pCi} / \mathrm{g}$ in vegetation. Cobalt-60 was the only other manmade gamma-emitting radionuclide that could be quantified, appearing in 40 of the 81 soil samples and 6 of the 46 vegetation samples. The maximum observed cobalt 60 concentrations were $0.4 \mathrm{pCi} / \mathrm{g}$ in soil and $0.3 \mathrm{pCi} / \mathrm{g}$ in vegetation.

Generally, cesium- 137 concentrations were significantly higher than cobalt- 60 concentrations; however, a consistent distribution or ratio between the two radionuclides was not evident in either soil or vegetation. Radionuclide concentrations were higher in soil than in vegetation, but the concentrations in vegetation generally followed the same trend as those in soil.
The vertical profile of cesium- 137 in the soil column of some samples did not consistently decrease with increasing depth. In an undisturbed environment, cesium-137 concentration would be expected to decrease with increasing depth, as was observed during the 1990 comprehensive survey. However, the shallow core samples examined during 1996 indicated a more homogenous distribution. The current observations may be an indication of either vertical migration through the soil or continued deposition of contaminated sediments during flood conditions.

\section{Strontium}

Strontium was quantified in 10 of the 81 soil samples and 9 of the 46 vegetation samples. The maximum strontium concentration in soil was $0.28 \mathrm{pCi} / \mathrm{g}$, while the maximum in vegetation was $1.61 \mathrm{pCi} / \mathrm{g}$. The available data set is relatively small, but it shows that the detectable strontium concentrations in vegetation are greater than those in soil. This may be an indication of uptake and concentration of strontium by the swamp vegetation; however, only one

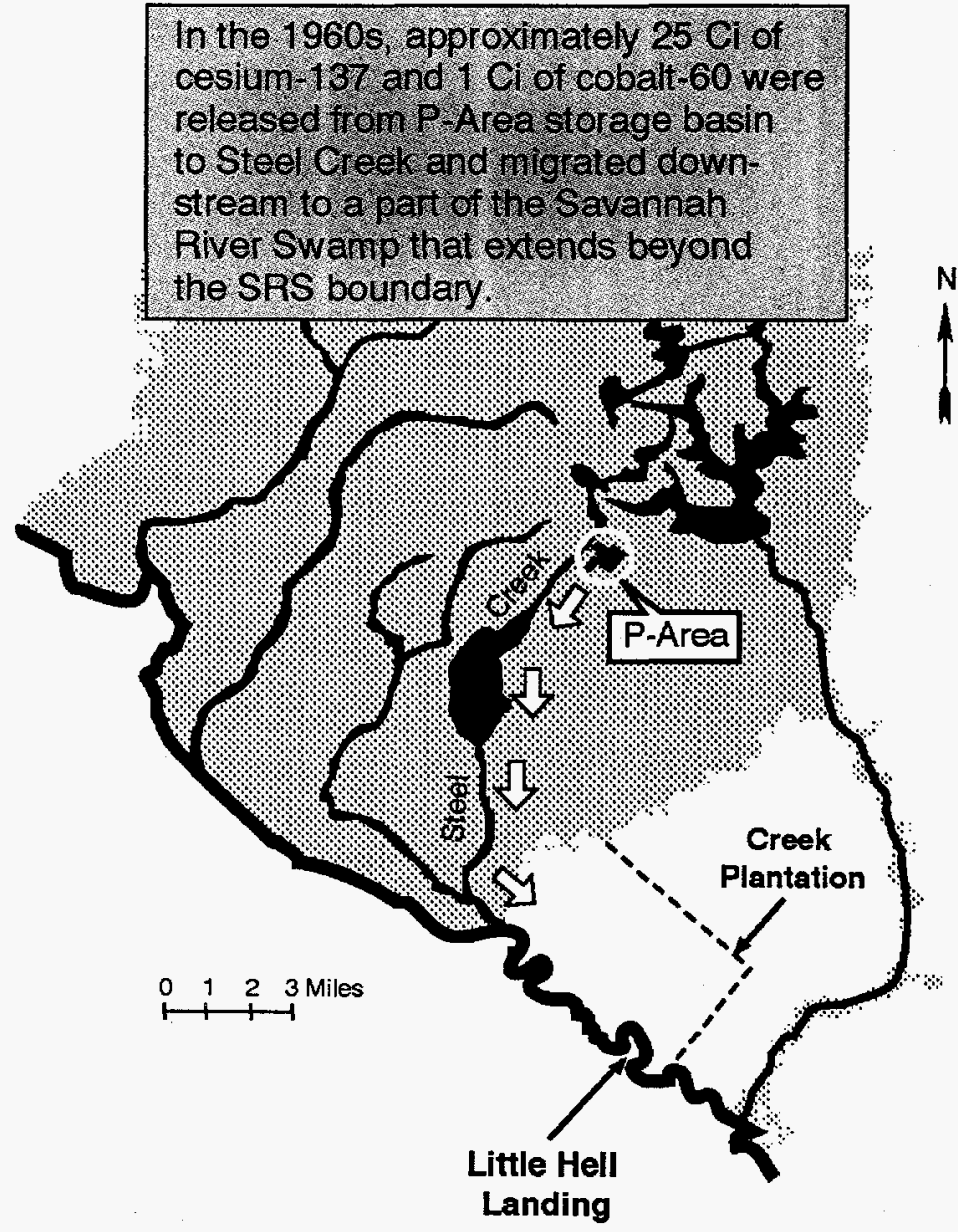

Figure 12-1 Swamp Contamination Radioactivity released from SRS operations contaminated the Savannah River Swamp between Steel Creek and Little Hell Landing during the 1960s.

94X06608.29.AIL 


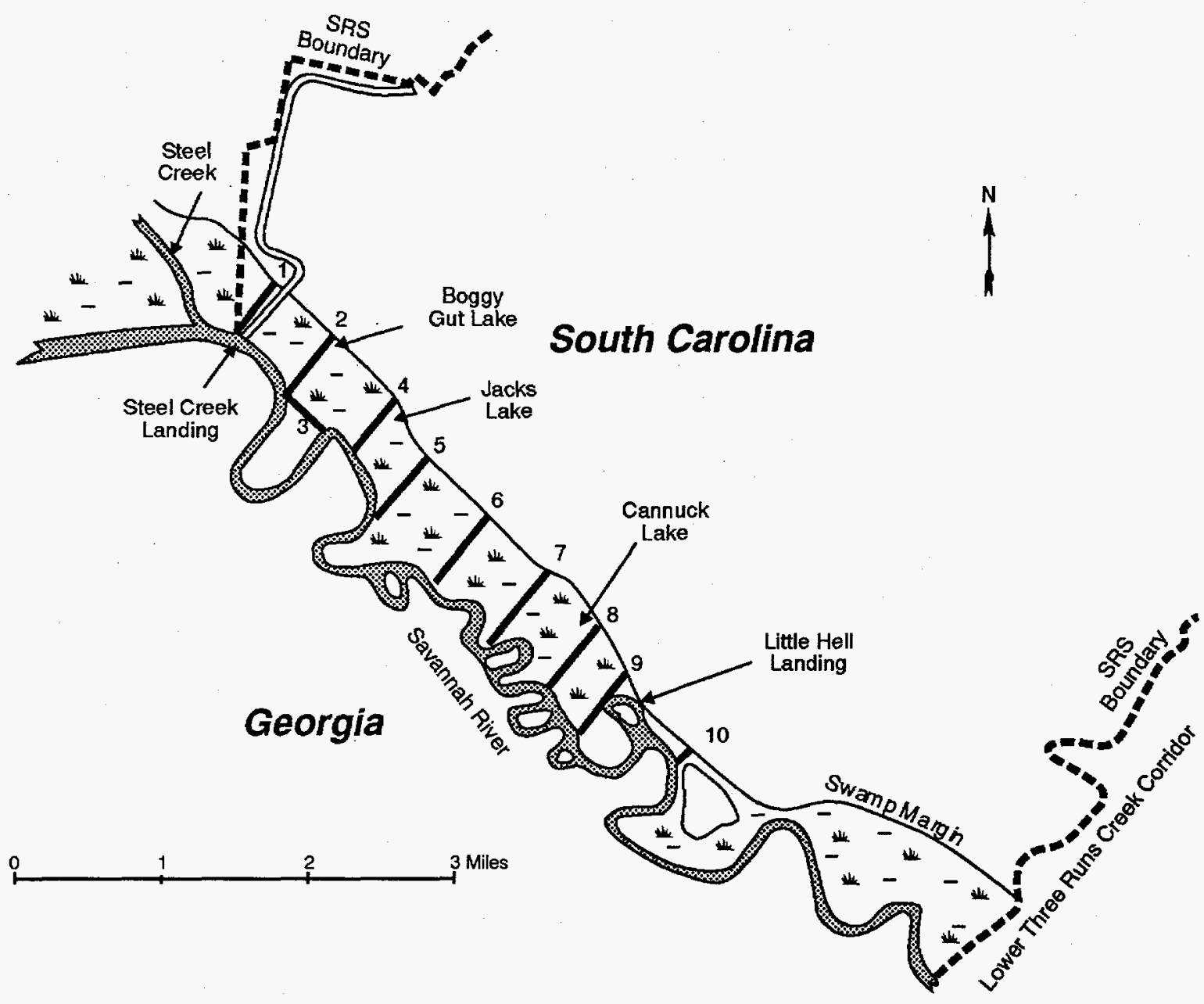

94X01185.12.AlL

Figure 12-2 Savannah River Swamp Sampling Trails

Ten sampling trails were established in the Savannah River Swamp in 1974 so that surveys could be conducted of the movement of contamination from SRS operations.

sampling location had detectable strontium in both soil and vegetation. The limited data set allows for few other conclusions on the partitioning or distribution of strontium.

\section{Conclusions}

The 1996 survey results generally followed trends observed in previous surveys. Over time, some changes in the spatial distribution of activity throughout the swamp have been observed, which indicates that some localized movement of activity may be occurring. However, there has been little change in the results from downstream locations T-9 and $\mathrm{T}-10$, which implies that activity is not migrating out of the identified contaminated area. Relative to the 1990 comprehensive survey, concentrations in shallow core samples generally were lower, while concentrations in vegetation appeared higher. However, the core samples show a fairly uniform vertical distribution of activity. Overall, these results show that although some limited spatial and vertical migration of activity may be occurring, the activity is remaining in the swamp area.

\section{Mitigation Action Plan for Pen Branch Reforestation}

The final Environmental Impact Statement for the continued operation of K-Reactor, L-Reactor, and P-Reactor at SRS [DOE, 1990] predicted several unavoidable impacts to the site's wetlands and resulted in the development of a Mitigation Action Plan (MAP) that documented DOE's approach to mitigating these impacts. The subsequent reduction in the production mission of the SRS reactors has 
resulted in the reevaluation of the mitigation strategies identified in the 1991 MAP and its 1992 update. The Mitigation for Wetlands Adversely Impacted by Operations is the only section of the original MAP that remains as an active program element; other program elements either have been completed or deemed unnecessary. At the direction of DOE, it has been agreed by all parties involved with the reporting process that the SRS Environmental Report will be used as the document to report annual progress on the reforestation portion of the commitment.

A precise history of the regulatory commitment for the reforestation can be found in the MAP 1992 update [DOE, 1992]. Since that time, the change in mission relating to $\mathrm{K}$-Reactor and the increased technical information on the extent of damage and natural recovery in the Pen Branch corridor and delta have altered details of the reforestation effort. The following paragraphs describe 1996 reforestation mitigation actions.

\section{Reforestation of the Pen Branch Corridor and Delta by Natural Succession}

Natural revegetation has been occurring in the Pen Branch delta since K-Reactor last operated for an extended period of time (1988). Through the use of aerial photography and aircraft-acquired multispectral data, it was determined in 1992 that 583 acres was included in the swamp and marsh area that either had been or could be affected, resulting in tree canopy loss or vegetation damage from K-Reactor thermal discharges [Blohm, 1995]. This is a substantial reduction from the 670 acres estimated in the final Environmental Impact Statement [DOE, 1990].

During 1995, an extensive survey of natural regeneration of forest species was conducted around the outer perimeter of the delta region of Pen Branch. Results of that survey indicated that approximately 100 acres of the delta had sufficient bald cypress (Taxodium distichum) seedlings and saplings to consider the areas reforested. Preliminary stocking tallies taken in 1996 continue to show the vigor and high densities of this natural regeneration. These areas are included in a Geographic Information System layer for mapping of the Pen Branch area. All areas of the Pen Branch corridor above Risher Pond Road (A-13.2) also are considered to have been reforested by natural regeneration to a bottomland hardwood forest type.

\section{Reforestation of the Pen Branch Corridor and Delta by Planting}

The Pen Branch corridor and delta are being reforested using indigenous wetlands species. Seeds were collected from individual trees at SRS and in the Upper Coastal Plain during 1992-1993 to ensure appropriate genetic material for use in the project. The seeds were planted and grown at a State of Georgia nursery during 1993-1995 for use in the Pen Branch seedling planting program. These seedlings-of species appropriate to the area being reforested-subsequently were transplanted to the Pen Branch wetland areas. The reforested areas will be managed until successful reforestation has been achieved. This is the preferred method of mitigation for Pen Branch because of the brief restoration time frame required by DOE commitments. Recent (1994-1995) observations indicate that cypress and tupelo are becoming reestablished naturally in portions of the Pen Branch delta, as noted above. Intervention into this natural process will be considered only to maximize survival of the desired species.

The initial and secondary seedling plantings of the entire corridor and delta areas, which it was determined would require intervention for successful mitigation, have been completed. This intervention consisted of planting approximately 31 acres of the lower corridor with a mixture of flood-tolerant hardwood species and cypress seedlings in 1993. An additional 47 acres of the upper corridor was planted with a mixture of bottomland hardwood species seedlings in 1994. Species planted have included water and pignut hickory, sycamore, green ash, swamp and water tupelo, black gum, persimmon, cherrybark and water oak, bald cypress, and swamp chestnut oak. In 1995, the upper corridor section was replanted with seedlings because of the mortality that resulted from feral hog predation on the original planted seedlings. Also in 1995, the delta area was planted for the first time with bald cypress, water tupelo, and-on drier ridges-green ash seedlings. Approximately 90 acres were planted at densities of 450-500 seedlings per acre. Approximately 85,000 seedlings have been planted during the 3 years of planting (1993-1995) in the corridor and delta areas. A regeneration survey conducted in 1996 found that approximately 250 seedlings per acre were becoming established in the corridor region. It is anticipated that this stocking level will provide sufficient numbers of trees to ensure reforestation success.

Within each of the areas that have been planted, there are areas that will serve as untreated controls to assess the effectiveness of the reforestation effort. Twenty-eight acres of the delta and 20 acres in the 


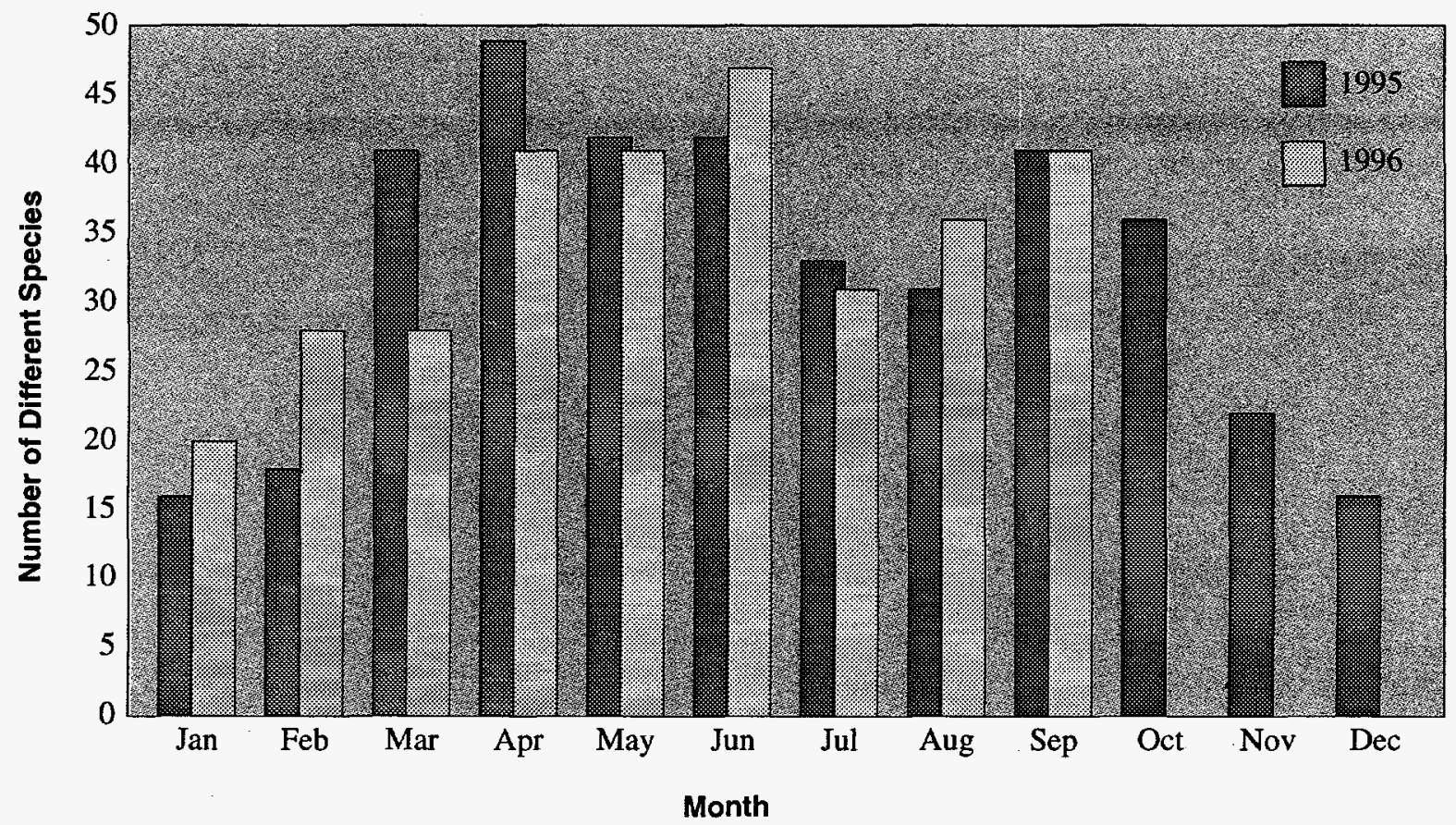

lleaf Graphic

Figure 12-3 Monthly Reptile and Amphibian Species Diversity in the Pen Branch Corridor Studies to identify species composition and relative abundance were concluded in September 1996.

corridor were left in these control sections. This has allowed research efforts on the success of the restoration to compare the treated and untreated areas for the purpose of measuring differences in ecological responses to the treatments. This control acreage is part of that committed to in the MAP. It will be assessed to determine if it will reforest naturally because of its proximity to the mitigated acreage; if it will not, it may receive plantings at a later date.

Because of the control/restoration comparison areas, a number of research and baselining activities have been conducted to document the recovery of the faunal component of the wetland system. Studies of aquatic macroinvertebrates and fish are occurring in the corridor reaches of the stream. Observations of neotropical bird utilization of the habitats were concluded during the spring of 1996. Studies to identify species composition and the relative abundance of small mammals, amphibians, and reptiles were concluded in the fall of 1996 to quantify recolonization of the bottomland hardwood forest. Figure 12-3 illustrates the species diversity findings with respect to reptiles and amphibians. Results indicated that species diversity in the Pen Branch system was slightly greater than in unimpacted systems. As the Pen Branch system matures, however, the diversity is expected to diminish.
These studies have been conducted by Clemson University, the University of South Carolina, the University of Georgia, the Savannah River Ecology Laboratory (SREL), and the University of South Carolina at Aiken. Additional modeling of hydrology has been completed by the Waterways Experiment Station of the U.S. Army Corps of Engineers. During 1996, a symposium was organized by the

Environmental Sciences Section of the Savannah River Technology Center to provide all parties involved in the restoration, monitoring, and research efforts the opportunity to share their findings. Additional topics of discussion included the identification of data gaps to document successful restoration and assessment criteria. The symposium's proceedings subsequently were published and distributed [Nelson, 1996].

An establishment report detailing all activities associated with the reforestation was issued in 1996 and serves as the operational guidebook of what silvicultural activities have occurred to accomplish the mitigation to this point [Dulohery, 1996].

Additional updates on the seedling growth and survival will be included in the SRS Environmental Report for 1997 to fulfill reporting requirements. 


\section{Compensatory Mitigation}

This option would provide equivalent mitigation at sites other than Pen Branch-either by enhancing degraded wetlands or by creating new wetlands. The option will be considered following evaluation of the success of reforesting the Pen Branch corridor and delta in the year 2000 . However, it is the least desired option and will be implemented only should the existing efforts in Pen Branch prove unsuccessful.

\section{Trans-River Flow Project}

Many regions of the United States are planning for increased water supply demands as a result of population and industrial growth. Groundwater often is the most practical source of new water supply because of its general good quality and availability near the source of need. However, groundwater is vulnerable to contamination and, once contaminated, presents near insoluble remediation problems. Thus, many communities are concerned about maintaining the quality of their groundwater reservoirs. One area of such concern is along the South Carolina-Georgia state line near SRS.

The site has produced nuclear materials for national defense since the early 1950s, and a variety of hazardous materials-including radionuclides (such as tritium), volatile organic compounds, and trace metals-are disposed of or stored at SRS locations. As a result, groundwater beneath an estimated 5 to 10 percent of the site has been contaminated.

The Trans-River Flow Project was initiated in 1988 to address Georgia officials' concerns about the possibility that tritium-contaminated groundwater was migrating from SRS to Georgia. USGS research has confirmed that no threat exists from the tritium in question [Heffner, 1997]. However, the USGS, in cooperation with the U.S. Department of Energy (DOE) and the Georgia Department of Natural Resources (GDNR) is continuing the DOE-funded Trans-River Flow Project, which describes groundwater flow and quality near the Savannah River. Detailed information about the project will be published in the proceedings of the 1997 Georgia Water Resources Conference, to be held March 20-22 at the University of Georgia, Athens [Clarke, 1997].

\section{Academy of Natural Sciences of Philadelphia River Quality Surveys}

\section{Overview}

The Environmental Research Division of ANSP has been conducting biological and water-quality surveys of the Savannah River since 1951. These surveys are designed to assess potential effects of SRS contaminants and warm water discharges on the general health of the river and its tributaries. This is accomplished by looking for patterns of biological disturbance that are geographically associated with the site, and for patterns of change over seasons or years that indicate improving or deteriorating conditions.

\section{Results}

Results of the 1996 ANSP studies on the Savannah River have been delayed pending finalization of a new contract based on recommendations of the 1996 "Rock Hill Initiative \#2" review, which is discussed in detail in chapter 3, "Environmental Program Information." It is expected that results of analyses of the 1996 data will be compiled after the new contract is placed-and that both 1996 and 1997 results will be reported in the SRS Environmental Report for 1997. 


\section{Applicable Guidelines, Standards, and Regulations}

$\mathrm{T}$ HE Savannah River Site (SRS) environmental monitoring program is designed to meet state and federal regulatory requirements for radiological and nonradiological programs. These requirements are stated in U.S. Department of Energy (DOE) orders 5400.1, "General Environmental Protection Program," and 5400.5, "Radiation Protection of the Public and the Environment"; in the National Emission Standards for Hazardous Air Pollutants (NESHAP); in the Comprehensive Environmental Response, Compensation, and Liability Act (CERCLA-also known as the Superfund); in the Resource Conservation and Recovery Act (RCRA); in the Clean Water Act (i.e., NPDES); and in the National Environmental Policy Act (NEPA). Compliance with environmental requirements is assessed by the South Carolina Department of Health and Environmental Control (SCDHEC) and the U.S. Environmental Protection Agency (EPA).

The SRS environmental monitoring program's objectives incorporate recommendations of the International Commission on Radiological Protection ("Principles of Monitoring for the Radiation Protection of the Public," ICRP Publication 43), of DOE Order 5400.1, and of DOE/EH-0173T, "Environmental Regulatory Guide for Radiological Effluent Monitoring and Environmental Surveillance."

More specific information about certain media is presented in the following paragraphs.

\section{Air}

DOE Order 5400.5 also establishes Derived Concentration Guides (DCGs) for radionuclides in air. DCGs, calculated by DOE using methodologies consistent with recommendations found in International Commission on Radiological Protection (ICRP) publications 26 and 30, are used as reference concentrations for conducting environmental protection programs at DOE sites and for making dose comparisons. DCGs are not considered release limits. DCGs are discussed in more detail on page 187 .

In addition, radiological airborne releases are subject to EPA regulations cited in 40 CFR 61 , Subpart H, NESHAP.

\section{SCDHEC regulates nonradioactive air} emissions-both criteria pollutants and toxic air pollutants-from SRS sources. Each source is permitted by SCDHEC, with specific limitations identified, as outlined in various South Carolina air pollution control regulations and standards. The applicable standards are source dependent; however, the primary standards that govern criteria air pollutants and ambient air quality are identified in SCDHEC Air Pollution Control Regulation 61-62.5, Standard No. 2, which lists eight criteria air

pollutants commonly used as indices of air quality (e.g., sulfur dioxide, nitrogen dioxide, and lead) and provides an allowable site boundary concentration for each pollutant. The standards for toxic air pollutants are identified in Regulation 61-62.5, Standard No. 8, which identifies 257 toxic air pollutants and their respective allowable site boundary concentrations. Specific permits for operating facilities are listed in appendix B, "SRS Environmental Permits."

SCDHEC airborne emission standards for each SRS permitted source may differ, based on size and type of facility, type and amount of expected emissions, and the year the facility was placed into operation. For example, for powerhouse boilers constructed before February 11, 1971, the particulate emission limit is 0.6 pounds per million BTU (British thermal unit) of boiler fuel heat input. Boilers constructed after 1971 must meet more stringent standards identified in 40 CFR 60, "New Source Performance Standards." For process and diesel engine stacks in existence prior to January 1,1986 , and powerhouse stacks built before February 11, 1971, the opacity standard is 40 percent. For new sources placed into operation after these dates, the opacity standard typically is 20 percent. 
Compliance with the various standards is determined in several ways. At the SRS powerhouses, stack compliance tests are performed every 2 years for each boiler by airborne emission specialists under contract to SRS. The tests include

- sampling of the boiler exhaust gases to determine particulate emission rates and carbon dioxide and oxygen concentrations

- laboratory analysis of coal for sulfur content, ash content, moisture content, and BTU output

Sulfur content and BTU output are used to calculate sulfur dioxide emissions. SCDHEC also conducts visible-emissions observations during the tests to verify compliance with opacity standards. The day-to-day control of particulate matter smaller than 10 microns is demonstrated by opacity meters in all SRS powerhouse stacks.

For the package steam generating boilers in $\mathrm{K}$-Area and P-Area, compliance with sulfur dioxide standards is determined by analysis of the fuel oil being purchased from the offsite vendor. The percent of sulfur in the fuel oil must be below 0.5.

Compliance with particulate emission standards was determined with mass-balance calculations.

Compliance by SRS diesel engines and other process stacks is determined during annual compliance inspections by the local SCDHEC district air manager. These inspections include a review of operating parameters, an examination of continuous-emission monitors (where required for process stacks), and a visible-emissions observation for opacity.

Compliance by all toxic air pollutant and criteria pollutant sources is also determined by using EPA-approved air dispersion models. Air dispersion modeling is extremely conservative unless refined models are used. The Industrial Source Complex Version No. 2 model was used to predict maximum ground-level concentrations occurring at or beyond the site boundary for new sources permitted during 1996.

\section{Liquid}

DOE Order 5400.5 also establishes DCGs for radionuclides in water. DCGs were calculated by DOE using methodologies consistent with recommendations found in ICRP Publications 26 and 30 and are used

- as reference concentrations for conducting environmental protection programs at DOE sites

- as screening values for considering best available technology for treatment of liquid effluents

- for making dose comparisons

DCGs are discussed in more detail on page 187.

DOE Order 5400.5 exempts aqueous tritium releases from best available technology requirements but not from ALARA considerations.

EPA drinking water standards (40 CFR 141) for radionuclides apply at the water treatment plants serving Beaufort and Jasper counties in South Carolina and Port Wentworth in Georgia. Drinking water standards for specific radionuclides are listed in appendix D, "Drinking Water Standards."

DOE Order 5400.5, chapter II, section 3a(4), requires that settleable solids in process waste streams be tested to ensure that no buildup of radionuclides occurs in the sediments of the receiving streams.
From January 1, 1996, through September 30, 1996, SRS discharged water into site streams and the Savannah River under four NPDES permits: two for industrial wastewater (SC0000175 and SC0044903) and two for stormwater runoff-SCR000000 for industrial discharge and SCR 100000 for construction discharge. A fifth NPDES permit-a no-discharge permit (ND0072125)-was issued to cover land application of sludge generated at onsite sanitary waste treatment plants. Industrial permit SC0000175 expired in 1988 and industrial permit $\mathrm{SC} 0044903$ expired in 1995. Because SRS had applied for a new permit, discharges were allowed to continue under the expired permits until October 1, 1996, when the new NPDES permit, SC0000175, was put into effect. Discharge points covered under the two old industrial wastewater permits, SCOOO175 and SC0044903, were included in the new SC0000175 permit, which remains in effect until September 30, 2001

Stormwater industrial permit SCR000000 covers 48 discharge locations sorted into 11 groups. A representative site from each group was sampled, as required by the permit. Construction permit SCR 100000 does not require sampling unless requested by SCDHEC to address specific discharge issues at a given construction site. SCDHEC did not request any such sampling in 1996. 
Chart 1

South Carolina Water Quality Standards for Freshwaters

Note: This is a partial list only of water quality standards for freshwaters.

\section{Parameters Standards}

a. Fecal coliform Not to exceed a geometric mean of $200 / 100 \mathrm{~mL}$, based on five consecutive samples during any 30 -day period; nor shall more than 10 percent of the total samples during any 30 -day period exceed $400 / 100 \mathrm{~mL}$.

b. pH Range between 6.0 and 8.5 .

c. Temperature

Generally, shall not be increased more than $5^{\circ} \mathrm{F}\left(2.8^{\circ} \mathrm{C}\right)$ above natural temperature conditions or be permitted to exceed a maximum of $90^{\circ} \mathrm{F}\left(32.2^{\circ} \mathrm{C}\right)$ as a result of the discharge of heated liquids. For exceptions, see E-6, Regulation 61-68, State of South Carolina Water Classifications and Standards (May 28, 1993).

\section{d. Dissolved oxygen}

e. Garbage, cinders, ashes, sludge, or other refuse

f. Treated wastes, toxic wastes, deleterious substances, colored or other wastes, except those in (e) above.

g. Ammonia, chlorine, and toxic pollutants listed in the federal Clean Water Act (307) and for which EPA has developed national criteria (to protect aquatic life).
Daily average not less than $5.0 \mathrm{mg} / \mathrm{L}$, with a low of $4.0 \mathrm{mg} / \mathrm{L}$.

None allowed.

None alone or in combination with other substances or wastes in sufficient amounts to make the waters unsafe or unsuitable for primary-contact recreation or to impair the waters for any other best usage as determined for the specific waters assigned to this class.

See E-7 (list of water quality standards based on organoleptic data) and $E-8$ (water quality criteria for protection of human health), Regulation 61-68, State of South Carolina Water Classifications and Standards (May 28, 1993).

SOURCE: [SCDHEC, 1993]

\section{Site Streams}

SRS streams are classified as "Freshwaters" by the South Carolina Pollution Control Act. Freshwaters are defined as surface water suitable for

- primary- and secondary-contact recreation and as a drinking water source after conventional treatment in accordance with SCDHEC requirements
- fishing and survival and propagation of a balanced indigenous aquatic community of fauna and flora

- industrial and agricultural uses

Chart 1 provides some of the specific guides used in water quality surveillance, but because some of these guides are not quantifiable, they are not tracked in response form (i.e., amount of garbage found) 


\section{Savannah River}

Because the Savannah River is defined under the

South Carolina Pollution Control Act as a
Freshwater system, the river is regulated in the same manner as are site streams (chart 1).

\section{Drinking Water}

SRS drinking water systems must meet the water quality criteria mandated by SCDHEC State Primary Drinking Water Regulations, R.61-68. Drinking water standards for specific contaminants are provided in appendix D, "Drinking Water Standards."

All 27 systems are monitored routinely for compliance with SCDHEC bacteriological water quality limits. The sampling frequency depends on the population served. All systems are monitored semiannually for chlorocarbon concentrations. SRS also monitors the 13 larger systems for lead and copper concentrations according to SCDHEC requirements. SCDHEC periodically collects samples from the 13 larger systems to determine compliance with chemical, synthetic organic, and volatile organic water quality limits.

\section{Groundwater}

The analytical results of samples taken from SRS monitoring wells that exceed various standards are discussed in this report. Constituents discussed are compared to final federal primary drinking water standards (DWS), or other standards if DWS do not exist, because groundwater aquifers are defined as potential drinking water sources by the South Carolina Pollution Control Act. [SCDHEC, 1985]. The DWS can be found in appendix D, "Drinking Water Standards." DWS are not always the standards applied by regulatory agencies to the SRS waste units under their jurisdiction. For instance, standards under RCRA are DWS, groundwater protection standards, background levels, and alternate concentration limits.

Two constituents having DWS, dichloromethane and bis(2-ethylhexyl) phthalate, are not discussed in this report. Both are common laboratory contaminants and are reported in groundwater samples with little or no reproducibility. Both are reported, with appropriate flags and qualifiers, in the data tables of the quarterly reports cited in chapter 10 , "Groundwater."

The standard used for lead is the SCDHEC DWS. The federal standard of $15 \mu \mathrm{g} / \mathrm{L}$ is a treatment standard for drinking water at the consumer's tap; thus, it is inappropriate for use as a groundwater standard.

Of the radionuclides discussed, only gross alpha, strontium-90, and tritium are compared to true primary DWS. The regulatory standards for radionuclide discharges from industrial and governmental facilities are set under the Clean Water Act, RCRA, and Nuclear Regulatory Commission and DOE regulations. The proposed drinking water maximum contaminant levels discussed in this report are only an adjunct to these release restrictions and are not used to regulate SRS groundwater.

The standard used for gross beta is a screening standard; when public drinking water exceeds this standard, the supplier is expected to analyze for individual beta and gamma emitters. A gross beta result above the standard is an indication that one or more radioisotopes are present in quantities that would exceed the EPA annual dose equivalent for persons consuming 2 liters daily. Thus, for the individual beta and gamma radioisotopes (other than strontium-90 and tritium), the standard discussed in this report is the activity per liter that would, if only that isotope were present, exceed the dose equivalent. Similarly, the standards for alpha emitters discussed in this report are calculated to present the same risk at the same rate of ingestion.

Although radium has a DWS of $5 \mathrm{pCi} / \mathrm{L}$ for the sum of radium-226 and radium-228, the standards discussed in this report are the proposed standards of $20 \mathrm{pCi} / \mathrm{L}$ for each isotope separately. Radium-226, an alpha emitter, and radium-228, a beta emitter, cannot be analyzed by a single method. Analyses for total alpha-emitting radium, which consists of radium-223, radium-224, and radium-226, are compared to the standard for radium-226. During 1997 , EPA-proposed standards of $20 \mathrm{pCi} / \mathrm{L}$ for radium- 226 and $20 \mathrm{pCi} / \mathrm{L}$ for radium-228 are expected to replace the $5 \mathrm{pCi} / \mathrm{L}$ interim standard.

Four other constituents without DWS are discussed in this report when their values exceed specified levels. These constituents are specific conductance at values equal to or greater than $100 \mu \mathrm{S} / \mathrm{cm}$, alkalinity $\left(\mathrm{as} \mathrm{CaCO}_{3}\right)$ at values equal to or greater than $100 \mathrm{mg} / \mathrm{L}$, total dissolved solids (TDS) at values equal to or greater than $200 \mathrm{mg} / \mathrm{L}$, and $\mathrm{pH}$ at 
values equal to or less than 4.0 or equal to or greater than 8.5. The selection of these values as standards for comparison is somewhat arbitrary; however, these values exceed levels usually found in background wells at SRS. The occurrence of elevated alkalinity (as $\mathrm{CaCO}_{3}$ ), specific conductance, $\mathrm{pH}$, and TDS within a single well may indicate leaching of the grouting material used in well construction, rather than degradation of the groundwater.

\section{Potential Dose}

The radiation protection standards followed by SRS are outlined in DOE Order 5400.5 and include U.S. Environmental protection Agency (EPA) regulations on the potential doses from airborne releases and treated drinking water.

The following radiation dose standards for protection of the public in the SRS vicinity are specified in DOE Order 5400.5.

Drinking Water Pathway ... 4 mrem per year Airborne Pathway ...... 10 mrem per year All Pathways ........ 100 mrem per year

The EPA annual dose standard of $10 \mathrm{mrem}$ $(0.1 \mathrm{mSv})$ for the atmospheric pathway, which is contained in "National Emission Standards for Hazardous Air Pollutants-Radionuclides (NESHAP)," 40 CFR Part 61, Subpart H, is adopted in DOE Order 5400.5.

These dose standards are based on recommendations of the International Commission on Radiological Protection (ICRP) and the National Council on Radiation Protection and Measurements (NCRP).

The DOE dose standard enforced at SRS for drinking water consumed from site drinking water systems, community drinking water systems, and downriver water treatment plants is consistent with the criteria contained in "National Interim Primary Drinking Water Regulations, 40 CFR Part 141." Under these regulations, persons consuming drinking water shall not receive an annual whole body dose-DOE Order 5400.5 interprets this dose as committed effective dose equivalent -of more than $4 \mathrm{mrem}(0.04 \mathrm{mSv})$. Both of these dose standards are based on a consumption of 2 liters of water per day. However, some radionuclide dose conversion factors (including tritium) differ between EPA and DOE. Because SRS must use

DOE-provided, ICRP-based dose conversion factors, a direct comparison of the estimated drinking water doses in chapter 7, "Potential Radiation Doses," to the EPA drinking water dose standard cannot be made. However, radionuclide concentrations found in drinking water are directly compared to the EPA drinking water concentration standards in chapter 6 , "Radiological Environmental Surveillance."

\section{Comparison of Average Concentra- tions in Airborne Emissions to DOE Derived Concentration Guides}

Average concentrations of radionuclides in airborne emissions are calculated by dividing the yearly release total of each radionuclide from each stack by the yearly stack flow quantities. These average concentrations then can be compared to the DOE derived concentration guides (DCGs), which are found in DOE Order $\mathbf{5 4 0 0 . 5}$ for each radionuclide.

DCGs are used as reference concentrations for conducting environmental protection programs at all DOE sites. DCGs, which are based on a 100-mrem exposure, are applicable at the point of discharge (prior to dilution or dispersion) under conditions of continuous exposure (assumed to be an average inhalation rate of 8,400 cubic meters per year). This means that the DOE DCGs are based on the highly conservative assumption that a member of the public has direct access to and continuously breathes (or is immersed in) the actual air effluent 24 hours a day, 365 days a year. However, because of the large distance between most SRS operating facilities and the site boundary, and because the wind rose at SRS shows no strong prevalence (chapter 7, "Potential Radiation Doses"), this scenario is improbable.

Average annual radionuclide concentrations in SRS air effluent can be referenced to DOE DCGs as a screening method to determine if existing effluent treatment systems are proper and effective.

\section{Comparison of Average Concentra- tions in Liquid Releases to DOE De- rived Concentration Guides}

In addition to dose standards, DOE Order 5400.5 imposes other control considerations on liquid releases. These considerations are applicable to direct discharges but not to seepage basin and Solid Waste Disposal Facility (SWDF) migration discharges. The DOE order lists DCG values for most radionuclides. DCGs are used as reference concentrations for conducting environmental protection programs at all DOE sites. These DCG values are not release limits but screening values for best available technology investigations and for 
determining whether existing effluent treatment systems are proper and effective.

Per DOE Order 5400.5, exceedance of the DCGs at any discharge point may require an investigation of best available technology waste treatment for the liquid effluents. Tritium in liquid effluents is specifically excluded from best available technology requirements; however, it is not excluded from other as-low-as-reasonably-achievable (ALARA) considerations. DOE DCG compliance is demonstrated when the sum of the fractional DCG values for all radionuclides detectable in the effluent is less than 1.00 , based on consecutive 12-month average concentrations.
DCGs, based on a 100-mrem exposure, are applicable at the point of discharge from the effluent conduit to the environment (prior to dilution or dispersion). They are based on the highly conservative assumption that a member of the public has continuous direct access to the actual liquid effluents and consumes 2 liters of the effluents every day, 365 days a year. However, because of security controls and the large distance between most SRS operating facilities and the site boundary, this scenario is highly improbable, if not impossible.

For each site facility that releases radioactivity, EMS compares the monthly liquid effluent concentrations and 12-month average concentrations against the DOE DCGs.

\section{Environmental Restoration and Waste Management}

SRS began its cleanup program in 1981. Two major federal statutes drive the site's environmental restoration and waste management activities: the Resource Conservation and Recovery Act (RCRA) and the Comprehensive Environmental Response, Compensation, and Liability Act (CERCLA). RCRA addresses the management of regulated hazardous waste and requires that permits be obtained for facilities that treat, store, or dispose of hazardous or mixed waste. It also requires that DOE facilities perform appropriate corrective action to address contaminants in the environment. CERCLA (also known as Superfund) addresses the uncontrolled release of hazardous substances and the cleanup of inactive waste sites. This act establishes a National Priority List of sites targeted for assessment and, if necessary, restoration. SRS was placed on this list December 21, 1989 [Fact Sheet, 1995]. SRS entered into an agreement with EPA and SCDHEC as to how SRS would be cleaned up. The agreement became effective in August 1993.

\section{Quality Assurance/Quality Control}

DOE Order 5700.6C, "Quality Assurance," sets requirements and guidelines for departmental quality assurance (QA) practices. WSRC developed an implementation plan to address the order, entitled "Revised Implementation Plan: DOE Order 5700.6C." To ensure compliance with regulations and to provide overall quality requirements for site programs, WSRC developed the Westinghouse Savannah River Company Quality Assurance Management Plan (WSRC-RP-92-225). The requirements of WSRC-RP-92-225 are implemented by the Westinghouse Savannah River Company Quality Assurance Manual (WSRC 1Q).

The Environmental Monitoring Section Quality Assurance Plan, Volume III (WSRC-3Q1-2), part of the EMS WSRC-3Q1 procedure series, was written to apply the QA requirements of WSRC 1Q to the environmental monitoring and surveillance program. The EMS WSRC-3Q1 procedure series includes procedures on sampling, radiochemistry, and water quality that emphasize the quality control requirements for EMS.

NESHAP defines specific QA requirements for monitoring radiological air emissions [EPA, 1989]. The EMS QA program's plan to comply with these requirements is found in WSRC-3Q1-2, Volume I, Attachment 3-1, "NESHAP QA Plan" (WSRC-IM-91-60).

To ensure valid and defensible monitoring data, the records and data generated by the monitoring program are maintained according to the requirements of DOE Order 1324.2A, "Records Disposition," and of WSRC 1Q. QA records include sampling and analytical procedure manuals, logbooks, chain-of-custody forms, calibration and training records, analytical notebooks, control charts, validated laboratory data, and environmental reports. These records are maintained and stored per the requirements of WSRC-1M-93-0060, WSRC Sitewide Records Inventory and Disposition Schedule. 


\section{Appendix $B$}

\section{SRS Environmental Permits}

Listed below are the construction and operating permits held by Savannah River Site. The permits are divided by type of permit; for each type, the permit number, permit title, and permitted source are provided.

Air Permits

\begin{tabular}{|c|c|}
\hline Permit Number & Permit Title \\
\hline $0080-0041-A-C A$ & $\begin{array}{l}\text { VADOSE ZONE SOIL VAPOR EXTRACTION UNIT; A-014 OUTFALL } \\
\text { (GROUNDWATER REMEDIATION), 782-3M }\end{array}$ \\
\hline A0080-0041-A-CB & $\begin{array}{l}\text { 320-GPM AIR STRIPPER, A-002; CATALYTIC OXIDATION UNIT } \\
\text { (A-001A OUTFALL); SRTC }\end{array}$ \\
\hline $0080-0041-\mathrm{A}-\mathrm{CC}$ & $\begin{array}{l}\text { A-AREA POWERHOUSE EFFLUENT TREATMENT AND REROUTING SYSTEM, } \\
784-A \text { (BAGHOUSE) }\end{array}$ \\
\hline $0080-0041-\mathrm{F}-\mathrm{CL}$ & TWO 20,000-GALLON UNDERGROUND STORAGE FUEL TANKS, 254-5F \\
\hline 0080-0041-G-CK & 500-KW PORTABLE DIESEL-GENERATOR SET, \#E-82643, ALL AREAS \\
\hline $0080-0041-G-C L$ & PORTABLE DIESEL-POWERED AIR COMPRESSOR, SRO \#7776, ALL AREAS \\
\hline 0080-0041-H-CG & $\begin{array}{l}\text { 350-KW EMERGENCY POWER DIESEL GENERATOR (254-11H) TO SERVE } \\
\text { CONSOLIDATED INCINERATION FACILITY (CIF), 261-H }\end{array}$ \\
\hline $0080-0041-\mathrm{H}-\mathrm{CG}$ & $\begin{array}{l}\text { 350-KW EMERGENCY POWER DIESEL GENERATOR (254-12H) TO SERVE } \\
\text { CONSOLIDATED INCINERATION FACILITY (CIF), 261-H }\end{array}$ \\
\hline 0080-0041-H-CG-R1 & $\begin{array}{l}\text { CONSOLIDATED INCINERATION FACILITY (CIF) FOR NONRADIOACTIVE } \\
\text { HAZARDOUS WASTE, } 261-\mathrm{H}\end{array}$ \\
\hline $0080-0041-\mathrm{H}-\mathrm{CH}$ & MODIFICATION TO 0080-0041-S13; LATE-WASH FACILITY, 241-10H \\
\hline $0080-0041-\mathrm{H}-\mathrm{Cl}$ & CONSOLIDATED INCINERATION FACILITY (CIF) ASHCRETE PROCESS \\
\hline 0080-0041-H-CK & $\begin{array}{l}\text { NEW SOLVENT STORAGE TANK FACILITY (FOUR 30,000-GALLON } \\
\text { UNDERGROUND TANKS, NEAR CIF, 261-H) }\end{array}$ \\
\hline 0080-0041-H-CL & TWO 20,000-GALLON UNDERGROUND STORAGE FUEL TANKS, 254-5H \\
\hline 0080-0041-M-CA & $\begin{array}{l}\text { VADOSE ZONE SOIL VAPOR EXTRACTION UNIT; M-AREA SEWER } \\
\text { (GROUNDWATER REMEDIATION), 782-5M }\end{array}$ \\
\hline 0080-0041-M-CB & $\begin{array}{l}\text { VADOSE ZONE SOIL VAPOR EXTRACTION UNIT; M-AREA BASIN } \\
\text { (GROUNDWATER REMEDIATION), 782-4M }\end{array}$ \\
\hline $0080-0041-\mathrm{M}-\mathrm{CC}$ & $\begin{array}{l}\text { VADOSE ZONE SOIL VAPOR EXTRACTION UNIT; M-AREA SOLVENT STORAGE } \\
\text { (GROUNDWATER REMEDIATION), 782-6M }\end{array}$ \\
\hline $0080-0041-\mathrm{M}-\mathrm{CD}$ & SOIL VAPOR EXTRACTION/CATALYTIC OXIDATION UNIT, 782-7M \\
\hline 0080-0041-M-CE & MIXED-WASTE VITRIFICATION PROCESS, M-AREA \\
\hline
\end{tabular}


Air Permits, continued

\begin{tabular}{|c|c|}
\hline Permit Number & Permit Title \\
\hline 0080-0041-M-CF-R1 & $\begin{array}{l}\text { CATALYTIC OXIDATION UNIT TO REDUCE VOC EMISSIONS FROM 610-GPM } \\
\text { M-1 AIR STRIPPER, M-AREA }\end{array}$ \\
\hline 0080-0041-M-CG & $\begin{array}{l}\text { MODIFICATION TO MIXED-WASTE VITRIFICATION PROCESS (NOx CONTROL } \\
\text { STRATEGIES), M-AREA }\end{array}$ \\
\hline $0080-0041-\mathrm{M}-\mathrm{CH}$ & SOIL VAPOR EXTRACTION/CATALYTIC OXIDATION UNIT, 782-8M \\
\hline 0080-0041-PORT-CB & 15,000-LB/HR PORTABLE PACKAGE STEAM GENERATOR \#1, GENERAL SITE \\
\hline 0080-0042-CN & OFF-GAS COMPONENTS TEST FACILITY, 678-T \\
\hline $0080-0045-\mathrm{Cl}$ & $\begin{array}{l}\text { NAVAL FUEL MATERIALS FACILITY (FMF) CEMENT AND FLY-ASH SILOS AND } \\
\text { BAGHOUSE, 247-F }\end{array}$ \\
\hline 0080-0045-CK & $\begin{array}{l}\text { NEW SPECIAL RECOVERY PROCESS WITH CYCLONE, SCRUBBERS, AND } \\
\text { HEPA FILTERS, } 221-\mathrm{F}\end{array}$ \\
\hline 0080-0046-CE & 150-KW EMERGENCY POWER DIESEL GENERATOR, 241-96H \\
\hline 0080-0046-CH & FUEL PROCESSING FACILITY (FPF) WITH HEPA FILTERS \\
\hline 0080-0048-CB & 800-KW EMERGENCY POWER DIESEL GENERATOR-A, 107-3P \\
\hline 0080-0048-CC & 800-KW EMERGENCY POWER DIESEL GENERATOR-B, 107-2P \\
\hline 0080-0049-CB & 800-KW EMERGENCY POWER DIESEL GENERATOR-A, 107-L \\
\hline 0080-0049-CC & 800-KW EMERGENCY POWER DIESEL GENERATOR-B, 107-L \\
\hline EXEMPTED & $\begin{array}{l}\text { 12,000-GALLON JET FUEL STORAGE TANK TO SERVE AVIATION OPERATIONS } \\
\text { DEPARTMENT FACILITY, B-AREA }\end{array}$ \\
\hline 0080-0041-A01 & 71.7-MMBTU/HR COAL BOILER \#1; CYCLONES, 784-A \\
\hline 0080-0041-A02 & 71.7-MMBTU/HR COAL BOILER \#2; CYCLONES, 784-A \\
\hline 0080-0041-A03 & 600-KW EMERGENCY POWER DIESEL GENERATOR, 794-A \\
\hline 0080-0041-A04 & 400-KW EMERGENCY POWER DIESEL GENERATOR, 773-A \\
\hline 0080-0041-A05 & 150-KW EMERGENCY POWER DIESEL GENERATOR, 751-2A \\
\hline 0080-0041-A06 & $\begin{array}{l}\text { 400-KW EMERGENCY POWER DIESEL GENERATOR (503-2A) TO SERVE } \\
\text { 735-A, 735-11A, 774-A, AND 773-A FEEDERS }\end{array}$ \\
\hline 0080-0041-A07 & 200-KW EMERGENCY POWER DIESEL GENERATOR, 703-A (C-WING) \\
\hline 0080-0041-A08 & 250-KW EMERGENCY POWER DIESEL GENERATOR, 754-4A \\
\hline 0080-0041-A09 & 455-KW EMERGENCY POWER DIESEL GENERATOR, 720-2A \\
\hline 0080-0041-A10 & $\begin{array}{l}\text { 1250-KW EMERGENCY POWER DIESEL GENERATOR \#1, 754-5A } \\
\text { (TO SERVE 703-44A) }\end{array}$ \\
\hline 0080-0041-A11 & $\begin{array}{l}\text { 1250-KW EMERGENCY POWER DIESEL GENERATOR \#2, 754-5A } \\
\text { (TO SERVE 703-44A) }\end{array}$ \\
\hline
\end{tabular}


Air Permits, continued

\begin{tabular}{|c|c|}
\hline Permit Number & Permit Title \\
\hline 0080-0041-A12 & $\begin{array}{l}\text { 70-GPM AIR STRIPPING COLUMN, A-001; CATALYTIC OXIDATION UNIT } \\
\text { (A-001A OUTFALL), SRTC }\end{array}$ \\
\hline 0080-0041-A14 & $\begin{array}{l}\text { 155-KW EMERGENCY POWER DIESEL GENERATOR, 737-2A (TO SERVE } \\
\text { SREL) }\end{array}$ \\
\hline 0080-0041-C06 & 365-KW EMERGENCY POWER DIESEL GENERATOR, 183-3C \\
\hline 0080-0041-D05 & 150-KW EMERGENCY POWER DIESEL GENERATOR, 501-D \\
\hline 0080-0041-F05 & URANIUM DISSOLUTION, 221-F \\
\hline 0080-0041-F06 & 200-KW CONTINUOUSLY RUNNING DIESEL GENERATOR, 254-5F \#1 \\
\hline 0080-0041-F07 & 200-KW CONTINUOUSLY RUNNING DIESEL GENERATOR, 254-5F \#2 \\
\hline 0080-0041-F08 & 175-KW EMERGENCY POWER DIESEL GENERATOR, 772-F \#1 \\
\hline 0080-0041-F09 & 175-KW EMERGENCY POWER DIESEL GENERATOR, 772-F \#2 \\
\hline 0080-0041-F10 & 350-KW EMERGENCY POWER DIESEL GENERATOR, 241-19F \\
\hline 0080-0041-F11 & 350-KW EMERGENCY POWER DIESEL GENERATOR, 235-F \\
\hline 0080-0041-F12 & 350-KW EMERGENCY POWER DIESEL GENERATOR, 254-4F \\
\hline $0080-0041-F 13$ & 250-KW EMERGENCY POWER DIESEL GENERATOR, 254-1F \\
\hline 0080-0041-F14 & 200-KW EMERGENCY POWER DIESEL GENERATOR, 241-74F \\
\hline 0080-0041-F15 & 600-KW EMERGENCY POWER DIESEL GENERATOR, 292-F \\
\hline 0080-0041-F16 & $\begin{array}{l}\text { 600-KW EMERGENCY POWER DIESEL GENERATOR, 247-1F NAVAL FUEL } \\
\text { (FMF) }\end{array}$ \\
\hline 0080-0041-F17 & 300-KW EMERGENCY POWER DIESEL GENERATOR, 254-7F \\
\hline 0080-0041-F18 & 415-KW EMERGENCY POWER DIESEL GENERATOR, 772-1F \\
\hline 0080-0041-F19 & 300-KW EMERGENCY POWER DIESEL GENERATOR, 292-2F \\
\hline 0080-0041-F20 & 300-KW EMERGENCY POWER DIESEL GENERATOR, 254-9F \\
\hline 0080-0041-F21 & 1000-KW EMERGENCY POWER DIESEL GENERATOR, 221-F \\
\hline 0080-0041-F22 & 600-KW EMERGENCY POWER DIESEL GENERATOR, 254-10F \\
\hline 0080-0041-F23 & 350-KW EMERGENCY POWER DIESEL GENERATOR, 254-8F \\
\hline 0080-0041-F24 & $\begin{array}{l}\text { NAVAL FUEL MATERIALS FACILITY (FMF) STACK; SCRUBBERS AND HEPA } \\
\text { FILTERS, 247-F }\end{array}$ \\
\hline 0080-0041-F25 & $\begin{array}{l}\text { NAVAL FUEL MATERIALS FACILITY (FMF) WASTEWATER TREATMENT } \\
\text { FACILITY; DEMISTER, 247-F }\end{array}$ \\
\hline 0080-0041-F26 & $\begin{array}{l}\text { NINE FINISHING VENTS, NINE SCRUBBERS, AND NINE HEPA FILTERS FOR } \\
\text { NAVAL FUEL MATERIALS FACILITY (FMF), } 247-F\end{array}$ \\
\hline
\end{tabular}


Air Permits, continued

\begin{tabular}{|c|c|}
\hline Permit Number & Permit Title \\
\hline 0080-0041-F27 & 455-KW EMERGENCY POWER DIESEL GENERATOR, 720-F \\
\hline $0080-0041-\mathrm{G} 01$ & $\begin{array}{l}\text { WASTE PAINT SOLVENTS DISTILLATION AND CONDENSATION UNIT \#1; CAR- } \\
\text { BON SCRUBBER, ALL AREAS }\end{array}$ \\
\hline $0080-0041-\mathrm{G} 02$ & $\begin{array}{l}\text { WASTE PAINT SOLVENTS DISTILLATION AND CONDENSATION UNIT \#2; CAR- } \\
\text { BON SCRUBBER, ALL AREAS }\end{array}$ \\
\hline 0080-0041-G03 & PORTABLE DIESEL-POWERED AIR COMPRESSOR, SME 52-112; ALL AREAS \\
\hline 0080-0041-G04 & PORTABLE DIESEL-POWERED AIR COMPRESSOR, SME 52-113; ALL AREAS \\
\hline 0080-0041-G05 & PORTABLE DIESEL-POWERED AIR COMPRESSOR, SME 52-114; ALL AREAS \\
\hline 0080-0041-G06 & PORTABLE DIESEL-POWERED AIR COMPRESSOR, SME 52-115; ALL AREAS \\
\hline 0080-0041-G07 & PORTABLE DIESEL-POWERED AIR COMPRESSOR, SME 52-116; ALL AREAS \\
\hline 0080-0041-G08 & PORTABLE DIESEL-POWERED AIR COMPRESSOR, SME 52-128; ALL AREAS \\
\hline 0080-0041-G09 & PORTABLE DIESEL-POWERED AIR COMPRESSOR, SME 52-129; ALL AREAS \\
\hline $0080-0041-G 10$ & PORTABLE DIESEL-POWERED AIR COMPRESSOR, SME 52-130; ALL AREAS \\
\hline $0080-0041-\mathrm{G} 11$ & PORTABLE DIESEL-POWERED AIR COMPRESSOR, SME 52-131; ALL AREAS \\
\hline 0080-0041-G12 & PORTABLE DIESEL-POWERED AIR COMPRESSOR, SME 52-132; ALL AREAS \\
\hline $0080-0041-G 13$ & 200-KW MOBILE EMERGENCY GENERATOR, SME 60-171; ALL AREAS \\
\hline $0080-0041-\mathrm{G} 14$ & $\begin{array}{l}\text { 15,000-LB/HR PORTABLE PACKAGE STEAM GENERATING BOILER \#2 (NSPS), } \\
\text { ALL AREAS }\end{array}$ \\
\hline 0080-0041-G15 & $\begin{array}{l}\text { PORTABLE NORKOT MAXIGRIND } 9100 \text { DIESEL-POWERED CHIPPER UNIT, } \\
\text { SME 36-25; ALL AREAS }\end{array}$ \\
\hline 0080-0041-G16 & 190-KW MOBILE EMERGENCY GENERATOR, SRO \#0391; ALL AREAS \\
\hline 0080-0041-G17 & 250-KW MOBILE EMERGENCY GENERATOR, SRO \#7835; ALL AREAS \\
\hline 0080-0041-G18 & PORTABLE SOIL VAPOR EXTRACTION UNIT, SRO \#5957; ALL AREAS \\
\hline $0080-0041-\mathrm{G} 19$ & 600-KW MOBILE EMERGENCY DIESEL GENERATOR, SRO \#5422 \\
\hline $0080-0041-G 20$ & 300-KW MOBILE EMERGENCY DIESEL GENERATOR, SRO \#5430 \\
\hline $0080-0041-G 21$ & 300-KW MOBILE EMERGENCY DIESEL GENERATOR, SRO \#6455 \\
\hline $0080-0041-G 22$ & 260-KW MOBILE EMERGENCY GENERATOR, SRO \#7850; ALL AREAS \\
\hline $0080-0041-G 23$ & 250-KW MOBILE EMERGENCY GENERATOR, SRO \#7858; ALL AREAS \\
\hline 0080-0041-G24 & $\begin{array}{l}\text { WASTE PAINT SOLVENTS DISTILLATION AND CONDENSATION UNIT \#3; } \\
\text { CARBON SCRUBBER, ALL AREAS }\end{array}$ \\
\hline $0080-0041-G 25$ & $\begin{array}{l}\text { WASTE PAINT SOLVENTS DISTILLATION AND CONDENSATION UNIT \#4; } \\
\text { CARBON SCRUBBER, ALL AREAS }\end{array}$ \\
\hline
\end{tabular}


Air Permits, continued

\begin{tabular}{|c|c|}
\hline Permit Number & Permit Title \\
\hline 0080-0041-G26 & $\begin{array}{l}\text { WASTE PAINT SOLVENTS DISTILLATION AND CONDENSATION UNIT \#5; } \\
\text { CARBON SCRUBBER, ALL AREAS }\end{array}$ \\
\hline 0080-0041-G27 & $\begin{array}{l}\text { 1000-KW EMERGENCY POWER DIESEL GENERATOR TO SERVE CENTRAL } \\
\text { SANITARY WASTEWATER TREATMENT FACILITY (CSWTF), 654-G }\end{array}$ \\
\hline $0080-0041-G 28$ & PORTABLE DIESEL-POWERED AIR COMPRESSOR, SRO \#5233; ALL AREAS \\
\hline 0080-0041-G29 & PORTABLE DIESEL-POWERED AIR COMPRESSOR, SRO \#5248; ALL AREAS \\
\hline 0080-0041-G30 & PORTABLE DIESEL-POWERED AIR COMPRESSOR, SRO \#5278; ALL AREAS \\
\hline $0080-0041-\mathrm{G} 31$ & PORTABLE DIESEL-POWERED AIR COMPRESSOR, SRO \#6940; ALL AREAS \\
\hline 0080-0041-G32 & PORTABLE DIESEL-POWERED AIR COMPRESSOR, SRO \#6941; ALL AREAS \\
\hline 0080-0041-G33 & PORTABLE DIESEL-POWERED AIR COMPRESSOR, SRO \#6943; ALL AREAS \\
\hline 0080-0041-G34 & PORTABLE DIESEL-POWERED AIR COMPRESSOR, SRO \#6944; ALL AREAS \\
\hline 0080-0041-G35 & PORTABLE DIESEL-POWERED AIR COMPRESSOR, SRO \#6945; ALL AREAS \\
\hline 0080-0041-H01 & 71.7-MMBTU/HR COAL BOILER \#1; 2 CYCLONES, 784-H \\
\hline 0080-0041- H02 & 71.7-MMBTU/HR COAL BOILER \#2; 2 CYCLONES, 784-H \\
\hline 0080-0041- & 71.7-MMBTU/HR COAL BOILER \#3; 2 CYCLONES, 784-H \\
\hline 0080-0041- H04 & $\begin{array}{l}\text { 400-LB/HR TYPE "O" WASTE INCINERATOR, BAGHOUSE AND HEPA FILTERS } \\
\text { (BETA-GAMMA INCINERATOR), 230-H }\end{array}$ \\
\hline 0080-0041-H05 & SEPARATION PROCESS, 221-H \\
\hline 0080-0041-H06 & 200-KW EMERGENCY POWER DIESEL GENERATOR, 234-4H \\
\hline 0080-0041-H07 & 200-KW EMERGENCY POWER DIESEL GENERATOR, 299-1H \\
\hline 0080-0041- H08 & 200-KW EMERGENCY POWER DIESEL GENERATOR, 241-74H \\
\hline 0080-0041-H09 & 250-KW EMERGENCY POWER DIESEL GENERATOR, 254-1H \\
\hline 0080-0041- H10 & 275-KW EMERGENCY POWER DIESEL GENERATOR, 254-3H \\
\hline 0080-0041-H11 & 300-KW EMERGENCY POWER DIESEL GENERATOR, 221-HB \\
\hline $0080-0041-\mathrm{H} 12$ & 300-KW CONTINUOUSLY RUNNING DIESEL GENERATOR, 254-5H, \#1 \\
\hline 0080-0041-H13 & 300-KW CONTINUOUSLY RUNNING DIESEL GENERATOR, 254-5H, \#2 \\
\hline 0080-0041-H14 & 300-KW EMERGENCY POWER DIESEL GENERATOR, 232-H \\
\hline $0080-0041-\mathrm{H} 15$ & 300-KW EMERGENCY POWER DIESEL GENERATOR, 234-H \\
\hline 0080-0041-H16 & 500-KW EMERGENCY POWER DIESEL GENERATOR, 232-H, \#2 \\
\hline 0080-0041-H17 & 500-KW EMERGENCY POWER DIESEL GENERATOR, 254-H \\
\hline
\end{tabular}


Air Permits, continued

\begin{tabular}{|c|c|}
\hline Permit Number & Permit Title \\
\hline 0080-0041-H18 & 600-KW EMERGENCY POWER DIESEL GENERATOR, 292-H \\
\hline 0080-0041- H19 & 1000-KW EMERGENCY POWER DIESEL GENERATOR, 221-H \\
\hline $0080-0041-\mathrm{H} 20$ & 500-KW EMERGENCY POWER DIESEL GENERATOR, 254-8H \\
\hline $0080-0041-\mathrm{H} 21$ & 400-KW EMERGENCY POWER DIESEL GENERATOR, 254-9H \\
\hline $0080-0041-\mathrm{H} 22$ & $\begin{array}{l}\text { 765-KW EMERGENCY POWER DIESEL GENERATOR (254-10H) TO SERVE } \\
233-\mathrm{H} \text { (RTF) }\end{array}$ \\
\hline $0080-0041-\mathrm{H} 23$ & 2500-GPM EMERGENCY DIESEL FIRE WATER PUMP \#1, 241-125H (ITP) \\
\hline $0080-0041-\mathrm{H} 24$ & 2500-GPM EMERGENCY DIESEL FIRE WATER PUMP \#2, 241-125H (ITP) \\
\hline $0080-0041-\mathrm{H} 25$ & 455-KW EMERGENCY POWER DIESEL GENERATOR, 720-H \\
\hline $0080-0041-\mathrm{H} 26$ & IN-TANK PRECIPITATION (ITP) TANK \#48; 241-948H \\
\hline 0080-0041-H27 & IN-TANK PRECIPITATION (ITP) TANK \#49; 241-949H \\
\hline $0080-0041-\mathrm{H} 28$ & IN-TANK PRECIPITATION (ITP) FILTER/STRIPPER BUILDING, 241-96H \\
\hline $0080-0041-\mathrm{H} 30$ & IN-TANK PRECIPITATION (ITP) TANK \#50; 241-950H \\
\hline $0080-0041-\mathrm{H} 31$ & IN-TANK PRECIPITATION (ITP) TANK \#22; 241-922H \\
\hline 0080-0041-H32 & $\begin{array}{l}\text { 12,500-GALLON NO. } 2 \text { FUEL OIL STORAGE TANK TO SERVE CONSOLIDATED } \\
\text { INCINERATION FACILITY (CIF) }\end{array}$ \\
\hline 0080-0041-K01 & 194.5-MMBTU/HR COAL BOILER, CYCLONES; UNIT \#1 \\
\hline $0080-0041-K 03$ & 1250-KW EMERGENCY POWER DIESEL GENERATOR, 108-1K \\
\hline 0080-0041-K04 & 1250-KW EMERGENCY POWER DIESEL GENERATOR, 108-2K \\
\hline 0080-0041-K05 & 150-KW EMERGENCY POWER DIESEL GENERATOR \#1, 108-4K \\
\hline 0080-0041-K06 & 150-KW EMERGENCY POWER DIESEL GENERATOR \#2, 108-4K \\
\hline 0080-0041-K07 & 200-KW EMERGENCY POWER DIESEL GENERATOR, 152-7K \\
\hline 0080-0041-K08 & $\begin{array}{l}\text { 365-KW EMERGENCY POWER DIESEL GENERATOR (183-3K) TO SERVE } \\
\text { 183-2K, 905-95K, AND 905-106K }\end{array}$ \\
\hline 0080-0041-K09 & 520-BHP EMERGENCY DIESEL BOOSTER PUMP, 191-K (SERVING 105-K) \\
\hline $0080-0041-K 10$ & 800-KW EMERGENCY POWER DIESEL GENERATOR-A, 107-K \\
\hline $0080-0041-K 11$ & 800-KW EMERGENCY POWER DIESEL GENERATOR-B, 107-K \\
\hline 0080-0041-K12 & 76.8-MMBTU/HR NO. 2 FUEL OIL-FIRED BOILER (NSPS SOURCE), K-AREA \\
\hline $0080-0041-K 13$ & $\begin{array}{l}\text { 38-MMBTU/HR NO. } 2 \text { FUEL OIL-FIRED PACKAGE STEAM GENERATOR RATED } \\
\text { AT } 30,000-L B / H R \text { STEAM PRODUCTION (NSPS SOURCE), K-AREA }\end{array}$ \\
\hline $0080-0041-K 14$ & 2500-GPM (375-BHP) EMERGENCY-FIRE WATER PUMP, 192-2K \\
\hline
\end{tabular}


Air Permits, continued

\begin{tabular}{|c|c|}
\hline Permit Number & Permit Title \\
\hline $0080-0041-K 15$ & $\begin{array}{l}30,000-G A L L O N \text { \#2 FUEL OIL STORAGE TANK, 500-02; 184-2K (NSPS } \\
\text { SOURCE) }\end{array}$ \\
\hline $0080-0041-K 15$ & $\begin{array}{l}\text { 30,000-GALLON \#2 FUEL OIL STORAGE TANK, 500-03; 184-2K (NSPS } \\
\text { SOURCE) }\end{array}$ \\
\hline 0080-0041-L01 & 1250-KW EMERGENCY POWER DIESEL GENERATOR, 108-1L \\
\hline 0080-0041-L02 & 1250-KW EMERGENCY POWER DIESEL GENERATOR, 108-2L \\
\hline 0080-0041-L03 & 520-BHP EMERGENCY DIESEL BOOSTER PUMP, 191-L \\
\hline 0080-0041-L04 & 150-KW EMERGENCY POWER DIESEL GENERATOR \#1, 108-4L \\
\hline 0080-0041-L05 & 150-KW EMERGENCY POWER DIESEL GENERATOR \#2, 108-4L \\
\hline 0080-0041-L06 & 200-KW EMERGENCY POWER DIESEL GENERATOR, 152-7L \\
\hline 0080-0041-L07 & 365-KW EMERGENCY POWER DIESEL GENERATOR, 183-3L \\
\hline 0080-0041-M02 & ALUMINUM TUBE CLEANING WITH NITRIC ACID, 321-M \\
\hline 0080-0041-M03 & $\begin{array}{l}\text { 200-KW EMERGENCY POWER DIESEL GENERATOR, 320-M } \\
\text { (REPLACED 150-KW GENERATOR) }\end{array}$ \\
\hline 0080-0041-M04 & 610-GPM M-1 AIR STRIPPER, M-AREA \\
\hline 0080-0041-N01 & $\begin{array}{l}\text { 2500-GPM (370-BHP) DIESEL FIRE PUMP, CENTRAL SHOPS } \\
\text { (MATERIALS MANAGEMENT RECEIVING AND STORAGE) }\end{array}$ \\
\hline 0080-0041-P02 & 194.5-MMBTU/HR COAL BOILER, CYCLONES, 184-P \#2 \\
\hline 0080-0041-P03 & 1250-KW EMERGENCY POWER DIESEL GENERATOR, 108-1P \\
\hline 0080-0041-P04 & 1250-KW EMERGENCY POWER DIESEL GENERATOR, 108-2P \\
\hline 0080-0041-P05 & 150-KW EMERGENCY POWER DIESEL GENERATOR, 108-4P, \#1 \\
\hline 0080-0041-P06 & 150-KW EMERGENCY POWER DIESEL GENERATOR, 108-4P, \#2 \\
\hline 0080-0041-P07 & 200-KW EMERGENCY POWER DIESEL GENERATOR, 152-7P \\
\hline 0080-0041-P08 & 365-KW EMERGENCY POWER DIESEL GENERATOR, 183-2P \\
\hline 0080-0041-P09 & 520-BHP EMERGENCY DIESEL BOOSTER PUMP, 191-P (SERVING 105-P) \\
\hline 0080-0041-S05 & 2050-KW EMERGENCY POWER DIESEL GENERATOR \#1, 292-S \\
\hline 0080-0041-S06 & 2050-KW EMERGENCY POWER DIESEL GENERATOR \#2, 292-S \\
\hline 0080-0041-S07 & 261-BHP EMERGENCY FIRE WATER PUMP, 980-S \\
\hline 0080-0041-508 & $\begin{array}{l}\text { DWPF VITRIFICATION BUILDING (PROVIDES VENTILATION FOR PERSONNEL } \\
\text { CORRIDOR, LABORATORIES, WELD TEST, AND CHEMICAL STORAGE TANKS } \\
\text { - ZONE 2, 221-S); HEPA FILTER }\end{array}$ \\
\hline
\end{tabular}


Air Permits, continued

\begin{tabular}{|c|c|}
\hline Permit Number & Permit Title \\
\hline 0080-0041-S09 & $\begin{array}{l}\text { DWPF PROCESS STACK (PROVIDES VENTILATION FOR PROCESS CELLS, } \\
\text { PROCESS VESSEL VENT, AND MELTER OFF-GAS - ZONE 1, 291-S); SAND } \\
\text { FILTER }\end{array}$ \\
\hline $0080-0041-510$ & $\begin{array}{l}\text { DWPF COLD-FEEDS FACILITY (CHEMICAL STORAGE TANKS FOR FORMIC } \\
\text { ACID, HYDROXYLAMINE NITRATE, OXALIC ACID, NITRIC ACID, SODIUM } \\
\text { HYDROXIDE, AND A GLASS FRIT-HANDLING SYSTEM WITH BAGHOUSE, } \\
422-S \text { ) }\end{array}$ \\
\hline $0080-0041-S 11$ & $\begin{array}{l}\text { DWPF } 150,000-G A L L O N \text { ORGANIC WASTE STORAGE TANK VENT (BENZENE } \\
\text { STORAGE, 430-S); INTERNAL FLOATING ROOF WITH PRIMARY AND SEC- } \\
\text { ONDARY SEALS, NITROGEN BLANKET, AND HEPA FILTER }\end{array}$ \\
\hline 0080-0041-S12 & $\begin{array}{l}\text { DWPF LOW-POINT PUMP PIT (TRANSFER OF RADIOACTIVE SLURRIES AND } \\
\text { SOLUTIONS, 511-S); HEPA FILTERS }\end{array}$ \\
\hline 0080-0041-T02 & PORTABLE 300-KW EMERGENCY POWER DIESEL GENERATOR, SRO \#0392 \\
\hline 0080-0041-T03 & 300-KW EMERGENCY POWER DIESEL GENERATOR, 672-T \\
\hline 0080-0041-T04 & 20-LB/HR SHIRCO INCINERATOR, HEPA FILTERS, 677-T \\
\hline 0080-0041-T05 & PRECIPITATE HYDROLYSIS EXPERIMENTAL FACILITY, 682-T \\
\hline 0080-0041-T06 & 1000-KW EMERGENCY POWER DIESEL GENERATOR, 654-1T \\
\hline 0080-0041-T07 & 300-KW EMERGENCY POWER DIESEL GENERATOR (654-T) TO SERVE 678-T \\
\hline 0080-0041-Z01 & 425-KW EMERGENCY POWER DIESEL GENERATOR, 956-Z \\
\hline 0080-0041-Z02 & SILO TO STORE CEMENT OR SLAG, WITH BAGHOUSE, 205-Z \\
\hline 0080-0041-Z03 & THREE FLY-ASH/CEMENT SILOS WITH BAGHOUSE, 205-Z \\
\hline 0080-0041-Z04 & WEIGH HOPPER WITH BAGHOUSE, 205-Z \\
\hline $0080-0041-Z 05$ & TWO PREMIX AIR BLENDERS WITH BAGHOUSE, 205-Z \\
\hline 0080-0041-Z06 & PREMIX FEED BIN WITH BAGHOUSE, 210-Z \\
\hline 0080-0041-Z07 & $\begin{array}{l}\text { GROUT MIXER WITH BAGHOUSE, SCRUBBER, AND TWO HEPA FILTERS (ONE } \\
\text { IN SERVICE, ONE STANDBY) TO INCLUDE VOC EMISSIONS FROM STACK, } \\
210-Z\end{array}$ \\
\hline 0080-0041-Z08 & LOW-POINT DRAIN TANK VENT WITH HEPA FILTER, 551-Z \\
\hline EXEMPTED & 2500-GPM (370-BHP) DIESEL FIRE PUMP, 902-5B \\
\hline EXEMPTED & 2500-GPM (266-BHP) DIESEL FIRE PUMP \#1, 902-3F \\
\hline EXEMPTED & 2500-GPM (266-BHP) DIESEL FIRE PUMP \#2, 902-3F \\
\hline EXEMPTED & $\begin{array}{l}\text { 250-KW EMERGENCY DIESEL GENERATOR, TELEPHONE SWITCH STATION, } \\
\text { 702-A }\end{array}$ \\
\hline
\end{tabular}




\section{U.S. Army Corps of Engineers Nationwide Permits}

\begin{tabular}{ll}
\hline Permit Number & Permit Title \\
NWP \#3 & REPLACEMENT OF BRIDGES 603-2G AND 603-3G ACROSS UPPER THREE \\
& CREEK, AIKEN COUNTY, SC \\
NWP \#3 & REPLACEMENT OF BRIDGES AT ROAD 8-1 AND ROAD 2-1 ON UPPER THR \\
& RUNS CREEK, AIKEN COUNTY, SC \\
NWP \#3 & REPLACEMENT OF BRIDGE, 603-72G, ON ROAD B OVER LOWER THREE RUN \\
& CREEK, BARNWELL COUNTY, SC \\
NWP \#3 & REPLACEMENT OF BRIDGE ON ROAD 4 OVER FOURMILE BRANCH, AIKEN \\
& COUNTY, SC \\
NWP \#12 & PIPE BRIDGE INSTALLATION FOR POTABLE WATER LINE ACROSS UPPER TH \\
& RUNS CREEK AND SITE WETLANDS CROSSING, AIKEN COUNTY, SC \\
NWP \#26 & EROSION CONTROL PROJECT IN THE Z CHANNEL BETWEEN Z-AREA AND \\
& UPPER THREE RUNS CREEK \\
NWP \#26 & EROSION CONTROL PROJECT IN THE F-2 OUTFALL CHANNEL TO UPPER \\
& THREE RUNS CREEK \\
NWP \#26 & EROSION CONTROL PROJECT IN THE F-1 OUTFALL CHANNEL TO UPPER \\
& THREE RUNS CREEK
\end{tabular}

Domestic Water Permits

The South Carolina Department of Health and Environmental Control (SCDHEC) has granted Westinghouse Savannah River Company's Environmental Protection Department the authority-now under the General Construction Permit Program (GCP), formerly under the Modified Permitting Program (MPP) - to review domestic water construction permit application packages and to issue domestic water construction and operating permits on behalf of SCDHEC. Several South Carolina municipalities have similar agreements with SCDHEC. All domestic water permits listed in this report that begin with " $G$ " fall under the GCP; those that begin with "M" fall under the MPP.

\begin{tabular}{ll}
\hline Permit Number & Permit Title \\
\hline 210966 & DOMESTIC WATER SYSTEM UPGRADE, PHASE II, ZONE 5 (A-AREA CENTRAL. \\
& TREATMENT PLANT) \\
306376 & $500,000-$ GALLON DOMESTIC WATER ELEVATED STORAGE TANK TO SERVE A- \\
& AREA AND B-AREA (DOMESTIC WATER SYSTEM UPGRADE, PHASE II, ZONE 4) \\
411337 & SODIUM HYPOCHLORITE SYSTEM, 780-1A \\
200092 & DOMESTIC WATER DEEP WELLS, 905-104L AND 904-105L, TO SERVE L-AREA \\
200279 & DOMESTIC WATER DEEP WELL, 905-120P, TO SERVE P-AREA \\
201715 & DOMESTIC WATER DEEP WELL, 905-107G, TO SERVE RAILROAD \\
202822 & CLASSIFICATION YARD \\
$202822 A 1$ & DOMESTIC WATER SYSTEM (TEST WELL \#1, “DIVISION A") TO SERVE D-AREA \\
202915 & DOMESTIC WATER SYSTEM (PUMP, PIPING, TREATMENT, STORAGE TANK) TO \\
& SERVE D-AREA \\
& DOMESTIC WATER WELL AND DISTRIBUTION SYSTEM TO SERVE \\
& CONSTRUCTION SUPPORT AREA, S-AREA
\end{tabular}


Domestic Water Permits, continued

\begin{tabular}{|c|c|}
\hline Permit Number & Permit Title \\
\hline 203427 & SODIUM HYPOCHLORITE SYSTEM, 280-F \\
\hline 203467 & SODIUM HYPOCHLORITE SYSTEM, 280-H \\
\hline 203590 & $\begin{array}{l}\text { DOMESTIC WATER WELL, 905-126G, TO SERVE 100-AREA FIRE STATION, 709-1G } \\
\text { (INTERSECTION OF ROAD C AND ROAD 7) }\end{array}$ \\
\hline 203628 & $\begin{array}{l}\text { DOMESTIC WATER WELL, 905-118G, TO SERVE PISTOL RANGE } \\
\text { (REPLACED WELL 905-11G) }\end{array}$ \\
\hline 203638 & $\begin{array}{l}\text { DOMESTIC WATER WELL, 905-117G, TO SERVE ALLENDALE BARRICADE } \\
\text { (REPLACED WELL 905-6G) }\end{array}$ \\
\hline 203786 & $\begin{array}{l}\text { DOMESTIC WATER WELL, 905-114G, TO SERVE RIVER WATER PUMPING } \\
\text { STATION, } 681-3 G \text { (REPLACED WELL 905-4G) }\end{array}$ \\
\hline 204138 & $\begin{array}{l}\text { DOMESTIC WATER DEEP WELL, 905-106K, TO SERVE K-AREA } \\
\text { (REPLACED WELL 905-94K) }\end{array}$ \\
\hline 204198 & $\begin{array}{l}\text { DOMESTIC WATER DEEP WELL, 905-119H, TO SERVE H-AREA } \\
\text { (REPLACED WELL 905-66H) }\end{array}$ \\
\hline 205142 & POLYPHOSPHATE SYSTEMS, 200-F-AREA \\
\hline 205217 & $\begin{array}{l}\text { UPGRADE INSTRUMENTATION 280-1H (CAUSTIC FEED SYSTEM); } \\
\text { (F-Area also covered under this permit) }\end{array}$ \\
\hline 205217 & $\begin{array}{l}\text { UPGRADE INSTRUMENTATION 280-1F (CAUSTIC FEED SYSTEM); } \\
\text { (H-Area also covered under this permit) }\end{array}$ \\
\hline 205702 & POLYPHOSPHATE SYSTEMS, 200-H-AREA \\
\hline 205877 & $\begin{array}{l}\text { DOMESTIC WATER WELL, 905-116G, PIPING AND STORAGE TANK TO SERVE } \\
\text { AUGUSTA BARRICADE, 701-6G (REPLACED WELL 905-10G) }\end{array}$ \\
\hline 206474 & $\begin{array}{l}\text { DOMESTIC WATER TEST WELL, 905-136G, TO SERVE CENTRAL SANITARY } \\
\text { WASTEWATER TREATMENT FACILITY (CSWTF) }\end{array}$ \\
\hline 206474A1 & $\begin{array}{l}\text { DOMESTIC WATER SYSTEM (PUMP, WELLHEAD PIPING, TREATMENT, TANK AND } \\
\text { DISTRIBUTION SYSTEM) TO SERVE CENTRAL SANITARY WASTEWATER TREAT- } \\
\text { MENT FACILITY (CSWTF) }\end{array}$ \\
\hline 206501 & $\begin{array}{l}\text { DOMESTIC WATER DEEP WELL, 905-125B (TEST WELL) TO SERVE B-AREA } \\
\text { (REPLACES WELL 905-59B) }\end{array}$ \\
\hline $206501 \mathrm{~A} 1$ & $\begin{array}{l}\text { DOMESTIC WATER DEEP WELL, 905-125B, (PUMP/PIPING/TREATMENT) TO } \\
\text { SERVE B-AREA }\end{array}$ \\
\hline 206575 & $\begin{array}{l}\text { DOMESTIC WATER DEEP WELLS, 905-112G AND 905-113G, TO SERVE A-AREA } \\
\text { AND M-AREA }\end{array}$ \\
\hline 207853 & DOMESTIC WATER SYSTEM (BACKUP TEST WELL) TO SERVE D-AREA \\
\hline $207853 A 1$ & $\begin{array}{l}\text { DOMESTIC WATER SYSTEM (BACKUP PUMP, PIPING, TREATMENT, STORAGE } \\
\text { TANK) TO SERVE D-AREA }\end{array}$ \\
\hline 208425 & $\begin{array}{l}\text { DOMESTIC WATER TEST WELL, 905-108G, TO SERVE ADVANCED TACTICAL } \\
\text { TRAINING ACADEMY (ATTA), 617-G }\end{array}$ \\
\hline
\end{tabular}


Domestic Water Permits, continued

\begin{tabular}{|c|c|}
\hline Permit Number & Permit Title \\
\hline $208425 A 1$ & $\begin{array}{l}\text { DOMESTIC WATER SYSTEM (PUMP, PIPING, TREATMENT, TANK) TO SERVE } \\
\text { ADVANCED TACTICAL TRAINING ACADEMY (ATTA), 617-G }\end{array}$ \\
\hline 208434 & $\begin{array}{l}\text { DOMESTIC WATER SYSTEMS (WELLS/PIPING/TREATMENT) TO SERVE ROAD } 2 \\
\text { BARRICADE 701-8G (WELL 905-111G), ROAD } 3 \text { BARRICADE 701-12G } \\
\text { (WELL 905-110G), AND ROAD } 6 \text { BARRICADE 701-13G (WELL 905-109G) }\end{array}$ \\
\hline 208866 & $\begin{array}{l}\text { DOMESTIC WATER WELL, 905-115G, TO SERVE AIKEN BARRICADE, 701-5G } \\
\text { (REPLACED WELL 905-69G) }\end{array}$ \\
\hline 209191 & $\begin{array}{l}\text { DOMESTIC WATER TEST WELL, 905-131G, TO SERVE SREL PAR POND } \\
\text { LABORATORY, 737-G }\end{array}$ \\
\hline $209191 \mathrm{~A} 1$ & $\begin{array}{l}\text { DOMESTIC WATER SYSTEM (PUMP, PIPING, TREATMENT, STORAGE TANK) TO } \\
\text { SERVE SREL PAR POND LABORATORY, 737-G }\end{array}$ \\
\hline 209454 & DOMESTIC WATER WELLS, 905-96G AND 905-97G, TO SERVE TNX-AREA \\
\hline 210657 & $\begin{array}{l}\text { DOMESTIC WATER DEEP WELL, 905-103F, AND DISTRIBUTION SYSTEM TO } \\
\text { SERVE F-AREA (REPLACED WELL 905-39F) }\end{array}$ \\
\hline 212745 & DOMESTIC WATER DEEP WELLLS, 905-1 AND 905-2, TO SERVE S-AREA \\
\hline 304134 & TNX-AREA DOMESTIC WATER TREATMENT PLANT MODIFICATIONS \\
\hline 306386 & $\begin{array}{l}\text { 650,000-GALLON DOMESTIC WATER ELEVATED STORAGE TANK TO SERVE } \\
\text { C-AREA AND N-AREA (DOMESTIC WATER UPGRADE, PHASE II, ZONE 4) }\end{array}$ \\
\hline 400203 & TNX-AREA HYDROPNEUMATIC DOMESTIC WATER STORAGE TANK \\
\hline 400347 & DOMESTIC WATER HEADERS, TNX-AREA \\
\hline 400737 & DOMESTIC WATER SYSTEM (PUMP, PIPING, STORAGE TANK) TO SERVE, Z-AREA \\
\hline 401118 & $\begin{array}{l}\text { DOMESTIC WATER LINE TO SERVE NEW WASTE TRANSFER FACILITY (NWTF), } \\
241-102 \mathrm{H}\end{array}$ \\
\hline 401354 & 250,000-GALLON DOMESTIC WATER STORAGE TANK, A-AREA \\
\hline 401446 & DOMESTIC WATER LINE TO SERVE PRODUCTION CONTROL FACILITY, 772-1F \\
\hline 401654 & B-AREA DOMESTIC WATER TREATMENT PLANT MODIFICATIONS \\
\hline 402186 & DOMESTIC WATER LINES TO SERVE S-AREA \\
\hline 402343 & H-AREA BACKUP BOOSTER PUMP ("AS BUILT") \\
\hline 402874 & SEGREGATED DOMESTIC WATER SUPPLY, $300 / 700$ AREA, PHASE I \\
\hline 402925-RI & $\begin{array}{l}\text { DOMESTIC WATER LINES TO SERVE TEMPORARY CONSTRUCTION BUILDINGS, } \\
\text { S-AREA }\end{array}$ \\
\hline 403434 & SEGREGATED DOMESTIC WATER SUPPLY, $300 / 700$ AREA, PHASE ॥ \\
\hline 404608 & DOMESTIC WATER LINE TO SERVE 717-K \\
\hline 404618 & DOMESTIC WATER LINE TO SERVE 705-C \\
\hline
\end{tabular}


Domestic Water Permits, continued

\begin{tabular}{|c|c|}
\hline Permit Number & Permit Title \\
\hline 405184 & DOMESTIC WATER LINE TO SERVE 773-41A AND 773-42A \\
\hline 405556 & DOMESTIC WATER LINES TO SERVE H-AREA \\
\hline 405566 & UPGRADE DOMESTIC WATER SYSTEM, 200-F \\
\hline 406137 & $\begin{array}{l}\text { DOMESTIC WATER LINE TO SERVE INTERIM STORAGE AND REDRUMMING } \\
\text { FACILITY, 645-1N AND 645-2N (FORMERLY 709-1G AND 709-2G) }\end{array}$ \\
\hline 406871E1 & DOMESTIC WATER LINE TO SERVE B-AREA ENGINEERING CENTER, 730-B \\
\hline $407705 \mathrm{M}$ & DOMESTIC WATER LINE TO SERVE C-AREA COMBINED DOMESTIC/FIRE SYSTEM \\
\hline 407830 & $\begin{array}{l}\text { DOMESTIC WATER LINE TO SERVE N-AREA MATERIAL MANAGEMENT } \\
\text { RECEIVING AND STORAGE FACILITIES (MMRSF), 731-N THROUGH 731-4N }\end{array}$ \\
\hline $408035 \mathrm{M}$ & $\begin{array}{l}\text { DOMESTIC WATER LINE TO SERVE B-AREA ENGINEERING AND OPERATIONS } \\
\text { SUPPORT FACILITY }\end{array}$ \\
\hline 408221 & K-AREA DOMESTIC WATER TREATMENT AND DISTRIBUTION SYSTEM UPGRADE \\
\hline 408285 & $\begin{array}{l}\text { DOMESTIC WATER LINE TO SERVE TNX-AREA SANITARY WASTEWATER } \\
\text { TREATMENT PLANT CHEMICAL FEED FACILITY, 607-41T }\end{array}$ \\
\hline $408505 \mathrm{M}$ & DOMESTIC WATER SYSTEM UPGRADE - PHASE 1 (D-AREA) \\
\hline 408552 & K-AREA FILTER BACKWASH SYSTEM \\
\hline 408595 & DOMESTIC WATER LINE TO SERVE CONSTRUCTION OFFICE BUILDING, 305-1M \\
\hline $409115 \mathrm{M}$ & DOMESTIC WATER SYSTEM UPGRADE - PHASE I (B-AREA) \\
\hline $409125 \mathrm{M}$ & DOMESTIC WATER SYSTEM UPGRADE - PHASE I (A-AREA) \\
\hline 409484 & DOMESTIC WATER LINE TO SERVE REACTOR SIMULATOR FACILITY, 707-C \\
\hline 409955 & $\begin{array}{l}\text { DOMESTIC WATER AND FIRE PROTECTION LINES TO SERVE HELICOPTER } \\
\text { FACILITY, 703-5G AND 703-6G }\end{array}$ \\
\hline $410155 \mathrm{M}$ & DOMESTIC WATER SYSTEM UPGRADE - PHASE 1 (N-AREA) \\
\hline 410406 & $\begin{array}{l}\text { DOMESTIC WATER LINE TO SERVE VEHICLE PROTECTION SHELTER SAFETY } \\
\text { SHOWER AND EYE-WASH STATION, 777-A }\end{array}$ \\
\hline 410956 & $\begin{array}{l}\text { DOMESTIC WATER UPGRADE, PHASE II, ZONE } 5 \text { (B-AREA BOOSTER PUMP AND } \\
\text { WATER TREATMENT PLANT MODIFICATIONS) }\end{array}$ \\
\hline 411357 & $\begin{array}{l}\text { DOMESTIC WATER LINE TO SERVE THREE SAFETY SHOWERS AT ETF-H LIFT } \\
\text { STATION }\end{array}$ \\
\hline 411995 & DOMESTIC WATER LINE TO SERVE 340-M AND 341-M \\
\hline 412255 & $\begin{array}{l}\text { DOMESTIC WATER LINE FROM DOMESTIC WATER DEEP WELLS (905-112G AND } \\
\text { 905-113G) TO SERVE A-AREA AND M-AREA }\end{array}$ \\
\hline 412917 & $\begin{array}{l}\text { DOMESTIC WATER LINE TO SERVE F/H ETF CONTROL BUILDING, } 241-84 \mathrm{H} \text { AND } \\
\text { F/H ETF TREATMENT BUILDING, } 241-81 \mathrm{H}\end{array}$ \\
\hline
\end{tabular}


Domestic Water Permits, continued

\begin{tabular}{|c|c|}
\hline Permit Number & Permit Title \\
\hline 510255 & $\begin{array}{l}\text { MODIFICATION TO D-AREA DOMESTIC WATER SYSTEM (SODIUM ALUMINATE } \\
\text { FEED SYSTEM) }\end{array}$ \\
\hline 603505 & $\begin{array}{l}\text { FORESTRY AREA DOMESTIC WATER TREATMENT PLANT MODIFICATIONS } \\
\text { (SODA ASH FEED SYSTEM) }\end{array}$ \\
\hline LS-1-W & $\begin{array}{l}\text { DOMESTIC WATER LINE TO SERVE TRITIUM FACILITIES SUPPORT BUILDING, } \\
235-\mathrm{H}\end{array}$ \\
\hline LS-106-W & $\begin{array}{l}\text { DOMESTIC WATER LINE TO SERVE CONSTRUCTION SUPPORT FACILITIES AT } \\
\text { DWPF AUXILIARY PUMP PIT, S-AREA }\end{array}$ \\
\hline$L S-11-W$ & $\begin{array}{l}\text { DOMESTIC WATER LINE TO SERVE NAVAL FUEL MATERIAL FACILITY (FMF), } \\
247-F\end{array}$ \\
\hline LS-115-W & $\begin{array}{l}\text { DOMESTIC WATER LINE TO SERVE CENTRAL SHOPS ADMINISTRATION } \\
\text { BUILDING (CSAB), 704-3N }\end{array}$ \\
\hline LS-118-W & DOMESTIC WATER LINE TO SERVE $719-4 A$ \\
\hline LS-119-W & DOMESTIC WATER LINE TO SERVE 730-M \\
\hline LS-139-W & $\begin{array}{l}\text { DOMESTIC WATER LINE TO SERVE REPLACEMENT TRITIUM FACILITY (RTF), } \\
\text { 233-H AND 249-H }\end{array}$ \\
\hline LS-168-W & DOMESTIC WATER LINE TO SERVE SUPPORT SERVICES BUILDING, 716-2A \\
\hline LS-178-W & DOMESTIC WATER LINE TO SERVE COMPUTER REPAIR BUILDING, 722-5A \\
\hline LS-185-W & DOMESTIC WATER LINE TO SERVE 703-41A \\
\hline LS-187-W & $\begin{array}{l}\text { DOMESTIC WATER LINE TO SERVE THREE SAFETY SHOWERS AT THE ETF-F } \\
\text { LIFT STATION }\end{array}$ \\
\hline LS-232-W & $\begin{array}{l}\text { TEMPORARY DOMESTIC WATER LINE TO SERVE TOILET TRAILER 704-47S AND } \\
\text { OFFICES 704-44S, 704-45S, AND 704-46S (Formerly FPF Construction Engineers' } \\
\text { Offices } 225-1 \mathrm{H}, 225-2 \mathrm{H} \text {, and } 225-3 \mathrm{H} \text { ) AND TOILET TRAILER } 704-47 \mathrm{H} \text { AND OF- } \\
\text { FICES } 704-27 \mathrm{H}, 704-32 \mathrm{H}, 704-37 \mathrm{H} \text {, AND } 704-42 \mathrm{H}\end{array}$ \\
\hline LS-233-W & $\begin{array}{l}\text { TEMPORARY DOMESTIC WATER LINE TO SERVE F/H ETF TOILET TRAILER, } \\
704-46 \mathrm{H}\end{array}$ \\
\hline LS-238-W & $\begin{array}{l}\text { DOMESTIC WATER LINE TO SERVE SECURITY FACILITIES; ENTRY CONTROL } \\
\text { FACILITY (ECF), 701-3H, AND CENTRAL ALARM STATION (CAS), 720-H }\end{array}$ \\
\hline LS-25-W & $\begin{array}{l}\text { DOMESTIC WATER LINE TO SERVE C-AREA SANITARY WASTEWATER } \\
\text { TREATMENT PLANT CHEMICAL FEED FACILITY, 607-9C }\end{array}$ \\
\hline LS-264-W & $\begin{array}{l}\text { DOMESTIC WATER LINE TO SERVE CONSTRUCTION QUALITY ASSURANCE } \\
\text { OFFICE BUILDING, 704-IN }\end{array}$ \\
\hline LS-265-W & $\begin{array}{l}\text { DOMESTIC WATER LINE TO SERVE EQUIPMENT STORAGE AND HEALTH } \\
\text { PROTECTION (HP) FACILITY, 221-25F }\end{array}$ \\
\hline LS-4-W & DOMESTIC WATER LINE TO SERVE OFFICE BUILDING, 703-41A \\
\hline LS-43-W & “AS BUILT” DOMESTIC WATER LINE TO SERVE 773-A, 773-41A, AND 773-42A \\
\hline
\end{tabular}


Domestic Water Permits, continued

\begin{tabular}{ll}
\hline Permit Number & Permit TitIe \\
\hline LS-55-W & DOMESTIC WATER LINE TO SERVE N-AREA SANITARY WASTEWATER \\
TREATMENT PLANT CHEMICAL FEED FACILITY, 607-38N \\
LS-56-W & DOMESTIC WATER LINE TO SERVE H-AREA SANITARY WASTEWATER \\
TREATMENT PLANT CHEMICAL FEED FACILITY, 607-20H \\
LS-57-W & DOMESTIC WATER LINE TO SERVE RADIOLOGICAL AND ENVIRONMENTAL \\
SUPPORT FACILITY, 735-11A & DOMESTIC WATER LINE TO SERVE ADMINISTRATION BUILDING, 704-S \\
LS-60-W & DOMESTIC WATER LINE TO SERVE S-AREA SANITARY WASTEWATER \\
LS-61-W & TREATMENT PLANT CHEMICAL FEED FACILITY, 980-S \\
LS-7-W & DOMESTIC WATER LINE TO SERVE NAVAL FUEL MATERIAL FACILITY (FMF), \\
221-17F, AND 221-18F & DOMESTIC WATER LINE TO SERVE 703-4A, 703-6A, AND 703-34A \\
LS-8-W & DOMESTIC WATER LINE TO SERVE CONSTRUCTION ADMINISTRATION OFFICE \\
LS-81-W & BUILDING, 704-6C \\
LS-82-W & DOMESTIC WATER LINE TO SERVE B-AREA SANITARY WASTEWATER \\
TREATMENT PLANT CHEMICAL FEED FACILITY, 607-2B \\
LS-91009
\end{tabular}

LS89017

DOMESTIC WATER LINE TO SERVE TEMPORARY MODULAR OFFICE TRAILERS 707-7K THROUGH 707-19K

LS89020

INSTALL BLOCK VALVE ON 200-F AREA DOMESTIC WATER WELL HEADER

LS89028

DOMESTIC WATER LINE TO SERVE GENERAL PHYSICS OFFICE, 777-18A

LS89029

DOMESTIC WATER LINE TO SERVE MATERIAL MANAGEMENT, RECEIVING, AND STORAGE FACILITIES (MMRSF) FIRE WATER STORAGE TANK MAKEUP WATER SYSTEM, 681-17N, AND $681-18 \mathrm{~N}$

LS91001

DOMESTIC WATER LINE TO SERVE TEMPORARY MODULAR OFFICE TRAILERS 773-62A THROUGH 773-70A

LS91005

DOMESTIC WATER LINE TO FILL IN-TANK PRECIPITATION (ITP) FIRE TANK, $241-20 \mathrm{H}$

LS91006

DOMESTIC WATER LINE TO FILL IN-TANK PRECIPITATION (ITP) FIRE TANK, 241-21H 
Domestic Water Permits, continued

\begin{tabular}{|c|c|}
\hline Permit Number & Permit Title \\
\hline LS91007 & $\begin{array}{l}\text { DOMESTIC WATER LINE REROUTE TO SERVE SAFETY SHOWER/EYE-WASH } \\
\text { STATIONS AT THE REPLACEMENT HIGH-LEVEL EVAPORATOR, H-AREA }\end{array}$ \\
\hline LS91010 & UPGRADE DOMESTIC WATER SYSTEMS INSTRUMENTS, B-AREA \\
\hline LS91011 & UPGRADE DOMESTIC WATER SYSTEMS INSTRUMENTS, 3/700 AREA \\
\hline LS91012 & UPGRADE DOMESTIC WATER SYSTEMS INSTRUMENTS, C-AREA \\
\hline LS91013 & UPGRADE DOMESTIC WATER SYSTEMS INSTRUMENTS, N-AREA \\
\hline LS91014 & UPGRADE DOMESTIC WATER SYSTEMS INSTRUMENTS, D-AREA \\
\hline LS91015 & UPGRADE DOMESTIC WATER SYSTEMS INSTRUMENTS, FORESTRY AREA \\
\hline LS91016 & UPGRADE DOMESTIC WATER SYSTEMS INSTRUMENTS, L-AREA \\
\hline LS91017 & UPGRADE DOMESTIC WATER SYSTEMS INSTRUMENTS, P-AREA \\
\hline LS91018 & UPGRADE DOMESTIC WATER SYSTEMS INSTRUMENTS, RAILROAD YARD \\
\hline G0017 & DOMESTIC WATER LINE TO SERVE SREL DISTANT LEARNING CENTER, 737-27A \\
\hline G0027 & DOMESTIC WATER UPGRADE, PHASE III (K-AREA TO L-AREA CONNECTOR) \\
\hline G0076 & $\begin{array}{l}\text { DOMESTIC WATER LINE TO SERVE SOLID WASTE MANAGEMENT FACILITIES } \\
\text { ACCESS }\end{array}$ \\
\hline G0016 & $\begin{array}{l}\text { DOMESTIC WATER UPGRADE, PHASE II, ZONE } 1 \text { (B-AREA, A-AREA, AND } \\
\text { FORESTRY AREA CONNECTOR) }\end{array}$ \\
\hline G0026 & $\begin{array}{l}\text { DOMESTIC WATER UPGRADE, PHASE II, ZONE } 2 \text { (B-AREA, F-AREA, C-AREA, } \\
\text { N-AREA, H-AREA, S-AREA, Z-AREA, AND FORESTRY AREA CONNECTOR) }\end{array}$ \\
\hline G0036 & $\begin{array}{l}\text { DOMESTIC WATER UPGRADE, PHASE II, ZONE } 3 \text { (D-AREA AND TNX-AREA } \\
\text { CONNECTOR) }\end{array}$ \\
\hline G0046 & $\begin{array}{l}\text { DOMESTIC WATER LINE TO SERVE DWPF LATE-WASH FACILITY RESTROOM } \\
\text { UNIT, } 512-8 S\end{array}$ \\
\hline G0056 & DOMESTIC WATER LINE TO SERVE H-AREA MEDICAL FACILITY, 719-H \\
\hline G0066 & DOMESTIC WATER LINE TO SERVE SMALL-ANIMAL CARE FACILITY, 737-24A \\
\hline M0075 & $\begin{array}{l}\text { DOMESTIC WATER LINE TO SERVE WASTE MANAGEMENT OFFICE AND } \\
\text { STORAGE BUILDING, } 241-102 \mathrm{H}\end{array}$ \\
\hline G0086 & T \& T RESTROOM TRAILER, 704-46H \\
\hline M0012E2 & DOMESTIC WATER LINE TO SERVE B-AREA FIRE PROTECTION SUPPLY SYSTEM \\
\hline M0013 & $\begin{array}{l}\text { DOMESTIC WATER LINE TO SERVE NITRIC TANK SAFETY SHOWER/EYE-WASH } \\
\text { STATION, 221-S }\end{array}$ \\
\hline M0014E1 & $\begin{array}{l}\text { DOMESTIC WATER LINE TO SERVE TRAINING CENTER, 766-H (FORMERLY } \\
225-\mathrm{H} \text { ) }\end{array}$ \\
\hline M0016 & DOMESTIC WATER UPGRADE - PHASE I (TNX-AREA) \\
\hline
\end{tabular}


Domestic Water Permits, continued

\begin{tabular}{|c|c|}
\hline Permit Number & Permit Title \\
\hline M0022 & DOMESTIC WATER LINE TO SERVE PORTABLE BOILER INSTALLATION, 183-2P, \\
\hline M0023E1 & $\begin{array}{l}\text { DOMESTIC WATER LINE TO SERVE CONSOLIDATED INCINERATION FACILITY } \\
\text { (CIF), } 261-\mathrm{H}\end{array}$ \\
\hline M0024 & $\begin{array}{l}\text { DOMESTIC WATER LINE REROUTE TO SERVE ESSENTIAL-MATERIALS } \\
\text { WAREHOUSE, 315-M }\end{array}$ \\
\hline M0025R2 & DOMESTIC WATER LINE TO SERVE DWPF LATE-WASH FACILITY \\
\hline M0032 & DOMESTIC WATER LINE TO SERVE PORTABLE BOILER INSTALLATION, 183-2K \\
\hline M0033E1 & $\begin{array}{l}\text { DOMESTIC WATER LINE TO SERVE F-AREA AND E ROAD FIRE PROTECTION } \\
\text { SUPPLY }\end{array}$ \\
\hline M0034 & $\begin{array}{l}\text { DOMESTIC WATER LINE TO SERVE FORESTRY AREA RESTROOM TRAILER, } \\
760-21 \mathrm{G}\end{array}$ \\
\hline M0035 & DOMESTIC WATER SYSTEM UPGRADE - PHASE I (FORESTRY AREA) \\
\hline M0042E1 & DOMESTIC WATER LINE TO SERVE LUNCHROOM TRAILER, 773-72A \\
\hline M0043 & DOMESTIC WATER LINE TO SERVE OPERATION SUPPORT BUILDING, 704-2H \\
\hline M0044 & $\begin{array}{l}\text { DOMESTIC WATER LINE TO SERVE ASBESTOS ABATEMENT SHOWERS, } 412-D \\
\text { AND 413-D }\end{array}$ \\
\hline M0045 & DOMESTIC WATER LINE TO SERVE 704-8T \\
\hline M0052 & DOMESTIC WATER LINE TO SERVE LUNCHROOM TRAILER, 740-16A \\
\hline M0053 & $\begin{array}{l}\text { DOMESTIC WATER LINE TO SERVE 221-S LAB TRAILERS SAFETY SHOWER/EYE- } \\
\text { WASH STATION }\end{array}$ \\
\hline M0054E1 & $\begin{array}{l}\text { DOMESTIC WATER LINE TO SERVE B-AREA UTILITIES UPGRADE; 735-4B AND } \\
735-2 B\end{array}$ \\
\hline M0055 & $\begin{array}{l}\text { DOMESTIC WATER LINE TO SERVE SRFS EDUCATION TRAILER RESTROOMS, } \\
760-22 \mathrm{G}\end{array}$ \\
\hline M0063R1 & $\begin{array}{l}\text { DOMESTIC WATER LINE TO SERVE ADMINISTRATIVE SUPPORT BUILDING, } \\
708-1 \mathrm{~B}\end{array}$ \\
\hline M0064E1 & $\begin{array}{l}\text { DOMESTIC WATER LINE TO SERVE COMPRESSED-GAS STORAGE FACILITY, } \\
731-6 N\end{array}$ \\
\hline M0065 & K-AREA DOMESTIC WATER LOOP COMPLETION \\
\hline M0072E2 & DOMESTIC WATER LINE TO SERVE FLAMMABLE-STORAGE FACILITY, 731-5N \\
\hline M0073E1 & $\begin{array}{l}\text { DOMESTIC WATER LINE TO SERVE SAFEGUARDS AND HEALTH PROTECTION } \\
\text { SHOP, 228-H }\end{array}$ \\
\hline M0074R1 & $\begin{array}{l}\text { DOMESTIC WATER LINE TO SERVE SAFETY SHOWER/EYE-WASH STATION, } \\
421-6 D\end{array}$ \\
\hline M0082 & $\begin{array}{l}\text { DOMESTIC WATER LINE TO SERVE CENTRAL SERVICES WORKS ENGINEERING } \\
\text { (CSWE) FACILITY, 717-11A }\end{array}$ \\
\hline
\end{tabular}


Domestic Water Permits, continued

\begin{tabular}{|c|c|}
\hline Permit Number & Permit Title \\
\hline M0083 & DOMESTIC WATER LINE TO SERVE RESTROOM TRAILER, 704-11K \\
\hline M0084E1 & $\begin{array}{l}\text { DOMESTIC WATER LINE TO SERVE TYPE III TANK SALT REMOVAL CONTROL' } \\
\text { BUILDING, } 241-2 \mathrm{H}\end{array}$ \\
\hline M0085 & DOMESTIC WATER LINE TO SERVE FORESTRY SERVICE BUILDING, 760-15G \\
\hline M0092 & DOMESTIC WATER LINE TO SERVE ENGINEERING SUPPORT BUILDING, 707-7F \\
\hline M0093 & D-AREA BACKUP WELL CONNECTOR \\
\hline M0102 & $\begin{array}{l}\text { DOMESTIC WATER LINE TO SERVE TEMPORARY MODULAR OFFICES, 233-20H } \\
\text { AND } 233-21 \mathrm{H}\end{array}$ \\
\hline M0103E1 & DOMESTIC WATER LINE TO SERVE DRINKING WATER FOUNTAIN, 740-4A \\
\hline M0112 & $\begin{array}{l}\text { DOMESTIC WATER LINE TO SERVE TEMPORARY MODULAR OFFICES, } 742-\mathrm{G} \\
\text { AND } 742-1 \mathrm{G} \text { THROUGH } 742-14 \mathrm{G}\end{array}$ \\
\hline M0113 & DOMESTIC WATER LINE TO SERVE 704-11K, 704-12K, AND 705-K \\
\hline M0122 & DOMESTIC WATER LINE TO SERVE SRTC MODULAR RESTROOM UNIT, 773-71A \\
\hline M0123E1. & $\begin{array}{l}\text { DOMESTIC WATER LINE TO SERVE SAFETY SHOWER/EYE-WASH STATIONS, } \\
\text { 673-T, 678-T, AND 679-8T }\end{array}$ \\
\hline \multicolumn{2}{|c|}{ Industrial Wastewater Permits } \\
\hline Permit Number & Permit Title \\
\hline 12888 & METALLURGICAL LABORATORY NEUTRALIZATION FACILITY, 723-A \\
\hline 16119 & F/H ETF PERMANENT pH ADJUSTMENT SYSTEM \\
\hline $17911-I W$ & $\begin{array}{l}\text { F-AREA SEEPAGE BASINS GROUNDWATER REMEDIATION (EXTRACTION/ } \\
\text { INJECTION PIPING NETWORK) }\end{array}$ \\
\hline 17912-IW & $\begin{array}{l}\text { H-AREA SEEPAGE BASINS GROUNDWATER REMEDIATION (EXTRACTION/ } \\
\text { INJECTION PIPING NETWORK) }\end{array}$ \\
\hline $17998-1 W$ & A-AREA POWERHOUSE EFFLUENT REROUTE SYSTEM, 784-A \\
\hline 18052-IW & $\begin{array}{l}\text { F-AREA SEEPAGE BASINS GROUNDWATER REMEDIATION (WASTEWATER } \\
\text { TREATMENT UNIT) }\end{array}$ \\
\hline 18053 & $\begin{array}{l}\text { H-AREA SEEPAGE BASINS GROUNDWATER REMEDIATION (WASTEWATER } \\
\text { TREATMENT UNIT) }\end{array}$ \\
\hline 18078-IW & 483-6D SURGE BASIN LINER REPLACEMENT \\
\hline 10253 & M-AREA 610-GPM AIR STRIPPER \\
\hline 10287 & LIQUID EFFLUENT TREATMENT FACILITIES (LETF), 300-M \\
\hline 10349 & 672-T TNX-AREA PROCESS SEWER TO OUTFALL X-008 \\
\hline 10358 & S-AREA OILWATER SEPARATOR \\
\hline
\end{tabular}


Industrial Wastewater Permits, continued

\begin{tabular}{|c|c|}
\hline Permit Number & Permit Title \\
\hline 10389 & M-AREA DRAIN LINE \\
\hline 10475 & NONCONTACT COOLING WATER DIVERSION, 300-M AREA \\
\hline 10696 & INTERIM SLUDGE STORAGE TANK, M-AREA \\
\hline 10765 & WASTEWATER NEUTRALIZATION FACILITY, 704-B \\
\hline 10949 & $\begin{array}{l}\text { TRADE WASTE-FLOW EQUALIZATION TANK, 607-18A, FOR SILVER } \\
\text { RECOVERY, 703-43A }\end{array}$ \\
\hline 11406 & FIRE BRIGADE TRAINING FACILITIES OILWATER SEPARATOR, 411-D \\
\hline 11411 & DWPF TREATED EFFLUENT LINE, S-AREA \\
\hline 11413 & DWPF CHEMICAL TREATMENT FACILITY, S-AREA \\
\hline 11497 & PRODUCTION CONTROL FACILITY SANITARY/PROCESS SEWER, 772-1F \\
\hline 11498 & FLOW-MONITORING STATION FOR NPDES OUTFALL L-007 \\
\hline 11588 & $\begin{array}{l}\text { POWERHOUSE EFFLUENT DIVERSION TO ASH BASIN; 400-D (H-Area also } \\
\text { covered under this permit) }\end{array}$ \\
\hline 11588 & $\begin{array}{l}\text { POWERHOUSE EFFLUENT DIVERSION TO ASH BASIN; 200-H (D-Area also } \\
\text { covered under this permit) }\end{array}$ \\
\hline 11589 & POWERHOUSE EFFLUENT DIVERSION TO ASH BASIN, 184-P \\
\hline 12622 & ORGANICS REMOVAL FACILITY (ORF), TNX-AREA \\
\hline 12633 & TNX-AREA EFFLUENT TREATMENT PLANT (ETP) \\
\hline 12683 & $\begin{array}{l}\text { INDUSTRIAL WASTEWATER TREATMENT FACILITY TO SERVE Z-AREA } \\
\text { SALTSTONE MANUFACTURING FACILITY }\end{array}$ \\
\hline 12782 & REPLACEMENT TRITIUM FACILITY (RTF) PROCESS SEWER \\
\hline 12870 & F/H EFFLUENT TREATMENT FACILITY (ETF), 241-81H \\
\hline 12894 & FILTRATE HOLD-TANK COVERS, M-AREA \\
\hline 12973 & P-AREA NEUTRALIZATION FACILITY, 183-2P \\
\hline 13105 & F/H ETF PROCESS SEWER LINES, F-AREA (H-Area also included under this permit) \\
\hline 13105 & F/H ETF PROCESS SEWER LINES, H-AREA (F-Area also included under this permit) \\
\hline 13154 & FLOW MEASUREMENT DEVICE, L-AREA \\
\hline 13354 & D-AREA NEUTRALIZATION FACILITY, 483-1D \\
\hline 13355 & F-AREA NEUTRALIZATION FACILITY, 280-1F \\
\hline 13356 & H-AREA NEUTRALIZATION FACILITY, 280-H \\
\hline 13357 & K-AREA NEUTRALIZATION FACILITY, 183-2K \\
\hline
\end{tabular}


Industrial Wastewater Permits, continued

\begin{tabular}{|c|c|}
\hline Permit Number & Permit Title \\
\hline 13431 & FLUME AT M-004 OUTFALL \\
\hline 13735 & INDUSTRIAL WASTEWATER pH CONTROL SYSTEM, 211-F \\
\hline 13978 & TNX-AREA ION-EXCHANGE FACILITY \\
\hline 14020 & MERCURY AND ORGANIC REMOVAL FACILITY FOR F/H ETF \\
\hline 14100 & REPAIR ASH BASIN DIKE 488-1D \\
\hline 14218 & $\begin{array}{l}\text { NPDES OUTFALL STRUCTURES F-012 AND F-013 (FLOW-MONITORING WEIR } \\
\text { BOX STRUCTURES) }\end{array}$ \\
\hline 14219 & $\begin{array}{l}\text { NPDES OUTFALL STRUCTURES H-017 AND H-018 (MONITORING WEIR BOX } \\
\text { STRUCTURES) }\end{array}$ \\
\hline 14338 & "AS BUILT" H-Z INTERAREA SALT SOLUTION TRANSFER LINE \\
\hline 14379 & UPPER THREE RUNS CREEK DIFFUSER FOR F/H ETF OUTFALL, H-016 \\
\hline 14520 & "AS BUILT" F/H ETF TANK 50 \\
\hline 14624 & $\begin{array}{l}\text { EXISTING F/H ETF AREA PROCESS SEWER LINES, F-AREA (H-Area also included } \\
\text { under this permit) }\end{array}$ \\
\hline 14624 & $\begin{array}{l}\text { EXISTING F/H ETF AREA PROCESS SEWER LINES, H-AREA (F-Area also included } \\
\text { under this permit) }\end{array}$ \\
\hline 14832 & $\begin{array}{l}\text { MODIFICATION TO M-AREA LIQUID EFFLUENT TREATMENT FACILITIES (LETF); } \\
\text { SUPERNATANT TRANSFER AND POLYMER ADDITION SYSTEMS }\end{array}$ \\
\hline 15256 & EVAPORATOR RECYCLE LINE FOR F/H ETF \\
\hline 15467 & $\begin{array}{l}\text { UPGRADE PROCESS SEWERS, 211-F/H ETF, F-AREA (H-Area also included under } \\
\text { this permit) }\end{array}$ \\
\hline 15467 & $\begin{array}{l}\text { UPGRADE PROCESS SEWERS, 211-F/H ETF, H-AREA (F-Area also included under } \\
\text { this permit) }\end{array}$ \\
\hline 15892 & F/H ETF INTERIM pH ADJUSTMENT SYSTEM (CAUSTIC AND ACID SUPPLY) \\
\hline 16449 & K-REACTOR EMERGENCY RETENTION BASIN PERCOLATION DRAIN FIELD \\
\hline 16478 & $\begin{array}{l}\text { FOUNDATIONS AND SUPPORTING STRUCTURE SURROUNDING CWST; K-AREA } \\
\text { RETENTION BASIN }\end{array}$ \\
\hline 16614 & K-REACTOR EMERGENCY RETENTION BASIN LINER AND COVER \\
\hline 16783 & "AS BUILT" DWPF INDUSTRIAL WASTEWATER TREATMENT FACILITY, S-AREA \\
\hline 16785 & K-AREA NATURAL-DRAFT COOLING TOWER THERMAL MITIGATION \\
\hline 16797 & $\begin{array}{l}\text { (70-GPM AIR STRIPPER) PROTOTYPE AIR STRIPPER COLUMN RELOCATION AND } \\
\text { RECOVERY WELL INSTALLATION }\end{array}$ \\
\hline 16938 & K-REACTOR RETENTION BASIN UMBRELLA TOP STRUCTURE \\
\hline 17022 & UPGRADE D-AREA NEUTRALIZATION FACILITY, 483-1D \\
\hline
\end{tabular}


Industrial Wastewater Permits, continued

\begin{tabular}{|c|c|}
\hline Permit Number & Permit Title \\
\hline $17424-1 W$ & $\begin{array}{l}\text { "AS BUILT" F-AREA HIGH-LEVEL RADIOACTIVE WASTE TANK FARM (H-Area also } \\
\text { covered under this permit) }\end{array}$ \\
\hline 17424-IW & $\begin{array}{l}\text { "AS BUILT" H-AREA HIGH-LEVEL RADIOACTIVE WASTE TANK FARM (F-Area also } \\
\text { covered under this permit) }\end{array}$ \\
\hline 17434-IW & TNX-AREA TRICKLE-FLOW BIOREACTOR UNIT \\
\hline $17588-I W$ & MOBILE TRICKLE-FLOW BIOREACTOR SYSTEM \\
\hline 17596-IW & DWPF PRECIPITATE-FEED LATE-WASH FACILITY \\
\hline 17614-IW & 250-GPM AIR STRIPPER (A-002), SRTC \\
\hline 17765-IW & $\begin{array}{l}\text { INVESTIGATION-DERIVED WASTE (IDW) TRANSFER STATION AT F/H EFFLUENT } \\
\text { TREATMENT FACILITY (ETF) }\end{array}$ \\
\hline 17816-IW & $\begin{array}{l}\text { MODIFICATION TO 735-11A LAB BUILDING PROCESS SEWER SYSTEM } \\
\text { NEUTRALIZATION FACILITY, 607-17A }\end{array}$ \\
\hline 17903-IW & TEMPORARY BOILER BLOWDOWN TRANSFER SYSTEM, 784-A \\
\hline 17938-IW & GROUNDWATER OPERABLE UNIT (GWOU) AIR STRIPPER, TNX-AREA \\
\hline 17980-IW & $\begin{array}{l}\text { "AS BUILT" 299-H MAINTENANCE AND DECONTAMINATION FACILITY WASTE } \\
\text { COLLECTION TANK AND CONVEYANCE SYSTEM }\end{array}$ \\
\hline 7289 & $\begin{array}{l}\text { "AS BUILT" WASTEWATER TREATMENT FACILITIES, A-AREA (M-Area also covered } \\
\text { under this permit) }\end{array}$ \\
\hline 7289 & $\begin{array}{l}\text { "AS BUILT" WASTEWATER TREATMENT FACILITIES, M-AREA (A-Area also covered } \\
\text { under this permit) }\end{array}$ \\
\hline 7290 & "AS BUILT" WASTEWATER TREATMENT FACILITIES, F-AREA \\
\hline 7291 & “AS BUILT" WASTEWATER TREATMENT FACILITIES, H-AREA \\
\hline 7292 & "AS BUILT" WASTEWATER TREATMENT FACILITIES, P-AREA \\
\hline 7293 & "AS BUILT" WASTEWATER TREATMENT FACILITIES, K-AREA \\
\hline 7294 & "AS BUILT" WASTEWATER TREATMENT FACILITIES, C-AREA \\
\hline 7295 & "AS BUILT" WASTEWATER TREATMENT FACILITIES, D-AREA \\
\hline 7296 & "AS BUILT" WASTEWATER TREATMENT FACILITIES, N-AREA \\
\hline LS-112-S & FIRE-TRAINING FACILITY PROCESS SEWER, 904-D \\
\hline LS-42-S & INERT L-FACILITY LOADING DOCK SEWER RELOCATION, 234-H \\
\hline LOA-7/10/95 & $\begin{array}{l}\text { M-AREA PROCESS WASTE INTERIM TREATMENT/STORAGE FACILITY (PWIT/SF) } \\
\text { SLUDGE VENDOR TREATMENT PROCESS; MODIFICATION TO M-AREA LIQUID } \\
\text { EFFLUENT TREATMENT FACILITY (LETF) }\end{array}$ \\
\hline
\end{tabular}


NPDES - Discharge Permits

\begin{tabular}{ll}
\hline Permit Number & Permit Title \\
\hline SC0000175 & 76 OUTFALLS AT SAVANNAH RIVER SITE \\
SC0044903 & SEVEN OUTFALLS AT SAVANNAH RIVER SITE
\end{tabular}

These permits were in effect until October 1, 1996, when a new NPDES permit (also numbered SC0000175) was issued. The new permit combined the previous permits into one and decreased the number of outfalls to 37 .

NPDES - No-Discharge Permit

\begin{tabular}{ll}
\hline Permit Number & Permit Title \\
\hline ND0072125 & $\begin{array}{l}\text { SRS SANITARY SLUDGE LAND APPLICATION SITE, FORESTS (SLUDGE FROM } \\
\text { ALL SWTPS) }\end{array}$ \\
NPDES - Stormwater Permits
\end{tabular}

\begin{tabular}{ll}
\hline Permit Number & Permit Title \\
\hline SCR000000 & 50 INDUSTRIAL STORMWATER OUTFALLS AT SAVANNAH RIVER SITE \\
SCR100000 & 15 NPDES-PERMITTED CONSTRUCTION STORMWATER SITES AT SAVANNAH \\
& RIVER SITE
\end{tabular}

RCRA Permit

\begin{tabular}{ll}
\hline Permit Number & Permit Title \\
\hline SCI80008989 & SEVEN PERMITTED RCRA FACILITIES AT SAVANNAH RIVER SITE \\
Sanitary Wastewater Permits
\end{tabular}

\begin{tabular}{ll}
\hline Permit Number & Permit Title \\
\hline $17,955-I W$ & SANITARY SEWER TO SERVE 241-102H \\
$17,956-I W$ & SANITARY SEWER TO SERVE 703-5B \\
$02-91040041$ & SEPTIC TANK AND TILE FIELD TO SERVE OFFICE BUILDING, 704-56H (A.K.A. \\
& 5002-H) \\
$02-92080098$ & SEPTIC TANK AND TILE FIELD TO SERVE SREL PAR POND LABORATORY, 737-G \\
$10132-P$ & SEPTIC TANK AND TILE FIELD TO SERVE TOILET TRAILER 704-47S AND OF- \\
& FICES 704-44S, 704-45S, AND 704-46S (FORMERLY FPF CONSTRUCTION ENGI- \\
& NEERS' OFFICES 225-1H, 225-2H, AND 225-3H) \\
10236 & SANITARY SEWER SYSTEM (LIFT STATION AND SEWER LINE) TO SERVE \\
& CHANGE STATION FACILITY, 241-58H \\
10314 & DWPF CONSTRUCTION SITE SANITARY SEWER SYSTEM, S-AREA \\
10499 & SANITARY SEWER TO SERVE DWPF, 200-S \\
10521 & CHEMICAL FEED FACILITY (607-16A) FOR A-AREA SANITARY WASTEWATER \\
& TREATMENT PLANTS, 607-7-1A, 607-7-2A, AND 607-23A
\end{tabular}


Sanitary Wastewater Permits, continued

\begin{tabular}{|c|c|}
\hline Permit Number & Permit Title \\
\hline 10522 & $\begin{array}{l}\text { CHEMICAL FEED FACILITY (607-19F) FOR F-AREA SANITARY WASTEWATER } \\
\text { TREATMENT PLANTS, } 607-7 F \text { AND } 607-21 \text { F }\end{array}$ \\
\hline 10523 & $\begin{array}{l}\text { CHEMICAL FEED FACILITY }(607-20 \mathrm{H}) \text { FOR H-AREA SANITARY WASTEWATER } \\
\text { TREATMENT PLANTS, } 607-7 \mathrm{H} \text { AND } 607-21 \mathrm{H}\end{array}$ \\
\hline 10524 & $\begin{array}{l}\text { CHEMICAL FEED FACILITY (607-22P) FOR P-AREA SANITARY WASTEWATER } \\
\text { TREATMENT PLANTS, } 607-7 P \text { AND 607-23P }\end{array}$ \\
\hline 10525 & $\begin{array}{l}\text { CHEMICAL FEED FACILITY (607-38N) FOR N-AREA SANITARY WASTEWATER } \\
\text { TREATMENT PLANTS, } 607-18 \mathrm{~N} \text { AND } 607-42 \mathrm{~N}\end{array}$ \\
\hline 10526 & $\begin{array}{l}\text { CHEMICAL FEED FACILITY (607-14D) FOR D-AREA SANITARY WASTEWATER } \\
\text { TREATMENT PLANT, 607-15D }\end{array}$ \\
\hline 10530 & $\begin{array}{l}\text { TNX-AREA 20,000-GALLON SANITARY WASTEWATER TREATMENT PLANT, } \\
607-40 T\end{array}$ \\
\hline 10533 & $\begin{array}{l}\text { SEPTIC TANK AND TILE FIELD (607-54G) TO SERVE DEER HUNT BUILDING, } \\
760-12 G\end{array}$ \\
\hline 10825 & SANITARY SEWER LIFT STATION (607-19A) TO SERVE 730-A \\
\hline 11407 & SANITARY SEWER LIFT STATION TO SERVE 321-M CHANGE ROOM \\
\hline 11442 & $\begin{array}{l}\text { SANITARY SEWER SYSTEM (LIFT STATION AND SEWER LINE) TO SERVE ECR/ } \\
\text { ICR CONTROL HOUSE, } 241-82 \mathrm{H}\end{array}$ \\
\hline 11687 & $\begin{array}{l}\text { SEPTIC TANK AND TILE FIELD TO SERVE WACKENHUT HELICOPTER FACILITY, } \\
703-5 B\end{array}$ \\
\hline 11755 & $\begin{array}{l}\text { SEPTIC TANK AND TILE FIELD TO SERVE 100-AREA FIRE STATION, 709-1G } \\
\text { (INTERSECTION OF ROAD C AND ROAD 7) }\end{array}$ \\
\hline 11847 & $\begin{array}{l}\text { EFFLUENT WEIR FOR TNX-AREA SANITARY WASTEWATER TREATMENT PLANT, } \\
607-40 T\end{array}$ \\
\hline 12386 & SANITARY SEWER TO SERVE 730-M \\
\hline 12695 & SANITARY SEWER TO SERVE REPLACEMENT TRITIUM FACILITY (RTF), 233-H \\
\hline 12725 & $\begin{array}{l}\text { 45,000-GALLON SANITARY FLOW EQUALIZATION BASIN (607-18F) FOR SANITARY } \\
\text { WASTEWATER TREATMENT PLANTS, 607-7F AND 607-21F (PHASE III) }\end{array}$ \\
\hline 12910 & H-AREA 30,000-GPD SANITARY WASTEWATER TREATMENT PLANT, 607-21H \\
\hline 13155 & NAVAL FUEL (FMF) FLOW MEASUREMENT DEVICE; OUTFALL F-003(A) \\
\hline 13156 & SANITARY SEWER TO SERVE 716-2A \\
\hline 13157 & SANITARY SEWER TO SERVE COMPUTER REPAIR BUILDING, 722-5A \\
\hline 13175 & $\begin{array}{l}\text { 97,500-GALLON SANITARY FLOW EQUALIZATION BASIN }(607-22 A) \text { FOR SAN- } \\
\text { ITARY WASTEWATER TREATMENT PLANTS, 607-7-1A, 607-7-2A, AND 607-23A }\end{array}$ \\
\hline 13291 & SEPTIC TANK AND TILE FIELD TO SERVE AUXILIARY PUMP PIT \\
\hline 13430 & F-AREA 30,000-GPD SANITARY WASTEWATER TREATMENT PLANT, 607-21F \\
\hline
\end{tabular}


Sanitary Wastewater Permits, continued

\begin{tabular}{|c|c|}
\hline Permit Number & Permit Title \\
\hline 13538 & $\begin{array}{l}\text { SEPTIC TANK AND TILE FIELD TO SERVE K-AREA COOLING TOWER } \\
\text { CONSTRUCTION TRAILER }\end{array}$ \\
\hline 13539 & $\begin{array}{l}\text { SEPTIC TANK AND TILE FIELD TO SERVE K-AREA COOLING TOWER ECR/ICR } \\
\text { BUILDING, 153-1K }\end{array}$ \\
\hline 13717 & SEPTIC TANK (831-1Z) AND TILE FIELD (831-2Z) TO SERVE Z-AREA \\
\hline 14311 & $\begin{array}{l}\text { INTERIM SODIUM HYPOCHLORITE DISINFECTION FOR C-AREA SANITARY } \\
\text { WASTEWATER TREATMENT PLANT, 607-7C }\end{array}$ \\
\hline 14312 & $\begin{array}{l}\text { INTERIM SODIUM HYPOCHLORITE DISINFECTION FOR K-AREA SANITARY } \\
\text { WASTEWATER TREATMENT PLANT, } 607-17 \mathrm{~K}\end{array}$ \\
\hline 14313 & $\begin{array}{l}\text { INTERIM SODIUM HYPOCHLORITE DISINFECTION FOR L-AREA SANITARY } \\
\text { WASTEWATER TREATMENT PLANT, } 607-16 \mathrm{~L}\end{array}$ \\
\hline 14314 & $\begin{array}{l}\text { INTERIM SODIUM HYPOCHLORITE DISINFECTION FOR P-AREA SANITARY } \\
\text { WASTEWATER TREATMENT PLANTS, } 607-7 P \text { AND } 607-23 P\end{array}$ \\
\hline 14315 & $\begin{array}{l}\text { INTERIM SODIUM HYPOCHLORITE DISINFECTION FOR F-AREA SANITARY } \\
\text { WASTEWATER TREATMENT PLANTS, } 607-7 F \text { AND 607-21F }\end{array}$ \\
\hline 14316 & $\begin{array}{l}\text { INTERIM SODIUM HYPOCHLORITE DISINFECTION FOR H-AREA SANITARY } \\
\text { WASTEWATER TREATMENT PLANTS, } 607-7 \mathrm{H} \text { AND } 607-21 \mathrm{H}\end{array}$ \\
\hline 14317 & $\begin{array}{l}\text { INTERIM SODIUM HYPOCHLORITE DISINFECTION FOR S-AREA SANITARY } \\
\text { WASTEWATER TREATMENT PLANTS, } 831-1 S \text { AND } 831-2 S\end{array}$ \\
\hline 14318 & $\begin{array}{l}\text { INTERIM SODIUM HYPOCHLORITE DISINFECTION FOR D-AREA SANITARY } \\
\text { WASTEWATER TREATMENT PLANT, } 607-15 D\end{array}$ \\
\hline 14320 & $\begin{array}{l}\text { INTERIM SODIUM HYPOCHLORITE DISINFECTION SYSTEM }(607-8 A) \text { FOR A-AREA } \\
\text { SANITARY WASTEWATER TREATMENT PLANTS, 607-7-1A, 607-7-2A, AND } \\
607-23 A\end{array}$ \\
\hline 14322 & $\begin{array}{l}\text { INTERIM SODIUM HYPOCHLORITE DISINFECTION FOR N-AREA SANITARY } \\
\text { WASTEWATER TREATMENT PLANTS, } 607-18 N \text { AND } 607-42 N\end{array}$ \\
\hline 14323 & $\begin{array}{l}\text { INTERIM SODIUM HYPOCHLORITE DISINFECTION FOR NAVAL FUEL (FMF) } \\
\text { SANITARY WASTEWATER TREATMENT PLANT, 607-17F }\end{array}$ \\
\hline 14324 & $\begin{array}{l}\text { INTERIM SODIUM HYPOCHLORITE DISINFECTION FOR TNX-AREA SANITARY } \\
\text { WASTEWATER TREATMENT PLANT, } 607-40 T\end{array}$ \\
\hline 14407 & $\begin{array}{l}\text { D-AREA } 20,000-G P D \text { SANITARY WASTEWATER TREATMENT PLANT EXPANSION, } \\
607-15 D\end{array}$ \\
\hline 14443 & SEPTIC TANK AND TILE FIELD TO SERVE $241-102 \mathrm{H}$ \\
\hline 15005 & $\begin{array}{l}\text { A-AREA } 65,000-G P D \text { SANITARY WASTEWATER TREATMENT PLANT EXPANSION, } \\
607-23 A\end{array}$ \\
\hline 15049 & $\begin{array}{l}\text { 35,000-GALLON SANITARY FLOW EQUALIZATION BASIN (607-19G) FOR N-AREA } \\
\text { SANITARY WASTEWATER TREATMENT PLANTS, 607-18G AND 607-42G }\end{array}$ \\
\hline 15416 & $\begin{array}{l}\text { 12,000-GALLON SANITARY FLOW EQUALIZATION BASIN (607-16K) FOR } \\
\text { SANITARY WASTEWATER TREATMENT PLANT, } 607-17 \mathrm{~K}\end{array}$ \\
\hline
\end{tabular}


Sanitary Wastewater Permits, continued

\begin{tabular}{|c|c|}
\hline Permit Number & Permit Title \\
\hline 15417 & $\begin{array}{l}\text { 11,000-GALLON SANITARY FLOW EQUALIZATION BASIN (607-24P) FOR P-AREA } \\
\text { SANITARY WASTEWATER TREATMENT PLANTS, 607-7P AND 607-23P }\end{array}$ \\
\hline 15418 & $\begin{array}{l}\text { 17,500-GALLON SANITARY FLOW EQUALIZATION BASIN }(607-15 \mathrm{~L}) \text { FOR SANITARY } \\
\text { WASTEWATER TREATMENT PLANT, } 607-16 \mathrm{~L}\end{array}$ \\
\hline 15419 & $\begin{array}{l}\text { SANITARY SEWER LIFT STATION TO SERVE REPLACEMENT TRITIUM FACILITY } \\
\text { (RTF) }\end{array}$ \\
\hline 15444 & SANITARY SEWER LIFT STATION TO SERVE 341-M \\
\hline 15506 & $\begin{array}{l}\text { 15,000-GALLON SANITARY FLOW EQUALIZATION BASIN (607-22F) FOR NAVAL } \\
\text { FUEL (FMF) SANITARY WASTEWATER TREATMENT PLANT, 607-17F }\end{array}$ \\
\hline 15530 & $\begin{array}{l}\text { 27,500-GALLON SANITARY FLOW EQUALIZATION BASIN }(607-4 C) \text { FOR SANITARY } \\
\text { WASTEWATER TREATMENT PLANT, } 607-7 C\end{array}$ \\
\hline 15740 & $\begin{array}{l}\text { SANITARY SEWER SYSTEM EXPANSION (TWO LIFT STATIONS AND SEWER LINE) } \\
\text { TO SERVE C-AREA }\end{array}$ \\
\hline 16477 & $\begin{array}{l}\text { SANITARY SEWER TO SERVE N-AREA MATERIAL MANAGEMENT RECEIVING AND } \\
\text { STORAGE FACILITIES (MMRSF), 731-N THROUGH } 731-4 N\end{array}$ \\
\hline 16784 & $\begin{array}{l}\text { TNX-AREA SANITARY WASTEWATER TREATMENT PLANT }(607-40 T) \text { EFFLUENT } \\
\text { REROUTE FROM OUTFALL } X-013 \text { TO X-008A }\end{array}$ \\
\hline 16961 & $\begin{array}{l}\text { SANITARY SEWER LINE FROM MATERIAL MANAGEMENT RECEIVING AND STOR- } \\
\text { AGE FACILITIES (MMRSF) TO N-AREA SANITARY WASTEWATER TREATMENT } \\
\text { PLANT }\end{array}$ \\
\hline 17057 & $\begin{array}{l}\text { B-AREA 80,000-GPD SANITARY WASTEWATER TREATMENT PLANT UPGRADE, } \\
\text { 607-4B (INCLUDES 40,000-GALLON FLOW EQUALIZATION BASIN) }\end{array}$ \\
\hline 17059 & SANITARY SEWER TO SERVE B-AREA ENGINEERING CENTER, 730-B \\
\hline 17156 & $\begin{array}{l}\text { FLOW CONTROL BOXES FOR TNX-AREA SANITARY WASTEWATER TREATMENT } \\
\text { PLANT, } 607-40 T\end{array}$ \\
\hline 17157 & $\begin{array}{l}\text { FLOW CONTROL BOXES FOR H-AREA SANITARY WASTEWATER TREATMENT } \\
\text { FACILITIES, } 607-7 \mathrm{H} \text { AND } 607-21 \mathrm{H}\end{array}$ \\
\hline 17232 & SANITARY SEWER TO SERVE 705-3C \\
\hline $17273-1 W$ & SANITARY SEWER TO SERVE 704-49S OFFICE BUILDING \\
\hline $17278-1 W$ & SANITARY SEWER TO SERVE 730-1M OFFICE BUILDING \\
\hline $17279-1 W$ & SANITARY SEWER TO SERVE 705-K OFFICE BUILDING \\
\hline 17383-IW & $\begin{array}{l}\text { SANITARY SEWER TO SERVE REPLACEMENT TRITIUM FACILITY (RTF) } \\
\text { TRAILERS, } 233-20 \mathrm{H} \text { AND } 233-21 \mathrm{H}\end{array}$ \\
\hline $17419-I W$ & SANITARY SEWER TO SERVE H-AREA TRAILERS, 742-10G THROUGH 742-12G \\
\hline $17499-1 W$ & SANITARY SEWER AND LIFT STATION TO SERVE 704-2H \\
\hline $17528-1 W$ & $\begin{array}{l}\text { SANITARY SEWER TO SERVE ENGINEERING SUPPORT FACILITY, 730-1B, AND } \\
\text { OPERATIONS SUPPORT FACILITIES, 730-2B AND 730-4B }\end{array}$ \\
\hline
\end{tabular}


Sanitary Wastewater Permits, continued

\begin{tabular}{|c|c|}
\hline Permit Number & Permit Title \\
\hline $17604-1 W$ & $\begin{array}{l}\text { SANITARY SEWER TO SERVE SITE TRAINING BUILDING, 766-H } \\
\text { (FORMERLY 225-H) }\end{array}$ \\
\hline 17643-IW & $\begin{array}{l}\text { COLLECTION SYSTEM FOR CENTRAL SANITARY WASTEWATER TREATMENT } \\
\text { FACILITY (CSWTF), ZONE 1A (FROM C ROAD [INCLUDING LS-3000A] TO CSWTF) }\end{array}$ \\
\hline 17646-IW & $\begin{array}{l}\text { COLLECTION SYSTEM FOR CENTRAL SANITARY WASTEWATER TREATMENT } \\
\text { FACILITY (CSWTF), ZONE } 1 \text { A (FROM LS-4000C TO LS-3000A) }\end{array}$ \\
\hline $17656-I W$ & $\begin{array}{l}\text { SANITARY SEWER TO SERVE HEALTH PROTECTION INSTRUMENT CALIBRATION } \\
\text { FACILITY, 735-2B, AND NEW WHOLE BODY COUNTER FACILITY, 735-4B }\end{array}$ \\
\hline $17676-I W$ & SANITARY SEWER TO SERVE 241-2H \\
\hline $17679-I W$ & $\begin{array}{l}\text { 1,050,000-GPD CENTRAL SANITARY WASTEWATER TREATMENT FACILITY } \\
\text { (CSWTF) TO SERVE A-AREA, B-AREA, C-AREA, F-AREA, H-AREA, N-AREA, NF- } \\
\text { AREA, AND S-AREA }\end{array}$ \\
\hline $17682-I W$ & SANITARY SEWER REROUTE TO SERVE SREL LIBRARY ADDITION, 737-A \\
\hline $17683-I W$ & $\begin{array}{l}\text { COLLECTION SYSTEM FOR CENTRAL SANITARY WASTEWATER TREATMENT } \\
\text { FACILITY (CSWTF), ZONE 1B (B-AREA, F-AREA, H-AREA, AND S-AREA) }\end{array}$ \\
\hline $17690-1 W$ & $\begin{array}{l}\text { COLLECTION SYSTEM FOR CENTRAL SANITARY WASTEWATER TREATMENT } \\
\text { FACILITY (CSWTF), ZONE } 2 \text { (A-AREA, C-AREA, AND N-AREA) }\end{array}$ \\
\hline 17715-IW & $\begin{array}{l}\text { UV DISINFECTION SYSTEM FOR D-AREA SANITARY WASTEWATER TREATMENT } \\
\text { PLANT }\end{array}$ \\
\hline 17719-IW & $\begin{array}{l}\text { UV DISINFECTION SYSTEM FOR P-AREA SANITARY WASTEWATER TREATMENT } \\
\text { PLANT }\end{array}$ \\
\hline $17721-1 \mathrm{~W}$ & $\begin{array}{l}\text { UV DISINFECTION SYSTEM FOR K-AREA SANITARY WASTEWATER TREATMENT } \\
\text { PLANT }\end{array}$ \\
\hline $17722-1 W$ & $\begin{array}{l}\text { UV DISINFECTION SYSTEM FOR TNX-AREA SANITARY WASTEWATER } \\
\text { TREATMENT PLANT }\end{array}$ \\
\hline 17726-IW & $\begin{array}{l}\text { UV DISINFECTION SYSTEM FOR L-AREA SANITARY WASTEWATER TREATMENT } \\
\text { PLANT }\end{array}$ \\
\hline $17842-1 W$ & $\begin{array}{l}\text { SANITARY SEWER AND LIFT STATION TO SERVE SREL ANIMAL-HOLDING } \\
\text { FACILITIES }\end{array}$ \\
\hline $17,981-\mathrm{IW}$ & SANITARY SEWER TO SERVE H-AREA MEDICAL FACILITY, 719-H \\
\hline 1995020076 & SEPTIC TANK AND TILE FIELD TO SERVE CENTRAL STAGING AREA, 704-13G \\
\hline 1995020100 & $\begin{array}{l}\text { SEPTIC TANK AND TILE FIELD TO SERVE CONSOLIDATED INCINERATION } \\
\text { FACILITY (CIF), 261-H }\end{array}$ \\
\hline 7947 & L-AREA 35,000-GPD SANITARY WASTEWATER TREATMENT PLANT, 607-16L \\
\hline $8611-P$ & $\begin{array}{l}\text { SEPTIC TANK AND TILE FIELD TO SERVE INTERIM STORAGE AND REDRUMMING } \\
\text { FACILITY, 645-1N (FORMERLY 709-1G), N-AREA }\end{array}$ \\
\hline 8670 & K-AREA $24,000-G P D$ SANITARY WASTEWATER TREATMENT PLANT, 607-17K \\
\hline
\end{tabular}


Sanitary Wastewater Permits, continued

\begin{tabular}{|c|c|}
\hline Permit Number & Permit Title \\
\hline 8928 & $\begin{array}{l}\text { NAVAL FUEL (FMF) 30,000-GPD SANITARY WASTEWATER TREATMENT PLANT, } \\
607-17 \mathrm{~F}\end{array}$ \\
\hline 9256P & $\begin{array}{l}\text { SEPTIC TANK AND TILE FIELD TO SERVE LANDFILL MONITORING BUILDING, } \\
642-E\end{array}$ \\
\hline 9326 & $\begin{array}{l}\text { H-AREA } 60,000-G P D \text { SANITARY WASTEWATER TREATMENT PLANT, 607-7H } \\
\text { (F-Area, N-Area, and P-Area also included under this permit) }\end{array}$ \\
\hline 9326 & $\begin{array}{l}\text { P-AREA 10,000-GPD SANITARY WASTEWATER TREATMENT PLANT, 607-23P } \\
\text { (F-Area, H-Area, and N-Area also included under this permit) }\end{array}$ \\
\hline 9326 & $\begin{array}{l}\text { N-AREA } 30,000-G P D(607-18 G) \text { AND 40,000-GPD (607-42G) SANITARY } \\
\text { WASTEWATER TREATMENT PLANTS (F-Area, H-Area, and P-Area also included un- } \\
\text { der this permit) }\end{array}$ \\
\hline 9326 & $\begin{array}{l}\text { F-AREA 60,000-GPD SANITARY WASTEWATER TREATMENT PLANT, 607-7F } \\
\text { (H-Area, N-Area, and P-Area also included under this permit) }\end{array}$ \\
\hline 9694 & $\begin{array}{l}\text { SANITARY SEWER SYSTEM (LIFT STATION AND SEWER LINE) TO SERVE 773-41A } \\
\text { and } 773-42 A\end{array}$ \\
\hline 9888 & $\begin{array}{l}\text { S-AREA, TWO 12,000-GPD SANITARY WASTEWATER TREATMENT PLANTS, } \\
831-1 S \text { AND } 831-2 S\end{array}$ \\
\hline 9940 & SANITARY SEWER TO SERVE REACTOR SIMULATOR FACILITY, 707-C \\
\hline 9983 & C-AREA, 55,000-GPD SANITARY WASTEWATER TREATMENT PLANT, 607-7C \\
\hline 9998 & SEPTIC TANK AND TILE FIELD TO SERVE F/H ETF CONTROL BUILDING, 241-84H \\
\hline LS-10-S & $\begin{array}{l}\text { SANITARY SEWER TO SERVE NAVAL FUEL MATERIAL FACILITY (FMF), 247-F AND } \\
248-\mathrm{F}\end{array}$ \\
\hline LS-129-S & SANITARY SEWER TO SERVE 719-4A \\
\hline LS-134-S & DWPF SANITARY SEWER LINE MODIFICATION, S-AREA \\
\hline LS-149-S & SANITARY SEWER TO SERVE TNX-AREA EFFLUENT TREATMENT PLANT, 904-T \\
\hline LS-158-S & SANITARY SEWER TO SERVE $3 / 700$ CONSTRUCTION FACILITY \\
\hline LS-2-S & SANITARY SEWER TO SERVE TRITIUM FACILITY SUPPORT BUILDING, 235-H \\
\hline LS-206-S & SEWER PIPE AND MANHOLE, 704-1T \\
\hline LS-227-S & SANITARY SEWER TO SERVE 705-C \\
\hline LS-228-S & SANITARY SEWER TO SERVE 717-K \\
\hline LS-239-S & $\begin{array}{l}\text { SANITARY SEWER TO SERVE SECURITY FACILITIES; ENTRY CONTROL FACILITY } \\
\text { (ECF), 701-4F; AND CENTRAL ALARM STATION (CAS), 720-F }\end{array}$ \\
\hline LS-240-S & $\begin{array}{l}\text { SANITARY SEWER TO SERVE 720-2A ( } 3 / 700 \text { AREA SECURITY UPGRADE, PACAS } \\
\text { FACILITY) }\end{array}$ \\
\hline LS-244-S & $\begin{array}{l}\text { SANITARY SEWER TO SERVE SECURITY FACILITIES; ENTRY CONTROL FACILITY } \\
\text { (ECF), 701-3H; AND CENTRAL ALARM STATION (CAS), 720-H }\end{array}$ \\
\hline
\end{tabular}


Sanitary Wastewater Permits, continued

\begin{tabular}{|c|c|}
\hline Permit Number & Permit Title \\
\hline LS-256-S & MACERATOR FOR F-AREA SANITARY FLOW EQUALIZATION BASIN, 607-18F \\
\hline LS-275-S & $\begin{array}{l}\text { SANITARY SEWER TO SERVE EQUIPMENT STORAGE AND HEALTH PROTECTION } \\
\text { FACILITY, 221-25F }\end{array}$ \\
\hline LS-3-S & SANITARY SEWER TO SERVE 703-41A \\
\hline LS-32-S & SANITARY SEWER TO SERVE WACKENHUT BUILDINGS 703-B AND 703-1B \\
\hline LS-335-S & $\begin{array}{l}\text { SANITARY SEWER TO SERVE TEMPORARY MODULAR OFFICE TRAILERS 704-7K } \\
\text { THROUGH 704-19K }\end{array}$ \\
\hline LS-336-S & "AS BUILT" OILWATER SEPARATOR, 716-A \\
\hline LS-337-S & "AS BUILT" OILWATER SEPARATOR, 722-4A \\
\hline LS-35-S & SANITARY SEWER RELOCATION TO SERVE 735-11A \\
\hline LS-351-S & $\begin{array}{l}\text { SANITARY SEWER TO SERVE TEMPORARY MODULAR OFFICE TRAILERS, 245-F } \\
\text { THROUGH } 245-12 \mathrm{~F}\end{array}$ \\
\hline LS-352-S & SANITARY SEWER TO SERVE N-AREA NEW EMPLOYEE PROCESSING CENTER \\
\hline LS-354-S & SANITARY SEWER TO SERVE TO SERVE GENERAL PHYSICS OFFICE, 777-18A \\
\hline LS-52-S & SANITARY SEWER TO SERVE 707-H \\
\hline LS-53-S & SANITARY SEWER TO SERVE CONSTRUCTION OFFICE BUILDING, M-AREA \\
\hline LS-62-S & SANITARY SEWER RELOCATION TO SERVE 717-F \\
\hline LS-78-S & $\begin{array}{l}\text { SANITARY SEWER TO SERVE CONSTRUCTION ADMINISTRATION BUILDING, } \\
\text { C-AREA }\end{array}$ \\
\hline LS-79-S & SANITARY SEWER TO SERVE N-AREA ELECTRICAL OFFICE BUILDING \\
\hline LS-80-S & SANITARY SEWER TO SERVE N-AREA RECEIVING AND STORES WAREHOUSE \\
\hline \multicolumn{2}{|c|}{ SCDHEC 401 (Water Quality) Permit } \\
\hline Permit Number & Permit Title \\
\hline SC 88-D-005 & F/H ETF DIFFUSER \\
\hline
\end{tabular}

SCDHEC Navigable Waters Permits

\begin{tabular}{ll}
\hline Permit Number & Permit Title \\
\hline SC 96-003 & $\begin{array}{l}\text { BRIDGE REPLACEMENTS AT ROAD C AND ROAD F AND UTILITY RELOCATION } \\
\text { OVER UPPER THREE RUNS CREEK, AIKEN COUNTY, SC }\end{array}$ \\
SC 96-005 & $\begin{array}{l}\text { REPLACEMENT OF BRIDGE, 603-72G, ON ROAD B OVER LOWER THREE RUNS } \\
\text { CREEK, BARNWELL COUNTY, SC }\end{array}$
\end{tabular}


SCDHEC Navigable Waters Permits, continued

\begin{tabular}{ll}
\hline Permit Number & Permit Title \\
\hline SC 96-009 & PIPE BRIDGE INSTALLATION FOR POTABLE WATER LINE ACROSS UPPER THREE \\
& RUNS CREEK, AIKEN COUNTY, SC \\
SC 96-031 & BRIDGE REPLACEMENTS AT ROAD 8-1 AND ROAD 2-1 ON UPPER THREE RUNS \\
& CREEK, AIKEN COUNTY, SC
\end{tabular}

Solid Waste Permits

\begin{tabular}{ll}
\hline Permit Number & Permit Title \\
\hline $025500-1120$ & SANITARY LANDFILL \\
$025500-1601$ & D-F STEAM-LINE INDUSTRIAL SOLID WASTE LANDFILL (ASBESTOS) \\
$025500-1602$ & F-AREA INERT-MATERIALS LANDFILL (RAILROAD TIE PILE) \\
$025500-1603$ & Z-AREA SALTSTONE DISPOSAL FACILITY \\
$025800-1901$ & BURMA ROAD INERT-MATERIALS LANDFILL \\
IWP-211 & H-AREA INERT-MATERIALS LANDFILL
\end{tabular}

Underground Injection Control Permits

\begin{tabular}{|c|c|}
\hline Permit Number & Permit Title \\
\hline $103 R$ & $\begin{array}{l}\text { INJECTION/EXTRACTION BIOREMEDIATION PROJECT NEAR THE M-AREA } \\
\text { SETTLING BASIN (One Class V.A.-G experimental technology injection well, AMH-1, } \\
\text { to remove TCE and PCE using methane solutions) }\end{array}$ \\
\hline 194 & $\begin{array}{l}\text { BIOREMEDIATION OPTIMIZATION TEST AT THE SANITARY LANDFILL, 740-G (Six- } \\
\text { Class V.A.-I aquifer remediation injection wells, AIW-1 through AIW-6) }\end{array}$ \\
\hline 201 & $\begin{array}{l}\text { PURGE-WATER MANAGEMENT SYSTEM DEMONSTRATION, TNX-AREA (One Class } \\
\text { V.A.-G experimental technology injection well, P-26D; Phase I, demonstrate unit at a } \\
\text { "clean" well) }\end{array}$ \\
\hline $201 \mathrm{M}$ & $\begin{array}{l}\text { PURGE-WATER MANAGEMENT SYSTEM DEMONSTRATION, M-AREA (One Class } \\
\text { V.A.-G experimental technology injection well, MCB-5; Phase II, demonstrate unit at a } \\
\text { "contaminated" well) }\end{array}$ \\
\hline 211 & $\begin{array}{l}\text { F-AREA SEEPAGE BASIN GROUNDWATER REMEDIATION (Ten Class V.A.-I aquifer } \\
\text { remediation injection wells, FIN-1 through FIN-10) }\end{array}$ \\
\hline 215 & $\begin{array}{l}\text { GROUNDWATER OPERABLE UNIT (GWOU) RECIRCULATION WELL, TNX-AREA } \\
\text { (One Class V.A.-I corrective-action injection well, TVR-1) }\end{array}$ \\
\hline 223 & $\begin{array}{l}\text { H-AREA SEEPAGE BASIN GROUNDWATER REMEDIATION (Ten Class V.A.-I aquifer } \\
\text { remediation injection wells, HIN-1 through HIN-10) }\end{array}$ \\
\hline 225 & $\begin{array}{l}\text { IN-SITU BIOREMEDIATION AT 108-3C (Eight Class V.A.-I aquifer remediation injection } \\
\text { wells) }\end{array}$ \\
\hline 237 & $\begin{array}{l}\text { IN-SITU BIOREMEDIATION AT 108-3L (Eleven Class V.A.-I aquifer remediation injec- } \\
\text { tion wells, } 104 \text { through 114) }\end{array}$ \\
\hline
\end{tabular}


Underground Injection Control Permits, continued

\begin{tabular}{|c|c|}
\hline Permit Number & Permit Title \\
\hline 244 & $\begin{array}{l}\text { H-AREA RETENTION BASIN PILOT INJECTION TEST (Twenty Class V.A.-G } \\
\text { experimental technology injection wells for Viscous Barrier Demonstration Project) }\end{array}$ \\
\hline 245 & $\begin{array}{l}\text { H-AREA COLLOID STUDY INJECTION TEST; SERIES I (One Class V.A.-G } \\
\text { experimental technology injection well, HIW-IID) }\end{array}$ \\
\hline 245II & $\begin{array}{l}\text { H-AREA COLLOID STUDY INJECTION TEST; SERIES II (One Class V.A.-G } \\
\text { experimental technology injection well, HIW-IID) }\end{array}$ \\
\hline 245III & $\begin{array}{l}\text { H-AREA COLLOID STUDY INJECTION TEST; SERIES III (One Class V.A.-G } \\
\text { experimental technology injection well, HIW-IID) }\end{array}$ \\
\hline 246 & $\begin{array}{l}\text { INJECTION/EXTRACTION TEST AT THE M-AREA SETTLING BASIN (Six Class V.A.-1 } \\
\text { aquifer remediation injection wells-MSB-22, 3D, } 11 \mathrm{~F}, 15 \mathrm{D}, 9 \mathrm{C} \text {, and MHT-9D-to } \\
\text { locate DNAPL using alcohol solutions) }\end{array}$ \\
\hline 256 & $\begin{array}{l}\text { D-AREA OIL SEEPAGE BASIN SOIL BIOVENTING REMEDIATION SYSTEM (Two } \\
\text { Class V.A.-I aquifer remediation horizontal injection wells, DOB-1HW and DOB-2HW) }\end{array}$ \\
\hline 257 & $\begin{array}{l}\text { SANITARY LANDFILL IN-SITU BIOREMEDIATION (Two Class V.A.-G experimental } \\
\text { technology horizontal injection wells, SLH-1 and SLH-2) }\end{array}$ \\
\hline 258 & $\begin{array}{l}\text { AM SOUTHERN SECTOR GROUNDWATER REMEDIATION (Twelve Class V.A.-I } \\
\text { aquifer remediation vertical recirculation wells, SSW-1 through SSW-12) }\end{array}$ \\
\hline 267 & $\begin{array}{l}\text { GEOCLEANSE PROCESS DEMONSTRATION NEAR THE M-AREA SEEPAGE BASIN } \\
\text { (Four Class V.A.-G aquifer remediation wells, MOX-1 through MOX }-4 \text {, to remove pure- } \\
\text { phase DNAPL) }\end{array}$ \\
\hline \multicolumn{2}{|c|}{ Underground Storage Tank Permits } \\
\hline Permit Number & Permit Title \\
\hline $\mathrm{N}-02-\mathrm{GF}-09465$ & N-AREA 15,000-GALLON UNDERGROUND GASOLINE STORAGE TANK, 728-N \\
\hline$N-02-G F-09465$ & N-AREA 15,000-GALLON UNDERGROUND DIESEL FUEL STORAGE TANK, 728-N \\
\hline$N-02-G F-09466$ & N-AREA 15,000-GALLON UNDERGROUND GASOLINE STORAGE TANK, 716-7N \\
\hline $\mathrm{N}-02-\mathrm{GF}-09466$ & N-AREA 15,000-GALLON UNDERGROUND DIESEL FUEL STORAGE TANK, 716-7N \\
\hline$N-02-G F-09468$ & $\begin{array}{l}\text { RAILROAD YARD 10,000-GALLON UNDERGROUND GASOLINE STORAGE TANK, } \\
715-1 \mathrm{G}\end{array}$ \\
\hline$N-02-G F-09469$ & $\begin{array}{l}\text { S-AREA 15,000-GALLON UNDERGROUND DIESEL FUEL STORAGE TANK \#1, } \\
200-S\end{array}$ \\
\hline$N-02-G F-09469$ & $\begin{array}{l}\text { S-AREA 15,000-GALLON UNDERGROUND DIESEL FUEL STORAGE TANK \#2, } \\
200-S\end{array}$ \\
\hline$N-02-G F-09473$ & H-AREA 13,300-GALLON UNDERGROUND DIESEL FUEL STORAGE TANK, 619-H \\
\hline$N-02-G F-09473$ & $\begin{array}{l}\text { H-AREA 20,000-GALLON UNDERGROUND DIESEL FUEL STORAGE TANK, 254-5H } \\
\# 1\end{array}$ \\
\hline $\mathrm{N}-02-\mathrm{GF}-09473$ & $\begin{array}{l}\text { H-AREA 20,000-GALLON UNDERGROUND DIESEL FUEL STORAGE TANK, } 254-5 \mathrm{H} \\
\# 2\end{array}$ \\
\hline
\end{tabular}


Underground Storage Tank Permits, continued

\begin{tabular}{|c|c|}
\hline Permit Number & Permit Title \\
\hline $\mathrm{N}-02-\mathrm{GF}-09473$ & F-AREA 13,300-GALLON UNDERGROUND DIESEL FUEL STORAGE TANK, 619-F \\
\hline N-02-GF-09473 & $\begin{array}{l}\text { F-AREA 20,000-GALLON UNDERGROUND DIESEL FUEL STORAGE TANK, 254-5F } \\
\# 1\end{array}$ \\
\hline $\mathrm{N}-02-\mathrm{GF}-09473$ & $\begin{array}{l}\text { F-AREA 20,000-GALLON UNDERGROUND DIESEL FUEL STORAGE TANK, 254-5F } \\
\# 2\end{array}$ \\
\hline $\mathrm{N}-02-\mathrm{GF}-09476$ & A-AREA 5,000-GALLON UNDERGROUND DIESEL FUEL STORAGE TANK, 754-5A \\
\hline $\mathrm{N}-02-\mathrm{GF}-09476$ & A-AREA 5,000-GALLON UNDERGROUND DIESEL FUEL STORAGE TANK, 703-A \\
\hline $\mathrm{N}-02-\mathrm{GF}-09479$ & $\begin{array}{l}\text { B-AREA 10,000-GALLON UNDERGROUND AVIATION FUEL STORAGE TANK, } \\
703-5 B\end{array}$ \\
\hline$P-02-G F-09467$ & $\begin{array}{l}\text { FORESTRY AREA 2000-GALLON UNDERGROUND GASOLINE STORAGE TANK, } \\
620-G(A)\end{array}$ \\
\hline $\mathrm{P}-02-\mathrm{GF}-09467$ & $\begin{array}{l}\text { FORESTRY AREA } 2000-G A L L O N \text { UNDERGROUND DIESEL FUEL STORAGE TANK, } \\
620-G(B)\end{array}$ \\
\hline$P-02-G F-10838$ & $\begin{array}{l}\text { H-AREA 10,000-GALLON UNDERGROUND GASOLINE STORAGE TANK, 715-2G } \\
\text { (A-Area, C-Area, K-Area, L-Area, N-Area, and P-Area also included) }\end{array}$ \\
\hline$P-02-G F-10838$ & $\begin{array}{l}\text { L-AREA 5000-GALLON UNDERGROUND GASOLINE STORAGE TANK, 715-L } \\
\text { (A-Area, C-Area, H-Area, K-Area, N-Area, and P-Area also included) }\end{array}$ \\
\hline$P-02-G F-10838$ & $\begin{array}{l}\text { C-AREA 5000-GALLON UNDERGROUND GASOLINE STORAGE TANK, 715-C } \\
\text { (A-Area, H-Area, K-Area, L-Area, N-Area, and P-Area also included) }\end{array}$ \\
\hline$P-02-G F-10838$ & $\begin{array}{l}\text { K-AREA 5000-GALLON UNDERGROUND GASOLINE STORAGE TANK, 715-K } \\
\text { (A-Area, C-Area, H-Area, L-Area, N-Area, and P-Area also included) }\end{array}$ \\
\hline P-02-GF-10838 & $\begin{array}{l}\text { P-AREA 5000-GALLON UNDERGROUND GASOLINE STORAGE TANK, 715-P } \\
\text { (A-Area, C-Area, H-Area, K-Area, L-Area, and N-Area also included) }\end{array}$ \\
\hline$P-02-G F-10838$ & $\begin{array}{l}\text { A-AREA 5000-GALLON UNDERGROUND GASOLINE STORAGE TANK, 715-AA } \\
\text { (C-Area, H-Area, K-Area, L-Area, N-Area, and P-Area also included) }\end{array}$ \\
\hline P-02-GF-10838 & $\begin{array}{l}\text { A-AREA 5000-GALLON UNDERGROUND DIESEL FUEL STORAGE TANK, 715-AB } \\
\text { (C-Area, H-Area, K-Area, L-Area, N-Area, and P-Area also included) }\end{array}$ \\
\hline P-02-GF-10838 & $\begin{array}{l}\text { A-AREA 5000-GALLON UNDERGROUND GASOLINE STORAGE TANK, 715-AC } \\
\text { (C-Area, H-Area, K-Area, L-Area, N-Area, and P-Area also included) }\end{array}$ \\
\hline$P-02-G F-10838$ & $\begin{array}{l}\text { N-AREA 10,000-GALLON UNDERGROUND GASOLINE STORAGE TANK, 715-N \#1 } \\
\text { (A-Area, C-Area, H-Area, K-Area, L-Area, and P-Area also included) }\end{array}$ \\
\hline$P-02-G F-10838$ & $\begin{array}{l}\text { N-AREA 10,000-GALLON UNDERGROUND DIESEL FUEL STORAGE TANK, 715-N } \\
\text { \#2 (A-Area, C-Area, H-Area, K-Area, L-Area, and P-Area also included) }\end{array}$ \\
\hline$P-02-G F-12476$ & A-AREA 5000-GALLON UNDERGROUND DIESEL FUEL STORAGE TANK, 754-6A \\
\hline
\end{tabular}




\section{Radionuclide and Chemical Nomenclature}

\begin{tabular}{|c|c|c|c|c|c|}
\hline Radionuclide & Symbol & Half-Life ${ }^{a, b}$ & Radionuclide & Symbol & Half-Life $a, b$ \\
\hline Americium-241 & $A m-241$ & $432.7 y$ & Osmium-185 & Os-185 & $93.6 \mathrm{~d}$ \\
\hline Americium-243 & $\mathrm{Am}-243$ & 7.37E3 y & Phosphorus-32 & P-32 & $14.28 d$ \\
\hline Antimony-125 & $\mathrm{Sb}-125$ & $2.758 y$ & Polonium-210 & Po-210 & $138.38 d$ \\
\hline Argon-41 & Ar-41 & $1.82 \mathrm{~h}$ & Plutonium-238 & Pu-238 & $87.7 y$ \\
\hline Beryllium-7 & $\mathrm{Be}-7$ & $53.28 \mathrm{~d}$ & Plutonium-239 & Pu-239 & $2.41 E 4 y$ \\
\hline Californium-252 & Cf-252 & $2.638 \mathrm{y}$ & Potassium-40 & $K-40$ & 1.28E9 y \\
\hline Carbon-14 & C-14 & $5,730 y$ & Promethium-147 & $\mathrm{Pm}-147$ & $2.6234 y$ \\
\hline Cerium-141 & $\mathrm{Ce}-141$ & $32.50 \mathrm{~d}$ & Ruthenium-103 & $R u-103$ & $39.27 d$ \\
\hline Cerium-144 & Ce-144 & $284.6 \mathrm{~d}$ & Ruthenium-106 & $R u-106$ & $1.020 y$ \\
\hline Cesium-134 & Cs-134 & $2.065 y$ & Selenium-75 & Se-75 & $119.78 d$ \\
\hline Cesium-137 & Cs-137 & $30.17 y$ & Strontium-89 & Sr-89 & $50.52 d$ \\
\hline Cobalt-58 & Co-58 & $70.88 d$ & Strontium-90 & Sr-90 & $29.1 \mathrm{y}$ \\
\hline Cobalt -60 & Co- 60 & $5.271 \mathrm{y}$ & Technetium-99 & Tc-99 & 2.13E5 y \\
\hline Curium-242 & $\mathrm{Cm}-242$ & $162.8 d$ & Tritium & $\mathrm{H}-3$ & $12.3 y$ \\
\hline Curium-244 & $\mathrm{Cm}-244$ & $18.1 y$ & Uranium-235 & $U-235$ & $7.04 E 8$ y \\
\hline lodine-129 & $\mid-129$ & 1.57E7 y & Uranium-238 & U-238 & 4.47E9 y \\
\hline lodine-131 & $\mid-131$ & $8.04 d$ & Xenon-133 & $\mathrm{Xe}-133$ & $5.243 \mathrm{~d}$ \\
\hline Krypton-85 & $\mathrm{Kr}-85$ & $10.73 y$ & Xenon-135 & $\mathrm{Xe}-135$ & $9.10 \mathrm{~h}$ \\
\hline Krypton-88 & $\mathrm{Kr}-88$ & $2.84 h$ & Yttrium-90 & $Y-90$ & $64.08 \mathrm{~h}$ \\
\hline Manganese-54 & $M n-54$ & $312.2 d$ & Zirconium-95 & Zr-95 & $64.02 \mathrm{~d}$ \\
\hline Niobium-95 & $\mathrm{Nb}-95$ & $34.97 d$ & & & \\
\hline
\end{tabular}

\section{Nomenclature for Common Chemical Analyses}

\section{Analysis}

Biochemical Oxygen Demand

Chemical Oxygen Demand

Dissolved Oxygen

Particulate Matter $<10$ microns

Polychlorinated Biphenyl

Perchloroethylene

Tetrachloroethylene

Total Dissolved Solids
Symbol

BOD

$\mathrm{COD}$

DO

$\mathrm{PM}_{10}$

PCB

PCE

TCE

TDS

\section{Analysis}

Total Organic Carbon

Total Organic Halogens

Total Phosphates

Total Solids

Total Suspended Solids

Volatile Organic Compound
Symbol

TOC

$\mathrm{TOH}$

$\mathrm{TPO}_{4}$

TS

TSS

VOC

a $h=$ hour; $d=$ day; $y=$ year

b Reference: Chart of the Nuclides, 14th edition, revised to April 1988, General Electric Company 
Nomenclature for Elements and Chemical Constituents

\begin{tabular}{ll|l} 
Constituent & Symbol & Constituent \\
Aluminum & $\mathrm{Al}$ & Mercury \\
Ammonia & $\mathrm{NH}_{3}$ & Nickel \\
Antimony & $\mathrm{Sb}$ & Nitrogen \\
Arsenic & $\mathrm{As}$ & Nitrate \\
Barium & $\mathrm{Ba}$ & Nitrite \\
Beryllium & $\mathrm{Be}$ & Oxygen \\
Cadmium & $\mathrm{Cd}$ & Ozone \\
Calcium & $\mathrm{Ca}$ & Phosphorus \\
Calcium Carbonate & $\mathrm{CaCO}$ & Phosphate \\
Carbon & $\mathrm{C}$ & Potassium \\
Chlorine & $\mathrm{Cl}$ & Radium \\
Chromium & $\mathrm{Cr}$ & Rhenium \\
Cobalt & $\mathrm{Co}$ & Selenium \\
Copper & $\mathrm{Cu}$ & Silver \\
Fluorine & $\mathrm{F}$ & Sodium \\
Iron & $\mathrm{Fe}$ & Sulfate \\
Lead & $\mathrm{Pb}$ & Sulfur Dioxide \\
Lithium & $\mathrm{Li}$ & Thallium \\
Magnesium & $\mathrm{Mg}$ & Uranium \\
Manganese & $\mathrm{Mn}$ & Vanadium \\
& & Zinc \\
\end{tabular}

Symbol
$\mathrm{Hg}$
$\mathrm{Ni}$
$\mathrm{N}$
$\mathrm{NO}_{3}$
$\mathrm{NO}_{2}$
$\mathrm{O}$
$\mathrm{O}_{3}$
$\mathrm{P}$
$\mathrm{PO}_{4}$
$\mathrm{~K}$
$\mathrm{Ra}$
$\mathrm{Re}$
$\mathrm{Se}$
$\mathrm{Ag}$
$\mathrm{Na}$
$\mathrm{SO}_{4}$
$\mathrm{SO}_{2}$
$\mathrm{TI}$
$\mathrm{U}$
$\mathrm{V}$
$\mathrm{Zn}$




\section{Drinking Water Standards}

\begin{tabular}{|c|c|c|c|c|}
\hline Analyte & Levela & Units & Status & Reference ${ }^{b}$ \\
\hline Alachlor & 0.002 & $\mathrm{mg} / \mathrm{L}$ & final & CFR, 1993 \\
\hline Aldicarb & 0.003 & $\mathrm{mg} / \mathrm{L}$ & final & CFR, 1993 \\
\hline Aldicarb sulfone & 0.002 & $\mathrm{mg} / \mathrm{L}$ & final & CFR, 1993 \\
\hline Aldicarb sulfoxide & 0.004 & $\mathrm{mg} / \mathrm{L}$ & final & CFR, 1993 \\
\hline Antimony & 0.006 & $\mathrm{mg} / \mathrm{L}$ & final & CFR, 1993 \\
\hline Antimony-125 & $3 . E+02$ & $\mathrm{pCi} / \mathrm{L}$ & interim final & EPA, 1977 \\
\hline Arsenic & 0.05 & $\mathrm{mg} / \mathrm{L}$ & final & CFR, 1993 \\
\hline Asbestos & $7,000,000$ & fibers $/ L^{c}$ & final & CFR, 1993 \\
\hline Atrazine & 0.003 & $\mathrm{mg} / \mathrm{L}$ & final & CFR, 1993 \\
\hline Barium & 2.0 & $\mathrm{mg} / \mathrm{L}$ & final & CFR, 1993 \\
\hline Barium-140 & $9 . E+01$ & pCi/L & interim final & EPA, 1977 \\
\hline Benzene & 0.005 & $\mathrm{mg} / \mathrm{L}$ & final & CFR, 1993 \\
\hline Benzo[a]pyrene & 0.0002 & $\mathrm{mg} / \mathrm{L}$ & final & SDWA,1992 \\
\hline Beryllium & 0.004 & $\mathrm{mg} / \mathrm{L}$ & final & CFR, 1993 \\
\hline Beryllium-7 & $6 . E+03$ & $\mathrm{pCi} / \mathrm{L}$ & interim final & EPA, 1977 \\
\hline $\begin{array}{l}\text { 2-sec-Butyl-4, 6-dinitrophenol } \\
\text { (Dinoseb) }\end{array}$ & 0.007 & $\mathrm{mg} / \mathrm{L}$ & final & CFR, 1993 \\
\hline Cadmium & 0.005 & mg/L & final & CFR, 1993 \\
\hline Carbofuran & 0.04 & $\mathrm{mg} / \mathrm{L}$ & final & CFR, 1993 \\
\hline Carbon-14 & $2 . E+03$ & $\mathrm{pCi} / \mathrm{L}$ & interim final & EPA, 1977 \\
\hline Carbon tetrachloride & 0.005 & $\mathrm{mg} / \mathrm{L}$ & final & CFR, 1993 \\
\hline Cerium-141 & 3.E+02 & pCill & interim final & EPA, 1977 \\
\hline Cesium-137 & $2 . E+02$ & $\mathrm{pCi} / \mathrm{L}$ & interim final & EPA, 1977 \\
\hline Chlordane & 0.002 & $\mathrm{mg} / \mathrm{L}$ & final & CFR, 1993 \\
\hline $\begin{array}{l}\text { Chlorobenzene (monochlorobon- } \\
\text { zene) }\end{array}$ & 0.1 & $\mathrm{mg} / \mathrm{L}$ & final & CFR, 1993 \\
\hline $\begin{array}{l}\text { Chloroethene } \\
\text { (Vinyl chloride) }\end{array}$ & 0.002 & $\mathrm{mg} / \mathrm{L}$ & final & CFR, 1993 \\
\hline Chloroform ${ }^{d}$ & 0.1 & $\mathrm{mg} / \mathrm{L}$ & final & CFR, 1993 \\
\hline
\end{tabular}

a Standards for beta- and gamma-emitting radionuclides are based on the 4-mrem/yr whole-body dose [EPA, 1991].

b References are found on page 225.

c Longer than $10 \mu \mathrm{m}$

d The level for total trihalomethanes is set at $0.1 \mathrm{mg} / \mathrm{L}$. Because bromated methanes are rarely detected in SRS groundwater, the Environmental Protection Department (EPD) presumes that most of the trihalomethanes present in site groundwater are chloroform. 


\begin{tabular}{|c|c|c|c|c|}
\hline Analyte & Levela $^{a}$ & Units & Status & Reference $^{b}$ \\
\hline Chromium & 0.1 & $\mathrm{mg} / \mathrm{L}$ & final & CFR, 1993 \\
\hline Chromium-51 & $6 . E+03$ & $\mathrm{pCi} / \mathrm{L}$ & interim final & EPA, 1977 \\
\hline Cobalt-58 & $9 . \mathrm{E}+03$ & $\mathrm{pCi} / \mathrm{L}$ & interim final & EPA, 1977 \\
\hline Cobalt-60 & $1 . E+02$ & pCill & interim final & EPA, 1977 \\
\hline Cyanide & 0.2 & $\mathrm{mg} / \mathrm{L}$ & final & CFR, 1993 \\
\hline Dalapon & 0.2 & $\mathrm{mg} / \mathrm{L}$ & final & CFR, 1993 \\
\hline Dibromochloropropane & 0.0002 & $\mathrm{mg} / \mathrm{L}$ & final & CFR, 1993 \\
\hline Di (2-ethylhexyl) adipate (Deha) & 0.4 & $\mathrm{mg} / \mathrm{L}$ & final & CFR, 1993 \\
\hline Di (2-ethylhexyl) phthalate & 0.006 & $\mathrm{mg} / \mathrm{L}$ & final & SDWA, 1992 \\
\hline 1,2-Dichlorobenzene & 0.6 & $\mathrm{mg} / \mathrm{L}$ & final & CFR, 1993 \\
\hline $\begin{array}{l}\text { 1,4-Dichlorobenzene } \\
\text { (p-Dichlorobenzene) }\end{array}$ & 0.075 & $\mathrm{mg} / \mathrm{L}$ & final & CFR, 1993 \\
\hline 1,2-Dichloroethane & 0.005 & $\mathrm{mg} / \mathrm{L}$ & final & CFR, 1993 \\
\hline cis-1,2-Dichloroethylene & 0.07 & $\mathrm{mg} / \mathrm{L}$ & final & CFR, 1993 \\
\hline trans-1,2-Dichloroethylene & 0.1 & $\mathrm{mg} / \mathrm{L}$ & final & CFR, 1993 \\
\hline 1,1-Dichloroethylene & 0.007 & $\mathrm{mg} / \mathrm{L}$ & final & CFR, 1993 \\
\hline $\begin{array}{l}\text { Dichloromethane } \\
\text { (Methylene chloride) }\end{array}$ & 0.005 & $\mathrm{mg} / \mathrm{L}$ & final & CFR, 1993 \\
\hline $\begin{array}{l}\text { 2,4-Dichlorophenoxyacetic acid } \\
(2,4-D)\end{array}$ & 0.07 & $\mathrm{mg} / \mathrm{L}$ & final & CFR, 1993 \\
\hline 1,2-Dichloropropane & 0.005 & $\mathrm{mg} / \mathrm{L}$ & final & CFR, 1993 \\
\hline Dioxin $(2,3,7,8-T C D D)$ & $3.00 E-08$ & $\mathrm{mg} / \mathrm{L}$ & final & CFR, 1993 \\
\hline Diquat & 0.02 & $\mathrm{mg} / \mathrm{L}$ & final & CFR, 1993 \\
\hline Endrin & 0.002 & $\mathrm{mg} / \mathrm{L}$ & final & CFR, 1993 \\
\hline Endothall & 0.1 & $\mathrm{mg} / \mathrm{L}$ & final & CFR, 1993 \\
\hline Ethylbenzene & 0.7 & $\mathrm{mg} / \mathrm{L}$ & final & CFR, 1993 \\
\hline Ethylene dibromide & 0.00005 & $\mathrm{mg} / \mathrm{L}$ & final & CFR, 1993 \\
\hline Europium-154 & $2 . E+02$ & $\mathrm{pCi} / \mathrm{L}$ & interim final & EPA, 1977 \\
\hline Europium-155 & $6 . E+02$ & $\mathrm{pCi} / \mathrm{L}$ & interim final & EPA, 1977 \\
\hline Fluoride & 4 & $\mathrm{mg} / \mathrm{L}$ & final & CFR, 1993 \\
\hline Glyphosate & 0.7 & $\mathrm{mg} / \mathrm{L}$ & final & CFR, 1993 \\
\hline Gross alpha & 15 & $\mathrm{pCi} / \mathrm{L}$ & final & CFR, 1993 \\
\hline Heptachlor & 0.0004 & $\mathrm{mg} / \mathrm{L}$ & final & CFR, 1993 \\
\hline Heptachlor epoxide & 0.0002 & $\mathrm{mg} / \mathrm{L}$ & final & CFR, 1993 \\
\hline Hexachlorobenzene & 0.001 & $\mathrm{mg} / \mathrm{L}$ & final & CFR, 1993 \\
\hline
\end{tabular}

a Standards for beta- and gamma-emitting radionuclides are based on the 4-mrem/yr whole-body dose [EPA, 1991].

b References are found on page 225. 


\begin{tabular}{|c|c|c|c|c|}
\hline Analyte & Levela $^{a}$ & Units & Status & Reference ${ }^{b}$ \\
\hline Hexachlorocyclopentadiene & 0.05 & $\mathrm{mg} / \mathrm{L}$ & final & CFR, 1993 \\
\hline lodine-129 & 1. $E+00$ & $\mathrm{pCi} / \mathrm{L}$ & interim final & EPA, 1977 \\
\hline lodine-131 & $3 . E+00$ & $\mathrm{pCi} / \mathrm{L}$ & interim final & EPA, 1977 \\
\hline Iron-55 & 2. $E+03$ & $\mathrm{pCi} / \mathrm{L}$ & interim final & EPA, 1977 \\
\hline Iron-59 & $2 . E+02$ & pCilL & interim final & EPA, 1977 \\
\hline Lanthanum-140 & $6 . E+01$ & $\mathrm{pCi} / \mathrm{L}$ & interim final & EPA, 1977 \\
\hline Lindane & 0.0002 & mg/L & final & CFR, 1993 \\
\hline Manganese-54 & 3.E+02 & pCi/L & interim final & EPA, 1977 \\
\hline Mercury & 0.002 & $\mathrm{mg} / \mathrm{L}$ & final & CFR, 1993 \\
\hline Methoxychlor & 0.04 & $\mathrm{mg} / \mathrm{L}$ & final & CFR, 1993 \\
\hline Nickel & 0.1 & $\mathrm{mg} / \mathrm{L}$ & final & CFR, 1993 \\
\hline Nickel-59 & $3 . E+02$ & pCi/L & interim final & EPA, 1977 \\
\hline Nickel-63 & $5 . E+01$ & $\mathrm{pCi} / \mathrm{L}$ & interim final & EPA, 1977 \\
\hline Niobium-95 & 3. $E+02$ & $\mathrm{pCi} / \mathrm{L}$ & interim final & EPA, 1977 \\
\hline Nitrate + Nitrite (As N) & 10 & $\mathrm{mg} / \mathrm{L}$ & final & CFR, 1993 \\
\hline Nitrate (as N) & 10 & $\mathrm{mg} / \mathrm{L}$ & final & CFR, 1993 \\
\hline Nitrite (as N) & 1 & $\mathrm{mg} / \mathrm{L}$ & final & CFR, 1993 \\
\hline Nonvolatile beta & 4 & $\mathrm{mrem} / \mathrm{yr}$ & final & CFR, 1993 \\
\hline Oxamyl (Vydate) & 0.2 & $\mathrm{mg} / \mathrm{L}$ & final & CFR, 1993 \\
\hline PCBs & 0.0005 & $\mathrm{mg} / \mathrm{L}$ & final & CFR, 1993 \\
\hline Pentachlorophenol & 0.001 & $\mathrm{mg} / \mathrm{L}$ & final & CFR, 1993 \\
\hline Picloram & 0.5 & $\mathrm{mg} / \mathrm{L}$ & final & SDWA, 1992 \\
\hline Radium-226/228 (Total) & 5 & $\mathrm{pCi} / \mathrm{L}$ & final & CFR, 1993 \\
\hline Ruthenium-103 & 2.E+02 & $\mathrm{pCi} / \mathrm{L}$ & interim final & EPA, 1977 \\
\hline Ruthenium-106 & 3.E+01 & $\mathrm{pCi} / \mathrm{L}$ & interim final & EPA, 1977 \\
\hline Selenium & 0.05 & $\mathrm{mg} / \mathrm{L}$ & final & CFR, 1993 \\
\hline Simazine & 0.004 & $\mathrm{mg} / \mathrm{L}$ & final & CFR, 1993 \\
\hline Strontium-89 & $2 . E+01$ & $\mathrm{pCi} / \mathrm{L}$ & interim final & EPA, 1977 \\
\hline Strontium-89/90 & $4.20 \mathrm{E}+01^{\mathrm{c}}$ & $\mathrm{pCi} / \mathrm{L}$ & final & CFR, 1993 \\
\hline Strontium-90 & $8 . E+\infty 0$ & pCill & final & CFR, 1993 \\
\hline Styrene & 0.1 & $\mathrm{mg} / \mathrm{L}$ & final & CFR, 1993 \\
\hline Technetium-99 & $9 . E+02$ & $\mathrm{pCil}$ & interim final & EPA, 1977 \\
\hline Tetrachloroethylene & 0.005 & $\mathrm{mg} / \mathrm{L}$ & final & CFR, 1993 \\
\hline Thallium & $0.002^{d}$ & $\mathrm{mg} / \mathrm{L}$ & final & CFR, 1993 \\
\hline Tin-113 & $3 . E+02$ & $\mathrm{pCi} / \mathrm{L}$ & interim final & EPA, 1977 \\
\hline
\end{tabular}

a Standards for beta- and gamma-emitting radionuclides are based on the 4-mrem/yr whole-body dose [EPA, 1991].
b References are found on page 225 .

c For double radionuclide analyses where each separate radionuclide has its own standard, the more stringent standard

d This is the lower of two proposed levels. 


\begin{tabular}{|c|c|c|c|c|}
\hline Analyte & Levela & Units & Status & Reference $^{b}$ \\
\hline Toluene & 1.0 & $\mathrm{mg} / \mathrm{L}$ & final & CFR, 1993 \\
\hline Total radium & 5 & $\mathrm{pCi} / \mathrm{L}$ & final & CFR, 1993 \\
\hline Toxaphene & 0.003 & $\mathrm{mg} / \mathrm{L}$ & final & CFR, 1993 \\
\hline 2,4,5-TP (Silvex) & 0.05 & $\mathrm{mg} / \mathrm{L}$ & final & CFR, 1993 \\
\hline 1,2,4-Trichlorobenzene & 0.07 & $\mathrm{mg} / \mathrm{L}$ & final & CFR, 1993 \\
\hline 1,1,1-Trichloroethane & 0.2 & $\mathrm{mg} / \mathrm{L}$ & final & CFR, 1993 \\
\hline 1,1,2-Trichloroethane & 0.005 & $\mathrm{mg} / \mathrm{L}$ & final & CFR, 1993 \\
\hline Trichloroethylene & 0.005 & $\mathrm{mg} / \mathrm{L}$ & final & CFR, 1993 \\
\hline $\begin{array}{l}\text { Total trihalomethanes }{ }^{c} \\
\text { (includes bromodichloro- } \\
\text { methane, bromoform, chlor- } \\
\text { _oform, and dibromochlor- } \\
\text { _omethane) }\end{array}$ & 0.1 & $\mathrm{mg} / \mathrm{L}$ & final & CFR, 1993 \\
\hline Tritium & 2. $E+01$ & $\mathrm{pCi} / \mathrm{mL}$ & final & CFR, 1993 \\
\hline Xylenes & 10 & $\mathrm{mg} / \mathrm{L}$ & final & CFR, 1993 \\
\hline Zinc-65 & 3.E+02 & pCilL & interim final & EPA. 1977 \\
\hline Zirconium-95 & 2. $E+02$ & $\mathrm{pCi} / \mathrm{L}$ & interim final & EPA. 1977 \\
\hline Zicronium/Niobium-95 & 2. $E+02$ & $\mathrm{pCi} / \mathrm{L}$ & interim final & EPA. 1977 \\
\hline
\end{tabular}

Standards for beta- and gamma-emitting radionuclides are based on the 4-mrem/yr whole-body dose [EPA, 1991]. References are found on page 225.

EMS does not test for total trihalomethanes, but each of these analytes is tested separately.

For double radionuclide analyses where each separate radionuclide has its own standard, the more stringent standard is used. 


\section{References}

CFR (Code of Federal Regulations), 1993. "National Primary Drinking Water Regulations," 40 CFR, Part 141, pp. 592-731, Washington, D.C.

EPA (U.S. Environmental Protection Agency), 1977. National Interim Primary Drinking Water Regulations, EPA-570/9-76-003. Washington, D.C.

EPA (U.S. Environmental Protection Agency), 1986. "Water Pollution Control; National Primary Drinking Water Regulations, Radionuclides (Proposed)," Federal Register, September, 1986, pp. 34835-34862. Washington, D.C.

EPA (U.S. Environmental Protection Agency), 1990. "National Primary and Secondary Drinking Water Regulations; Synthetic Organic Chemicals and Inorganic Chemicals; Proposed Rule," Federal Register, July 25, 1990, pp. 30369-30448, Washington, D.C.

EPA (U.S. Environmental Protection Agency), 1991. "National Primary Drinking Water Regulations; Radionuclides; Proposed Rule," Federal Register, July 18, 1991, pp. 33052-33127, Washington, D.C.

SDWA (Safe Drinking Water Act-Phase V Rule, Synthetic Organic Chemicals and Inorganic Chemicals), 1992. "National Primary Drinking Water Regulations; Synthetic Organic Chemicals and Inorganic Chemicals; Final Rule," Federal Register, July 17, 1992, 57:138:31776, Washington, D.C. 



\section{Appendix E}

\section{Environmental Monitoring Reports}

Reports of the routine environmental monitoring program at Savannah River Site (SRS) have been prepared periodically since before construction of the site in 1951. The monitoring report numbering system and titles have been changed several times to reflect the evolving progress in the concepts of environmental monitoring. The amount of detailed information contained in the reports also varies from time to time and probably reflects the relative importance and emphasis given to topics by different authors.

Except for July-December 1953, reports were issued semiannually from 1951 to 1962, then annually beginning in 1963. Attempts to find a report for July-December 1953 have been unsuccessful. The onsite report was discontinued in 1985, when the onsite and offsite reports were merged into a single publication.

Some of the monitoring reports originally contained secret information, primarily radioactive release values that could be related to production rates. The secret information in these reports was deleted in the mid-1970s, and a deleted version (DEL) of the report was issued.

\section{Onsite Reports}

\section{Natural Radioactivity Content of the Savannah River Plant}

DP27 Jun 1951-Jan 1953

Works Technical Department Data Record, Health Physics Site Survey Data
$\begin{array}{llll}\text { DPSPU 54-11-12 } & \text { Jan-Jul } 1953 & \text { No report } & \text { Jul-Dec } 1953\end{array}$

Radioactivity in the Environment of the Savannah River Plant

DP92

$$
\text { Jan-Jul } 1954
$$

\section{Semiannual Progress Report-Regional \\ DPSP 55-25-34 Jul-Dec 1954}

DPSP 56-25-13 Jan-Jun 1955

\section{Health Physics Regional Monitoring}

$\begin{array}{lc}\text { DPSP 56-25-54 (DEL) } & \text { Jul-Dec } 1955 \\ \text { DPSP 56-25-4 (DEL) } & \text { Jan-Jun } 1956 \\ \text { DPSP 57-25-15 (DEL) } & \text { Jul-Dec } 1956 \\ \text { DPSP 57-25-43 (DEL) } & \text { Jan-Jun } 1957 \\ \text { DPSP 58-25-17 (DEL) } & \text { Jul-Dec } 1957 \\ \text { DPSP 58-25-38 (DEL) } & \text { Jan-Jun 1958 } \\ \text { DPSPU 59-11-23 } & \text { Jul-Dec } 1958 \\ \text { DPSPU 59-11-30 } & \text { Jan-Jun 1959 }\end{array}$

$\begin{array}{lr}\text { DPSPU 60-11-9 } & \text { Jul-Dec } 1959 \\ \text { DPSP 60-25-26 (DEL) } & \text { Jan-Jun } 1960 \\ \text { DPSP 61-25-4 (DEL) } & \text { Jul-Dec } 1960 \\ \text { DPSP 62-25-2 (DEL) } & \text { Jan-Jun } 1961 \\ \text { DPSP 62-25-9 (DEL) } & \text { Jul-Dec } 1961 \\ \text { DPSP 63-25-3 (DEL) } & \text { Jan-Jun } 1962 \\ \text { DPSP 63-25-10 (DEL) } & \text { Jul-Dec } 1962\end{array}$

Environmental Monitoring at the Savannah River Plant

$\begin{array}{lll}\text { DPSPU 64-11-12 } & \text { Jan-Dec } 1963 & \text { DPST 71-302 } \\ \text { DPST 65-302 } & \text { Jan-Dec 1964 } & \text { DPSPU 72-302 } \\ \text { DPST 66-302 } & \text { Jan-Dec 1965 } & \text { DPSPU 73-302 } \\ \text { DPST 67-302 } & \text { Jan-Dec 1966 } & \text { DPSPU 74-302 } \\ \text { DPST 68-302 } & \text { Jan-Dec 1967 } & \text { DPSPU 75-302 } \\ \text { DPST 69-302 } & \text { Jan-Dec 1968 } & \text { DPSPU 76-302 } \\ \text { DPST 70-302 } & \text { Jan-Dec 1969 } & \text { DPSPU 77-302 }\end{array}$

Jan-Dec 1970

Jan-Dec 1971

Jan-Dec 1972

Jan-Dec 1973

Jan-Dec 1974

Jan-Dec 1975

Jan-Dec 1976 
Environmental Monitoring at the Savannah River Plant (cont.)

$\begin{array}{llll}\text { DPSPU 78-302 } & \text { Jan-Dec 1977 } & \text { DPSPU 82-302 } & \text { Jan-Dec 1981 } \\ \text { DPSPU 79-302 } & \text { Jan-Dec 1978 } & \text { DPSPU 83-302 } & \text { Jan-Dec 1982 } \\ \text { DPSPU 80-302 } & \text { Jan-Dec 1979 } & \text { DPSPU 84-302 } & \text { Jan-Dec 1983 } \\ \text { DPSPU 81-302 } & \text { Jan-Dec 1980 } & \text { DPSPU 85-302 } & \text { Jan-Dec 1984 }\end{array}$

\section{Offsite Reports}

Results of the environmental monitoring program that affected the offsite environment have been reported to the public since 1959. These reports contained data from the site boundary and beyond. The offsite report was discontinued in 1985, when the on- and offsite reports were merged into a single publication. A listing of the offsite reports follows.

\section{The Effect of the Savannah River Plant on Environmental Radioactivity}

$\begin{array}{llll}\text { No document number } & \text { Jan-Mar 1960 } & \text { DPST 65-30-2 } & \text { Jan-Jun } 1965 \\ \text { No document number } & \text { Apr-Jun 1960 } & \text { DPST 66-30-1 } & \text { Jul-Dec } 1965 \\ \text { No document number } & \text { Jul-Sep 1960 } & \text { DPST 66-30-2 } & \text { Jan-Jun 1966 } \\ \text { No document number } & \text { Oct-Dec 1960 } & \text { DPST 67-30-1 } & \text { Jul-Dec } 1966 \\ \text { No document number } & \text { Jan-Mar 1961 } & \text { DPST 67-30-2 } & \text { Jan-Jun } 1967 \\ \text { No document number } & \text { Apr-Jun 1961 } & \text { DPST 68-30-1 } & \text { Jul-Dec 1967 } \\ \text { No document number } & \text { Jul-Sep 1961 } & \text { DPST 68-30-2 } & \text { Jan-Jun 1968 } \\ \text { DPSPU 62-30-11 } & \text { Oct-Dec 1961 } & \text { DPST 69-30-1 } & \text { Jul-Dec } 1968 \\ \text { DPSPU 62-30-24 } & \text { Jan-Jun 1962 } & \text { DPST 69-30-2 } & \text { Jan-Jun 1969 } \\ \text { DPSPU 63-30-12 } & \text { Jul-Dec 1962 } & \text { DPST 70-30-1 } & \text { Jul-Dec 1969 } \\ \text { DPSPU 63-30-1 } & \text { Jan-Jun 1963 } & \text { DPST 70-30-2 } & \text { Jan-Jun 1970 } \\ \text { DPSPU 64-30-1 } & \text { Jul-Dec 1963 } & \text { DPST 71-30-1 } & \text { Jul-Dec 1970 } \\ \text { DPSPU 64-30-2 } & \text { Jan-Jun 1964 } & \text { DPST 71-30-16 } & \text { Jan-Jun 1971 } \\ \text { DPSPU 65-30-1 } & \text { Jul-Dec 1964 } & \text { DPST }\end{array}$

\section{Environmental Monitoring in the Vicinity of the Savannah River Plant}

$\begin{array}{llll}\text { DPSPU 72-30-1 } & \text { Jan-Dec 1971 } & \text { DPSPU 79-30-1 } & \text { Jan-Dec } 1978 \\ \text { DPSPU 73-30-1 } & \text { Jan-Dec 1972 } & \text { DPSPU 80-30-1 } & \text { Jan-Dec } 1979 \\ \text { DPSPU 74-30-1 } & \text { Jan-Dec 1973 } & \text { DPSPU 81-30-1 } & \text { Jan-Dec } 1980 \\ \text { DPSPU 75-30-1 } & \text { Jan-Dec 1974 } & \text { DPSPU 82-30-1 } & \text { Jan-Dec } 1981 \\ \text { DPSPU 76-30-1 } & \text { Jan-Dec 1975 } & \text { DPSPU 83-30-1 } & \text { Jan-Dec 1982 } \\ \text { DPSPU 77-30-1 } & \text { Jan-Dec 1976 } & \text { DPSPU 84-30-1 } & \text { Jan-Dec 1983 }\end{array}$

\section{Savannah River Plant Environmental Report}

DPSPU 85-30-1

Jan-Dec 1984

\section{Combined Onsite and Offsite Reports}

In 1985, the onsite and offsite environmental monitoring reports were merged into a single publication. A listing of these reports follows.

\section{Savannah River Site Environmental Report}

$\begin{array}{llll}\text { DPSPU 86-30-1 } & \text { Jan-Dec 1985 } & \text { WSRC-TR-92-186 } & \text { Jan-Dec } 1991 \\ \text { DPSPU 87-30-1 } & \text { Jan-Dec 1986 } & \text { WSRC-TR-93-075 } & \text { Jan-Dec } 1992 \\ \text { DPSPU 88-30-1 } & \text { Jan-Dec 1987 } & \text { WSRC-TR-94-075 } & \text { Jan-Dec } 1993 \\ \text { WSRC-RP-89-59-1a } & \text { Jan-Dec 1988 } & \text { WSRC-TR-95-075 } & \text { Jan-Dec 1994 } \\ \text { WSRC-IM-90-60 } & \text { Jan-Dec 1989 } & \text { WSRC-TR-96-0075 } & \text { Jan-Dec 1995 }\end{array}$

\section{Savannah River Site Environmental Data}

$\begin{array}{ll}\text { WSRC-TR-93-077 } & \text { Jan-Dec } 1992 \\ \text { WSRC-TR-94-077 } & \text { Jan-Dec } 1993\end{array}$
WSRC-TR-95-077

WSRC-TR-96-0077
Jan-Dec 1994

Jan-Dec 1995 


\section{Appendix $F$ Errata from 1995 Report}

The following information was reported incorrectly in the Savannah River Site Environmental Report for 1995 (WSRC-TR-96-0075):

Page 43, right column, second full paragraph: WSRC-TR-075 should have been WSRCTR-95-075. Savannah River Site Environmental Data for 1995 should have been Savannah River Site Environmental Data for 1994 (WSRC-TR-95-077).

Page 62, left column, first paragraph, last sentence: The value $1.7 \mathrm{E}+13 \mathrm{~Bq}$ should have been $1.7 \mathrm{E}+14 \mathrm{~Bq}$.

Page 62, right column, first full paragraph, second line: The value $11 \mathrm{mCi}$ should have been $111 \mathrm{mCi}$.

Page 123, map: The L3R-2 sediment sampling location in figure 9-2, "SRS Stream and Savannah River Nonradiological Sediment Sampling Locations," should have been labeled L3R-3.

Page 201, right column, last paragraph, last sentence: Sentence, which ends incorrectly on page
202, should have read as follows: Boilers constructed after 1971 must meet more stringent standards identified in 40 CFR 60, "New Source Performance Standards."

Page 202, left column, top line on page: Sentence, which begins incorrectly on page 201 , should have read as follows: For process and diesel engine stacks in existence prior to January 1, 1986, and powerhouse stacks built before February 11, 1971, the opacity standard is 40 percent.

Page 204, left column, first paragraph under "Drinking Water" header: Reference to appendix D, "Drinking Water Quality Standards," should have been to appendix D, "Drinking Water Standards." 



\section{Glossary}

\section{A}

absorption - Process by which the number and energy of particles or photons entering a body of matter is reduced by interaction with the matter.

accuracy - Closeness of the result of a measurement to the true value of the quantity.

activity - See radioactivity.

adsorption - Surface retention of solid, liquid, or gas molecules, atoms, or ions by a solid or liquid, as opposed to absorption, the penetration of substances into the bulk of the solid or liquid.

air flow - Rate of flow, measured by mass or volume per unit of time.

air stripping - Process used to decontaminate groundwater by pumping the water to the surface,"stripping" or evaporating the chemicals in a specially-designed tower, and pumping the cleansed water back to the environment.

aliquot - Quantity of sample being used for analysis.

alkalinity - Alkalinity is a measure of the buffering capacity of water, and since $\mathrm{pH}$ has a direct effect on organisms as well as an indirect effect on the toxicity of certain other pollutants in the water, the buffering capacity is important to water quality.

alpha particle - Positively charged particle emitted from the nucleus of an atom having the same charge and mass as that of a helium nucleus (two protons and two neutrons).

ambient air - Surrounding atmosphere as it exists around people, plants, and structures.

analyte - Constituent or parameter that is being analyzed.

analytical detection limit - Lowest reasonably accurate concentration of an analyte that can be detected; this value varies depending on the method, instrument, and dilution used.

anion - Negatively charged ion.

anomaly - Deviation beyond normal variations.
Appendix IX - List of constituents specified by Appendix IX of the Code of Federal Regulations, Title 40, Part 264. Analyses for Appendix IX constituents are required by the Resource Conservation and Recovery Act under specified conditions.

aquifer - Saturated, permeable geologic unit that can transmit significant quantities of water under ordinary hydraulic gradients.

aquitard - Geologic unit that inhibits the flow of water.

atom - Smallest particle of an element capable of entering into a chemical reaction.

Atomic Energy Commission - Federal agency created in 1946 to manage the development, use, and control of nuclear energy for military and civilian application. It was abolished by the Energy Reorganization Act of 1974 and succeeded by the Energy Research and Development Administration (now part of the U.S. Department of Energy and the U.S. Nuclear Regulatory Commission).

bailer - Container lowered into a well to remove water. The bailer is allowed to fill with water and then is removed from the well.

best available demonstrated technology - One or more specified treatment technologies or treatment to meet certain concentration limits for hazardous constituents (required by Resource Conservation and Recovery Act Land Disposal Restrictions treatment standards).

best available technology - Technology that is the best available at the time to treat waste. See best available demonstrated technology.

best management practices - Sound engineering practices that are not, however, required by regulation or by law.

beta particle - Negatively charged particle emitted from the nucleus of an atom. It has a mass and charge equal to those of an electron. 
blank - Control sample that is identical, in principle, to the sample of interest, except that the substance being analyzed is absent. In such cases, the measured value or signal for the substance being analyzed is believed to be due to artifacts. Under certain circumstances, that value may be subtracted from the measured value to give a net result reflecting the amount of the substance in the sample. The Environmental Protection Agency does not permit the subtraction of blank results in Environmental Protection Agency-regulated analyses.

blind blank - Sample container of deionized water sent to a laboratory under an alias name as a quality control check.

blind replicate - In the Environmental Monitoring Section groundwater monitoring program, a second sample taken from the same well at the same time as the primary sample, assigned an alias well name, and sent to a laboratory for analysis (as an unknown to the analyst).

blind sample - Control sample of known concentration in which the expected values of the constituent are unknown to the analyst.

borrow pit - Excavation dug to provide material such as sand and gravel (borrow) to be used as fill elsewhere.

Brailsford pump - Surface water sampling device which is stationed on a stand above a stream. The device, which continuously samples stream water, consists of an all-plastic valveless piston driven by a Brailsford small electric motor. The variable pump speed is set normally at 0.75 gallons/day.

calibration - Determination of variance from a standard of accuracy of a measuring instrument to ascertain necessary correction factors.

Carolina bay - Type of shallow depression commonly found on the coastal Carolina plains. Carolina bays are typically circular or oval. Some are wet or marshy, while others are dry.

cation - Positively charged ion.
Central Savannah River Area (CSRA) - Eighteencounty area in Georgia and South Carolina surrounding Augusta, Georgia. The Savannah River Site is included in the Central Savannah River Area. Counties are Richmond, Columbia, McDuffie, Burke, Emanuel, Glascock, Jenkins, Jefferson, Lincoln, Screven, Taliaferro, Warren, and Wilkes in Georgia and Aiken, Edgefield, Allendale, Barnwell, and McCormick in South Carolina.

chain-of-custody - Form that documents sample collection, transport, analysis, and disposal.

chemical oxygen demand - Indicates the quantity of oxidizable materials present in a water and varies with water composition, concentrations of reagent, temperature, period of contact, and other factors.

chlorocarbons - Compounds of carbon and chlorine, or carbon, hydrogen, and chlorine, such as carbon tetrachloride, chloroform, tetrachloroethylene, etc. They are among the most significant and widespread environmental contaminants. Classified as hazardous wastes, chlorocarbons may have a tendency to cause detrimental effects, such as birth defects.

cleanup - Actions taken to deal with release or potential release of hazardous substances. This may mean complete removal of the substance; it also may mean stabilizing, containing, or otherwise treating the substance so that it does not affect human health or the environment.

closure - Control of a hazardous waste management facility under Resource Conservation and Recovery Act requirements.

compliance - Fulfillment of applicable requirements of a plan or schedule ordered or approved by government authority.

composite - Blending of more than one portion to make a sample for analysis.

comprehensive analyses - Group of analyses that forms the core of the Environmental Monitoring Section groundwater monitoring program each quarter.

Comprehensive Environmental Response, Compensation, and Liability Act (CERCLA) - This act addresses the cleanup of hazardous substances and establishes a National Priorities List of sites targeted for assessment and, if necessary, restoration (commonly known as "Superfund"). 
Comprehensive Environmental Response, Compensation, and Liability Act (CERCLA)-reportable release - Release to the environment that exceeds reportable quantities as defined by the Comprehensive Environmental Response, Compensation, and Liability Act.

concentration - Amount of a substance contained in a unit volume or mass of a sample.

conductivity - Measure of water's capacity to convey an electric current. This property is related to the total concentration of the ionized substances in a water and the temperature at which the measurement is made.

confined aquifer - Fully saturated aquifer with an aquitard lying above it.

contamination - Deposition of unwanted material on the surfaces of structures, areas, objects, or personnel.

cosmic radiation - Ionizing radiation with very high energies, originating outside the earth's atmosphere. Cosmic radiation is one source contributing to natural background radiation.

count-Signal that announces an ionization event within a counter; a measure of the radiation from an object or device.

counter - General designation applied to radiation detection instruments or survey meters that detect and measure radiation.

counting geometry - Well-defined sample size and shape for which a counting system has been calibrated.

criteria pollutant - any of the pollutants commonly used as indices for air quality that can have a serious effect on human health and the environment, including sulfur dioxide, nitrogen dioxide, total suspended particulates, $\mathrm{PM}_{10}$, carbon monoxide, ozone, gaseous fluorides, and lead.

criticality - Condition in which a nuclear reactor is just self-sustaining. curie - Unit of radioactivity. One curie is defined as 3.7 $\times 10^{10}$ ( 37 billion) disintegrations per second. Several fractions and multiples of the curie are commonly used:

kilocurie $(\mathrm{kCl})-10^{3} \mathrm{Ci}$, one thousand curies; $3.7 \mathrm{x}$ $10^{13}$ disintegrations per second.

millicurie $(\mathrm{mCi})-10^{-3} \mathrm{Ci}$, one-thousandth of a curie; $3.7 \times 10^{7}$ disintegrations per second.

microcurie $(\mu \mathrm{Ci})-10^{-6} \mathrm{Ci}$, one-millionth of a curie; $3.7 \times 10^{4}$ disintegrations per second.

picocurie (pCi) $-10^{-12} \mathrm{Ci}$, one-trillionth of a curie; 0.037 disintegrations per second.

decay (radioactive) - Spontaneous transformation of one radionuclide into a different radioactive or nonradioactive nuclide, or into a different energy state of the same radionuclide.

decay time - Time taken by a quantity to decay to a stated fraction of its initial value.

decontamination and decommissioning - See environmental restoration.

derived concentration guide - Concentration of a radionuclide in air or water that, under conditions of continuous exposure for one year by one exposure mode (i.e., ingestion of water, submersion in air or inhalation), would result in either an effective dose equivalent of $0.1 \mathrm{rem}(1 \mathrm{mSv})$ or a dose equivalent of $5 \mathrm{rem}$ ( 50 $\mathrm{mSv}$ ) to any tissue, including skin and lens of the eye. The guides for radionuclides in air and water are given in Department of Energy Order 5400.5.

desorption - Process of removing a sorbed substance by the reverse of adsorption or absorption.

detector - Material or device (instrument) that is sensitive to radiation and can produce a signal suitable for measurement or analysis.

diatometer - Diatom collection equipment consisting of a series of microscope slides in a holder that is used to determine the amount of algae in a water system.

diatoms - Unicellular or colonial algae of the class $\mathrm{Ba}$ cillariophyceae, having siliceous cell walls with two overlapping, symmetrical parts. Diatoms represent the predominant periphyton (attached algae) in most water bodies and have been shown to be reliable indicators of water quality. 
disintegration (nuclear) - Spontaneous nuclear transformation (radioactivity) characterized by the emission of energy and/or mass from the nucleus of an atom.

dissolved oxygen - Desirable indicator of satisfactory water quality in terms of low residuals of biologically available organic materials. Dissolved oxygen prevents the chemical reduction and subsequent leaching of iron and manganese from sediments.

dose - Energy imparted to matter by ionizing radiation. The unit of absorbed dose is the rad, equal to 0.01 joules per kilogram in any medium.

absorbed dose - Quantity of radiation energy absorbed by an organ, divided by the organ's mass. Absorbed dose is expressed in units of rad (or gray) (1 $\mathrm{rad}=0.01 \mathrm{~Gy}$ ).

dose equivalent - Product of the absorbed dose (rad) in tissue and a quality factor. Dose equivalent is expressed in units of rem (or sievert) $(1 \mathrm{rem}=0.01$ sievert).

committed dose equivalent - Calculated total dose equivalent to a tissue or organ over a 50-year period after known intake of a radionuclide into the body. Contributions from external dose are not included. Committed dose equivalent is expressed in units of rem (or sievert).

committed effective dose equivalent - Sum of the committed dose equivalents to various tissues in the body, each multiplied by the appropriate weighting factor. Committed effective dose equivalent is expressed in units of rem (or sievert).

effective dose equivalent - Sum of the dose equivalents received by all organs or tissues of the body after each one has been multiplied by an appropriate weighting factor. The effective dose equivalent includes the committed effective dose equivalent from internal deposition of radionuclides and the effective dose equivalent attributable to sources external to the body.

collective dose equivalent/collective effective dose equivalent - Sums of the dose equivalents or effective dose equivalents of all individuals in an exposed population within a 50 -mile $(80-\mathrm{km})$ radius, and expressed in units of person-rem (or personsievert). When the collective dose equivalent of interest is for a specific organ, the units would be organ-rem (or organ-sievert). The 50-mile distance is measured from a point located centrally with respect to major facilities or DOE program activities.

dosimeter - Portable detection device for measuring the total accumulated exposure to ionizing radiation.

dosimetry - Theory and application of principles and techniques involved in the measurement and recording of radiation doses. Its practical aspect is concerned with using various types of radiation instruments to make measurements.

downgradient - In the direction of decreasing hydrostatic head.

downgradient well - Well that is installed hydraulically downgradient of a site and may be capable of detecting migration of contaminants from a site.

drinking water standards - Federal primary drinking water standards, both proposed and final, as set forth by EPA.

duplicate result - Result derived by taking a portion of a primary sample and performing the identical analysis on that portion as is performed on the primary sample.

effluent - Liquid or gaseous waste discharge to the environment.

effluent monitoring - Collection and analysis of samples or measurements of liquid and gaseous effluents for purposes of characterizing and quantifying the release of contaminants, assessing radiation exposures of members of the public, and demonstrating compliance with applicable standards.

environmental monitoring - Program at Savannah River Site that includes effluent monitoring and environmental surveillance with dual purpose of (1) showing compliance with federal, state, and local regulations, as well as with U.S. Department of Energy orders, and (2) monitoring any effects of site operations on onsite and offsite natural resources and on human health.

environmental restoration - Department of Energy program that directs the assessment and cleanup of its sites (remediation) and facilities (decontamination and decommissioning) contaminated with waste as a result of nuclear-related activities. 
environmental surveillance - Collection and analysis of samples of air, water, soil, foodstuffs, biota, and other media from Department of Energy sites and their environs and the measurement of external radiation for purposes of demonstrating compliance with applicable standards, assessing radiation exposures to members of the public, and assessing effects, if any, on the local environment.

equipment blank - Sample container of deionized water that has been pumped through or has filled a sampling device (e.g., well pump bailer). Laboratory analysis of the blank can identify potential contaminants in water, sample container, or analytical equipment.

exceedance-Term used by the Environmental Protection Agency and the South Carolina Department of Health and Environmental Control that denotes a report value is more than the upper guide limit. This term is found on the Discharge Monitoring Report forms that are submitted to the Environmental Protection Agency or the South Carolina Department of Health and Environmental Control.

exposure (radiation) - Incidence of radiation on living or inanimate material by accident or intent. Background exposure is the exposure to natural background ionizing radiation. Occupational exposure is that exposure to ionizing radiation which takes place during a person's working hours. Population exposure is the exposure to the total number of persons who inhabit an area.

exposure pathway - Route that materials follow to get to the environment and then to people.

external radiation - Exposure to ionizing radiation when the radiation source is located outside the body.

fecal coliform - Coliform group comprises all of the aerobic, nonspore-forming, rod-shaped bacteria. The test determines the presence or absence of coliform organisms.

Federal Facility Agreement (FFA) - Agreement negotiated among the Department of Energy, the Environmental Protection Agency, and the South Carolina Department of Health and Environmental Control, specifying how the Savannah River Site will address contamination or potential contamination to meet regulatory requirements at the Savannah River Site waste units identified for evaluation and, if necessary, cleanup. feral hog - Hog that has reverted to the wild state from domestication.

field blank - Sample container of deionized water generated by filling the sample container at the sample location and treated as a groundwater sample.

food web - Series of organisms related by predatorprey and consumer-resource interactions; the entirety of interrelated food chains in an ecological community.

formation - Mappable unit of consolidated or unconsolidated geologic material of a characteristic lithology or assemblage of lithologies.

frit - Fused or partially fused materials used in glassmaking.

$\mathbf{G}$

gamma ray - High-energy, short wavelength electromagnetic radiation emitted from the nucleus of an excited atom. Gamma rays are identical to $\mathrm{X}$-rays except for the source of the emission.

gamma-emitting radionuclide - Radionuclide that emits gamma rays.

gamma spectrometry - System consisting of a detector, associated electronics, and a multichannel analyzer that is used to analyze samples for gamma-emitting radionuclides.

gas chromatographic volatile organic analyses (GC VOA) - Analytical technique detecting and quantifying volatile organic compounds in a sample by gas chromatography.

Gaussian puff/plume model - Computer simulated atmospheric dispersion of a release using a Gaussian (normal) statistical distribution to determine concentrations in air.

Geiger-Mueller counter - Highly sensitive, gas-filled radiation detector, which operates at voltages sufficiently high to produce ionization. The counter is used primarily in the detection of gamma radiation and beta emission. It is named for Hans Geiger and W. Mueller, who invented it in 1928.

genotoxicology - Study of the effects of chemicals or radioactive contaminants on the genetics of individual animals or plants.

grab sample - Sample collected instantaneously with a glass or plastic bottle placed below the water surface to collect surface water samples (also called dip samples). 
groundwater (unconfined) - Groundwater exposed to the unsaturated zone.

H

half-life (biological) - Time required for a biological system, such as that of a human, to eliminate by natural processes half the amount of a substance (such as a radioactive material) that has entered it.

half-life (radiological) - Time required for half of a given number of atoms of a specific radionuclide to decay. Each nuclide has a unique half-life.

head reversal - Hydrologic phenomenon in which a deeper formation has a higher water pressure than a more shallow formation in the same location. This condition results in a tendency for groundwater to flow upward from the deeper media to the more shallow formation.

heavy water - Water in which the molecules contain oxygen and deuterium, an isotope of hydrogen that is heavier than ordinary hydrogen.

herbaceous - Having little or no woody tissue.

herbicides/pesticides - Suite of analyses consisting of 2,4-dichlorophenoxyacetic acid, endrin, lindane, methoxychlor, toxaphene, and 2,4,5-TP (silvex).

hydraulic gradient - Difference in hydraulic head over a specified distance.

hydraulic head - Elevation of the water in a well or piezometer.

hydrogeology - Hydrologic aspects of site geology.

hydrology-Science that treats the occurrence, circulation, distribution, and properties of the waters of the earth, and their reaction with the environment.

in situ - In its original place. Field measurements taken without removing the sample from its origin; remediation performed while groundwater remains below the surface.

inorganic - Involving matter other than plant or animal. internal dose factor - Factor used to convert intakes of radionuclides to dose equivalents.

internal radiation - Internal radiation occurs when natural radionuclides enter the body by ingestion of foods, milk, and water, and by inhalation. Radon is the major contributor to the annual dose equivalent for internal radionuclides.

ion-Atom or compound that carries an electrical charge.

ion exchange - Process in which a solution containing soluble ions is passed over a solid ion exchange column that removes the soluble ions by exchanging them with labile ions from the surface of the column. The process is reversible so that the trapped ions are removed (eluted) from the column and the column is regenerated.

irradiation - Exposure to radiation.

Isco sampler - Portable, microprocessor-controlled water sampler that utilizes a peristaltic pump for sample collection. The sampler may be used with a flowmeter to obtain a flow-proportional sample or without a flowmeter to obtain a time-proportional sample.

isotopes - Forms of an element having the same number of protons in their nuclei but differing in the number of neutrons.

long-lived isotope - Radionuclide that decays at such a slow rate that a quantity of it will exist for an extended period (half-life is greater than three years).

short-lived isotope - Radionuclide that decays so rapidly that a given quantity is transformed almost completely into decay products within a short period (half-life is two days or less).

laboratory blank - Deionized water sample generated by the laboratory; a laboratory blank is analyzed with each batch of samples as an in-house check of analytical procedures. Also called an internal blank.

layup - To put in condition for possible future use.

liquid scintillation cocktail - Solution combined with a radioactive sample which converts the energy of the particle emitted during radioactive decay into light, which is detected by a liquid scintillation counter. 
liquid scintillation counter - Combination of phosphor, photomultiplier tube, and associated circuits for counting light emissions produced in the phosphors.

lower limit of detection (LLD) - Smallest concentration/amount of analyte that can be reliably detected in a sample at a 95 percent confidence level.

$\mathbf{M}$

macroinvertebrates - Size-based classification used for a variety of insects and other small invertebrates; as defined by the Environmental Protection Agency, those organisms that are retained by a No. 30 (590 micron) U.S. Standard Sieve.

macrophyte - A plant that can be observed with the naked eye.

manmade radiation - Radiation sources such as consumer products, medical procedures, and nuclear industry.

maximally exposed individual - Hypothetical individual who remains in an uncontrolled area and would, when all potential routes of exposure from a facility's operations are considered, receive the greatest possible dose equivalent.

mean relative difference (MRD) - Percentage error based on statistical analysis.

mercury - Silver-white, liquid metal solidifying at $-38.9^{\circ} \mathrm{C}$ to form a tin-white, ductile, malleable mass. It is widely distributed in the environment and biologically is a nonessential or nonbeneficial element. Human poisoning due to this highly toxic element has been clinically recognized.

microbes - Microscopic organisms.

migration-Transfer or movement of a material through the air, soil, or groundwater.

milliroentgen (mR) - Measure of X-ray or gamma radiation. The unit is one-thousandth of a roentgen.

minimum detectable concentration (MDC) - Smallest amount or concentration of a radionuclide that can be distinguished in a sample by a given measurement system at a preselected counting time and at a given confidence level. monitoring - Process whereby the quantity and quality of factors that can affect the environment and/or human health are measured periodically in order to regulate and control potential impacts.

$\mathrm{N}$

natural radiation - Radiation arising from cosmic and other naturally occurring radionuclide (such as radon) sources present in the environment.

nonpoint source - any source that does not meet the definition for point source (National Emission Standards for Hazardous Air Pollutants radionuclide program).

nonroutine radioactive release - Unplanned or nonscheduled release of radioactivity to the environment.

nuclide - Atom specified by its atomic weight, atomic number, and energy state. A radionuclide is a radioactive nuclide.

organic - Of, relating to, or derived from living organisms (plant or animal).

outcrop - Place where groundwater is discharged to the surface. Springs, swamps, and beds of streams and rivers are the outcrops of the water table.

outfall - Point of discharge (e.g., drain or pipe) of wastewater or other effluents into a ditch, pond, or river.

paddlewheel sampler - Water sampling device, constructed of a Lexan ${ }^{A}$ wheel, suspended on two pontoons and anchored in streams and rivers.

parameter - Analytical constituent; chemical compound(s) or property for which an analytical request may be submitted.

parts per million (ppm) - Unit measure of concentration equivalent to the weight/volume ratio expressed as $\mathrm{mg} / \mathrm{L}$.

percolation - Slow movement of a liquid through a porous material. 
permeability - Physical property that describes the ease with which water may move through the pore spaces and cracks in a solid.

person-rem - Collective dose to a population group. For example, a dose of one rem to 10 individuals results in a collective dose of 10 person-rem.

$\mathrm{pH}$ - Measure of the hydrogen ion concentration in an aqueous solution. Acidic solutions have a $\mathrm{pH}$ from $0-6$, basic solutions have a $\mathrm{pH}>7$, and neutral solutions have a $\mathrm{pH}=7$.

piezometer - Instrument used to measure the potentiometric surface of the groundwater. Also, a well designed for this purpose.

plume - Volume of contaminated air or water originating at a point-source emission (e.g., a smokestack) or a waste source (e.g., a hazardous waste disposal site).

point of compliance - Vertical surface located at the hydraulically downgradient limit of the waste management area that extends down into the uppermost aquifer underlying the regulated units.

point source - stack or vent (National Emission Standards for Hazardous Air Pollutants radionuclide program).

population dose commitment - See collective dose equivalent under dose.

priority pollutants - Group of approximately 130 chemicals (about 110 are organics) that appear on an Environmental Protection Agency list because they are toxic and relatively common in industrial discharges.

process sewer - Pipe or drain, generally located underground, used to carry off process water and/or waste matter.

process water - Water used within a system process.

purge - To remove water prior to sampling, generally by pumping or bailing.

purge water - Water that has been removed prior to sampling; water that has been released to seepage basins to allow a significant part of tritium to decay before the water outcrops to surface streams and flows to the Savannah River.
Q

quality assurance (QA) - Any action in environmental monitoring to assure the reliability of monitoring and measurement data.

quality control (QC) - In environmental monitoring, the routine application of procedures to obtain the required standards of performance in monitoring and measurement processes.

R

rad - Unit of absorbed dose deposited in a volume of material.

radiation detection instruments - Devices that detect and record the characteristics of ionizing radiation.

radioactivity - Spontaneous emission of radiation, generally alpha or beta particles, or gamma rays, from the nucleus of an unstable isotope.

radioisotopes - Radioactive isotopes.

radionuclide - Unstable nuclide capable of spontaneous transformation into other nuclides by changing its nuclear configuration or energy level. This transformation is accompanied by the emission of photons or particles.

real-time instrumentation - Operation in which programmed responses to an event are essentially simultaneous with the event itself.

reforestation - Process of planting new trees on land once forested.

release - Any discharge to the environment. Environment is broadly defined as any water, land, or ambient air.

rem - Unit of dose equivalent (absorbed dose in rads $x$ the radiation quality factor). Dose equivalent is frequently reported in units of millirem (mrem) which is one-thousandth of a rem.

remediation - Assessment and cleanup of Department of Energy sites contaminated with waste as a result of past activities. See environmental restoration.

replicate - In the Environmental Monitoring Section groundwater monitoring program, a second sample from the same well taken at the same time as the primary sample and sent to the same laboratory for analysis. 
replicate result - Analytical result of a blind replicate sample. See blind replicate.

Resource Conservation and Recovery Act (RCRA) - Federal legislation that regulates the transport, treatment, and disposal of solid and hazardous wastes. This act also requires corrective action for releases of hazardous waste at inactive waste units.

Resource Conservation and Recovery Act (RCRA) closure certification - Certification prepared within 60 days of closure by the owner or operator of an individual waste disposal unit at a facility or an incinerator, tank, or container storage facility, and a qualified, independent, registered professional engineer. The document certifies that the facility or unit was closed in accordance with the approved facility closure plan.

Resource Conservation and Recovery Act (RCRA) interim status - Statutorily conferred authorization for a hazardous waste management unit to operate pending issuance or denial of its Resource Conservation and Recovery Act permit. Interim status provisions, contained in 40 CFR Part 265, allow a facility to operate legally. The facility is considered to be operating under a permit until the Environmental Protection Agency takes final administrative action on that facility's permit application.

Resource Conservation and Recovery Act (RCRA) site - Solid waste management unit under Resource Conservation and Recovery Act regulation. See Resource Conservation and Recovery Act.

retention basin - Unlined basin used for emergency, temporary storage of potentially contaminated cooling water from chemical separations activities.

RFI Program - RCRA Facility Investigation Program; Environmental Protection Agency-regulated investigation of a solid waste management unit with regard to its potential impact on the environment.

RFI/RI - RCRA Facility Investigation/Remedial Investigation. See RFI/RI Program.

RFIRI Program - RCRA Facility Investigation/Remedial Investigation Program. At the Savannah River Site, the expansion of the RFI Program to include Comprehensive Environmental Response, Compensation, and Liability Act and hazardous substance regulations.

roentgen - Unit of exposure from $\mathrm{X}$ - or gamma rays. One roentgen equals $2.58 \times 10^{-4}$ coulombs per kilogram of air. routine radioactive release - Planned or scheduled release of radioactivity to the environment.

\section{$\mathbf{s}$}

screen zone - In well construction, the section of a formation that contains the screen, or perforated pipe that allows water to enter the well.

seep - Area, generally small, where water percolates slowly to the land surface.

seepage basin - Excavation that receives wastewater. Insoluble materials settle out on the floor of the basin and soluble materials seep with the water through the soil column where they are removed partially by ion exchange with the soil. Construction may include dikes to prevent overflow or surface runoff.

sensitivity - Capability of methodology or instruments to discriminate between samples with differing concentrations or containing varying amounts of analyte.

set-aside areas - Thirty areas covering 14,288 acres set aside to protect rare, threatened, and endangered biota, as well as unique habitats.

settleable solids - Material settling out of suspension within a defined period.

settling basin - Temporary holding basin (excavation) that receives wastewater which is subsequently discharged.

sidegradient well - Well that intercepts groundwater flowing next to a site; a sidegradient well is located neither upgradient nor downgradient to the monitored site.

Sievert (Sv) - SI (International System of Units) unit of dose equivalent, $1 \mathrm{~Sv}=100 \mathrm{rem}$.

site stream - Any natural stream on the Savannah River Site. Surface drainage of the site is via these streams to the Savannah River.

Solid Waste Disposal Facility - Place for burying unwanted radioactive material to prevent escape of radioactivity. The surrounding water acts as a shield. Such material is placed in watertight, noncorrosive containers so that it cannot leach out and invade underground water.

source - Point or object from which radiation or contamination emanates. 
source check - Radioactive source with a known amount of radioactivity used to check the performance of the radiation detector instrument.

source term - Quantity of radioactivity released in a set period of time that is traceable to the starting point of an effluent stream or migration pathway.

specific conductance - Ability of water to conduct electricity; this ability varies in proportion to the amount of ionized minerals in the water.

spike - Addition of a known amount of reference material containing the analyte of interest to a blank sample.

split sample - Two samples from the same well, taken at the same time, and sent to two different laboratories for analysis.

stable - Not radioactive or not easily decomposed or otherwise modified chemically.

stack - Vertical pipe or flue designed to exhaust airborne gases and suspended particulate matter.

standard deviation - Indication of the dispersion of a set of results around their average.

stormwater runoff - Surface streams that appear after precipitation.

strata - Beds, layers, or zones of rocks.

substrate - Substance, base, surface, or medium in which an organism lives and grows.

Superfund - see Comprehensive Environmental Response, Compensation, and Liability Act (CERCLA).

supernatant - Portion of a liquid above settled materials in a tank or other vessel.

surface water - All water on the surface of the earth, as distinguished from groundwater.

$\mathbf{T}$

tank farm - Installation of interconnected underground tanks for storage of high-level radioactive liquid wastes.

temperature - Thermal state of a body considered with its ability to communicate heat to other bodies. terrestrial radiation - Ionizing radiation emitted from radioactive materials, primarily potassium- 40 , thorium, and uranium, in the earth's soils. Terrestrial radiation contributes to natural background radiation.

thermoluminescent dosimeter (TLD) - Device used to measure external gamma radiation.

total activity - Total quantity of radioactive decay particles that are emitted from a sample.

total dissolved solids - Dissolved solids and total dissolved solids are terms generally associated with freshwater systems and consist of inorganic salts, small amounts of organic matter and dissolved materials.

total organic halogens - Measure of the total concentration of organic compounds that have one or more halogen atoms.

total phosphorus - When concentrations exceed $25 \mathrm{mg} / \mathrm{L}$ at the time of the spring turnover on a volumeweighted basis in lakes or reservoirs, it may occasionally stimulate excessive or nuisance growths of algae and other aquatic plants.

total solids - Sum of total dissolved solids and suspended solids.

total suspended particulates - Refers to the concentration of particulates in suspension in the air irrespective of the nature, source, or size of the particulates.

transmissive zone - Zone of sediments sufficiently porous and permeable to allow the flow of groundwater through the zone.

transport pathway - pathway by which a released contaminant physically is transported from its point of discharge to a point of potential exposure to humans. Typical transport pathways include the atmosphere, surface water, and groundwater.

transuranic waste - Solid radioactive waste containing primarily alpha-emitting elements heavier than uranium.

turbidity - Measure of the concentration of sediment or suspended particles in solution.

upgradient - In the direction of increasing hydrostatic head.

V

vadose zone - Soil zone located above the water table. 
vitrification - Process of changing into glass.

volatile organic compounds - Broad range of organic compounds, commonly halogenated, that vaporize at ambient, or relatively low, temperatures (e.g., acetone, benzene, chloroform, and methyl alcohol).

waste unit - Inactive area that is known to have received contamination or had a release to the environment.

water table - Planar, underground surface beneath which earth materials, as soil or rock, are saturated with water.

watershed - Region draining into a river, river system, or body of water. weighting factor - Value used to calculate dose equivalents. It is tissue specific and represents the fraction of the total health risk resulting from uniform, whole-body irradiation that could be contributed to that particular tissue. The weighting factors used in this report are recommended by the International Commission on Radiological Protection (Publication 26).

wetlands - Lowland area, such as a marsh or swamp, inundated or saturated by surface or groundwater sufficiently to support hydrophytic vegetation typically adapted for life in saturated soils.

wind rose - Diagram in which statistical information concerning direction and speed of the wind at a location is summarized.

worldwide fallout - Radioactive debris from atmospheric weapons tests that has been deposited on the earth's surface after being airborne and cycling around the earth. 



\section{References}

Arnett, 1993 Arnett, M.W., L.K. Karapatakis, and A.R. Mamatey, 1993, Savannah River Site Environmental Report for 1993, WSRC-TR-94-075, Savannah River Site, Aiken, S.C.

Bebbington, 1990 Bebbington, W.P., 1990, History of Du Pont at the Savannah River Site, E.I. du Pont de Nemours and Company, Wilmington, Del.

BEIR V, 1990 National Research Council, 1990, Health Effects of Exposure to Low Levels of Ionizing Radiation, BEIR V Report, Washington, D.C., 1982.

Blohm, 1995 Blohm, J.D., 1995, Pen Branch Stream Corridor and Delta Wetlands Change Assessment, Savannah River Site, EGG-11265-1013, Savannah River Site, Aiken, S.C. (available to the public from the National Technical Information Service, U.S. Department of Commerce, 5285 Port Royal, Springfield, Va. 22161)

CAB, 1994-1995 Savannah River Site Citizens Advisory Board, Annual Report 1994-1995, Savannah River Site, Aiken, S.C.

CDC Task 3, 1995 Till, J.E., et al., Savannah River Site Dose Reconstruction Project, Phase I, Data Retrieval and Assessment, Task 3, Evaluation of Materials Released from the Savannah River Site, RAC Report No. 1-CDC-SRS-95-Final, June 1995, Radiological Assessments Corporation, Neeses, S.C.

CDC Task 4, 1995 Till, J.E., et al., Savannah River Site Dose Reconstruction Project, Phase I, Data Retrieval and Assessment, Task 4, Identifying Sources of Environmental Monitoring and Research Data, RAC Report No. 2-CDC-SRS-95-Final, June 1995, Radiological Assessments Corporation, Neeses, S.C.

Clarke, 1997 Clarke, J.S. (U.S. Geological Survey), 1997, "Groundwater Flow and Stream Aquifer Relations Near the Savannah River Site, Georgia and South Carolina," Proceedings of the 1997 Georgia Water Resources Conference, University of Georgia, Athens, Ga.

Davis et al., 1989 Davis, H.A., D.K. Martin, and J.L. Todd, 1989, Savannah River Site Environmental Report for 1988, WSRC-RP-89-59-1, Savannah River Site, Aiken, S.C.

DOE, 1988 U.S. Department of Energy, 1988, External and Internal Dose Conversion Factors for Calculation of Dose to the Public, DOE/EH-0070\&71, U.S. Department of Energy, Washington, D.C.

DOE, 1990 U.S. Department of Energy, 1990, Final Environmental Impact Statement, Continued Operation of $K$-, L-, and P-Reactors, Savannah River Site, Aiken, South Carolina, DOE/EIS-0147.

DOE, 1991 U.S. Department of Energy, 1991, Environmental Regulatory Guide for Radiological Effluent Monitoring and Environmental Surveillance, DOE/EH-0173T, National Technical Information Service, Springfield, Va.

DOE, 1992 U.S. Department of Energy, 1992, Mitigation Action Plan, 1992 Annual Update, Continued Operation of $K-, L$-, and P-Reactors, Environmental Impact Statement, DOE/EIS-0147.

DOE, 1996 U.S. Department of Energy, 1996. Nuclear Weapons Nonproliferation Policy Concerning Foreign Research Reactor Spent Nuclear Fuel, Record of Decision, Washington, D.C.

Dulohery, 1996 Dulohery, N.J., C.S. Bunton, C.C. Trettin, and W.H. McKee, Jr., 1996, Reforestation of the Pen Branch Corridor and Delta, U.S. Department of Agriculture Forest Service, Establishment Report, Center for Forested Wetlands Research, Charleston, S.C.

EPA, 1989 U.S. Environmental Protection Agency, 1989, "National Emission Standards for Hazardous Air Pollutants; Radionuclides," Title 40 Code of Federal Regulations, Part 61, Volume 54, No. 240, Washington, D.C.

EPA, 1991 U.S. Environmental Protection Agency, 1991, Risk Assessment Guidance for Superfund, Volume I: Human Health Evaluation Manual Supplemental Guidance "Standard Default Exposure Factors," OSWER Directive: 9285.6-03, Washington, D.C. 
EPA, 1995 U.S. Environmental Protection Agency, 1995, Health Effects Assessment Summary Tables FY 1995, 11/95 Supplement, Publication 9200.6-303 (95-1), Washington, D.C.

Fact Sheet, 1995 Westinghouse Savannah River Company, 1992, "Environmental Restoration," Fact Sheet, WSRC-MS-96-0623, Savannah River Site, Aiken, S.C.

Fact Sheet, 1996a Westinghouse Savannah River Company, 1996, "Savannah River Site," Fact Sheet, WSRC-MS-96-0620, Rev 1, Savannah River Site, Aiken, S.C.

Fact Sheet, 1996b Westinghouse Savannah River Company, 1996, "Savannah River Ecology Laboratory," Fact Sheet, WSRC-MS-97-0231, Savannah River Site, Aiken, S.C.

Fact Sheet, 1996c Westinghouse Savannah River Company, 1996, "High-Level Waste Processing Facilities," Fact Sheet, WSRC-MS-96-0619, Rev 1, Savannah River Site, Aiken, S.C.

Fact Sheet, 1996d Westinghouse Savannah River Company, 1996, "F Canyon," Fact Sheet, WSRC-MS-97-0230, Savannah River Site, Aiken, S.C.

Fact Sheet, 1996e Westinghouse Savannah River Company, 1996, "FB Line," Fact Sheet, WSRC-MS-97-0229, Savannah River Site, Aiken, S.C.

Fact Sheet, 1996f Westinghouse Savannah River Company, 1996, "H Canyon," Fact Sheet, WSRC-MS-97-0228, Savannah River Site, Aiken, S.C.

Fact Sheet, 1996g Westinghouse Savannah River Company, 1996, "HB Line," Fact Sheet, WSRC-MS-97-0225, Savannah River Site, Aiken, S.C.

Fledderman, 1995 Fledderman, P.D., 1995, Interview with William G. Weil, Water Operations Superintendent - City of Savannah Industrial and Domestic Water Supply, January 9, 1995, Savannah, Ga.

Hamby, 1991 Hamby, D.M., 1991, Land and Water Use Characteristics in the Vicinity of the Savannah River Site (U), WSRC-RP-91-17, Savannah River Site, Aiken, S.C.

Hamby, 1993 Hamby, D.M., 1993, "A Probabilistic Estimation of Atmospheric Tritium Dose," Health Physics, Volume 65, Number 1, Williams \& Wilkins, Baltimore, Md.

Hamby and Bauer, 1994 Hamby, D.M., and L.R. Bauer, 1994, "The Vegetation-to-air Concentration Ratio in a Specific Activity Atmospheric Tritium Model," Health Physics, Volume 66, Number 3, Williams \& Wilkins, Baltimore, Md.

Hamby and Parker, 1991 Hamby, D.M., and M.J. Parker, 1991, Gaussian Dispersion and Dosimetric Modeling Sensitivity to Area-Specific 1982-1986 Meteorological Data Collected at the Savannah River Site (U), WSRC-RP-91-909, Westinghouse Savannah River Company, Aiken, S.C.

Heffner, 1997 Heffner, J.D., 1997, Summary Memo ["Tritium in Groundwater (U)," ESH-EMS-97-0557, June 9, 1997] from Trans-River Flow Project Meeting with P.D. Fledderman and A.R. Mamatey, April 7, 1997, Savannah River Site, Aiken, S.C.

Hunter, 1990 Hunter, C.H., 1990, A Climatological Description of the Savannah River Site, WSRC-RP-89-313, Savannah River Site, Aiken, S.C.

ICRP, 1990 International Commission on Radiation Protection, 1990, Recommendations of the ICRP, Publication 60, Elmsford, N.Y.

Klaassen et al., 1986 Klaassen, C.D., M.D. Amdur, and J. Doull (editors), 1986, Casarett and Doull's Toxicology, The Basic Science of Poisons, third edition, MacMillan Pharmacology 33:120-126, New York, N.Y.

Looney et al., 1993 Looney, B.B., et al, 1993, Projected Tritium Releases from F \& H Area Seepage Basins and the Solid Waste Disposal Facilities to Fourmile Branch (U), WSRC-RP-93-459, Savannah River Site, Aiken, S.C.

NCRP, 1987 National Council on Radiation Protection and Measurements, 1987, Ionizing Radiation Exposure of the Population of the United States, NCRP Report No. 93, Bethesda, Md. 
Nelson, 1996 Nelson, E.A., 1996, The Restoration of Pen Branch: Defining and Measuring the Progress of a Thermally Impacted Stream Becoming a Functional Wetland Ecosystem, WSRC-MS-96-0257X, Savannah River Site, Aiken, S.C.

NRC, 1977 U.S. Nuclear Regulatory Commission, 1977, Regulatory Guide 1.109, Calculation of Annual Doses to Man from Routine Releases of Reactor Effluents for the Purpose of Evaluating Compliance with 10 CFR 50, Appendix I, Revision 1, Washington, D.C.

SCDHEC, 1985 South Carolina Department of Health and Environmental Control, 1985, Savannah River Plant, Aiken, Allendale, and Barnwell Counties, NPDES Permit 0000175, Columbia, S.C.

SCDHEC, 1993 South Carolina Department of Health and Environmental Control, 1993, South Carolina State Primary Drinking Water Regulations R.61-68, "Water Classifications and Standards," Columbia, S.C.

Soldat et al., 1974 Soldat, J.K., N.M. Robinson, and D.A. Baker, 1974, Models and Computer Codes for Evaluating Environmental Radiation Doses, BNWL-1754, Battelle Pacific Northwest Laboratories.

SRFS, 1982 Savannah River Forest Station, 1982, "Thirty Years of Progress," Savannah River Forest Station Savannah River Plant Newspaper, January 1982, Savannah River Forest Station, Department of Agriculture, Aiken, S.C.

SRS Data, 1997 Environmental Protection Department Environmental Monitoring Section, 1996, Savannah River Site Environmental Data for 1996, WSRC-TR-97-0077, Savannah River Site, Aiken, S.C.

SRS EM Program, 1995 Savannah River Site Environmental Monitoring Section Plans and Procedures, WSRC-3Q1-2, Volume 1, Section 1100, Savannah River Site, Aiken, S.C.

SWD, 1997 Pollution Prevention-Everybody's Business, 1997, Solid Waste Division, Westinghouse Savannah River Company, Dunaway \& Fletcher, North Augusta, S.C.

WSRC, 1996 Westinghouse Savannah River Company, 1996, Comprehensive Review of Environmental Monitoring Programs at Savannah River Site (U), WSRC-RP-96-308, Savannah River Site, Aiken, S.C. 


\section{Index}

\section{A}

A-Area, 9

A-Area and M-Area, groundwater monitoring results, 146

Academy of Natural Sciences of Philadelphia river quality surveys, 182

actinide transport, 70

Affirmative Procurement Plan, 47

air, radiological surveillance of, 76

sampling stations for, 77

air dispersion modeling, 124, 129

air emissions inventory, 27

airborne emissions

nonradiological monitoring of, 121

radiological monitoring of, 61

comparison of average concentrations to

Derived Concentration Guides, 63

diffuse and fugitive sources, 62

results of, 62

ambient air quality, 123, 129

appraisals and surveillances of environmental program, 32

aquatic food products. See fish, radiological surveillance of

areas of Savannah River Site

A-Area, 9

administration, 9

B-Area, 9

D-Area, 7

F-Area, 7

G-Area, 9

general, 9

H-Area, 7

Heavy Water Reprocessing Area, 7

M-Area, 5

Multipurpose Pilot Plant Campus, 9

N-Area, 9

reactor, 5

reactor materials, 5

separations, 7

TNX, 9

waste management, 8

as low as reasonably achievable concept, 61

asbestos removal program, 27
Atomic Energy Commission, 1

Atoms for Peace program, 9

B-Area, 9

groundwater monitoring results, 166

bald eagle, 29

Baseline Risk Assessment, 17

Beaufort-Jasper Water Treatment Plant, 3

beavers, radiological surveillance of, 91

beef. See food products, radiological surveillance of

blind sample program for quality assurance, 169

Bridging Amendment, 14

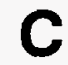

C-Area, groundwater monitoring results, 148

CAP88, 106

Central Savannah River Area Radiological

Environmental Monitoring Program, 49

Chemical Commodity Management Center, 48

chemicals, management of excess, 48

chemicals, metals, and pesticides pits, groundwater monitoring results, 159

Citizens Advisory Board, recommendations of, 58

City of Savannah Industrial and Domestic Water Supply Plant, 3

Clean Air Act, 26

compliance with National Emissions Standards of Hazardous Air Pollutants, 115

Clean Water Act, 24

construction in navigable waters, 25

dredge and fill permitting, 25

National Pollutant Discharge Elimination

System program, 24

reportable occurrences, 30

cleanup, definition of term, 51

climate of Savannah River Site, 2

coal-fired boilers

capacities of, 122 
nonradiological airborne emissions standards for, 121

stack test results of, 123

compensatory mitigation, 182

Comprehensive Environmental Response, Compensation, and Liability Act, 15, 17 reportable occurrences, 30,31

conservation of energy, 47

Consolidated Incineration Facility, 8, 56

construction and operating permits, 34

contamination of Savannah River Swamp, 178

continuous monitoring, 62,64

cooling tower, K-Reactor, 7

C-Reactor, history of, 5

criteria pollutant air emissions (1995), 123

critical pathways analysis, 45

CRITR, 120

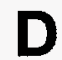

D-Area, 7

groundwater monitoring results, 151

power plant, 7

data validation and quality assurance, 171

decontamination and decommissioning of

facilities, 33

deer

dose from consumption of, 115

radiological surveillance of, 90

Defense Waste Processing Facility, 8, 58

Derived Concentration Guides, 63, 65

diffuse and fugitive sources, radioactive releases

from, 62

dose

calculating by Savannah River Site, 105

calculating for children, 106

calculation models, 106

contributions to average individual, 116

definition of in this report, 105

to maximally exposed individual, 105

10-year history, 116

uncertainty in calculation of, 108

dose calculation results

air pathway, 112

atmospheric concentrations, 112 atmospheric source terms, 112

collective dose (population dose), 115

maximally exposed individual, 113, 114

National Emissions Standards for Hazardous

Air Pollutants compliance, 115

all-pathway, 115

comparison of, to standard, 117

deer and hog consumption pathway, 115

dose to aquatic animal organisms, 119

drinking water pathway, 111

fish consumption pathway, 117

liquid pathway, 109

collective effective dose equivalent (population dose), 112

irrigation, 112

liquid release source terms, 109

maximally exposed individual, 111

maximally exposed individual, (sector-specific), 114

sportsman dose, 115

deer and hog consumption pathway, 115

fish consumption pathway, 117

Dose Reconstruction Study, 46

drinking water

nonradiological surveillance of, 130

radiological surveillance of, 85

Du Pont, 1

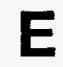

E.I. du Pont de Nemours and Company, 1

E-Area

groundwater monitoring results, 154

Vaults, 8

economic development and transfer of technology, 11

effluent monitoring, definition of, 42

effluent monitoring responsibilities (radiological), 61

Effluent Treatment Facility; 8 description of operations, 8

Emergency Planning and Community

Right-to-Know Act, 17

reportable occurrences, 31

endangered and threatened species, 4

Endangered Species Act, 29

energy conservation, 47

Environmental Advisory Committee, 49

Environmental Bulletin, 50 
environmental compliance

33/50 Pollution Prevention Program, 18

appraisals and surveillances of programs, 32

Clean Air Act, 26

Clean Water Act

construction in navigable waters, 25

dredge and fill permitting, 25

National Pollutant Discharge Elimination

System program, 24

reportable occurrences, 30

Comprehensive Environmental Response,

Compensation, and Liability Act, 17

reportable occurrences, 30,31

courtesy notifications to regulators, 31

Emergency Planning and Community

Right-to-Know Act, 17

reportable occurrences, 31

Endangered Species Act, 29

Executive Order 12856, 19

Federal Facility Agreement, 17

Federal Facility Compliance Act, 14

Federal Insecticide, Fungicide, and Rodenticide Act, 25

floodplain management (Executive Order

$$
\text { 11988), } 30
$$

key regulations for, 15

land disposal restrictions, 14

National Emission Standards for Hazardous Air Pollutants, 26

National Environmental Policy Act, 19

National Historic Preservation Act, 29

National Pollutant Discharge Elimination System, 24

permits, 33

Resource Conservation and Recovery Act, 13 300-3004(u) Program, 16

Notice of Violation, 16

Safe Drinking Water Act, 22

Site Item Reportability and Issues Management Program, 31

toxic chemical releases, 19,20

Toxic Substances Control Act, 28

training, 33

underground storage tanks, 15

Waste Minimization Program, 16

wetlands protection (Executive Order 11990), 30

environmental justice, 49

environmental monitoring program, 41

1996 changes in, 46

environmental regulations for, 44

measurement capabilities as factors in, 46

objectives of, 44

of nonradioactive materials, 41 of radioactive contaminants, 42

policy for, 44

public concerns about releases, 45

rationale for, 44

Environmental Outreach and Education Program, 50

environmental release response and reporting, 30

environmental restoration

1996 achievements, 52

definition of term, 51

description of program, 52

regulations for, 52

environmental surveillance, definition of, 42

Executive Order

11988, 30

11990,30

12856, 19

Extended Sludge Processing Facility, 8

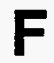

F-Area, groundwater monitoring results, 154

F-Canyon operations, 7

FB-Line operations, 7

Federal Facility Agreement, 17

Federal Facility Compliance Act, 14

Federal Insecticide, Fungicide, and Rodenticide Act, 25

fish

dose from consumption of, 117

nonradiological surveillance of, 132

radiological surveillance of, 88

risk from consumption of, 119

sampling locations for, 89

fish monitoring plan, 117

floodplain management (Executive Order 11988), 30

flow rate measurements, 62,65

food products, radiological surveillance of, 87

freshwater fish. See fish, radiological surveillance of

Freshwaters, definition of, 129

fruit. See food products, radiological surveillance of 


\section{G}

G-Area, 9

gamma radiation, radiological surveillance of, 78

geology of Savannah River Site, 2

grassy vegetation. See vegetation, radiological surveillance of

greens. See food products, radiological surveillance of

groundwater

and quality assurance, 174

changes in 1996 monitoring program for, 143

description of monitoring program for, 139-144

monitoring well network (map), 136

movement of, 135

overall summary of monitoring results, 135

quality control for, 142

groundwater monitoring results, 144-167

A-Area and M-Area, 146

B-Area, 166

C-Area, 148

chemicals, metals, and pesticides pits, 159

D-Area, 151

E-Area, 154

F-Area, 154

H-Area, 154

K-Area, 156

L-Area, 159

N-Area, 161

overall summary of, 135

P-Area, 162

R-Area, 164

S-Area, 154

Sanitary Landfill, 166

TNX, 151

Z-Area, 154

\section{H}

H-Area, groundwater monitoring results, 154

H-Canyon operations, 7

Handshake II training exercise, 49

hazardous waste, 55

HB-Line operations, 7

Heavy Water Reprocessing Area, 7

Heavy Water Rework Facility, 7

high-level waste, 56 hogs

dose from consumption of, 115

radiological surveillance of, 90

hydrology of Savannah River Site, 2

In-Tank Precipitation Facility, 8, 57, 58

information exchange, 49

inorganic contaminants, in sediment, 132

interlaboratory comparison

Department of Energy Quality Assurance Program, 171

Environmental Protection Agency Quality Assurance Division, 171

for National Pollutant Discharge Elimination System, 173

intralaboratory comparison, for National Pollutant Discharge Elimination System, 173

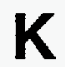

K-Area, groundwater monitoring results, 156

key regulations for environmental compliance, 15

K-Reactor cooling tower, 7

history of, 7

L-Lake, construction of, 2

L-Area, groundwater monitoring results, 159

laboratory data record reviews and quality assurance, 175

LADTAPII, 106

land disposal restrictions, 14

land resources of Savannah River Site, 4

liquid discharges

nonradiological monitoring of, 124

radiological monitoring of, 64 comparison of average concentrations to Derived Concentration Guides, 65 results of, 65

Liquid Effluent Treatment Facility, description of operations, 5

liquid effluents, direct discharges of, 65 
low-level waste, 54

L-Reactor, history of, 5

\section{M}

M-Area, 5

marine fish. See fish, radiological surveillance of

MAXIGASP, 106

mercury in fish, 132

meteorological data as input for dose calculations, 106

mission of Savannah River Site, 4

mitigation, compensatory, 182

Mitigation Action Plan for Pen Branch

Reforestation, 179

mixed waste, 55

\section{$\mathbf{N}$}

N-Area, 9

groundwater monitoring results, 161

National Emissions Standards for Hazardous Air Pollutants, 26

compliance with for dose calculation, 115

National Environmental Policy Act, 19

documentation activities, 23

types of activities, 21, 23

National Environmental Research Park, designation of Savannah River Site as, 4

National Historic Preservation Act, 29

National Pollutant Discharge Elimination System, 24

1996 exceedances, 126,127

and quality assurance, 173

Environmental Protection Agency control sample program, 173

history of exceedances, 125

permits, 124, 184

program results, 124

National Priority List, 16, 52

Natural Resources Environmental Education Program, 50

nonradiological monitoring and surveillance. See individual medium

Notice of Violation, Resource Conservation and Recovery Act, 16
Off-Site Fuels Policy, 9

Oil Pollution Prevention regulation, 25

ozone-depleting substances, $26,28,48$

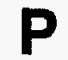

P-Area, groundwater monitoring results, 162

PAR Pond, construction of, 2

pathways

examples of exposure, 45

surveillance of, as part of radiological surveillance program, 75

Pen Branch reforestation

by natural succession, 180

by planting, 180

permits for environmental compliance, 33

construction and operating, 34

pesticides and herbicides in sediment, 132

pesticides, herbicides, and volatile organic

compounds, SCDHEC sampling locations for, 131

plant and animal life at Savannah River Site, 4

pollution prevention, 47, 55

33/50 Pollution Prevention Program, 18

Executive Order 12856, 19

Pollution Prevention Act of 1990, 18

POPGASP, 106

population database and distribution as input for dose calculations, 106

P-Reactor, history of, 5

public

concerns about releases, 45

involvement of stakeholders, 58

notification to, about environmental plans and activities, 50

outreach, 49

Public Involvement Program, 58

purple coneflower, 29

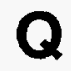

quality assurance definition of terms, 171

external program, 171

for Environmental Monitoring Section

laboratories, 169 
for groundwater analyses, 174

for National Pollutant Discharge Elimination

System analyses, 173

for soil and sediment analyses, 175

for stream and river water analyses, 173

for subcontracted laboratories, 172

internal program, 169

relevant guidance documents for, 170

Quality Assurance Division (Environmental Protection Agency), 171

Quality Assurance Program (Department of Energy), 171

quality control practices for groundwater, 142

\section{$\mathbf{R}$}

R-Reactor, history of, 5

R-Area, groundwater monitoring results, 164

Radiation Assessment Program, 120

radiological effluent monitoring responsibilities, 61

radiological monitoring and surveillance. See individual medium

rainwater, radiological surveillance of, 77

reactor areas, 5

reactor materials area, 5

reactors, history of, 5

real-time instrumentation, 61

Receiving Basin for Offsite Fuel, 7

recycling, of solid waste, 47

red-cockaded woodpecker, 29

regulated units at SRS, 18

Replacement Tritium Facility, 7

reportable occurrences for environmental compliance, 30

Comprehensive Emergency Response, Compensation, and Liability Act, 31

reporting

courtesy notifications to regulators, 31

of environmental releases, 30

research and development at Savannah River Site, 9

Resource Conservation and Recovery Act, 13

300-4(u) Program, 16

Notice of Violation, 16 risk from consumption of fish, 117

compared to dose standards, 119

river flow rate data as input for dose calculations, 108

river water system shutdown, 34

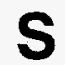

S-Area, groundwater monitoring results, 154

Safe Drinking Water Act, 22

Saltstone Facility, 8, 58

sampling locations

nonradiological

fish, 89

sediment, 133

surface water, 131

radiological

air, 77

fish, 89

sediment, 94

soil, 93

surface water (seepage basins, streams,

Savannah River), 81

vegetation, 96

sampling trails for Savannah River Swamp survey (map), 179

Sanitary Landfill, groundwater monitoring results, 166

sanitary waste, 54

Savannah River, radiological surveillance of, 84

sampling locations for, 81

tritium release transport, 85

Savannah River Archaeological Research

Program, 11

and public outreach, 50

Savannah River Ecology Laboratory, 10

and public outreach, 50

Savannah River Forest Station, 10 and public outreach, 50

Savannah River Site and transfer of technology, 11

areas, 6

climate of, 2

criteria for locale for, 1

geology of, 2

history, 1

hydrology of, 2

land resources of, 4

location of, 2,3

map of areas, 6 
mission of, 4

plant and animal life at, 4

research and development at, 9

tours of, 49

water resources of, 2

wildlife at, 4

Savannah River Swamp survey, 177

sampling trails for, (map), 179

Savannah River Technology Center, 9

sediment

nonradiological surveillance of, 132

sampling locations for, 133

radiological surveillance of, 92

sampling locations for, 94

seepage basins

history of, in F-Area and H-Area, 8

migration results, 67

radiological surveillance of, 80

sampling locations for, 81

separations areas, 7

settleable solids, discontinuance of sampling for, 70

shortnose sturgeon, 29

Site Item Reportability and Issues Management Program, 31

unusual occurrences reported through, 32

soil, radiological surveillance of, 92

sampling locations for, 93

solid waste, 54

1996 accomplishments of program, 55

hazardous, 55

low-level, 54

mixed, 55

sanitary, 54

strategy for addressing legacy of, 55

transuranic, 54

Solid Waste Disposal Facility, 8

migration results, 67

radiological results of vegetation samples at; 98

South Carolina Electric and Gas Company and D-Area Power Plant, 7

Speakers Bureau, 49

spent fuel activities at Savannah River Site, 9

SRS Domestic Water Consolidation Preliminary

Engineering Report, 24

stakeholder involvement, 58

steam boilers, capacities of, 123

stratospheric ozone protection, 28 streams, radiological surveillance of, 82

sampling locations for, 81

tritium release transport, 85

subcontracted laboratories, 172

Superfund Amendments and Reauthorization Act, 17

Superfund List. See Comprehensive

Environmental Response, Compensation, and

Liability Act

Supplier Environmental and Waste Management Information Exchange and vendor partnership achievements, 56

surface water

See also seepage basins, streams, Savannah

River (radiological surveillance of)

nonradiological surveillance of, 129

sampling locations for, 131

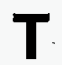

tank closures

high-level waste, 57

solvent storage, 56

tank farms, 8

evaporator facilities, 57

terrestrial food products. See food products, radiological surveillance of

thermoluminescent dosimeter program, 78

and public concern, 45

Tier II Inventory Report, 17

Title V operating program, 27

TNX, 9

groundwater monitoring results, 151

tours of Savannah River Site, 49

toxic air pollutant air sources, stack test results of, 124

Toxic Chemical Release Inventory, 17

decline in reportable release quantities, 47

toxic chemicals, releases of, 19, 20

Toxic Substances Control Act, 28

training

for environmental awareness, 48

for environmental compliance, 33

for quality assurance, 169

Trans-River Flow Project, 182

transfer of technology, 11

transition of site facilities, 33 
transuranic waste, 54,56

Traveling Lecturers Program, 49

tritium migration into Georgia from Savannah

River Site, 182

tritium release transport in streams and Savannah

River, 85

turkeys, radiological surveillance of, 91

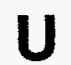

underground storage tanks, 15

unplanned releases, response to, 30

\section{V}

vegetation, radiological surveillance of, 95 results of quarterly samples, 97

results of chemical, retention, and seepage basin samples, 97

results of Solid Waste Disposal samples, 98 sampling locations for, 96

Visitors Program, 49

\section{W}

waste management

definition of term, 51

high-level, 56

1996 accomplishments of, 57

regulations for, 52

solid, 54

1996 accomplishments of, 55

waste management areas, 8

waste minimization, 47,55

Waste Minimization Program, 16

waste tanks, description of, 8

water quality and quality assurance, 173

water resources of Savannah River Site, 2

wetlands protection, 30

wildlife at Savannah River Site, 4

wind rose for Savannah River Site, 107

wood stork, 10, 29

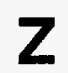

Z-Area, groundwater monitoring results, 154 


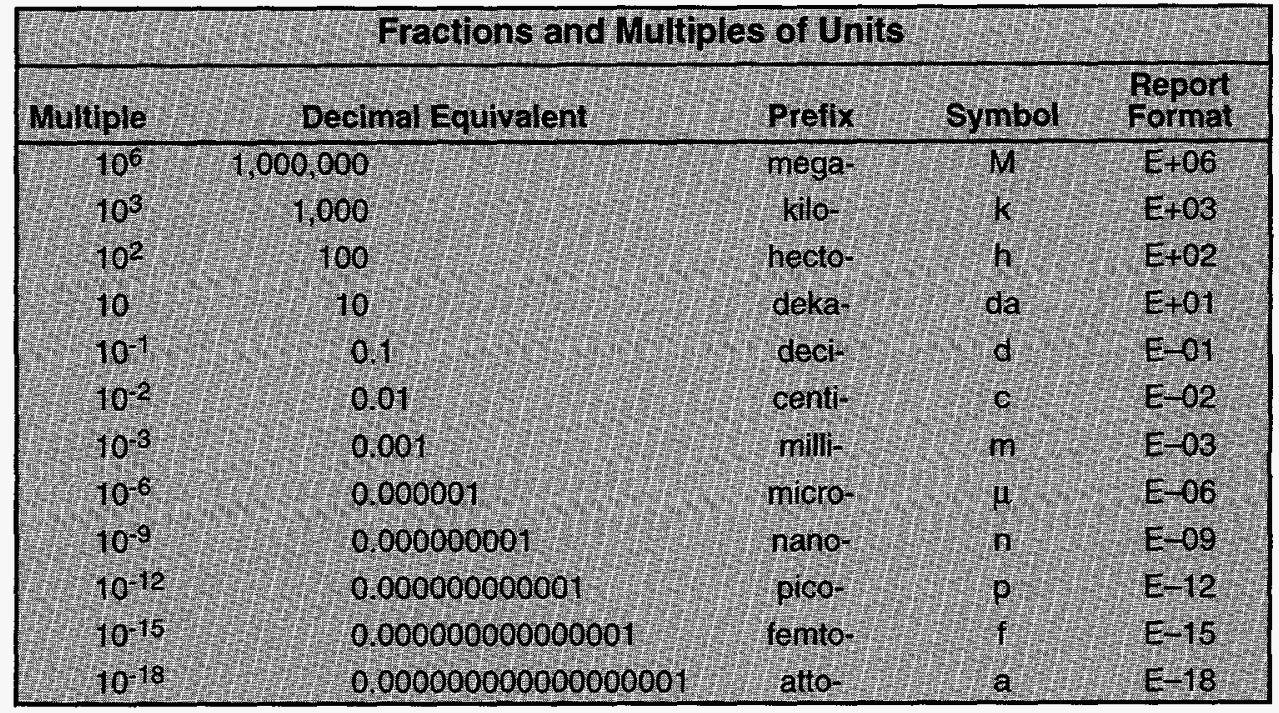

\begin{tabular}{|lcc|}
\hline & Conversion Table (Units of Radiation Measure) \\
\hline Current System & Systéme International & Conversion \\
\hline curie (Ci) & becquerel $(\mathrm{Bq})$ & $1 \mathrm{G}=3.7 \times 10^{10} \mathrm{~Bq}$ \\
$\mathrm{rad}(\mathrm{radiation}$ absorbed dose) & gray $(\mathrm{G})$ & $\mathrm{rad}=0.01 \mathrm{~Gy}$ \\
$\mathrm{rem}(\mathrm{roentgen}$ equivalent man) & sievert (SV) & $1 \mathrm{rem}=0.01 \mathrm{SV}$ \\
\hline
\end{tabular}

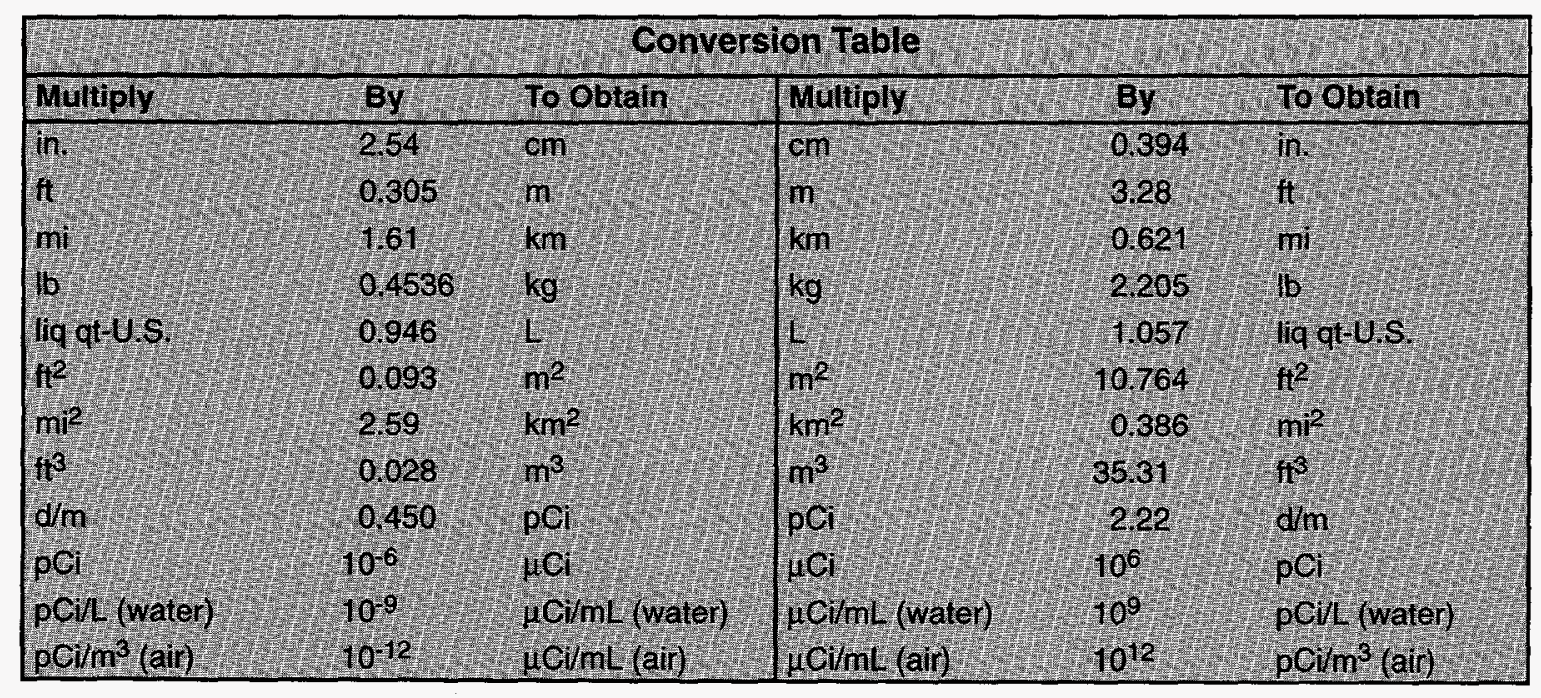

